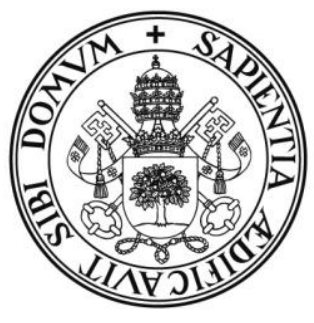

Universidad deValladolid

ESCUELA DE MAGISTERIO DE SEGOVIA

DEPARTAMENTO DE PEDAGOGÍA

TESIS DOCTORAL:

\title{
INICIACIÓN A LA EDUCACIÓN AUDITIVA DESDE UN CONTEXTO TONAL EN LA ASIGNATURA DE LENGUAJE MUSICAL
}

Presentada por Elena Berrón Ruiz para optar al grado de

Doctora por la Universidad de Valladolid

\author{
Dirigida por: \\ Dr. José Juan Barba Martín \\ Dr. Francisco José Balsera Gómez
}



Si buscas resultados diferentes, no hagas siempre lo mismo.

(A. Einstein) 



\section{AGRADECIMIENTOS}

La presente tesis doctoral, hecha con gran rigurosidad, dedicación y esfuerzo, pero también con mucho cariño, es fruto del respeto hacia las personas y la confianza en las relaciones y potencialidades humanas, ya que los aspectos emocionales, la empatía y el afán de superación, más aún que lo cognitivo, han movido nuestras acciones educativas y científicas hasta llevarlas al puerto deseado.

Son muchas las personas que me han acompañado en este largo y apasionante viaje y a las que deseo expresar mi más sincero agradecimiento por su necesaria y altruista colaboración, así como por el apoyo que me han brindado para poder sacarlo adelante.

En primer lugar, agradezco a mis directores Dr. José Juan Barba Martín y Dr. Francisco José Balsera Gómez la paciencia que han tenido conmigo y la confianza depositada en mí. El entusiasmo que me han transmitido, las discusiones, sus sabios, constructivos y siempre acertados consejos, su dedicación, sus palabras de ánimo y el empujón que me han dado para desconectar en los momentos de bloqueo me han permitido crecer personal y profesionalmente y conocerme mejor a mí misma, ayudándome a valorar el bosque más allá de los árboles.

Mi más sincero agradecimiento también a mi familia, especialmente a mis padres, abuela, hermanos y sobrinos, a quienes quiero, respeto y debo mucho de lo que soy actualmente, por la confianza que me han trasmitido desde pequeña para elegir con libertad y desarrollar mi personalidad y porque siempre están ahí para lo que sea necesario, a pesar de que muchas veces no les dedique el tiempo que me gustaría.

No puedo olvidarme tampoco de mis grandes e incondicionales amigas: Marta, María, Ana y Lourdes por su apoyo incansable, su alegría contagiosa, su comprensión, su gran paciencia, por permanecer a mi lado y por creer en 
mí incluso en momentos en los que ni yo misma lo hago. Mi vida es mucho mejor y más fácil sintiéndolas tan cerca y son personas claves para no desfallecer en mis proyectos y hacer realidad mis ilusiones.

Siento gran admiración por los expertos entrevistados en esta tesis: Emilio Molina, Berenice Gómez Briones y Encarnación López de Arenosa, y valoro enormemente que hayan compartido sus conocimientos, su tiempo y su buen hacer conmigo, ya que sus aportaciones han sido fundamentales para conocer de primera mano cómo se está llevando a cabo la educación auditiva en los conservatorios de nuestro país y me han abierto el camino para trabajar en la mejora de dicho campo. Asimismo, deseo expresar mi respeto a Ana López, Pedro Cañada, Marién González, Francisco Javier López, Ángel Rodríguez, Fátima Fernández, Pilar Lago, Daniel Roca, Silvia Raposo, Federico Calcagno, Sara Tendero, Ana Sánchez, César Ausejo, Gabriel Robles Ojeda, Ana María Navarrete, Félix Sierra y a todos aquellos docentes y personas encantadoras con los que he participado en congresos, cursos, grupos de trabajo o seminarios de educación musical, porque me han contagiado su pasión hacia la música y, de forma más específica, hacia la docencia en el Lenguaje Musical y me han ayudado a resolver muchas inquietudes.

Igualmente, debo mi reconocimiento a los conservatorios de Ávila, Segovia, Zaragoza, Huesca, Cantabria, Córdoba, Madrid y Murcia que me han abierto sus puertas y han colaborado en este estudio cumplimentando cuestionarios, especialmente a los profesores de Lenguaje Musical de los mismos, que han sido los encargados de administrárselos a sus alumnos.

Por otra parte, siento especial cariño y gratitud hacia todos mis colegas docentes, pasados y presentes, tanto del cuerpo de maestros como del conservatorio o del ámbito universitario, con quienes he aprendido y aprendo cada día a mejorar en mi profesión y me entusiasmo más por la educación, compartiendo inquietudes y largas reflexiones para mejorar los procesos de enseñanza-aprendizaje. Pero no solo estoy agradecida a los compañeros que me han apoyado y con los que he podido coordinarme para emprender proyectos comunes, sino también a todos aquellos que no han compartido mis planteamientos, ya que han fortalecido mi carácter y me han incitado a justificar adecuadamente cada una de mis propuestas, lo cual me ha ayudado a ratificar su validez.

También deseo agradecer a los padres y madres de mis alumnos su buena disposición para participar en el proceso de aprendizaje de sus hijos y en este trabajo de investigación, del que son parte fundamental. La confianza depositada en mí, su cercanía, cariño y el apoyo que me han mostrado con gestos y palabras me han servido de aliento, aumentando mi responsabilidad 
docente y mi apuesta por desarrollar una educación compartida. Especialmente, quiero destacar la labor de Eva Mónica de Miguel por ayudarme a presentar los resultados mediante el montaje de videos y fotografías.

Y, por supuesto, quiero felicitar a todos mis alumnos del Conservatorio Profesional de Música de Segovia, los verdaderos protagonistas y destinatarios de este estudio, por su gran implicación en las actividades propuestas sin escatimar esfuerzos y por todo lo que me ilusionan y me enseñan cada día, reforzándome la idea de que lo más importante no es lo que queremos enseñar los profesores, sino lo que realmente pueden aprender ellos si nos adaptamos a sus características y les motivamos de forma adecuada, atendiendo a su singularidad.

Finalmente, quiero dar gracias a todas las personas que me han acompañado en mi camino, por descubrirme una vida llena de aprendizajes, experiencias y alegría, poniendo el énfasis en el ser por encima del tener y en el respeto y la entrega a los demás más allá del prestigio u otros méritos. Sin duda, estos valores han guiado la realización de esta tesis, donde ha primado el interés por cada persona implicada por encima de otras motivaciones profesionales, formativas o científicas.

Sinceramente, muchas gracias a todos lo que, de una u otra forma, formáis parte de este bonito y enriquecedor proyecto. 



\section{ÍNDICE}

CAPÍTULO I INTRODUCCIÓN

1. Introducción 1

2. Mi experiencia personal: pequeña historia de vida 2

2.1. Mis años como estudiante de música 2

2.2. Mi comienzo como profesora: dificultades de mis alumnos 6

2.3. En busca de una nueva metodología para el trabajo auditivo 7

3. ¿Qué pregunta clave nos surge? 10

4. Importancia del tema elegido en esta tesis 11

5. Estructura de la tesis 16

CAPÍTULO II LA EDUCACIÓN AUDITIVA DESDE UNA 19 PERSPECTIVA MUSICAL

1. Introducción 19

2. El proceso auditivo 20

2.1. Anatomía y fisiología del oído 20

2.2. La audición musical 23

2.2.1. Procesos cognitivos implicados en la audición musical 25

2.2.2. Evolución de la audición musical en las etapas vitales $\quad 26$

3. Delimitación del concepto de "educación del oído musical" 29

4. Factores fundamentales que intervienen en la educación auditiva 32 musical

4.1. La atención en la escucha musical 33

4.2. La memoria musical 37

4.3. La percepción y el reconocimiento auditivo musical 40

4.4. La influencia del canto en la formación del oído musical 42

4.5. La audición interior 45 
5. Otros aspectos que contribuyen a la educación auditiva 49

5.1. La motivación 49

5.2. La reducción de la ansiedad 52

5.3. El desarrollo de la creatividad 54

6. Aportaciones a la educación auditiva desde distintos métodos de 57 educación musical

6.1. Aportaciones de grandes pedagogos musicales reconocidos $\quad 58$ a nivel internacional

6.2. Aportaciones de pedagogos musicales españoles 60

\section{CAPÍTULO III EL SISTEMA MUSICAL TONAL-ARMÓNICO 67}

1. Introducción 67

2. El sonido musical y sus cualidades $\quad 68$

3. Características del sistema musical tonal-armónico 73

3.1. La tonalidad $\quad 74$

3.2. La armonía $\quad 78$

3.2. El acorde 81

4. El oído musical en el contexto de la tonalidad 83

4.1. La discriminación tonal 84

4.2. La audición relativa y absoluta 87

4.2.1. El oído relativo $\quad 88$

4.2.2. El oído absoluto 90

4.3. El oído musical melódico 93

4.3.1. La identificación auditiva de los grados de la escala 94

4.3.2. La percepción de las relaciones de alturas y del 95 contorno melódico

4.3.3. La identificación auditiva de los intervalos melódicos 97

4.4. El oído musical armónico 101

4.4.1. Percepción auditiva de la consonancia y la disonancia 105

4.4.2. La identificación auditiva de los intervalos armónicos 108

4.4.3. Desarrollo de la percepción armónica en la infancia $\quad 110$

\section{CAPÍTULO IV LA ASIGNATURA DE LENGUAJE MUSICAL 115 DENTRO DE LAS ENSEÑANZAS MUSICALES}

1. Introducción

2. La educación musical en el sistema educativo español 115

3. La educación musical en los conservatorios españoles 117 
3.1. Marco legislativo general para todo el territorio nacional

3.1.1. Enseñanzas elementales

3.1.2. Enseñanzas profesionales 121

3.1.3. Enseñanzas superiores 124

3.2. La educación musical en los conservatorios de Castilla- 125

León

3.2.1. Enseñanzas elementales 128

3.2.2. Enseñanzas profesionales 129

3.2.3. Enseñanzas superiores 131

3.3. La educación musical en el Conservatorio Profesional de 133

Música de Segovia

3.3.1. Situación y entorno del conservatorio 133

3.3.2. Principios y objetivos generales 134

3.3.3. Organización general del centro 136

3.3.4. Plan de estudios 137

3.3.5. Reglamento de régimen interior 138

4. La asignatura de Lenguaje Musical 138

4.1. Evolución histórica del Lenguaje Musical 138

4.2. El Lenguaje Musical en los conservatorios $\quad 140$

4.2.1. Plan de estudios de $1917 \quad 141$

4.2.2. Plan de estudios de $1942 \quad 141$

4.2.3. Plan de estudios de $1955 \quad 141$

4.2.4. Plan de estuios de 1966

4.2.5. Ley de Ordenación General del Sistema Educativo 143 de 1990

4.2.6. Ley Orgánica de Educación de $2006 \quad 147$

4.2.7. Ley Orgánica para la Mejora de la Calidad 148 Educativa de 2013

4.3. Cómo se trabaja el Lenguaje Musical en el conservatorio $\quad 148$

4.3.1. Educar en competencias básicas desde la 149 asignatura de Lenguaje Musical

4.3.2. Principios metodológicos generales de 151 intervención educativa

4.3.3. Principios pedagógico-musicales 152

4.3.4. Estrategias para la enseñanza del Lenguaje $\quad 152$ Musical

4.3.5. Agrupamiento del alumnad 155

4.3.6. Organización del espacio 156

4.3.7. Organización del tiempo 157

4.3.8. Materiales y recursos didácticos 157

4.4. La educación auditiva en la asignatura de Lenguaje 160

Musical

4.4.1. La educación auditiva dentro del currículo de 160 Lenguaje Musical en el conservatorio de Segovia 
4.4.2. El dictado musical

4.4.3. La utilidad de las canciones para la educación auditiva

4.4.4. Aportaciones de las TIC para el desarrollo auditivo

CAPÍTULO $\mathrm{V}$ NUESTRA PROPUESTA METODOLÓGICA PARA LA EDUCACIÓN AUDITIVA DESDE UN CONTEXTO TONAL

1. Introducción

2. La educación auditiva desde un contexto tonal

3. Ejes prioritarios de trabajo

4. Objetivos didácticos

5. Recursos educativos y actividades realizadas

5.1. Actividades y recursos de discriminación rítmica

5.2. Actividades y recursos de discriminación melódica y 183 armónica

5.2.1. Identificación auditiva de los acordes tonales $\quad 183$

5.2.2. Reconocimiento auditivo de intervalos 184

5.2.3. Invención y adaptación de motivos rítmico-melódicos 184

5.2.4. Aprendizaje, análisis y transcripción de canciones 186

5.2.5. Nuestra principal aportación: la creación de canciones 189

5.3. Conocimiento teórico de los códigos del Lenguaje Musical $\quad 190$

5.3.1. Acordes tonales 190

5.3.2. Melodía: notas reales y notas de adorno 192

5.3.3. Desarrollo de motivos melódicos 194

5.3.4. Nociones básicas de instrumentación 196

5.4. Ejercicios para el desarrollo de la memoria auditiva 197

5.4.1. Utilización de la fononimia de Kodály 197

5.4.2. Interpretación de melodías y fragmentos de memoria 197

5.4.3. Notas, ritmos y secuencias rítmico-melódicas 200 encadenadas

5.5. Otros aspectos claves: motivación, creatividad y ansiedad 201 
1. Introducción 203

2. Definición del objeto de estudio 203

3. Diseño general de la investigación 204

3.1. Investigación cualitativa 204

3.2. Métodos de investigación utilizados 207

3.2.1. Investigación-acción entendida como investigación 208 en el aula

3.2.2. Estudio de casos 210

3.3. Configuración de la muestra 213

3.4. Acceso al campo 214

3.5. Plan de trabajo y temporalización 215

4. Técnicas e instrumentos para la recogida de datos 218

4.1. Diario de la profesora 218

4.2. Entrevistas 221

4.2.1. Entrevistas individuales 223

4.2.1.1. Entrevistas a expertos 223

4.2.1.2. Entrevistas a padres y profesores-tutores 225

4.2.2. Entrevistas grupales a padres y alumnos 227

4.3. Cuestionarios 230

4.3.1. Cuestionarios cerrados sobres motivación y 233

dificultades en Lenguaje Musical

4.3.1.1. Elaboración y validación del cuestionario $\quad 233$

4.3.1.2. Descripción del cuestionario 234

4.3.1.3. Difusión y aplicación del cuestionario 235

4.3.2. Cuestionarios abiertos de autoevaluación sobre el 236 desarrollo y aplicación de la nueva metodología

4.4. Análisis de documentos 237

4.4.1.Publicaciones didácticas para la enseñanza del 238 Lenguaje Musical

4.4.2. Documentos oficiales 238

4.4.3. Correos electrónicos 239

4.4.4. Trabajos y exámenes del alumnado 239

4.4.5. Videos y fotografías 240

4.5. Temporalización para la recogida de datos 240

5. Análisis de los datos 242

5.1. El análisis de datos en la tesis 243

5.1.1. Organización de los datos procedentes de las 243 distintas técnicas e instrumentos

5.1.2. Definición de categorías para el registro y la 247 reducción de los datos

5.1.3. Análisis descriptivo e interpretativo de los datos $\quad 249$ 
5.2. Proceso de anonimato y confidencialidad

5.3. Proceso de codificación de los documentos

6. Análisis del rigor metodológico de la investigación

6.1. Credibilidad

6.2. Confirmabilidad

258

6.3. Transferibilidad

259

6.4. Dependencia

CAPÍTULO VII ANÁLISIS DE LOS CONTENIDOS TRABAJADOS A PARTIR DE NUESTRA PROPUESTA METOLÓGICA

1. Introducción

2. El ritmo musical 263

2.1. La importancia de la experimentación rítmica 264

2.2. El ritmo musical estudiado como métrica 265

2.2.1. Formación de lectores de partituras versus formación 266 de músicos integrales

2.2.2. La lectura rítmica en el solfeo tradicional 268

2.3. Utilidad del lenguaje verbal para el aprendizaje rítmico $\quad 272$

2.4. Nuestra propuesta de trabajo rítmico discriminativo y 274 creativo a partir de refranes

2.4.1. Descripción de la propuesta $\quad 274$

2.4.2. Motivación de los alumnos hacia los refranes $\quad 277$

2.4.3. Dificultades del alumnado para inventar nuevas letras 278

2.4.4. Utilidad del trabajo realizado a partir de refranes $\quad 280$

3. Los contenidos melódicos y armónicos 281

3.1. Entonación y discriminación auditiva: relaciones y 282 dificultades

3.2. Trabajo de la entonación y la educación auditiva desde el 289 marco tonal-armónico

3.3. Transcripción, análisis y creación de canciones desde el 294 contexto tonal-armónico

3.3.1. Descripción de la experiencia 295

3.3.1.1. Canciones transcritas y analizadas en clase 295

3.3.1.2. Canciones creadas por los propios alumnos $\quad 298$

3.3.2. Resultados obtenidos 300

3.3.2.1. Motivación hacia la actividad 300

3.3.2.2. Dificultades encontradas 302

3.3.2.3. Utilidad de la actividad 303

3.3.2.4. Tiempo invertido 305

3.3.3. Consideraciones finales 306 
4. La teoría musical 306

4.1. Importancia de la teoría para el aprendizaje musical 306

4.2. Contenidos teóricos a trabajar en Lenguaje Musical 308

4.2.1. Conexión entre la teoría y la práctica 309

4.3. Priorización de contenidos teóricos en nuestra propuesta $\quad 310$

metodológica

4.3.1. Adquisición y dominio de los contenidos teóricos $\quad 312$

4.3.2. El papel de la metodología en el aprendizaje teórico $\quad 314$

4.3.3. Críticas y apoyos a nuestras propuestas teóricas $\quad 317$

5. El dictado tradicional 318

5.1. Actitud y dificultades de los alumnos ante los dictados 319 musicales tradicionales

5.2. Importancia de reducir la ansiedad y el miedo al bloqueo en 323 los dictados

5.3. Estrategias para trabajar los dictados 326

5.3.1.Estrategias y recursos utilizados por los expertos $\quad 327$

5.3.2. Sugerencias de los alumnos acerca de los dictados $\quad 330$

5.3.3. Nuestras alternativas al dictado tradicional y actitud 331

de los alumnos ante las mismas

5.4. Dictados tradicionales realizados en este estudio 337

6. La memoria musical 341

6.1. Importancia de la memoria en la educación musical $\quad 342$

6.1.1. El papel de la memoria en la reproducción musical 343

6.1.2. Utilidad de la memoria para la creación musical $\quad 344$

6.1.3. La memoria en la realización de dictados musicales $\quad 344$

6.2. El juego y las actividades creativas como estrategias para 345

desarrollar la memoria

6.3. Prueba de memoria auditiva 347

6.3.1. Análisis de los resultados obtenidos $\quad 347$

7. La creatividad 351

7.1. Importancia de la creatividad en la sociedad actual 351

7.2. La creatividad en las enseñanzas musicales 352

7.2.1. La falta de creatividad en nuestros conservatorios $\quad 353$

7.2.2. La necesidad de potenciar la creatividad musical $\quad 354$

7.2.3. Deseo del alumnado por expresarse de forma creativa 355

7.3. La composición musical como estrategia creativa 357

7.3.1. El análisis como punto de partida de la composición $\quad 358$

7.3.2. Pautas para organizar el trabajo compositivo $\quad 359$ 
CAPÍTULO VIII ANÁLISIS DE LA INNOVACIÓN Y LA

CALIDAD EDUCATIVA

1. Introducción

2. Importancia concedida a los distintos contenidos de la asignatura 363

2.1. Importancia de los estudios musicales 364

2.2. Importancia de la asignatura de Lenguaje Musical 365

2.2.1. La enseñanza del Lenguaje Musical en otros países $\quad 365$

2.2.2. El Lenguaje Musical en España 366

2.3. Priorización de contenidos para crear una buena base musical 367

2.3.1. Equilibrio en la atención educativa de los contenidos 368

2.3.2. Priorización de los contenidos de desarrollo auditivo $\quad 370$

2.3.3. Contenidos específicos demandados por los 372 profesores de instrumento

3. Innovación educativa

3.1. La educación musical en el siglo XXI 373

3.1.1. Revisión de planteamientos pedagógicos y de 374 materiales didácticos

3.2. La innovación frente a la estabilidad de lo tradicional 376

3.2.1. Las dificultades y el cuestionamiento de la novedad 376

3.2.2. Importancia de arriesgarse para mejorar la educación $\quad 378$

3.3. Lo invisible y lo visible de la innovación 379

3.4. El fin justifica los medios, pero adaptándose a la realidad $\quad 380$

3.4.1. Utilización de las TICs en la educación musical actual 382

3.5. Paciencia y perseverancia para la obtención de resultados $\quad 384$

3.6. La importancia del apoyo de la comunidad educativa 385

4. Calidad y utilidad de los aprendizajes 387

4.1. ¿Qué entendemos por una enseñanza de calidad? 388

4.1.1. Planificación adecuada del tiempo 389

4.1.2. Adecuación de los materiales y recursos educativos $\quad 390$

4.1.3. La figura del docente como factor de calidad 391

4.2. Calidad de los aprendizajes adquiridos en Lenguaje Musical 392

4.2.1. Valoración de la asignatura por parte de los alumnos 392

4.2.2. Perspectiva de las familias sobre el Lenguaje Musical 395

4.2.3. Calidad de la asignatura percibida por profesores $\quad 397$

4.2.4. Calificaciones obtenidas por los alumnos 399

4.2.5. Calificaciones de la prueba de acceso a las 401 enseñanzas profesionales dos años después

4.3. Utilidad de los aprendizajes para el desarrollo musical e 404 integral

5. Coordinación docente 409

5.1. La tendencia al trabajo individualista en los conservatorios $\quad 410$

5.2. Búsqueda de una mayor coordinación entre el profesorado $\quad 412$ 5.2.1. Dificultades para trabajar de forma coordinada 413 
5.2.2. El profesorado de los conservatorios también puede 415 coordinarse

5.2.3. Beneficios educativos de la coordinación docente 416

5.3. Intercambio de experiencias entre distintos profesionales 417

\section{CAPÍTULO IX ANÁLISIS DE LOS ASPECTOS EMOCIONALES Y SOCIO-AFECTIVOS}

1. Introducción

2. Motivación

2.1. La motivación como factor imprescindible en educación

2.1.1. Motivación y aprendizaje de los alumnos

2.1.2. Motivación e implicación docente

2.2. Motivaciones para iniciar los estudios de conservatorio $\quad 423$

2.3. Motivación de los alumnos hacia el Lenguaje Musical 426

2.3.1. El Lenguaje Musical frente a otras asignaturas del 427 conservatorio

2.3.2. Motivación hacia los distintos contenidos de la asignatura

2.3.3. Otros aspectos motivadores de nuestras clases de Lenguaje Musical

\section{Ansiedad}

\section{3}

434

3.1. Ansiedad generada por los límites de tiempo

3.1.1. Ansiedad de los alumnos por el exceso de actividades 438

3.1.2. La sensación de falta de tiempo en la práctica docente $\quad 440$

3.2. La ansiedad en la asignatura de Lenguaje Musical 440

3.2.1. Ansiedad por las relaciones entre profesores-alumnos 441

3.2.2. Ansiedad debida a los contenidos y al ritmo de trabajo 443

3.2.2.1. Énfasis en la confianza y en la aceptación de 443 los errores

3.2.2.2. Atención a la ansiedad generada en los padres 446

3.3. Ansiedad debida a las interpretaciones musicales en público 448

3.3.1. Causas de la ansiedad escénica 449

3.3.2. Pautas para reducir la ansiedad escénica $\quad 452$

4. Relaciones

4.1. Relaciones particulares de las enseñanzas en conservatorios $\quad 457$

4.2. Análisis de las relaciones establecidas en este estudio $\quad 458$

4.2.1. Relaciones entre la profesora y los alumnos $\quad 459$

4.2.2. Relaciones entre los propios alumnos 462

4.2.3. Relaciones con las familias y su implicación educativa 465

4.2.4. Relaciones de la profesora y otros docentes del centro 467

4.3. El correo electrónico como facilitador de vínculos afectivos 467 
5. Exhibición de trabajos

5.1. Exposición en el aula de las creaciones de los alumnos

5.1.1. Motivación hacia la presentación de trabajos en clase

5.1.2. Interiorización del protocolo artístico en escena

5.1.3. Aceptación de críticas constructivas

5.1.4. Decoración del aula con los trabajos realizados

5.2. Presentación de trabajos a la comunidad educativa

5.2.1. Exposición por los pasillos del centro

5.2.2. Teatro-audición sobre nuestra forma de trabajar

\section{CAPÍTULO X CONCLUSIONES}

1. Introducción

2. Conclusiones de la investigación

2.1. Conclusiones respecto al tema central de la tesis

2.2. Conclusiones relativas a los objetivos específicos

2.2.1. Dificultades en el ámbito de la audición musical

2.2.2. Utilidad del conocimiento armónico para la

2.2.3. Eficacia de nuestras estrategias metodológicas

2.2.4. Respuesta de la comunidad educativa

2.2.5. Barreras encontradas y estrategias para superarlas

3. Dificultades y limitaciones de la investigación

4. Sugerencias para futuras investigaciones

\section{ÍNDICE DE ANEXOS (En DVD's aparte)}

Anexo I. Elementos del currículo de Lenguaje Musical en las enseñanzas elementales de Castilla y León

Anexo II. Ejercicios de entonación de escalas y arpegios

a. Plantillas con los ejercicios

b. Audios de los ejercicios

Anexo III. Autorización para participar en la investigación

Anexo IV. Diario de la profesora-investigadora

Anexo V. Grabaciones de audio y transcripciones de entrevistas individuales y grupales realizadas a expertos, padres, 
profesores y alumnos

a. Entrevistas a expertos

b. Entrevistas a profesores-tutores

c. Entrevistas a familiares (padres y madres)

d. Entrevistas a alumnos

Anexo VI. Cuestionarios de Lenguaje Musical y sus resultados
a. Cuestionarios cumplimentados
b. Resultados de los cuestionarios en tablas de excel
c. Resultados de los cuestionarios en gráficas

Anexo VII. Cuestionarios de autoevaluación de los alumnos

Anexo VIII.Correos electrónicos intercambiados entre la profesora

y distintos miembros de la comunidad educativa

Anexo IX. Trabajos de los alumnos
a. Refranes
b. Canciones transcritas en clase
c. Canciones creadas por los alumnos
d. Lectura rítmica
e. Interpretación de lecciones de entonación

Anexo X. Exámenes
a. Dictados
b. Exámenes de teoría

Anexo XI. Prueba de memoria auditiva
a. Ficha para anotar las respuestas
b. Ejercicios escuchados
c. Soluciones de los ejercicios
d. Respuestas de los alumnos en octubre
e. Respuestas de los alumnos en junio

Anexo XII. Calificaciones obtenidas en Lenguaje Musical

a. Calificación global de la asignatura

b. Calificaciones por apartados

c. Calificaciones obtenidas en la prueba de acceso a las enseñanzas profesionales

Anexo XIII.Análisis de datos con el programa Atlas-ti

a. Documentos de categorización

b. Reporte de resultados ofrecidos por el programa

Anexo XIV.Guión para crear canciones

Anexo XV. Manual del programa MuseScore adaptado

Anexo XVI. Carta manuscrita de una madre dirigida a la profesora

Anexo XVII.Videos y fotografías
a. Aula y grupos de Lenguaje Musical
b. Acordes de las tonalidades trabajadas
c. Presentación de las canciones de los alumnos
d. Exposición de trabajos por los pasillos del centro
e. Teatro-audición de Lenguaje Musical 


\section{ÍNDICE DE FIGURAS}

Figura 1. Anatomía del oído (Wikipedia) 22

Figura 2. Modos de audición de Smalley, Schachtel y Schaeffer 23

(Mora, 2009, p. 35)

Figura 3. Capacidades que se deben desarrollar en la educación 31 auditiva (Miranda, 2003, p. 78)

Figura 4. Esquema de la escucha musical (Abbadie \& Gillie, 1976, p. 35 54)

Figura 5. Proceso de formación de la audición interior (López de Arenosa, 2004, p. 114)

Figura 6. Vibración de los sonidos agudos y graves (INTEF)

Figura 7. Vibración de los sonidos largos y cortos (INTEF)

Figura 8. Vibración de los sonidos fuertes y débiles (INTEF)

Figura 9. Vibración de los sonidos fundamentales y complejos (INTEF)

Figura 10. Relación entre las actividades didácticas basadas en el sonido en la asignatura de Lenguaje Musical (Cañada, López, \& Molina, 2005, p. 5)

Figura 11. Serie de armónicos naturales de un sonido musical (Lerdahl \& Jackendoff, 2003, p. 322)

Figura 12. Comparación entre los niveles del lenguaje y los niveles de las relaciones armónicas (LaRue, 1989, p. 30)

Figura 13. Hipótesis acerca del oído absoluto de Vera (2000, citado por Balo, 2014, p. 104)

Figura 14. Teorías perceptivas de Lundin (tomado de Balo, 2014, p. 107 53)

Figura 15. Clasificación de los intervalos armónicos (Fuente: 109 creación propia)

Figura 16. Percepción de las cadencias de Imberty (1969, citado por 113 Costa-Giomi, 2001, p. 49)

Figura 17. Mapa conceptual de la canción (López de Arenosa, 2004, 170 p. 60)

Figura 18. Ejes de trabajo para la educación auditiva en nuestro planteamiento metodológico (Fuente: creación propia)

Figura 19. Adivinanza de palabras rítmicas realizada por un alumno 180 de $1^{\circ}$

Figura 20. Frase rítmica realizada por los alumnos de primero 180

Figura 21. Frase rítmica realizada por los alumnos de segundo 180

Figura 22. Ficha utilizada para el refrán 4 del segundo curso 182

Figura 23. Adaptación de un motivo con notas reales a acordes en 185 posición fundamental

Figura 24. Adaptación de un motivo con notas reales a acordes 186 enlazados armónicamente 
Figura 25. Adaptación de un motivo con notas de paso y floreos a 186 acordes enlazados

Figura 26. Adaptación de un motivo con apoyaturas a acordes en 186 posición fundamental

Figura 27. Construcción de los acordes de T, S y D a partir de las 191 notas de la escala

Figura 28. Acordes transportados o colocados

Figura 29. Acordes enlazados o descolocados 192

Figura 30. Notas reales de un acorde 192

Figura 31. Fragmento musical formado por notas reales de los 193 acordes

Figura 32. Fragmento musical con floreos 193

Figura 33. Fragmento musical con notas de paso 193

Figura 34. Fragmento musical con apoyaturas 194

Figura 35. Desarrollo melódico por la repetición de un motivo 195

Figura 36. Desarrollo melódico mediante la adaptación de un motivo 195 por transporte

Figura 37. Desarrollo melódico mediante la adaptación de un motivo 195 por enlace armónico

Figura 38. Desarrollo melódico mediante cambio de nivel de un 195 motivo sobre un acorde

Figura 39. Instrumentación de una melodía 196

Figura 40. Práctica de notas utilizando la fononimia de Kodály 197

Figura 41. Ejercicios de calentamiento de la voz y de preparación del 199 oído para Do Mayor

Figura 42. Ejemplo de notas encadenadas 200

Figura 43. Ejemplo de ritmos encadenados 200

Figura 44. Ejemplo de secuencias rítmico-melódicas encadenadas 200

Figura 45. Plan de trabajo de la investigación 217

Figura 46. Guión de la entrevista individual a padres 226

Figura 47. Guión de la entrevista individual a profesores-tutores 227

Figura 48. Plantilla con las respuestas ofrecidas por un alumno en la 245 prueba de memoria auditiva

Figura 49. Refrán resuelto por un alumno de primero 275

$\begin{array}{ll}\text { Figura 50. Refrán resuelto por un alumno de segundo } & 276\end{array}$

Figura 51. Errores cometidos por un alumno de primero al inventar 278 una nueva letra

Figura 52. Errores cometidos por un alumno de segundo al inventar 279 una nueva letra

Figura 53. Letra correcta inventada por un alumno de primero 279

Figura 54. Letra correcta inventada por un alumno de segundo 280

Figura 55. Canción transcrita de oído por un alumno de segundo 297

Figura 56. Canción compuesta por un alumno de segundo siguiendo 298 las pautas de la canción anterior 
Figura 57. Canción compuesta por un alumno de primero con la indicación de los errores cometidos

Figura 58. Versión corregida de la canción anterior

Figura 59. Dictados hechos por un alumno de primero de las 338 enseñanzas elementales a lo largo del curso

Figura 60. Dictados hechos por un alumno de segundo de las enseñanzas elementales a lo largo del curso

\section{ÍNDICE DE GRÁFICAS}

Gráfica 1. Respuestas de los alumnos a la pregunta 10 de los 268 cuestionarios: Considero que mis dificultades en ritmo se deben a:

Gráfica 2. Respuestas de los alumnos a la pregunta 11 de los cuestionarios: Considero que mis dificultades en entonación se deben a:

Gráfica 3. Respuestas de los alumnos a la pregunta 13 de los cuestionarios: Considero que mis dificultades en teoría se deben a:

Gráfica 4. Respuestas de los alumnos a la pregunta 6 de los cuestionarios: ¿Qué es lo que te resulta más difícil?

Gráfica 5. Respuestas de los alumnos a la pregunta 9 de los cuestionarios: Dentro del bloque auditivo, ¿qué es lo que te resulta más difícil?

Gráfica 6. Respuestas de los alumnos a la pregunta 8 de los cuestionarios: Dentro del bloque auditivo, ¿qué es lo que más te gusta?

Gráfica 7. Respuestas de los alumnos a la pregunta 12 de los cuestionarios: Considero que mis dificultades en dictado se deben $a$

Gráfica 8. Resultados de la prueba de memoria auditiva realizada en octubre por los alumnos del primer curso

Gráfica 9. Resultados de la prueba de memoria auditiva realizada en mayo por los alumnos del primer curso

Gráfica 10. Resultados de la prueba de memoria auditiva realizada en octubre por los alumnos del segundo curso

Gráfica 11. Resultados de la prueba de memoria auditiva realizada en mayo por los alumnos del segundo curso

Gráfica 12. Respuestas de los alumnos a la pregunta 1 de los cuestionarios: ¿Para qué quieres aprender música en el conservatorio?

Gráfica 13. Respuestas de los alumnos a la pregunta 7 de los 
cuestionarios: ¿Qué te parece más importante para llegar a ser un buen músico?

Gráfica 14. Calificaciones finales obtenidas por los alumnos en 399 Lenguaje Musical

Gráfica 15. Calificaciones obtenidas por los alumnos de primero de 400 las EE. EE. en cada uno de los apartados de Lenguaje Musical

Gráfica 16. Calificaciones obtenidas por los alumnos de segundo de las EE. EE. en cada uno de los apartados de Lenguaje Musical

Gráfica 17. Calificaciones obtenidas por nuestros alumnos en la prueba de acceso a las enseñanzas profesionales dos años después

Gráfica 18. Respuestas de los alumnos a la pregunta 2 de los cuestionarios: De las asignaturas que estudias en el conservatorio, ¿cuál te gusta más?

Gráfica 19. Respuestas de los alumnos a la pregunta 3 de los cuestionarios: En general, ¿qué opinas de la asignatura de Lenguaje Musical?

Gráfica 20. Respuestas de mis alumnos a la pregunta 2 de los cuestionarios: De las asignaturas que estudias en el conservatorio, ¿cuál te gusta más?

Gráfica 21. Respuestas de mis alumnos a la pregunta 3 de los cuestionarios: En general, ¿qué opinas de la asignatura de Lenguaje Musical?

Gráfica 22. Respuestas de los alumnos a la pregunta 4 de los cuestionarios: ¿Qué es lo que más te gusta del Lenguaje Musical?

Gráfica 23. Respuestas de los alumnos a la pregunta 5 de los 434 cuestionarios: ¿Qué es lo que te resulta más fácil?

\section{ÍNDICE DE TABLAS}

Tabla 1. Reporte de buscadores de Internet a palabras claves, 12 realizado el 4 de agosto de 2014

Tabla 2. Los estilos de liderazgo del profesor de música (Balsera \& 51 Gallego, 2010, adaptado de Goleman, 2002)

Tabla 3. Manifestación de la ansiedad en los músicos (Balsera \& 52 Gallego, 2010, p.53)

Tabla 4. Integración de Conservatorios de Música de entidades 126 locales en la Administración Autonómica de Castilla y León 
Tabla 5. Conservatorios de Castilla y León

126

Tabla 6. Dedicación horaria por asignatura y curso para todas las especialidades de las enseñanzas elementales de música. (Fuente: Decreto 60/2007, Anexo III)

Tabla 7. Distribución general de créditos ECTS en las distintas especialidades de las Enseñanzas Superiores de Grado en Música en Castilla y León. (Fuente: Decreto 57/2011, Anexo I)

Tabla 8. Plan de estudios del Conservatorio Profesional de Música de Segovia.

Tabla 9. Comparación entre las competencias establecidas por la LOE y la LOMCE. (Fuente: creación propia)

Tabla 10. Distribución de las partes y fracciones fuertes y débiles en función de cada compás o pulso

Tabla 11. Cronograma del proceso seguido en la investigación 217

Tabla 12. Guión para las entrevistas grupales 229

Tabla 13. Cuestionarios recibidos de cada conservatorio 236

Tabla 14. Cronograma del proceso seguido para la recogida de 241 datos

Tabla 15. Organización de las categorías de análisis en bloques de 249 contenido

Tabla 16. Resumen de codificación del profesorado

Tabla 17. Resumen de codificación del alumnado (alumnos individuales)

Tabla 18. Resumen de codificación del alumnado (grupos de 251 alumnos)

Tabla 19. Resumen de codificación de las familias de los alumnos (familiares individuales)

Tabla 20. Codificación de las familias de los alumnos (grupos de familiares)

Tabla 21. Codificación de los expertos 252

Tabla 22. Ejemplo de codificación del diario de clase 253

Tabla 23. Codificación de los cuestionarios cerrados de Lenguaje 253 Musical

Tabla 24. Ejemplo de codificación de los cuestionarios de 253 autoevaluación dirigidos a los alumnos

Tabla 25. Ejemplo de codificación de las entrevistas individuales $\quad 254$

Tabla 26. Ejemplo de codificación de las entrevistas grupales 254

Tabla 27. Ejemplo de codificación de los correos electrónicos 256

Tabla 28. Ejemplo de codificación de los trabajos y los exámenes 257 de los alumnos 


\section{CAPÍTULO I: INTRODUCCIÓN}

\section{Introducción}

Buendía, Colás y Hernández (1999) definen la investigación educativa como el estudio que permite "obtener un conocimiento, una explicación y una comprensión científica de los fenómenos educativos, así como solucionar los problemas educativos y sociales" (p. 3).

Nuestra experiencia profesional nos ha demostrado que los profesores emplean muchísimo conocimiento anecdótico, de "receta" dictada por un compañero o de propia cosecha, pero, a pesar de que en este haya un fondo de sabiduría, es indisciplinado. Dicho de otra forma, los profesores actúan con frecuencia por intuición. Aunque es justo reconocer que dicha intuición suele descansar en una sólida base de conocimiento aprendido, consideramos que carece de rigor científico y que, por tanto, no constituye la base más adecuada para la acción profesional. Por tanto, con la intención de mejorar nuestra propia práctica docente, compartimos el convencimiento de Fernández Pérez (1988) acerca de que:

La presencia de los profesores es imprescindible en el proceso de la investigación educativa, y no solo para que sea investigación "sobre" la educación (siendo ellos objetos de la misma, investigados), sino, además, para que pueda ser investigación "para" la educación (siendo ellos, al mismo tiempo, investigadores). (p. 141)

Siguiendo a Díaz (2010), consideramos que en el campo de la educación musical resulta aún más necesario que el profesorado incluya en su formación docente "la ejercitación y la participación en investigaciones, así como el conocimiento de métodos de investigación educativa" (p. 135), para que no quede relegada con respecto a otras enseñanzas, como tradicionalmente ha venido sucediendo. De esta manera, contribuiremos al 
desarrollo de una enseñanza y un aprendizaje de la música más eficaz en nuestro sistema educativo y en todos sus ámbitos.

La tesis doctoral es considerada por muchos escritores como un trabajo mecanografiado en el que el doctorando ofrece su punto de vista sobre una cuestión determinada (López-Bernad, 2015). Se necesitan muchas cualidades conjuntas e incentivos que lleven a una persona a la realización de un trabajo de tal envergadura, resultando primordial la motivación del investigador hacia la tarea, con el fin de conseguir dar respuesta a preguntas que despierten su interés y que resulten significativas para la comunidad científica. Solo de este modo, el doctorando podrá dejar constancia de su personalidad en cada línea, en cada párrafo y en cada página como respuesta a esos porqués que le inquietan.

Este primer capítulo está dedicado a la justificación y delimitación del objeto de estudio. Comenzaremos exponiendo las razones que motivaron su elección, a partir de la descripción de mis años de estudiante en el conservatorio y de las carencias observabadas en mi propia formación respecto a habilidades que poseían los músicos aficionados, relacionadas con la intución armónica y el desarrollo del oído interior. Mi paso por magisterio y la realización de los estudios superiores de Pedagogía Musical me ayudaron a superar una etapa de crisis en la que estaba dispuesta a abandonar toda relación con el conservatorio y me devolvieron la ilusión por dedicarme a la música, pero abordándola desde el campo de la docencia y, posteriormente, de la investigación. Todo ello, unido a las dificultades que manifestaban mis alumnos en la realización de dictados tradicionales y al convencimiento de que se les debe ofrecer una educación auditiva más amplia que la asociada a los mismos, nos condujo a emprender el presente trabajo. Tras su justificación, delimitaremos claramente el objeto de estudio, concretándolo en objetivos más específicos, y fundamentaremos su significatividad científica en la escasez de investigaciones previas realizadas sobre el mismo. Por último, realizaremos una presentación general de los distintos capítulos en los que se estructura la tesis, con la finalidad de ofrecer al lector una primera idea de la profundidad del trabajo realizado.

\section{Mi experiencia personal: pequeña historia de vida}

\subsection{Mis años como estudiante de música}

A los 8 años inicié mis estudios musicales en el Conservatorio Profesional de Música Tomás Luis de Victoria de Ávila, por la especialidad de piano. Siempre fui buena estudiante pero, a medida que iban pasando los años, empecé a preocuparme, porque sentía que algo estaba fallando en mi formación, especialmente en lo relativo a la educación auditiva, a pesar de 
que mis notas en Solfeo y Teoría de la Música (nombre que tenía el Lenguaje Musical en el antiguo plan de estudios de 1966) eran muy buenas.

Aún recuerdo de memoria los dictados a una voz y a dos voces de mi examen final de $5^{\circ}$ de Solfeo. El examen fue en el auditorio, junto a los alumnos de todos los demás grupos, porque, al ser el último curso, nos evaluaba un tribunal constituido por tres profesores. Aunque los nervios me invadían, el dictado me salió perfecto y saqué un 10. Por aquel entonces, yo estaba convencida de que tenía buen oído, debido a mis buenas notas y a que era capaz de hacer sin dificultad aquello que se me demandaba desde el propio sistema educativo: escribe esto que estás escuchando.

No obstante, fue años más tarde cuando comprobé que mi formación musical tenía lagunas. Empecé a ir a campamentos y veía cómo distintas personas, que se definían a sí mismas como "analfabetas musicales", eran capaces de sacar la guitarra y acompañar múltiples canciones, sin la atadura de una partitura que les fuera indicando lo que tenían que tocar en cada momento. Yo también sabía tocar la guitarra y me agobiaba cuando me decían: "Ahora toca tú algo, Elena", porque no me sentía capaz de improvisar nada. Fue entonces cuando comprendí que era una esclava de la partitura y que no me sentía segura para acompañar una simple canción de campamento si no me daban un papel donde estuvieran anotados los acordes.

Iban pasando los años y mi formación musical era cada vez más completa, pero seguía sin poder hacer aquello que los aficionados realizaban con total naturalidad. Es cierto que nunca me puse a explorar qué acordes le pegaban a una canción por el simple gusto de hacerlo, ya que no tenía tiempo para andar con experimentos. Compaginar los estudios del instituto con los del conservatorio era muy duro y con hacer lo que me mandaban mis profesores tenía suficiente. Mis notas seguían siendo muy buenas, por lo que, de alguna manera, yo confiaba en que sería capaz de hacer todo aquello que se le demandaba a un músico profesional, pero poco a poco me fui desengañando. Seguía envidiando a los músicos aficionados por su espontaneidad y facilidad para tocar la guitarra o el piano, que eran los instrumentos que yo conocía, especialmente cuando se trataba de improvisar los acompañamientos para las canciones que cantaba la gente, muy propio de los ambientes festivos.

El instrumento que yo aprendí a tocar en el conservatorio era el piano. Tras muchos años de estudio y muchas horas invertidas en soledad "dando a las teclas", conseguí terminar los estudios conducentes a la titulación profesional de dicha especialidad (hasta $8^{\circ}$ de piano, según el plan de 1966). Lo poco que sabía de guitarra lo había aprendido en un ambiente muy distinto: mi madre me enseñó la posición de unos pocos acordes con los que 
me acompañaba mientras cantaba distintas canciones de un cuadernillo de música popular, y me gustó tanto que seguí aprendiendo de forma autodidacta. Eso sí, siempre tenía delante la hoja con la letra de la canción y el nombre de los acordes que debía tocar en cada momento, ya que la necesitaba para sentirme segura. Imagino que esta dependencia se debía al hecho de que, en el conservatorio, estudiaba continuamente mirando la partitura y solo tuve que esforzarme por memorizar una o dos obras en cada curso, porque era lo obligatorio para aprobar la asignatura. Ahora comprendo que se podía decir que era una excelente machacateclas, una alumna brillante e, incluso, una gran intérprete, pero que no una buena música.

Lo más preocupante de todo esto es que, a pesar de tener la partitura delante, si venían amigos a casa y llegaba el momento de cantar, yo me sentía mucho más cómoda y segura acompañando con la guitarra que con el piano. ¡Tal fue la manía que le cogí a tantas horas de estudio y con tan poco aprendizaje significativo! Aprendí a dar a las teclas, sí, pero no a amar el instrumento y, con el paso del tiempo, empecé a perder la seguridad hacia él. Llegó un momento en que estaba más pendiente de las notas falsas que se me escapaban que de la musicalidad que conseguía.

El contacto con otras personas que habían realizado igualmente estudios profesionales $\mathrm{o}$, incluso, superiores de música en distintas especialidades (piano, violín, chelo, flauta, etc.) me hizo comprender que este rechazo hacia el propio instrumento con el que tantísimas horas de estudio habíamos pasado era un mal común. Mi sensación ante esta situación era un tanto contrariada: por un lado, sentía alivio al ser comprendida y al comprobar que el problema no era yo, sino que algo en el sistema estaba fallando para que hubiera tantas generaciones de músicos frustrados y enemistados con su instrumento; pero, por otro lado, sentía indignación ante un aprendizaje mal realizado, tan esclavo y tan poco agradecido, con el que no había disfrutado sino, más bien, sufrido. ¿Era justa esta situación? Evidentemente, no, lo cual me hacía replantearme si había alguna posibilidad de reconciliación con el instrumento odiado.

La docencia me entusiasmaba desde niña y, al terminar el COU, decidí estudiar Magisterio por la especialidad de Educación Musical. Fue una buena decisión porque, el hecho de seguir aprendiendo en un contexto diferente y más distendido, me ayudó a recuperar la ilusión hacia la música que, de alguna manera, estaba perdiendo. Paralelamente, terminé los estudios profesionales correspondientes a los títulos de Piano y de Solfeo, Teoría de la Música, Transposición y Acompañamiento. Estaba decidida a finalizar ahí mi formación musical y me matriculé en Psicopedagogía, pero un encuentro fortuito en un curso de verano hizo que me presentara a las pruebas de 
acceso a los estudios superiores de Pedagogía Musical en el Conservatorio Superior de Música de Madrid. Saqué buena nota y conseguí plaza en dicha especialidad, por lo que pospuse mis estudios de Psicopedagogía para más adelante.

Los dos años que estuve estudiando en Madrid disfruté mucho, seguramente debido a que el peso de mi formación ya no recaía sobre mis dotes como intérprete en un escenario, sino sobre la mejor manera de facilitar el aprendizaje a mis futuros alumnos, lo cual era más acorde con mi personalidad.

El mismo año que terminé mis estudios superiores de música, aprobé la oposición de acceso al cuerpo de maestros por la especialidad de Educación Musical. Hice muy buen examen y obtuve el primer puesto de Castilla y León, lo cual me permitió trabajar en el mismo colegio que estudié de niña, donde aún continuaban muchos de mis antiguos maestros, que pasaron a ser mis compañeros. La experiencia fue fantástica y muy enriquecedora, pero el enfoque de la música en la escuela es muy diferente al de los estudios profesionales y echaba de menos poner en práctica distintas ideas que llevaba tiempo gestando sobre una nueva forma de enseñar en los conservatorios.

Participé en el concurso de traslados, me cambié a la especialidad de Educación Primaria y estuve siete años trabajando en distintos colegios pertenecientes tanto al entorno rural como al urbano. Durante ese tiempo, realicé los estudios de Psicopedagogía por la UNED y pude vivir la experiencia de trabajar como profesora de Lenguaje Musical en la Escuela Municipal de Música de mi ciudad. Allí estuve apenas cuatro meses, pero fue tiempo suficiente para comprender que mi vocación docente y musical se hacía realidad impartiendo dicha asignatura.

Tras unos años de parón instrumental en los que el piano de mi casa estuvo totalmente cerrado, decidí volver a abrirlo para utilizarlo en contextos alejados del escenario del conservatorio. Fue entonces cuando empecé a acompañar canciones en conciertos benéficos y a tocar en bodas de amigos, pero en estas ocasiones me negaba a utilizar partitura. Quería dar un nuevo enfoque a mi manera de tocar, más libre y menos académico, dejándome llevar sin estar pendiente de ser fiel a algo escrito. Eso sí, para mí seguía siendo indispensable tener una hoja delante que me fuera indicando los acordes que debía utilizar en cada momento, lo cual era un claro síntoma de que la educación de mi oído no había sido correcta, porque no era capaz de identificar de forma espontánea si pegaba poner tónica, dominante, subdominante u otro acorde más complejo desde el punto de vista armónico. 
Por ello, por mi propia frustración ante un aprendizaje mal adquirido, pienso que la educación intuitiva del oído debe tener lugar desde el comienzo de las enseñanzas musicales, y que no debemos tener miedo de poner nombre a lo que los alumnos ya están escuchando y cantando desde pequeños. Estamos inmersos en una cultura musical tonal y los niños que estudien en un conservatorio deben saberlo y utilizarlo de forma intuitiva, pero también consciente, desde el principio, porque es cuando el cerebro está más abierto a la recepción de estímulos. De esta manera evitaremos que se encuentren, de pronto, con lo que me pasó a mí, que no sabía reconocer ni poner nombre a la armonía subyacente a aquello que estaba cantando o escuchando a tiempo real, lo cual exige entrenamiento.

Este tema me interesaba mucho y decicí abordarlo desde dentro, comprobando si, después de diez años sin mantener ningún tipo de contacto con el conservatorio, habían cambiado las cosas, por lo que me preparé la oposición de acceso al cuerpo de profesores de música y artes escénicas por la especialidad de Lenguaje Musical.

\subsection{Mi comienzo como profesora: dificultades de mis alumnos}

En el curso académico 2010-2011, tras aprobar el correspondiente procedimiento selectivo, pedí excedencia en el cuerpo de maestros y comencé mi ejercicio profesional como profesora de Lenguaje Musical en el Conservatorio Profesional de Música de Segovia. Dicha asignatura se imparte a lo largo de seis cursos: los cuatro primeros forman parte del currículo de las enseñanzas elementales de música y los dos últimos pertenecen a las enseñanzas profesionales.

Lo primero que me llamó la atención fue comprobar que la educación auditiva aún se seguía trabajando y evaluando con los tradicionales dictados, a una o dos voces, que realizaba yo en mis estudios de Solfeo hace casi 30 años. La única novedad que observé con respecto a la manera en que se realizaban durante mi época de estudiante era que, gracias a los avances tecnológicos, ahora los alumnos podían disponer de unos cuadernillos y unos CD's para seguir practicando la realización de dictados en casa, pero eso no suponía ningún cambio sustancial: aumentaba la cantidad de prácticas, pero no la forma de trabajarlos, por lo que seguían perdurando las limitaciones de un aprendizaje incompleto.

Además, a principio de curso, cuando realicé la evaluación inicial de los alumnos que me habían asignado, comprobé que la mayoría de los que cursaban $4^{\circ}$ de las enseñanzas elementales manifestaban importantes dificultades en la resolución de dictados musicales y en la interpretación de lecciones de entonación, lo cual indicaba que, durante los años anteriores, no 
habían recibido una formación adecuada en el campo de la educación auditiva. Esta situación me motivó a emprender, durante el curso siguiente (2011-2012), una investigación centrada en las dificultades vocales y auditivas que presentaban los alumnos desde que iniciaban sus estudios en el conservatorio, la cual constituyó mi trabajo fin de máster, dentro de mi programa de doctorado. Para un mayor conocimiento de este tema se puede consultar: "Dificultades vocales y auditivas en el primer curso de Lenguaje Musical: relaciones entre el dictado y la entonación” (Berrón, 2012).

Una de las conclusiones de dicho estudio, que puede ser considerado el punto de partida de esta tesis, es que el dictado musical está relacionado con el desarrollo del oído interior y que las dificultades presentadas en su realización se pueden superar con una adecuada intervención educativa, es decir, planteando un buen método y asegurándonos de que los alumnos lo siguen correctamente.

Por todo ello, me dispuse a encontrar ese método de enseñanza y aprendizaje que permitiera a los alumnos adquirir una educación auditiva desde una perspectiva más amplia que la asociada a la realización de dictados, pero que, al mismo tiempo, les permitiera resolverlos adecuadamente, para poder hacer frente a los exámenes que tradicionalmente continúan realizándose en los conservatorios.

\subsection{En busca de una nueva metodología para el trabajo auditivo}

Después del intenso trabajo realizado sobre la identificación de las dificultades vocales y auditivas presentadas por mis alumnos y motivada por los resultados obtenidos en el mismo, no podía quedarme ahí. Una vez detectadas dichas dificultades, debía continuar reflexionando sobre cuál sería la forma más adecuada para ayudar a mis alumnos a prevenirlas y superarlas. Necesitaba cambiar el método, mi forma de enseñar, para que realizaran aprendizajes significativos conducentes a una verdadera educación musical y dediqué la mayor parte del verano a reflexionar sobre ello.

Esta reflexión me llevó a leer múltiples libros, artículos y trabajos de investigación desarrollados no solo en España, donde resultan escasos, sino también en otros países. También me recorrí librerías y bibliotecas y estuve consultando los libros que se utilizaban en distintos conservatorios de nuestro país. En este sentido, Internet me resultó de gran utilidad, ya que en las páginas Web de muchos conservatorios podía encontrar los materiales que se utilizaban para las clases de Lenguaje Musical, que eran de autores como: Ana María Navarrete Porta, Manuel Moreno Buendía, Gabriel Robles

Ojeda, Encarnación López de Arenosa, Ibáñez-Cursá, Félix Sierra Iturriaga... En ellos había maquetaciones más o menos atractivas y 
diferentes secuenciaciones de contenidos en función de uno u otro planteamiento metodológico, pero no observaba cambios sustanciales respecto a la manera en que me enseñaron a mí el Lenguaje Musical hace tres décadas.

¿Sería que el sistema era válido para otros estudiantes, aunque conmigo los resultados no hubieran sido óptimos? Me costaba creerlo, pero, aunque hubiera sido así, estaba convencida de que los tiempos habían cambiado y que el acceso al conocimiento ya no era igual que en el siglo pasado, ya los niños viven inmersos en una sociedad muy diferente, por lo que deberíamos adaptarnos a los nuevos tiempos y reconducir los métodos de enseñanza para poder ofrecer una educación actualizada.

¿Es posible que, desde mi perspectiva de alumna, no hubiera llegado a comprender bien el planteamiento subyacente en esas lecciones de ritmo y entonación y, sobre todo, en la realización reiterada de torturadores dictados musicales carentes de sentido para mí? No quería perder tiempo en especulaciones y decidí ponerme en contacto con grandes pedagogos a los que estimo, pero con los que nunca me había parado a hablar sobre cuál era su forma de concebir la educación musical y sobre el porqué de los materiales que habían elaborado para llevarla a cabo.

Empecé entrevistando a Encarnación López de Arenosa, una excelente persona con una brillante trayectoria profesional, que me ayudó a comprender la evolución que habían seguido las enseñanzas musicales en nuestro país y me abrió los ojos hacia las nuevas tendencias, centradas en el la psicología del alumno y presentando los contenidos de una forma más globalizada, progresiva e integradora. Dicha pedagoga musical apostaba por la educación auditiva como base para una formación de calidad y sus palabras me llenaron de ideas, aumentando mi deseo por enseñar adecuadamente a mis alumnos.

Ese mismo verano, participé en un curso impartido en Salamanca por el Instituto de Educación Musical fundado por Emilio Molina. Había múltiples modalidades y yo me apunté a la que hacía referencia a la "Formación del Profesorado para aplicar la Metodología IEM". Nunca había oído hablar de dicha metodología, pero me pareció interesante conocerla. Allí estuve en contacto con grandes músicos que tenían planteamientos pedagógicos muy distintos a los que yo conocía hasta ese momento. Aproveché para entrevistar a Emilio Molina y a algunos de los profesores que trabajan en su misma línea, como Pedro Cañada y Ana López, personas encantadoras que irradiaban su disfrute con la música y la docencia. 
Además, compré varios de sus materiales con el propósito de analizarlos en profundidad y encontré especialmente interesantes sus libros de Lenguaje Musical, los de Teoría y los Cuadernos de Audición. La forma de abordar la educación auditiva desde una perspectiva tonal a través de canciones, introduciendo a los alumnos en la experimentación, comprensión y manejo de los acordes desde el principio, me pareció un camino lógico para construir aprendizajes más globales y sólidos, pasando de lo general a lo específico.

El trabajo a partir de canciones lo observé también en materiales publicados por otros autores, como los libros de Lenguaje Musical de Félix Sierra (1997) y el método Cantabile de Arenal, Escudero y Gómez (2008), editado más recientemente. Una de las autoras del método Cantabile, Berenice Gómez Briones, buena amiga, también me concedió una entrevista y me demostró que era posible llevar a cabo una enseñanza integradora de todos los contenidos musicales, con un planteamiento similar al de las unidades didácticas que estudian los alumnos en la enseñanza obligatoria, mucho más cercano a su psicología y a su forma de adquirir conocimientos.

No obstante, lamentablemente, la tradición pesa demasiado y la utilización de estos métodos es minoritaria en los conservatorios de nuestro país, en los que todavía predomina la enseñanza a través de la lectura e interpretación reiterada de lecciones de ritmo y de entonación, ordenadas según la secuenciación de los contenidos de trabajo, pero alejadas del mundo y psicología infantil. Esta realidad es aún es más alarmante en el campo de la educación auditiva, ya que en los dictados tradicionales los alumnos se ven forzados a transcribir algo que acaban de escuchar y, muchas veces, carente de sentido para ellos, por lo que vimos necesario incidir sobre ello.

Tras este verano reflexivo, conseguí que mis intenciones educativas fueran cobrando forma en un método que, aunque participaba de algunas de las ideas que me habían sugerido los materiales analizados y los expertos entrevistados, tenía mis matices personales. Está claro que cada "maestrillo tiene su librillo" y que un método nunca es válido por sí mismo, ya que su éxito depende de muchos factores, especialmente de las características del docente que lo aplica, de los alumnos y del contexto en el que se desarrolle.

Pensando en todos estos factores, en septiembre de aquel año 2012 empecé a aplicar en el aula mis nuevas propuestas, con la mirada muy atenta y con mucha ilusión. Comezaba así un curso intenso, caracterizado por la reflexión continua y la toma de decisiones, para reconducir el proceso en los casos que veía necesario. El análisis de las consecuencias educativas resultantes de la aplicación de todas estas propuestas metodológicas constituye el objeto fundamental de esta tesis. 


\section{3. ¿Qué pregunta clave nos surge?}

Uno de los mayores retos a los que se enfrenta un profesor de conservatorio es mantener su actividad artística a la vez que trabaja en su formación permanente como docente y como músico. $\mathrm{Si}$ a estas aspiraciones le sumamos la función investigadora, se pueden conseguir resultados muy interesantes, como es el caso de la presente tesis. Esta es el resultado de una investigación realizada por una profesora que vive diariamente la realidad del proceso educativo en las clases de Lenguaje Musical y que ha podido extraer, de primera mano, elementos interesantes como objeto de estudio.

En el libro Introducción a la investigación en educación musical, Díaz (2006) llama la atención sobre las diferencias que existen entre la elaboración de un proyecto didáctico y un proyecto de investigación, ya que, en el ámbito que nos ocupa, la distinción entre ambos conceptos se presta a confusión. Al respecto, consideramos relevante destacar que al final del proyecto didáctico se tiene que evaluar el aprendizaje, es decir, qué es lo que ha aprendido el alumnado. En cambio, al final del proyecto de investigación hay que interpretar los resultados en función del problema de partida y de las teorías existentes, para valorar la novedad aportada.

La experiencia adquirida a lo largo de los años como estudiante en el conservatorio y como profesora de Lenguaje Musical nos ha permitido tomar conciencia de la enorme importancia que tiene la adquisición de una buena formación auditiva. De hecho, estamos convencidos de que la educación auditiva constituye el aspecto principal a la hora de formar musicalmente a los alumnos.

Por otra parte, en nuestra asignatura todavía predomina la creencia de que un músico tiene buen oído si es capaz de resolver adecuadamente los dictados tradicionales. No obstante, consideramos que los profesores no debemos conformarnos con que los alumnos adquieran dicha competencia, ya que la excelencia auditiva va mucho más allá. Desde nuestro punto de vista, un músico tiene buen oído si es capaz de dotar de significado a la música que está oyendo, externamente o en su interior, lo cual incluye identificar, al menos, los aspectos melódicos, rítmicos, formales y armónicos, por lo que la idea de educación auditiva que defendemos es mucho más amplia. De ahí se extrae el tema abordado en esta tesis, en la que evaluaremos la eficacia de una propuesta metodológica que persigue dicho propósito en la formación de los alumnos.

Asimismo, puesto que la música de nuestro entorno sociocultural se construye según las bases del sistema tonal-armónico, y teniendo en cuenta que la asignatura desde la cual queremos abordar este trabajo es el Lenguaje 
Musical, el tema central de nuestra investigación queda expresado en la siguiente pregunta:

¿Es posible mejorar la educación auditiva a través de una metodología integradora basada en el sistema tonal-armónico desde el inicio de los estudios en la asignatura de Lenguaje Musical?

Para dar respuesta a esta pregunta de forma más operativa y práctica, la hemos matizado estableciendo una serie de objetivos de investigación:

- Conocer las dificultades del alumnado en el ámbito de la audición musical desde la asignatura de Lenguaje Musical y cómo reducirlas.

- Determinar la utilidad de iniciar a los alumnos en el conocimiento de las bases de la armonía tonal para mejorar su desarrollo auditivo.

- Valorar la eficacia de nuestras estrategias metodológicas para ofrecer una educación auditiva integradora, significativa y motivadora.

- Analizar la respuesta de la comunidad educativa hacia las actividades propuestas durante el proceso de enseñanza-aprendizaje.

- Identificar las barreras encontradas a lo largo del proceso educativo y las estrategias desarrolladas para superarlas.

\section{Importancia del tema elegido en esta tesis}

Al plantear un nuevo trabajo, todo investigador debe familiarizarse con los estudios que se han realizado previamente en el campo que resulta de su interés, ya que, de no hacerlo, puede reiterar una investigación que otros ya han finalizado (Gordon, 1986). Para investigar hay que tener conocimiento del tema e información sobre el mismo, ya que, según recoge Díaz (2012), "estos dos factores nos ayudarán a vislumbrar si nuestro proyecto inicial puede aportar conocimiento a la comunidad científica y educativa" (p. 4), requisito imprescindible en el ámbito que nos ocupa. Por ello, la revisión de la literatura referente al problema de estudio es una de las tareas principales de cualquier investigador, para lo cual resulta fundamental la consulta de bases de datos y de revistas especializadas.

Utilizando palabras claves de nuestro trabajo para realizar una búsqueda en distintas bases de datos, encontramos los siguientes resultados. 
Tabla 1:

Reporte de buscadores de Internet a palabras claves, realizado el 4 de agosto de 2014

\begin{tabular}{lcccc}
\hline \multicolumn{1}{c}{ Palabras clave } & Dialnet & Teseo & ERIC & E-Journals \\
\hline Educación auditiva musical & 272 & 1 & 25 & 30 \\
Sistema musical tonal & 20 & 1 & 187 & 215 \\
Asignatura de Lenguaje Musical & 21 & 5 & & \\
• Musical Language & & & 82 & 288 \\
• Music Schools & & & 1882 & 1354 \\
\hline
\end{tabular}

Para entender adecuadamente estos datos, debemos aclarar que en ERIC y en E-Journals se ha realizado la búsqueda en inglés, utilizando los siguientes descriptores del Tesauro: Music Audiation, para "Educación auditiva musical"; Tonal Harmonious music system, en ERIC, y Tonal music, en EJournals, para "Sistema musical tonal"; y Musical Language y Music Schools, para "Asignatura de Lenguaje Musical".

El hecho de haber utilizado distintas palabras claves en ERIC y E-Journals para referirnos al "Sistema musical tonal" se debe a que, al poner Tonal music en ERIC, obteníamos solo 21 resultados y aparecían temas que no nos interesaban. Lo mismo nos ocurría en E-Journals al poner Tonal Harmonious music system, ya que nos ofrecía 488 resultados con muchos temas mezclados.

Asimismo, ante el hecho de que la asignatura de Lenguaje Musical, como tal, no forma parte de los planes de estudio de las enseñanzas musicales de otros países, hemos considerado necesario realizar dos búsquedas para encontrar información relacionada con la misma, de ahí que hayamos utilizado las palabras clave Musical Language y Music Schools. Aún así, salvo escasas excepciones, los artículos aparecidos al respecto en ambas bases de datos no eran específicos de nuestro objeto de estudio.

Estos datos extraídos de varias bases de datos nos muestran que el tema planteado en esta tesis es bastante novedoso, ya que existen pocos trabajos que guarden una relación directa con el mismo, tanto a nivel nacional como internacional.

Continuando con la revisión de la literatura precedente comprobamos que, aunque existen numerosos estudios sobre percepción auditiva llevados a cado en laboratorios y relacionados con planteamientos pedagógicos conductistas, son menos los trabajos que analizan el problema desde el aula 
y con un planteamiento constructivista y, mucho menos aún, aplicados al campo musical; de ahí la importancia de nuestra investigación. Así lo expresaba Malbrán (2007b) al afirmar que "una cuestión corriente en los encuentros de investigadores y educadores es la falta de relación entre ambas áreas y el interrogante de cómo hacer para saltar esta brecha" (p. 115). En este sentido, dado nuestro perfil docente-investigador y siguiendo a Fernández (1988), destacaremos que:

\begin{abstract}
Los profesores cuentan, al menos de entrada, con la insustituible ventaja de estar viviendo "la acción", poder conocer con más facilidad las peculiaridades relevantes de "cada caso" y tener acceso más fiable a los aspectos "cualitativos" de los significados en juego en la interacción simbólica que toda comunicación educativa es, al pertenecer al género de la interacción humana. (p. 157)
\end{abstract}

La pedagogía musical ha tenido una gran expansión en el siglo XX, de ahí que se haya desarrollado como área propia de estudio, independiente de la musicología, creándose múltiples metodologías de enseñanza-aprendizaje de la música para todas las edades, sobre todo para las más tempranas. Por otro lado, en la actualidad, los principios teóricos y metodológicos de la pedagogía general han calado profundamente en los procedimientos de investigación que se utilizan en educación musical. Además, tanto la educación en general como, de forma específica, la educación musical han incorporado las aportaciones de la psicología cognitiva, la psicología social, la filosofía, la antropología y la etnomusicología, entre otras muchas disciplinas.

La investigación en el campo educativo nos ha proporcionado importantes transformaciones en la manera de organizar la enseñanza y el aprendizaje de la música. Bajo su influencia, las concepciones teóricas se han diversificado, algunas de forma radical, bien sea bajo la perspectiva social, la cultural, la psicológica, la filosófica o la musicológica. Sin embargo, sabemos que nos queda mucho por hacer. El campo es muy amplio y somos conscientes de que en los países de lenguas neolatinas llevamos cierto retraso con respecto a los países anglosajones.

Ahora, cuando en muchos foros se debate cuál será el futuro de la educación musical, parece más importante que nunca revisar el pasado e informarse sobre lo que está sucediendo en el presente. No obstante, Díaz y Giráldez (2007) nos alertan de que "no siempre resulta fácil, sobre todo para quienes recurren a la bibliografía en castellano, puesto que, mal que nos pese, la mayor parte de la producción se realiza en otros idiomas, fundamentalmente el inglés" (p. 11). Además, las ediciones en español tienen una gran deuda con el numeroso público formado por los educadores musicales: la ostensible carencia de traducciones de importantes obras fruto de la 
investigación musical que resultan sustanciales para la didáctica de la música.

La investigación musical española no puede dar la espalda a lo que ocurre en el resto del mundo, donde nuestros colegas extranjeros de muchos países están publicando un altísimo número de buenos trabajos de tipo empírico en revistas internacionales indexadas en bases de datos de prestigio: ERIC, Social Sciences Citation Index, Journal Citation Report (JCR), Arts \& Humanities Citation Index, SCOPUS, JSTOR, etc. Entre las revistas especializadas encontramos: Journal of Research in Music Education (JRME), Bulletin of the Council for Research in Music Education, Music Education Research, Contributions to Music Education, Musicae Scientiae, Psychology of Music, etc. No obstante, también encontramos publicaciones sobre investigación musical en revistas menos específicas de nuestro objeto de estudio, como: Arts Education Policy Review, Quality \& Quantity, Review of Educational Research, Communication Theory, Educational Researcher, Learning and Instruction, Global Studies in Education, etc. La lista de revistas sería interminable, pero es sencillo localizarlas en los listados de las bases de datos citadas. Para una información más detallada pueden consultarse los trabajos de Galera y Pérez (2008); Lorenzo, Herrera y Hernández (2007); Giráldez (2010); Lorenzo (2014).

Porta (2014) reflexiona sobre la posición de la investigación en educación musical en el espacio de la difusión científica. En su trabajo concluye que "es necesario revisar las políticas editoriales porque el rechazo de artículos no siempre obedece a criterios de calidad" (p. 611) y que las razones de la publicación son debidas, en ocasiones, a "factores ajenos a la excelencia que hablan de un sistema de medida no correspondiente al objeto medido" ( $\mathrm{p}$. 612), siendo esta la causa de que gran parte de los trabajos españoles de educación musical queden fuera de los circuitos internacionales. No obstante, en nuestro país también contamos con varias revistas que, cada vez, van teniendo mayor presencia. Entre las principales revistas españolas de educación musical y artística destacamos: Arte, individuo y sociedad, Música y Educación, Eufonía, Leeme y Revista Internacional de Educación Musical, aunque también encontramos publicaciones de música y de didáctica musical en revistas interdisciplinares como: Cultura y Educación, Revista española de Pedagogía, Educación XXI, Psicodidáctica, Comunicar y Revista de Educación.

Afortunadamente, durante los últimos años, en España estamos experimentando un gran avance, ya que la capacidad investigadora empieza a ser un requisito para muchos de los profesionales de la música, lo cual estimula la atención a la investigación de buena parte del profesorado, sea o no universitario. Este hecho supone un incremento de la mejora de la calidad 
de la enseñanza de la música, ya que, como apunta Imbernón (2002), "sin investigación, no hay campo de conocimiento, hay tradición, rutina, copia, reproducción, dependencia y estatismo" (p. 7). Hoy en día, contamos con publicaciones, tesis doctorales y proyectos de investigación que avalan la importancia que los profesionales de la música conceden a la investigación educativa, y esto es así, según Díaz (2010), "desde el convencimiento de que la pedagogía y la didáctica musical no deben estar apoyadas únicamente en la intuición y la reflexión filosófica, sino en procedimientos científicos como los que nos aporta la investigación sistemática" (p. 134).

No obstante, centrándonos de forma más específica en el estado de la cuestión de nuestro objeto de estudio, no podemos mostrarnos tan optimistas, ya que nos encontramos ante una circunstancia peculiar y bastante extendida en el tiempo: la falta de investigación e investigadores en los conservatorios superiores de música. En España, el hecho de que los conservatorios superiores no estén incluidos dentro de la universidad ha supuesto una serie de consecuencias que han perjudicado el desarrollo de la investigación musical. Al respecto, López-Bernad (2015) señala que:

La subestima de la música dentro del sistema educativo debido a una pérdida de conciencia histórica sobre la importancia de la misma, la falta de recursos materiales o la ausencia de una normativa que ayude al pleno desarrollo de los conservatorios de música, se ha traducido en un número escaso de investigaciones relacionadas y en pocos investigadores en este campo. (pp. 4-5)

En la actualidad, a pesar de que existan institutos para el desarrollo de la investigación musical en algunas universidades, másteres específicos sobre música o programas de doctorado sobre interpretación musical y otras especialidades relacionadas, la investigación musical sobre los problemas en los conservatorios (en alza) se dirige todavía desde las universidades. Esto provoca que, hasta que no se consiga salvar la brecha existente entre la universidad y las enseñanzas musicales superiores, las investigaciones quedarán supeditadas a investigadores externos, corriendo el peligro que apunta López-Bernad (2015) de "quedar plasmadas únicamente en papel dentro del ámbito académico, sin revertir sus beneficios de manera completa en una aplicación directa y plena en los conservatorios" (p. 5).

Por todo lo dicho, y a modo de conclusión, señalaremos que para poder encontrar un punto de partida en nuestra investigación ha sido absolutamente necesario buscar fuentes en otros países. Sin duda, la mayor bibliografía al respecto pertenece a los Estados Unidos de América. No obstante, también hemos encontrado algunas fuentes francesas, alemanas, suizas, canadienses, noruegas, australianas, británicas y procedentes de distintos países latinoamericanos (Argentina, Chile, México...). Estas últimas aluden a temas más 
didácticos y, entre sus revistas especializadas, destacamos los Cuadernos Interamericanos de Investigación en Educación Musical (México), Resonancias (Chile) y Revista da ABEM (Argentina), por citar algunas de ellas.

Finalmente, cabe decir que, para conocer el estado de la cuestión de un tema de estudio, también resultan interesantes los intercambios de información entre especialistas en distintos foros: encuentros, congresos, seminarios... Al respecto, cabe destacar los esfuerzos realizados por la ISME (International Society for Music Education), que es la única entidad en el mundo reconocida por la UNESCO en materia de Educación Musical y que cuenta en la actualidad con alrededor de 80 países miembros (Díaz, 2005). Desde la ISME se organizan encuentros de excelente nivel científico en diferentes latitudes, que suponen una gran oportunidad para compartir experiencias y constituyen fuentes generadoras de iniciativas futuras de los participantes.

En nuestro país, contamos con la Sociedad para la Educación Musical del Estado Español (SEM-EE), que es una organización afiliada a la ISME y sin ánimo de lucro cuyo principal objetivo es estimular la educación musical como parte integral de la educación general, atendiendo de forma específica a las necesidades y los intereses de músicos y profesores del estado español y sirviendo de enlace para contactar con entidades de otros países. A modo de ejemplo, y dada su relevancia para conocer el estado de la cuestión en relación a la temática de esta tesis, señalaremos que la SEM-EE ha colaborado en la organización del Congreso de Educación e Investigación Musical (CEIMUS), que ya ha realizado su tercera edición, contando con gran afluencia de profesionales de la música.

\section{Estructura de la tesis}

Como hemos visto, en el primer capítulo hemos expuesto los motivos que nos han conducido a la elaboración de la presente tesis doctoral. A continuación, hemos definido de forma precisa del objeto de estudio y lo hemos concretado en objetivos más específicos, decisión avalada por el reducido número de trabajos científicos relacionados con el mismo, como hemos podido comprobar en el análisis del estado de la cuestión. Por último, en este apartado haremos una pequeña descripción de los contenidos tratados en los demás capítulos del trabajo que presentamos, para irnos familiarizando con ellos.

Los tres capítulos siguientes responden al marco teórico de la investigación, que fundamenta su solidez y conexión con la comunidad científica y ha sido realizado a partir de una amplia bibliografía constituída por libros, teorías, 
artículos e investigaciones, sirviendo de base para la realización del presente estudio.

En el capítulo segundo analizaremos el concepto de educación auditiva desde el punto de vista musical, partiendo de la descripción del proceso auditivo y centrándonos, a continuación, en los principales factores que intervienen en la misma: la atención en la escucha musical, la memoria, la percepción y el reconocimiento auditivo, la influencia del canto en la formación del oído musical y la audición interior. Además, destacaremos la importancia que ejercen sobre ella otros aspectos como la motivación, la reducción de la ansiedad y el desarrollo de la creatividad, y terminaremos señalando las aportaciones que se han hecho para su desarrollo desde distintos métodos de educación musical.

El capítulo tercero recoge las características del sistema musical tonalarmónico propio de nuestra cultura, en el que, además de tener presentes las cualidades del sonido, resultan fundamentales los conceptos de tonalidad, armonía y acorde. En él desarrollaremos las claves para llevar a cabo el trabajo auditivo dentro de un contexto tonal, lo cual nos llevará a analizar cómo tiene lugar la discriminación tonal, el desarrollo de la audición relativa y absoluta y la educación del oído musical melódico y armónico.

El capítulo cuarto desarrolla el marco legislativo que regula las enseñanzas musicales en los conservatorios dentro del sistema educativo español y, más concretamente, en Castilla y León y en el conservatorio de Segovia, donde tiene lugar el trabajo de campo de nuestro estudio. Veremos la evolución histórica que ha experimentado la asignatura de Lenguaje Musical a través de distintos planes de estudios y señalaremos los elementos organizativos y curriculares que han servido de base para nuestras propuestas.

La tesis continúa con dos capítulos dedicados a aspectos metodológicos: el primero referido a la metodología didáctica desarrollada en el aula y el segundo centrado en el proceso de la investigación.

Así, en el capítulo quinto expondremos nuestro nuevo planteamiento didáctico para llevar a cabo la educación auditiva de nuestros alumnos desde la asignatura de Lenguaje Musical, partiendo de un enfoque novedoso y utilizando estrategias educativas integradoras dentro del contexto tonalarmónico.

Por su parte, el capítulo sexto describe con precisión la investigación que hemos realizado, es decir, los objetivos, el enfoque metodológico, la fijación de la muestra, la aproximación a las fuentes, la temporalización, las técnicas 
e instrumentos para la recogida de información, el proceso de análisis de los datos y la valoración de su rigor metodológico.

Los capítulos séptimo, octavo y noveno se dedican al análisis de los datos obtenidos a partir de la gran variedad de técnicas e instrumentos utilizados. Cada uno de ellos se ocupa de unos aspectos: el séptimo recoge el análisis de los contenidos trabajados a partir de nuestra propuesta metodológica, el octavo se centra en la innovación y la calidad educativa y el noveno analiza los aspectos emocionales y socio-afectivos.

Las conclusiones de la investigación en relación a los objetivos propuestos se recogen en el capítulo décimo donde, además, señalaremos las dificultades y limitaciones que hemos encontrado en su realización y presentaremos algunas sugerencias para futuros estudios.

Por último, se presentan las referencias bibliográficas consultadas y los anexos, que incluyen los diarios, las entrevistas con sus transcripciones, los distintos tipos de cuestionarios utilizados, los correos electrónicos, diversos trabajos y exámenes realizados por los alumnos, fotografías y videos que muestran las actividades desarrolladas y todos los demás documentos relevantes que han formado parte de la investigación y que iremos citando a lo largo de la tesis. Dada su gran extensión, dichos anexos se encuentran recogidos aparte en varios DVD's. 


\section{CAPÍTULO II: LA EDUCACIÓN AUDITIVA DESDE UNA PERSPECTIVA MUSICAL}

\section{Introducción}

El entrenamiento auditivo debe ser una prioridad para todo estudiante de música, ya que el sonido es la materia prima con la cual se elabora la música y es la base de todos los procesos pedagógicos en este sentido. El sonido puede estar presente físicamente y escucharse a través del órgano del oído, pero también puede estar en la mente del ser humano. Esto ocurre, por ejemplo, cuando pensamos en el himno nacional de nuestro país sin necesidad de cantarlo, lo cual se denomina oído interno, también llamado oído de la mente (Malbrán, 2007a).

Históricamente, la formación musical de los alumnos que asistían a centros donde se impartían enseñanzas profesionales de música se basaba en dos grandes aspectos: por un lado, se dirigía hacia la adquisición y el desarrollo de las habilidades destinadas a la interpretación instrumental y, por otra parte, hacia el conocimiento teórico, sobre el papel, de la sintaxis musical. Afortunadamente, gracias a las aportaciones procedentes de diversas perspectivas metodológicas y de los avances científicos adquiridos por medio de la investigación en psicología de la música, ha comenzado a considerarse también seriamente la importancia de desarrollar el oído musical. Al respecto, Willems (2001) afirma que mediante la educación se puede despertar, dirigir y desarrollar el funcionamiento del oído, lo cual tiene gran importancia ya que, si no se le atiende adecuadamente, puede llegar a atrofiarse.

En la actualidad, la partitura juega un rol principal en la mayoría de los ámbitos académicos de estudio musical. Incluso, comienza a confundirse con el lenguaje (la música) en sí mismo, hasta tal punto que, en muchos ámbitos, 
conocer la lectoescritura musical es sinónimo de conocer el lenguaje musical y de poseer desarrollo auditivo (Shifres, 2010).

Por todo ello, a lo largo de este capítulo, aclararemos en qué consiste la educación auditiva desde una perspectiva musical. En primer lugar, analizaremos el proceso auditivo, desde la recepción del sonido a través del órgano del oído hasta su procesamiento cognitivo al llegar al cerebro. Después, delimitaremos el concepto de "educación del oído musical" y nos detendremos en cada uno de los factores fundamentales que intervienen en la misma: la atención en la escucha musical, la memoria, la percepción y el reconocimiento auditivo, la influencia del canto en la formación del oído musical y la audición interior. Asimismo, destacaremos otros aspectos que contribuyen a facilitar la educación auditiva, como son la motivación, la reducción de la ansiedad y el desarrollo de la creatividad. Finalmente, señalaremos las aportaciones a la educación auditiva que se han hecho desde distintos métodos de educación musical, tanto en el ámbito internacional como en el nacional.

\section{El proceso auditivo}

Palacios (2001) afirma que escuchar enseña a ordenar el mundo y desarrolla habilidades para resolver ecuaciones sonoras. En el plano musical, permite relacionar sonidos, buscar parentescos, reconocer las caras de los temas que ya han sonado y descubrir qué hay bajo los disfraces de las variaciones.

Por su parte, Willems (2001) señala que la audición es una de las bases esenciales de la musicalidad y que el amor al sonido es la mejor introducción al amor a la música. Para él, el oído afinado es comparable a un ojo que ve a través de una lente de aumento, ya que se vuelve dueño de lo infinitamente pequeño.

Para comprender bien todo este proceso, dedicaremos este apartado a analizar los aspectos anatómicos y físiológicos del órgano del oído para, posteriormente, detenernos en los procesos cognitivos específicos de la audición musical, interesándonos especialmente por su evolución en las diferentes etapas vitales.

\subsection{Anatomía y fisiología del oído}

$\mathrm{Si}$, originalmente, el oído era un simple aparato concebido para detectar las variaciones de presión, en el curso de su evolución ha demostrado que también podía analizarlas. 
Para oír necesitamos un mecanismo que convierta las ondas sonoras en actividad neural (Myers, 2005). De ello se encarga el oído, que es un órgano de gran complejidad en el que se distinguen tres partes:

- El oído externo comprende el pabellón auricular u oreja y el conducto auditivo externo. El pabellón auricular tiene la misión de concentrar las ondas sonoras y llevarlas hasta dicho conducto auditivo externo.

- El oído medio o caja del tímpano es una cavidad de pequeño tamaño que está llena de aire. Su pared externa la constituye la membrana timpánica, que lo separa del oído externo. La membrana timpánica vibra al entrar en contacto con las ondas sonoras. Sus vibraciones son recogidas por tres huesecillos, llamados martillo, yunque y estribo, que actúan a modo de palanca. El sonido se transmite luego a la ventana oval, situada en el oído medio y de aquí pasa al oído interno. En el oído medio se encuentra también la trompa de Eustaquio, que está en comunicación con la zona de la faringe y tiene la misión de mantener la presión aérea de la caja timpánica al mismo nivel que el que existe en la atmósfera.

- El oído interno está alojado en una serie de cavidades irregulares excavadas en el hueso temporal, que reciben el nombre de laberinto óseo; en su interior se encuentra el laberinto membranoso. Entre ambos laberintos hay un líquido claro y transparente llamado perilinfa, y en el interior del laberinto membranoso hay otro líquido que recibe el nombre de endolinfa. Las cavidades formadas por el laberinto óseo dan lugar al vestíbulo, al caracol y a los tres conductos semicirculares. El vestíbulo está situado en la parte anterior del caracol y transmite a éste, a través de la perilinfa, las vibraciones que le llegan de la ventana oval. El caracol o cóclea es una cavidad espiral cuya misión es conducir estas vibraciones al órgano de Corti, que se encuentra en su interior. Por su parte, los tres conductos semicirculares están relacionados con el sentido del equilibrio. El órgano de Corti es un verdadero órgano terminal de la audición. Está formado por unas células que transforman las vibraciones sonoras en estímulos nerviosos. Alrededor de estas células comienza el nervio auditivo, que transmite los estímulos al cerebro, donde son transformados en sensaciones acústicas. 


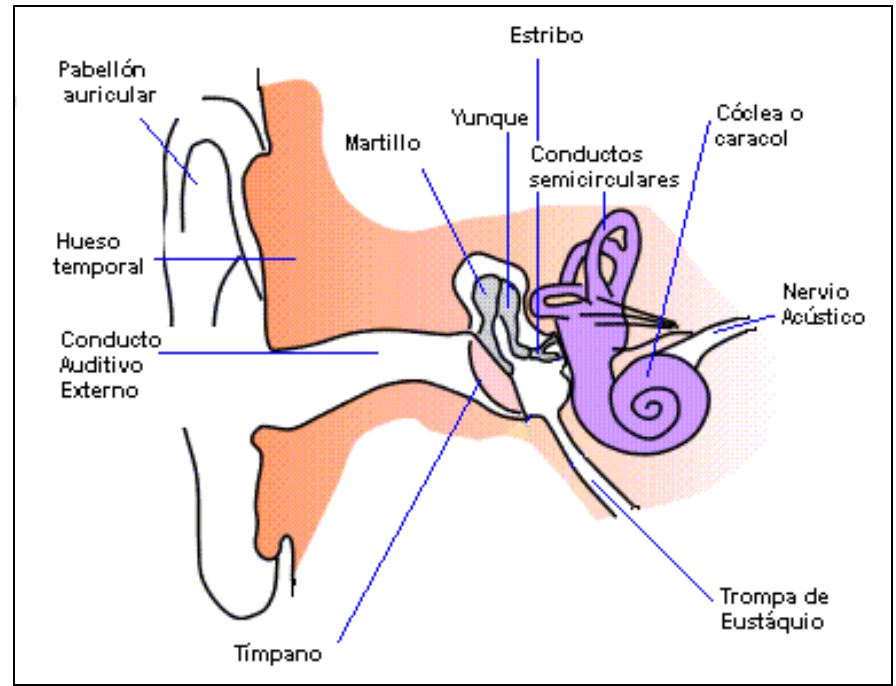

Figura 1. Anatomía del oído (Wikipedia)

Cada vez que escuchamos cualquier sonido, nuestros oídos transforman las señales acústicas en impulsos neuronales que el cerebro interpreta. En la primera fase de este proceso, las ondas sonoras entran en el oído y recorren el conducto auditivo externo hasta llegar al tímpano, que hace vibrar la cadena de huesecillos (ya en el oído medio). Estas vibraciones llegan a la ventana oval y de ahí al caracol, en el oído interno. En esta zona se encuentran unas células ciliadas que transforman el sonido en impulsos nerviosos, los cuales se transmiten al cerebro a través del nervio auditivo. Si algún elemento falla en este complejo proceso se producen pérdidas de audición en mayor o menor grado.

El oído está enmarcado en el plano frecuencial por un umbral mínimo, por debajo del cual los sonidos demasiado bajos para que él los perciba son designados como «infrasonidos», y por un umbral máximo, más allá del cual los sonidos se le escapan, volviéndose inaudibles y recibiendo el nombre de «ultrasonidos». Entre estos dos límites se extienden los sonidos llamados «audibles» por el oído humano que, en realidad, "solo puede oír aquellos sonidos cuyas frecuencias son superiores a $20 \mathrm{~Hz}$ e inferiores a $20.000 \mathrm{~Hz}$ " (Weiten, 2006, p. 154). Los extremos graves o agudos, es decir, las zonas fronterizas de nuestras capacidades perceptivas son de un mal rendimiento en lo que atañe a la respuesta de nuestro órgano sensorial. La zona óptima es la comprendida entre los 50 y 5.000 hertzios. 


\subsection{La audición musical}

Mora (2009) indica que, aunque el oído es el órgano receptor inicial de la sensación sonora, esta se procesa en el cerebro. La percepción tiene lugar en el sistema auditivo central a través de cinco fases: detección o localización, discriminación, identificación, reconocimiento y comprensión.

Los modos de audición son modelos que explican cómo se produce el proceso de percepción sonora, esto es, cómo se dota de significación a los sonidos. Así, Schachtel (1962, citado por Mora, 2009) describió un modo de audición autocéntrico, basado en el sentimiento de satisfacción o insatisfacción del sujeto ante el estímulo sonoro, y un modo de audición alocéntrico, que se centra en el propio significado y evocación del sonido. Para Smalley (1992, citado por Mora, 2009), los modos de audición se plasman en tres momentos: el modo de audición indicativo, que actúa como un signo que ha de ser descrifrado; el reflexivo, basado en la respuesta emocional que provoca en el sujeto el sonido percibido; y el interactivo, que requiere una atención activa del sujeto. Sin embargo, Schaeffer (1988, citado por Mora, 2009) establece que el proceso auditivo consiste en oír, escuchar, entender y comprender el sonido. Veamos más claramente estas tres posturas en el siguiente gráfico.

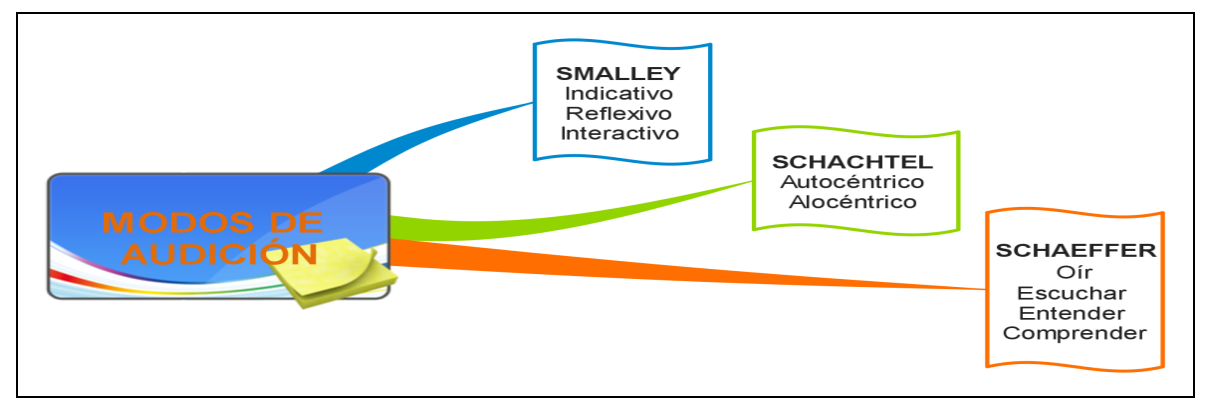

Figura 2. Modos de audición de Smalley, Schachtel y Schaeffer (Mora, 2009, p. 35)

Serafine (1988, citado por Lacárcel, 2001) asegura que la audición musical "es considerada como una actividad organizada y construida de los hechos temporales oídos en una composición" (p. 32). Cualquier pieza musical se convierte en una manifestación artística originada por una acción voluntaria que busca el placer estético. Por ello, la música es un modo de expresión que comporta un acto de comunicación y que incide profundamente en el terreno del dominio interno y personal de cada individuo, en los sentimientos y en las emociones de una forma única, personal y libre (Malagarriga \& Valls, 2003). 
Malbrán (1996), define la audición musical como:

- Un modo múltiple y simultáneo de procesamiento musical, ya que:

[...] requiere escuchar, formar una representación mental de lo que se está escuchando, predecir cómo va a seguir el discurso musical, comparar con lo que realmente sucedió mientras se sigue escuchando. (p. 68)

- Una actividad, dado que:

[...] pone en juego habilidades y disposiciones de alto orden que integran la reflexión, el pensamiento constructivo, la actitud significativa y la persistencia en la atención. (p. 68)

- Una de las claves del desarrollo musical, puesto que:

[...] facilitar su acceso resulta un compromiso; convertirla en fuente de placer, una aspiración. (p. 68)

Por su parte, Copland (2008) considera que la escucha musical se produce en tres planos distintos: el plano sensual, el plano expresivo y el plano puramente musical.

- El primero, el plano sensual, se corresponde con los momentos en los que oímos música sin pensar en ella ni analizarla.

- El segundo plano, el expresivo, hace referencia a la capacidad que tiene la música para expresar estados de ánimo y emociones con sutiles matices y diferencias.

- El tercer plano, el puramente musical, alude a la audición de melodías, ritmos, armonías y timbres de una forma más consciente y a la capacidad de entender estos aspectos.

No obstante, también afirma que nunca se escucha en este plano o en aquel otro, sino de forma interrelacionada, de tal manera que es posible escuchar de los tres modos a la vez.

La audición es una de las bases de la musicalidad sin la cual esta quedaría incompleta (Hernández, Hernández, \& De Moya, 2011). Por lo tanto, la audición se convierte en uno de los pilares imprescindibles en el desarrollo musical infantil, contribuyendo a mejorar la concentración, la atención, la discriminación tímbrica, el sentido rítmico, estético y musical.

Wuytack (1971, citado por Hernández, Hernández, \& De Moya, 2011) manifiesta la necesidad de desarrollar una audición activa desde los primeros años, defendiendo la idea de que la actividad práctica preceda a la teórica. 
De este modo, también propone tres planos relacionados con la audición que mejorarán la escucha activa: el plano sensorial, por el que los niños descubren sensaciones y emociones gracias a la música, el plano descriptivo, utilizando historias reales o imaginarias y, por último, el plano musical, en el que se deberán reconocer la altura, timbre, intensidad y duración de la música, así como secuencias melódicas y rítmicas binarias y ternarias.

Para Sanuy (1996), la primera forma de escuchar música podría compararse con un baño que nos inunda, dándose generalmente una respuesta motriz al estímulo sonoro; es lo que ella denomina escucha sensorial. Un segundo caso es la llamada escucha afectiva, muy importante en la actividad grupal, que ayuda a la comunicación y a la expresividad, además de repercutir en el estado de ánimo. La tercera forma de escuchar sería la musical, que precisa de una actitud consciente y analítica con el fin de mover nuestra inteligencia para reconocer timbres, ritmos, melodías, tonalidades, etc.

Finalmente, señalaremos que Lago (2004) formula los siguientes modos de audición: la audición inconsciente, la audición asociada, la audición sensitiva o consciente y la audición musical. La audición inconsciente es aquella que nadie percibe a su alrededor, como la música de los centros comerciales, restaurantes, etc. La audición asociada es aquella que acompaña a otros estímulos, como al cine o al teatro. La audición sensitiva o consciente es aquella en la que el oyente siente una satisfacción plena y en la que debe ser consciente su deseo de oír. Por último, la audición musical implica el análisis de lo escuchado, tanto de los aspectos que la integran como de sus ejecutantes u otros aspectos, siendo desarrollada por personas con formación musical.

\subsubsection{Procesos cognitivos implicados en la audición musical}

Despins (2013) considera que la música es el medio más eficaz para desarrollar y aumentar el equilibrio entre los dos hemisferios cerebrales porque, mientras hay actividades que requieren la acción del hemisferio izquierdo para regular la secuencia temporal y serial, simultáneamente se produce otra actividad relacionada con la expresión emocional que viene regulada por el hemisferio derecho. En este sentido, Arias (2007, citado por Jauset, 2011) afirma que el aspecto melódico pertenece al hemisferio derecho, mientras que el izquierdo tiene un componente más analítico, expresándolo de esta manera: "El hemisferio derecho es el especializado en el aspecto más holístico de la música y el izquierdo en el analítico" (p. 32).

Por el contrario, Jensen (2010) plantea que "los músicos procesan la música en su hemisferio izquierdo, no en el derecho, como haría una persona novata". En este sentido, científicos de la Universidad alemana de 
Heidelberg hicieron público un estudio que plantea que una zona del cerebro que se encuentra directamente relacionada con el procesamiento de los sonidos es mayor y más sensible en los músicos profesionales que en el resto de las personas. Esa zona se llama "Giro de Heschl" y se encuentra situada en la región de la corteza cerebral que procesa los sonidos (Martínez, 2009).

En este orden de cosas, queremos destacar la aportación de Ortiz (1999), quien afirma que la música permite un equilibrio dinámico entre las capacidades hemisféricas izquierdas y las derechas, lo que permite un aprendizaje mucho más equilibrado y adaptado al medio ambiente y a las propias capacidades de cada cerebro individual.

Por su parte, Willems (2001, citado por Trallero, 2008) expone que la audición del ritmo se localiza en el nivel bulbar del cerebro, mientras que la melodía tiene lugar en el nivel encefálico y la armonía se percibe en el nivel cortical, encargado de controlar las actividades más intelectuales.

Myers (2005) recoge dos teorías encargadas de explicar cómo diferenciamos los tonos altos de los bajos o los distintos sonidos que escuchamos habitualmente. La primera es la Teoría del Lugar de Von Helmholtz, la cual establece que escuchamos distintos tonos porque las diversas ondas sonoras generan actividades en diferentes lugares de la membrana basilar de la cóclea. La segunda es la Teoría de la Frecuencia de Georg von Békésy que, según señala Myers (2005), propone una explicación alternativa para diferenciar los tonos, según la cual:

Las ondas sonoras que penetran en el oído provocan vibraciones en la membrana basilar, que a su vez crea impulsos nerviosos que se dirigen al cerebro al mismo ritmo que las ondas sonoras. Si la onda sonora tiene una frecuencia de 100 ondas por segundo, entonces el nervio auditivo transporta 100 impulsos por segundo. Por lo tanto, el cerebro puede determinar el tono sobre la base de la frecuencia de los impulsos nerviosos. (p. 98)

Finalmente, destacaremos que Tomatis (1987) ha investigado el importante papel que posee el oído al controlar la fonación, la imagen corporal y el control motor. Tomatis demostró que, si se mejoran las capacidades auditivas del ejecutante a través del proceso de escucha, adquiere un mayor dominio de su voz y del instrumento.

\subsubsection{Evolución de la audición musical en las etapas vitales}

El estudio ontogénico puede entenderse como el estudio de una serie de cambios ordenados y relativamente permanentes en las estructuras físicas, neurológicas y psicológicas que suponen modificaciones en el comportamiento, en las emociones y en las formas de interacción social del 
sistema auditivo. El estudio ontogénico en niños tuvo poca transcendencia en el espacio de la psicología evolutiva hasta la década de los setenta. Munar, Rosselló, Mas, Morente y Quetgles (2002) exponen tres razones principales:

[...] el sistema auditivo no tiene una respuesta observable unívoca a la estimulación acústica, la dificultad para controlar las características de los estímulos sonoros y el limitado conocimiento anatómico y sensorial del sistema auditivo. (p. 57)

Tres avances ayudaron a superar los obstáculos anteriores: la asunción de distintos sistemas de respuesta para medir el funcionamiento del sistema auditivo, el avance de la física acústica y la tecnología de alta fidelidad, así como las investigaciones del premio Nobel von Békèsy en el campo de la anatomía fisiológica del sistema auditivo durante los años sesenta (Munar et al., 2002).

Tomatis (1987, citado por Torres, 2011) afirma que en la séptima semana de gestación el feto puede empezar a oír y que, alrededor de la semana diecisiete, todos los sistemas sensoriales son operativos. A su vez, Munar et al. (2002) han dejado constancia de estudios que demuestran que, en el útero, no solo se oyen ruidos de la madre y del feto, sino que también se registran ruidos de procedencia externa, incluyendo sonidos del habla. Lecanuet (1998, citado por Balo, 2014) establece que la experiencia prenatal puede convertirse en un tipo de aprendizaje específico, cuyos efectos se evidenciarán en algunas situaciones de después del nacimiento. Sin embargo, no está claro que se pueda verificar con suficientes argumentos empíricos que la función auditiva se inicie en este periodo. En este sentido, la audición del feto debe ser de una naturaleza diferente a la nuestra, ya que no están presentes una serie de atributos del proceso auditivo, como la audición consciente. A pesar de ello, existe la creencia generalizada de que el niño oye antes de nacer.

Balo (2014) señala que "durante el primer año de vida, los bebés desarrollan un mapa perceptual de neuronas responsables en el córtex de la audición" ( $\mathrm{p}$. 107). Kuhl (1986, citado por Jensen, 2010), de la Universidad de Washington, indica que los circuitos de esta zona asignan tanto células como puntos receptores para lo que se consideran los primeros sonidos de supervivencia. Este mapa se forma escuchando sonidos tempranos, y los acentos y las pronunciaciones de palabras son una gran parte de ellos.

Todos los sonidos modelan el cerebro, al igual que la música y el ritmo. Por otra parte, todos los bebés son receptivos a la música y son capaces de distinguirla bastante bien. No obstante, a medida que el bebé va creciendo, se constatan diferencias evidentes entre el oído externo del niño y del adulto, 
de consecuencias funcionales. En el canal auditivo infantil se producen efectos desiguales de resonancia, debido a que este es de menor longitud, afectando a la tonalidad, percibiéndola más aguda que los adultos. Asimismo, manifiestan un sesgo en la localización del sonido, debido a la mayor presencia de frecuencias altas (Munar et. al, 2002).

Todo ello posibilita que el niño entre cero y dos años ensaye e imite los sonidos o tonos que oye y posea ciertas aptitudes y prerrequisitos que podrían ser la base para un buen desarrollo musical (Lacárcel, 2001).

Bentley (2003, citado por Trallero, 2008) ha llevado a cabo distintas investigaciones en torno a la audición de los niños en distintas edades. Sus conclusiones pueden resumirse en las siguientes:

- En todas las edades de la niñez se desarrolla más intensamente la memoria rítmica que la tonal. La aptitud para analizar acordes se desarrolla con más lentitud que el resto.

- En las aptitudes musicales no hay diferencias entre ambos sexos.

- Las aptitudes musicales durante la niñez están mínimamente relacionadas con la inteligencia.

- Con el crecimiento se acrecientan las aptitudes musicales, aunque el incremento anual es pequeño.

- La mayoría de los niños de siete años son capaces de discriminar diferencias de un cuarto de tono. La mitad de los niños de diez y once años, la mayoría de doce e incluso mayores son capaces de auditar octavos de tono.

- La discriminación del tono "parece ser más exacta en los sonidos cercanos a la mitad del registro vocal que en los sonidos de los extremos del registro vocal o fuera de él".

- En la memoria tonal, la última nota de cada serie es la más sencilla de recordar.

Finalizando el período preescolar, hay una mejora del dominio de la altura y del contorno melódico, mientras que, al final de la primera infancia, los rasgos principales del desarrollo melódico son los que se corresponden con la representación precisa de las relaciones altura-intervalo, esto es, con las características formales del sistema tonal (Trallero, 2008). 


\title{
3. Delimitación del concepto de "educación del oído musical"
}

Willems (2001) señala que tener oído musical se refiere a la habilidad de comprender auditivamente todos los elementos que constituyen el discurso musical y hace la siguiente reflexión sobre dicho oído y los distintos ámbitos de la naturaleza humana:

\begin{abstract}
En realidad, el don auditivo es un conjunto de fenómenos muy complejos que requiere la participación de tres campos diferentes: la sensorialidad auditiva, la sensibilidad afectivo-auditiva y la inteligencia auditiva. Añadimos, además, que cada uno de estos tres campos requiere distintas facultades. (p. 26)
\end{abstract}

En el aprendizaje de cualquier lenguaje artístico, hay que considerar la existencia de determinados aspectos fundamentales que vienen dados por la naturaleza del propio lenguaje. Por lo que respecta a la música, este elemento básico y generador es el sonido, el cual es definido por la Real Academia Española (2014) de la siguiente manera:

Sensación producida en el órgano del oído por el movimiento vibratorio de los cuerpos, transmitido por un medio elástico, como el aire. (Sonido, s.f.)

Para conocer a fondo y llegar a dominar conscientemente el lenguaje musical hay que desarrollar, a lo largo de todo el proceso de enseñanza y aprendizaje, unas habilidades que proporcionen una sólida formación auditiva musical. Por este motivo, de acuerdo con Alberich (2010), creemos firmemente que "la formación del oído musical es, en realidad, uno de los aspectos fundamentales y también una de las claves de la verdadera educación musical" (p. 5).

Partiendo de la base de que todo aprendizaje musical pasa, en líneas generales, por la educación global del oído, Schönberg (1974) defiende que "la percepción sensible provoca asociaciones y relaciona el sonido, el oído y el mundo sensorial. De la acción conjunta de estos tres factores depende todo lo que en música hay de arte" (p. 14).

Ur (1984) opina que los profesores deben preparar a los estudiantes para la comprensión auditiva en la vida real. Además, afirma que los ejercicios de escucha son más efectivos si se estructuran alrededor de una tarea, es decir, si "se requiere que los estudiantes realicen alguna actividad en respuesta a lo que escuchan para demostrar su comprensión” (p. 47). 
En la misma línea, Lerdahl y Jackendoff (2003) consideran que "una teoría de la música se debería originar y fundamentar plenamente en las experiencias musicales de los oyentes y, también, en la descripción que ellos hacen de las mismas" (p. 1). Para estos autores, los oyentes son los únicos expertos en la comprensión del lenguaje musical, lo cual les llevó a elaborar una teoría gramatical llamada Teoría generativa de la música tonal, distinguiendo cuatro niveles de análisis: estructura de grupos, estructura métrica, reducción de unidades temporales y reducción del desarrollo tonal.

Para López de Arenosa (2008b), llegar a la música por la comprensión de su lenguaje a través del oído continúa siendo un reto pendiente en la educación musical, lo cual implica varios elementos:

- Educación, no adiestramiento.

- Comprensión, no imitación conducida.

- Lenguaje con significación, no técnicas de lectura y escritura.

- Por el oído, vehículo natural e imprescindible, no por la vista.

Por tanto, alcanzar un buen oído musical demanda llevar a cabo un trabajo riguroso, constante, minucioso y sistematizado, a través del cual, según Malbrán (1996), la formación "avanza hacia la discriminación de diferencias y matices cada vez más sutiles" (p. 60) y "progresa de la atención selectiva de componentes aislados del discurso musical a la consideración de elementos que se yuxtaponen, combinan y superponen de diferentes modos" (p. 61).

Por lo que respecta a las características de la educación auditiva, Malbrán (2006) especifica las siguientes:

- La experiencia parte de aquello que es más conocido y familiar para ir a aquello que no lo es tanto.

- La información se comprende y retiene buscando relaciones.

- La distribución normal de la habilidad musical da fe de su educabilidad.

- El campo del conocimiento presenta una evolución significativa.

- La comprensión auditiva es multidimensional.

- La enseñanza conceptual requiere abstracciones de alto nivel. 
- La decodificación de símbolos de contenidos significativos se basa en las experiencias previas.

- La implicación del estudiante en el desarrollo del proceso es decisivo para su propio progreso.

- La implicación del profesor en el desarrollo del proceso es decisiva para el logro de las metas marcadas.

Todas estas consideraciones ponen de manifiesto, por un lado, la enorme complejidad que supone la educación auditiva musical y, por otro, la necesidad de poner en juego muy pronto todas las competencias musicales.

Asimismo, Giráldez (1997) defiende que hay que tener en cuenta la relación existente entre la comprensión auditiva y el desarrollo de actividades relacionadas con la interpretación, la improvisación, la composición y la lectoescritura y, en la misma línea, Miranda (2003) señala que las capacidades fundamentales que intervienen en la educación auditiva son: la percepción, la interiorización, la expresión y el reconocimiento. A continuación, se muestra un cuadro donde recoge la manera de desarrollar cada una de ellas:

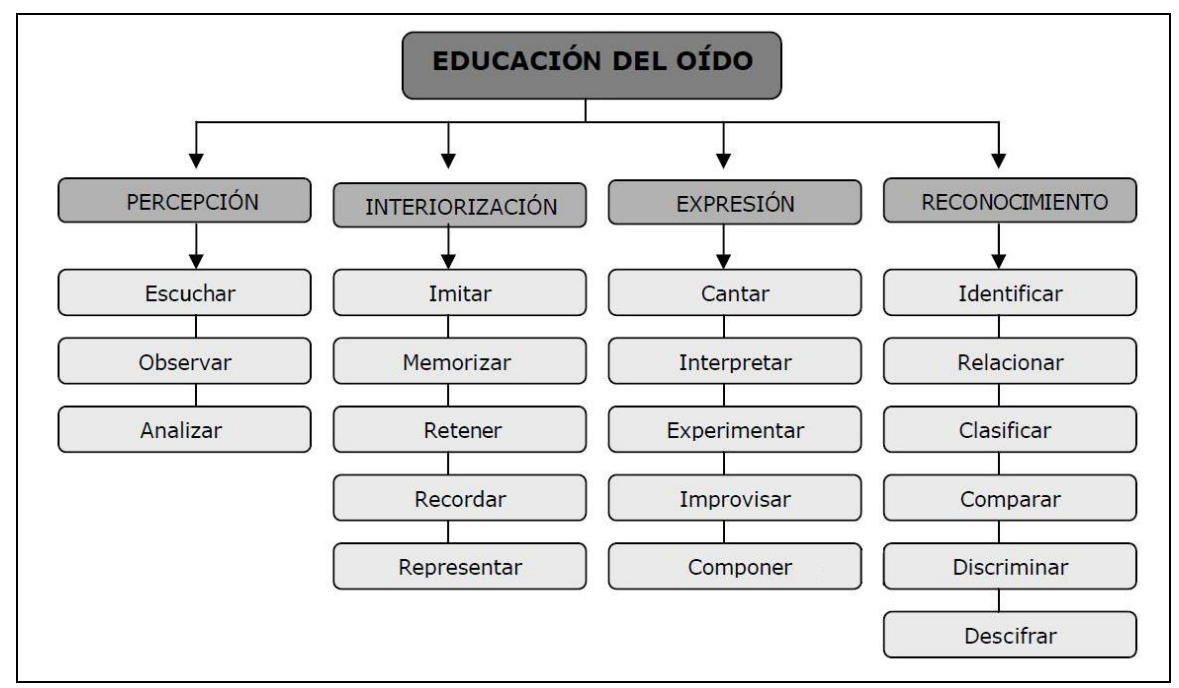

Figura 3. Capacidades que se deben desarrollar en la educación auditiva (Miranda, 2003, p. 78)

Por su parte, Willems (2001) afirma que mediante la educación podemos despertar, dirigir y desarrollar el funcionamiento del oído musical y señala 
tres pasos generales a seguir para llevar a cabo una adecuada educación auditiva:

1. Hacer que el niño experimente el sonido y entrenarlo a escuchar bien. Para ello son indispensables los juguetes musicales, así como todo el material sonoro creado o reunido con este fin.

2. Despertar en el niño el amor al sonido, alimentar el deseo de reproducir lo que ha oído y familiarizarlo con el campo melódico haciendo que cante bellas canciones; desarrollar así la memoria auditiva; recurrir a su imaginación auditiva y despertar en él el deseo de crear, de improvisar.

3. Despertar en él la conciencia sensorial, afectiva y mental del mundo sonoro. La escritura y la lectura se insertan, poco a poco, en la experiencia sonora sensorial y afectiva. (p. 63)

Consideramos que el hecho de atribuir a las habilidades auditivas musicales un carácter innato ha sido, probablemente, una de las causas por las cuales aún no se ha progresado suficientemente en las técnicas para el desarrollo del oído musical. Afortunadamente, hoy en día sabemos que se puede desarrollar como cualquier otra destreza, mediante la secuenciación de contenidos y una adecuada progresión didáctica. Estamos de acuerdo con Alborés (2008) en la idea de que la formación auditiva es una tarea fundamental que acompaña al músico durante toda su vida y que depende primordialmente de la enseñanza recibida y, también, del trabajo individual realizado tanto en sus estudios como en su vida profesional. En definitiva, pensamos que son decisivas todas las experiencias musicales cotidianas que se hayan ido acumulando a lo largo de la vida, destacando especialmente las más tempranas, las cuales consideramos particularmente decisivas en la formación del futuro músico profesional.

\section{Factores fundamentales que intervienen en la educación auditiva musical}

En el proceso de formación del oído musical intervienen muchas capacidades y habilidades que interaccionan y se complementan. Antes de explicarlas, consideramos adecuado precisar el significado de los términos capacidad y habilidad, los cuales, según Monereo et al. (1998), se pueden definir de la siguiente manera:

Hablamos de capacidad para referirnos a un conjunto de disposiciones genéticas que tenemos desde el momento de nacer (y probablemente antes) y que nos permiten ejecutar una serie de conductas muy relacionadas con 
nuestra supervivencia. [...] Las habilidades serían capacidades que se pueden expresar mediante comportamientos en cualquier momento porque se han desarrollado por medio de la práctica, es decir, por vía procedimental. (p. 28)

Por tanto, entendemos que las capacidades hacen referencia a "todas aquellas disposiciones innatas que, una vez desarrolladas a través de la experiencia, dan lugar a habilidades individuales" (Ponsatí, 2011, p. 20). Dicho de otra manera, para poder ser hábil en la realización de una determinada tarea es necesario contar previamente con la capacidad potencial necesaria y con el domino de algunos procedimientos que permitan al alumno llevar a término con éxito la citada tarea.

A continuación, nos proponemos exponer algunas de las capacidades y habilidades básicas e imprescindibles que intervienen en la formación del oído musical: la atención en la escucha musical, la memoria musical, la identificación y el reconocimiento auditivo musical, el canto y la audición interior.

\subsection{La atención en la escucha musical}

Una de las primeras capacidades fundamentales que hay que desarrollar a la hora de formar el oído musical es la escucha, definida por López de Arenosa (2006) de la siguiente manera:

La escucha musical para un músico es algo más que el disfrute sensual de los sonidos. Se trata, además, de entender lo que allí sucede y de tener puntos de referencia para la reflexión. (prólogo)

Maneveau (1993) también justifica la importancia de la escucha musical afirmando que "hay que enseñar y aprender a escuchar para oír y entender la música" (p. 268). Asimismo, Lynch y Mendelsohn (2002) defienden: "hoy en día, reconocemos que la capacidad auditiva es un proceso activo y que las personas que son buenas al escuchar son tan activas como la persona que envía el mensaje" (p. 193).

Tomatis (1987), investigador dedicado a resolver problemas auditivos desde el punto de vista médico, delimita la diferencia entre oír y escuchar en los siguientes términos:

Oír y escuchar son dos procesos diferentes. Oír es la percepción pasiva de los sonidos, mientras que escuchar es un acto voluntario que requiere del deseo de usar el oído para enfocar los sonidos seleccionados. (p. 4) 
Dicho de otra forma, para oír basta con tener un oído sano y un sonido perceptible pero, para escuchar, se necesita la intención de hacerlo. La acción de escuchar es voluntaria e implica intencionalidad por parte del sujeto, a diferencia de oír, que significa, sin más, percibir sonidos por el oído. Oír es un proceso fisiológico y escuchar es un proceso psicológico. Cuando oímos, estamos utilizando nuestro sistema auditivo pero, cuando escuchamos, entran en juego otras funciones cognitivas: poner atención, recordar, razonar e interpretar, lo cual nos permite dar sentido a lo que se oye.

En el mismo sentido, pero desde una perspectiva lingüística, Echeverría, en su libro Ontología del lenguaje (2002), nos habla de la escucha como una parte fundamental de la comunicación humana, afirmando que:

Lo que diferencia el escuchar del oír es el hecho de que, cuando escuchamos, generamos un mundo interpretativo. El acto de escuchar siempre implica comprensión y, por lo tanto, interpretación. Cuando atribuimos una interpretación a un sonido, pasamos del fenómeno del oír al fenómeno del escuchar. Escuchar es oír más interpretar. No hay escucha si no hay involucrada una actividad interpretativa. (p. 23)

Por tanto, el hecho de escuchar conlleva implícitos diferentes procesos psicológicos relacionados con la atención y la percepción. Alonso (2004), en su tesis doctoral Optimización de la atención a través de un programa de intervención musical, expone la idea de que, a menudo, no se detectan actividades físicas concretas, asumiéndose el hecho de que la escucha musical es una acción pasiva, cuando en realidad no es así. El autor continúa su reflexión diciendo que la activación de la atención, la percepción y la memoria hace posible que la acción de escuchar se relacione con diversas imágenes mentales y sentimientos, y concluye esta idea afirmando:

Por consiguiente, la escucha no es una tarea pasiva, ya el sujeto contribuye a estructurar y a asignar un significado a lo que escucha, es capaz de detectar anomalías en el mensaje auditivo y puede responsabilizarse en cierta medida del grado de placer que experimente. (p. 168)

La atención es un componente de la escucha, en términos de disposición consciente, fundamental para la audición musical. En los experimentos de Dowling (1973, citado por Sloboda, 1993), que consistieron en hacer oír dos melodías familiares simultáneamente y pedir a los oyentes que las identificaran, el efecto inicial que se produjo en los participantes fue que la mezcla de las dos melodías se hizo incomprensible y casi imposible de reconocer. Modificando el proceso, se pidió a los oyentes prestar atención, únicamente, a la melodía del oído izquierdo. En la mayoría de los casos esta fue reconocida fácilmente. Posteriormente se atendió a la del derecho y 
también se determinó cuál era. Un efecto en la vida cotidiana que puede ayudar a comprender mejor esta distinción de acciones mezcladas es que se puede conversar mientras se conduce un automóvil, o escuchar música mientras se llevan a cabo los oficios del hogar, pero no se puede escuchar una conversación de radio mientras se lee un libro, en tanto son acciones que implican el ejercicio de una atención elaborada.

En esta línea de ideas, Cano y Nieto (2006) proponen el paso de la audición pasiva a la escucha atenta y activa de una forma paulatina, la cual permite el desarrollo de capacidades básicas como la disciplina de silencio, la memoria, la comparación, el descubrimiento, la concentración y la creatividad, es decir, todos los componentes de la audio-percepción.

Por su parte, Abbadie y Gillie (1976) afirman que oír y escuchar son dos capacidades básicas en el proceso de audición que no pueden relacionarse si no se introduce entre ellas una "pedagogía de la audición", algo que permite pasar del acto de oír al de escuchar y del acto de escuchar al de escuchar muy bien. Sus ideas quedan recogidas en el siguiente esquema:

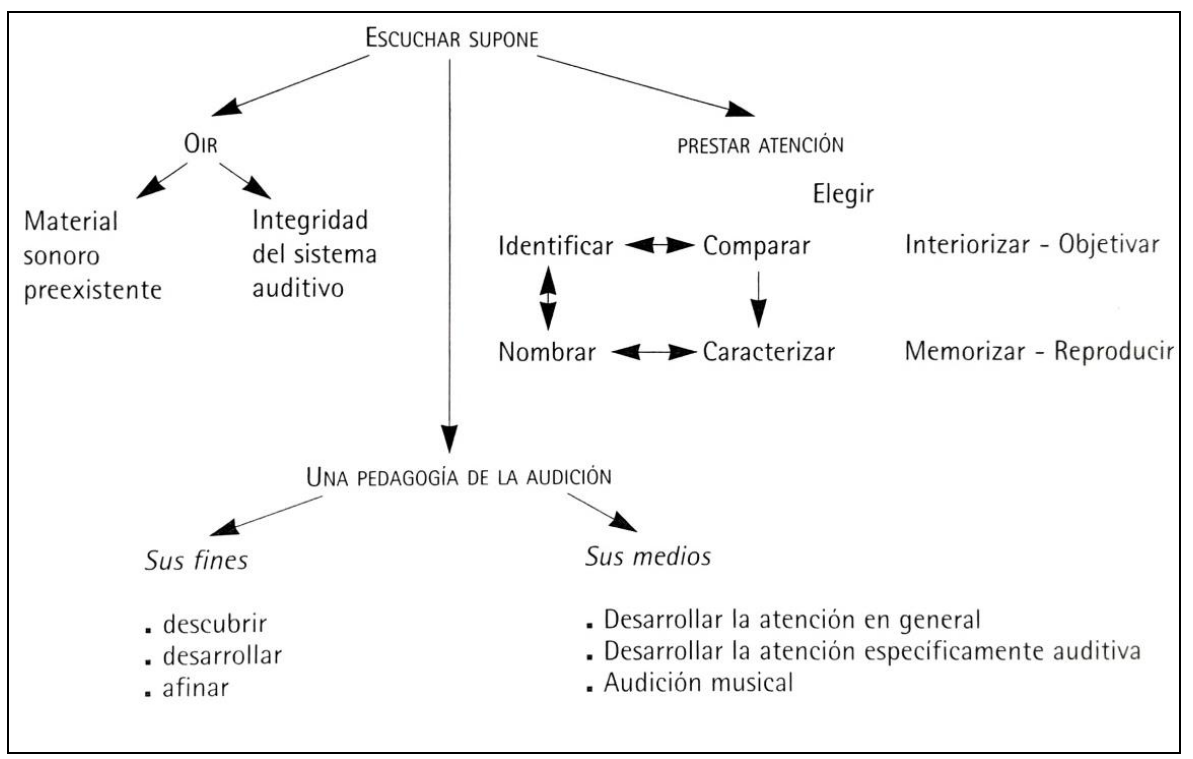

Figura 4. Esquema de la escucha musical (Abbadie \& Gillie, 1976, p. 54)

Respecto a cómo escuchar, Galvin (1988) estima que este proceso requiere de cuatro pasos fundamentales. El primer paso es la recepción y consiste en poner nuestro sentido del oído a trabajar. En este primer paso, la persona decide escuchar o, lo que es lo mismo, la persona empieza a clasificar entre 
lo que constituye únicamente "ruido" y lo que él o ella realmente desea o debe escuchar. El segundo paso es la interpretación. En este nivel, el receptor activa todas sus experiencias y vivencias para decodificar lo que acaba de escuchar. El paso número tres es la evaluación, que consiste en decidir qué hacer con el mensaje; por ejemplo: “¿Estoy o no de acuerdo?, ¿Requiero más información?, ¿Qué es lo importante de todo lo que he escuchado?", y otras preguntas similares. Por último, el paso final en este proceso es la respuesta, que no tiene que ser necesariamente una respuesta oral, ya que puede ser perfectamente cualquier otra reacción.

Sentir, escuchar y entender son los tres verbos que Willems (2001), en su libro El oído musical, utiliza para expresar las funciones auditivas, las cuales pertenecen a tres campos bien diferenciados. "La acción de sentir designa la función sensorial, la de escuchar añade una emoción y, finalmente, la de entender indica la toma de conciencia de aquello que se ha escuchado" (p. 50). Para Willems, estas tres acciones, que representan las actividades más características de la audición, nos pueden servir como punto de partida para establecer las bases prácticas de la cultura auditiva.

Otro aspecto importante es el que apunta Akoschky (1996) al afirmar que el comportamiento de la escucha musical no es igual para todos los individuos, sino que, en realidad, depende de diversos factores: de los intereses de cada sujeto, de sus experiencias y conocimientos previos, de las características de lo que se percibe y, finalmente, de la situación y del contexto donde tiene lugar la percepción.

Desde el punto de vista educativo, la escucha musical se relaciona íntimamente con aspectos que influyen de manera decisiva en el proceso de enseñanza y aprendizaje de la música, como: la motivación, la atención, la concentración, la voluntad, el esfuerzo y la participación. Compartimos la opinión de Akoschky, Alsina, Díaz y Giráldez (2008) al considerar la escucha como uno de los contenidos de aprendizaje fundamentales de la educación musical. De hecho, tal y como constatan estos autores, "es primordial que a la hora de aprender todos los contenidos musicales estos se articulen a través de la escucha" (p. 58). En este sentido, Vilar (1994), en la introducción de su libro Recursos para aprender a escuchar música, hace referencia a la falta habitual de efectuar un tipo de enseñanza sistematizada del acto de escuchar: "el aprendizaje de la escucha se ha desvinculado de la interpretación y de la creación, y escuchar música ha sido, tradicionalmente, un aprendizaje informal" (p. 11). 


\subsection{La memoria musical}

Un factor imprescindible que hay que tener en cuenta en educación y, por tanto, también en la educación auditiva es el de la memoria, ya que, en palabras de López de Arenosa (2006):

La implicación de la memoria parece uno de los grandes cometidos de la Educación Auditiva. Es la memoria la que nos faculta el "oído interno" o la capacidad de reproducir internamente, sin escuchar nada, lo que tenemos delante en partitura, o bien reconocer lo que entra por nuestro oído en cualquier situación de escucha y nos hace capaces de poderlo reproducir escrito, entonado o ejecutado en el instrumento. (prólogo)

Para Córdoba, Coto y Ramírez (2005) lo que una persona escucha es, la mayoría de las veces, de carácter efímero, por lo cual, generalmente, la persona no puede revisar lo escuchado y reevaluarlo, como sí ocurre, por ejemplo, en la lectura. Por tanto, la comprensión de la escucha requiere, en gran medida, el uso de la memoria, ya que la persona debe almacenar la información para poder responder a ella.

Luria (1987, citada por Casals et al., 2005), en su libro Atención y Memoria, define la memoria como:

[...] la capacidad de retención y reproducción de las huellas de la experiencia anterior, lo que permite que el ser humano pueda acumular información y contar con los indicios de la experiencia anterior tras desaparecer los fenómenos que la motivaron. (p. 9)

El cerebro humano organiza y estructura el universo sonoro formando imágenes auditivas, cuyo significado expresan Pressnitzer y Mc Adams (2002, citados por Mónaco, 2007):

Una imagen auditiva puede ser definida como una representación psicológica de una entidad sonora que revela una cierta coherencia en su comportamiento acústico. (p. 113)

Según Mónaco (2007), en la formación de estas imágenes auditivas intervienen, por un lado, la percepción de las vibraciones acústicas y, por otro, diversos procesos cognitivos muy complejos que suponen atención, conocimiento cultural y organización temporal de la percepción. Otro aspecto que destaca Mónaco es el de la expectativa, que va unida íntimamente a la memoria. Esta autora señala que, en realidad, "los eventos auditivos que esperan escuchar los oyentes dependen, en gran medida, de los conocimientos aprendidos previamente" (p. 113). 
Por tanto, la capacidad de retención de la persona que escucha se va desarrollando por medio de modelos asociativos que se crean a partir de experiencias previas. Sin ellas no se puede llegar a la comprensión de elementos estructurales, ya que estos se desconocen, no tienen huella en el recuerdo. "La memoria necesita asentarse en referentes claros, por eso es tan importante la comprensión de los elementos que se manejan" (López de Arenosa, 2006, prólogo). En este sentido, resulta interesante destacar los estudios de Highben y Palmer (2004) y de Bernardi et al. (2013), que examinaron los efectos de dos tipos de práctica mental (la práctica auditiva y la práctica motora) en la ejecución de una pieza de memoria al piano. Al respecto, consideramos relevante destacar que la investigación práctica en la memoria musical es bastante reciente y no se ha extendido a todos los instrumentos, centrándose sobre todo en el piano, por ser el instrumento que mayor memorización exige (Eguilaz, 2009; Aiello \& Williamon, 2002).

Lavignac (1961, citado en Cuartero \& Payri, 2010) diferencia 3 tipos de memoria musical básicas: del oído, de la vista y de los dedos, mientras que Willems (1984), en su libro Las bases psicológicas de la educación musical, matiza la diferencia entre la memoria musical propiamente dicha y la instrumental, agrupando en la primera la rítmica, la auditiva, la mental y la intuitiva y, en la segunda la visual, la táctil y la muscular. Otros autores, como Barbacci (1965), Marín (2004) y Peral (2006) consideran que en la actividad musical se llegan a emplear siete tipos diferentes de memorias: visual, auditiva, analítica, muscular, táctil, rítmica, nominal y emocional. Siguiendo a Marín (2004), vamos a describir cada una de ellas.

1. Memoria visual: Memoria utilizada para retener lo captado a través de la vista. Su aplicación musical consiste en la memorización de los rasgos más significativos de la partitura, la memorización de las posiciones necesarias para la ejecución instumental, así como también el desarrollo de la memoria visual del instrumento.

2. Memoria auditiva: La misión de esta memoria consiste en almacenar los estímulos sensoriales auditivos y, también, aquellos que producen la imaginación auditiva. Se encarga del control auditivo, proporcionando al intérprete juicios de valor acerca de la calidad de la ejecución. El autor destaca que, para desarrollar esta memoria, es necesario que previamente se haya efectuado una educación auditiva dirigida a tres de las cualidades del sonido: altura, intensidad y timbre.

3. Memoria analítica: Es la facultad de analizar y retener lo leído. Esta memoria nos permite recordar todos los aspectos musicales de la obra analizada y estudiada previamente: elementos formales, armónicos, melódicos, rítmicos, etc. Es la más intelectual de las memorias 
musicales y suele ayudar al resto de memorias, salvando de las amnesias en determinados momentos de "lapsus".

4. Memoria muscular y táctil: La primera de ellas, la memoria muscular, es la encargada de recordar, de manera inconsciente, todos aquellos movimientos que son necesarios para la ejecución instrumental de una determinada obra musical. La segunda, la memoria táctil, se ocupa de los aspectos relacionados con la presión y el ataque de cada uno de los sonidos que se interpreten.

5. Memoria rítmica: Nos permite recordar los ritmos y, también, los movimientos rítmicos. Cabe destacar que esta memoria se encuentra relacionada con la muscular, la auditiva, la analítica y la nominal, con las cuales se desarrolla de manera paralela.

6. Memoria nominal: Es una memoria verbal que se encuentra asociada a la memoria auditiva y que se emplea para recordar el nombre de las notas musicales de una determinada canción o fragmento musical.

7. Memoria emocional: Memoria que recoge los aspectos interpretativos de la obra musical, previamente diseñados e interiorizados. Por tanto, hace referencia a aspectos relativos a la velocidad, los matices, la acentuación, etc.

Por su parte, Dierssen (2001) afirma que existe una cualidad musical especialmente relevante para determinados sectores de músicos profesionales, como los directores o los compositores. Se trata de la memoria tonal, o memoria para configuraciones secuenciales de tonos, y de la imaginería auditiva, entendida como la representación auditiva musical en ausencia de sonido físico.

Lauricia (2004) apunta la existencia de diversos factores que inciden directamente en la memorización de la música: la duración del fragmento musical, la memoria a corto plazo del sujeto, sus experiencias musicales previas y las relaciones estructurales internas del mismo. Para conseguir una buena memoria musical también ha de existir repetición, que no es necesario que sea insistente, sino que ha de tener significación. En este sentido, Chapuis (1995) escribe:

El acto de repetir es necesario para poner en marcha, interiorizar y exteriorizar, para adquirir soltura, vocabulario y sintaxis. [...] No es trata de una repetición mecánica, obligatoria, forzada, sino de la repetición gozosa que hace renacer, redescubrir aquello que creíamos conocer. (p. 2)

Por último, cabe destacar que la canción, suma de melodía y texto, es uno de los elementos "primitivos" que más inciden en la ejercitación de la memoria 
infantil. Willems (1995) considera que las canciones ocupan el primer lugar en el desarrollo de la memoria musical.

La memoria rítmica (de orden motriz), la del sonido (de orden sensorial) y la memoria melódica (de orden afectivo) tienen mucha importancia en la educación musical de los principiantes. En las canciones, las distintas memorias están sostenidas por las palabras. Más adelante lo serán por el nombre de las notas, los grados y el conocimiento de los intervalos y los acordes. (p. 22)

En la misma línea, Malagarriga (2002) comenta así la incidencia que las canciones tienen en la memoria:

Cuando el niño ya puede comenzar a cantar, las canciones infantiles que aprenda contribuirán a desvelar su memoria, y esta condiciona la capacidad de pensar el desarrollo sonoro. (p. 32)

\subsection{La percepción y el reconocimiento auditivo musical}

Al escuchar un sonido, una serie de sonidos o una pieza musical se perciben diferentes aspectos de los mismos. Giráldez (1997) señala que "la experiencia y el conocimiento son factores que inciden directamente en la percepción auditiva" (p. 66). En este sentido, Abbadie y Gillie (1976) afirman que la percepción será tanto más elaborada cuantos más conocimientos y experiencia tenga el sujeto: el melómano o el músico, escuchan, oyen mejor, distinguen y analizan de una manera más fina que un sujeto poco cultivado o poco entrenado, quien no presta ninguna atención al mundo del sonido.

En la misma línea, Akoschky (1996) indica que la percepción no se comporta siempre del mismo modo. Hay diferentes maneras de percibir el mismo fenómeno, dependiendo de tres factores: del sujeto, su interés, su experiencia y sus conocimientos previos, de las características y rasgos particulares del objeto a percibir, y de la situación o el contexto en que tenga lugar ese acto perceptivo.

Goetzen y Marro (1999) resaltan la idea de que los procesos perceptivoauditivos complejos no pueden explicarse únicamente empleando términos fisiológicos, sino que es muy probable que estos procesos se encuentren en estrecha relación con niveles cerebrales superiores.

Las capacidades perceptivas de las personas son inherentes a la condición humana pero, concretamente, la percepción auditiva musical es una capacidad innata que hay que desarrollar. Aguilar (2002), en su libro 
Aprender a escuchar música, nos habla de la percepción de las relaciones de las alturas de la siguiente manera:

El aumento o disminución constante de la frecuencia de un sonido [...] es percibido como un continuo infinito de alturas cuyos límites perceptivos -grave y agudo- coinciden con la capacidad del aparato auditivo de identificar sonidos. (p. 102)

Enseñar al estudiante a escuchar (Misas \& Tobón, 2007) supone transmitirle una audición profunda de la música en toda su expresión, de forma que adquiera las herramientas indispensables para su reconocimiento. La agudeza auditiva se desarrolla de dos maneras distintas y complementarias. La primera consiste en diferenciar sonidos, tomados sucesivamente; la segunda, en percibir sonidos simultaneados. En los ejercicios de la primera categoría se puede distinguir entre la sensación de movimiento sonoro y la de altura del sonido (grave-agudo, bajo-alto). "Alto" y "bajo" son términos relativamente convencionales; el movimiento, por el contrario, es indiscutible, porque provoca correspondencias fisiológicas de movimiento en el órgano del oído. Algunos niños no tienen ninguna noción del movimiento sonoro. Cuando ya se ha adquirido la sensación de movimiento sonoro, puede suceder que el niño llame "alto" a lo que nosotros llamamos "bajo" y viceversa, lo cual exigirá una reeducación, partiendo de los grandes movimientos para llegar, posteriormente, a los pequeños, es decir, yendo de las grandes a las pequeñas distancias (intervalos). Inicialmente, el niño transcribirá los movimientos de subida y de bajada utilizando gráficos que le encaminarán, sin darse, cuenta hacia el dictado musical. Por su parte, los ejercicios de la segunda categoría entrenan a los alumnos para percibir simultaneidades de varios sonidos consonantes y disonantes, de manera que aprenderán a disociar los sonidos unidos en un acorde o en un agregado. Este trabajo es tan necesario para el desarrollo sensorial del oído como para el de la conciencia mental sonora.

Bregman (1990) señala que el espacio acústico en el que actuamos suele ser complejo. Denomina escenas auditivas al recorte que realiza la persona cuando aísla del paisaje sonoro la porción de información auditiva a la que está atendiendo; al mismo tiempo que agrega cierta información acústica, procura ignorar la no pertinente. En este sentido, la escucha atenta y reflexiva de la música es un modo de operar sobre señales acústicas identificadas como componentes de discursos musicales, ignorando otras que puedan producirse en simultaneidad. Si dejamos total libertad al desarrollo del órgano auditivo, este se acostumbrará automáticamente a la percepción simultánea, ya sea de un sonido fundamental con sus armónicos (lo que constituye el timbre), ya sea de varios sonidos bajo la forma de un acorde grabado como un todo. Por ello, en la preparación auditiva nos vemos 
obligados a provocar un trabajo de análisis mediante el cual el oído aprende a disociar los sonidos percibidos en conjunto para identificarlos de forma independiente.

Cerraremos este apartado señalando algunas indicaciones fundamentales que aporta Hemsy de Gainza (1964) para iniciar a los alumnos en el reconocimiento auditivo musical. Estas son:

- Es más sencillo reconocer series de sonidos que ascienden o descienden a velocidad moderada que distinguir sonidos aislados de diferentes alturas.

- Cuanto más amplio sea el intervalo entre ambos sonidos más evidente resultará su diferenciación.

- Los intervalos consonantes se priorizarán con respecto a los disonantes en el trabajo melódico, es decir, los intervalos de tercera, cuarta, quinta y octava y la consonancia imperfecta de sexta se imponen a los intervalos de segunda y de séptima.

- La simultaneidad o superposición de elementos atractivos ajenos a la altura dificulta la percepción melódica pura.

- Las melodías que poseen frases muy definidas y que contrastan se escuchan y se cantan mejor que aquellas en las que las frases presentan entre sí leves variaciones.

\subsection{La influencia del canto en la formación del oído musical}

El ser humano puede expresarse musicalmente de diversas maneras, ya sea a través de su propia voz, de un instrumento o de una composición escrita. De todas ellas, la expresión musical por medio de la voz cantada es la que mejor permite manifestar la realidad vital interna de las personas $\mathrm{y}$, por tanto, desarrollar su sensibilidad artística y su comunicación (Ponsatí, 2011). Al respecto, Maideu (1997) se refiere al canto diciendo que "debería ser considerado como el lenguaje propio y genuino de la vida interior de todas las personas" (p. 59).

El valor educativo del canto y los beneficios de su práctica se recogen en numerosos trabajos de reconocidos autores y pedagogos: Ward (1964), Jaques-Dalroze (1965), Orff (1930, citado por Sanuy \& González, 1969), Kodály (1911, citado por Szönyi, 1976), Hemsy de Gainza (1977), Willems (1984), Paynter (1991), Schafer (1992), Martenot (1993), Molina (2005), Campbell (1998), López de Arenosa (2004), Sierra (2008), Sloboda (1993), Díaz y Giráldez (2007), entre otros. 
El canto está presente en la vida de los hombres desde los primeros meses de su vida y, según Barceló (1995), es contemplado como "uno de los medios de expresión más antiguos del ser humano" (p. 47). Asimismo, el canto es considerado una habilidad susceptible de ser desarrollada, por lo que se convierte en un centro de interés para la educación en general y, particularmente, para la educación musical (Maldonado \& Muñoz, 2009). Además, el canto es un medio de comunicación que permite la expresión de emociones y favorece la socialización (Muñoz, 2009).

En este sentido, destacamos la aportación de Pascual (2002), el cual expone algunos argumentos que corroboran la influencia positiva del canto en la formación de los alumnos:

- Cualquier actividad puede y debe ser realizada a través de la práctica de canciones adecuadas: lateralidad, esquema corporal, percepción espacio-temporal, experiencias relacionadas con la audición, actividades de preescritura.

- Es fuente de gran motivación, satisfacción y desarrollo de la autoestima de los alumnos.

- Contribuye al desarrollo del gusto artístico y la sensibilidad estética.

- Trabaja la técnica de la respiración, articulación, emisión y colocación de la voz.

- Favorece el desarrollo del lenguaje en su faceta comprensiva y expresiva (diagnóstica y terapéutica).

- Es un importante medio de socialización e integración grupal. (p. 240)

Tal y como argumenta Hemsy de Gainza (1977), todos los bebés, de manera espontánea, se interesan considerablemente por los estímulos sonoros y musicales que se les presentan, es decir, les llama tanto la atención su presencia que hace que los escuchen, interpreten y reproduzcan cada vez más fielmente. Este interés inicial, asegura la autora, "es, sin duda, el generador de la futura musicalidad del niño" (p. 3) y debería ser aprovechado por los adultos que lo rodean para contribuir a la estimulación de su sensibilidad auditiva. Asimismo, considera que, evolutivamente, la progresión en el aprendizaje tanto de un lenguaje como del lenguaje musical es equivalente, expresándolo de la siguiente manera:

Todas las personas aprenderían a cantar correctamente y, más aún, a leer y escribir sus propias ideas musicales si los padres y maestros se abocaran a la enseñanza del canto con la misma paciencia, convicción y cuidado que los anima a transmitir el idioma materno a sus vástagos (p. 3). 
La mayoría de los pedagogos coinciden al considerar la voz como un instrumento de primer orden, al que califican empleando diversas expresiones: el más perfecto, el más bonito, el más próximo, el más accesible, el más natural... Kodály (1911, citado por Szönyi, 1976), lo expresa de la siguiente manera:

La mejor manera de llegar a las aptitudes musicales que todos poseemos es a través del instrumento más accesible a cada uno de nosotros: la voz humana. Este camino está abierto no solo a los privilegiados sino también a la gran masa. (p. 13)

La voz es también el instrumento que mejor permite desarrollar una buena formación auditiva musical. Según Campbell (1998), "la voz de los niños, dada la infinidad de posibilidades educativas y expresivas que posee, se convierte en un apoyo fundamental para su formación auditiva musical" ( $\mathrm{p}$. 4). Por su parte, para Kühn (2003) "la expresión vocal cantada beneficia firmemente la audición interior del sonido" (p. 17), sin perder de vista, sin embargo, que en el proceso de enseñanza y aprendizaje son diversas las tareas fundamentales que continuamente deberían interaccionar: escuchar, cantar, tocar y escribir. En la misma línea que Kühn, Barceló (1995) destaca la complejidad del fenómeno del canto indicando que "requiere la participación del oído, que es el que, en realidad, tiene el control del sonido" (p. 39). En otras palabras, la acción de cantar es conducida activamente por la escucha del propio canto, motivo por el cual una práctica vocal continuada puede ofrecer la seguridad de conseguir una sólida audición interior, ya que, poco a poco, se va independizando del canto exterior producido. Asimismo, para Willems (1981) el canto es "el principio y el alma de la música" (p. 137) y considera que cantar canciones y temas previamente memorizados constituye, en realidad, la base del desarrollo del pensamiento interior de la música.

Otros autores, como Lacárcel (2001) y Muñoz (2001) afirman que el hecho de cantar, además de influir en la dimensión socio-afectiva y comunicativa de los niños, constituye la base de la construcción del conocimiento musical.

Al hablar de la formación musical, Fuentes y Cervera (1989) destacan que en el aprendizaje de la música hay tres aspectos que están estrechamente relacionados y que se tienen que ir desarrollando de manera simultánea, ya que representan diferentes facetas de la misma realidad: la educación del oído, la educación de la voz y la entonación precisa.

Voz y oído, aunque facultades distintas, coinciden en la entonación, ya que entonar es cantar ajustado al tono, afinando la voz, es decir, respetando las alturas. Para cantar hace falta percibir el sonido (oído) que se quiere 
reproducir, y luego realizarlo (voz) en su justa altura (entonación). Esta capacidad de reproducción es lo que denominamos entonación. (p. 155)

Con estas palabras se comprende que es difícil hablar de la voz sin hablar del oído. Durante el acto de cantar, el oído, que actúa como captor auditivo, recoge una parte de los sonidos producidos para asegurar su control, analiza la producción sonora y envía al cerebro las informaciones requeridas para continuar la actividad del canto, siguiendo los criterios que respondan a la intencionalidad inicial. El oído es, por tanto, un regulador superior. Todo se organiza a su alrededor para que el acto de cantar pueda realizarse de la forma deseada. Mediante bucles de control, envía las órdenes precisas, a través del cerebro y los nervios, a todos los órganos que están implicados en la función del canto, para garantizar que la emisión corresponda a los deseos del órgano de comando.

En este sentido, resulta relevante citar el trabajo desarrollado por Tomatis (1987), que basó su método de reeducación de la escucha en tres leyes:

1. La voz contiene únicamente los sonidos que el oído capta.

2. Si se le da al oído la posibilidad de escuchar correctamente, se mejora instantánea e inconscientemente la emisión vocal.

3. Es posible transformar la fonación por una estimulación auditiva sostenida durante un cierto tiempo (ley de remanencia).

Compartimos con Willems (1984) el convencimiento de que los nombres de las notas son los ganchos que ayudan a retener los sonidos y que, en la educación musical, es preciso utilizarlos tempranamente, tomándolos no como teoría, sino como simple rotulación, como denominación de los sonidos, similar al empleo de las palabras en la vida corriente. Por ello, es conveniente cantar utilizando los nombres de las notas como etiquetas, para asociar el sonido y el nombre y contribuir, de este modo, a un mayor desarrollo del oído musical.

\subsection{La audición interior}

En su obra Las bases psicológicas de la educación musical, el prestigioso pedagogo Willems (1984) define la audición interior como:

[...] el pensamiento, la ideación musical sonora. Esta no significa solamente imaginar notas, sino también escuchar y recibir pasivamente los sonidos de la imaginación. (p. 89). 
Asimismo, en su obra El oído musical, Willems (2001) comenta que el órgano del oído es el intermediario entre el mundo objetivo de las vibraciones y el mundo subjetivo de las imágenes sonoras: "el mundo sensorial solo es la introducción a un mundo más abstracto" (p. 47).

Martenot (1993) reflexionaba sobre la necesidad de desarrollar la audición interior, tanto para la propia formación musical como por su elevado valor educativo, de la siguiente manera:

El desarrollo de la audición interior es indispensable para formar buenos músicos, y el niño -lo mismo que el adulto- debe ejercitarse con frecuencia en pensar frases musicales que escucha interiormente. Esta captación, exteriormente silenciosa y que exige una atención sostenida, tiene un profundo valor educativo. (pp. 21-22)

Entendemos que, "para poder utilizar y manipular el sonido, hay que tener plena consciencia del mismo, tanto cuando está presente físicamente como cuando solo está en nuestra mente" (Ponsatí, 2011). Kühn (2003) lo expresa de esta forma:

A mi entender, el último objetivo de la educación del oído reside en la capacidad de lograr una audición consciente, diferenciadora, inteligente, y también capaz de juzgar, unida a la capacidad de hacer sonar interiormente la música que uno lea, sin oírla. (p. 16)

Esta completa consciencia del sonido nos permitirá manejarlo en los momentos de creación -tanto al componer como al improvisar-, en los de interpretación vocal e instrumental y en los de reconocimiento auditivo. Podemos pensar en el caso concreto de la elaboración de una simple melodía, la cual imaginamos antes de escribirla o de interpretarla por medio de la voz o de un instrumental musical.

López de Arenosa (2004) nos habla de la audición interior en los siguientes términos:

Hablar de oído interno supone hablar del archivo natural que nos hacemos de los eventos sonoros, dándonos capacidad de imaginar sin oír, rememorar lo que hemos oído, escuchado y procesado en diferentes y repetidas ocasiones. Captar, asimismo, desde lo general hasta el detalle de lo que escuchamos, pudiendo llevarlo a la escritura por comparación y asociación con los modelos integrados en nuestras imágenes musicales internas. (p. 117)

Dicha pedagoga musical recoge el proceso de formación de la audición interior en el siguiente esquema: 


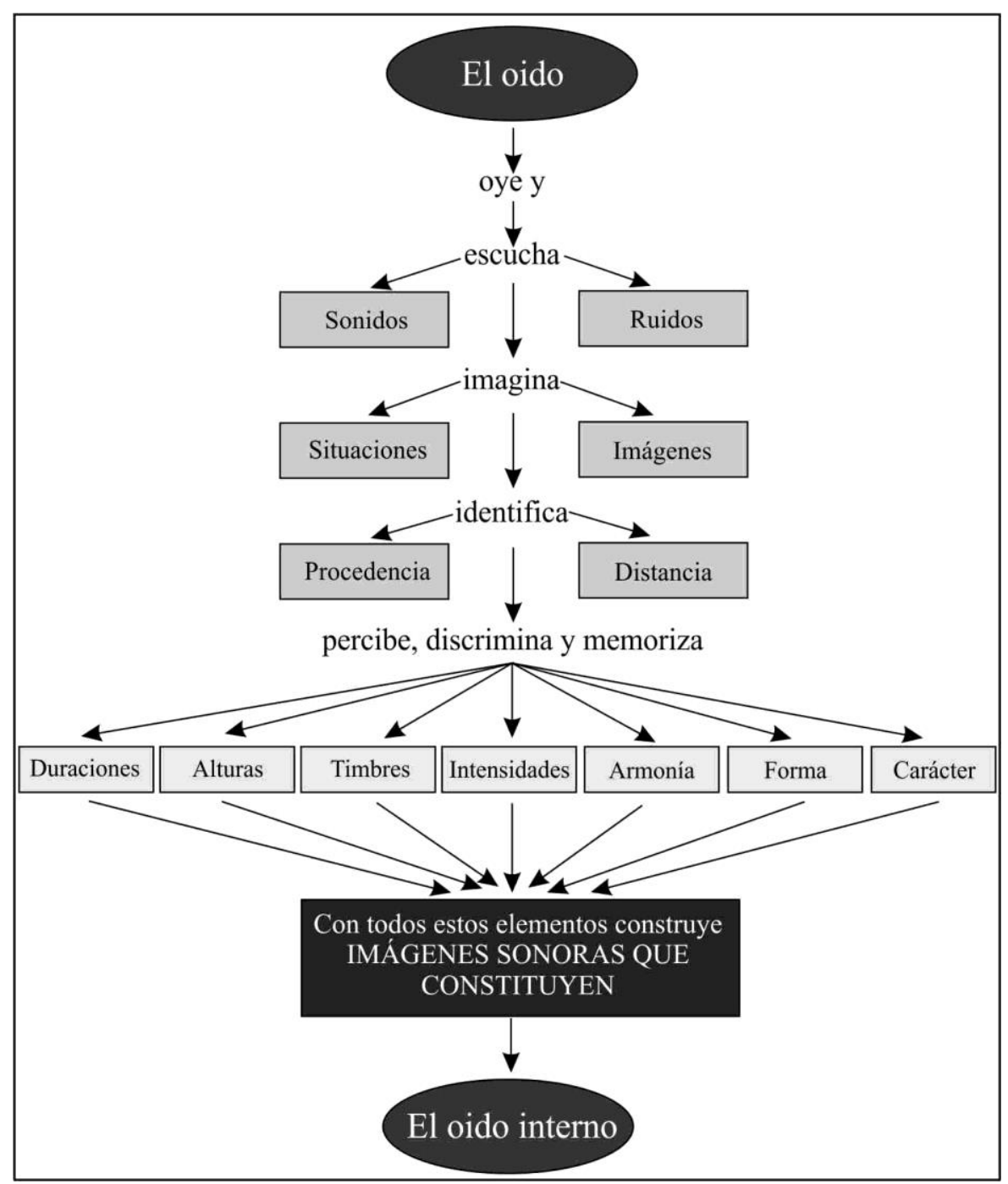

Figura 5. Proceso de formación de la audición interior (López de Arenosa, 2004, p. 114)

A la hora de hablar de la audición interior, Delalande (1995) utiliza la expresión canto interiorizado. Para él, la llamada audición interior, más que un acto de audición, es un acto de cantar, aunque verdaderamente no se emitan sonidos. El autor argumenta su idea diciendo que, pese a que se interrumpen las operaciones mentales relacionadas con la transmisión hasta la boca y el diafragma, sí que se realizan todas aquellas que dirigen el canto. Delalande añade que la adquisición del hábito producir-escuchar permite 
hacer una simulación mental de los gestos de producción, expresándolo de la siguiente manera:

Los niños aprenden a leer en voz alta y solo cuando dominan esto logran leer mentalmente. El canto no se diferente. Me imagino que si jamás hubiéramos cantado no tendríamos ninguna idea de lo que puede ser esa "escucha interior". Por eso, enriquecemos la escucha desde que asociamos un acto corporal a la música, desde que hacemos preceder el hacer al escuchar. (pp. 109-110)

Durante las últimas décadas, en los Estados Unidos, a partir de un extenso número de trabajos de investigación, Edwin E. Gordon ha ido desarrollando su llamada Music Learning Theory. Esta Teoría del Aprendizaje Musical "consiste en un modelo de propuesta didáctica sistemática y secuenciada para la enseñanza y aprendizaje de la música a través de la audiation" (González, 2007a, p. 173), un término que hace referencia al pensamiento musical. Gordon (1997) ofrece una definición simplificada del término audiation:

La audiation es a la música lo que el pensamiento es al lenguaje. Sin audiation, la notación no nos puede enseñar nada; solo nos puede ayudar a recordar lo que ya hemos aprendido mediante audiation. (p. 3)

La audiation es el fundamento de la musicalidad y tiene lugar cuando escuchamos y comprendemos música sin que el sonido esté necesariamente presente. Todos podemos audiate en cierta medida: lo podemos hacer mientras escuchamos, leemos una partitura, tocamos de oído, improvisamos, componemos o escribimos música, pero, de la misma forma que el pensamiento no puede enseñarse, tampoco puede enseñarse la audiation, solamente puede promoverse, estimularse. Por ello, es importante crear situaciones educativas ricas en las que estos procesos puedan generarse repetidamente. El profesorado debe proporcionar a los alumnos, de forma ordenada, aquellos elementos de la música -los patrones tonales y rítmicosque les permitan aprender a audiate por ellos mismos, de la misma forma que aprenden a pensar por sí mismos.

Algunos autores tienden a asimilar la audiation al oído interno o la audición interior, pero Gordon (1997) insiste en que para aquella es imprescindible la comprensión, mientras que no lo es para el oído interno. Por ejemplo, algunas personas tienen la habilidad de audiate plenamente las estructuras sonoras verticales, esto es, los acordes, las funciones, las tonalidades y modulaciones, mientras que otras personas son capaces de comprender las estructuras horizontales de la música y centran su capacidad de audiate en la línea melódica especialmente. 
Desde el ámbito educativo, coincidimos con Giráldez (1997) al considerar que, "si se quiere mejorar la manera de enseñar, es imprescindible conocer la manera de aprender de las personas" (p. 70). De hecho, todo conocimiento, sea o no de tipo musical, se organiza y se representa de alguna manera en nuestra mente. Malbrán (1996) apunta que hay diferentes procedimientos, como probar, repetir, corregir los errores..., que hacen posible la construcción de las diferentes representaciones mentales, cuya posesión permite que, después de haberse consolidado en unidades de pensamiento musical, podamos recurrir a ellas en el momento necesario.

Estamos convencidos de que conseguir una buena audición interior no es ningún tipo de complemento, sino que se trata del objetivo más importante y esencial de la formación musical. Por ello, los docentes deben ayudar a sus alumnos a desarrollarla, creando buenos momentos de aprendizaje en los cuales les estimule y motive a pensar musicalmente de manera autónoma.

\section{Otros aspectos que contribuyen a la educación auditiva}

Para adquirir una comprensión más completa del proceso de la educación auditiva, también hemos considerado necesaria la fundamentación teórica de otros aspectos que consideramos de gran trascendencia. Tal es el caso de la motivación hacia el entrenamiento del oído musical, la reducción de la ansiedad y el desarrollo de la creatividad de los alumnos.

\subsection{La motivación}

Un aspecto importante a tener presente en el entrenamiento auditivo de los alumnos es, según Trallero (2008), "la creación de un ambiente adecuado y motivador que facilite el desarrollo de sus capacidades musicales" (p. 39). Esta opinión es compartida por Hemsy de Gainza (1964), que destaca la necesidad de estimular la curiosidad en la educación sensorial del niño.

Los aspectos emocionales de la música son tal vez los de mayor impacto en la experiencia. La música puede representar emociones, pero también suscitarlas (Juslin, 2005). Escuchar implica estar atento a lo que se quiere oír y esta atención voluntaria es lo que permite al oyente elegir entre los distintos estímulos sonoros que recibe de forma simultánea, en función de sus intereses o motivaciones (Abbadie \& Gillie, 1976):

La atención, indispensable para el acto de escuchar, puede ser mayor o menor, y mayor o menor será la audición que de ella se deriva. Cuanto más nos interesa, sorprende, indigna, trastorna lo que escuchamos, más atención ponemos y más nos olvidamos de lo que no es objeto de la audición. (p. 78) 
En este mismo sentido, Delalande (1995) afirma que:

Hay, por lo menos, una condición psicológica que debería respetarse: la motivación. Solo escuchamos, en efecto, lo que tenemos buenas razones para escuchar. Sin motivación no hay escucha. Esa es una ley general. (p. 92)

Otro aspecto fundamental a tener en cuenta desde el ámbito de la educación auditiva es la relación que se establezca entre el profesor y los alumnos, ya que contribuye decisivamente en el grado de motivación hacia las actividades propuestas y facilita la construcción de aprendizajes significativos. Utilizando la terminología de Reddin (1997, citado por Gallego et al., 1999), los profesores de música se deben caracterizar por ejercer una dirección "integradora". Deben ser personas a las que les guste "formar parte de las cosas, unir y hacer grandes esfuerzos para conseguir involucrarse tanto con las personas como con los grupos con los que trabajan" (p. 302). Además, han de ser personas a las que les guste la comunicación tanto personal como grupal, que estén orientadas hacia el futuro y que privilegien el trabajo en equipo.

Por tanto, el profesor debe ser un líber capaz de constituir un grupo de música emocionalmente inteligente, aumentando la autoconciencia grupal. Es necesario encauzar las emociones de los estudiantes para sacar lo mejor de estos (Gallego \& Gallego, 2004). Solo cuando los miembros del grupo sean capaces de enfrentarse a su entorno emocional, se podrán llevar a cabo procesos de toma de decisiones que promuevan el cambio y conduzcan al éxito deseado (Goleman, 2002).

Coincidimos con la opinión de Goleman acerca de que liderar es una tarea claramente emocional, ya que para establecer una serie de normas e incrementar la armonía y participación del alumnado se necesita un elevado desarrollo de las habilidades emocionales. Es importante que el docente, como líder, esté en contacto continuo con las emociones para conseguir ser empático, requisito indispensable para que el educando actúe con creatividad y de forma eficaz. Tal y como señalan Balsera y Gallego (2010), "el profesor debe encauzar las emociones en una dirección positiva para generar un entorno emocional apropiado" (p. 64). Para conseguirlo, es necesario utilizar estilos de liderazgo que promuevan el rendimiento, como el estilo visionario, el democrático, el afiliativo o el socrático. 
Tabla 2:

Los estilos de liderazgo del profesor de música (Balsera \& Gallego, 2010, adaptado de Goleman, 2002)

\begin{tabular}{|c|c|}
\hline Estilo de liderazgo & Características \\
\hline Visionario & $\begin{array}{l}\text { El profesor determina la dirección que } \\
\text { debe seguir el alumno sin imponer la } \\
\text { forma en que debe actuar, dejando } \\
\text { libertad para la innovación. }\end{array}$ \\
\hline Democrático & $\begin{array}{l}\text { El docente promueve la participación de } \\
\text { los alumnos y se muestra interesado en } \\
\text { conocer los pensamientos y } \\
\text { preocupaciones de sus estudiantes. } \\
\text { Importancia del trabajo en equipo, la } \\
\text { gestión de los conflictos y la influencia. }\end{array}$ \\
\hline Afiliativo & $\begin{array}{l}\text { Comparte abiertamente las emociones. Al } \\
\text { profesor le interesan de igual manera los } \\
\text { objetivos y las necesidades emocionales } \\
\text { de sus alumnos. Juega un importante papel } \\
\text { la empatía. }\end{array}$ \\
\hline Socrático & $\begin{array}{l}\text { Se centra en las relaciones personales. } \\
\text { Desde esta perspectica, el docente } \\
\text { aconseja, estimula y guía a sus alumnos } \\
\text { para desarrollar todas sus habilidades. } \\
\text { Los estudiantes se sienten motivados y } \\
\text { apoyados por el profesor, por lo que } \\
\text { tienden a asumir más responsabilidades. }\end{array}$ \\
\hline
\end{tabular}

Por otra parte, cuanto más llamativos y diferentes sean los métodos utilizados en el aula de música para la educación del oído, mayor efectividad tendrán. Segovia y Beltrán (1998) proponen una reforma en el modelo del sistema educativo, desarrollando una metodología acorde con lo que denominan "Aula Inteligente". Estos profesores definen el Aula Inteligente como:

[...] una comunidad de aprendizaje cuyo objetivo principal es el desarrollo de la inteligencia y de los valores de cada uno de los alumnos, que planifican, realizan y regulan sus propias actividades con la mediación de los profesores, que utilizan métodos didácticos diversificados y proponen tareas auténticas, evaluadas por alumnos y profesores, en un espacio multiuso y tecnológicamente equipado, en el que se vive la cultura de la calidad y la mejora permanente. (p. 265) 


\subsection{La reducción de la ansiedad}

Miguel-Tobal (1990) define la ansiedad como:

Una respuesta emocional o patrón de respuestas (triple sistema de respuestas) que engloba aspectos cognitivos displacenteros, de tensión y aprensión; aspectos fisiológicos, caracterizados por un alto grado de activación del sistema nervioso autónomo y aspectos motores que suelen implicar comportamientos poco ajustados y escasamente adaptativos. La respuesta de ansiedad puede ser elicitada tanto por estímulos externos o situacionales como por estímulos internos al sujeto (respuestas anticipatorias), tales como pensamientos, ideas, imágenes, etc., que son percibidos por el individuo como peligrosos o amenazantes. (p. 310)

La gran exigencia de los estudios musicales provoca, en numerosas ocasiones, que el alumnado se vea sometido a situaciones de tensión extremadamente duras (Balo, Lago \& Ponce, 2014). Al respecto, Gallego et al. (1999) exponen que la ansiedad puede tener su origen en las siguientes causas: un déficit en las habilidades sociales y emocionales, una evaluación cognitiva errónea de su respuesta emocional y/o una exposición repetida a experiencias aversivas en situaciones sociales o personales.

Balsera y Gallego (2010) señalan que, en los músicos, la ansiedad se manifiesta de forma física, conductual o cognitiva, tal y como recoge la siguiente tabla.

Tabla 3:

Manifestación de la ansiedad en los músicos (Balsera \& Gallego, 2010, p.53)

\begin{tabular}{|c|c|c|}
\hline Señales físicas & Señales conductuales & Señales cognitivas \\
\hline - Taquicardia & - Dificultades para & - Mente en blanco \\
\hline - Temblores & dormir & - Ideas de perfección \\
\hline - Sudoración & - Inquietud & - Distracción \\
\hline - Tensión muscular & - Dificultad para & - Preocupación por \\
\hline $\begin{array}{l}\text { - Ganas de orinar con } \\
\text { frecuencia }\end{array}$ & & $\begin{array}{l}\text { cometer trampas o } \\
\text { quedarse paralizado }\end{array}$ \\
\hline \multicolumn{3}{|l|}{$\begin{array}{l}\text { - Sensación de } \\
\text { opresión en el pecho }\end{array}$} \\
\hline $\begin{array}{l}\text { - Disminución o } \\
\text { aumento del apetito }\end{array}$ & & \\
\hline
\end{tabular}


Los alumnos necesitan controlar esa ansiedad y ser capaces de enfrentarse constructivamente a sus miedos e inseguridades. El autocontrol de los propios sentimientos y el manejo adecuado de las emociones son síntomas de madurez personal y desarrollo emocional. El autocontrol es una herramienta que evita que nos dejemos llevar por los sentimientos en un momento determinado, "una capacidad para afrontar los contratiempos emocionales que nos deparan los avatares del destino y que nos emancipa de la esclavitud de de las pasiones" (Goleman, 1996, p. 94). Compartimos la idea de Gallego et al. (1999) acerca de que:

[...] el autocontrol puede ser enseñado y aprendido y debe convertirse en un objetivo pedagógico en el sentido de que implica asumir responsabilidad, determinar secuencias de acciones y generar previsiones, al mismo tiempo que es un medio necesario para lograr la autonomía. Por ello, es imprescindible seleccionar técnicas y elaborar estrategias para generar en niños, jóvenes y educadores modos de control de las propias emociones y reducir así su vulnerabilidad a condiciones externas e internas. (p. 79)

El dictado musical, es decir, la escucha y posterior transcripción de fragmentos musicales, es una actividad habitual en las enseñanzas de Lenguaje Musical de los conservatorios que suele ir acompañada de connotaciones negativas para los alumnos y, como consecuencia de ello, del desagrado en su realización. Así lo expresan Gallego et al. (1999):

[...] parece evidente que el trabajo auditivo en el aula de Lenguaje Musical requiere una revisión profunda y meditada. Las opiniones expresadas por los alumnos y los comentarios en relación a qué emociones experimentan cuando realizan un dictado musical son aspectos a tener muy en cuenta a la hora de buscar mejoras en el momento de diseñar y realizar la intervención en el aula (p. 9).

En este sentido, Kühn (2003), en su libro La formación musical del oído, advierte que el estado personal de un alumno puede influir de manera decisiva en el entrenamiento auditivo, hasta el punto de aumentar o disminuir la capacidad auditiva del oyente, motivo por el cual constata la necesidad de crear un ambiente relajado que propicie la atención y la concentración. "Una concentración relajada es una de las claves de la capacidad auditiva" (p. 10). Además, nos dice el autor que, en muchas ocasiones, "el hecho de trabajar en grupo puede ser un factor negativo, ya que es realmente difícil agrupar a los alumnos teniendo en cuenta su capacidad auditiva" (p. 9), lo cual puede generar ansiedad a los que tengan mayores dificultades al comprobar que otros no las poseen.

La musicóloga Eloise Ristad (1997, citada por Maxwell, 2000) afirma que, "cuando nos damos permiso para fallar, al mismo tiempo nos estamos dando 
permiso para superarnos" (p. 32). Partiendo de esta premisa, creemos en la necesidad de desterrar los fallos en el aula de Lenguaje Musical y de convertirlos en experiencias que ayuden a nuestro alumnado a crecer musicalmente, aprendiendo de ellos y no condenándolos. Aprender consiste en adquirir conocimientos a través del error, analizándolo y rehaciendo el aprendizaje.

Siguiendo a Sanmartí (2007), sabemos que los estudiantes de éxito son aquellos que cometen errores, los detectan y los superan. Como no todos tienen esa capacidad, es tarea del profesor promoverla, enseñando a los alumnos a reconocer sus errores y a analizarlos, motivándoles para que tomen sus propias decisiones acerca de qué aspecto cambiar con el fin de mejorar y permitiéndoles el derecho de disfrutar tanto en el proceso como en el resultado final.

Resumimos todas estas ideas señalando que en toda actividad de educación auditiva se debe instaurar una atmósfera adecuada de relajación y de disfrute, sin dramatizar los errores y convirtiéndolos en experiencias de aprendizaje.

\subsection{El desarrollo de la creatividad}

La creatividad es la capacidad de hacer o crear algo nuevo, diferente y original. Entre las definiciones de distintos autores que recoge Torre (1995), destacamos tres:

- Creatividad es la capacidad para generar algo nuevo, ya sea un producto, una técnica, un modo de enfocar la realidad (Gervilla, 1992).

- Capacidad o aptitud para generar alternativas a partir de una información dada, poniendo el énfasis en la variedad, cantidad y relevancia de los resultados (Guilfrod, 1971).

- Capacidad y actitud para generar ideas nuevas y comunicarlas (Torre, 1991).

La creatividad es una dimensión compleja de la personalidad del individuo que implica la movilización de una serie de procesos mentales para la elaboración de productos nuevos y originales. Debido a esta peculiaridad, en el ámbito educativo, y más concretamente en la educación musical, el trabajo creativo propiamente dicho se suele dejar al margen en detrimento de otras actividades menos complejas y más mecánicas como son la práctica vocal, instrumental o corporal. Sin embargo, consideramos que los centros del siglo XXI dirigidos a la formación musical, sin dejar al margen la enseñanza de 
los conceptos y las destrezas musicales, deben desarrollar la creatividad en los alumnos si pretenden alcanzar su formación integral.

Tal y como indican Hernández, Hernández y Milán (2010), los rasgos de comportamiento de una persona creativa pueden dividirse en aptitudes, intereses, actitudes y temperamento:

La aptitud es la disposición para aprender a hacer cierto tipo de cosas y está influenciada por la interacción entre la determinación genética y la ambiental. El interés es la inclinación o necesidad que conduce a una persona a emprender tal o cual tipo de actividad. La actitud es la tendencia a favorecer o no un cierto tipo de objeto o de situación. El temperamento designa el conjunto de sus disposiciones emocionales: optimismo, melancolía, seguridad o nerviosismo. (p. 12)

Toda persona posee un potencial creativo, pero necesita de unos procesos formativos que le ayuden a desarrollarlo (Bravo \& De Moya, 2006). Al respecto, Rogers (1991) plantea las condiciones que propician el desarrollo de la creatividad en el ámbito educativo: trabajo en grupo, ambiente de libertad, libre expresión, estimulación de ideas nuevas y originales, clima de confianza, de aceptación y respeto a la persona, eliminación de la amenaza de la evaluación, independencia y libertad de proyectar y seleccionar diversas opciones. Por su parte, De Moya (2005) concede una gran importancia al profesor en la facilitación de la creatividad de sus estudiantes, destacando entre las condiciones para una enseñanza creativa la relación entre el profesor y los alumnos, lo cual implica una actitud constructiva, de confianza en las potencialidades de los alumnos, así como el conocimiento de sus características y funcionamiento psicológico.

Las enseñanzas musicales, al trabajar con un material especial y particularmente artístico, pueden contribuir de manera significativa a la canalización de la expresión creativa del alumnado (Hernández, Hernández, \& Milán, 2007). De esta forma, el aula de música es el espacio propicio para llevar a cabo los procesos creativos que, en un entorno de libertad expresiva de ideas, emociones y sentimientos, lleven al estudiante a la manifestación de su rico mundo interior. En este sentido, consideramos que el profesor de música que apueste por la realización de actividades creativas debe primar el proceso de creación y participación de los alumnos y no tanto los resultados.

Lamentablemente, las actividades musicales se han centrado siempre en el canto, en la práctica instrumental o en la lecto-escritura musical, pero la creación musical ha quedado en un segundo plano. Por ello, insistimos en la necesidad de que la educación musical permita al niño descubrir, sentir y expresarse a través del hecho sonoro o, lo que es lo mismo, que el proceso de 
enseñanza-aprendizaje musical vaya encaminado a favorecer el desarrollo de la creatividad (Bernal, 2003).

Estableciendo una comparativa con el lenguaje verbal, Chomsky (1957) señala que el uso creativo del lenguaje, entendido como la capacidad de entender y producir oraciones que uno nunca ha oído antes, es la cuestión fundamental que debe afrontar quien se ocupe de la implementación psicológica de la estructura lingüística. Advierte que el dominio de la lengua materna no puede requerir que uno haya memorizado el conjunto de oraciones posibles, porque eso supondría tanto una capacidad de memoria infinita como un plazo infinito para la exposición a ese conjunto. Por tanto, la capacidad de identificar y producir oraciones nuevas debe ser atribuida a la interiorización de un conjunto de principios o reglas que caracterizan lo que supone la oracionalidad. En este sentido, Jackendoff (1998), parafraseando la observación de Chomsky, señala que en el dictado musical o en la creación de melodías y canciones sucede exactamente lo mismo, "el músico profesional está en condiciones de transcribir lo que escucha sea conocido (familiar) o desconocido (no familiar) para él” (p. 61), de tal modo que debe tener interiorizado un conjunto de principios y reglas que caracterizan conjuntamente lo que supone, para crear o para reconocer, una frase musical. En la misma línea, López de Arenosa (2006) defiende que:

Conocer un lenguaje implica la capacidad de poder utilizarlo de una manera personal. Si, a lo largo de su dilatado período formativo, el músico fuera capaz de utilizar en forma autónoma y consecuente los elementos que va adquiriendo, nos pondríamos en un parangón claro con nuestro uso del lenguaje hablado. (prólogo)

La tradicional formación musical llevada a cabo en los conservatorios centra sus esfuerzos en procurar el máximo desarrollo de las cualidades interpretativas, incidiendo en los ejercicios técnicos y en la repetición y teniendo como objetivo principal, y a veces casi único, la interpretación de un repertorio. Frente a esta tendencia aún tan presente, Molina (2008) defiende que la formación musical "ha de ser equilibrada convenientemente con actividades derivadas del análisis y la improvisación que permitan a los alumnos comprender el lenguaje musical en profundidad y eviten el deterioro paulatino de sus facultades creadoras" (p. 272).

La creatividad es una herramienta fundamental para que el músico no se quede en la repetición de lo que ya está hecho, sino que busque nuevas maneras de expresarse y, de esta forma, se llegue a la evolución del arte de los sonidos con una mirada prospectiva. Gértrudix y Gértrudix (2012) señalan que "los lugares de representación de la música han estado definidos por la equipolencia entre su valor expresivo y su valor de transmisión" (p. 
175). Si el músico es creativo y, además, es un facilitador del aprendizaje, es muy probable que se convierta en un profesor creativo que no tendrá ocasión de ser repetitivo y rutinario. El docente tradicional es memorista, mientras que el creativo es innovador y siempre estará en proceso de cambio.

Finalmente, señalaremos que, para Malbrán (2006), los diferentes avances científicos alcanzados a través de la investigación en psicología de la música ofrecen una gran ayuda a los docentes encargados de llevar a cabo la formación musical auditiva, al aportarles importantes modelos teóricos y aproximaciones metodológicas. Según Malbrán, la comunidad científica considera que, en realidad, aún no se ha escrito una teoría musical fundamentada en aquello que verdaderamente escuchan y entienden los oyentes, sino que la formación musical se ha basado plenamente en las normas de la teoría musical tradicional, dejando de lado los aspectos creativos. En relación con esta idea, hemos considerado conveniente terminar este apartado recogiendo la siguiente reflexión de la autora:

La educación auditiva, como operación de la mente en tiempo real que procesa la gramática y sintaxis musical, exige una nueva concepción de la enseñanza. Es la asignatura clave para la formación musical y, como tal, requiere habilidades musicales (auditivas, de interpretación y de composición) y el arreglo de situaciones de aprendizaje que permitan probar, conjeturar, equivocarse para volverlo a intentar, interactuar con los padres y desarrollar vías propias de especulación musical y conceptual. Su inserción como camino formativo de desarrollo expresivo y mental es el gran desafío que nos debemos los pedagogos, investigadores y diseñadores de currículo. (p. 61)

\section{Aportaciones a la educación auditiva desde distintos métodos de educación musical}

El conocimiento de los principales métodos de educación musical es imprescindible para poder emprender la enseñanza de la música. Unos principios sólidos y unas pautas claras aseguran suficientemente el terreno donde apoyar los pasos que deben ser dados en el camino de la docencia. Al respecto, Díaz y Giráldez (2007) señalan que:

Los últimos ochenta años han sido, probablemente, los más productivos en la historia de la educación musical. Las propuestas metodológicas y teóricas se han ido sucediendo y multiplicando a una velocidad cada vez mayor y, evidentemente, muchas cosas han cambiado y siguen cambiando. Por ello, ahora, cuando en muchos foros se debate cuál será el futuro de la educación musical, parece más importante que nunca revisar el pasado e informase sobre lo que está sucediendo en el presente. (p. 11) 
Existen muchos grados y formas de uso y aplicación de los distintos métodos dedicados a la enseñanza de la música. De acuerdo con Willems (1975), no se trata de seguir a ciegas el dictado de un método, sino de comprender sus principios fundamentales y, para comprenderlos, es imprescindible pasar por la crisis que generan la duda y el cuestionamiento.

No es necesario tener un método, sino método. Porque, al seguir los principios psicológicos se redescubren para uno mismo los principios esenciales. Incluso decimos que mientras el profesor no haya redescubierto por sí mismo estos principios, aún no los habrá comprendido. (p. 34)

Por ello, consideramos que un buen pedagogo musical tiene la obligación de conocer y estudiar a fondo los métodos más importantes que existen dentro de su especialidad, pero tiene aún mayor obligación de cultivar su espíritu, su mente, su personalidad, para poder decidir libremente sin naufragar en ellos.

\subsection{Aportaciones de grandes pedagogos musicales reconocidos a nivel internacional}

A principios del siglo XX es cuando empieza a surgir la necesidad de racionalizar y sistematizar la enseñanza musical, que hasta entonces se reducía a adquirir cierta habilidad instrumental o compositiva. El movimiento de revolución y renovación pedagógica conocido como "Escuela Nueva" da a la música el impulso definitivo. Con ella, se termina el tradicionalismo y se instauran los principios de libertad, actividad y creatividad en la educación. A partir de los años 20 y 30 comienzan a notarse sus efectos en la pedagogía musical, surgiendo pedagogos de gran trascendencia a nivel internacional, como Dalcroze, Willems, Kodály, Orff, Suzuki, Ward y Martenot, entre otros, cuyo pensamiento es el punto de partida de una larga serie de transformaciones metodológicas en el campo de la enseñanza y el aprendizaje de la música.

El punto de partida de las corrientes pedagógico-musicales promovidas por estos autores es la consideración de que la música forma parte de la realidad del niño. Así, la educación musical puede ser atendida en una doble vertiente: educación para la música y educación a través de la música. A partir de esta última surge la integración de la música en la escuela ordinaria, para que esté al alcance de todos y no de unos pocos. Aquí la música pierde el carácter elitista que tenía en el anterior siglo XIX.

Los principales criterios que hemos extraído de estos métodos para el trabajo docente presentado en esta tesis son: 
- El descubrimiento del movimiento corporal como factor esencial para el desarrollo rítmico del ser humano. (Dalcroze, Orff)

- El descubrimiento del valor rítmico y expresivo del lenguaje hablado y su relación con el lenguaje musical. (Kodaly, Orff)

- Realización de juegos rítmicos: tarjetas rítmicas, ecos, dictados o preguntas-respuestas. (Martenot)

- La exploración del mundo sonoro que nos rodea. (Murray Schafer)

- La importancia de la improvisación. (Orff)

- El descubrimiento y la valoración del aspecto vocal y de la expresividad y flexibilidad rítmico-melódica. (Ward)

- Utilización del propio folklore como punto de partida del aprendizaje del lenguaje musical. (Orff, Kodaly, Willems)

- Uso de la fononimia. (Kodaly, Ward, Martenot)

- Utilización de instrumentos corporales y de pequeña percusión. (Orff)

- La importancia de la relajación corporal y de la respiración. (Ward, Dalcroze, Suzuki, Martenot)

- La inseparabilidad de toda pedagogía de una psicología general y evolutiva. (Willems)

- La utilización de lenguajes propios de la música contemporánea, la creatividad y la escucha múltiple. (Murray Schafer)

- El uso de musicogramas para la representación de fragmentos u obras musicales. (Wuytack)

En la actualidad, siguen apareciendo métodos que aportan nuevos enfoques a partir del trabajo directo con los niños, pero, a pesar de que los distintos métodos puedan parecer distantes en sus propuestas, siguen unos principios o fundamentos básicos generales y comparten muchos de sus objetivos. Dicho de otra forma, en cuestión de principios, las coincidencias son mayores que las divergencias y la diversidad, únicamente, se encuentra en los contextos, las estrategias, los recursos o los materiales necesarios para alcanzarlos.

En este sentido, basándonos en Miranda (2003), consideramos relevante destacar que las diferentes metodologías del siglo XX y de los primeros años 
del siglo XXI, por lo que respecta a la educación auditiva, coinciden en los siguientes aspectos fundamentales:

- El desarrollo auditivo de los niños se ha de realizar en las primeras edades, adecuándolo siempre a su nivel.

- Antes de la comprensión, interpretación o creación hay que realizar un trabajo sensorial rítmico y melódico.

- Utilizar la voz, ya que es el instrumento musical más propio y natural que puede desarrollar el hombre, cuidando el sonido y la afinación.

- La audición interior, como actividad intelectual en la cual la música se nos representa en nuestro interior.

- Hacer un trabajo con un sentido musical y globalizador en el cual se presente la música escrita por grandes compositores.

- Realizar un trabajo conjunto de todos los elementos musicales que intervienen en el hecho sonoro, pero también un trabajo separado correspondiente al ritmo, a la melodía y a la armonía.

- Presentar y utilizar textos musicales, ya sean de compositores clásicos o modernos.

- Análisis conceptual de los aspectos formales y tímbricos de obras escuchadas.

- El análisis y el aprendizaje de la teoría musical ha de hacerse siempre como consecuencia de la necesidad de entender, de analizar y de descifrar el hecho sonoro que se propone.

- Cantar todo lo que se descifra es una forma de asegurar y dar consistencia a los ejercicios de reconocimiento.

- En el trabajo de la educación auditiva hay que crear siempre un ambiente motivador que estimule el interés por el análisis del mundo sonoro que nos envuelve.

\subsection{Aportaciones de pedagogos musicales españoles}

Durante el primer tercio del siglo XX, los principios de la Escuela Nueva dejaron sentir su influencia en la educación musical; la pedagogía musical empezó a adoptar un carácter más definido que buscaba lenguajes más activos, creativos y participativos. 
En España, durante el siglo XX, y a pesar de que la atención a la educación musical comenzó con más de cincuenta años de retraso con respecto a otros países europeos, han destacado una serie de músicos-pedagogos cuya preocupación ha sido difundir la enseñanza de la música en la educación general, bien impulsando los métodos musicales creados fuera de España o mediante la creación de métodos propios de enseñanza. Entre ellos podemos citar a Joan Llongueras i Badía, Ireneu Segarra i Malla, María Rosa Funt Fuster, Montserrat Sanuy Simón, Luis Elizalde Ochoa y María De los Ángeles Conculleuga Mazcaray. Para un mayor conocimiento de dichos autores puede consultarse Díaz y Giráldez (2007).

A pesar de que la mayoría de los músicos y pedagogos españoles se han dedicado a estudiar cómo plantear la enseñanza musical en la educación general, en los últimos años empieza a apreciarse también una mayor preocupación por renovar los métodos de enseñanza en los centros que ofrecen una formación musical profesional, como es el caso de los conservatorios.

En este sentido, consideramos relevante destacar los planteamientos pedagógicos de los tres expertos entrevistados en esta investigación (cuya trayectoria profesional se detalla más adelante en el apartado 4.2.1.1. del capítulo VI de la tesis), dado el peso que han tenido para nosotros como base en la elaboración de la misma. Son muchas las propuestas que estos autores hacen en sus publicaciones, pero aquí vamos a señalar únicamente las que nos han servido directamente como punto de partida y fundamentación teórica de esta tesis.

\section{A). Emilio Molina Fernández (Metodología IEM)}

El Instituto de Educación Musical (IEM) es una asociación sin ánimo de lucro dirigida por Emilio Molina y fundada en 1997, aunque hay libros publicados ya desde el año 1984 que iniciaban este gran proyecto sin ser del todo conscientes. Esta asociación está formada por un heterogéneo y nutrido número de profesores procedentes de toda España y centra sus esfuerzos en promover y potenciar un renovador sistema para la enseñanza y el aprendizaje de la música, denominado La improvisación como sistema pedagógico.

El conjunto de las ideas y las publicaciones emanadas de esta asociación forma la Metodología IEM, que se perfila como una nueva forma de afrontar la enseñanza musical en cualquiera de sus niveles y especialidades, partiendo de la premisa de que la interpretación, entendida como un derivado exclusivo de la técnica, no puede constituir el objetivo primordial de la educación musical instrumental en los conservatorios y centros musicales profesionales. 
Si unimos al objetivo técnico la comprensión de la partitura que proporciona el análisis, tendremos un músico más completo que podrá disfrutar de su instrumento tanto si llega a ser un gran intérprete como si no. El análisis musical nos acerca a las frases, los motivos, la armonía, los patrones, la sintaxis, el discurso, la conducción, el descubrimiento de las ideas que dan origen a la obra, su desarrollo y evolución, su expansión, sus puntos culminantes y su desenlace. Por ello, Molina (2008) afirma que "el análisis es la herramienta principal de un músico ante una partitura" (p. 258).

La Metodología IEM se fundamenta en el desarrollo integral de la creatividad, ya que parte de que "la improvisación motiva el aprendizaje de la música actuando como motor en la adquisición y práctica del conocimiento" (Cañada, López, \& Molina, 2005, p. 5), y requiere del profesor una perspectiva totalmente distinta a la tradicional, que estaba basada en leer y repetir. La improvisación, apoyada en el análisis (fuente de conocimientos), posibilita la aprehensión de los conceptos y refuerza su asimilación y permanencia. Los recursos que nos aporta la improvisación se derivan de un tratamiento metodológico consciente y estratificado que tiene en cuenta la forma, la melodía, la armonía y la textura. Molina (2008) señala que la improvisación nos ayuda a interiorizar las reglas que rigen el lenguaje, aportar recursos de trabajo adaptables a cualquier alumno y nivel, desarrollar la capacidad auditiva, potenciar la memoria, impulsar la capacidad interpretativa, alimentar la expresividad y la imaginación creadora. Con todo, hay que resaltar, además, que la improvisación no es un fin en sí misma, sino una consecuencia del conocimiento del lenguaje.

Las aportaciones más características de las propuestas pedagógicas de la Metodología IEM se pueden resumir en las siguientes (Molina, 2008):

- Globalización, coherencia y visión integral. Las ideas propuestas son aplicables a cada uno de los niveles y materias de la educación musical.

- La utilización de la improvisación.

- La incorporación temprana de la armonía, ya que se considera que las herramientas armónicas, al igual que las rítmicas, las melódicas y las formales son indispensables para el trabajo creativo.

- La potenciación del análisis como medio de comprender los procesos musicales, así como la inmediata utilización práctica de los elementos analizados.

- Desarrollo de todos los aspectos creativos y de la investigación del alumno como medio de aprendizaje. 
Actualmente, existe un gran número de publicaciones basadas en dicha metodología y dirigidas al trabajo del lenguaje, la teoría, la educación auditiva, los instrumentos melódicos y armónicos, los grupos corales e instrumentales, el acompañamiento, la armonía y la composición. Los libros dedicados a la asignatura de Lenguaje Musical pretenden conseguir "una formación integral basada en el conocimiento y control del lenguaje musical, desarrollando la creatividad que se deduce y potencia a partir de la comprensión de los elementos sintácticos y morfológicos del sistema tonal" (Molina, 2004, p. 5), que es el que se toma como punto de partida, aunque en niveles superiores se verá enriquecido por la proyección lógica hacia otros sistemas compositivos. El sistema funciona de modo que el alumno aprenda los conocimientos que el profesor desea para poder expresarse musicalmente, de tal manera que "el alumno no recibe ninguna explicación teórica que él no necesite para inventar sus propias canciones" (Cañada, López, \& Molina, 2004, p. 6).

\section{B). Berenice Gómez Briones (Método Cantábile)}

Berenice Gómez Briones es una de las coautoras de Cantábile, uno de los manuales más actuales para la enseñanza y el aprendizaje del Lenguaje Musical en los conservatorios españoles. La edición del libro dirigido al primer curso es del año 2009 y, en años sucesivos, fueron editándose los de los siguientes cursos, hasta completar los cuatro que conforman las enseñanzas elementales de música, ya en el 2012.

Supone una propuesta didáctica adaptada a la LOE (Ley Orgánica 2/2006, de 3 de mayo, de Educación) que trabaja las diversas competencias básicas y está estructurada en distintas unidades didácticas, en las cuales la presentación de los contenidos, la organización, la estructura, la progresión y la metodología se adaptan a la edad, intereses y motivaciones del alumnado.

Este método integra todos campos o parámetros que se trabajan en el Lenguaje Musical: el ritmo, la entonación, la audición y la teoría musical, incidiendo en la psicomotricidad, la creatividad y la lecto-escritura. El hilo conductor de cada unidad es una canción original presentada al comienzo de la misma, la cual contiene todo el material tanto rítmico como melódico que se pretende trabajar.

La intención de las autoras al crear el método era que los alumnos pudieran encontrar en un único libro todo el material necesario para trabajar la asignatura. Asimismo, buscaban conectar directamente con la psicología infantil al presentar, como protagonista, a un niño que les va acompañando a lo largo de las unidades didácticas, ayudándoles a interiorizar conceptos claves para el aprendizaje musical mediante ejercicios, juegos y dibujos con colores que facilitan su entendimiento. Este niño va creciendo en el libro 
destinado a cada uno de los cursos al tiempo que lo hacen los propios alumnos. Además, las situaciones a las que se va enfrentando a lo largo del manual son acordes a las que se puedan encontrar los niños de estas edades (mayoritariamente, entre 8 y 12 años), de forma que se identifiquen totalmente con él.

El método Cantábile hace especial hincapié en cantar, tanto a capela como con acompañamiento (con piano en clase, o con el CD que incluye el método en casa), y en la educación auditiva (dictados), "presentando los contenidos teórico-prácticos de forma clara, relacionados con la canción y dotando al aprendizaje de la teoría de una coherencia y aplicación práctica inmediata" (Escudero, Gómez, \& Pérez, 2009, p. 7). La utilización de las nuevas tecnologías en el aprendizaje del Lenguaje Musical supone un elemento relevante dentro de esta propuesta. Además de aplicaciones para su utilización en la pizarra digital, se ofrece al alumno un material en soporte $\mathrm{CD}$ con los dictados del libro y con los acompañamientos instrumentales de las canciones propuestas. Incluye también un libro del profesor, que supone un material fundamental para el docente, a modo de guía, que le ayudará en todo momento, además de servirle como elemento de apoyo a la evaluación de los alumnos y de su propia actividad docente.

Resulta interesante destacar todos estos aspectos del método, porque este tipo de propuestas didácticas globalizadas, centradas en el alumno y que incluyen recursos que implican la utilización de las nuevas tecnologías son frecuentes en las enseñanzas generales, pero aún resultan muy novedosas en las enseñanzas musicales impartidas en centros especializados, como es el caso de los conservatorios.

\section{C). Encarnación López de Arenosa (Educación Auditiva)}

Esta autora enfatiza la idea de que "la música suena" y que, por tanto, es el oído quien, antes que la vista, tiene que ser el receptor, informador e identificador de lo que suena, desde el ruido hasta el más sofisticado de los sonidos (López de Arenosa, 2008).

En sus numerosas publicaciones, fruto de su trabajo intenso y de su dilatada experiencia en el campo de la educación musical, muestra gran interés por la educación auditiva e insiste en que todo cuanto sucede en una clase de música pasa por el oído, desde la palabra a la entonación, la audición o el instrumento.

Parte del hecho de que la educación auditiva es un concepto mucho más amplio que la simple realización de dictados musicales para obtener una calificación en una materia que, después, no vuelve a existir. Su cometido es el de poder "escuchar y reproducir vocal y gráficamente lo escuchado o 
comentar sus aspectos más salientes, improvisar situaciones similares y reconocer sucesos de la misma naturaleza en la música que se escucha en conciertos y en la que se interpreta", ya que "no educamos para una calificación circunstancial, sino para lograr una actitud permanente de alerta" que lleve a la reflexión sobre lo que se está escuchando (López de Arenosa, 2006, prólogo).

En la música tonal que escuchamos e interpretamos en nuestro contexto socio-cultural aparecen reiteradamente giros melódicos y comportamientos armónicos que podríamos denominar "tópicos", tales como: semicadencias en la dominante, alteraciones características como la ascendente del $4^{\circ}$ grado en el modo mayor, diferentes tipos de escala menor que dan paso a coloraciones modales, y flexiones y modulaciones generalmente a los tonos relativos armónicos. Para que los alumnos puedan llegar a identificarlos y manejarlos con soltura, debe realizarse un trabajo progresivo, que debe iniciarse con la toma de conciencia de todo aquello que los niños ya conocen, de forma inconsciente, por "aculturación" del entorno que les rodea, sin que se haya hecho aún sobre ellos un trabajo de formación ordenada. En este sentido, López de Arenosa (2004) señala que:

[...] los niños pueden identificar con absoluta facilidad aspectos musicales como: el carácter de una pieza, el sonido que les gustaría para terminar algo incompleto, el número de frases que perciben en una pieza breve, el carácter abierto o cerrado de dichas frases, la sensación de desplazamiento armónico y lo apropiado o inapropiado de una armonización, sobre todo en momentos cadenciales. (p. 121)

Por ello, en las audiciones musicales trabajadas en el aula considera fundamental "reproducir, en pequeño esquema, sucesos sonoros que, en un determinado estilo musical, se reiteran un considerable número de veces y van a servir, en consecuencia, de base a unas audiciones progresivamente más amplias y más complejas" (López de Arenosa, 2004, p. 128). De esta manera, los niños adquirirán modelos que se almacenarán en su oído interno y que les servirán de referencia para la percepción de lo escuchado en nuevas ocasiones, de lo visto en distintas partituras o de lo concebido mentalmente.

En el prólogo de su publicación Educación Auditiva: Dictado Musical (2006), da unas pautas al profesorado para la realización de dictados musicales que nos han resultado de gran utilidad para nuestro planteamiento didáctico en el aula, entre las cuales destacamos las siguientes:

- Debe estimularse la memoria musical mediante la reflexión sobre lo que se está escuchando, ya que repetir una y otra vez un mismo fragmento es una falsa facilitación didáctica. 
- La forma de proceder puede ser, por ejemplo, escuchar la totalidad del trabajo un par de veces y solicitar después comentarios a lo escuchado porque, cuando lo escuchado se ha entendido, buena parte del objetivo está lograda, además de resultar notablemente más sencillo escribirlo después con precisión.

- Para facilitar la comprensión, insiste en la importancia de realizar dictados breves que contengan giros, flexiones o modulaciones comunes y hasta casi "reglamentarias" en la música tonal.

Asimismo, plantea el trabajo auditivo en el aula con un carácter de taller, para eliminar la sensación de que se trata de una constatación de habilidades, especialmente acusada cuando los alumnos se enfrentan a la resolución de dictados musicales tradicionales por escrito. El hecho de convertir dicha tarea en un trabajo de reflexión colectiva, comentado, compartido y eliminando el miedo a demostrar incompetencia hace que los avances sean muy favorables y que se entrene un tipo de hábito de escucha que ya no deberán abandonar a lo largo de su vida como músicos, que es de lo que se trata. 


\section{CAPÍTULO III: EL SISTEMA MUSICAL TONAL-ARMÓNICO}

\section{Introducción}

En el campo de la pedagogía musical, los docentes no podemos olvidar que los niños que acuden a nuestras aulas ya saben mucha música, por lo que nuestra misión es aflorarla, haciéndoles conscientes de sus elementos. En este sentido, López de Arenosa (2004) señala que los giros melódicos, las armonías y las cadencias de aquello que cantan y escuchan los niños están dejando unos sedimentos en su estructura cerebral, que son los que permiten crear el lenguaje sonoro. Por ello, consideramos que no tiene sentido empezar a explicarles cuestiones teóricas, como los nombres de las notas y su colocación en el pentagrama, si no pueden relacionarlo con lo que ya saben. En otras palabras, al igual que ocurre con el lenguaje verbal, los niños primero han de tener cierta comprensión intuitiva y práctica de la música que cantan y que escuchan y, cuando esto esté adquirido, ya vendrá el interés por conocer su escritura.

En nuestro contexto socio-cultural, la música que cantamos y escuchamos a diario se rige por las normas del sistema tonal-armónico, al cual dedicaremos el presente capítulo, ya que, según Malbrán (1996), las melodías "se presentan, retienen y analizan con el acompañamiento armónico y como discurso completo" (p. 68).

Comenzaremos este capítulo hablando del sonido musical y señalando sus cualidades. A continuación, nos detendremos en las características del sistema tonal-armónico, abordando los conceptos de tonalidad, armonía y acorde. Finalmente, nos centraremos en el análisis del trabajo auditivo enmarcado dentro del contexto de la tonalidad. 


\section{El sonido musical y sus cualidades}

Como hemos visto en el capítulo anterior (apartado 2.1), a través del oído percibimos fenómenos vibratorios. De la misma forma que, cuando se lanza una piedra al agua, las ondas superficiales se dispersan en círculos, el sonido emitido por una fuente sonora se propaga en ondas sonoras o vibraciones de presión en el aire. La parte de la Física que estudia los fenómenos sonoros, su producción, transmisión y cualidades se denomina Acústica.

Los sonidos pueden ser sencillos, como los tonos puros (con un solo componente de frecuencia), y complejos, como el habla o el ruido (varios componentes de frecuencia). Normalmente, los sonidos que oímos diariamente son de este segundo tipo.

El sonido es el principio originario de la música, sin el cual esta no existiría. A la hora de hablar del sonido musical, hay que tener presentes sus cuatro cualidades (altura, duración, intensidad y timbre), ya que de ellas emergen los elementos fundamentales que conforman el discurso musical: el ritmo, la melodía, la armonía, la textura, la instrumentación y la forma.

- La altura es la cualidad que permite distinguir los sonidos graves de los agudos y depende de la frecuencia, es decir, del número de vibraciones por unidad de tiempo. La unidad de medida de la frecuencia es el hercio $(\mathrm{Hz})$, que equivale a una vibración por segundo. A mayor número de vibraciones por segundo, más agudo será el sonido $\mathrm{y}$, a menor número de vibraciones, será más grave. Gráficamente, la diferencia entre un sonido agudo y un sonido grave podría representarse de la siguiente manera:

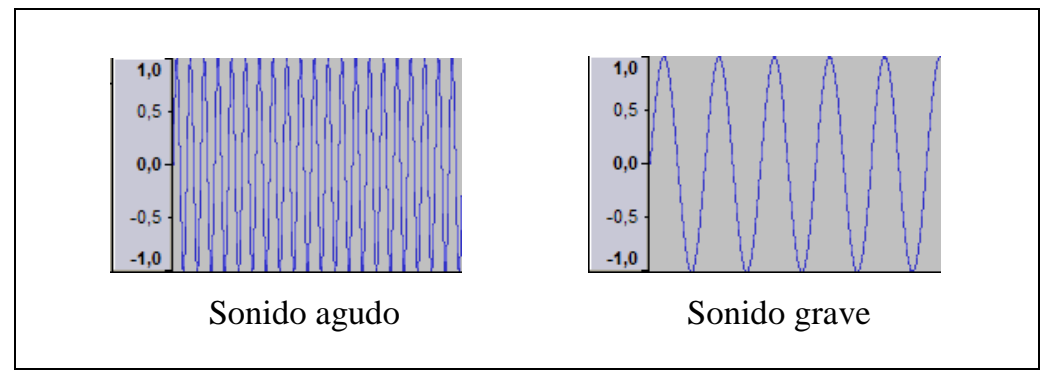

Figura 6. Vibración de los sonidos agudos y graves (INTEF)

El proceso de igualar las frecuencias de las diferentes notas entre los diversos instrumentos y/o con relación a un punto de referencia 
(denominado diapasón, que fija la frecuencia de la nota la3 en 440 Hz.) es conocido con el nombre de afinación. Las distintas familias de instrumentos cuentan con sistemas de afinación diferentes, pero, para poder igualarlos, tienden a una afinación "temperada", en la que todos los semitonos (distancia mínima que puede haber entre dos notas dentro de la música occidental) son iguales.

- La duración se relaciona con el tiempo que permanece la vibración y, gráficamente, se representa de esta forma:

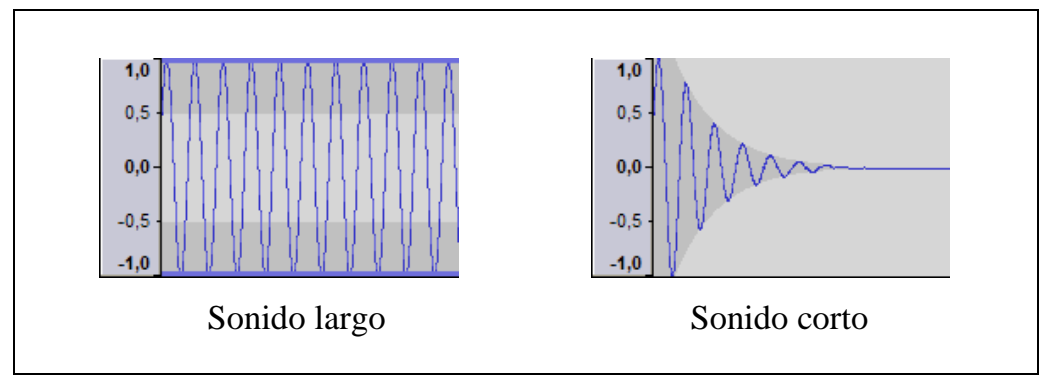

Figura 7. Vibración de los sonidos largos y cortos (INTEF)

El tiempo máximo de permanencia de la vibración está muchas veces limitado por las características del instrumento musical. En música, la medición del tiempo de los sonidos no se realiza uno a uno, sino por comparación con los demás (relación entre las distintas figuras musicales). No obstante, esta referencia relativa de duraciones necesita una referencia superior para poder establecer su duración absoluta, lo cual se consigue mediante indicaciones metronómicas, que se expresan en número de "pulsaciones" por minuto (bpm: beats per minute). Cuanto mayor sea el número de la indicación metronómica, más rápido se interpretará la música y a la inversa.

- La intensidad es la fuerza con la que se manifiesta cada sonido y depende de la amplitud de onda de las vibraciones. A su vez, esta amplitud es consecuencia de la fuerza ejercida sobre el cuerpo sonoro: a mayor fuerza impulsora, mayor amplitud de vibración y, por tanto, mayor intensidad. Su unidad de medida es el decibelio(db). Cada incremento de $10 \mathrm{dbs}$ nuestro oído lo percibe como el doble de intensidad. Los sonidos superiores a los $120 \mathrm{db}$ entran en el denominado "umbral del dolor", es decir, provocan sensación de dolor en el oído humano, volviéndose insoportables. En la representación 
gráfica de un sonido fuerte observamos que posee una mayor amplitud de onda que cuando se trata de un sonido débil:

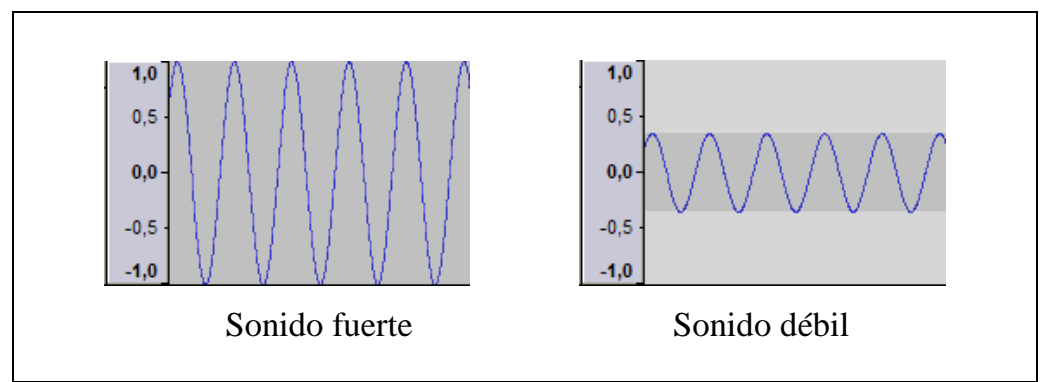

Figura 8. Vibración de los sonidos fuertes y débiles (INTEF)

Los sonidos de los distintos instrumentos musicales no tienen las mismas posibilidades de potencia sonora. Esta realidad se reconoce claramente, por ejemplo, en la disposición de los instrumentos dentro de una orquesta, donde los instrumentos con mayor potencia sonora son colocados hacia atrás. Sin embargo, hoy en día y gracias a los avances de la tecnología de amplificación del sonido, los posibles desequilibrios se pueden compensar con una adecuada utilización de los micrófonos y la mesa de mezclas.

- Por último, el timbre es la cualidad que permite distinguir sonidos idénticos producidos por instrumentos diferentes. Esto se debe a que cada sonido fundamental, o de mayor intensidad, está siempre acompañado de otros (llamados armónicos) cuya frecuencia es múltiplo del mismo. Los armónicos son los que dan al sonido fundamental su color y carácter.

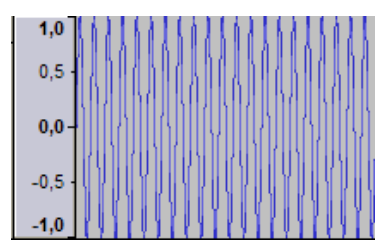

Sonido fundamental

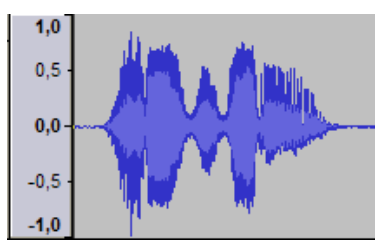

Sonido complejo

Figura 9. Vibración de los sonidos fundamentales y complejos (INTEF) 
Tal y como señalan Loebach et al. (2009), en la percepción de las cualidades de un sonido musical intervienen dos procesos cognitivos:

- Mecanismos sensoriales que gobiernan cómo se traduce la energía física del sonido en el ambiente a los impulsos eléctricos utilizados por el cerebro (proceso "bottom-up").

- Mecanismos perceptuales cognitivos que gobiernan cómo identificamos e interpretamos los sonidos (proceso "top-down").

En el proceso "bottom-up", el cerebro extrae rasgos básicos de la música, usando una red neuronal especializada que descompone la señal original en información acerca de la altura, el timbre, la ubicación espacial, intensidad, reverberación ambiental, duración de tonos, y el tiempo de inicio para diferentes sonidos (y para diferentes componentes de los sonidos complejos). Estas operaciones son llevadas a cabo en paralelo por circuitos neuronales que computan estos valores y que pueden operar independientemente. Así, por ejemplo, el circuito para la altura no necesita esperar que el circuito de duraciones termine para poder realizar sus cálculos.

El proceso "top-down" integra la información de esos rasgos mientras que son extraídos en el proceso "botton-up" y establece predicciones acerca de lo que seguirá a continuación. Estas expectativas "top-down" pueden causar que percibamos falsamente cosas a través de algún replanteo del circuito en los procesadores "bottom-up". Los procesos "top-down" y "bottom-up" se informan el uno al otro en forma constante, de tal manera que, al mismo tiempo que los rasgos están siendo analizados individualmente, también están siendo integrados en un todo perceptual (Levitin, 2006).

Martínez (2005) y Martínez y Anta (2008) señalan que la comprensión de la música está sembrada de procesos de proyección metafórica, donde las metáforas orientacionales juegan un rol fundamental. Pensemos en los siguientes esquemas-imágenes:

- Verticalidad, por ejemplo, al decir la melodía sube, la nota más alta o caer a tierra.

- Adelante-atrás y las expresiones la melodía retorna o volver a la primera frase.

- Origen-camino-meta, que puede encontrarse en resolver en la tónica, comienza en modo menor y termina en el relativo mayor.

Siguiendo esta corriente, encontramos un cuerpo importante de investigaciones (Herrera, 2009; Jacquier, 2009; Kohn \& Eitan, 2009; Larson, 
2004; Martínez, 2008; Pereira Ghiena, 2009; Zbikowski, 2002), que indagan la presencia de estos procesos de proyección metafórica en la comprensión de la música. Los trabajos realizados con niños por Kohn y Eitan (2009) muestran que tales procesos estarían instalados en la cognición desde edades tempranas y aludiendo a los diferentes parámetros musicales.

Por otra parte, Furnó (2003) señala que "los procesos perceptivos, atencionales y de memoria intervienen en el momento de construir las representaciones conceptuales sobre el sonido musical" (p. 91). El hombre construye esquemas clasificatorios de distinta índole que le permiten ordenar los hechos y fenómenos para comprender el mundo. De modo análogo, el conocimiento relativo al sonido en contextos musicales requiere la utilización de principios y categorías que posibiliten su comprensión y acrecienten las posibilidades de obtener placer estético a partir de la escucha musical. Así, los sonidos musicales pueden organizarse según criterios categóricos y estructurarse como abstracciones conceptuales. Comprender mecanismos implicados en procesos de conceptualización supone:

- Explorar semejanzas y diferencias entre los sonidos.

- Abstraer rasgos comunes de sonidos percibidos.

- Encontrar principios que vinculen los rasgos sonoros abstraídos.

- Desplegar estrategias heurísticas para resolver problemas de relaciones entre sonidos.

- Traducir en palabras los rasgos del sonido (denominar atributos, describir similitudes o diferencias, utilizar metáforas).

- Comunicar características del atributo percibido mediante otros códigos (gestos, imitación vocal, etc.).

Finalmente, hemos considerado apropiado concluir este apartado acerca del sonido musical señalando que, durante los últimos años, dentro de la asignatura de Lenguaje musical la educación del oído ha ido adquiriendo mucha más importancia $y$, para conseguirla, se plantean toda una serie de actividades didácticas interrelacionadas basadas en el sonido, tal y como ilustra el siguiente esquema de Cañada, López y Molina (2005): 


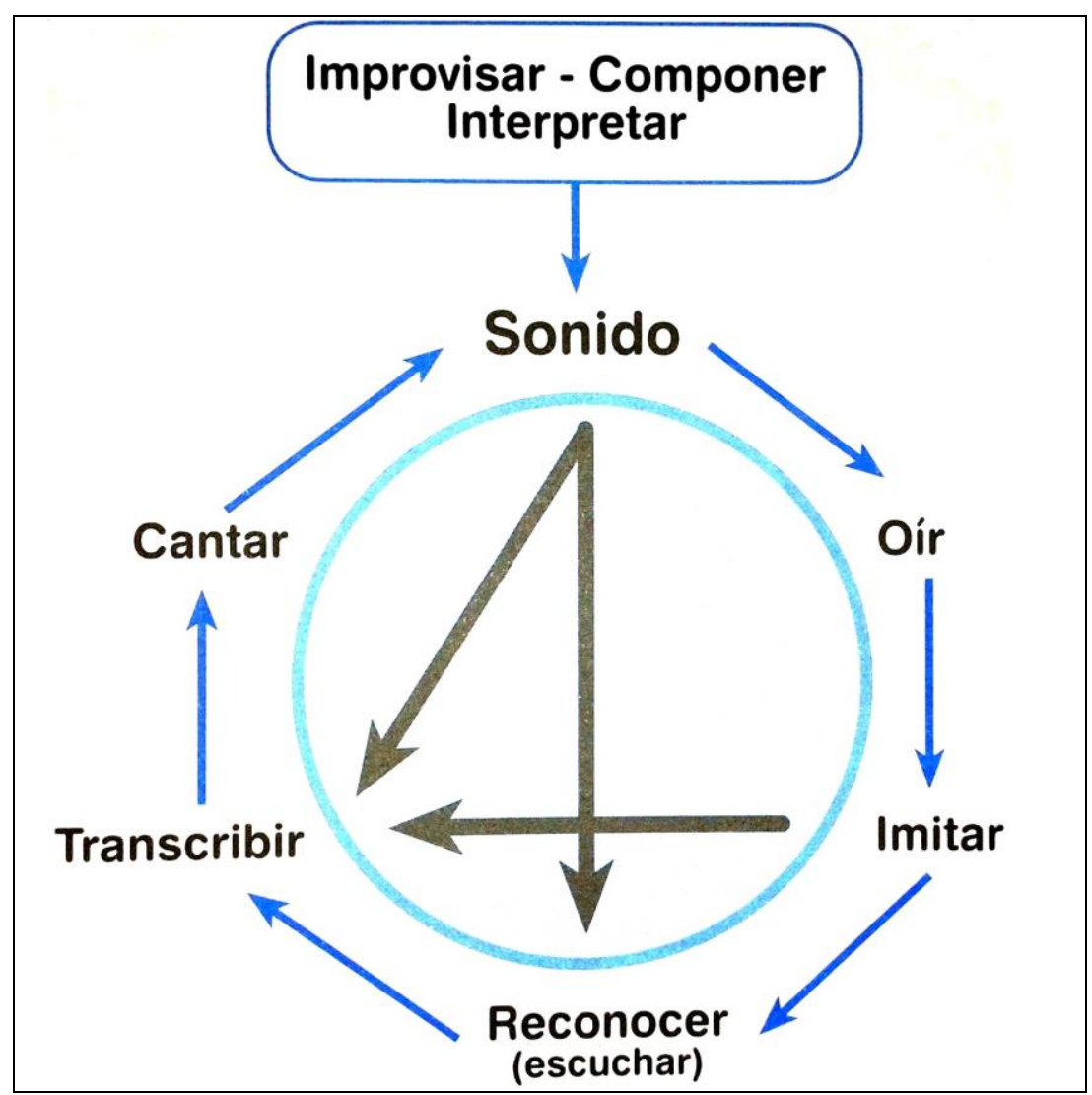

Figura 10. Relación entre las actividades didácticas basadas en el sonido en la asignatura de Lenguaje Musical (Cañada, López, \& Molina, 2005, p. 5)

\section{Características del sistema musical tonal-armónico}

Es frecuente establecer paralelismos entre los lenguajes verbal y musical. Aiello (1994b) atribuye las analogías entre ambos al tipo de estructura que presentan y, también, al hecho de que tanto el uno como el otro transcurren en el tiempo teniendo algún tipo de significado para el oyente. Este autor apunta la idea de que una frase musical es una estructura psicológica y que es la ambigüedad intrínseca a la música lo que la diferencia del lenguaje verbal. Para ejemplificar esta ambigüedad podemos pensar, por un lado, en las numerosas melodías que pueden surgir a partir de un determinado esquema armónico y, por otro, en la gran cantidad de armonías diferentes que puede sugerir una melodía concreta. Tal como señala Aiello, "mientras que el lenguaje verbal tiende a ser más lineal, la música, en cambio, deja lugar a la complejidad y la simultaneidad" (p. 44). 
Ya desde las primeras etapas del estudio de la música son diversos los aspectos musicales del currículo que los alumnos deberían aprender a identificar auditivamente, ya que se consideran básicos y fundamentales: duración, métrica, altura, textura, timbre, registro, dinámica, articulación, carácter, forma, etc.

Es innegable que todos estos aspectos musicales tienen una gran importancia, pero, del mismo modo, no podemos obviar la manera en que se construye la música tonal. Por ello, dedicaremos este apartado a clarificar sus elementos definitorios: la tonalidad, la armonía y el acorde, señalando las investigaciones realizadas al respecto.

\subsection{La tonalidad}

La coherencia de una obra musical tonal descansa fundamentalmente en una determinada manera de organizar las alturas musicales que la componen. El compositor norteamericano y profesor de música en Harvard Walter Piston (1998) define el término tonalidad de la siguiente manera:

La tonalidad es el conjunto organizado de notas alrededor de una tónica. Esto significa que hay una nota central soportada, de una forma u otra, por todas las demás notas. [...] También podemos hablar de tonalidad en un sentido mucho más amplio, abarcando el conjunto concreto de las escalas mayores y menores, los diversos tipos de armonía; así, la música en la época de la práctica común es música que manifiesta la tonalidad en general, y decimos que representa el sistema tonal. (p. 49)

Entendemos, por tanto, que el concepto de tonalidad se utiliza principalmente para designar un sistema jerárquico de relaciones entre las alturas, formando melodías y armonías que están guiadas por el elemento más importante, central y estable, llamado tónica. Al respecto, Ponsatí (2011) señala que:

Melodía y armonía no están en absoluto aisladas ni desconectadas, sino que, entre ellas, se establece una interacción constante, hasta el extremo de afirmar que la una puede considerarse una extensión de la otra. (p. 52)

Para Schönberg (1969), en este sistema, y a partir de una tónica como punto de referencia dado, determinados elementos (notas, acordes o regiones tonales) resultan estructuralmente más importantes que otros, en tanto que son musicalmente más estables.

Mientras que la percepción auditiva de la melodía se realiza generalmente de manera horizontal, la de la armonía, en cambio, suele efectuarse de forma vertical. Teniendo en cuenta solo la melodía, las investigaciones indican que 
el oyente supone ciertas estructuras armónicas a partir del material melódico del que dispone (Lerdahl \& Jackendoff, 1983; Platt \& Racine, 1994). En cuanto a la armonía, Butler (1989) opina que afecta directamente a la memorización de melodías y, también, a los criterios sobre la tonalidad.

La tonalidad se desarrolló a partir del siglo XVII como una evolución del sistema modal y fue perdiendo supremacía desde finales del siglo XIX. A partir de este momento, y con la extensión del cromatismo, se fueron igualando todos los sonidos y, por lo tanto, comenzaron a confundirse las funciones tonales, lo cual no permitía localizar la tónica con facilidad.

Históricamente, el planteamiento que ha predominado en la explicación del fundamento de la tonalidad ha sido el que ha recurrido a la serie de armónicos naturales. Este razonamiento se remonta, por lo menos, hasta Rameau (1683- 1764). Dos partidarios más recientes han sido Hindemith (1946) y Bernstein (1976). Una parte del razonamiento tiene que ver con los sonidos simultáneos. Observamos que, después de cantar al unísono con otra persona, cantar en octavas es lo siguiente más fácil, y esto se hace a menudo sin un esfuerzo consciente. Incluso, tal y como señalan Lerdahl y Jackendoff (2003), "la gente llega a cantar en quintas a veces pensando que están cantando al unísono, pero este fenómeno es menos sobresaliente que el de la octava" (p. 322). Para explicar estos resultados, se ha observado que la octava y la quinta son los intervalos formados por los dos primeros armónicos de la serie de armónicos naturales, tal y como se aprecia en la figura 11:

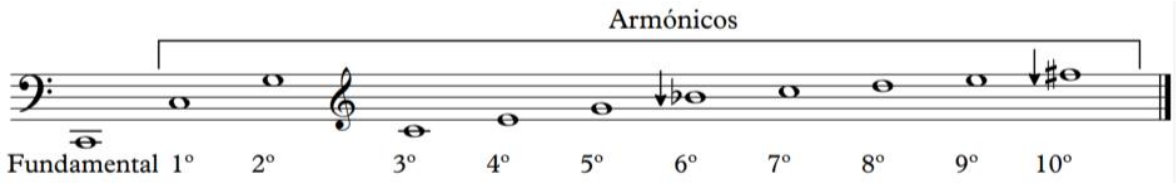

Figura 11. Serie de armónicos naturales de un sonido musical (Lerdahl \& Jackendoff, 2003, p. 322)

La teoría es que podemos considerar similares, más agradables o más fáciles de cantar dos tonos si uno de ellos forma un unísono con un armónico natural del otro o si son armónicos de la misma nota fundamental. De este modo, este razonamiento continúa diciendo que el inventario interválico de la música ha ido aumentando gradualmente en complejidad y sofisticación a medida que la gente ha ido empleando más armónicos naturales (Lerdahl \& Jackendoff, 2003). Esta hipótesis parece explicar ciertos procesos en la historia de la música occidental, ya que después de la quinta, el siguiente intervalo armónico en aparecer, en la Edad Media, fue la cuarta (el intervalo 
entre los armónicos segundo y tercero) y, después de esto, empezó a hacer su aparición la tercera mayor (el intervalo entre los armónicos tercero y cuarto). Al hacer sonar simultáneamente los armónicos del primero al cuarto llegamos al acorde tríada mayor, el elemento fundamental de la música tonal occidental. Asimismo, construyendo una tríada sobre el segundo armónico y sobre el primero, obtenemos el contraste dominante-tónica indispensable en la armonía clásica. Luego, podemos añadir al vocabulario la dominante de la dominante, la subdominante (cuyo segundo armónico natural es la fundamental original) y así sucesivamente, hasta tener el sistema completo de la tonalidad occidental, todo él supuestamente derivado de las consonancias generadas por la serie de armónicos naturales (también conocida como fenómeno físico armónico). Así es el razonamiento de Bernstein (1976) y de Helmholzt (1885), aunque este último lo trata con más cautela.

No obstante, un examen más detallado revela dificultades en este planteamiento, ya que, aunque hubo un período temprano de la historia de la música occidental en que la cuarta era consonante y la tercera disonante, no mucho después de la introducción de la tercera mayor como consonancia, la cuarta entre el bajo y cualquiera de las otras voces empezó a tratarse como disonante, requiriendo resolución. Esta fue su condición en el período clásico. Además, no hay manera de derivar la tríada menor de la serie de armónicos naturales. Es verdad que la tercera menor puede considerarse algo menos estable que la mayor, pero en el período clásico se trató como consonancia. Como la cuarta (generada por la serie de armónicos naturales) es disonante y la tercera menor (no generada por la serie de armónicos) es consonante, puede concluirse que la derivación de la serie de armónicos naturales no es una condición ni suficiente ni necesaria para la consonancia. Dicho de otra forma, como más allá de la octava, la quinta y, quizá, la tercera mayor es difícil hacer ninguna conexión útil entre la serie de armónicos naturales y la tonalidad, queda demostrado que la tonalidad no es simplemente la respuesta del hombre a los aspectos físicos del sonido, sino que más bien, como el lenguaje, la tonalidad proporciona en la música indicios para una organización cognitiva con su propia lógica. Utilizando las palabras de Lerdahl y Jackendoff (2003):

La mente no sigue simplemente el camino físico de menor resistencia, como diría la hipótesis de la serie de armónicos naturales, sino que crea su propia manera de organizar combinaciones de tonos en esquemas coherentes. (p. 325)

Desde el punto de vista de la cognición musical, diversos estudios consideran que la formación auditiva se fundamenta en dos grandes 
universos: la configuración métrica y la configuración tonal. Malbrán (2007a) lo argumenta diciendo:

Los investigadores en cognición musical consideran las jerarquías métrica y tonal como los grandes organizadores de la comprensión musical. Adscribir la configuración métrica y tonal a un sistema internamente consistente es una herramienta fundamental para analizar auditivamente la música tonal. (p. 7)

En relación con la estabilidad de algunas notas, acordes o regiones tonales, la psicología de la música ha validado experimentalmente diversas hipótesis propuestas por la teoría musical (Bharucha, 1984; Krumhansl \& Kessler, 1982). Los resultados indican que, en un contexto tonal de referencia, determinados elementos se perciben más compatibles o estables que otros. Los elementos menos compatibles o inestables tienen la necesidad de resolver hacia un elemento de mayor estabilidad: el centro tonal.

Por tanto, la percepción y elaboración de las relaciones tonales compromete al auditor en una serie de procesos mentales por medio de los cuales las relaciones entre los sonidos de la obra musical -desde una perspectiva psicológica- se representan en la mente de un modo jerárquico. Dicha jerarquía puede explicarse en términos de que la mente atribuye a los sonidos una importancia y una posición relativa dentro del sistema tonal, a partir de la adjudicación de una tónica (Krumhansl, 2004). Asimismo, en la audición de las alturas intervienen procesos de naturaleza psicoacústica que aluden a los aspectos sensorial y perceptivo de la audición (Parncutt, 1988; Terhardt, 1978).

En la misma línea, Dowling (1994) destaca que "las notas de una melodía se entienden como un tejido de relaciones contextuales relacionadas con otras notas de la melodía en el marco de una tonalidad y no como estímulos individuales aislados" (p. 149). Por ello, las melodías son más fácilmente reconocidas y retenidas si se presentan en un contexto tonal asequible.

Por último, refiriéndose a la configuración tonal, queremos destacar a Deutch y Feroe (1981), los cuales señalan que, "en el momento de escuchar un fragmento musical, se activan determinadas normas musicales que tenemos alojadas en la memoria a largo plazo" (p. 503). En este sentido, Malbrán (2007a) afirma que "hay consenso en considerar que todas las personas que comparten la música tonal disponen de unos esquemas internos que son la base de las relaciones entre las alturas del sistema tonal" (p. 69), reforzados por los patrones armónicos presentes en nuestra cultura y que hemos ido asimilando por aculturación. Dichas progresiones armónicas han sido objeto de distintos estudios, como veremos a continuación. 


\subsection{La armonía}

El término armonía tiene muchos significados, tanto musicales como extramusicales, relacionados de alguna manera entre sí. Deriva del griego

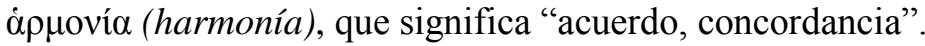

En general, la armonía es el equilibrio de las proporciones entre las distintas partes de un todo y su resultado siempre connota belleza. Desde el ámbito musical, el estudio de la armonía presenta dos versiones: el estudio descriptivo, es decir, las observaciones de la práctica musical, y el estudio prescriptivo, es decir, la transformación de esta práctica musical en un conjunto de normas de supuesta validez universal.

A lo largo de la historia de la música, el término armonía ha presentado diferentes significados, los cuales son fruto directo de la evolución de la audición musical en Occidente. Este hecho, según Alain (1981), "constata con claridad la relatividad del lenguaje musical, así como también las indefinidas posibilidades de adaptación del oído musical" (p. 6). En este sentido, en la antigua Grecia el término Harmonía se empleaba para designar los diferentes modos o escalas que constituían el sistema musical griego, formadas por una serie de sonidos ordenados descendentemente. Durante la Edad Media y el Renacimiento, la simultaneidad sonora surgía como resultado de la combinación de las diferentes melodías de la obra, es decir, del contrapunto, sin tener una conciencia clara de los acordes, que se fueron forjando con el nacimiento de la melodía acompañada y del bajo continuo ya en el periodo Barroco.

El concepto de armonía, tal y como lo entendemos actualmente, es bastante reciente. Chailley (1987) lo define diciendo:

Desde el siglo XVIII el término armonía designa de forma particular la ciencia de los acordes concebidos verticalmente, es decir, en su sonoridad global, así como de sus encadenamientos, por oposición al contrapunto, que considera las relaciones entre sonidos de manera horizontal, a saber, según las líneas melódicas superpuestas (punctum contra punctum), a las cuales pertenece aisladamente cada nota del acorde considerado. (p. 69)

De esta manera, se suele entender que la armonía se refiere al aspecto "vertical" de la música (simultaneidad sonora, bloques de acordes), diferenciándola de la melodía, que hace referencia a la dimensión "horizontal" (sucesión de notas con carácter expresivo). La idea de verticalidad y horizontalidad es una metáfora explicativa, relacionada con la disposición de las notas musicales en una partitura: verticalmente, se escriben las notas que se interpretan a la vez y, horizontalmente, las que se interpretan de forma sucesiva. Sin embargo, en el estudio de la armonía 
también se incluyen las sucesiones horizontales de los acordes y su efecto sobre el fluir general de la música. En este sentido, en la música occidental, podemos definir la armonía como la disciplina que estudia la organización de diversas notas superpuestas formando acordes y el encadenamiento de los mismos en progresiones armónicas. Por tanto, se ocupa de los acordes y de sus relaciones.

El Traité de l'harmonie de Rameau (1722) fue el primer texto acerca de la práctica musical que incluía el término "armonía" en el título. Sin embargo, como hemos visto, no significa que esa fuera la primera discusión teórica acerca de este tema. Como todo texto teórico (particularmente de esta época), se basa en la observación de la práctica: Rameau observa la práctica musical de su época y elabora algunas reglas, otorgándole una supuesta validez general. Especial importancia tiene en su desarrollo el fenómeno de la resonancia armónica para la justificación de los distintos elementos. Este y otros textos similares tienden a relevar y a codificar las relaciones musicales que estaban íntimamente vinculadas con la evolución de la tonalidad desde el Renacimiento hasta fines del Romanticismo.

LaRue (1989) nos ofrece una visión más amplia acerca de la armonía y, en algunos aspectos, incluso opuesta a la que hemos expuesto de Chailley (1987):

La armonía, vista como elemento analítico del estilo, no solo comprende el fenómeno del acorde asociado con el término, sino también todas las demás relaciones de combinaciones verticales sucesivas, incluyendo el contrapunto, las formas menos organizadas de la polifonía, y los procedimientos disonantes que no hacen uso de las estructuras o relaciones familiares de los acordes. (p. 30)

Este autor se refiere a la complejidad de las relaciones armónicas estableciendo un claro paralelismo con el lenguaje hablado, ya que ambos tipos de lenguajes disponen de diferentes niveles de interrelación. Las palabras, la gramática y la sintaxis del lenguaje hablado se identifican, respectivamente, con los acordes, las progresiones y la tonalidad del lenguaje musical. LaRue (1989) expresa esta comparación con el diseño de la siguiente figura: 


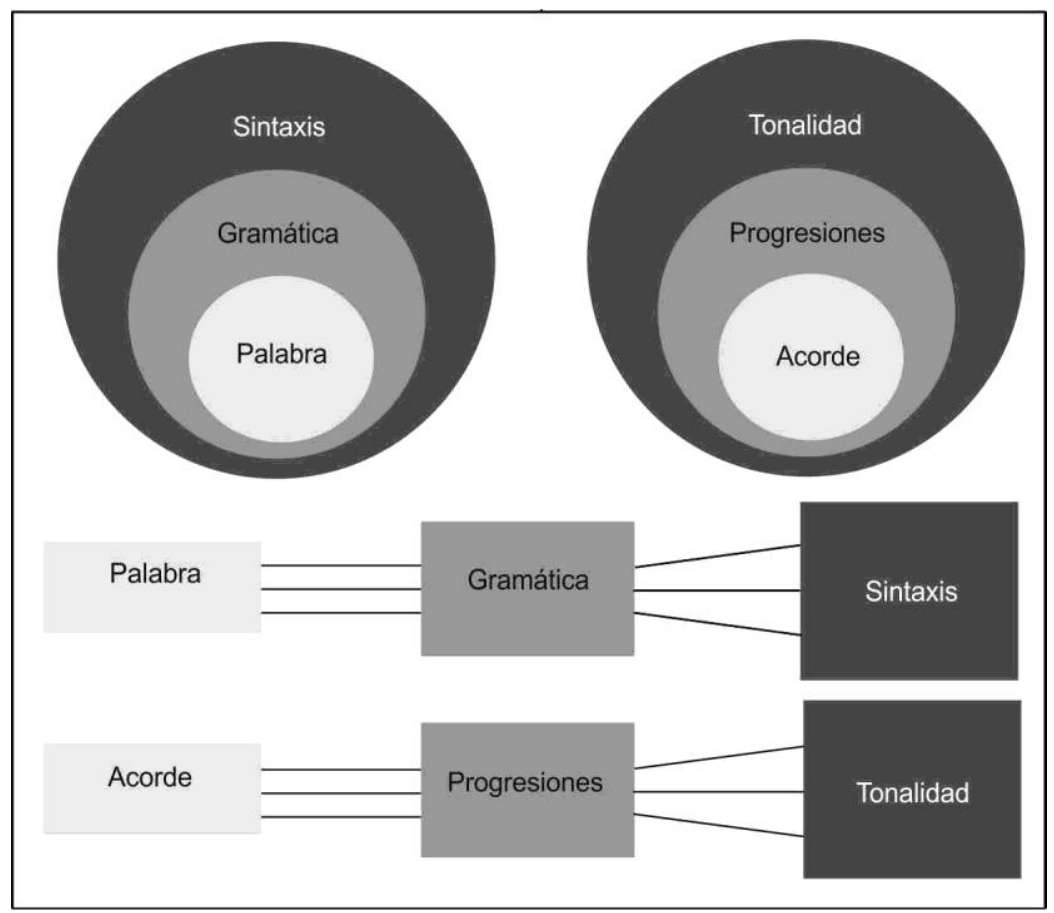

Figura 12. Comparación entre los niveles del lenguaje y los niveles de las relaciones armónicas (LaRue, 1989, p. 30)

Por otra parte, como hemos visto en el apartado anterior, los principios de la tonalidad fundamentan la organización de las alturas en la música de Occidente de los últimos cuatrocientos años. La nota tónica es el eje del sistema y las sucesiones de tríadas de acordes articulan su estructura (Cross, West, \& Howell, 1991). En relación a esto, queremos destacar que las principales teorías armónicas organizan el campo tonal sobre la base de los acordes de I, IV y V grados, cuyas alturas componentes completan la escala (Piston, 1998; Schenker, 1990; Schönberg, 1974).

Los modelos de la teoría musical sostienen que la jerarquía tonal otorga diferentes grados de importancia a las notas de la escala, y es así como a cada uno de los grados se le asigna una función de acuerdo a su posición relativa dentro de la misma. Desde el punto de vista psicológico, estas diferencias de función generan esquemas de tensión y distensión, en los que las notas poco importantes se presentan como más inestables y conducen a las notas más importantes, que son las que le otorgan estabilidad al sistema (Bigand, 1994). En el caso de la música tonal, la tónica y la dominante son las notas pilares, y la subdominante les sigue en importancia. Estudios experimentales (Krumhanls, 2000) han confirmado esta presunción, tanto 
para las alturas de la escala como para las sucesiones armónicas de acordes (Barucha \& Krumhanls, 1983, citado por Krumhansl, 2000), a los cuales dedicaremos el siguiente apartado.

\subsection{El acorde}

En música, se llama acorde a la combinación de tres o más notas diferentes que suenan simultáneamente y que, según la teoría tradicional descrita por Rameau (1722), se forma a partir de la superposición de terceras. Como hemos avanzado anteriormente, Rameau sienta las bases científicas de la armonía justificando el acorde tríada en el fenómeno físico armónico: de hecho, como hemos visto, el acorde Perfecto Mayor, formado por $3^{\mathrm{a}} \mathrm{M}$ y $5^{\mathrm{a}}$ $\mathrm{J}$, se forma con los primeros armónicos.

La Real Academia Española (2014) define el acorde musical como el "conjunto de tres o más sonidos diferentes combinados armónicamente" (Acorde, s.f.). Esta definición sugiere que, en la teoría tradicional y funcional de la armonía, dicha simultaneidad de sonidos ha de tener una finalidad precisa, ligada al desarrollo armónico de la música (Boulez, 1981), es decir, el acorde aislado pierde su sentido en la música tonal. Así, en un determinado contexto, algunos acordes tienen un sentido conclusivo y en otros, en cambio, lo tienen transitorio, ya que este sentido es relativo y depende de su relación con el conjunto de la composición. Por ello, en la música académica europea del periodo comprendido desde finales del siglo XVII hasta comienzos del XX, incluso el oído menos cultivado puede distinguir cuándo está próximo o distante el final de una frase musical.

No obstante, ya desde finales del siglo XIX y principios del XX, el acorde fue perdiendo poco a poco sus funciones estructurales hasta llegar a convertirse en una agregación sonora con posibilidades de tensión y relajación internas. Al respecto, autores como Chailley (1987) o Maneveau (1993) argumentan que la conquista de la armonía ha sido la conquista de la disonancia y señalan que muchos músicos y especialistas, desde hace décadas, se han sentido impresionados porque se puede trazar una especie de historia de la música o de la armonía señalando las sucesivas integraciones de los diferentes armónicos en el acorde. En este sentido, como ya hemos apuntado en el apartado 3.1 dedicado a la tonalidad, en la Edad Media los intervalos consonantes eran la $8^{\mathrm{a}}$, la $5^{\mathrm{a}}$ y la $4^{\mathrm{a}}$ (consonancias perfectas); desde el Trecento italiano y durante el Renacimiento, la $3^{\mathrm{a}}$ se introduce como consonancia en la sonoridad simultanea; en el Barroco, la $7^{\mathrm{a}}$ entra a formar parte del acorde como disonancia e, incluso, la $9^{\text {a }}$ durante el Clasicismo y el Romanticismo; el Impresionismo gusta de emplear algunos intervalos añadidos al acorde, como la $6^{\mathrm{a}}$ o la $4^{\mathrm{a}}$ añadida, etc.; y, ya en el siglo XX, 
todas las combinaciones sonoras están permitidas y dejan de ser extrañas a nuestros oídos.

Según Piston (1998) los acordes derivan del movimiento de las voces y la mayor parte de la música tonal está concebida como una armonía a cuatro partes en la que, por lo general, la línea de la soprano se configura como la voz melódica: "La línea de la soprano se oye instintivamente como una melodía" (p. 23). Además, para este autor, la coherencia armónica y la coherencia melódica serían interdependientes.

Los acordes pueden ser construidos a partir de cualquier nota de la escala. Esta nota base se denomina fundamental del acorde. Cuando la nota más grave del acorde (llamada bajo armónico) coincide con la fundamental, se dice que el acorde está "en estado fundamental". Es la posición más estable y rotunda del acorde y se utiliza, por ejemplo, para terminar una frase musical. Cuando la nota más grave del acorde es otra distinta, se dice que el acorde está "en inversión" o "invertido". La primera inversión presenta la tercera del acorde en el bajo, la segunda inversión presenta la quinta y así sucesivamente. Los acordes invertidos son menos estables y rotundos y, en general, se utilizan para facilitar el enlace entre los distintos acordes y para suavizar la línea del bajo, evitando que discurra "dando saltos".

Para el modelo psicoacústico, en la percepción del acorde, la saliencia de una de sus alturas componentes la dota de una predominancia que la configura como la fundamental del acorde. En estudios con pares de tríadas (Thompson \& Parncutt, 1997) se ha comprobado que la posición de los sonidos extremos de las tríadas y el movimiento del bajo tienen incidencia en el reconocimiento auditivo del grado de semejanza entre dos tríadas. Sin embargo, en una secuencia de más de dos acordes, enlazados a cuatro voces y en diferentes texturas, la marcha armónica y el enlace de las voces determina un tipo de audición diferente, pues las trayectorias melódicas de las diferentes voces pueden configurarse como corrientes de eventos que se perciben de manera independiente (Martínez, 2008).

El procedimiento de identificación auditiva y de cifrado de una secuencia de funciones armónicas (acordes) en tiempo real puede caracterizarse como una tarea de naturaleza compleja cuya resolución, según Bigand (1994), requiere:

1. Construir una representación interna a partir del input.

2. Vincular dicha representación con la base de conocimiento previo.

3. Seleccionar el rótulo correspondiente.

4. Escribir la respuesta, sin dejar de seguir escuchando. 
Durante el procesamiento de las relaciones armónicas, en la respuesta del auditor intervienen, por un lado, la construcción de esquemas basados en la frecuentación de la música de la propia cultura y acumulados en la memoria a largo plazo (en el caso de la armonía, las fórmulas armónicas básicas, tales como las cadencias) y, por otro lado, procedimientos mediante los cuales se combinan los conocimientos musicales con el feedback perceptual (McAdams, 1978, citado en Bigand, 1994).

Finalmente, consideramos importante destacar que la audición de una secuencia de funciones armónicas puede concebirse como una competencia conformada por una meta inmediata, que consiste en la recepción y el procesamiento de cada acorde, y otra meta de continuidad o desarrollo, determinada por la presentación de los acordes en cadena. La primera meta vincula el componente acústico de la música con su correlato sensorial y perceptual, mientras que la segunda atiende a la naturaleza temporal y secuencial de la misma, que trasciende la capacidad de la memoria a corto plazo y hace que el auditor necesite establecer relaciones de ida y vuelta entre los eventos en el devenir de la información musical, poniendo en juego capacidades de orden intelectual (Bigand, 1994).

\section{El oído musical en el contexto de la tonalidad}

La psicología de la música, desde una perspectiva psicométrica y con el objetivo de obtener resultados útiles para poder mejorar la enseñanza musical, se ha propuesto medir las aptitudes musicales de los niños. Por ello, desde el inicio del siglo XX hasta nuestros días, se han realizado constantes investigaciones elaborando diferentes tests o pruebas que recogen aspectos fundamentales para la actividad musical, como son: la altura, la duración, la intensidad, el timbre, la memoria tonal y la percepción armónica.

Los docentes observamos y comentamos reiteradamente la gran dificultad que tienen los alumnos en la realización de tareas tan habituales como pueden ser: la lectura cantada de un fragmento a primera vista, la transcripción escrita de un fragmento rítmico, melódico, polifónico o armónico previamente escuchado, la improvisación (cantada o con un determinado instrumento) de una simple frase musical, la armonización consciente de una melodía, etc. Seguramente, si los docentes nos replanteásemos el tratamiento de la práctica auditiva de los diferentes elementos musicales a partir de la elaboración de propuestas metodológicas adecuadas, los alumnos podrían llevar a cabo con éxito todas las prácticas mencionadas anteriormente. En este sentido, consideramos idónea la siguiente reflexión de Malbrán (2006): 
[...] son acciones en general vistas como habilidades patrimonio de los "dotados" o "talentosos" en lugar de entenderlas como muestras de una persona que ha recibido adecuada formación para la música. (p. 51)

Al respecto, y desde el marco tonal-armónico objeto de nuestro estudio, Mackamul (1982) propone iniciar la audición interválica simultáneamente a la audición tonal. La audición interválica permite la discriminación de los intervalos por sí mismos, mientras que la segunda permite auditarlos en su relación con la tónica. En cuanto al oído armónico, considera necesario comenzar a conocer, sentir y reconocer los enlaces de los acordes para, posteriormente, avanzar a cuestiones más complejas.

Todos estos aspectos interdependientes serán tratados a continuación, centrándonos en la discriminación tonal, la diferenciación entre el oído relativo y el absoluto, y las investigaciones dedicadas al estudio del oído musical, desde el punto de vista tanto melódico como armónico.

\subsection{La discriminación tonal}

Diversos autores ponen de manifiesto la necesidad de desarrollar una habilidad llamada discriminación tonal, definida por Laucirica (1999) como "la comparación entre dos sonidos en lo que se refiere a su altura" (p. 118). Laucirica (2004) argumenta la importancia que tiene la discriminación tonal en la práctica musical por el hecho de que se trata de una actividad que se realiza muy a menudo, sobre todo por cantantes e instrumentistas de afinación no fijada, cuando tienen que cantar o tocar con otras personas. La autora distingue, sin embargo, entre la discriminación tonal activa y la pasiva:

Mientras que la primera se refiere a la habilidad de discriminar mientras se emite el sonido, la segunda, en cambio, hace referencia tanto a la habilidad de indicar si dos sonidos escuchados son iguales o diferentes como al reconocimiento del movimiento ascendente o descendente de ambos. (pp. 87-88)

Laucirica (2004) señala que, en las diferentes pruebas estandarizadas, las distancias de altura oscilan entre diversos tonos y 1/50 de tono, pero que "también son conocidas las propuestas de los seguidores de la metodología Willems, los cuales presentan distancias de hasta 1/200 de tono" (p. 88).

Aunque hay unanimidad entre los investigadores al considerar que los niños, a medida que van creciendo, mejoran progresivamente en la tarea relacionada con la discriminación tonal, difieren, en cambio, en los niveles concretos de discriminación conseguidos en cada una de las edades (Lacárcel, 1992). Al respecto, de acuerdo con los resultados de sus 
investigaciones, Bentley (1967, citado por Lacárcel, 1992) afirma que, "mientras que los niños y las niñas de 7 años de edad pueden llegar a diferenciar hasta $1 / 4$ de tono, los de 12 , en cambio, consiguen discriminar hasta $1 / 8$ de tono" (p. 42).

Además, Laucirica (1999) defiende que el desarrollo de la discriminación tonal podría estar relacionado con la experiencia musical, argumentándolo de la siguiente manera:

Parece razonable que la interpretación musical con un instrumento de afinación fija o la mera interpretación en grupo de cámara u orquesta favorezca y desarrolle la discriminación tonal. (p. 119)

Existen dos teorías que explicitan la percepción del tono o altura de los sonidos, ambas recogidas por Merino (2006). La Teoría de la Periodicidad establece que, cuando el complejo psicoacústico recibe con regularidad una sucesión de pulsos acústicos, detrae de ellos una sensación de tono cuya frecuencia se corresponde con la frecuencia con que se suceden los estímulos. Según esta teoría, el cerebro es el que capta la sensación de sonido, mientras que el oído sería un mero captador de impulsos. La segunda teoría es la llamada Teoría de la Localización, que permite explicar, además, la sensación de timbre, motivo por el cual es más completa que la anterior. Merino afirma la veracidad de una y otra por lo que "lo más acertado es aceptar que los mecanismos de percepción participan de una y otra formas de actuación" (p. 82).

Por otra parte, en la música occidental se considera relevante la aptitud para notar la presencia o ausencia del centro tonal de una pieza musical (Colwell, 1969, citado por Vera, 2000; Gordon, 1977). Gordon (1979, citado por Lafarga \& Sanz, 1998), que contempla la percepción del sentido tonal como una habilidad básica en el desarrollo del entendimiento musical, puntualiza que el sentido de la tonalidad no ha de confundirse con el sentido de la cadencia, ya que son dos habilidades diferentes. Según este autor, "el sentido de la tonalidad puede apreciarse demandando a los niños que, después de escuchar un fragmento musical, determinen el sonido de reposo, es decir, la tónica" (p. 108).

En la misma línea, varios autores han realizado estudios centrados en la adquisición del sentido tonal, como: Gordon (1979, citado por Vera, 2000), Hargreaves (2002), Imberty (1968, citado por Lacárcel, 1992), Moog (1976, citado por Glover, 2004), Zenatti (1975), etc. A continuación, siguiendo a Ponsatí (2011), se sintetizan las aportaciones de algunos de ellos: 
- Brehmer (1925, citado por Lafarga \& Sanz, 1998), en las conclusiones de su investigación, afirma que "los niños de 6 años de edad pueden advertir la sensación de final que provoca la presencia del acorde triada de tónica" (p. 108).

- Reimers (1927, citado por Lafarga \& Sanz, 1998) sostiene que "para los niños de 9 años de edad, la tónica es la nota más adecuada para concluir una melodía" (p. 108).

- Teplov (1966) constata que "los niños de 8 años de edad, dependiendo de la nota final del fragmento presentado, pueden distinguir entre melodías acabadas o inacabadas" (p. 109).

- Zenatti (1969, citada por Lafarga \& Sanz, 1998), refiriéndose a la capacidad para discriminar melodías tonales y atonales, concluye que hacia los 5 años de edad, esta depende del azar y que "es entre los 6 y los 8 años cuando comienza a surgir la preferencia por el sentido tonal, la cual continúa acentuándose hasta los 13 años” (p. 109) y, en algunas de las tareas musicales, aún prosigue hasta los 16 .

- Imberty (1969, citado por Lacárcel, 2001) realizó toda una serie de experimentos sobre diferentes aspectos relacionados con la adquisición de la tonalidad. En uno de ellos, niños y niñas de diferentes edades tuvieron que escuchar diversos fragmentos de corales de Bach. En función de las cadencias, se les pidió que respondieran si los fragmentos que habían escuchado eran "completos", "incompletos" o "no lo sé". Este autor llegó a las siguientes conclusiones:

- La mayoría de los niños y niñas de 6 años estimaron los fragmentos como "completos", independientemente de dónde acabasen, indicando que tenían poca discriminación del lugar de las cadencias.

- Se observa un progreso significativo con los alumnos de 8 años de edad, ya que podían reconocer como "incompleta" una frase sin cadencia. También percibían la diferencia entre la tónica y la dominante y captaban la función de la cadencia perfecta (VI).

- Hacia los 10 años, la semicadencia también era significativa para los niños. La mayoría no aceptaban como completas las cadencias perfectas donde la resolución melódica se hacía caer sobre la mediante. 
En otro experimento, Imberty (1969, citado por Lacárcel, 2001) pretendía observar si los niños detectaban los cambios de clave y de modo, presentándoles diferentes versiones de melodías que les eran familiares. Encontró que los niños de 7 años se dieron cuenta de los cambios de clave en medio de melodías que les eran familiares y que los niños de 8 años advirtieron, también, los cambios de los modos mayor y menor.

Asimismo, en la adquisición del sentido de la tonalidad, hay que tener presente un aspecto muy importante y decisivo: la aculturación musical. Hargreaves (2002) señala que "tanto la adquisición del sentido de la tonalidad como la del lenguaje verbal son del todo comparables" (p. 106), ya que ambos se adquieren gracias a la familiaridad con los mismos, y diferencia claramente entre los conceptos de aculturación y de entrenamiento musical, especificando que, mientras que el primero se refiere a los progresos musicales que se dan de una manera natural sin la intervención de la voluntad, el segundo, en cambio, necesita el uso de medios conscientes dirigidos a optimizar determinadas habilidades musicales. En este sentido, la adquisición de la tonalidad parece ser una cuestión más relacionada con la aculturación y maduración musical que con el entrenamiento, ya que, tal y como han argumentado diferentes teóricos, la agudeza auditiva que adquieren los niños y las niñas se relaciona directamente con la música a la cual están expuestos (Hargreaves, 2002; Moog, 1976, citado por Glover, 2004; Zenatti, 1975).

\subsection{La audición relativa y absoluta}

Los tipos de audición absoluta y relativa son, para muchos teóricos, dos modalidades auditivas totalmente independientes y contrarias. No obstante, Laucirica (2004) afirma que los resultados de las investigaciones llevadas a cabo en los últimos años nos indican que, a pesar de la enorme complejidad que presenta la audición musical humana, las personas de una o de otra tendencia muestra rasgos de la modalidad perceptiva opuesta.

En la misma línea, Hemsy de Gainza (1977) defiende que ni el oído absoluto ni el relativo existen en forma pura o exclusiva. Los músicos que poseen audición relativa utilizan muchas referencias sonoras absolutas de las que no son conscientes. Por otra parte, las personas que poseen oído absoluto y que han trabajado su oído utilizan, a su vez, la audición relativa en multitud de ocasiones. En este sentido, defiende que es preciso desarrollar en los alumnos ambas audiciones, aprovechando la gran cantidad de sonidos ricos y variados entre los que viven inmersos. 
A continuación, nos centraremos de forma específica en cada uno de estos dos tipos de audición, la relativa y la absoluta, pero antes consideramos fundamental destacar que existe una diferencia fundamental entre ambas habilidades: mientras que la presencia del oído absoluto es radical (está o no presente), el oído relativo se manifiesta gradualmente (estará más o menos desarrollado).

\subsubsection{El oído relativo}

El oído relativo es una parte central del talento musical, así que perfeccionarlo tiene efectos muy positivos para los artistas. Puede definirse como la habilidad para identificar intervalos entre dos o más notas, sin la ayuda de tener las notas referenciadas. En este sentido, Levitin (2004) define el oído relativo de la siguiente manera:

El oído relativo es la capacidad de identificar los intervalos musicales como "tercera menor" o "cuarta justa," y es la capacidad similar para designar a una nota con una referencia inicial dada de antemano, en función de un proceso de identificación relativa. (p. 106)

Entendemos, entonces, que la audición relativa hace referencia a las relaciones que se crean entre las alturas del sonido, como, por ejemplo, la determinación de si un sonido es más agudo o más grave respecto a otro, o si dos sonidos están muy cercanos o lejanos entre sí y, por tanto, si forman un intervalo más estrecho o más amplio. De hecho, la audición relativa se puede ejemplificar a través de las similitudes que se crean entre dos intervalos que tienen la misma ratio de frecuencias pero diferentes sonidos absolutos (Russo \& Thompson, 2005b). Cantar con otra persona en el mismo tono, diferenciar una tríada mayor de una menor e identificar las progresiones de los acordes clásicos I-IV-V en las canciones escuchadas requiere desarrollar el oído relativo.

Desde el punto de vista perceptivo, Laucirica (1999) se expresa en los siguientes términos.

La audición relativa consiste en la identificación de un sonido cuando se compara con un punto de referencia dado, o en la categorización del intervalo musical. Así, la audición relativa pasiva (o de carácter perceptivo) se manifiesta mediante la identificación de intervalos y el reconocimiento de melodías transportadas. (p. 119)

Hargreaves (2002), ante las investigaciones realizadas por diferentes teóricos, argumenta que las personas con oído relativo desarrollan internamente una escala de alturas que representa con exactitud las diversas relaciones sonoras que se establecen entre los doce semitonos de la escala 
tonal occidental. No obstante, estas personas necesitan una referencia tonal previa. Según Takeuchk y Hulse (1993, citados por Russo \& Thompson, 2005b), el procesamiento de la audición relativa se hace evidente aproximadamente con los 6 años de edad. Este tipo de procesamiento es considerado indispensable para poder disfrutar con plenitud de la música (Trehub \& Hannon, 2006).

Vera (2000) afirma que las personas con oído absoluto son una minoría, incluso entre los músicos profesionales, en contraste con las personas que tienen oído relativo, habitual en aquellas personas educadas musicalmente, por lo que no es necesariamente un componente de aptitud musical.

Desde el punto de vista de la enseñanza, Alborés (2008), a pesar de expresar la conveniencia de trabajar ambos tipos de audición, reflexiona sobre la importancia de que, en los inicios, se prioricen tanto la entonación como la audición absolutas. Paralelamente sugiere que se vaya desarrollando la audición relativa efectuando diversas tareas: el transporte cantado, el aprendizaje de canciones con letra cantándolas en diferentes tonalidades, el reconocimiento auditivo de melodías que se encuentran situadas en diferentes registros y, finalmente, la entonación precisa, comparación e identificación de los diversos intervalos.

Malbrán (2007a) señala que la única diferencia entre músicos con gran desarrollo auditivo es que los de oído relativo precisan de un diapasón y los de oído absoluto lo poseen incorporado a su cuerpo. Asimismo, apuesta por la idea de que el desarrollo de la audición relativa es primordial para la obtención de una formación auditiva competente. Según la autora, desde siempre se ha otorgado un valor excesivo al oído absoluto, llegando al punto de considerar que una persona con este requisito posee de entrada todas las cualidades musicales necesarias. Para Malbrán, son diversas las razones que dificultan poder admitir esta suposición como cierta. En primer lugar, las personas con oído absoluto muestran dificultades a la hora de identificar con exactitud los movimientos de las alturas de los sonidos y, también, las relaciones sonoras que provienen de fuentes de sonido desconocidas. En segundo lugar, les es muy difícil efectuar una interpretación precisa "a capella" de los sonidos, ya que su emisión presenta pequeñas variaciones de altura. En último lugar, presentan dificultades para identificar las funciones armónicas, las cuales, habitualmente, no se designan con el nombre de las notas.

Por ello, a partir de nuestra propia experiencia como músicos y como docentes, consideramos que desde las aulas es necesario efectuar un buen trabajo auditivo que posibilite a los alumnos desarrollar ambas habilidades, es decir, tanto el oído absoluto como el relativo. Al respecto, nos ha parecido 
adecuado finalizar este apartado incorporando la siguiente reflexión de Miranda (2003):

El tipo de aprendizaje musical y el entrenamiento sistemático posibilita al músico profundizar más en un tipo u otro de educación auditiva. La educación simultánea del oído absoluto y relativo, en nuestra opinión, es una forma de complementar y enriquecer la manera de escuchar y comprender mejor el mensaje musical. (p. 64)

\subsubsection{El oído absoluto}

El oído absoluto u oído perfecto es la capacidad para identificar correctamente el nombre musical o la frecuencia de un sonido dado (Hargreaves, 2002). La posesión de esta habilidad se considera entre los músicos como un valioso talento, pero no implica necesariamente una mayor destreza en otras capacidades musicales más allá de la identificación frecuencial exacta (Takeuchi \& Hulse, 1993). Entre las ventajas que aporta, podemos citar que ayuda a comenzar a cantar en la nota correcta cuando no hay acompañamiento, a cantar a primera vista con precisión, a escuchar partituras musicales sin necesidad de tocarlas, etc.

Sin embargo, esta habilidad puede tener desventajas. En este sentido, Malbrán (2007a) asegura que el oído absoluto se ha sobrevalorado y muestra algunas de las dificultades de aquellos que lo poseen. Así, por ejemplo, nos habla de que, cuando la fuente de sonido es desconocida, es decir, son fuentes electrónicas o sonidos no convencionales, los absolutistas no identifican con precisión el movimiento de las alturas y se declaran incompetentes para analizar las relaciones sonoras. También demuestran dificultades en los sonidos vocales a capella, ya que están condicionados a discriminar sonidos tónicos de afinación fija. Además, las secuencias armónicas suponen un problema para ellos, ya que suelen prestar atención a la línea principal.

En la misma línea, Takeuchi y Hulse (1993) señalan que "los poseedores de oído absoluto son capaces de nombrar con precisión la clase de tono, esto es, identificar un sonido como do o la\#, pero no así la octava en la que está localizado" (p. 346). Además, las personas que poseen oído absoluto son menos flexibles a la hora de aprender una nueva escala y presentan otras carencias en tareas musicales que implican juicios acerca de intervalos musicales o en ejercicios tonales de memoria a corto plazo en los que no se utilizan etiquetas verbales como guía (Deutsch et al., 2004; Miyazaki, 1993). Y es que, efectivamente, el oído absoluto es una habilidad más lingüísticoperceptiva que musical, ya que "la asociación de frecuencias absolutas a etiquetas verbales es cognitivamente equivalente a los procesos de denominación de los colores" (Deutsch et al., 2004, p. 131). 
Hindemith (1946) señala que lo que se entiende por oído absoluto es "una capacidad altamente desarrollada para comparar con rapidez una impresión auditiva con arquetipos acústicos almacenados en nuestra memoria" (p. 63), que depende, en gran medida, del instrumento que se toque. Algunos músicos tienen "oído casi absoluto", muy parecido al oído absoluto, pero que afecta a un único sonido. Así, por ejemplo, algunos instrumentistas de oboe, que habitualmente tocan el la440 para la afinación del instrumento en la orquesta, y los violinistas, que tocan esa misma nota en la cuerda al aire, son capaces de recordar y cantar esa nota sin ningún problema por lo que, a partir de ella, pueden producir cualquier otra nota utilizando el oído relativo (Trallero, 2008).

Por su parte, Vera (2000, citado por Balo, 2014) indica que existen varias hipótesis acerca del oído absoluto:

- Hipótesis de la discriminación: Afirma que las personas con oído absoluto tendrán una buena aptitud para llevar a cabo discriminaciones sensoriales a lo largo de un continuo de tono.

- Hipótesis de la discriminación tonal: Sugiere la existencia de una aguda sensibilidad en zonas específicas más que una superior discriminación a lo largo de toda la gama de frecuencias.

- Hipótesis de la memoria generalizada para el tono: Mantiene que el oído absoluto viene dado por la aptitud para almacenar información en la memoria.

- Hipótesis del estándar interno: Defiende que las personas con oído absoluto identifican las notas porque las comparan con estándares internos. 


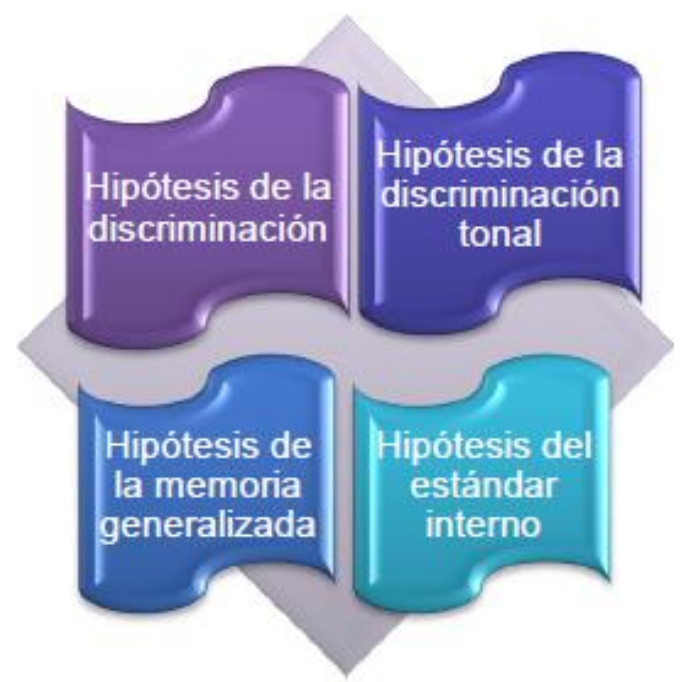

Figura 13. Hipótesis acerca del oído absoluto de Vera (2000, citado por Balo, 2014, p. 104)

Teplov (1966, citado por Trallero, 2008) establece dos tipos de oído absoluto: el activo y el pasivo. El oído absoluto pasivo es capaz de reconocer la altura de los sonidos y darles su nombre, mientras que el oído absoluto activo puede reconocer y reproducir la altura de un sonido a partir de la indicación de su nombre o altura. También señala que las personas que poseen audición absoluta activa suelen tener también la pasiva, aunque no sucede al revés.

Uno de los temas más interesantes relacionados con el oído absoluto gira en torno a saber en qué medida puede ser aprendido. Revesz (1953) y Bachem (1937) consideraron que el oído absoluto era un don innato que se manifestaba al margen de cualquier entrenamiento. Sin embargo, la Teoría del Aprendizaje de Oakes (1951) contempla que la adquisición del oído absoluto se debe a refuerzos apropiados derivados del entorno. Incluso, Hargreaves (2002) indica que muchas personas poseen una propensión innata para el oído absoluto, pero que una mala experiencia musical impide que esta se desarrolle.

Jaques-Dalcroze (1965, citado por González, 2013) afirma que el oído innato se puede adquirir a través del estudio, siempre que se comience a edades tempranas y que preceda al estudio del instrumento. Lo expresa de la siguiente manera: 
El oído percibe ritmos. Por medio de ejercicios diarios repetidos, se puede adquirir una memoria del sonido, agudizando y estimulando las facultades críticas. Esto capacitará al alumno para comparar la percepción de ritmos con su representación. (p. 75)

Para terminar, señalaremos que Hemsy de Gainza (1964, citada por Balo, 2014) afirma que los niños que poseen oído absoluto no son necesariamente conscientes de los intervalos y de las relaciones de tensión y distensión melódica, por lo que es interesante que conozcan las ventajas que obtendrían haciendo consciente lo que oyen. Esta pedagoga destaca la conveniencia de "dar a todos los niños una cierta orientación dentro de su propio campo auditivo [...] y despertar la sensibilidad del niño respecto a los sonidos, en la forma más amplia posible”. (p. 106)

\subsection{El oído musical melódico}

Según Lacárcel (2001), "nuestra mente es capaz de discriminar entre una agrupación aleatoria e intranscendente de sonidos más o menos agradables y una estructura $u$ ordenación significativa y/o reconocible" (p. 75). Asimismo, señala que, en los niños, la percepción del elemento melódico de la música provoca reacciones de la más diversa índole, destacando la predominancia de las manifestaciones afectivo-emocionales. A medida que se enriquece la experiencia musical del niño, la comprensión de la melodía se va desarrollando paulatinamente, recordándose con más precisión aquellas melodías que forman parte de su bagaje cultural. La autora expresa esta idea de la siguiente manera:

Cuando un niño es capaz de discriminar si una melodía es ejecutada incorrectamente o existe algún error, quiere esto decir que ha tomado conciencia de los elementos que forman la melodía y que se compone de un determinado intervalo, tono, compás o ritmo, etc. (p. 75)

Por otra parte, Morán (2010) puntualiza que la forma en que agrupamos los sonidos depende de nuestras expectativas, que se hallan en relación con nuestros conocimientos musicales. Además, debido a que la polisemia es una característica del arte, siempre podremos encontrar nuevas formas de agrupación. Así, por ejemplo, al escuchar versiones distintas de una misma obra, agruparemos los sonidos en forma completamente diferente, ya que las intenciones del intérprete o recreador de la música no son las mismas.

Existen varias investigaciones dedicadas al estudio de la percepción melódica. Así, por ejemplo, Zenatti (1983, citado por Hargreaves, 2002) investigó la percepción de la melodía en el contrapunto, solicitando a los sujetos que descubrieran una melodía integrada en varias fugas. En su estudio halló un progreso uniforme entre los ocho y los diez años, aunque 
también comprobó que, incluso niños de doce años, tuvieron dificultad en ello. Otra investigación similar fue llevado a cabo por Dowling (1994, citado por Morán, 2010), quien hizo escuchar a distintos sujetos varias melodías intercaladas. Inicialmente, los sujetos comunicaron que escuchaban sonidos inconexos. Posteriormente, se les comunicó el nombre de las audiciones y, en esta ocasión, fueron capaces de reconocerlas sin ninguna dificultad, ya que, tal y como concluyó el autor, aplicaron las representaciones de esas melodías que tenían guardadas en su memoria.

Vamos a profundizar en los elementos fundamentales de la percepción melódica, centrándonos en el estudio de la identificación auditiva de los grados de la escala, la percepción de las relaciones de alturas y del contorno melódico, y la identificación auditiva de los intervalos melódicos.

\subsubsection{La identificación auditiva de los grados de la escala}

Los sonidos fundamentales que constituyen una obra o fragmento musical, ya sea escuchado o leído, pueden ordenarse formando una escala. Malbrán (2007a) se refiere a la escala musical de la siguiente manera:

La escala es el sustrato de organización de una secuencia melódica; la habilidad de los auditores consiste en inferir la escala sobre la cual se ha construido un tema musical. (p. 137)

De acuerdo con Willems (1984, citado por Ponsatí, 2011), "la escala musical, a menudo, se presenta como un elemento que suele cantarse de manera espontánea sin suponer ninguna complicación ni dificultad para los alumnos" (p. 74). En muchas ocasiones, su presentación y conceptualización se inicia con la escritura, aspecto que, según Butler (1992, citado en Malbrán 2007a), debería ser posterior a la identificación auditiva de cada uno de sus correspondientes componentes. De hecho, consideramos que, desde el punto de vista de la enseñanza musical, para aprender una escala no es necesario conocer, de entrada, la sucesión de los tonos y semitonos que la componen, pero, sin embargo, sí que es necesario percibir la relación que establece la primera nota con cada uno de los sonidos de la escala. En este sentido, Willems (1984a) expresa la siguiente idea:

Un niño que canta una escala -y lo mismo un adulto- no canta tonos y semitonos, sino que, en el espacio de una octava, consciente e inconscientemente establecida, canta una serie de intervalos a partir de la tónica. (p. 75)

Por tanto, la escala musical está formada por un determinado esquema ya establecido de distancias (tonos y semitonos) distribuidos en el ámbito de una octava. No obstante, hay que tener presente que, en realidad, lo que está 
sucediendo es que se está creando un vínculo sonoro distintivo entre cada uno de los sonidos de la escala y la nota inicial. Tal como sigue añadiendo Willems (1984a) "estas relaciones, estos intervalos, poseen valores físicos y psíquicos característicos" (p. 75).

El autor también destaca que a cada uno de los grados de la escala se le ha atribuido una determinada función tonal. Malbrán (2007a) resume esta idea al afirmar que "el contexto armónico determina el recorrido por tonos y semitonos según la escala implicada $\mathrm{y}$, concomitantemente, la diferente cualidad interválica" (p. 137).

Por su parte, Karpinski (2000) considera que, para poder identificar correctamente los grados de la escala de una determinada melodía, "previamente hay que percibir el contorno melódico y las alturas de los sonidos, así como inferir la tónica" (p. 50). Continúa argumentando el autor que, en muchas ocasiones, los oyentes pueden llegar a identificar de manera casi intuitiva los grados de la escala de un determinado motivo melódico que se encuentra en un contexto tonal, pero que, no obstante, también hay ocasiones en las que no lo consiguen tan fácilmente, razón por la cual se hace necesario desarrollar esta habilidad auditiva. En este sentido, señala que es muy importante la constante asociación de un conjunto de etiquetas con los diferentes grados, ya que ello permitirá que, con el paso del tiempo, muchos de los oyentes acaben efectuando la vinculación. "Para llegar a su automatización, puede emplearse una técnica que permite a los oyentes calcular el grado de la escala de los sonidos en relación a la tónica" (p. 52).

\subsubsection{La percepción de las relaciones de alturas y del contorno melódico}

Uno de los atributos más abstractos en la percepción musical de una sucesión melódica es la identificación auditiva del movimiento (metafórico) de las alturas. La relación entre los sonidos graves y agudos se identifica frecuentemente con las dimensiones alto/bajo, pero, en realidad, esta es una construcción hipotética. En este sentido, Malbrán (2007a) señala que "los sonidos no son más bajos o más altos; al ser diferentes en frecuencia, cambian en su cualidad de altura" (p. 99). La asociación con niveles espaciales es una convención, una forma de representación de antiquísima data. Un argumento a favor de la asociación con las dimensiones alto/bajo podría vincularse con la autopercepción -por cierto, no fácil- de la ubicación más alta en la laringe de los sonidos agudos respecto a los graves. En otros casos, como ocurre con el comportamiento de la altura en la ejecución de algunos instrumentos, dicha asociación no resulta posible: en el violonchelo, los sonidos más agudos son hacia abajo; en el piano, en un plano horizontal, están hacia la derecha, igual que en la flauta travesera. Estas divergencias, 
continúa Malbrán (2007a), muestran que "la asociación que las personas pueden realizar entre localización de las alturas sonoras y espacio físico no es lineal ni directa" (p.100).

Schönberg (1977, citado por Deutsch, 1999) afirmaba que:

Los elementos de una idea musical son en parte integrados al plano horizontal, en tanto sean sonidos sucesivos, y al vertical si son simultáneos. La unidad del espacio musical exige una percepción absoluta y unitaria. Sin embargo, en este espacio no hay ni alto ni bajo, ni derecha/izquierda, ni adelante/atrás como referencia absoluta. (p. 131)

No obstante, esta asociación (concepto no natural) resulta imprescindible para el aprendizaje de la notación musical en Occidente, aunque implica una analogía que a veces es de difícil representación.

La preponderancia de la altura del sonido sobre otros parámetros puede observarse en el desarrollo histórico de las teorías musicales y de la escritura. En la actualidad, la partitura desempeña un papel principal en la mayoría de los ámbitos académicos de estudio musical, desconociendo que la misma es solo un dispositivo metalingüístico para transmitir y conservar algunos aspectos del lenguaje musical (Herrera, 2010).

Por otra parte, en cognición musical, un concepto que cuenta con amplia investigación es el de contorno melódico, esto es, el trazado del movimiento de las alturas de una melodía, ya sea en el espacio gráfico o en nuestra mente, cuando escuchamos. Este diseño de la superficie melódica conforma "figuras" relativas a cómo se suceden las alturas de la melodía en el desarrollo discursivo.

Según Cook (1999), el contorno es "la silueta de una melodía cuyo diseño ignora la medida de los intervalos y solo considera el movimiento de ascenso y descenso de sus patrones" (p. 38). Por su parte, Malbrán (2007a) se refiere al contorno melódico diciendo que:

En el momento en que se escucha una determinada melodía esta puede representarse, tanto gráficamente como mentalmente, con una línea que describa el movimiento de las alturas sin detallar con exactitud los intervalos que la constituyen. (p. 100)

Karpinski (2000) afirma que, "entre la inferencia de la tónica y la identificación de los grados de la escala, hay un paso que es primordial: la percepción del contorno melódico" (p. 48). El autor advierte la posibilidad de que los oyentes muestren grandes dificultades a la hora de nombrar los sonidos que van asociados a los grados de la escala de una melodía si, 
previamente, no han sido capaces de determinar el contorno melódico, el cual retienen en la memoria a corto plazo. Karpinski señala dos aspectos que son fundamentales para la percepción del contorno melódico, la realización precisa de los cuales facilita enormemente la identificación de los grados de la escala: por un lado, el sentido ascendente y descendente de los sonidos y, por otro, la amplitud de su movimiento, considerado tanto por grados conjuntos como por salto.

Terminaremos este apartado destacando que, tal y como afirma Aiello (1994a), en muchas ocasiones, a pesar de no poder reconocer, reproducir o recordar fielmente una melodía escuchada, sí que es posible representar un contorno melódico que se aproxime a la melodía original. Al respecto, Dowling (1994) señala que el contorno melódico suele ser empleado comúnmente por los compositores en la creación de sus obras musicales, dado que es una característica, cualidad o peculiaridad de la música que destaca en la primera audición. Según este autor, los resultados de los estudios efectuados en este sentido confirman la importancia que tiene el contorno melódico en las melodías que se escuchan por primera vez. En estos experimentos se pide al oyente que escuche una melodía que le es completamente desconocida y que después la reconozca al ser presentada nuevamente, teniendo en cuenta que la segunda vez se le expone tanto transportada como con varias diferencias interválicas.

\subsubsection{La identificación auditiva de los intervalos melódicos}

Backus (1969, citado en Costa et al., 2000) define los intervalos musicales contemplándolos desde dos puntos de vista diferentes: el musical y el físico. Mientras que en términos musicales este autor se refiere a ellos como "la distancia que hay entre dos sonidos expresada en tonos y semitonos" (p. 4), en términos físicos, en cambio, lo hace diciendo que "se trata de la relación que se establece entre la frecuencia de la vibración de un sonido y la del otro" (p. 4).

Los sonidos pueden presentarse de manera sucesiva o simultánea, es decir, formando intervalos melódicos o armónicos, los cuales nos conducen, respectivamente, hacia la melodía y la armonía. En este apartado, haremos referencia únicamente a la identificación auditiva de los intervalos melódicos, dejando los intervalos armónicos para más adelante.

Lacárcel (2001) afirma que "la melodía se sustenta gracias a la existencia de su elemento principal: los intervalos melódicos" (p. 76). Por este motivo, la autora considera que su identificación y comprensión resulta fundamental para el desarrollo cognitivo de la música. 
Malbrán (2007a), por su parte, se refiere a los intervalos diciendo:

El intervalo de altura es la unidad de percepción básica en melodías y escalas. Los intervalos contenidos en las escalas constituyen el material tonal estándar sobre el cual se ha basado virtualmente toda la música de Occidente. (p. 138)

Willems (1984b), después de reflexionar sobre la relación que se establece entre la melodía y el intervalo melódico, concluye que el intervalo es, en realidad, el principio de la melodía. Asimismo, considera que la naturaleza del intervalo melódico es múltiple y le otorga los siguientes valores: cuantitativo o cualitativo, ascendente o descendente, positivo o negativo, valor determinado por el lugar que ocupa el intervalo, y tonal o atonal. En el inicio del desarrollo auditivo de los intervalos melódicos, por lo que respecta al aspecto cuantitativo, Willems destaca la importancia de realizar, cantando afinadamente, diferentes ejercicios siguiendo el siguiente proceso: el ordenamiento del sonido sin el nombre de las notas, el ordenamiento del nombre de las notas sin el sonido y, finalmente, el ordenamiento del sonido con el nombre de las notas. En cuanto al aspecto cualitativo de los intervalos melódicos, Willems considera importante estudiar el potencial afectivo y el valor expresivo de cada uno de ellos. Recomienda ejercitarse a: escuchar los sonidos de los intervalos y su carácter, anotar las impresiones producidas por la audición de los distintos intervalos (generalmente subjetivas y diferentes de un día a otro), escoger canciones y temas clásicos con el inicio de los diferentes intervalos, crear e improvisar temas basados en un determinado intervalo $\mathrm{y}$, finalmente, transportar a diferentes tonalidades los temas $\mathrm{y}$ canciones de intervalos.

Kühn (2003), de acuerdo con Willems, señala la importancia de desarrollar la capacidad de reconocer auditivamente los intervalos y, también, de designarlos con confianza y firmeza. Sin embargo, tiene una opinión contraria respecto al procedimiento de utilizar el comienzo de canciones o de determinadas obras para recordar los intervalos. Lo argumenta diciendo:

Esto termina por crear más barreras que las que deja abiertas. Puede ayudarnos a reconocer algún intervalo individual o abstracto, pero falla en el caso de una sucesión de dos o más movimientos de intervalo, y, de un modo más decisivo, dentro del contexto musical, sobre todo en un contexto atonal. (p. 22)

Fruto de los resultados obtenidos por sus investigaciones, Kühn (2003) nos alerta de problemas especiales en el trabajo interválico merecedores de que se les preste una atención especial al hacer los ejercicios: 
1. Los intervalos descendentes son más difíciles de captar que los ascendentes, especialmente las sextas y séptimas.

2. Los intervalos simultáneos (las notas suenan al mismo tiempo) suelen ser más difíciles de reconocer que los sucesivos (suena una nota después de otra).

3. Los intervalos complementarios (es decir, aquellos que se complementan en una octava) son muy fáciles de confundir al sonar simultáneamente, como la segunda menor y la séptima Mayor, por ejemplo.

4. También la diferenciación de la cuarta aumentada o quinta disminuida, la séptima menor, la séptima mayor y la novena menor provocan, a menudo, problemas.

Asimismo, Deutsch (1999) afirma que intervalos idénticos de diferentes octavas no son equivalentes desde el punto de vista perceptivo.

Consideramos fundamental destacar que, a lo largo del tiempo, se han llevado a cabo diversas investigaciones destinadas a conocer algunos de los factores que pueden incidir en la identificación auditiva de los intervalos melódicos. A continuación, basándonos en Ponsatí (2011), detallaremos algunas de las aportaciones más difundidas en este sentido.

- Relacionadas con los factores culturales: Según Laucirica (2004), los factores culturales "hacen que los sujetos incorporen en su estándar interno de afinación los intervalos que son propios de su cultura" ( $\mathrm{p}$. 2). Por este motivo, Rakowski (1990, citado por Laucirica, 2004), considera fundamental el fenómeno de la enculturación musical en la percepción y reproducción de los intervalos, así como también los diversos factores acústicos, psicológicos o de expresión musical.

- Relacionadas con el sentido ascendente y descendente: Por lo que respecta al sentido ascendente y descendente de los intervalos melódicos, Kühn (2003) constata la dificultad en el reconocimiento auditivo de los descendentes, especialmente los de sexta y séptima, frente a los ascendentes.

- Relacionadas con el tamaño del intervalo: Sobre los aspectos que inciden en la identificación del tamaño de un intervalo, Russo y Thompson (2005a) opinan que esta depende, por un lado, del nivel de formación musical del oyente, por otro, del registro de altura donde se ubica el intervalo y, finalmente, del sentido ascendente o descendente del mismo. Bentley (1967), en cuanto a qué intervalos son más 
difíciles de apreciar auditivamente, afirma que, "en primer lugar, lo son los semitonos, seguidamente los tonos y, para acabar, los de mayor amplitud" (p. 120). Laucirica (1999), en cambio, sugiere que tanto los oyentes con oído absoluto como los de oído relativo perciben con más facilidad los intervalos menores a la tercera mayor, los de quinta justa y los de octava justa, ya que estos son los más frecuentes y, armónicamente, los más importantes.

Deutsch (1969, citado por Russo \& Thompson, 2005a), refiriéndose a intervalos de gran amplitud, sugiere que es más rápida la identificación de un intervalo menor a la octava que de uno mayor a la misma. En este sentido, apunta que esta identificación, en realidad, se produce en dos etapas sucesivas: en primer lugar, uno de los dos sonidos del intervalo se transporta mentalmente hasta el registro del otro y, en segundo lugar, se efectua la propia identificación auditiva.

- Relacionadas con el contexto: En cuanto a la relación establecida entre la identificación auditiva y la existencia o falta de contexto, Wapnick, Bourassa y Sampson (1982, citados por Karpinski, 2000) descubrieron que los músicos podían diferenciarlos y etiquetarlos mejor si los intervalos se encontraban inmersos en un contexto. Hay un pensamiento común al considerar que el contexto tonal modifica la percepción de intervalos cualitativamente iguales. Así, Krumhansl (2004) establece que las funciones tonales modifican nuestra percepción de los sonidos, percibiéndose con más facilidad los intervalos compuestos por sonidos relevantes desde el punto de vista armónico, como la tónica, dominante o mediante, porque en la línea melódica ejercen funciones cadenciales.

- Relacionadas con la audición absoluta y relativa: Russo y Thompson (2005a) apuntan la idea de que la base del concepto de intervalo musical se encuentra en la audición relativa. Por su parte, Levitin (1996, citado por Laucirica, 1999) expone que las personas con oído absoluto muestran más dificultad en la identificación interválica que aquellas que disponen de oído relativo. Tal como indican Berenguel y Westdal (1991, citado por Laucirica, 1999), las personas con oído absoluto, para decidir la relación sonora de un intervalo, lo hacen de manera indirecta, ya que, a menudo, previamente necesitan determinar la altura absoluta de cada uno de sus sonidos. Por el contrario, según Laucirica (1999), "las personas con audición relativa reconocen directamente la relación creada entre los dos sonidos" (p. 121).

- Relacionadas con el aprendizaje: Por último, pensando en el sistema de enseñanza-aprendizaje de los intervalos melódicos que resulta más aplicable y efectivo, Lake (1993, citado por Karpinski, 2000) 
argumenta que, con el objetivo de adaptarse mejor a las diversas melodías que pueden presentarse, es adecuado disponer de una estrategia que emplee los intervalos $\mathrm{y}$, también, los grados de la escala. Dado que, según este autor, el citado recurso interválico funciona mejor en melodías poco precisas tonalmente $\mathrm{y}$ completamente atonales, considera más sensato trasladar el estudio de los intervalos a un momento muy posterior en la secuencia de enseñanza-aprendizaje. No obstante, la opinión de Karpinski (2000) en este sentido es que los métodos interválicos no deberían retrasarse demasiado tiempo.

En cuanto a los intervalos musicales considerados más importantes y necesarios, Bonet (1984) constata que se resumen en tres: los intervalos ascendentes y descendentes de segunda, de tercera y de cuarta. Para este autor, "conocer el alfabeto musical significa conocer todas las relaciones posibles entre una nota y las otras seis" (p. 14). Lacárcel (2001), por su parte, concluye que la edad más adecuada para comenzar a comprender el carácter del intervalo se sitúa alrededor de los 7 años. Para esta investigadora, el intervalo que resulta más familiar a los niños pequeños $\mathrm{y}$, también, el que más utilizan en sus improvisaciones y canciones es, concretamente, el de tercera menor.

\subsection{El oído musical armónico}

Aprender a escuchar armónicamente constituye una parte crucial de la formación musical, motivo por el cual, en el transcurso de los últimos años, el interés en la percepción armónica de la música ha ido creciendo considerablemente gracias a la intervención de psicólogos, especialistas en acústica, teóricos de la música, informáticos, neurocientíficos y de todos aquellos que, de una u otra forma, contribuyen al progreso de esta disciplina.

De acuerdo con Costa-Giomi (2001), la armonía constituye uno de los elementos más costosos de percibir auditivamente. Krumhansl (2004), por su parte, señala que "se hace muy difícil separar la melodía de la armonía, ya que cada una de ellas, en realidad, está influenciada por la otra" (p. 262). De hecho, Meyer (2005) apunta la idea de que el oyente deduce la armonía tanto si esta se encuentra realmente presente como si no. Sin embargo, la visión de Sloboda (1993) es que, a nivel estructural, la música tiende a construirse porque tiene una identidad melódica "horizontal" y una función armónica "vertical". Por tanto, podemos pensar que la armonía y la melodía pueden percibirse tanto de manera conjunta como independiente.

En relación a la percepción de los acordes mayores y menores, Cook y Hayashi (2010) afirman que estos acordes se describen como estables, 
finales $y$ resueltos porque se emplean habitualmente $y$ estamos acostumbrados a ellos, mientras que otros acordes se consideran extraños, ambiguos, no resueltos e, incluso, disonantes, simplemente porque se usan con menor frecuencia. Igualmente, establecen que:

Sean cuales sean las preferencias por la disonancia y las armonías sin resolver, parece que es esencial algún tipo de equilibrio [...] entre la tensión armónica y la resolución -género a género e individuo a individuo- para asegurar los altibajos emocionales que hacen de la música algo placentero. (p. 132)

Por su parte, Dutto (2007) argumenta que el análisis de los aspectos armónicos de una obra musical tonal requiere "la comprensión de los procesos cadenciales, de las relaciones entre todos los componentes que allí participan, así como de la jerarquía que se establece entre ellos" (p. 1). Para Meyer (2005), cuando un acorde o una breve melodía están formados por dos intervalos semejantes de la misma magnitud, el centro tonal se vuelve ambiguo y la música asume un carácter inestable. Por su parte, Malbrán (2007a) se refiere a las relaciones armónicas como "el entramado fundamental de la música tonal" (p. 139) y advierte que estas constituyen, en realidad, uno de los procesos más complejos. En relación con el momento de su enseñanza-aprendizaje, la autora expresa la siguiente idea:

La experiencia auditivo-armónica forma parte de los procesos iniciales; sin embargo, en general, su práctica comienza de forma tardía, probablemente por considerarla meta de llegada. La representación de simultaneidades sonoras en la mente es una de las más complejas habilidades comprometidas en el desarrollo de competencias de un músico profesional. (p. 139)

Estamos totalmente de acuerdo con Karpinski (2000), Malbrán (2007a) y Alborés (2008) en la idea de que, ya que el oído armónico constituye una parte crucial de la formación en la música occidental, se necesita partir de referentes armónicos ya desde los primeros momentos de manera sistemática. Coincidiendo con el pensamiento de Alberich (2009), creemos que es cierto que, durante muchos años, en la enseñanza tradicional del Lenguaje Musical, la audición del parámetro armónico ha estado prácticamente olvidada, ya que mayoritariamente se han enseñado determinados aspectos relacionados con la formación y el enlace de los acordes, únicamente desde el punto de vista teórico y sobre el papel.

En este sentido, para Morris y Ferguson (1931, citados por Karpinski, 2000), hablar de la formación del oído y del estudio de la armonía significa referirse a lo mismo, ya que tanto en la una como en el otro interviene una única facultad interior. Dicho en otras palabras, si lo que se pretende es conocer a 
fondo la armonía, entonces hay que entrenar el oído, y al contrario, es decir, para mejorar la audición es necesario el estudio tanto de la armonía como del contrapunto.

Igualmente, Karpinski (2000, citado por Ponsatí, 2011), en su libro Aural skills acquisition: the development of listening, Reading and performing skills in college-level musicians, examina cuidadosamente diversas maneras de abordar la audición armónica, las cuales se exponen a continuación:

- Transcripción de las voces: Según este procedimiento, la identificación auditiva de las armonías que se dan en una determinada textura polifónica puede obtenerse gracias a la realización de la transcripción independiente de sus voces. Por el contrario, dado que se deduce la armonía después de hacer un análisis previo de las líneas melódicas, la opinión de Chittum (1969, citado por Karpinski, 2000) en este sentido es que, en realidad, esta técnica no capacita verdaderamente al oyente para el reconocimiento auditivo del movimiento armónico. De hecho, tal como dice Karpinski (2000), "se están haciendo diversos dictados melódicos en vez de uno armónico" (p. 118).

- Arpegios: Empleando este método, a medida que las armonías se van sucediendo, los oyentes arpegian los sonidos de cada uno de los acordes que se presentan. Tal y como apuntan Rahn y McKay (1988, citados por Karpinski, 2000), es a partir de las partes más pequeñas como se llega a una conclusión sobre el conjunto musical. Karpinski (2000), sin embargo, destaca que, si bien este sistema puede resultar práctico en contextos con ritmos armónicos lentos, no es nada práctico, y se hace incluso pesado, en contextos más rápidos, como, por ejemplo, en obras corales.

- Gestalt: Esta técnica demanda a los oyentes que aprendan a identificar los acordes como entidades completas, reconociendo su función tonal. En este sentido, Karpinski (2000) apunta que, con la utilización de este procedimiento, se intenta estudiar el reconocimiento puro de la armonía, el cual, a pesar de ser muy difícil de desarrollar, finalmente puede llegar a ser bastante rápido y fluido.

- La línea del bajo como base de la función armónica: En este método se considera esencial una buena percepción de la línea del bajo, que es, según los grandes compositores y teóricos de la historia de la música, la que fundamenta la función armónica. Para Karpinski (2000) este trabajo es, simplemente, otra forma de audición melódica. 
- Inversión: Los oyentes que utilizan este procedimiento asocian la información de la línea del bajo con la percepción de las inversiones de los acordes, las cuales, previamente, se han aprendido a identificar aisladamente.

- Cualidades de los acordes: Esta técnica gira alrededor de la intersección de la línea del bajo y de las cualidades de los acordes y, según Karpinski (2000), resulta insuficiente para dirigir a los oyentes mucho más allá de las situaciones auditivas más limitadas. Así pues, para poder valorar la función armónica de cualquier verticalidad, hay que elaborar un método híbrido que incorpore tanto la inversión como la cualidad del acorde con el grado del bajo. Para alcanzar este fin, Karpinski recomienda que los oyentes trabajen, al principio, en la rápida identificación de la cualidad e inversión de los acordes, aislando los unos de los otros.

- La progresión de las voces y la armonía: Con la utilización de este procedimiento, los oyentes desarrollan la percepción de la progresión de las voces relacionándolas con la función armónica. Para poder determinar las funciones de las sucesiones de los acordes, por un lado, aprenden a seguir, recordar, comprender y escribir con notas la línea del bajo y, por otro, aprenden a seguir determinadas pistas cruciales que se encuentran ubicadas en lugares concretos. Para Karpinski (2000), este método requiere que en una pequeña cantidad de tiempo se realice una gran cantidad de pensamiento teórico.

Otro aspecto muy importante para la adquisición de las destrezas armónicas es el fenómeno de la enculturación (Hargreaves, 2002), el cual, mientras los oyentes escuchan la música, "permite que se vayan generando expectativas de lo que pasará en la melodía, el ritmo, el timbre, la armonía... en definitiva, en todos los aspectos formales de la música" (p. 106). Loui y Wessel (2007) se refieren concretamente al significado de la expresión expectativas armónicas como la "anticipación de los efectos psicológicos de los modelos de progresiones de acordes" (p. 1.084). Estas expectativas armónicas, tal y como demuestran Bigand, McAdams y Forêt (2000, citados por Loui \& Wessel, 2007), se presentan tanto en los individuos con formación musical como en aquellos que no han recibido ninguna instrucción. No obstante, Meyer (2005) destaca que la experiencia musical está directamente relacionada con la resolución de estas expectativas.

A continuación, estudiaremos más detenidamente distintos aspectos relacionados con el desarrollo del oído musical armónico que consideramos fundamentales para esta tesis: la percepción auditiva de la consonancia y la disonancia, la identificación auditiva de los intervalos armónicos y el desarrollo de la percepción armónica durante la infancia. 


\subsubsection{Percepción auditiva de la consonancia y la disonancia}

En música, la disonancia y la consonancia son nociones subjetivas según las cuales ciertos acordes o intervalos armónicos se consideran más o menos tensos que otros, respectivamente.

La consonancia es el conjunto de sonidos que percibimos de forma distendida, siendo aceptados por nuestro oído. Hoy en día, en nuestro contexto socio-cultural, se aceptan como consonancias los intervalos de octava justa, quinta justa, cuarta justa, tercera mayor, tercera menor, sexta mayor y sexta menor. También se consideran consonantes los intervalos compuestos que derivan de estos.

La disonancia es el conjunto de sonidos que percibimos con tensión y, por tal razón, tienden a ser rechazados por nuestro oído (Chailley, 1985, citado por Costa et al., 2000). Usualmente, se consideran como disonancias los intervalos de segunda menor, segunda mayor, cuarta aumentada o quinta disminuida (también llamado tritono), séptima menor y séptima mayor. También se consideran disonantes los intervalos compuestos que derivan de ellos. Al respecto, Cabello, Molina y Roca (2002) afirman que:

Todo sonido genera una serie de armónicos que se oyen a la vez que el sonido principal pero en menor proporción. Los intervalos producidos por los primeros armónicos son consonantes y cuanto más nos alejemos de estos más disonantes nos parecerán. (p. 10)

En cuanto a los acordes consonantes, son aquellos que contienen notas que forman intervalos consonantes entre sí, mientras que los acordes disonantes son lo que contienen uno o más intervalos disonantes.

Tradicionalmente, la consonancia era una propiedad por la cual los intervalos y los acordes se separaban en agradables o desagradables al oído, considerándose consonantes los primeros y disonantes los segundos. Ahora bien, en la percepción humana no solo intervienen factores físicos, sino también (y sobre todo) factores culturales. Lo que un hombre del siglo XV percibía como disonante, puede no llamar la atención a uno del siglo XXI, y una combinación de sonidos que sugiere una sensación de "reposo" a un japonés, puede no sugerírselo a un mejicano. Por tanto, dichos conceptos son subjetivos y culturales. De hecho, han ido evolucionando a través de la historia y hoy consideramos agradables muchas sonoridades que habrían perturbado profundamente a oyentes de tiempos pasados. Por ello, Chailley y Challan (1964) señalan que: 
No existen fronteras violentas y definitivas entre la consonancia y su contraria, la disonancia, sino una disminución progresiva del sentimiento de consonancia en las reuniones armónicas de notas. (p. 5)

Incluso, la música dodecafónica del siglo XX llegó a ampliar el concepto de consonancia a todos los acordes y a negar la disonancia porque, según este tipo de música, dichas atribuciones solo dependen de nuestra particular percepción (Lorente, 1965). En este sentido, para Schönberg (1974) los conceptos de consonancia y de disonancia, entendidos como antítesis, son erróneos. Lo argumenta de la siguiente manera:

Depende solo de la creciente capacidad del oído analizador para familiarizarse con los armónicos más lejanos, ampliando así el concepto de "sonido susceptible de hacerse arte", el que todos estos fenómenos naturales tengan un puesto en el conjunto. (p. 16)

Hargreaves (2002) distingue entre consonancia tonal o sensitiva que es, esencialmente, una "definición perceptual en la que la consonancia de un intervalo de dos sonidos se define en términos de la relación entre sus frecuencias" (p. 106) y consonancia musical, que "tiene en cuenta las reglas y convenciones de la música de la cultura y depende del contexto" (p. 106). También señala que estas dos interpretaciones se consideran complementarias.

Los resultados de las investigaciones llevadas a cabo por Davies (1978, citado por Hargreaves, 2002) establecen que hay una unanimidad en aceptar la octava justa y la quinta justa como consonantes, así como en considerar las segundas y las séptimas como disonantes. En cuanto al resto de los intervalos, las opiniones varían de unos autores a otros. Lundin (2001, citado por Balo, 2014) explica este fenómeno a través de dos teorías. La primera, llamada Teoría de la Ley Natural, está basada en las características físicas de los intervalos y se refiere fundamentalmente a la consonancia sensitiva de Hargreaves descrita anteriormente, mientras que la segunda, denominada Teoría Cultural, gira en torno a considerar que la consonancia y la disonancia son fenómenos aprendidos que evolucionan a lo largo del tiempo en un entorno cultural concreto. En el siguiente gráfico, tomado de Balo (2014), podemos observar las investigaciones relacionadas con estas dos teorías. 


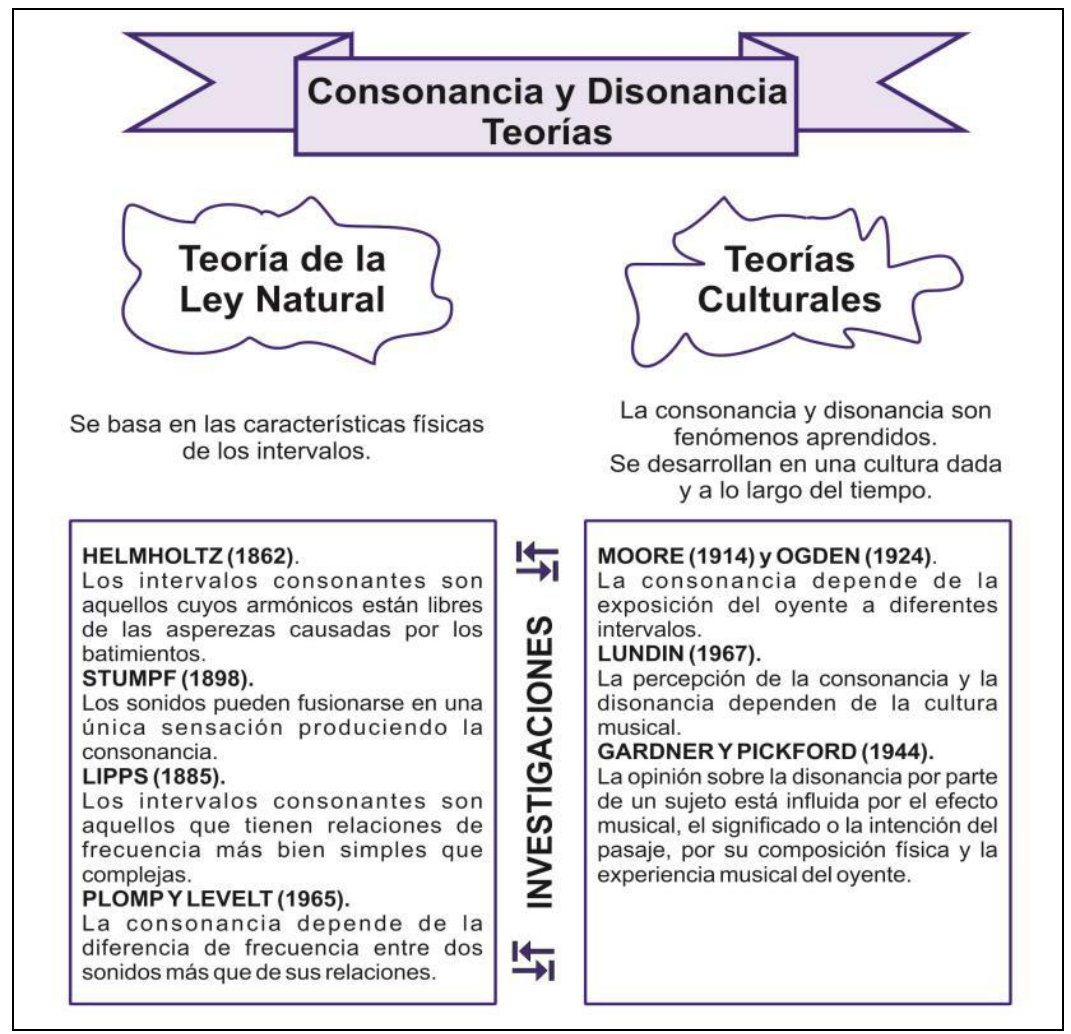

Figura 14. Teorías perceptivas de Lundin (tomado de Balo, 2014, p. 53)

Costa-Giomi (2001), en su artículo El desarrollo de la percepción armónica durante la infancia, hace una revisión de las investigaciones sobre las habilidades perceptuales armónicas, entre las cuales figuran aquellas que hacen referencia a la percepción de la consonancia y la disonancia en esta etapa vital. La autora argumenta que los resultados obtenidos en los diversos estudios indican de manera consistente que, hacia los 8 años, los niños manifiestan predilección hacia las versiones consonantes, pero no en edades anteriores. Al respecto, destacaremos las investigaciones de Moog (1976, citado por Costa-Giomi, 2001), que reflejaron que los niños menores de 6 años no podían percibir la armonía, ya que no mostraban ninguna atracción ni repulsión ante el efecto que les producía la consonancia y la disonancia. Igualmente, Rupp (1915, citado por Dillon \& Sternberg, 1986) afirmó que niños de 6 años no demostraron descontento cuando se les hizo escuchar una melodía en mi mayor interpretada con un acompañamiento en fa mayor. Del mismo modo, Revesz (1954, citado por Costa-Giomi, 2001) estableció que los niños pequeños eran indiferentes a la armonía, ya que aceptaban todas las armonizaciones, fueran consonantes o disonantes. 
Por su parte, los estudios de Valentine (1962, citado por Hargreaves, 2002) dieron como resultado que, hasta los 9 años de edad, los niños no mostraban mayor preferencia por la consonancia o la disonancia. En cambio, hacia los 11 años, los niños ya sí mostraban una clara predilección por la consonancia y expresaban desagrado por la disonancia, asemejándose al patrón adulto. En relación con este tema, Sloboda (1985, citado por Costa-Giomi, 2001) confirma que esta preferencia puede explicarse a través del fenómeno de la aculturación: "el proceso de aculturamiento puede explicar la indiferencia de los niños pequeños a la disonancia y el fuerte rechazo de los más grandes a la disonancia" (p. 46).

\subsubsection{La identificación auditiva de los intervalos armónicos}

El estudio de los intervalos armónicos constituye la base de los acordes y, por tanto, de la armonía. En una educación musical basada en el trabajo auditivo, los intervalos armónicos juegan un papel muy importante, ya que son considerados un elemento de transición, ayudándonos a pasar del terreno melódico al armónico.

Willems (1984b) considera que para participar auditivamente de la armonía musical contamos con: el órgano auditivo, la sensibilidad afectiva y la inteligencia humana. Este tercer elemento nos permitirá dotar de significado a sonidos que suenan simultáneamente, ya que "nos da la posibilidad de analizar y de sintetizar los sonidos de acordes y de agregados" (p. 153). Además, con el objetivo principal de conseguir la identificación auditiva de los intervalos armónicos, recomienda diversos ejercicios, entre los cuales destacan: el canto de los sonidos de los intervalos, su reproducción instrumental, la escritura de intervalos dictados, la escritura a dos voces de un fragmento polifónico dictado y la lectura interior de textos a dos voces.

Igualmente, desde un punto de vista educativo, Karpinski (2000) considera que "la identificación de intervalos es tal vez la más ubicua de todas las actividades atomistas de entrenamiento auditivo" (p. 52) y Hemsy de Gainza (1964) señala la importancia de aprender a percibir auditivamente y de manera simultánea los intervalos, destacando que "los mismos alumnos descubrirán el rasgo que caracteriza auditivamente a cada una de estas superposiciones" (p. 154). Por su parte, Erzsébeth (1997, citado por Miranda, 2003) considera que los cánones y las obras vocales a dos voces son la mejor introducción al estudio de los intervalos armónicos, afirmando que "el canto de diversas voces es la base para la interiorización y la comprensión de las sonoridades armónicas" (p. 45).

Respecto a la audición de frases polifónicas, Kühn (2003) opina que no se ha de separar nunca la simultaneidad de las voces. Por un lado, se ha de captar 
la voz individual en su independencia lineal pero, por otro, se han de captar la acción conjunta de las voces, los procesos de sonido y la relación recíproca de estos. Por tanto, Kühn considera que hay que escuchar, a la vez, la relación horizontal y la vertical: "[...] constituiría un fallo unilateral fijarse en exclusiva en el devenir horizontal. Atienda, por lo tanto, siempre y al mismo tiempo a la relación vertical" (p. 66).

Si bien existen diversos criterios a la hora de clasificar los intervalos musicales armónicos, destacamos aquel que para Schenker (1990), Krumhansl (2000) y Justus y Bharucha (2002) es el más importante: el que se basa en la consonancia y disonancia. Este criterio establece como consonantes todos los intervalos que se relacionan directamente, o a través de su inversión, con las relaciones simples $1,2,3$ y 5 de la serie de armónicos; nos referimos concretamente a los intervalos de primera o unísono (armónico 1), octava (armónico 2), quinta (armónico 3), cuarta (inversión de la quinta), tercera (armónico 5) y sexta (inversión de la tercera). El resto de los intervalos son considerados disonantes: segunda y séptima, tanto mayores como menores, y todos los intervalos aumentados y disminuidos. Dentro de los intervalos consonantes, se realiza una subclasificación en: consonantes perfectos o justos (unísono, cuarta, quinta y octava) y consonantes imperfectos (terceras y sextas).

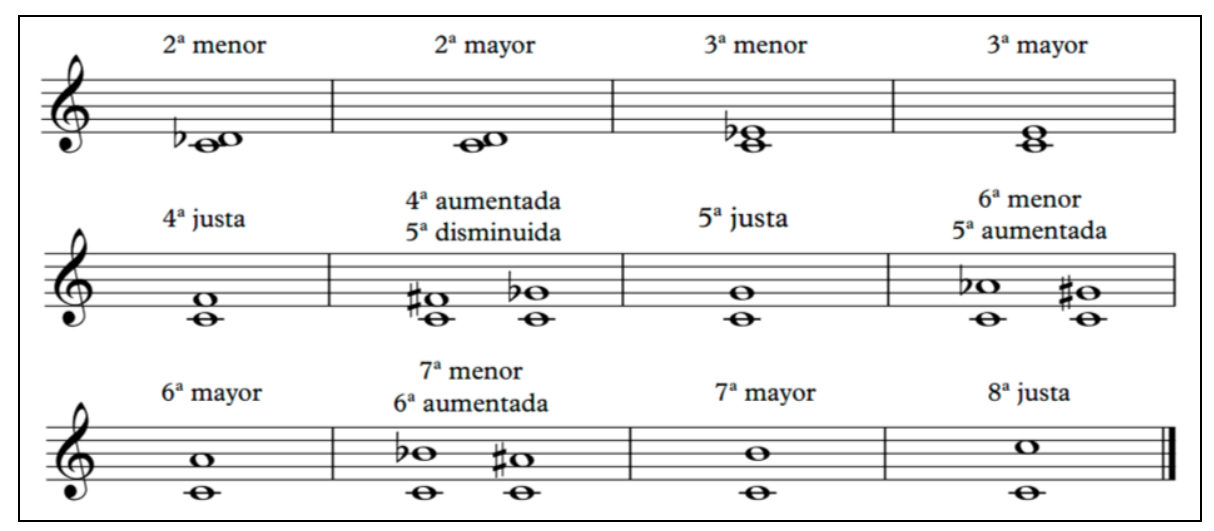

Figura 15. Clasificación de los intervalos armónicos (Fuente: creación propia)

Tal y como señala Persichetti (1985), mientras que las propiedades físicas del intervalo no cambian nunca, es decir, se mantienen intactas, su uso, en cambio, puede variar de manera radical dependiendo del contexto de la obra a la cual pertenece.

El grado de facilidad y dificultad en la identificación auditiva de los intervalos armónicos musicales por parte de los oyentes depende de muchos 
factores, los cuales tienen que ver con su modo de presentación, es decir, la interpretación secuencial o simultánea de los sonidos (Balzano \& Liesch, 1982; Killam et al., 1975; Samplaski, 2005), la duración de la interpretación de los sonidos de los intervalos (Plomp et al., 1973, citados por Balzano et al., 1982), la influencia del contexto musical (Taylor, 1972, citado por Balzano et al., 1982), el timbre y el orden de presentación (Kuusi, 2007).

De acuerdo con Samplaski (2005), la confusión que se produce en la identificación auditiva de los intervalos armónicos está muy relacionada con la semejanza de estos, es decir, que es más probable que se confundan entre sí los intervalos que son similares que no aquellos que no se parecen en nada. Samplaski detalla los siguientes modelos de confusión interválica: intervalos de tamaño parecido, intervalos de tipo parecido, intervalos de la misma clase interválica, intervalos de la misma categoría de disonancia acústica y, finalmente, la interacción de alguno de los factores anteriores y posiblemente de otros.

Terminaremos este apartado señalando que todos estos conocimientos ayudarán, tanto a los estudiantes como al profesorado, a la hora de planificar el desarrollo de esta habilidad para obtener los mejores resultados, ya que, como dice Romero (2008):

\begin{abstract}
Saber imaginar, reconocer y entonar perfectamente intervalos son las herramientas básicas para realizar procesos de audición e interpretación conscientes, de música de todos los periodos históricos, especialmente de la música del siglo XX, ya que la mayor parte de los diversos sistemas y métodos de construcción sonora que se han creado en esta época se basan en procesos de estructuración de los intervalos. (p. 31)
\end{abstract}

\title{
4.4.3. Desarrollo de la percepción armónica en la infancia
}

La percepción armónica es uno de los componentes determinantes de la habilidad musical que aparece en la mayoría de los test que miden el talento musical. Entre dichos test, Costa-Giomi (2001) destaca los siguientes: Measures of Musical Ability, Bentley; Musical Aptitude Profile, Gordon; The Measurement of Musical Talent, Seashore; Indiana Oregon Music Discrimination Test, Long, y Wing Standarized Tests of Intelligencel Test of Musicality, Gaston (pp. 43-44). En general, estos tests están diseñados para ser usados con niños mayores de 9 años y son inadecuados para medir las habilidades musicales de niños más pequeños. Por otro lado, observamos que los tests de habilidades musicales que pueden ser usados con niños menores de 9 años, no incluyen ninguna medición de percepción armónica (Primary Measures of Musical Audiation, Gordon; Intermediaet Measures of Musica Audiation, Gordon). Una de las razones por las cuales este tipo de percepción es excluida en estos tests para niños de poca edad es que la 
medición de la percepción armónica durante la infancia es particularmente problemática y otra razón puede ser que el desarrollo armónico no es evidente hasta aproximadamente los 9 años. Moog (1976) ha llegado a decir que los niños pequeños son "sordos a la armonía hasta el fin de los seis años y posiblemente por mucho tiempo más" (p. 136).

Hecha esta aclaración, son diversos los trabajos que se han centrado en el estudio del desarrollo de la percepción armónica durante la infancia, cuyos resultados nos proporcionan una información muy valiosa para la enseñanza. En este apartado, señalaremos las principales aportaciones extraídas de los trabajos más difundidos.

Hickman (1969, citado por Costa-Giomi, 2001) estudió la percepción de intervalos y acordes con niños de 8 a 14 años, encontrando que incluso los niños de 8 años podían identificar sutiles variaciones armónicas. Igualmente, Zenatti (1969, citado por Costa-Giomi, 2001) investigó la percepción armónica de los niños demandándoles que, ante la presentación de pares similares de progresiones armónicas, identificaran el acorde que experimentaba un cambio sustancial. Dicho cambio consistía, por ejemplo, en sustituir el acorde de tónica por el de dominante o a la inversa. Esta autora concluyó que, si bien los niños de 6 años podían identificar esta alteración en progresiones muy cortas (de dos acordes), no podían hacerlo, en cambio, en progresiones más extensas.

Costa-Giomi (1994a, citada por Gudmundsdottir, 1999) añadió a las conclusiones de Zenatti que los niños no identificaban cambios de acordes cuando estas progresiones iban acompañadas por una melodía aunque, si esta melodía era tocada por un timbre o registro muy diferente, los niños sí podían identificar más cambios armónicos.

Los estudios de Taylor (1973) y Thackray (1973), ambos citados por Cheston (1994), demostraron que, hacia los 8-9 años, los niños habían progresado en su percepción armónica de una forma digna de ser tenida en cuenta. En el mismo sentido, Costa-Giomi (2001) comprobó que la mayoría de los niños de tercero y cuarto grado identificaron correctamente los acompañamientos armónicos de frases musicales que incluían los acordes de tónica y dominante, por lo que concluyó que hacia los 9-10 años se producía un verdadero cambio en su progreso respecto a la percepción de las funciones tonales. Esta variación era, según la autora, fruto del desarrollo natural del niño y no del aprendizaje.

Los estudios de Petzold (1966, citado por Costa-Giomi, 2001) reflejan que, al pedir a niños de entre 6 y 11 años que cantaran canciones tres veces utilizando cada vez un tipo diferente de acompañamiento armónico, la 
precisión del canto no variaba. Sin embargo, en un estudio similar, Sterling (1985) reflejó que los niños cantaron mejor cuando el acompañamiento consistía simplemente en la reproducción exacta de la melodía o en una progresión tonal de acordes. Sin embargo, estas diferencias eran obvias solamente en ciertas canciones, lo cual tal vez explique por qué Petzold halló resultados contrarios a los de Sterlings. En la misma línea, Costa-Giomi (2001) también encontró que los niños variaron su afinación al cantar una canción conocida con diferentes acompañamientos. Por todo ello, puede concluirse que los niños son perceptivos a los acompañamientos armónicos, pero que esta percepción está influenciada por otras características de la música como, por ejemplo, la melodía y el grado de familiarización con el estímulo.

Investigaciones más globales de la percepción armónica, como las de Imberty (1969, citado por Costa-Giomi, 2001), que estudió la percepción de cadencias armónicas y melódicas, reflejan que el desarrollo en la percepción de las cadencias tiene cuatro etapas:

- Primera etapa (hasta los 6 años): Aún no son capaces de percibir las cadencias.

- Segunda (desde los 6 años y medio hasta los 7): Ya pueden percibir las cadencias.

- Tercera etapa (de los 8 a los 10 años): Distinguen entre una cadencia perfecta y la omisión de la misma relacionándola con el material que la precede.

- Cuarta etapa (a partir de los 10 años): Las melodías cadenciales y no cadenciales son claramente diferenciadas, al igual que las semicadencias. También son entendidas las funciones de dominante y de tónica.

Veámoslas más claramente en el siguiente esquema: 


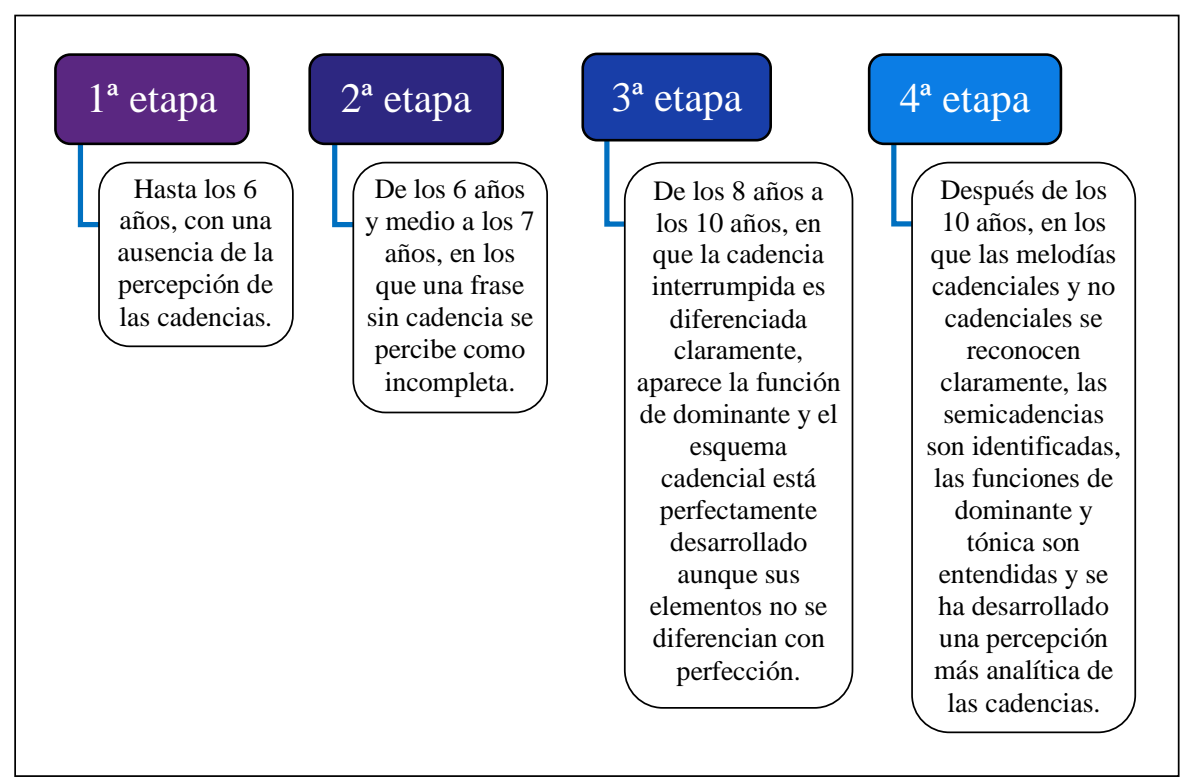

Figura 16. Percepción de las cadencias de Imberty (1969, citado por CostaGiomi, 2001, p. 49)

Sloboda (1985, citado por Cheston, 1994), después de analizar el comportamiento musical de los niños, concluye que:

- Hacia los 2 años y medio de edad, los niños cantan patrones melódicos que reflejan estructuras tonales.

- Alrededor de los 3 años, cuando cantan, comienzan a emplear intervalos definidos de la escala diatónica.

- A los 5 años, los niños ya son capaces de cantar manteniendo la tonalidad o el centro tonal de una canción. (p. 49)

Otros métodos de investigación de la percepción armónica de los niños se basan en la comparación de estímulos semejantes o diferentes. Por ejemplo, Pflederer (1964) estudió cómo la transformación del acompañamiento de una canción afectaba a la conservación de la melodía, ya que encontró que los niños de 5 y 8 años pensaban que la melodía había cambiado cuando, en realidad, lo que había cambiado era el acompañamiento. Más tarde, Pflederer y Schrest (1968) completaron una experiencia similar usando fragmentos melódicos de Bartok, de su "Música para niños". En este caso, el agregado de un acompañamiento armónico a las melodías fue percibido por los niños como la adición de otro instrumento o un cambio de tempo. 
Por su parte, Zenatti (1975) pone su interés en la importancia de la aculturación, que hace referencia a los desarrollos musicales que surgen espontáneamente, es decir, sin ningún esfuerzo o dirección auto-consciente. En sus estudios destacan los resultados en cuanto a la diferencia de sexo, ya que los niños, en algunos niveles de edad, parecen revelar menor aculturación que las niñas. Zenatti afirma que esto puede ser como consecuencia del mayor interés de los niños por la música atonal contemporánea o por su falta de interés general por la música en relación a otros intereses.

Pensando en las aplicaciones de los conceptos armónicos para la enseñanzaaprendizaje, Costa-Giomi (2001) concluye que estos no parecen ser efectivos antes de los 9 años de edad. A pesar de todo, la autora sugiere que, mucho antes, los niños pueden emplear estos elementos en actividades imitativas y experimentales, los cuales, alcanzada la edad adecuada, podrán ser utilizados para reforzar los conceptos armónicos. Hemos considerado conveniente concluir este capítulo del marco teórico con una reflexión de dicha autora que nos ha animado a emprender el trabajo presentado en esta tesis:

El encauzamiento de las habilidades perceptuales armónicas en estos niños a través de actividades interesantes y variadas, y que al mismo tiempo posibiliten la instrucción formal de las funciones armónicas, es uno de los desafíos que los maestros tendrán que afrontar. (p. 53) 


\section{CAPÍTULO IV: LA ASIGNATURA DE LENGUAJE MUSICAL DENTRO DE LAS ENSEÑANZAS MUSICALES}

\section{Introducción}

En los capítulos anteriores hemos tratado ampliamente la fundamentación teórica de la educación auditiva y, más concretamente, su tratamiento desde el marco tonal-armónico, que es el sistema musical imperante en nuestro entorno socio-cultural.

Consideramos que la tercera parte de nuestro marco teórico debía ser, necesariamente, su contextualización dentro del sistema educativo español y, más concretamente, en los conservatorios de nuestro país, centrándonos de forma específica en la asignatura de Lenguaje Musical, desde la cual se aborda el trabajo de educación auditiva presentado en esta tesis. De todo ello hablaremos a continuación.

\section{La educación musical en el sistema educativo español}

Al hablar de educación musical debemos distinguir tres ámbitos de formación claramente diferenciados, a pesar de que a lo largo de la historia hayan podido llegar a confundirse y alguno de ellos haya estado menos definido: la música como parte de la formación general, la formación musical profesional y la formación docente para el ámbito musical.

En España, el marco legislativo actual distingue entre educación musical con valor de educación general y educación musical con sentido profesional. Ya en la Ley 14/1970, de 4 de agosto, General de Educación y Financiamiento de la Reforma Educativa (LGE) se contemplaba la música como parte del currículo de la educación general, pero no será hasta la Ley Orgánica 
1/1990, de 3 de octubre, de Ordenación General del Sistema Educativo (LOGSE) cuando realmente la música pase a formar parte del currículo de la educación obligatoria, siendo impartida por profesorado especializado (se crea la especialidad de Maestro de Educación Musical). La educación musical fuera de este ámbito se denomina educación de régimen especial, reconociendo dos ámbitos de desarrollo: los conservatorios y las escuelas de música.

Por su parte, la Ley Orgánica 2/2006, de 3 de mayo, de Educación (LOE) mantiene el concepto de enseñanzas de régimen especial -aunque no con el rango de Título como hacía la LOGSE- para las enseñanzas profesionales (artículo 3.6 de la LOE), pero además establece el concepto de educación artística en la educación general. Al respecto, cabe destacar que la educación artística aparece con esa denominación como área en el currículo de educación primaria (artículo 18.2 de la LOE); en la educación secundaria obligatoria, se determina que tanto la música como la educación plástica y visual formen parte del currículo general obligatorio de los alumnos (artículos 24 y 25 de la LOE); y, en el bachillerato, se establecen por ley tres modalidades: "Artes", "Ciencias y tecnología" y "Humanidades y Ciencias Sociales" (artículo 34 de la LOE). Ante tales datos, podemos afirmar que, con la LOE, la educación artística queda integrada en el sistema general de formación de manera clara y distinta de la que corresponde a las enseñanzas artísticas de carácter profesional (artículo 45 de la LOE). Se sigue, por tanto, que la formación artística es un ámbito de intervención pedagógica que puede ser abordado desde la formación general del individuo y como ámbito de especialización o profesionalización.

Actualmente, la oferta de enseñanza musical fuera de los niveles educativos generales, es decir, la dirigida a la formación musical profesional o vocacional, cuenta con dos vías: la reglada y la no reglada. La primera se desarrolla en los conservatorios de música y en la universidad, y está encaminada a la obtención de títulos con validez académica y profesional. La segunda modalidad se circunscribe al ámbito de las escuelas de música, que se regulan por normas de las diferentes administraciones educativas. La formación musical profesional se imparte en los conservatorios de música y en el Grado Universitario de Historia y Ciencias de la Música. Además, algunas universidades han aprobado títulos propios relacionados con la gestión cultural y artística y con la Musicoterapia.

Tres son las vías de formación para ejercer la función docente en los diferentes ámbitos del sistema educativo en la especialidad de música: las Titulaciones Superiores de la especialidad de Pedagogía expedidas por los conservatorios de música, la Diplomatura Universitaria de Maestro en la especialidad de Música, sustituida en la LOE por los Grados de Maestro en 
Educación Primaria con menciones en la especialidad Música, y la Licenciatura o Grado de Historia y Ciencias de la Música u otras titulaciones superiores complementadas por la formación pedagógica especializada.

Nosotros en esta tesis nos vamos a centrar en los estudios musicales reglados de los conservatorios, dirigidos a formar profesionales de la música.

\section{La educación musical en los conservatorios españoles}

La enseñanza musical en los conservatorios tiene un desarrollo normativo y unas particularidades que debemos tener en cuenta para comprender las propuestas que presentamos.

Por ello, dedicaremos este apartado a destacar los aspectos más relevantes del marco legislativo establecido, de forma general, para todo el territorio nacional y, a continuación, nos detendremos en su concreción para los conservatorios de Castilla y León, diferenciando los tres niveles fijados: enseñanzas elementales, profesionales y superiores.

Por último, de forma más específica, señalaremos las particularidades del Conservatorio Profesional de Música de Segovia, en el cual hemos llevado a cabo nuestro estudio.

\subsection{Marco legislativo general para todo el territorio nacional}

Los conservatorios de música son centros educativos donde se imparten enseñanzas de régimen especial, que responden a una formación musical especializada. Su objetivo es formar músicos a través de unas enseñanzas profesionales, por lo que su currículo es sustancialmente diferente al establecido para las enseñanzas de música dentro de la enseñanza general.

Con la entrada en vigor de la LOGSE ( $L O$ 1/1990) comienza una transformación de todo el sistema educativo, suponiendo la primera reforma de los estudios musicales que se realiza con profundidad desde el Decreto 2618/1966, de 10 de septiembre, sobre Reglamentación General de los Conservatorios de Música (Decreto 2618/1966).

A través de dicha Ley Orgánica, se busca superar las deficiencias del sistema anterior y preparar a los futuros profesionales de la música de una manera más acorde al resto de países europeos. Roche (1994) destaca las siguientes novedades de la misma:

- Se delimitan los tipos de centros, especialidades y grados de enseñanza. 
- Se equipara la titulación de Profesor Superior a la de Licenciado Universitario.

- Se realiza una separación de los centros superiores de los de enseñanzas profesionales.

- El currículo se establece de una manera más ordenada y espaciada.

- Se busca la homogeneidad pedagógica de las diferentes asignaturas.

- La música, en conjunto, adquiere mayor presencia.

- Aumento del tiempo lectivo del instrumento principal.

- La evaluación del alumnado se obtiene a través de la evaluación conjunta.

- Coordinación con las enseñanzas de régimen general. Se desarrollan los centros integrados donde poder cursar ambas enseñanzas, las de régimen general y las de música.

Con la LOGSE ( $L O$ 1/1990) la organización de los estudios musicales en los conservatorios queda regulada en tres etapas (art. 39.1):

- Grado elemental, con una duración de cuatro cursos académicos.

- Grado medio, compuesto por tres ciclos, con dos cursos académicos cada uno.

- Grado superior, que comprende un solo ciclo, cuya duración se determina en función de las características de estas enseñanzas.

Las titulaciones que se establecen para las enseñanzas musicales en los conservatorios son: Certificado de Estudios tras cursar grado elemental, Título Profesional en la especialidad correspondiente al superar el tercer ciclo de grado medio y Título Superior una vez cursado satisfactoriamente el grado superior.

La ordenación anterior no fue revisada hasta la Ley Orgánica 2/2006, de 3 de mayo, de Educación (LOE), que dedica el capítulo VI de su título I a las Enseñanzas Artísticas, entre las que se encuentran las Enseñanzas de Música, cuya finalidad es "proporcionar al alumnado una formación artística de calidad y garantizar la cualificación de los futuros profesionales de la música" (art. 45.1). La LOE ( $L O$ 2/2006) establece los aspectos básicos del currículo con el fin de garantizar una formación común a todos los alumnos del estado español y la validez de los títulos correspondientes, pero 
posteriormente son desarrollados por las administraciones educativas de las diferentes comunidades autónomas.

En esta Ley se cambia la denominación de las etapas educativas, cuya nueva nomenclatura es: enseñanzas elementales, enseñanzas profesionales $\mathrm{y}$ enseñanzas superiores (art. 45). Además, la nueva Ley aporta las siguientes novedades:

- Se deja en manos de las distintas administraciones educativas la determinación de las características y la organización de las enseñanzas elementales (art. 48.1.).

- Las enseñanzas profesionales de música se organizan en un grado de seis cursos de duración.

- Los alumnos pueden, con carácter excepcional y previa orientación del profesorado, matricularse en más de un curso cuando así lo permite su capacidad de aprendizaje (art. 48.2.).

- Continúa el mandato de facilitar la simultaneidad con las enseñanzas generales, es decir, las administraciones educativas deben facilitar la posibilidad de cursar las enseñanzas artísticas profesionales y la educación secundaria. Para ello, se ofrece la posibilidad de utilizar el sistema de convalidaciones y, además, los alumnos pueden cursar sus estudios en centros integrados.

- Desparece el requisito de formación pedagógica inicial para los docentes que impartan las enseñanzas de grado elemental, pidiéndose este requisito solo en las enseñanzas profesionales.

- Tras la superación de las enseñanzas profesionales, se expide el título profesional correspondiente (art. 50.1).

La Ley Orgánica 8/2013, de 9 de diciembre, para la Mejora de la Calidad Educativa (LOMCE) es la última reforma educativa. La aplicación de la misma ha comenzado en el curso académico 2014-2015. Las novedades más destacables que presenta la nueva Ley en su Capítulo VI, destinado a las enseñanzas artísticas, son las siguientes:

- Se crea un "Consejo Superior de Enseñanzas Artísticas".

- La titulación, una vez superado el grado profesional, cambia de nomenclatura, considerándose tal titulación como "Técnico de las Enseñanzas Profesionales de Música”. 
Dado que la LOMCE ( $L O$ 8/2013) considera que son las administraciones autonómicas las que han de determinar las características y ordenación de las enseñanzas musicales en los conservatorios, habrá que esperar al desarrollo de la Ley mediante los Reales Decretos, Decretos y Órdenes correspondientes.

A continuación, desarrollaremos los tres niveles en los cuales se estructuran las enseñanzas regladas de música (enseñanzas elementales, enseñanzas profesionales y enseñanzas superiores), incidiendo en los aspectos que caracterizan a cada uno de ellos.

\subsubsection{Enseñanzas elementales}

Las enseñanzas elementales se organizan en un grado de cuatro cursos de duración, los cuales, durante el curso académico 2012-2013, periodo en el que hemos llevado a cabo el trabajo de campo para la elaboración de esta tesis, se regían por la $\operatorname{LOE}(L O 2 / 2006)$.

En el currículo del nivel elemental se podrán ofertar las siguientes especialidades instrumentales: Acordeón, Arpa, Clarinete, Clave, Contrabajo, Fagot, Flauta travesera, Flauta de Pico, Guitarra, Instrumentos de Púa, Oboe, Percusión, Piano, Saxofón, Trompa, Trompeta, Trombón, Tuba, Viola, Viola da Gamba, Violín, Violoncelo.

Para acceder al curso primero de las enseñanzas elementales de música será necesario superar una prueba de acceso en la que se valorarán únicamente las aptitudes musicales de los aspirantes y se deben tener cumplidos los 8 años de edad dentro del año natural en que se realice la prueba. Para acceder directamente a un curso distinto será preciso superar una prueba específica de acceso en la que el aspirante deberá demostrar tener los conocimientos necesarios para cursar con aprovechamiento estas enseñanzas.

La evaluación del alumnado, que se realizará teniendo en cuenta los objetivos educativos y los criterios de evaluación establecidos, será continua e integradora, pero diferenciada según las distintas asignaturas del currículo. La evaluación la realizará el conjunto de los profesores del alumno coordinados por el profesor tutor. La evaluación y calificación final de los alumnos se realizará en el mes de junio. No obstante, los centros organizarán en el mes de septiembre las oportunas pruebas extraordinarias con el fin de facilitar a los alumnos la recuperación de las asignaturas con evaluación negativa.

Los alumnos promocionarán de curso cuando tengan superadas todas las asignaturas o tengan evaluación negativa, como máximo, en una asignatura. 
Para los alumnos que promocionen con una asignatura pendiente referida a la práctica instrumental, la recuperación deberá realizarse en la clase del curso siguiente. En el caso de que la asignatura sea Lenguaje Musical, el alumno deberá asistir a las clases de los dos cursos.

El límite de permanencia en el nivel elemental será de cinco años, sin que, en ningún caso, los alumnos puedan permanecer más de dos años en el mismo curso, excepto en el $4^{\circ}$ curso, siempre y cuando no se hayan agotado los cinco años de permanencia. Con carácter excepcional, se podrá ampliar un año la permanencia en supuestos que imposibiliten el normal desarrollo de los estudios. Al terminar la enseñanza elemental se expedirá un certificado de estudios acreditativo de las enseñanzas cursadas.

\subsubsection{Enseñanzas profesionales}

Las enseñanzas profesionales tienen una duración de seis cursos. El Real Decreto 1577/2006, de 22 de diciembre, por el que se fijan los aspectos básicos del currículo de las Enseñanzas Profesionales de Música (RD 1577/2006) desarrolla la LOE ( $L O$ 2/2006) y deposita en manos de las administraciones educativas el establecimiento del currículo de las enseñanzas profesionales de música, aunque fija los aspectos básicos que, en todo caso, habrán de recoger (art. 5). En sus disposiciones encontramos muchos aspectos básicos de las enseñanzas profesionales, algunos de los cuales destacaremos en este apartado.

El artículo 3 está dedicado a los objetivos específicos de las enseñanzas profesionales de música. En él se señala que dichas enseñanzas deberán contribuir a que los alumnos y alumnas adquieran las siguientes capacidades:

a). Superar con dominio y capacidad crítica los contenidos y objetivos planteados en las asignaturas que componen el currículo de la especialidad elegida.

b). Conocer los elementos básicos de los lenguajes musicales, sus características, funciones y transformaciones en los distintos contextos históricos.

c). Utilizar el oído interno como base de la afinación, de la audición armónica y de la interpretación musical.

d). Formar una imagen ajustada de las posibilidades y características musicales de cada uno, tanto a nivel individual como en relación con el grupo, con la disposición necesaria para saber integrarse como un miembro más del mismo o para actuar como responsable del conjunto. 
e). Compartir vivencias musicales de grupo en el aula y fuera de ella que permitan enriquecer la relación afectiva con la música a través del canto y de participación instrumental en grupo.

f). Valorar el cuerpo y la mente para utilizar con seguridad la técnica y poder concentrarse en la audición e interpretación.

g). Interrelacionar y aplicar los conocimientos adquiridos en todas las asignaturas que componen el currículo, en las vivencias y en las experiencia propias para conseguir una interpretación artística de calidad.

h). Conocer y aplicar las técnicas del instrumento o de la voz de acuerdo con las exigencias de las obras.

i). Adquirir y demostrar los reflejos necesarios para resolver eventualidades que surjan en la interpretación.

j). Cultivar la improvisación y la transposición como elementos inherentes a la creatividad musical.

k). Interpretar, individualmente o dentro de la agrupación correspondiente, obras escritas en todos los lenguajes musicales, profundizando en el conocimiento de los diferentes estilos y épocas, así como en los recursos interpretativos de cada uno de ellos.

1). Actuar en público con autocontrol, dominio de la memoria y capacidad comunicativa.

Las especialidades que pueden cursarse en las enseñanzas profesionales son las que citamos a continuación: Acordeón, Arpa, Bajo eléctrico, Cante flamenco, Canto, Clarinete, Clave, Contrabajo, Dulzaina, Fagot, Flabiol i Tamborí, Flauta travesera, Flauta de pico, Gaita, Guitarra, Guitarra eléctrica, Guitarra flamenca, Instrumentos de cuerda pulsada del renacimiento y barroco, Instrumentos de púa, Oboe, Órgano, Percusión, Piano, Saxofón, Tenora, Tible, Trombón, Trompa, Trompeta, Tuba, Txistu, Viola, Viola da gamba, Violín, Violoncello. Además, se permite a los alumnos cursar más de una especialidad, aunque las asignaturas comunes se cursarán exclusivamente por una de ellas (art. 10).

Por otro lado, se fijan dos tipos de asignaturas:

- Las asignaturas comunes a todas las especialidades, que son Instrumento o voz, Lenguaje musical y Armonía. 
- Las asignaturas propias de la especialidad, que podrán ser Música de Cámara, Orquesta, Banda, Conjunto, Coro o Idiomas aplicados al Canto.

Las enseñanzas mínimas específicas de cada asignatura se establecen en el anexo I del $R D$ 1577/2006 al que nos referimos y, en el anexo II de dicha norma, se regula el horario escolar mínimo por especialidades. Asimismo, se establece que las administraciones educativas podrán añadir otras asignaturas dentro de las diferentes especialidades que integran las enseñanzas profesionales de música y potenciar en sus currículos distintos perfiles dentro de cada especialidad en los dos últimos cursos de las citadas enseñanzas.

Los resultados de evaluación final de las distintas asignaturas se expresarán de forma numérica de 1 a 10 sin decimales. Las calificaciones iguales o superiores a cinco serán positivas y las inferiores serán negativas.

El acceso a los estudios profesionales se hará mediante prueba específica, tanto para acceder al primer curso de las enseñanzas profesionales como para acceder al resto de los cursos, aunque no se hayan realizado los anteriores. En esta prueba el aspirante debe demostrar que puede cursar con aprovechamiento las enseñanzas a las que pretende acceder (art. 7).

El límite de permanencia en estas enseñanzas es de ocho años, no pudiendo permanecer el alumno más de dos años en el mismo curso, excepto en $6^{\circ}$. Con carácter excepcional, se podrá ampliar en un año este límite de permanencia. Los alumnos promocionarán de curso cuando hayan superado las asignaturas cursadas o tengan evaluación negativa, como máximo, en dos asignaturas. La recuperación de las asignaturas pendientes se realizará en la clase del curso siguiente si dichas asignaturas se refieren a la práctica instrumental o vocal. En el resto de las asignaturas, se deberá asistir a las clases de las asignaturas no superadas. Los alumnos de $6^{\circ}$ que tengan pendientes tres asignaturas o más deberán repetir el curso en su totalidad, pero si la calificación negativa es en una o dos asignaturas podrán cursar exclusivamente las asignaturas pendientes.

El título profesional en la especialidad correspondiente se obtiene tras la superación del último curso de las enseñanzas profesionales (art. 14). Asimismo, el alumnado que finalice las enseñanzas profesionales de música obtendrá el título de Bachiller, si supera las materias comunes del bachillerato, aunque no haya realizado el bachillerato de la modalidad de artes en su vía específica de música y danza. 
Estos estudios transcurren mientras se cursa la enseñanza general, por lo que la LOE ( $L O$ 2/2006), en su artículo 47, establece que "las administraciones educativas facilitarán al alumnado la posibilidad de cursar simultáneamente las enseñanzas artísticas profesionales y la educación secundaria". Para ello, se habrán de adoptar las medidas necesarias que incluirán, entre otras, las convalidaciones y la creación de centros integrados. Una de estas medidas es el Bachillerato en Música, que es una buena opción para que nuestros estudiantes puedan cursar la enseñanza obligatoria con la musical de una manera más lógica y sin el sobreesfuerzo que supone la carga lectiva de ambos estudios.

\subsubsection{Enseñanzas superiores}

La duración de los estudios que conforman las enseñanzas superiores depende de la especialidad que se escoja.

Estas enseñanzas se rigen por el Real Decreto 631/2010, de 14 de mayo, por el que se regula el contenido básico de las Enseñanzas Artísticas Superiores de Grado en Música establecidas en la Ley Orgánica 2/2006, de 3 de mayo, de Educación (RD 631/2010). En dicho Real Decreto se establece que, en el curso académico 2010-2011, se iniciará la implantación progresiva de las enseñanzas artísticas superiores de grado en música (Disposición adicional tercera) con las siguientes especialidades: Composición, Dirección, Interpretación, Musicología, Pedagogía, Producción y gestión y Sonología (art. 4.2). Sin embargo, también se deja abierta la posibilidad de que las administraciones educativas propongan la creación de nuevas especialidades (art. 8).

Además, se indica que el contenido básico de estas enseñanzas artísticas superiores establecidas en la LOE ( $L O$ 2/2006) será completado por las administraciones educativas, que fijarán el plan de estudios, una vez vista la propuesta de los centros, hasta llegar a un total de 240 créditos (art. 7). Para ello, las materias establecidas en el $R D$ 631/2010 se organizarán en una o varias asignaturas, se podrá completar el plan de estudios con otras materias no establecidas en el Real Decreto, que habrán de concretarse también en asignaturas, y se podrán establecer asignaturas optativas.

Para acceder a las enseñanzas de música conducentes al Título de Graduado en Música se habrá de superar una prueba específica (art. 5). En dicha prueba se habrá de acreditar que el alumno posee los conocimientos y habilidades profesionales necesarios para cursar con aprovechamiento las correspondientes enseñanzas. Esta norma nos remite al artículo 12 del Real Decreto 1614/2009, de 26 de octubre, por el que se establece la Ordenación de las Enseñanzas Artísticas Superiores reguladas por la Ley Orgánica 
2/2006, de 3 de mayo, de Educación (RD 1614/2009), donde, además, se exige estar en posesión del título de Bachiller o haber superado la prueba de acceso a la universidad para mayores de 25 años.

El anexo I del $R D$ 1614/2009 establece las competencias que han de poseer los Graduados en Música al finalizar sus estudios, divididas en competencias transversales, generales y específicas (dependiendo de la especialidad que se elija). Asimismo, diseña los perfiles profesionales de cada una de las especialidades en las titulaciones de Grado.

En su artículo 5, dicho Real Decreto establece el sistema de calificaciones, que serán las que siguen: 0-4,9: Suspenso (SS), 5,0-6,9: Aprobado (AP), 7,08,9: Notable (NT), 9,0-10: Sobresaliente (SB). Los estudiantes cuya calificación sea igual o superior a 9,0 podrán recibir la mención de Matrícula de Honor. Su número no podrá exceder del cinco por ciento de los estudiantes matriculados en una asignatura en el correspondiente curso académico, salvo que el número de estudiantes matriculados sea inferior a 20, en cuyo caso se podrá conceder una sola Matrícula de Honor.

Asimismo, cabe destacar que los alumnos que terminaban las Enseñanzas Artísticas Superiores de Grado en Música obtenían el "Título de Graduado o Graduada en Música" en la especialidad de que se trate (artículo 4 del $R D$ $631 / 2010$ y artículo 8.2 del $R D$ 1614/2009). No obstante, recientemente se ha publicado el Real Decreto 21/2015, de 23 de enero, por el que se modifica el Real Decreto 1614/2009, cambiando de nuevo la denominación por: "Título Superior de Música" (art. 8.2).

\subsection{La educación musical en los conservatorios de Castilla-León}

Las enseñanzas de música impartidas en los conservatorios de Castilla y León gozan de una larga tradición. Su consideración social aumenta de forma paralela al nivel de exigencia y preparación que conllevan.

Durante años, han existido conservatorios dependientes tanto de la administración autonómica como de entidades locales (ayuntamientos o diputaciones provinciales). No obstante, mediante el Acuerdo de Pacto Local de Castilla y León, del 3 de noviembre de 2005, todos los conservatorios de la comunidad pasaron a integrarse en la administración autonómica, quedando regulados por un mismo marco normativo. Concretamente, esta medida afectó a los conservatorios de música de Burgos, León, Valladolid y Zamora, tal y como aparece recogido en el anexo XIV de dicho Acuerdo. 
Tabla 4:

Integración de Conservatorios de Música de entidades locales en la Administración Autonómica de Castilla y León

\begin{tabular}{lc}
\hline \multicolumn{1}{c}{ Centro } & Titularidad previa al acuerdo \\
\hline $\begin{array}{l}\text { Conservatorio profesional de música de Burgos } \\
\text { (Sin cesión de uso del inmueble) }\end{array}$ & Ayuntamiento \\
$\begin{array}{l}\text { Conservatorio profesional de música de León } \\
\text { (Con trasferencia del inmueble y equipamientos) }\end{array}$ & Diputación Provincial \\
$\begin{array}{l}\text { Conservatorio profesional de música Valladolid } \\
\text { (Sin cesión de uso del inmueble) }\end{array}$ & Diputación Provincial \\
$\begin{array}{l}\text { Conservatorio profesional de música de Zamora } \\
\text { (Con trasferencia del inmueble y equipamientos) }\end{array}$ & Diputación Provincial \\
\hline
\end{tabular}

Por ello, actualmente, todos los conservatorios dependen de la Consejería de Educación de la Junta de Castilla y León, con sede en Valladolid. De ellos, once son conservatorios profesionales $y$ uno es superior, siendo los siguientes:

Tabla 5:

Conservatorios de Castilla y León

\begin{tabular}{|c|c|c|}
\hline Centro & Localidad & Provincia \\
\hline $\begin{array}{l}\text { Conservatorio Profesional de Música Tomás Luis de } \\
\text { Victoria }\end{array}$ & Ávila & Ávila \\
\hline Conservatorio Profesional de Música Rafael Frühbeck & Burgos & Burgos \\
\hline Conservatorio Profesional de Música Ángel Barja & Astorga & León \\
\hline Conservatorio Profesional de Música de León & León & León \\
\hline Conservatorio Profesional de Música Cristóbal Halffter & Ponferrada & León \\
\hline Conservatorio Profesional de Música de Palencia & Palencia & Palencia \\
\hline Conservatorio Profesional de Música de Salamanca & Salamanca & Salamanca \\
\hline Conservatorio Profesional de Música de Segovia & Segovia & Segovia \\
\hline Conservatorio Profesional de Música Oreste Camarca & Soria & Soria \\
\hline Conservatorio Profesional de Música de Valladolid & Valladolid & Valladolid \\
\hline Conservatorio Profesional de Música de Zamora & Zamora & Zamora \\
\hline Conservatorio Superior de Música de Castilla y León & Salamanca & Salamanca \\
\hline
\end{tabular}


Todo sistema de enseñanza precisa de un marco normativo que regule aspectos tan importantes para la vida de un centro como son la composición de los órganos de gobierno o de coordinación. No obstante, pese a su larga trayectoria en el sistema educativo español, estas enseñanzas no han dispuesto, hasta el año 2005, de un marco normativo equiparable en rango al de otras enseñanzas propias de los niveles obligatorios o postobligatorios, estando reguladas por Instrucciones o aplicándoseles, por analogía, el Reglamento Orgánico propio de los Institutos de Educación Secundaria.

Al respecto, el Reglamento Orgánico de los conservatorios de Castilla y León está recogido en el Decreto 65/2005, de 15 de septiembre, por el que se aprueba el Reglamento Orgánico de los centros que imparten Enseñanzas Escolares de Régimen Especial (Decreto 65/2005), donde se desarrollan, entre otros aspectos, los relativos a sus órganos de gobierno, órganos de participación en el control y gestión y órganos de coordinación, así como a la autonomía de gestión económica y pedagógica de dichos centros.

De forma más específica, la Orden EDU/1188/2005, de 21 de septiembre, por la que se regula la organización y funcionamiento de los conservatorios profesionales de música de Castilla y León establece la organización y el funcionamiento de los conservatorios profesionales de música, como desarrollo de lo dispuesto en el Decreto 65/2005, encargándose de:

- Establecer la composición de los órganos de gobierno de los conservatorios profesionales de música.

- Concretar los procedimientos y plazos en los que deben efectuar sus tareas los órganos de coordinación docente, además de regular su número y composición.

- Fijar el calendario de actuaciones para la elaboración, desarrollo y evaluación de la programación general anual, proyecto educativo, proyecto curricular y programaciones didácticas.

- Determinar las circunstancias y límites a los que debe atenerse el horario general del centro y los criterios que deben presidir la elaboración del horario de los alumnos y profesorado.

A continuación, señalaremos algunas particularidades que caracterizan a los conservatorios de Castilla y León en sus tres niveles: elemental, profesional y superior. 


\subsubsection{Enseñanzas elementales}

Las enseñanzas elementales de música en Castilla y León están reguladas por el Decreto 60/2007, de 7 de junio, por el que se establece el currículo de las enseñanzas elementales y profesionales de música de Castilla y León (Decreto 60/2007).

En dicho Decreto se establece que la finalidad de las enseñanzas elementales de música es proporcionar a los alumnos una formación artística de carácter integral, mediante el desarrollo de la personalidad y sensibilidad del alumno en el ámbito musical, orientada a la consecución de tres funciones básicas: formativa, orientadora y preparatoria para estudios posteriores. Para ello, las enseñanzas elementales de música tendrán como objetivo contribuir a desarrollar en el alumnado las siguientes capacidades:

a). Superar los contenidos y objetivos planteados en las asignaturas que componen el currículo de la especialidad elegida.

b). Conocer y comprender los elementos básicos del lenguaje musical, sus características, funciones y aplicarlos en la práctica instrumental y vocal.

c). Adquirir una formación técnica instrumental adecuada que permita la comprensión y la interpretación correctas de un repertorio básico así como la posibilidad de acceder a niveles más avanzados de las enseñanzas musicales.

d). Utilizar el oído interior como base de la afinación, de la audición y de la interpretación musical.

e). Adquirir el hábito de interpretar música en grupo y adaptarse equilibradamente al conjunto.

f). Actuar en público con autocontrol, dominio de la memoria y capacidad comunicativa.

g). Valorar el silencio como elemento indispensable para el desarrollo de la concentración, la audición interna y el pensamiento musical.

h). Apreciar la importancia de la música como lenguaje artístico y medio de expresión cultural de los pueblos en los distintos contextos históricos.

i). Expresarse con sensibilidad musical y estética para interpretar y disfrutar la música de las diferentes épocas y estilos y para enriquecer sus posibilidades de comunicación y realización personal. 
Todas las especialidades que integran el currículo de las enseñanzas elementales contienen tres asignaturas: Lenguaje Musical, Instrumento y Coro. La distribución de las asignaturas por curso y especialidad, así como su dedicación horaria semanal son las siguientes:

Tabla 6:

Dedicación horaria por asignatura y curso para todas las especialidades de las enseñanzas elementales de música. (Fuente: Decreto 60/2007, anexo III)

\begin{tabular}{|l|l|l|l|l|l|}
\hline \multicolumn{2}{|c|}{ ASIGNATURAS } & \multicolumn{4}{c|}{ HORAS LECTIVAS SEMANALES } \\
\cline { 2 - 6 } & $1^{\circ}$ & $2^{\circ}$ & $3^{\circ}$ & $4^{\circ}$ \\
\hline \multirow{3}{*}{ Instrumento } & $\begin{array}{l}\text { Clase } \\
\text { individual }\end{array}$ & 1 & 1 & 1 & 1 \\
\cline { 2 - 6 } & $\begin{array}{l}\text { Clase } \\
\text { colectiva }\end{array}$ & 1 & 1 & 1 & 1 \\
\hline Lenguaje Musical & 2 & 2 & 2 & 2 \\
\hline Coro & & & 1 & 1 \\
\hline Totales & 4 & 4 & 5 & 5 \\
\hline
\end{tabular}

Los objetivos, contenidos y criterios de evaluación que conforman el currículo específico de cada una de las asignaturas están recogidos en el anexo I del citado Decreto.

Asimismo, tal y como se determina en el artículo 6.4, "los alumnos de estas enseñanzas, siempre que hayan superado las pruebas de acceso correspondientes, podrán simultanear el estudio de dos especialidades". Las condiciones establecidas para ello están recogidas en la Orden EDU/321/2013, de 8 de mayo, por la que se regula la simultaneidad de especialidades en las enseñanzas elementales y profesionales de música, en la Comunidad de Castilla y León.

\subsubsection{Enseñanzas profesionales}

Los objetivos específicos de las enseñanzas profesionales de música, para Castilla y León son los establecidos en el artículo 3 del RD 1577/2006 y, además, los siguientes:

a). Asimilar los posibles cambios estéticos y nuevas tendencias profesionales.

b). Desarrollar valores estéticos y culturales que les permita encaminarse hacia la práctica del buen gusto y refinamiento necesarios dentro de nuestra sociedad. 
c). Evaluar estéticamente, de acuerdo con criterios correctos, los fenómenos culturales coetáneos.

d). Desarrollar una actividad creadora e imaginativa.

e). Conocer e interpretar obras escritas en lenguajes musicales contemporáneos, como toma de contacto con la música de nuestro tiempo.

De conformidad con el artículo 6 del RD 1577/2006, el Decreto 60/2007 establece que las asignaturas que integran el currículo de las enseñanzas profesionales se organizarán de la siguiente forma:

a). Asignaturas comunes a todas las especialidades: Instrumento o voz, Lenguaje musical, Armonía e Historia de la Música.

b). Asignaturas propias de la especialidad. Dependiendo de la especialidad que se curse se deberá realizar, Música de Cámara, Orquesta, Banda, Conjunto, Coro, Idiomas aplicados al canto, Piano complementario, Clave complementario, Acompañamiento o Bajo Continuo.

c). Asignaturas optativas:

- Además de las asignaturas propias de cada especialidad, todos los alumnos tendrán que cursar una de estas dos opciones:

- Opción 1: Análisis y dos asignaturas optativas de libre elección.

- Opción 2: Fundamentos de composición y una asignatura optativa de libre elección.

- Las asignaturas optativas de libre elección serán elegidas de entre las que cada centro proponga dentro de su Proyecto Educativo, previa autorización de la Consejería competente en materia de educación, pudiendo ser asignaturas propias de otra especialidad que no curse el alumno. Dentro de las asignaturas optativas de libre elección, los centros deberán ofertar de forma obligatoria la asignatura de Educación Auditiva. La regulación de dichas asignaturas está establecida en la Orden EDU/938/2009, de 28 de abril, por la que se regula la impartición, organización y autorización de las asignaturas optativas y perfiles educativos correspondientes a los cursos quinto y sexto de las enseñanzas profesionales de música en la Comunidad de Castilla y León.

La distribución de las asignaturas por curso y especialidad, así como la dedicación horaria semanal, se recogen en el anexo IV del Decreto referido y la relación numérica profesor/alumno es la siguiente: 
a). En las clases de enseñanza instrumental o vocal individual: 1/1.

b). En las clases de enseñanza no instrumentales:

- Lenguaje Musical, Armonía, Historia de la Música, Educación Auditiva: 1/15.

- Análisis: 1/10.

- Fundamentos de Composición: 1/8.

c). En las clases de conjunto, música de cámara, orquesta, banda, coro u otras clases colectivas de instrumento, la relación numérica profesoralumno quedará determinada por el número de alumnos matriculados y/o por la agrupación de que se trate.

Los elementos curriculares específicos de cada una de las asignaturas (objetivos, contenidos y criterios de evaluación) están recogidos en el anexo II del Decreto 60/2007, pero no introducen ninguna modificación con respecto a las enseñanzas mínimas establecidas para las enseñanzas profesionales de música en el Anexo I del RD 1577/2006.

Por su parte, los aspectos relativos a la evaluación de estas enseñanzas están especificados en la Orden EDU/1118/2008, de 19 de junio, por la que se regula la evaluación de las enseñanzas elementales y profesionales de música en Castilla y León.

\subsubsection{Enseñanzas superiores}

De acuerdo con la disposición adicional tercera del $R D$ 631/2010, en el curso académico 2010-2011 se inició la implantación progresiva de las enseñanzas artísticas superiores de Grado en Música en las especialidades existentes en la Comunidad de Castilla y León: Composición, Interpretación y Musicología, cuyos planes de estudios para el primer curso se establecieron, con carácter experimental, en la Orden EDU/1367/2010, de 29 de septiembre, por la que se establece con carácter experimental el plan de estudios para el primer curso de las Enseñanzas Artísticas Superiores de Grado en la Comunidad de Castilla y León.

Con la experiencia recogida, se procedió al establecimiento del plan de estudios en su totalidad, que se hizo efectivo en el Decreto 57/2011, de 15 de septiembre, por el que se establece el Plan de Estudios de las Especialidades de Composición, Interpretación y Musicología, de las Enseñanzas Artísticas Superiores de Grado en Música en la Comunidad de Castilla y León. 
La configuración de los nuevos planes de estudios de las enseñanzas artísticas superiores de Grado en el Espacio Europeo de Educación Superior conlleva que estos planes de estudios se fundamenten en la adquisición de competencias por parte del alumnado, en la aplicación de una nueva metodología de aprendizaje, en la adecuación de los procedimientos de evaluación, así como en la utilización de los créditos europeos como unidad de medida que refleja los resultados del aprendizaje y el volumen de trabajo realizado por el estudiante.

En el anexo I del Decreto 57/2011, se establece la estructura, ordenación y carga lectiva del plan de estudios, concretando la distribución general de créditos ECTS en materias de formación básica, materias obligatorias de especialidad, asignaturas optativas y trabajo fin de grado.

Tabla 7:

Distribución general de créditos ECTS en las distintas especialidades de las Enseñanzas Superiores de Grado en Música en Castilla y León. (Fuente: Decreto 57/2011, anexo I)

\begin{tabular}{|c|c|c|c|c|c|}
\hline Especialidad & $\begin{array}{c}\text { Materias de formación } \\
\text { básica }\end{array}$ & $\begin{array}{c}\text { Materias obligatorias } \\
\text { de especialidad }\end{array}$ & $\begin{array}{c}\text { Asignaturas } \\
\text { optativas }\end{array}$ & $\begin{array}{c}\text { Trabajo } \\
\text { Fin Grado }\end{array}$ & $\begin{array}{c}\text { Total } \\
\text { ECTS }\end{array}$ \\
\hline Composición & 24 & 194 & 16 & 6 & 240 \\
\hline Interpretación & 24 & de 182 a 194 & de 16 a 28 & 6 & 240 \\
\hline Musicología & de 24 a 26 & de 172 a 178 & de 12 a 16 & 26 & 240 \\
\hline
\end{tabular}

Dicho Decreto establece también la distribución de las asignaturas de cada materia por cursos y especialidades e itinerarios académicos con su asignación de créditos ECTS, así como las competencias, las horas lectivas anuales y el contenido de cada asignatura. Asimismo, regula la evaluación y el sistema de calificaciones, matriculación, convocatorias, promoción y permanencia, reconocimiento y transferencia de créditos y el trabajo fin de grado.

Por su parte, la Orden EDU/1221/2011, de 29 de septiembre, por la que se regulan determinados aspectos relacionados con la ordenación académica de las enseñanzas artísticas superiores de Grado en Música, en Arte Dramático y en Artes Plásticas en la Comunidad de Castilla y León, desarrolla aspectos relacionados con el valor horario del crédito ECTS, la evaluación del proceso de aprendizaje del alumnado, el traslado de expediente, el sistema de garantía de la calidad de estas enseñanzas, la estructura de la guía académica, la propuesta de asignaturas optativas por parte de los centros, los documentos acreditativos para solicitar la matrícula parcial para primer curso, los procedimientos de acogida y orientación de alumnos de nuevo ingreso, posibles medidas de atención a las personas con 
discapacidad y la relación numérica máxima profesor-alumnado para las enseñanzas artísticas superiores de Grado en Música.

\subsection{La educación musical en el Conservatorio Profesional de Música de Segovia}

A partir del marco legislativo que acabamos de describir y que está definido, en primera instancia, para todo el estado español, y, de forma más específica, para los conservatorios de música de Castilla y León, cada centro elabora su Proyecto Educativo de Centro (PEC), en el cual se definen los principios de identidad del centro, los objetivos institucionales y el organigrama general. Tal y como señala Díez (2008):

El PEC, como conjunto coherente de declaraciones destinadas a dirigir un proceso de intervención educativa, habrá de combinar los planteamientos generales que orientan la acción con los planteamientos específicos que facilitan la intervención y su evolución. No se trata de elaborar un compendio pormenorizado, sino una escueta y clara delimitación de los fines que se persiguen, estableciendo el "carácter propio" que confiere personalidad característica al centro. Ha de ser un documento que ayuda a establecer prioridades, que se han de operativizar en el plan anual y en las programaciones de la actividad docente, de modo que lleguen a los alumnos y puedan evaluarse. En definitiva, es el documento que da unidad de criterios a la actuación de la organización escolar. (p. 5)

Para plantear las propuestas presentadas en este trabajo, nos hemos basado en el Proyecto Educativo de Centro (PEC) del Conservatorio Profesional de Música de Segovia del curso 2012-2013, en el cual se ha llevado a cabo la recogida de datos de esta tesis doctoral. No es nuestro objetivo ofrecer una descripción detallada de dicho PEC, sino destacar aquellos aspectos que consideramos más relevantes en relación a nuestro objeto de estudio, como veremos a continuación.

\subsubsection{Situación y entorno del conservatorio}

El Conservatorio Profesional de Música de Segovia se encuentra ubicado en una amplia parcela, situada en el barrio de Nueva Segovia. El edificio es de nueva construcción y consta de 37 aulas distribuidas en cuatro plantas, 13 cabinas de estudio y un Auditorio con capacidad para 400 personas. Dispone, además, de una Biblioteca, una sala de profesores, una sala para el personal administrativo, tres despachos para el equipo directivo y varios almacenes. El centro está adecuadamente equipado: los recursos organizativos, personales y materiales, sin llegar a ser excesivos, se consideran suficientes, y sus instalaciones, al ser nuevas, se encuentran en perfecto estado, contando con aulas luminosas y bien acondicionadas. 
Los alumnos matriculados en este centro provienen principalmente de la capital y el nivel socioeconómico de sus familias se puede catalogar como medio. La situación geográfica del conservatorio, alejado del centro de la ciudad, obliga al alumnado a utilizar un medio de transporte. Ello unido al hecho de que parte del alumnado no vive en Segovia capital, sino en localidades próximas a la ciudad, hace necesario, en muchos casos, contar también con la disponibilidad horaria de los padres y su correspondiente margen de tiempo para efectuar los desplazamientos.

\subsubsection{Principios y objetivos generales}

El objetivo principal de este conservatorio es dotar a los alumnos de una formación musical que les proporcione el nivel de expresión artística propio de unos estudios especializados cuya meta sea el ejercicio profesional, sin menoscabo de la consecución de una formación musical básica para aquellos alumnos que no finalicen sus estudios.

Esta formación musical debe mantener un equilibrio entre el conocimiento de los aspectos teóricos, el desarrollo de las técnicas instrumentales y una paulatina profundización de los aspectos estético-formales y estilísticos que conforman el hecho musical, para ofrecer así una amplia panorámica ante un posible futuro profesional.

Los principios generales que presiden la labor educativa desarrollada por el Conservatorio Profesional de Música de Segovia quedan resumidos en el PEC de la siguiente manera (pp. 2 y 3):

a). Favorecer al máximo las relaciones interdisciplinares, con el fin de lograr un mayor conocimiento por parte del profesorado de las particularidades de cada área o especialidad y, por consiguiente, lograr una mayor cohesión y continuidad en el desarrollo de las programaciones didácticas.

b). Coordinar las programaciones, tanto dentro de los distintos departamentos como entre los departamentos instrumentales y los teórico-prácticos, buscando siempre la mayor objetividad y la mejor organización de los contenidos.

c). Favorecer todo tipo de foros de debate sobre cualquier tema que se considere de interés didáctico-musical o cualquier otro que pueda afectar a la consecución de los fines, dando mayor dinamismo a todos los órganos consultivos y de gobierno del centro (Equipo Directivo, Claustro de Profesores, Departamentos Didácticos, Comisión de Coordinación Pedagógica y Consejo Escolar). 
d). Fomentar las relaciones con otras entidades, tanto educativas como culturales o de otra índole, que favorezcan tanto el mejor desarrollo de las actividades extraescolares de los alumnos como el acercamiento de nuestra actividad docente y musical a la sociedad.

e). Plantear la apertura del centro a la ciudad, a través de conciertos de alumnos y profesores, colaboración con actividades de teatro, danza, etc.

f). Buscar formulas para facilitar la integración de las enseñanzas generales con las musicales, llegando a acuerdos con centros de la ciudad.

g). Favorecer la motivación del alumnado apoyando iniciativas tales como la asistencia de alumnos y profesores a los conciertos y audiciones que se realicen en el Auditorio del Conservatorio, la realización de intercambios con otros centros de la Comunidad o fuera de ella, la organización de cursos para alumnos y la coordinación entre las clases colectivas de distintas especialidades instrumentales.

h). Preparar a los alumnos para poder continuar sus estudios en los Centros Superiores de Música.

i). Implicar a todos los estamentos de la comunidad educativa (especialmente a padres y alumnos) en lo que significa la formación integral del futuro músico, activando y promoviendo todo tipo de acciones tutoriales para la mejor comprensión por parte de estos estamentos de las necesidades y problemática que conllevan los estudios musicales.

Teniendo en cuenta estos principios generales, el objetivo general de las enseñanzas elementales deberá ser formar una cantera de alumnos, fomentando la afición a la música y la máxima creatividad, permitiendo que acceda a estos estudios el mayor número de gente posible. Por su parte, el objetivo de las enseñanzas profesionales deberá ser dotar a los alumnos de los medios técnicos y formativos para poder acceder a una futura profesionalización.

Además de los señalados en los artículos 7 y 8 del Decreto 60/2007, el Conservatorio Profesional de Música de Segovia pretende alcanzar los siguientes objetivos recogidos en su PEC (p. 4):

1. Despertar y cultivar en el alumnado el amor por el arte y conseguir que, a través de la música, enriquezca su vida interior y desarrolle su sensibilidad. 
2. Orientar la educación musical hacia las diversas posibilidades laborales.

3. Desarrollar un modelo de enseñanza que tenga en cuenta las peculiaridades de cada alumno.

4. Promover una enseñanza innovadora y autocrítica.

5. Aprovechar los valores intrínsecos de la música para lograr un clima de integración, respeto y participación en nuestro conservatorio.

6. Incentivar el afán de superación, la autodisciplina y la autocrítica.

7. Fomentar la cordialidad dentro del conservatorio y en sus diversas relaciones externas.

\subsubsection{Organización general del centro}

Es fundamental generar un marco organizativo que facilite la actividad docente y que garantice el desarrollo eficaz del proceso educativo, permitiendo, además, que proporcione toda la información necesaria para favorecer la participación de todos los miembros de la comunidad educativa. Del mismo modo, es importante establecer cauces de colaboración con las instituciones, públicas o privadas, del entorno del centro.

Todo ello queda perfectamente establecido en el PEC del Conservatorio Profesional de Música de Segovia. Al respecto, los aspectos que consideramos de mayor relevancia para nuestro estudio son:

- El centro permanece abierto de lunes a viernes de 8:00 a 22:30 horas, pero las actividades lectivas se desarrollan principalmente por la tarde.

- Los grupos de Lenguaje Musical se formaran tratando de unir alumnos de la misma especialidad instrumental, para facilitar la organización de sus clases colectivas de instrumento.

- Se ofrece un servicio de préstamo de instrumentos a los alumnos del centro con la finalidad de facilitar que estos puedan iniciar sus estudios musicales, teniendo preferencia los alumnos que se matriculen por primera vez de primer curso de grado elemental.

\subsubsection{Plan de estudios}

El plan de estudios del Conservatorio Profesional de Música de Segovia se recoge en la tabla 8, donde podemos observar que la asignatura de Lenguaje Musical se imparte en los seis primeros cursos durante dos horas semanales. 


\subsubsection{Reglamento de régimen interior}

Para poder alcanzar las metas establecidas por el centro, el PEC incluye el Reglamento de Régimen Interno (RRI), que permite regular la organización del centro y la actuación de todos los órganos de participación y decisión, tanto de profesores como de los alumnos, padres y personal no docente, de acuerdo con los siguientes criterios generales:

a). Colaboración entre los distintos sectores de la comunidad educativa, fomentando al máximo el diálogo y la participación.

b). Transparencia en la información y en la gestión.

c). Deliberación y toma de decisiones colegiadas y, siempre que sea posible, consensuadas.

En este sentido, el RRI establece las normas que permiten regular:

1. La organización y el funcionamiento del centro.

2. La participación de todos los miembros de la comunidad educativa.

3. Los derechos y deberes del alumnado, de los padres, del profesorado y del personal no docente.

4. Los procedimientos para la resolución de los conflictos que alteren la convivencia escolar.

\section{La asignatura de Lenguaje Musical}

Aunque no es nuestro propósito hacer un estudio profundo sobre el desarrollo del Lenguaje Musical en España, sí hemos considerado oportuno situar al lector en las aportaciones históricas más relevantes para nuestra investigación. Por ello, dedicaremos la primera parte de este apartado a hablar sobre su evolución y desarrollo en las distintas leyes.

Posteriormente, nos detendremos en las particularidades del proceso educativo de la asignatura de Lenguaje Musical en nuestros conservatorios y, de forma más específica, veremos cómo se aborda la educación auditiva desde dicha asignatura.

\subsection{Evolución histórica del Lenguaje Musical}

La materia de Lenguaje Musical, como veremos más adelante, ha sido denominada durante varios siglos "Solfeo". Según el Diccionario Harvard de la Música (Randel, 2004), "se denomina Solfeo, especialmente desde finales 
del siglo XVIII hasta la actualidad, el canto de escalas, intervalos y ejercicios melódicos con las sílabas de solmisación" (p. 944).

La asignatura y/o materia de Solfeo se ha llamado de diferentes formas a lo largo de la historia. Por ejemplo: Guido D’Arezzo (980-1050), lo denominó "Solmisación", Engelbert d'Admont (1250-1332) "Ars Solfandi”, Carissimi (1605-1674) "Ars cantandi", etc. El Solfeo, que abarca primordialmente la lectura rítmica y la entonación, pasó a denominarse, en el año 1917, "Solfeo y Teoría de la Música" y, ya con la implantación de la LOGSE (LO 1/1990), adquirió su denominación actual de "Lenguaje Musical".

Desde la antigüedad clásica, en Occidente siempre se ha utilizado la lectura musical para desarrollar la voz, cantando ejercicios de intervalos, escalas, etc., pero este "método musical" no se siguió llevando a cabo en la época medieval, en la cual la enseñanza de la música se impartía en los monasterios, donde se formaban niños cantores. Gracias a la figura del monje benedictino, teórico y pedagogo musical Guido d'Arezzo (980-1050), podemos hablar de la aparición del solfeo elemental, ya que estableció lo que hoy conocemos como pentagrama, el uso del monocordio para desarrollar el oído, la utilización de las sílabas " $u t$, $r e, m i$, fa, sol, la" para denominar las notas musicales (la nota " $s i$ " se introdujo más tarde), el uso de la escala de 21 sonidos diatónicos divididas en hexacordos según el sistema de solmisación y de las mudanzas, etc. Todas y cada una de estas invenciones fueron desarrolladas con carácter didáctico para el aprendizaje de la música.

En Europa, a partir del siglo XIII, se produjo la separación entre la música teórica y la música práctica. La música teórica se estudiaba en las universidades recién creadas como parte del Quadrivium (Aritmética, Geometría, Astronomía y Música), pero la música práctica, como la educación del oído y de la voz, se estudiaba en las escuelas, donde el objetivo era aprender a cantar bien. Para ello utilizaban manuales sencillos donde se explicaban las mudanzas, la mano guidoniana y los signos musicales más frecuentes.

Durante el siglo XVII se utilizaban ejercicios compuestos por los maestros italianos, especialistas en ornamentación, para desarrollar la agilidad vocal. A estos ejercicios se les llamaron "solfeggi", pero en esta época no se publicaban, ya que un maestro cantor tenía que ser capaz de componer sus propios ejercicios. En este mismo siglo, el musicólogo Giovanni Battista Doni cambió el nombre de la nota $u t$ por el actual $d o$, para facilitar su pronunciación. Unas teorías apuntan a que el origen del nombre es de carácter religioso, pues do viene de Dominus (Señor), mientras que otras teorías sostienen que proviene de su apellido: Doni. 
En el año 1783 se creó la École Royal de Chant et Declamation de París, que se transformó, en el año 1974, en el Institut National de Musique, lo que supuso una influencia enorme para el resto de capitales europeas, que crearon su propio conservatorio de música. En Francia, en el año 1784 se creó el Conservatorio de París donde se produjo, entre otras innovaciones, la inclusión del Solfeo como base de los estudios musicales. A lo largo de los siglos XIX y XX, el Solfeo se desarrolló de forma sistemática y se dio a conocer popularmente gracias a las publicaciones de "Solfeggi" y los métodos italianos en París.

La primera publicación importante sobre un método de Solfeo fue "Solfége d'Italie avec la base chiffrée" en el año 1772, seguido de "Solfége des solféges", método publicado en 1910-1911 por Danhauser, Lemoine y Lavignac, el cual influyó mucho en los métodos posteriores.

No hay que olvidar tampoco las contribuciones que hizo el pedagogo suizo Pestalozzi (1746-1827) a la educación musical, inspirando la aparición de los métodos llamados de la Escuela Nueva o de la Pedagogía Musical Activa del siglo XX, a los que pertenecían figuras como Dalcroze, Willems, Orff, Kódaly, etc. Los métodos pedagógicos del siglo XX comparten una serie de principios, fundamentados en una educación dirigida para todo el mundo, en la iniciación musical temprana, conociendo y teniendo en cuenta el desarrollo evolutivo del niño, en el sentir de la música mediante el cuerpo antes de llegar a la intelectualización, en la importancia de la creatividad, etc., como ya hemos visto anteriormente en esta tesis.

\subsection{El Lenguaje Musical en los conservatorios}

Defendemos la idea de que el Lenguaje Musical es una de las especialidades más importantes dentro de un conservatorio de música. Es tan importante porque crea las bases fundamentales de las capacidades musicales que desarrollará el alumno junto con las clases de la especialidad instrumental.

El Lenguaje Musical es una asignatura grupal y común a todas las diferentes especialidades instrumentales, con las que está totalmente interrelacionada. $\mathrm{Al}$ respecto, en el $R D$ 1577/2006 se establece que el Lenguaje Musical debe desvelarles todos los conceptos y facilitarles la tarea de realizar, analizar, comprender y aprender cuanto las obras significan.

El Lenguaje Musical tiene como misión principal, por una parte, desarrollar todas las capacidades vocales, rítmicas, motoras, auditivas y expresivas, de modo que sea un instrumento útil y eficaz de comunicación; y, por otra parte, practicar y conocer los diferentes signos y grafismos que la música utiliza para ser plasmada en un papel $\mathrm{y}$, posteriormente, para ser interpretada. En el anexo I del $R D$ 1577/2006 se define otro de los fines de 
esta materia: "El Lenguaje Musical proporciona la comprensión de los elementos y reglas que configuran dicho lenguaje, proporcionando así al alumno y a la alumna la capacidad de expresarse musicalmente, a través de la improvisación, la interpretación o la creación de pequeñas obras".

En la actualidad, la asignatura de Lenguaje Musical en los conservatorios españoles se realiza en seis cursos diferentes: cuatro cursos en las enseñanzas elementales, y dos cursos en las enseñanzas profesionales.

A continuación, siguiendo a González (2013), realizaremos una mirada histórica por los diferentes planes de estudios por los que ha ido evolucionando la asignatura de Lenguaje Musical en nuestro país.

\subsubsection{Plan de estudios de 1917}

En esta época las enseñanzas de conservatorio se rigen por el Real Decreto de 25 de agosto de 1917, por el que se establece el Reglamento para el gobierno y régimen del Real Conservatorio de Música y Declamación, estando divididas en dos secciones, la sección de Música y la sección de Declamación. La sección de Música se divide en tres carreras: compositor, instrumentista o cantor, que cuentan con la asignatura troncal de Solfeo y Teoría de la Música.

Dicha asignatura de Solfeo y Teoría de la Música se distribuye en tres cursos diferentes que se realizan antes de comenzar los estudios de un instrumento, aunque sí se puede simultanear el primer curso de instrumento con el tercer curso de Solfeo y Teoría de la Música.

\subsubsection{Plan de estudios de 1942}

Con el Decreto de 15 de junio de 1942, sobre organización de los Conservatorios de Música y Declamación, el Real Conservatorio de Madrid adquiere el rango de Conservatorio Superior y sus enseñanzas se dividen en cátedras numerarias o en asignaturas especiales. La asignatura de Solfeo y Teoría de la Música pertenece al grupo de clases especiales y es impartida tanto en el Conservatorio de Madrid como en los conservatorios elementales y profesionales del resto de España. Los contenidos de la asignatura de Solfeo y Teoría de la Música son los mismos que en el plan de 1917.

\subsubsection{Plan de estudios de 1955}

A partir de la Orden de 30 de mayo de 1955, por la que se aprueba el nuevo cuestionario para la enseñanza de "Solfeo y Teoría de la Música" en los conservatorios oficiales de música, la asignatura de Solfeo y Teoría de la 
Música se organiza en 4 cursos diferentes, en los que se hace una distinción entre la práctica y la teoría. Para poder estudiar un instrumento había que realizar previamente el primer curso de Solfeo y Teoría de la Música.

A continuación, recogemos los contenidos establecidos por la citada Orden para cada uno de los cursos.

a). Primer curso de Solfeo y Teoría de la Música (curso de ingreso).

- Práctica:

- Compases de 2/4, 3/4 y 4/4.

- Figuras: redonda, blanca, negra, corchea, semicorchea.

- Alteraciones: todas las accidentales sencillas.

- Tonos: Do M y La m.

- Claves: dominio de Sol $2^{\mathrm{a}}$ y conocimientos de Fa $4^{\mathrm{a}}$.

- Silencios: igual a figuras.

- Puntillo, ligadura, calderón.

- Aires principales.

- Síncopas y notas a contratiempo en sus cuatro especies.

- Teoría: La que corresponde a la parte práctica citada.

b). Segundo curso de Solfeo y Teoría de la Música (curso elemental)

- Práctica. El contenido del primer curso más:

- Compases de 2/2, 3/8, 6/8, 9/8 y 12/8.

- Figuras: fusa y semifusa.

- Tonos: hasta de tres alteraciones propias.

- Modos: mayor y menor.

- Clave de Do $1^{a}$. Doble puntillo.

- Signos de repetición.

- Principales alteraciones del aire o movimiento.

- Subdivisión del compás.

- Tresillos y seisillos.

- Dosillos y cuatrillos.

- Notas de adorno sin abreviaturas.

- Teoría. La que corresponde a la parte práctica citada, más intervalos y tonos en toda su amplitud.

c). Tercer curso de Solfeo y Teoría de la Música (curso elemental)

- Práctica. El contenido de los dos primeros más:

- Compases de 3/2, 4/2, 2/8,4/8 y de amalgama.

- Figuras antiguas y sus silencios. 
- Claves de Do $2^{\mathrm{a}}$, Do $3^{\mathrm{a}}$, Do $4^{\mathrm{a}}$ y Fa $3^{\mathrm{a}}$.

- Alteraciones dobles.

- Tonos: todos.

- Valores irregulares.

- Abreviaturas de las notas de adorno.

- Carácter.

- Teoría. La que corresponde a la práctica citada.

d). Cuarto curso de Solfeo y Teoría de la Música (curso superior)

- Práctica:

- Transporte.

- Repentización.

- Solfeo artístico.

- Escritura y dictado musical.

- Dominio de las materias estudiadas en los cursos anteriores.

- Modos antiguos y populares.

- Teoría. La que corresponde a la parte práctica citada.

Asimismo, queremos destacar que con esta Orden el dictado musical aparece, por primera vez, en el currículo de la asignatura. El último curso de Solfeo y Teoría de la Música era enseñado por un catedrático, siempre y cuando lo hubiera, y debía realizarse antes de terminar las enseñanzas elementales de un instrumento.

\subsubsection{Plan de estudios de 1966}

El Decreto 2618/1966 establece un nuevo plan de estudios para los conservatorios españoles. La asignatura de Solfeo y Teoría de la Música pasa a realizarse en cinco cursos diferentes: cuatro cursos en el grado elemental y un curso en el grado medio, aunque se deja abierta la posibilidad de que el director del centro pueda añadir un curso preparatorio previo a los anteriores. En cuanto a los contenidos de la asignatura Solfeo y Teoría de la Música, se mantienen los citados en la orden de 1955.

\subsubsection{Ley de Ordenación General del Sistema Educativo de 1990}

La LOGSE (LO 1/1990) denomina a las enseñanzas musicales como enseñanzas de régimen especial, separándolas de los estudios de régimen general.

Las enseñanzas musicales se distribuyen en: grado elemental (cuatro cursos), grado profesional (seis cursos) y grado superior (cuatro o cinco cursos). Por 
primera vez, se sustituye el nombre de Solfeo por el de Lenguaje Musical. La asignatura de Lenguaje Musical se imparte en los cuatro cursos de grado elemental y en los dos primeros cursos de grado profesional.

En el Real Decreto 756/1992, de 26 de junio, por el que se establecen los aspectos básicos del currículo de los grados elemental y medio de las enseñanzas de música (RD 756/1992) encontramos: "La finalidad esencial de los contenidos del Lenguaje musical es el desarrollo de las capacidades vocales, rítmicas, psicoafectivas, psicomotoras, auditivas y expresivas, de modo que el código musical pueda convertirse en instrumento útil y eficaz de comunicación y representación; funciones básicas que aparecen en la práctica musical al igual que en toda actividad lingüística" (anexo I.a).

Los contenidos de la asignatura de Lenguaje Musical que se establecen para el grado elemental son:

a). Ritmo:

- Percepción, identificación e interiorización del pulso.

- Percepción e identificación del acento.

- Unidades métricas: reconocimiento de compases binarios, ternarios y cuaternarios.

- Figuras rítmicas. Fórmulas rítmicas básicas. Simultaneidad de ritmos.

- Tempo y agógica.

- Práctica, identificación y conocimiento de fórmulas rítmicas básicas originadas por el pulso binario o ternario.

- Práctica, identificación y conocimiento de grupos de valoración especial contenidos en un pulso.

- Práctica, identificación y conocimiento de signos que modifican la duración (puntillos, ligaduras).

- Práctica, identificación y conocimiento de hechos rítmicos característicos: síncopa, anacrusa, etc.

- Práctica e identificación de campos de compás con interpretación de equivalencias pulso $=$ pulso o figura $=$ figura.

b). Entonación, audición, expresión:

- Conocimiento de la voz y su funcionamiento. Respiración, emisión, articulación, etc.

- La altura: tono, intensidad, color, duración, afinación determinada e indeterminada, etc.

- Sensibilización y práctica auditiva y vocal de los movimientos melódicos. 
- Reproducción memorizada vocal o escrita de fragmentos melódicos o canciones.

- Práctica de lectura de notas unido a la emisión vocal del sonido que les corresponde. Claves de Sol en segunda y Fa en cuarta.

- Reconocimiento auditivo o reproducción vocal de intervalos melódicos simples, mayores, menores y justos, dentro y fuera del concepto tonal.

- Reconocimiento auditivo de intervalos armónicos simples, mayores, menores y justos.

- Interpretación vocal de obras adecuadas al nivel con o sin texto, con o sin acompañamiento.

- Práctica de lectura de notas escritas horizontal o verticalmente en claves de sol en segunda, fa en tercera y, en su caso, las claves propias del instrumento trabajado por el alumno.

- Sensibilización y conocimiento de grados y funciones tonales, escalas, alteraciones.

- Sensibilización, identificación, y reconocimiento de elementos básicos armónicos y formales: tonalidad, modalidad, cadencias, modulaciones, frases, ordenaciones-repeticiones, imitaciones, variaciones, contraste, sobre obras adaptadas al nivel.

- Reproducción de dictados rítmicos, melódicos y rítmicomelódicos a una voz.

- Identificación de errores o diferencias entre un fragmento escrito y lo escuchado.

- Identificación, conocimiento e interpretación de los términos y signos que afectan a la expresión.

- Utilización improvisada de los elementos del lenguaje con o sin propuesta previa.

Por su parte, los contenidos de la asignatura de Lenguaje Musical fijados para el grado profesional son:

a). Rítmicos:

- Práctica, identificación y conocimiento de compases originados por dos o más pulsos desiguales.

- Conocimiento y práctica de metros irregulares con estructuras fijas o variables.

- Polirrítmias y polimetrías.

- Reconocimiento y práctica de grupos de valoración especial con duraciones y posiciones métricas varias.

- Práctica de ritmos simultáneos que suponen divisiones distintas de la unidad. 
- Práctica de estructuras rítmicas atípicas en compases convencionales.

- Ritmos "aksak", "cojos", o de valor añadido.

- Práctica de música sin compasear.

- Reconocimiento y practica de ritmos que caracterizan la música de jazz, pop, etc.

- Práctica de cambios de compás con unidades iguales o diferentes y aplicación de las equivalencias indicadas.

- Desarrollo de hábitos interpretativos a partir del conocimiento y análisis de los elementos rítmicos.

b). Melódico-armónicos:

- Práctica auditiva y vocal de estructuras tonales enriquecidas en su lenguaje por flexiones o modulaciones sencillas, con reconocimiento analítico del proceso.

- Práctica auditiva y vocal de obras modales en sus diversas manifestaciones históricas y folklóricas.

- Práctica de interválica pura (no tonal) y aplicación a obras postonales o atonales.

- Reconocimiento auditivo y análisis de estructuras tonales y formales no complejas.

- Improvisación sobre esquemas armónicos y formales establecidos o libres.

- Aplicación vocal o escrita de bajos armónicos a obras propuestas de dificultad adaptada al nivel.

- Desarrollo de hábitos interpretativos a partir del conocimiento y análisis de los elementos melódico-armónicos.

c). Lecto-escritura:

- Práctica de lectura horizontal de notas con los ritmos escritos e indicaciones metronómicas diversas.

- Lectura de agrupaciones verticales de notas.

- Conocimiento y práctica de las normas de escritura melódica y armónica.

- Practica de lectura de notas, sin clave, ateniéndose al dibujo interválico.

- Practica de identificación y escritura de notas en su registro correcto.

- Conocimiento del ámbito sonoro de las claves. Iniciación a las grafías contemporáneas. 
d). Audición:

- Práctica de identificación de elementos rítmicos, melódicos, modulatorios, cadenciales, formales, tímbricos y estilísticos en las obras escuchadas.

- Identificación de errores o diferencias entre un fragmento escrito y lo escuchado.

- Memorización, previa a la escritura de frases o fragmentos progresivamente más amplios.

- Escritura de temas conocidos y memorización en diferentes alturas, tonalidades.

- Realización escrita de dictados a una y dos voces.

- Identificación de acordes.

- Audición de obras o fragmentos en los que se reconozcan elementos estudiados.

e). Expresión y ornamentación:

- Conocimiento y aplicación de signos y términos relativos a la dinámica y agógica.

- Conocimiento y aplicación de los signos que modifican el ataque de los sonidos.

- Conocimiento de los signos característicos en la escritura de los instrumentos.

- Conocimiento y aplicación de ornamentos adecuándolos a la época de la obra interpretada.

Para la consulta de los objetivos y los criterios de evaluación específicos del Lenguaje Musical tanto en el grado elemental como en el grado profesional remitimos al lector a los anexos I.a) y I.b) del $R D$ 756/1992.

\subsubsection{Ley Orgánica de Educación de 2006}

Mediante la LOE ( $L O$ 2/2006) se establecen nuevos principios sobre los que se fundamenta el sistema educativo.

Las enseñanzas musicales siguen considerándose como enseñanzas de régimen especial, pero ya no se organizan en grado elemental, grado profesional y grado superior, sino en enseñanzas elementales, enseñanzas profesionales y enseñanzas superiores.

Respecto a la asignatura de Lenguaje Musical, se mantiene su distribución en seis cursos: cuatro en las enseñanzas elementales y dos en las enseñanzas profesionales. También se mantienen los mismos objetivos, contenidos y 
criterios de evaluación del plan de estudios establecido a partir de la anterior LOGSE ( $L O$ 1/1990), aunque se deja en manos de las administraciones educativas de cada Comunidad Autónoma la determinación de las características y la organización de las enseñanzas elementales.

\subsubsection{Ley Orgánica para la Mejora de la Calidad Educativa de 2013}

Como ya comentamos en el apartado 4.2.1., la última reforma educativa es la planteada en la LOMCE ( $L O$ 8/2013), cuya aplicación se ha iniciado en el curso académico 2014-2015.

Ya se han publicado algunos Reales Decretos, Decretos y Órdenes que determinan las nuevas características, la ordenación y el currículo de enseñanzas pertenecientes a distintos niveles y ámbitos educativos, tanto de primaria, como de secundaria, bachillerato, formación profesional básica e, incluso, el acceso a las enseñanzas universitarias. No obstante, para las enseñanzas musicales en los conservatorios aún tendremos que esperar hasta que sean publicados los desarrollos normativos correspondientes.

Al respecto, el apartado 3 del artículo 6.bis de la LOMCE ( $L O$ 8/2013), relativo a la distribución de competencias para la elaboración del currículo, determina que para las enseñanzas artísticas profesionales el Gobierno fijará los objetivos, competencias, contenidos y criterios de evaluación del currículo básico, que supondrán el 55 por 100 de los horarios escolares para las Comunidades Autónomas que tengan lengua cooficial y el 65 por 100 para el resto. Asimismo, en el artículo 46 de dicha Ley Orgánica, relativo a la ordenación de las enseñanzas artísticas se establece que "la definición del contenido de las enseñanzas artísticas superiores, así como la evaluación de las mismas, se hará en el contexto de la ordenación de la educación superior española en el marco europeo y con la participación del Consejo Superior de Enseñanzas Artísticas y, en su caso, del Consejo de Coordinación Universitaria".

\subsection{Cómo se trabaja el Lenguaje Musical en el conservatorio}

La finalidad esencial del Lenguaje Musical es el desarrollo de las capacidades vocales, rítmicas, psicomotrices, auditivas, expresivas y de lecto-escritura, de modo que el código musical pueda convertirse en instrumento útil de expresión y representación, funciones básicas que aparecen en la práctica musical, al igual que en toda actividad comunicativa.

Es importante destacar esta finalidad comunicativa para adoptar un enfoque basado en el conocimiento de un sistema de signos que solo adquieren 
sentido cuando están interrelacionados, cuando configuran un discurso. Por ello, la adquisición de los conocimientos del Lenguaje Musical se apoya en procedimientos que desarrollan las destrezas necesarias para la producción y recepción de mensajes. Igualmente, es esencial que los alumnos vean que lo aprendido es útil en su práctica instrumental.

A continuación, veremos los principios metodológicos, las estrategias didácticas y los aspectos organizativos que guían el proceso de enseñanzaaprendizaje de la asignatura de Lenguaje Musical. También destacaremos una serie de materiales y recursos para su utilización dentro y fuera del aula.

\subsubsection{Educar en competencias básicas desde la asignatura de Lenguaje Musical}

Entre los cambios que ha presentado la LOMCE ( $L O$ 8/2013) está el referido a las competencias básicas, introducidas por primera vez como elementos curriculares con la LOE ( $L O$ 2/2006). Con la LOMCE, dichas competencias básicas pasan a denominarse competencias clave o, simplemente, competencias, y quedan reducidas a siete, en lugar de las ocho que estableció la LOE, tal y como muestra la tabla 9.

Tabla 9:

Comparación entre las competencias establecidas por la LOE y la LOMCE. (Fuente: creación propia)

\begin{tabular}{|c|c|}
\hline Competencias LOMCE & Competencias básicas LOE \\
\hline 1. Comunicación lingüística & $\begin{array}{l}\text { 1. Competencia en comunicación } \\
\text { lingüística }\end{array}$ \\
\hline $\begin{array}{l}\text { 2. Competencia matemática y } \\
\text { competencias básicas en ciencia y } \\
\text { tecnología }\end{array}$ & 2. Competencia matemática \\
\hline 3. Competencia digital & $\begin{array}{l}\text { 3. Competencia en el conocimiento y la } \\
\text { interacción con el mundo físico }\end{array}$ \\
\hline 4. Aprender a aprender & $\begin{array}{l}\text { 4. Tratamiento de la información y } \\
\text { competencia digital }\end{array}$ \\
\hline 5. Competencias sociales y cívicas & 5. Competencia social y ciudadana \\
\hline $\begin{array}{l}\text { 6. Sentido de iniciativa y espíritu } \\
\text { emprendedor }\end{array}$ & 6. Competencia cultural y artística \\
\hline \multirow[t]{2}{*}{$\begin{array}{l}\text { 7. Conciencia y expresiones } \\
\text { culturales }\end{array}$} & $\begin{array}{l}\text { 7. Competencia para aprender a } \\
\text { aprender }\end{array}$ \\
\hline & 8. Autonomía e iniciativa personal \\
\hline
\end{tabular}


Las diferencias más significativas radican en la agrupación de la Competencia matemática y la Competencia en conocimiento e interacción con el mundo físico (LOE) en la Competencia matemática y competencias básicas en ciencia y tecnología (LOMCE), además de la introducción del elemento emprendedor en la competencia Sentido de la iniciativa y espíritu emprendedor (LOMCE), que antes se llamaba Autonomía e iniciativa personal (LOE). También, la antigua Competencia cultural y artística (LOE) pasa a ser Conciencia y expresiones culturales (LOMCE). No obstante, queremos destacar el hecho de que, a pesar de estos cambios en la nomenclatura, no existen cambios sustanciales con respecto al contenido de las competencias básicas de la Ley anterior.

A continuación, describiremos de qué manera se contribuye al desarrollo de cada una de estas competencias desde la asignatura de Lenguaje Musical.

- Comunicación lingüística: Esta asignatura ofrece al alumno la posibilidad de adquirir y ampliar conocimientos propios del lenguaje musical, enriqueciendo, en consecuencia, su vocabulario y contribuyendo al desarrollo de la expresión verbal. Actividades como la escritura y lectura de canciones, junto con la improvisación, favorecerán el desarrollo de dicha competencia.

- Competencia matemática y competencias básicas en ciencia y tecnología: La educación rítmica, a través de la lectura y de la escritura, el conocimiento de diferentes compases y figuras, así como los ejercicios teóricos basados en la escritura de escalas, intervalos, acordes y procesos cadenciales, contribuyen al desarrollo de la competencia matemática. Asimismo, desde la asignatura de Lenguaje Musical se insiste en la concienciación de preservar un entorno físico agradable y saludable, teniendo en cuenta las consecuencias de la contaminación acústica y valorando el silencio como elemento indispensable para desarrollar hábitos saludables.

- Competencia digital: Se proponen una serie de actividades que requieren del uso de recursos tecnológicos y digitales, contribuyendo a que los alumnos se familiaricen con ellos, como herramientas de gran importancia en la sociedad actual: aplicaciones de Internet; programas específicos para el entrenamiento auditivo y cognitivo del lenguaje musical, como Len-mus y Earmaster School; programas de edición musical, como MuseScore, Finale y Sibelius; programas para la exposición o realización de determinadas actividades, como el Power Point y el Word; programas educativos, como las aplicaciones Jclic y La caza de tesoros, entre otros. Además, actualmente debemos tener en cuenta las posibilidades que ofrecen las tablets y la pizarra digital 
(Gallego \& Gatica, 2010), que incorporan distintos softwares de gran aplicación para el ámbito de la educación musical.

- Aprender a aprender: Desde la asignatura de Lenguaje Musical se potencia un aprendizaje guiado y autónomo a través de las actividades que el alumno debe realizar semanalmente. Se le ofrecen diferentes soluciones para determinadas cuestiones y será el propio alumno quien, movido por la motivación, sea consciente de sus posibilidades y haga uso de los recursos como manera de progresar. Actividades como la realización de dictados o la creación musical a través de la improvisación, favorecen especialmente esta competencia, ya que se ponen en juego muchas capacidades: la concentración, la memoria y el análisis, entre otras.

- Competencias sociales y cívicas: La creación musical muchas veces va a ser un trabajo en equipo. Las actividades grupales requieren de unas normas e instrucciones, de un cuidado de los materiales y del uso del espacio de una manera concreta, lo que va a contribuir directamente al desarrollo de esta competencia. Además de requerirse un trabajo cooperativo, también se va a desarrollar el juicio crítico y otros valores de respeto y escucha hacia los demás.

- Sentido de iniciativa y espíritu emprendedor: El alumno debe planificar el trabajo a realizar y organizar su tiempo de estudio, lo que desarrolla directamente esta competencia. Además, hay actividades como la creación musical que exigen actuar con autonomía, poner en marcha iniciativas emprendedoras, barajar posibilidades y adoptar soluciones diversas. Se inculcan, por otro lado, actitudes de superación, favoreciendo en todo momento la motivación del alumno, contribuyendo, en consecuencia, al aumento de la confianza en sí mismo y a la mejora de su autoestima.

- Conciencia y expresiones culturales: La asignatura de Lenguaje musical contribuye directamente al desarrollo de esta competencia, ya que posibilita que el alumno entre en contacto con un repertorio variado y rico de diversas épocas, culturas y estilos, favoreciendo que tenga una visión abierta para comprender el mundo que le rodea, desarrollando una actitud de respeto y elaborando sus propios juicios.

\subsubsection{Principios metodológicos generales de intervención educativa}

Para que el proceso de enseñanza y aprendizaje se desarrolle de forma adecuada, es importante tener presentes distintos principios metodológicos que emanan de una concepción constructivista del aprendizaje y que son: 
- Partir del nivel de desarrollo del alumno, teniendo en cuenta tanto su momento de desarrollo psico-evolutivo como sus conocimientos y experiencias previas.

- Considerar al alumno como el protagonista en la construcción de sus propios aprendizajes, favoreciendo el desarrollo de su actividad mental.

- Asegurar la construcción de aprendizajes significativos.

- Garantizar la funcionalidad de los aprendizajes, en situaciones de la vida cotidiana o en su enfrentamiento con otros aprendizajes.

- Organizar los contenidos a través de un enfoque globalizador, relacionando unos con otros.

- Proporcionar situaciones de aprendizaje significativas para los alumnos, con el fin de que resulten motivadoras.

- Considerar la actividad lúdica como un recurso especialmente adecuado para el trabajo de la música.

- Impulsar las relaciones entre iguales.

- Cooperación con las familias.

Además de estos principios de intervención educativa, en nuestra práctica docente debemos prestar atención a otros aspectos pedagógicos, como son: mantener una actitud positiva, claridad de exposición, trato adecuado (sin autoritarismo ni paternalismo por parte del profesorado), seguridad y confianza, contacto visual, actividades creativas, cooperación y metodología activa.

\subsubsection{Principios pedagógico-musicales}

Consideramos que estos principios ya han sido descritos suficientemente en los apartados 6.1 y 6.2 del capítulo II esta tesis. Por tanto, remitimos a los lectores a dichos apartados relativos, respectivamente, a las "Aportaciones de grandes pedagogos musicales reconocidos a nivel internacional" y a las "Aportaciones de pedagogos musicales españoles".

\subsubsection{Estrategias para la enseñanza del Lenguaje Musical}

Casi todos los alumnos que ingresan en las enseñanzas elementales de los conservatorios de música tienen una edad comprendida entre los 8 y los 11 años, edades determinantes donde se puede influir muy decisivamente en el 
aprendizaje del alumno, condicionando su posterior afición y dedicación al mundo musical. Es imprescindible, por tanto, desarrollar y cuidar el estimulo que se ejerza sobre el niño, de manera que este se sienta atraído hacia el aprendizaje de la música.

Dentro de la asignatura de Lenguaje Musical se trabajan diferentes aspectos: la educación vocal, el ritmo, la audición, la teoría musical, la creatividad y la improvisación. El análisis de diversas publicaciones didácticas dirigidas a la enseñanza del Lenguaje Musical en nuestro país nos ha permitido extraer una serie de generalidades respecto a cómo suele abordarse el trabajo de cada uno de ellos, las cuales presentamos a continuación.

Compartimos con González (2013) que la educación vocal normalmente se desarrolla mediante ejercicios vocales, lecciones de entonación y canciones de dificultad progresiva. Las canciones se suelen aprender mediante la imitación del profesor, especialmente al inicio de los estudios musicales. Los dos caminos que se usan con más frecuencia para aprender a cantar son: el empleo de canciones compuestas por las notas $m i$ y sol, añadiendo posteriormente la nota la y, de forma progresiva, el resto de las notas hasta completar la escala de do mayor; o bien empezando con las notas do y sol, añadiendo luego la nota mi y, sucesivamente, las demás notas. Después de trabajar las notas de la escala de do mayor y sus grados tonales, se aborda el estudio de la escala de la menor y, a continuación, se van añadiendo, poco a poco, el resto de escalas mayores y menores con sus respectivas armaduras, de menos a más alteraciones.

También se desarrolla el canto de intervalos de todos los tipos y especies. Aquí también hay diferentes opiniones: unos métodos comienzan cantando intervalos de $2^{\mathrm{a}}$ y $3^{\mathrm{a}}$ y luego van añadiendo los demás, y otros empiezan con intervalos de $5^{\mathrm{a}}$ y $4^{\mathrm{a}}$. La fononimia del método Kodály se suele utilizar para afianzar y aprender los sonidos. Asimismo, lo ideal es realizar un calentamiento vocal antes de comenzar a cantar, para preparar la voz y no provocar lesiones.

Toda la educación vocal está directamente ligada al aspecto de la audición. La audición comienza diferenciando si la melodía asciende o desciende, si es fuerte o es piano o si entre dos fragmentos melódicos cambia algo, todo o si son exactamente iguales. Respecto a los sonidos, en unos métodos se defiende la idea de que, para empezar, cuanto más separados estén, mejor y más pronto se asimilarán y discriminarán. Otra línea de pensamiento está en diferenciar sonidos según los grados y acordes tonales de una determinada tonalidad. 
La audición se suele trabajar a partir de dictados musicales, donde encontramos las mismas discrepancias que a la hora de aprender a cantar, es decir, en la determinación de qué notas e intervalos son los adecuados para empezar a identificar. Los dictados musicales son ejercicios que habitualmente no entusiasman a los niños, porque muchas veces son ejercicios repetitivos, aburridos y con poca o nula carga musical. Otra forma de desarrollar la audición es identificando errores de una partitura, rellenando huecos de un fragmento que está incompleto, discriminando distintos matices, diferenciando los términos de movimiento o a través de la escucha y el análisis de diferentes obras.

El ritmo se ha venido trabajando a través de la lectura de notas y figuras, es decir, de la lectura rítmica. Normalmente se hace con ejercicios austeros, nada musicales, mezclando figuras y silencios con diferentes valores. En este sentido, también se producen divergencias en los distintos métodos respecto al aprendizaje separado o simultáneo del ritmo y de la melodía: hay quienes prefieren enseñar el ritmo por un lado y la melodía por otro y quienes prefieren enseñar ambos aspectos a la vez.

En la lectura rítmica es frecuente comenzar a trabajar prestando atención solo a la duración de las figuras o al nombre de las notas, uniendo posteriormente ambos aspectos. La imagen más común es la del niño que se encuentra sentado en la silla percutiendo el ritmo o marcando el pulso mientras dice el nombre de las notas con su duración correspondiente. También suelen darse discrepancias acerca de la forma de marcar el compás, si percutiendo todos los pulsos abajo o realizando el dibujo de cada compás con el brazo, pero esto no es tan importante como el hecho de que el ritmo no se suele trabajar unido al movimiento corporal, práctica que consideramos necesaria porque permite interiorizar los diferentes ritmos, términos de movimiento, pulso, etc. de una forma más vivencial y natural.

Desde hace años, han existido distintas líneas de pensamiento respecto a cuál es la figura más idónea para comenzar a abordar la educación rítmica. Antiguamente, se comenzaba por las figuras de mayor duración, como la redonda, y de ahí se iba pasando a las figuras con menor duración, pero, actualmente, se suele empezar por las figuras que están más interiorizadas por la actividad del niño, que son la negra y la corchea. No obstante, hoy en día aún no hay un acuerdo sobre este tema. Del mismo modo, se intenta asociar la palabra al ritmo, utilizando frases, refranes, etc., que ayuden a la correcta realización de un ritmo dado.

En cuanto a la teoría musical, que es otro de los aspectos que se trabajan dentro del Lenguaje Musical, se comienza escribiendo notas sobre el pentagrama, identificando su nombre, dibujando las líneas divisorias 
dependiendo del compás, rellenando compases con diferentes figuras, etc. Siempre se suele empezar trabajando la clave de sol y luego la de $f a$, aunque a veces se simultanean las dos. Se trabajan ejercicios de constitución y análisis de escalas, de intervalos y de todo el trabajo referido a las tonalidades.

La creación y la improvisación son los aspectos que menos se han trabajado tradicionalmente en las clases de Lenguaje Musical de nuestros conservatorios pero, afortunadamente, poco a poco están empezando a tener más presencia en los nuevos métodos de enseñanza musical, lo cual también defendemos con nuestras propuestas en esta tesis.

Para cerrar este apartado, consideramos importante subrayar que, a pesar de la división que hemos utilizado para facilitar la explicación de cómo se trabajan los distintos contenidos del Lenguaje Musical, defendemos llevar a cabo un trabajo globalizador de todos ellos, de manera que ninguno sea percibido de forma aislada, ya que están íntimamente interrelacionados.

\subsubsection{Agrupamiento del alumnado}

Iniciamos este apartado destacando la importancia del trabajo en grupo en la asignatura de Lenguaje Musical, ya que, si la finalidad última de todo lenguaje es la comunicación, es necesario que haya relación entre los alumnos y alumnas, y entre estos y el profesor. Una actuación abierta, participativa y desinhibida en la acción musical se propicia armonizando las capacidades y necesidades individuales con las del grupo. De esta forma, se contribuye al afianzamiento y perfeccionamiento tanto del ámbito personal como del grupal.

No obstante, adoptar un único modelo de agrupamiento con independencia de la diversidad de características del conjunto de alumnos y de las actividades de enseñanza-aprendizaje limita el potencial enriquecedor del proceso educativo. Por ello, consideramos que deben combinarse distintos tipos de agrupamiento de los alumnos en función de la actividad.

En general, para el desarrollo de las distintas actividades se utilizará el denominado gran grupo, constituido por la totalidad de los alumnos de la clase, que, como marca la legislación vigente, no debe exceder de 15. Es el agrupamiento más adecuado para realizar explicaciones de temas, aclaraciones de conceptos, actividades de movimiento e interpretaciones vocales o instrumentales.

Por otra parte, para determinadas actividades conviene agrupar al alumnado en pequeños grupos, por ejemplo, cuando se hacen interpretaciones 
musicales a varias voces o cuando se acompaña una canción con distintos acompañamientos rítmicos o rítmico-melódicos simultáneamente.

Igualmente, en la clase de Lenguaje Musical también se llevan a cabo actividades que exigen un trabajo individual, como ocurre en la realización de dictados musicales, actividades de teoría musical, interpretaciones musicales individuales (aunque conviene aclarar que siempre estará participando activamente toda la clase para valorar cómo ha sido la interpretación de cada alumno y aprender de sus aciertos y errores) y cuando se realiza algún trabajo informático.

No debemos olvidar tampoco la posibilidad de hacer alguna actividad que implique la participación de distintos grupos de alumnos del conservatorio, en coordinación con otros profesores del mismo.

\subsubsection{Organización del espacio}

El espacio en el que se lleva a cabo la enseñanza del Lenguaje Musical debe ser un aula amplia y convenientemente insonorizada. En general, se propone la colocación de los alumnos en forma de "U" o semicírculo, de manera que se pueda disponer de un espacio central en el aula para las actividades de movimiento. Además, este tipo de distribución de los alumnos favorece que el profesor pueda dirigir mejor las interpretaciones vocales e instrumentales e incrementa las posibilidades de interacción grupal.

No obstante, la organización del espacio debe ser flexible y adaptarse a las distintas actividades que se vayan a desarrollar, colocándose los alumnos unas veces de forma individual mirando hacia la pizarra, otras veces sentados por parejas, formando pequeños grupos, de pie en el centro del aula y retirando el mobiliario hacia las paredes, etc. Esta amplitud de posibilidades favorece el desarrollo de actividades cooperativas, hábitos de trabajo en grupo, responsabilidad y respeto. Para facilitar la movilidad de los alumnos y el cambio de la disposición de los mismos dentro del aula, es recomendable contar con sillas que tengan una pala incorporada, ya que son más fáciles de manejar que cuando se dispone de mesas y sillas independientes.

También pueden utilizarse, en determinados momentos, otros espacios del centro, como la biblioteca, el aula de informática o el auditorio.

Por último, conviene señalar que existen otros espacios de interés didácticomusical que, aunque no los organice el profesor, sí puede utilizarlos. En este sentido, es interesante la asistencia a algún acontecimiento artístico-musical, siempre y cuando se seleccione y organice bien la actividad, motivando y preparando adecuadamente a los alumnos. Recordemos que, por mucha 
música que escuche un alumno a través de cualquier medio audiovisual o tecnológico, no debe perder de vista que la música la crean e interpretan personas y que, por ello, es un arte vivo y no un telón de fondo que está presente en cualquier lugar y de cualquier forma.

\subsubsection{Organización del tiempo}

La organización del tiempo se contempla desde dos perspectivas diferenciadas:

- La confección de un horario semanal general, teniendo en cuenta que el alumno recibe dos clases de Lenguaje Musical cada semana, ambas con una duración de una hora.

- La planificación de la actividad docente en cada curso académico, secuenciando los contenidos a lo largo de toda la etapa educativa.

Asimismo, dentro de cada sesión de Lenguaje Musical las actividades deben presentar una temporalización sistemática, distribuyéndose según:

- Actividades de introducción/motivación, en las que se presentan los contenidos de forma estimulante y atractiva para el alumno.

- Actividades de evaluación de conocimientos previos, que permiten relacionar lo nuevo con lo que el alumno ya sabe para potenciar la construcción de aprendizajes significativos.

- Actividades de desarrollo, con las que se trabajan los contenidos que permitirán desarrollar las capacidades que se pretenden.

- Actividades de consolidación/resumen, que sintetizan lo tratado en cada sesión y las pueden realizar los alumnos como tarea en sus casas para reforzar los contenidos vistos en clase.

- Igualmente, se deben prever actividades para atender a la diversidad del alumnado, tanto de refuerzo, para aquellos que tengan más dificultades, como de ampliación, para los que demuestren una mayor capacidad.

\subsubsection{Materiales y recursos didácticos}

La asignatura de Lenguaje Musical precisa de unos materiales y recursos didácticos específicos. El cuidado y la responsabilidad del buen estado del aula y de los materiales debe ser una finalidad educativa. En primer lugar, para el desarrollo de las clases es necesario contar con un aula correctamente 
equipada, espaciosa y aislada de ruidos. Además, como ya hemos apuntado anteriormente, consideramos que, en vez de sillas y mesas convencionales, es mejor utilizar sillas apilables con pala que faciliten diversos agrupamientos y mayor movilidad.

Como base de la asignatura cada niño debe contar con material didáctico, ya sea de elaboración por parte del propio docente o publicado por distintas editoriales, que incluya: repertorio para entonar, lecturas musicales, actividades de educación auditiva, dictados musicales, ejercicios de escritura musical y explicaciones teóricas. En el trabajo que presentamos en esta tesis, para los alumnos de primero y de segundo de las enseñanzas elementales hemos optado por utilizar, como base, los libros de Nuevo Lenguaje Musical I y II de Robles Ojeda (2003) para el trabajo del ritmo y de la entonación y los de Teoría y de Audición de Cañada, López y Molina (2004 y 2005, respectivamente) para abordar los demás aspectos. No obstante, también hemos empleado varios materiales de creación propia para poder poner en práctica nuestro nuevo planteamiento metodológico, tal y como expondremos en el capítulo $\mathrm{V}$.

Además, para el correcto desarrollo de la asignatura, consideramos que se debería disponer de los siguientes materiales y recursos didácticos:

\section{- Materiales impresos:}

- Bibliografía específica que abarque todos los campos de la educación musical: expresión vocal e instrumental, movimiento y danza, lenguaje musical, historia de la música, compositores, etc.

- Revistas musicales actuales de Pedagogía Musical y con datos de interés sobre la materia.

- Partituras adaptadas a las necesidades del alumnado.

- Carteles y láminas con instrumentos y compositores.

- Papel pautado.

\section{- Instrumentos musicales:}

- Un instrumento de teclado (preferiblemente un piano en buenas condiciones mecánicas y bien afinado) y una guitarra para uso del profesor (o de algún alumno que sepa tocar dichos instrumentos).

- Instrumentos de pequeña percusión de membrana, madera y metal (panderos, claves, triángulos, caja china, crótalos, pandereta, etc.). Deben ser numerosos y variados. 
- Instrumentos de láminas: carillones, metalófonos (soprano, alto y bajo) y xilófonos (soprano, alto y bajo), de tal manera que todos los alumnos puedan disponer de uno de ellos para las interpretaciones.

- Flauta de pico aportada por los alumnos, ya que la trabajan durante toda la escolaridad obligatoria (Educación Primaria y Secundaria) y podemos aprovechar su utilización en las clases del conservatorio.

- Instrumentos que producen efectos especiales, como el palo de lluvia, el flexatón, los silbatos, la sirena y el cuco.

- Instrumentos construidos o aportados por los propios alumnos.

- Instrumentos no convencionales, como es el caso de distintos objetos cotidianos que pueden usarse como fuente de sonidos (vasos, botellas, hojas, etc.).

Los instrumentos musicales deberán tener una mínima calidad de sonido (afinación y color) que asegure una buena interpretación.

- Materiales audiovisuales e informáticos:

- Aparato de reproducción de sonido con altavoces y con unidades de CD, de USB y de tarjetas SD. Es conveniente que reproduzca audios en distintos formatos.

- Micrófonos y equipo de grabación de sonidos.

- Ordenadores con tarjeta de audio, impresora y puerto MIDI (para conectar el ordenador al sintetizador), conexión a Internet, grabadora, lector de CD's y DVD's, y otros elementos multimedia.

- Colección de CD's y DVD's variados recogidos en una fonoteca.

- Programas abiertos y cerrados de informática musical (Finale, Encore, Sibelius, MuseScore, Clic, Sonar, Lenmus, etc.).

- Blogs o páginas Web's con información musical a las que se puede acceder a través de Internet.

- Televisión y reproductor de DVD,s.

- Retroproyector, proyector de diapositivas y pantalla. Todo ello se puede sustituir por una pizarra digital, si el aula dispone de ella.

- También sería conveniente que el alumno dispusiera de equipo de música y ordenador en casa, para poder trabajar de manera eficaz algunas de las tareas propuestas. 


\section{- Otros materiales:}

- Pizarra normal y pautada.

- Atriles plegables.

- Armarios donde poder guardar los instrumentos, las partituras, los libros, los CD's y DVD's, etc.

- Bancos o mesas donde colocar los instrumentos de láminas más grandes cuando se vayan a tocar.

- Metrónomos y diapasones.

- Lápices y gomas (cada alumno aportará los suyos).

\subsection{La educación auditiva en la asignatura de Lenguaje Musical}

La comprensión auditiva es una capacidad que hay que desarrollar sistemáticamente en las enseñanzas musicales, por ser el oído la base de la recepción musical. Para ello, es fundamental tener un buen planteamiento metodológico, ya que incide de forma directa en la eficacia del proceso de enseñanza y aprendizaje.

Iniciaremos el presente apartado ubicando el trabajo de la educación auditiva dentro del currículo de Lenguaje Musical del conservatorio de Segovia. A continuación, nos detendremos en la justificación teórica del dictado musical según distintos autores y en la utilidad que presentan las canciones para llevar a cabo una buena educación auditiva. Asimismo, para terminar, señalaremos las posibilidades que ofrecen los nuevos recursos tecnógicos para el desarrollo del oído musical.

\subsubsection{La educación auditiva dentro del currículo de Lenguaje Musical en el conservatorio de Segovia}

El trabajo que presentamos se ubica en el contexto de los estudios de Lenguaje Musical de las enseñanzas elementales, concretamente en los dos primeros cursos. Por este motivo, se ha considerado oportuno incluir, como fundamento teórico, los elementos curriculares relativos a la educación auditiva correspondientes a estos niveles y que aparecían recogidos en la programación didáctica de dicha asignatura en el Conservatorio Profesional de Música de Segovia durante el curso académico 2012-2013, que es donde y cuando hemos puesto en práctica y sometido a evaluación nuestras propuestas.

Como hemos señalado anteriormente, la programación de la asignatura de Lenguaje Musical a la que nos referimos está basada en el Decreto 60/2007, 
de conformidad con las competencias atribuidas a Castilla y León en el artículo 35.1 del Estatuto de Autonomía. El citado Decreto se promulga al amparo del $R D$ 1577/2006 y, en primera instancia, a partir de lo establecido en la LOE ( $L O 2 / 2006)$ que, en su artículo 6, define el currículo como el "conjunto de objetivos, competencias básicas, contenidos, métodos pedagógicos y criterios de evaluación de cada una las de enseñanzas".

La parte del currículo establecida por el citado Decreto 60/2007 es igual para todos los conservatorios de Castilla y León, suponiendo el primer nivel de concreción curricular. En lo que a nosotros nos concierne, esta parte es la relativa a los objetivos generales de las enseñanzas elementales, así como los objetivos específicos, los contenidos y los criterios de evaluación de la asignatura de Lenguaje Musical, los cuales hemos recogido en el anexo I.

El segundo nivel de concreción lo constituyen el Proyecto Educativo y el Proyecto Curricular del Centro, concediendo a los centros una cierta autonomía para elaborar sus propias normas de organización y funcionamiento, de acuerdo con su identidad propia, el contexto y sus necesidades específicas. Su elaboración se basa, asimismo, en la Orden EDU/1188/2005.

Finalmente, el currículo se completa en el tercer nivel de concreción, que queda recogido en un documento denominado Programación Didáctica y que es competencia directa de cada Departamento Didáctico, el cual lo elabora atendiendo a las premisas y principios del Proyecto Educativo del Centro y articulando el proceso de enseñanza-aprendizaje de manera que esté orientado a su grupos concretos de alumnos.

A continuación, se detallan los aspectos del currículo que hacen referencia de forma específica a la Educación Auditiva en los dos primeros cursos de las enseñanzas elementales y que forman parte de la Programación Didáctica de la especialidad de Lenguaje Musical del Conservatorio de Segovia, integrada dentro del Departamento de Asignaturas Teóricas.

En el primer curso encontramos los siguientes elementos curriculares:

\section{- Objetivos:}

- Representar e interpretar los símbolos gráficos del lenguaje musical convencional según las dificultades propias del curso.

- Desarrollar y utilizar la memoria auditiva para reproducir lo escuchado y representarlo gráficamente según las dificultades recogidas en el apartado de Audición dentro de los contenidos.

- Desarrollar el lenguaje tonal como base del conocimiento musical. 
- Desarrollar la sensibilidad y creatividad a través de la audición, interpretación e improvisación.

- Realizar actividades de grupo que permitan enriquecer su relación con la música a través del canto, del movimiento y de la audición.

- Contenidos:

- Cualidades del sonido: altura, intensidad, color y duración.

- Reconocimiento de movimientos melódicos ascendentes y descendentes.

- Memorización de fragmentos melódicos.

- Reconocimiento auditivo de los intervalos melódicos de $2^{\mathrm{a}}$ y $3^{\mathrm{a}}$ mayores y menores y de $4^{\mathrm{a}}, 5^{\mathrm{a}}$ y $8^{\mathrm{a}}$ justa, que se forman entre los distintos grados de la escala de Do Mayor.

- Identificación auditiva de diferencias rítmicas y melódicas entre lo escuchado y lo escrito.

- Realización de dictados rítmicos y/o melódicos con las formulaciones estudiadas.

- Criterios de evaluación:

- Identificar y entonar intervalos armónicos o melódicos mayores, menores o justos en registro medio.

- Reproducir por escrito fragmentos musicales escuchados.

Por su parte, en el segundo curso encontramos los siguientes aspectos del currículo:

\section{- Objetivos:}

Los mismos que para el primer curso y además:

- Demostrar un desarrollo suficiente del oído interno que permita percibir y diferenciar las características y particularidades del hecho musical y la interiorización de patrones para una interpretación equilibrada.

- Contenidos:

- Reconocimiento auditivo de los grados de una escala diatónica.

- Reconocimiento conceptual y auditivo de la tonalidad y modalidad de una obra.

- Reconocimiento auditivo de intervalos melódicos de $2^{\mathrm{a}}, 3^{\mathrm{a}}$ y $6^{\mathrm{a}}$ mayores y menores, y de $4^{\mathrm{a}}, 5^{\mathrm{a}}$ y $8^{\mathrm{a}}$ justas.

- Reconocimiento auditivo de los intervalos armónicos simples de $8^{\mathrm{a}}, 5^{\mathrm{a}}$ y $4^{\mathrm{a}}$ justas y $2^{\mathrm{a}}, 3^{\mathrm{a}}$ y $6^{\mathrm{a}}$ mayores y menores. 
- Reconocimiento conceptual y auditivo de funciones armónicas básicas.

- Reconocimiento auditivo del compás,

- Reconocimiento auditivo de las alteraciones accidentales que afecten al $6^{\circ}$ y $7^{\circ}$ grados del modo menor.

- Reproducción escrita de dictados rítmicos, melódicos y rítmicomelódicos que progresivamente irán incluyendo el reconocimiento de sonidos, de formulaciones rítmicas, de fragmentos rítmicomelódicos, del compás, de la tonalidad y modalidad y de las alteraciones accidentales.

\section{- Criterios de evaluación:}

Los mismos que para el primer curso y además:

- Reconocer auditivamente el pulso de una obra o fragmento, así como el acento periódico.

- Identificar auditivamente el modo de una obra o fragmento.

También resulta necesario señalar que, en el Conservatorio Profesional de Música de Segovia, la asignatura de Lenguaje Musical se estructura en tres bloques interrelacionados que se evalúan por separado:

- Lectura rítmica

- Bloque auditivo: incluye entonación y dictado

- Teoría

Nos vamos a centrar en el segundo de ellos, por constituir el objeto de nuestro estudio. La entonación y el dictado son dos trabajos complementarios que se basan en el desarrollo del oído interior, por eso se evalúan juntos dentro de un mismo bloque. La entonación consciente consiste en que los niños saben cómo suena cada uno de los sonidos y son capaces de cantarlos por sí mismos sin haberlos escuchado previamente (no por imitación). Por ello, colocar bien la voz es un aspecto importante, pero no suficiente, para poder afirmar que un niño entona bien. El dictado supone la actividad contraria: el alumno escucha una serie de sonidos medidos y debe plasmarlos en un papel, utilizando los códigos propios de la lectoescritura musical. El dictado es, habitualmente, la actividad que más cuesta a los alumnos de Lenguaje Musical, como veremos en el siguiente apartado.

\subsubsection{El dictado musical}

El músico, dentro de su formación profesional, entrena el oído de manera que pueda escribir lo que escucha o piensa musicalmente. 
El dictado musical es un proceso complejo que consiste en que el alumno escucha una serie de sonidos medidos y debe plasmarlos en un papel, utilizando los códigos propios de la lecto-escritura musical (aunque también se puede demandar una respuesta oral o interpretativa en vez de escrita). Martínez (2007) lo define de la siguiente manera:

El dictado musical es una herramienta de desarrollo de la cognición musical que trabaja de modo simultáneo lectura, escritura, memoria, audición y ejecución musical con miras a la construcción de la competencia auditiva dentro de un proceso global de formación del oído musical a través de la memoria. (p. 29)

Gary Karpinski (2000, citado por Paney, 2007) describe cuatro fases en la realización de un dictado: audición, memoria, entendimiento y notación.

La primera fase, audición, se refiere al proceso psicológico actual de los sonidos que recibe el oído y los transmite al cerebro. Una vez la melodía es oída, la siguiente fase que se requiere, en el dictado melódico, es la memoria. La evocación exacta es un prerrequisito para todos los pasos siguientes en el proceso. La tercera fase, entendimiento, es crucial para el éxito de la notación. La etapa final, notación, se refiere al acto de escribir las figuras de nota y el ritmo en el pentagrama, trasladando el entendimiento de la melodía dentro de la notación tradicional. (p. 9)

El dictado es, por lo general, la actividad que más dificultades provoca a los alumnos de Lenguaje Musical. Es una tarea compleja que engloba todo lo trabajado en los demás ámbitos (ritmo, entonación y teoría). En este sentido, Malbrán (1996) nos habla de la dificultad que supone la transcripción de un fragmento musical:

La tetralogía oído que escucha, mente que memoriza/procesa, boca que canta/imita, mano que escribe, es indicativa de lo complejo que resulta codificar lo que se ha escuchado. (p. 67)

En muchas ocasiones, la realización de dictados musicales crea ansiedad y serias dificultades a alumnos de todas las edades y de todos los niveles, llevándoles incluso a abandonar su ilusión por una carrera profesional, aunque sus resultados en otras materias fueran satisfactorios. Louvier (1996) comenta que la rigidez en la precisión de la notación es un hecho perturbador para la audición atenta, ya que el cerebro no se puede concentrar totalmente en dos problemas a la vez:

El espacio que abarca la memoria auditiva no tiene tiempo de ser asegurado cuando los trozos que hay que memorizar son demasiado largos para ser captados integralmente (alturas, ritmos, dinámicas, timbres...). (p. 24) 
Por este motivo, antes de realizar un dictado musical es imprescindible crear un clima de confianza, de calma y de silencio. En este sentido, resulta conveniente proporcionar a los alumnos unos minutos para controlar su propia respiración, lo que contribuye a la serenidad interior y, como consecuencia, a una mayor sensibilidad auditiva y mental.

Asimismo, para poder realizar la transcripción musical de los dictados con seguridad es importante trabajar previamente de forma independiente los distintos elementos que los conforman. Por ello, el proceso de formación de un músico debe contar con espacios de entrenamiento para identificar la tonalidad, el compás, los intervalos, el ritmo, la melodía, la armonía, el sonido inicial, el tipo de comienzo o el número de compases que tiene el dictado, entre otros.

Martenot (1993) considera que el dictado musical representa un elemento básico en la formación musical de los alumnos tan importante como la lectura vocal, aunque ambos procesos mentales se producen en sentido inverso. En el caso del dictado se trata de representar los sonidos escuchados por medio de los signos de escritura correspondientes. En la lectura vocal, en cambio, se trata de que los signos escritos provoquen el pensamiento y la emisión de los sonidos representados.

Ahora bien, debemos destacar la importancia del cultivo de automatismos en la relación sonido-nombre, los cuales se consiguen en gran medida a través de asociaciones musculares. Así, por ejemplo, gracias a la asociación de los movimientos de un brazo con los de los músculos de la laringe, los niños logran, por instinto, la correcta sensación de la dirección ascendente o descendente de una sucesión de sonidos. Del mismo modo, la preparación para el dictado musical necesita una asociación muscular entre esos mismos músculos y la laringe, con los que actúan en la pronunciación del nombre de las notas. Esto reafirma la hipótesis de que, cuanto más cante el alumno diciendo al mismo tiempo el nombre de las notas, mejor asociará en su memoria la relación entre los sonidos y nombre de cada nota. Si además ha practicado la memorización y luego la reproducción vocal de un grupo melódico de sonidos, cuando la laringe esboce los movimientos de los sonidos de un fragmento del dictado, los nombres de los sonidos correspondientes surgirán instintivamente en su interior.

En la misma línea, Miranda (2003) considera muy importante preparar el reconocimiento auditivo haciendo ejercicios de imitación, de memoria, de entonación melódica y de creación, y Willems (1995) cree que una de las mejores maneras para preparar los dictados es la práctica de la improvisación con el nombre las notas. Igualmente, Malbrán (1996) defiende que identificar auditivamente motivos musicales ya transcritos y examinar los 
resultados obtenidos en la transcripción ayuda a evaluar los propios progresos. Sin embargo, hay que tener en cuenta que es importante llegar a lo que se ha escrito como si lo hiciera otra persona, es decir, ignorando la información memorizada. En caso contrario se corre el riesgo de no darnos cuenta de los errores.

Por otra parte, Misas y Tobón (2007) consideran que el dictado no es un fin en sí mismo, sino un medio para el estudio de la música, constituyendo un sintetizador de conocimientos musicales y la práctica primordial para el desarrollo del oído consciente. El dictado favorece la unidad entre sonido y escritura, como indica Valenzuela (2001), forzando a la comprensión de lo que se escucha, a pesar de que ocupa mucho tiempo en la clase. Propone, como solución, que los dictados se memoricen y transporten como tarea en casa.

Desde otro punto de vista, López de Arenosa (2004) sostiene que el concepto de audición es mucho más amplio que el que se vincula con el dictado tradicional, que no es más que la concreción de la escucha, una actividad ocasional que posibilita al alumno transcribir lo que escucha en un determinado momento. Por eso, "la audición no debe convertirse en un ejercicio escrito antes de haber hecho muchas pruebas previas de identificación a través del dictado oral" (p. 119). Dicho esto, López de Arenosa apunta que, especialmente en las etapas iniciales del dictado, aunque siempre debería ser así, es necesario tener un cuidado exquisito en todos los aspectos que conforman el dictado musical. Esto es:

- Claridad del compás en el inicio.

- Coherencia rítmica a lo largo del dictado.

- Claridad cadencial y articulación de frases.

- Lógica melódica.

En cuanto a los dictados a dos voces, López de Arenosa (2004) sostiene que es fundamental la escucha de dos voces desde el inicio de los estudios de música ya que, de no ser así, se corre el riesgo de anular la capacidad de percibir simultaneidades.

Desde su perpectiva, la pedagoga Hemsy de Gainza (1964) señala las siguientes pautas en la realización de un dictado musical:

- Audición de la tonalidad y escritura de las alteraciones correspondientes.

- Percepción y escritura del compás. 
- Después de haber entonado la primera frase, determinar las notas correspondientes situando el sonido con el que se inicia dicha frase, tomando el acorde como referencia.

- Escritura de los sonidos de la primera frase, primero dibujando solo las cabezas para finalizar escribiendo las plicas.

- Percepción y escritura de los valores rítmicos.

- Escritura de las líneas divisorias previa revisión de la frase por si hubiera anacrusa.

- Entonar y marcar el compás con el fin de verificar la exactitud de la frase.

Finalmente, destacaremos que Misas y Tobón (2007) establecen que "es necesario entender el dictado musical como un proceso dinámico, en constante evolución y que necesita revisión permanente" (p. 23). Por eso, entre los procedimientos más importantes están:

- Graduar los pasos con el fin de garantizar el éxito en la relación enseñanza-aprendizaje.

- Cumplir un orden estricto en la introducción de los temas y profundizar en cada uno de ellos teniendo en cuenta el grado de dificultad de cada uno.

- Proporcionar ejemplos y ejercicios adecuados a los niveles del alumnado.

- Llevar a cabo un trabajo análogo de lectura musical, de tal modo que el alumno perfecciona su audición interna al mismo tiempo que trabaja la lectura melódica, rítmica y melódico-rítmica.

\subsubsection{La utilidad de las canciones para la educación auditiva}

Como hemos visto a lo largo de todo este capítulo, son muchos los aspectos de los que se ocupa la asignatura de Lenguaje Musical, como el reconocimiento auditivo, la entonación, la lectura, la escritura, la creación y la conceptualización teórica. Esta disciplina, que va profundizando poco a poco en cada uno de ellos, nos permitirá, finalmente, conocer y comprender todos los elementos constitutivos del discurso musical. Para Hemsy de Gainza (1964), los contenidos que se han de aprender no avanzan linealmente, sino que lo hacen de manera concéntrica, formando círculos que se van expandiendo cada vez más. Esta autora considera que para poder aprender algo es necesario que, previamente, se haya percibido como una 
unidad entera con significado. En este sentido, las canciones tienen un papel primordial.

Siguiendo a Ponsatí (2011), consideramos que "la actividad musical, a pesar de la diversidad de elementos que la conforman, gira alrededor de un eje fundamental: la canción" (p. 40). Hemsy de Gainza (1964) se refiere a este aspecto diciendo:

La misma canción que el pequeño entona con entusiasmo le dará oportunidad para entrenar sus facultades sensoriales, para moverse rítmicamente o para acompañar con sus instrumentos de percusión, así como también para "apreciar" los elementos musicales y para desarrollar su capacidad imaginativa o creadora. (p. 208)

Tanto los principales pedagogos clásicos como los más innovadores valoran muy especialmente el papel de la canción en la educación musical, entre los que destacamos a: Frega (2005), Jaques-Dalcroze (1965), Kodály (1911, citado por Szönyi, 1976), López de Arenosa (2004), Maneveau (1993), Martenot (1993), Molina (2004), Segarra (1998, citado por Badia i Baucells, 2005), Suzuki (1969, citado por Malagarriga, 2002), Swanwick (1991), Willems (1967), etc. De hecho, todos estos autores están de acuerdo en afirmar que el aprendizaje de un buen repertorio de canciones se convierte en un punto de partida esencial y excelente para la enseñanza musical, ya que permite que los alumnos descubran el funcionamiento del lenguaje musical, al mismo tiempo que desarrollan la expresión instrumental y el movimiento. Igualmente, Hemsy de Gainza (1964) opina que una sencilla canción infantil puede enriquecer enormemente la experiencia musical del niño, estimulando su imaginación y creatividad. Además, tal y como expone Jurado (1993), "es el recurso más asequible en el aprendizaje musical del niño" (p. 27).

Estamos plenamente de acuerdo con Alborés (2008) al considerar la canción como "una pequeña obra musical, la cual hace posible que, en el momento adecuado, puedan presentarse los contenidos que se han de aprender de una manera viva y con significado" (p. 112). Tal y como apunta Garmendia (1981), "de una canción no se aprende nada más la melodía, sino que, desde el primer momento, los alumnos sintetizan todos los aspectos que la conforman: el fraseo, la dinámica, el carácter, el movimiento, etc." (p. 9). Dicho de otra manera, a través de la globalidad el alumnado adquiere todo el contenido expresivo de una canción. En este sentido, Bruner (1969, citado por López Arenosa, 2004) habla de la canción como una estructura con significado, ya que, "como lenguaje, la aprendemos repitiendo frases con sentido y no palabras aisladas" (p. 61). 
Alborés (2008) también remarca la importancia de la memorización de la letra, ya que "contribuye a facilitar y reforzar la retención y asimilación de todos los aspectos musicales relacionados con la canción” (p. 112). En su reflexión acerca del aprendizaje de las canciones, esta autora subraya el valor de la imitación oral, diciendo que es gracias a este recurso como se aprende a cantar para, posteriormente, poder llegar a interpretar los signos gráficos de todos los conocimientos musicales que, gradualmente, se han ido asimilando.

Por su parte, Pascual (2002) indica que, si bien las canciones permiten trabajar la síntesis de los elementos musicales (ritmo, melodía, forma, articulación, carácter, etc.), también contribuyen a desarrollar, entre otras, las siguientes capacidades:

- Captación rítmica (pulso, acento, duraciones).

- Captación melódica (alturas, melodías, etc.).

- Captación del hecho sonoro musical, tímbrico, etc. (las cualidades del sonido)

- Captación del sentido estético-musical y de proporción (la forma).

- Interiorización y memorización rítmica y melódica.

- Expresión de matices, carácter, dinámica, etc.

- Expresión por el movimiento.

- Improvisación creativa (rítmica, melódica, armónica, etc.).

- Conocimiento de su propia voz al hablar y al cantar.

- Práctica de grafías convencionales y no convencionales.

- Interpretación de instrumentos sencillos.

- Conocimiento del folklore, autores y música a través del tiempo. (pp. 240-241)

López de Arenosa (2004) también reflexiona sobre las cualidades de la canción, señalando que nos permite acceder al lenguaje de la música desde los inicios, a través de su aprendizaje oral y de la memoria. Es, por tanto, una herramienta crucial que nos da las bases del lenguaje musical. Esta autora nos ofrece el siguiente mapa conceptual de la canción: 


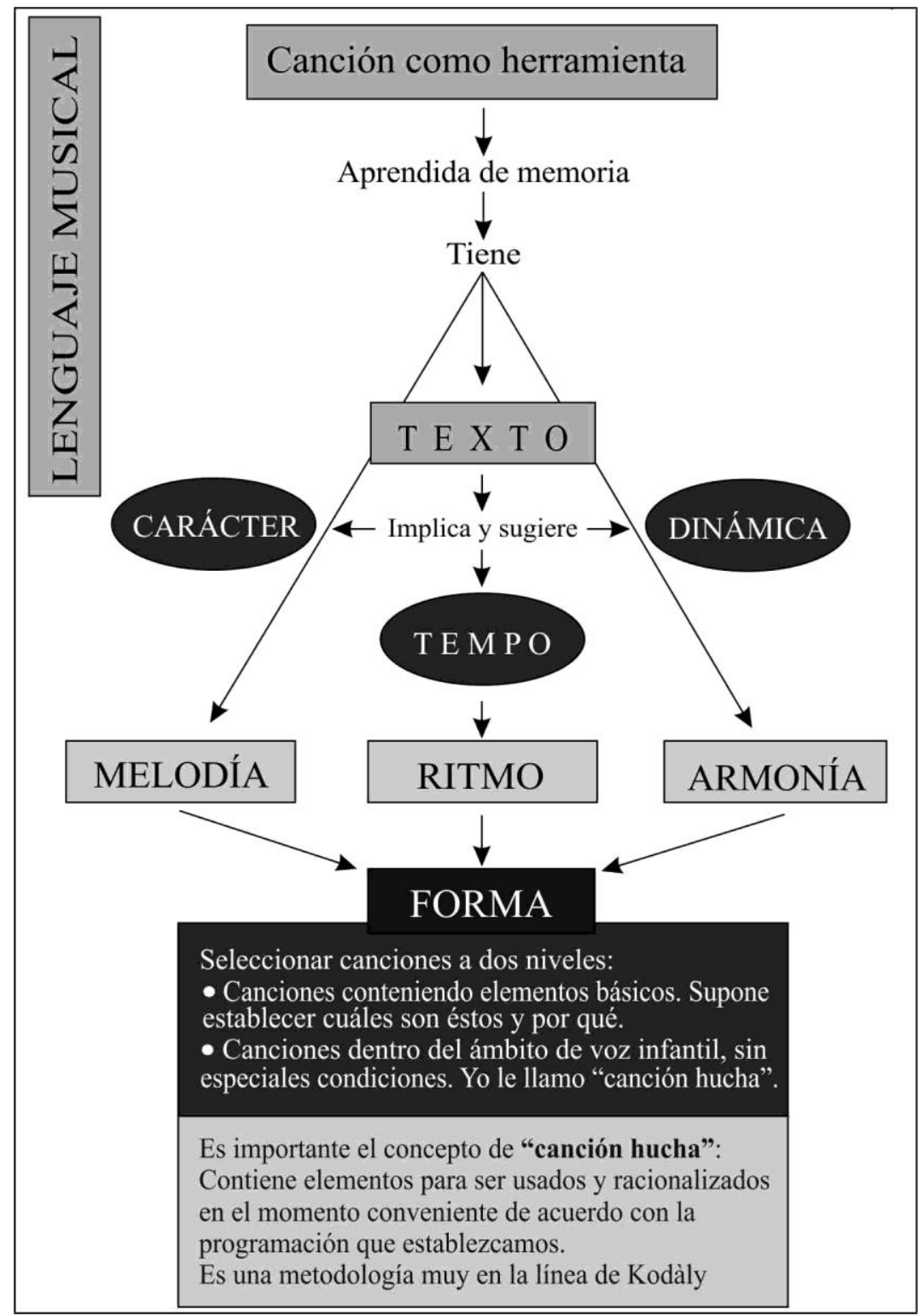

Figura 17. Mapa conceptual de la canción (López de Arenosa, 2004, p. 60)

Nos ha parecido ilustrativo concluir este apartado con una idea de Muñoz (2009), quien defiende la canción popular como "un espacio común de las personas, que forma de alguna manera su identidad, y por eso las tenemos en nuestra memoria colectiva" (p. 327). Por este motivo, Casals (1993) la considera un elemento indispensable para el estudio de la música, expresándolo de la siguiente manera: 
Al igual que hay una lengua materna en la que se debe apoyar el estudio del lenguaje, también hay una expresión musical materna en la cual debe fundamentarse el estudio de la música; esta es, en nuestro caso, la canción popular. (p. 56)

\subsubsection{Aportaciones de las TIC para el desarrollo auditivo}

Para concluir, apoyándonos en Balo, Lago y Ponce de León (2014), nos gustaría enumerar algunas herramientas que consideramos de utilidad para la confección y realización de ejercicios que contribuyan al desarrollo auditivo de los alumnos, analizando las ventajas que aporta cada una de ellas:

- Editores de sonido: Editores como Audacity o Nuendo pueden servir al profesor para confeccionar ejercicios de dictado, al permitir fácilmente la fragmentación de una pieza musical grabada. Podemos preparar grabaciones que incluyan repeticiones de cada fragmento las veces que deseemos, copiando y pegando los fragmentos en cuestión e intercalando las pausas necesarias. La confección de estos ejercicios grabados podría estar pensada para que el alumno realizase el dictado de forma autónoma en casa o bien para que la grabación fuera reproducida en el aula. En el primer caso, la preparación de ejercicios que el alumno pueda realizar fuera del aula le permitirá trabajar sin las presiones de tiempo que, a veces, provocan los estados de ansiedad mencionados anteriormente. En este sentido, el alumno puede repetir la grabación las veces que haga falta tomándose el tiempo necesario para reflexionar sobre el contenido musical antes de transcribirlo. Estas grabaciones preparadas previamente con un editor de sonido también ofrecen beneficios al utilizarse en el aula, ya que permiten al profesor dedicarse a supervisar las realizaciones de los alumnos sin necesidad de preocuparse de la interpretación del dictado.

- Editores de partituras: Editores como MuseScore, Sibelius y Finale nos pueden ayudar no solo a componer e imprimir con calidad ejercicios de audición a una o varias voces, sino que podemos extraer un fichero de audio de la partitura. Podemos aplicar distintos timbres sintetizados a cada una de las voces antes de crear el correspondiente fichero de audio, ya que la utilización de timbres variados permitirá al alumno familiarizarse con la sonoridad de diversos instrumentos y además facilitará la discriminación de voces simultáneas al emplear timbres diferentes para cada una de ellas, lo cual puede ser recomendable en las primeras etapas de un trabajo polifónico.

- Programas de entrenamiento auditivo: Son aplicaciones que permiten desarrollar el oído utilizando ejercicios organizados de reconocimiento de escalas, intervalos, etc. Un ejemplo en castellano es 
Lenmus (www.lenmus.org), un programa gratuito que nos permite $\mathrm{y}$ facilita la práctica de la teoría, el lenguaje musical y el desarrollo auditivo. Cada uno de los ejercicios se puede personalizar adecuándolo a un determinado nivel. También posibilita la selección de distintos timbres para realizar los ejercicios auditivos. Otro ejemplo es Music Trainers (www.musictheory.net), un entrenador auditivo que incluso podría ser utilizado desde el teléfono móvil. El alumno puede decidir trabajar específicamente sobre aquellos aspectos donde encuentra más dificultad, sin miedo al error y realizando este entrenamiento en los momentos más idóneos, incluso aprovechando desplazamientos en el caso de que se instale alguna de estas aplicaciones en un dispositivo móvil. El trabajo sobre elementos concretos como intervalos o escalas es un entrenamiento complementario de gran utilidad para mejorar las habilidades de transcripción de fragmentos escuchados.

- Fonotecas Virtuales: El uso de fonotecas en la red, como la Fonoteca Virtual Naxos (www.naxos.com) puede permitir un trabajo auditivo sobre obras de géneros y estilos muy diversos. Podemos pedir a los alumnos que transcriban algún fragmento perteneciente a obras de los grandes compositores, en vez de ejercicios confeccionados específicamente para la clase de Lenguaje Musical. 


\section{CAPÍTULO $V$ : NUESTRA PROPUESTA METODOLÓGICA PARA LA EDUCACIÓN AUDITIVA DESDE UN CONTEXTO TONAL}

\section{Introducción}

Al tratarse de un estudio basado en la aplicación en el aula de una nueva propuesta metodológica, nos vemos en la necesidad de dedicar un capítulo a describir nuestro planteamiento didáctico y las nuevas estrategias que hemos utilizado para llevar a cabo la educación auditiva desde la asignatura de Lenguaje Musical. Para ello, partimos del convencimiento de que la educación auditiva es un concepto mucho más amplio que el asociado a la resolución de dictados musicales tradicionales y de que debe basarse en el contexto tonal-armónico propio de nuestra cultura, el cual consideramos que debe comenzar a conocer y manipular el alumnado desde que inicia sus estudios en el conservatorio.

Las propuestas realizadas y puestas en práctica en el aula están basadas en el marco legislativo comentado en el capítulo anterior, que es el que regula nuestras actuaciones docentes. Como dicho marco legislativo ya ha sido descrito en profundidad, no consideramos necesario volver a recogerlo nuevamente en este capítulo, por lo que nos centraremos en el planteamiento de nuestra propuesta metodológica, en la exposición de objetivos didácticos específicos y en la descripción detallada de las actividades desarrolladas.

\section{La educación auditiva desde un contexto tonal}

Durante siglos, se ha pensado que la enseñanza musical se basaba en el talento, de tal manera que un alumno era apto o no apto para la música en función de sus capacidades. No obstante, desde principios del siglo XX se empezaron a desarrollar distintas corrientes pedagógico-musicales que 
enfatizaban la importancia de una buena educación y del empleo de estrategias metodológicas adecuadas para que el aprendizaje de la música fuera accesible a todos los alumnos, en lo cual creemos como docentes. Consideramos que el talento musical no es un rasgo innato capaz de transmitirse de forma hereditaria, aunque algunos tengan mayor facilidad que otros, sino que confiamos en que una buena labor pedagógica podrá hacer de cualquier alumno una persona musicalmente educada.

La música suena y, por tanto, su vía de captación y comprensión es el oído, sentido capaz de percibir, reconocer, identificar, discriminar y analizar lo sonoro, extrayendo de ello una serie de conclusiones que, progresivamente matizadas y orientadas, conduzcan a una verdadera educación musical, superando el simple adiestramiento conductista en la ejecución e interpretación que, desgraciadamente, se sigue utilizando con frecuencia en las aulas de nuestro país.

Tanto el llamado dictado musical como otros aspectos más globales de la educación auditiva son objeto de trabajo para los alumnos de todos los conservatorios españoles. Los planteamientos constructivistas aplicados a la enseñanza de la educación auditiva suponen un profundo cambio en el entendimiento de esta importante parcela de la educación musical y nos llevan a plantearnos preguntas como las siguientes: ¿cómo hay que entender el "aprendizaje significativo" en el terreno de la educación auditiva?, ¿con qué criterios se han de estructurar los ejercicios que se realicen en ella para que los alumnos puedan atribuirles un sentido?

Desde la concepción constructivista, aprender cualquier contenido educativo supone, según Miras (2004), "atribuirle un sentido y construir los significados implicados en el mismo. Ahora bien, esta construcción no se lleva a cabo partiendo de cero, ni siquiera en los momentos iniciales de la enseñanza" (p. 47). Por tanto, nuestro propósito contiene tres ideas fundamentales: la necesidad de atribuir sentido a lo que se quiere aprender, la importancia de la construcción de significados y la existencia de ciertos conocimientos previos.

Los conocimientos que forman parte de la cultura musical de los niños tienen que ver con la música de su entorno. En este sentido, Hargreaves (2002) afirma que "a los cinco años, los niños poseen un amplio repertorio de canciones tradicionales infantiles 'estándar' de su cultura, con las cuales pueden realizar tareas de reconocimiento y memoria mucho mejor que con el material musical no familiar" (p. 89).

En nuestro contexto cultural, Sierra (2008) señala que: "Hoy en día, las canciones comerciales difundidas por los medios de comunicación y 
recogidas en distintos formatos de audio y video constituyen las verdaderas 'canciones tradicionales infantiles estándar' de la cultura occidental" (p. 15), y estas canciones responden melódica y armónicamente a los tópicos tonales derivados de la tradición clásica europea: funciones, cadencias, sensaciones de final o de continuidad implícitas en la música, etc. Contando de antemano con que los alumnos llegan al aula con estos conocimientos previos, y ya en el terreno de lo plenamente consciente, ¿cómo se educa musicalmente el sentido del oído? O, dicho de otra forma, ¿cómo hay que enseñar la educación auditiva?

El estudio que proponemos en esta tesis doctoral parte de la conveniencia de basar la educación auditiva, muy especialmente en los primeros niveles, en la música tonal. Trabajar desde la armonía nos lleva a plantear la enseñanza desde las funciones armónicas y no desde las escalas, ni desde el intervalo o el acorde fuera del contexto melódico-armónico.

Se debe buscar ese tópico interiorizado ya por el alumno para poder reconocerlo y ponerle nombre, pero este reconocimiento no debe buscarse solo en los ejercicios que realice dentro del ámbito escolar, sino más bien en la música que escucha fuera de dicho contexto, que es la que sin duda mayor peso ha ejercido en la adquisición de sus conocimientos previos y en el proceso de aculturación defendido por López de Arenosa (2004).

Para llevar a cabo estas ideas debemos hablar al alumnado sobre los acordes y las funciones armónicas antes de lo que habitualmente se suele hacer; no nos parece mucho más complicado que explicarles los intervalos o los distintos tipos de escalas. No obstante, esto no significa, ni mucho menos, que deban explicarse las reglas de la armonía, al igual que un alumno aprende a utilizar el compás de $2 / 4$ sin tener que conocer la génesis del mismo.

A lo largo de este capítulo veremos cómo hemos trabajado estos contenidos armónicos de forma integrada con el resto de los contenidos que se abordan tradicionalmente desde la asignatura de Lenguaje Musical y de otros que consideramos igualmente importantes, como son el desarrollo de la memoria musical, la motivación, la creatividad y la reducción de la ansiedad, adaptándonos a las capacidades y a las características psicológicas de los alumnos.

\section{Ejes prioritarios de trabajo}

Tras clarificar lo que queríamos conseguir con nuestra intervención educativa, debíamos identificar cuáles eran los ejes prioritarios sobre los que tendríamos que trabajar. De esta forma, determinamos que una óptima 
educación auditiva debía integrar todos los ámbitos que se trabajan en la asignatura de Lenguaje Musical, es decir, el desarrollo rítmico, el desarrollo melódico/armónico (que relacionamos con los tradicionales apartados de entonación y dictado) y los aspectos teóricos. Pero, además, consideramos fundamental contemplar el entrenamiento de la memoria musical y cuidar en todo momento otros tres factores muy significativos en todo proceso de aprendizaje, pero más aún, si cabe, en las enseñanzas artísticas: la motivación, la reducción de la ansiedad y el desarrollo de la creatividad.

La figura 18 muestra de forma gráfica nuestro planteamiento metodológico. 


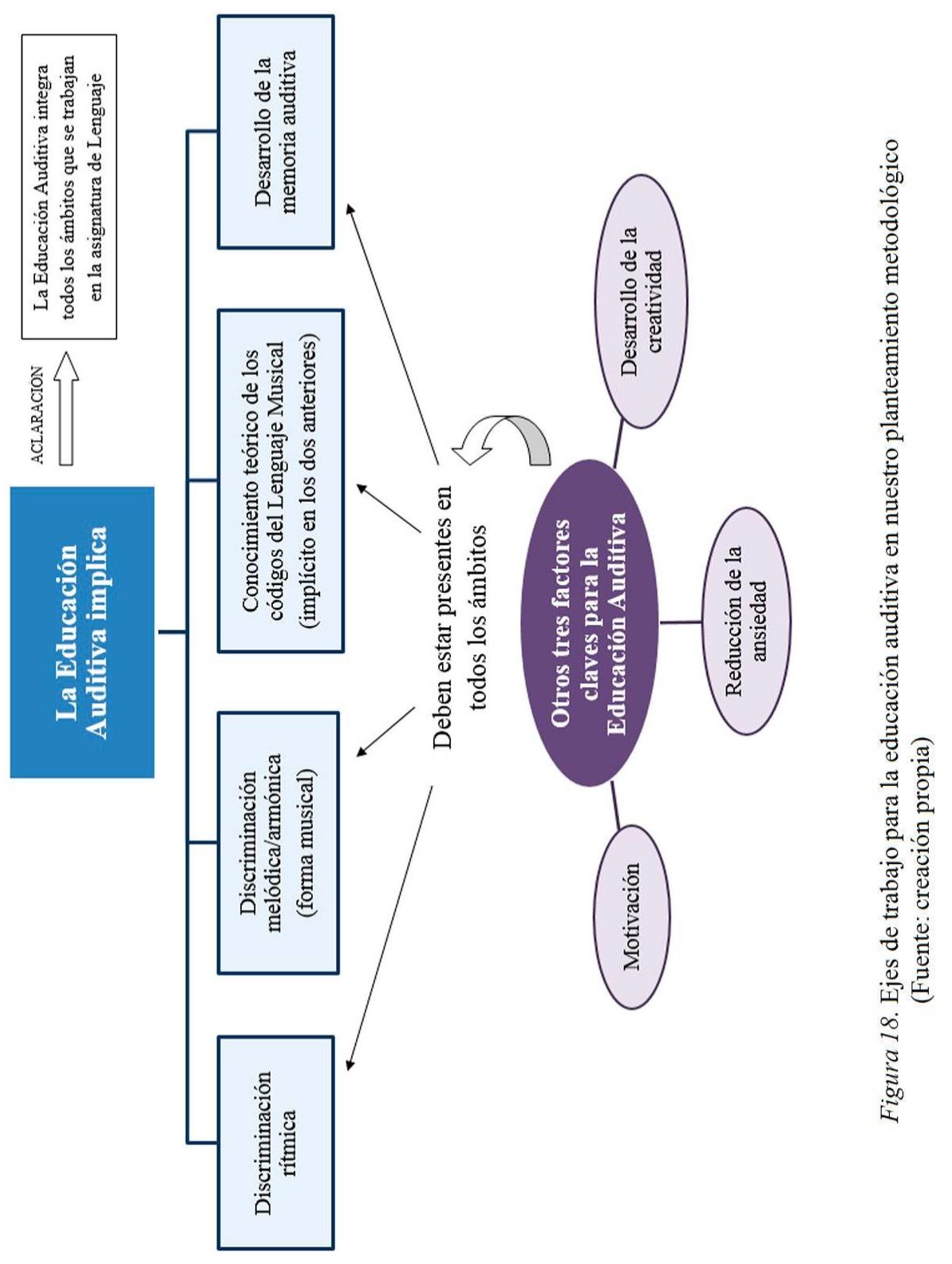




\section{Objetivos didácticos}

A parte de los objetivos, contenidos y criterios de evaluación recogidos en el apartado 4.4.1. del capítulo anterior, relativo a la educación auditiva dentro del currículo de Lenguaje Musical en el conservatorio de Segovia, los cuales no consideramos necesario repetir nuevamente, con nuestras propuestas metodológicas perseguimos también otra serie de objetivos que, aunque no son específicos del ámbito auditivo, sí que consideramos fundamentales para lograr una enseñanza musical de calidad, ya que su consecución repercute igualmente en una educación auditiva más completa. Concretamente, los objetivos didácticos que perseguimos con nuestras propuestas son:

- Mejorar el desarrollo auditivo mediante el conocimiento de las bases de la armonía tonal.

- Aumentar la motivación del alumnado hacia la asignatura de Lenguaje Musical.

- Contribuir al desarrollo de la creatividad.

- Ejercitar la memoria musical.

- Mejorar los hábitos de estudio y la capacidad de autocrítica de los alumnos.

- Implicar a las familias en el proceso de aprendizaje de sus hijos.

- Reducir la ansiedad ante las tareas musicales, especialmente las que implican una puesta en escena.

- Aprovechar las posibilidades que ofrecen las TIC en la formación musical.

\section{Recursos educativos y actividades realizadas}

Una vez identificados los ejes de nuestro trabajo, el siguiente paso fue plantear de qué manera trabajaríamos cada uno de ellos.

A pesar de que en este apartado describiremos las estrategias y actividades que hemos puesto en práctica en el aula, consideramos importante destacar que el desarrollo de todas ellas está más detallado en los capítulos de análisis de esta tesis, donde, además, se van exponiendo las dificultades encontradas inicialmente en su puesta en práctica y los buenos resultados obtenidos cuando los alumnos se familiarizaron con las mismas. 
Igualmente, es necesario señalar que, en la música, todo está relacionado (ritmo, melodía, armonía, discriminación auditiva, memoria, creatividad...), por lo que a veces resulta un tanto artificial la distribución de las actividades en los distintos apartados que hemos utilizado para facilitar su explicación. No obstante, hemos asignado cada actividad al apartado con el que considerábamos que había una mayor identificación en los objetivos que perseguíamos al realizarla.

\subsection{Actividades y recursos de discriminación rítmica}

La utilización del lenguaje verbal para trabajar el ritmo musical ha sido avalado por grandes pedadogos musicales del siglo XX (Kodály, Orff...).

Nosotros empleamos con frecuencia la sílaba rítmica "ta" para trabajar en el aula la lectura de nuevas agrupaciones rítmicas antes de combinarlas con la lectura de notas $\mathrm{y}$, al principio, también nos valemos de algunas palabras para la presentación de ritmos básicos que compartan su misma acentuación, tales como:

- Palabras monosílabas, como pan y sol, para la negra.

- Palabras llanas de dos sílabas, como nube y casa, para dos corcheas.

- Adverbios sobresdrújulos de cuatro sílabas, como fácilmente y hábilmente, para cuatro semicorcheas.

- Palabras esdrújulas de tres sílabas, como música y pájaro para los tresillos.

Estos recursos nos han resultado siempre muy útiles para la lectura rítmica en nuestro ejercicio profesional, pero no los aprovechábamos para nada más. Sin embargo, en este estudio decidimos aplicarlos para llevar a cabo ejercicios de discriminación auditiva a través de dos propuestas: adivinanzas de palabras y de frases rítmicas y trabajos de discriminación rítmica y de creación a partir de refranes.

\subsubsection{Adivinanzas de palabras y de frases rítmicas}

Consiste en asociar cada figura o grupo rítmico a distintas palabras que compartan su misma acentuación. Las primeras sugerencias las realizaba la profesora para facilitar la comprensión del ejercicio y después eran los alumnos quienes proponían sus propias palabras, elaborando largas listas. Después, de cada grupo de palabras seleccionamos una (por ejemplo, sol para la negra y nube para las dos corcheas) y la profesora percutía con un pandero combinaciones de las mismas en grupos de cuatro pulsos, las cuales 
debían repetir los alumnos con palmadas y diciendo los nombres asociados. El resultado lo dibujaban en su cuaderno (en nuestro ejemplo, utilizando soles y nubes) y, a continuación, escribían encima de los dibujos cómo sería su representación con figuras musicales.

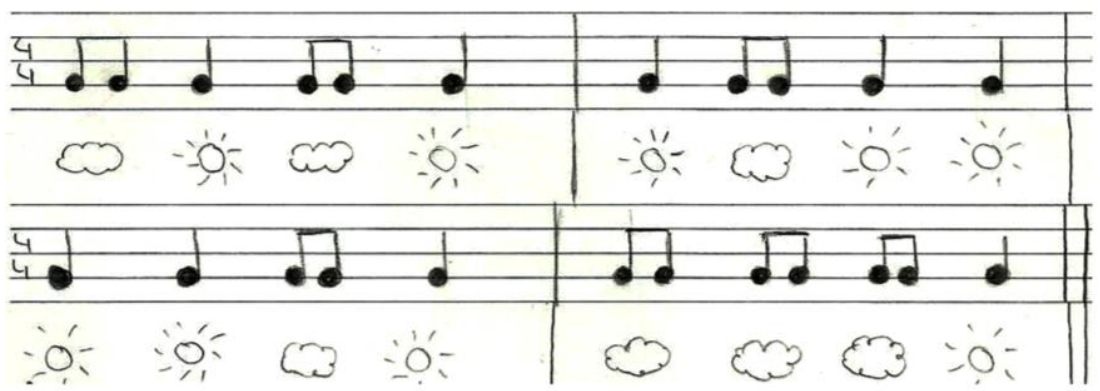

Figura 19. Adivinanza de palabras rítmicas realizada por un alumno de $1^{\circ}$

El siguiente paso consistía en adivinar el ritmo de frases lingüísticas completas propuestas por los alumnos y que incluyeran las figuraciones que estuviéramos trabajando es ese momento. Para ello, primero decíamos la frase rítmicamente mientras marcábamos el pulso con palmadas o con el brazo y, después, sustituíamos la letra por la sílaba "ta" y centrábamos la atención en identificar si en cada pulso entraba un único "ta" o varios, y nos preguntábamos si en este último caso tenían todos la misma duración o había algunos más largos que otros. Tras estas preguntas reflexivas concluíamos de qué forma se escribiría eso en el compás que estuviéramos utilizando. También contemplábamos la posibilidad de que existieran silencios si se cortaba el sonido y, en el segundo curso, podían aparecer combinaciones más complejas que incluyeran blancas, puntillos o ligaduras.

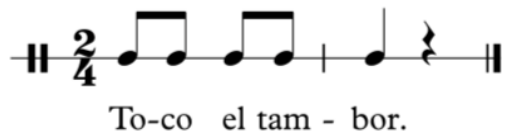

Figura 20. Frase rítmica realizada por los alumnos de primero

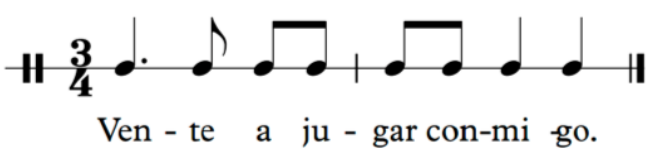

Figura 21. Frase rítmica realizada por los alumnos de segundo 
Se trataba, por tanto, de realizar dictados rítmicos pero presentándolos como juegos de adivinanzas auditivas creadas por ellos mismos, lo cual resultaba mucho más motivador para los alumnos.

\subsubsection{Identificación rítmica y creación a partir de refranes}

Siguiendo el mismo planteamiento y dinámica de las actividades anteriores, pero con el propósito de hacer más explícitas las pautas a seguir para identificar secuencias rítmicas, diseñamos siete fichas de trabajo a partir de refranes para cada curso, en las cuales los alumnos debían ir completando varios pasos hasta llegar a escribir su ritmo con la letra debajo.

Las fichas diseñadas para los alumnos del primer curso constaban de cuatro pasos: identificación de las figuras y los silencios que aparecían en el refrán, separación del texto en sílabas, escritura del ritmo con el texto debajo e invención de una nueva letra cuidando que los acentos linguísticos coincidieran con los musicales. Por su parte, las fichas utilizadas con los alumnos de segundo incluían otros dos pasos previos: identificación del compás y el tipo de comienzo. 
ESCRITURA RÍTMICA DE REFRANES ( $2^{\circ}$ Lenguaje Musical)

REFRÁN

A rey muerto, rey puesto.

\section{PASO 1: IDENTIFICACIÓN DEL COMPÁS}

Número de pulsos: $2 \quad 3 \quad 4$

Subdivisión: Binaria Ternaria

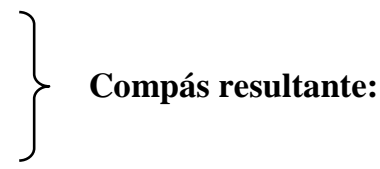

PASO 2: COMIENZO

PASO 3: FIGURAS Y SILENCIOS

Tético Acéfalo Anacrúsico

PASO 4: SEPARACIÓN DEL TEXTO EN SÍLABAS

PASO 5: ESCRITURA DEL RITMO CON EL TEXTO

PASO 6: INVENCIÓN DE UNA NUEVA LETRA

Figura 22. Ficha utilizada para el refrán 4 del segundo curso

Nuevamente, nos encontrábamos ante unos dictados rítmicos camuflados en forma de "taller de refranes", lo cual añadía a la actividad un componente lúdico muy atrayente para los alumnos. 


\subsection{Actividades y recursos de discriminación melódica y armónica}

En nuestro contexto sociocultural, la música que consumimos se rige por las reglas de la armonía tonal. Por este motivo, estamos convencidos de que la base más sólida para llevar a cabo una buena educación auditiva debía proporcionarla dicha armonía, basándonos fundamentalmente en la utilización de los acordes tonales, generadores de tensión y de reposo en el discurso musical.

Paradójicamente, en los planes de estudio de los conservatorios no se inician los estudios de armonía hasta el tercer curso de las enseñanzas profesionales, por lo que, si no asumimos la responsabilidad de tratar con anterioridad ciertos conceptos armónicos, tales como la formación de los acordes y su relación con la construcción de melodías, nos encontraremos con que los alumnos tendrán una visión parcial sobre la música que han estado estudiando durante los seis cursos anteriores.

Conscientes de esta necesidad, en esta investigación nos planteamos basar la educación vocal y auditiva en la música tonal, formando a los alumnos en la comprensión, la discriminación y el manejo de los acordes de tónica, subdominante y dominante desde el inicio de sus estudios musicales, utilizando para ello una metodología adaptada a sus capacidades y psicología infantil.

En este sentido, hemos llevado a cabo en el aula distintas estrategias metodológicas que describiremos a continuación.

\subsubsection{Identificación auditiva de los acordes tonales}

Presentamos a los alumnos el concepto de acorde como conjunto de notas que suenan a la vez y que nos producen una determinada sensación. Tanto en primero como en segundo mostramos a la vez los acordes de dominante y de tónica para que sintieran el contraste entre la tensión del primero y el reposo del segundo, reservando el acorde de subdominante para un poco más adelante, el cual presentamos como un acorde "intermedio", ya que no produce tanta tensión como el de dominante ni tanto reposo como el de tónica.

A lo largo de todo el curso, hemos jugado a identificar auditivamente series de acordes que iba tocando la profesora en el piano, representándolos corporalmente de esta manera: levantando los brazos cuando lo que escuchaban les producía sensación de tensión (dominante), bajándolos cuando sentían reposo (tónica) o dejándolos en cruz delante del pecho 
cuando la sensación percibida se encontraba a medio camino entre ambos (subdominante).

En un primer momento, para facilitar el reconocimiento auditivo los acordes se tocaban en el piano utilizando una única posición, pero progresivamente fuimos aumentando la dificultad cambiándolos tanto de posición como de octava.

\subsubsection{Reconocimiento auditivo de intervalos}

De forma teórica, explicamos el concepto de intervalo como la distancia que hay entre dos notas. Ya desde primero de Lenguaje Musical, analizamos intervalos en función de su distancia (intervalos de $2^{\mathrm{a}}, 3^{\mathrm{a}}, 4^{\mathrm{a}}, 5^{\mathrm{a}}, 6^{\mathrm{a}} \ldots$ ) y su sentido (ascendente/descendente), incorporando la especie en el segundo curso (mayor/menor, justo y aumentado/disminuido). Tras una breve explicación teórica, el trabajo que hemos realizado con los intervalos ha sido eminentemente práctico, jugando a identificarlos auditivamente. Para ello, proporcionamos a los alumnos dos tipos de estrategias o referencias sonoras:

- Escalas y arpegios: Con los alumnos de primero, únicamente trabajamos el reconocimiento auditivo de los intervalos de segunda mayor, de tercera mayor y de quinta justa, aunque en ningún momento hicimos referencia a la especie del intervalo, ya que dicha explicación la reservamos para el segundo curso. Las pautas que utilizábamos eran las siguientes: si las dos notas sonaban como el principio de una escala estábamos ante un intervalo de segunda $\mathrm{y}$, si sonaban como un arpegio, podían ser terceras (si eran las dos primeras notas) o quintas (si eran la primera nota y la tercera).

- Comienzo de distintas canciones: A partir del segundo curso, como ya sí que vemos la especie de los intervalos, utilizamos canciones que comienzan con cada uno de ellos como recurso para reconocerlos. Por ejemplo, asociamos el intervalo de cuarta justa con el comienzo de la canción Pinocho fue a pescar, el de tercera mayor con la canción Soy la reina de los mares y el de quinta justa con la banda sonora de Supermán.

\subsubsection{Invención y adaptación de motivos rítmico-melódicos}

La construcción de melodías mediante la invención de un motivo rítmicomelódico a partir de un acorde y su adaptación a otros acordes diferentes es, desde nuestro punto de vista, una de las actividades más significativas para que los niños comprendan la relación existente entre una melodía y los acordes que la sustentan. 
La actividad consistía en que un alumno proponía un motivo escogiendo las notas que quisiera del acorde de tónica (por ejemplo, mi-sol-mi) y cantándolas con un ritmo también escogido por él (por ejemplo, en un compás de 3/4, negra con puntillo, corchea y negra). Después, el resto de la clase debía repetirlo y adaptarlo de memoria a las notas de los demás acordes que estuviéramos utilizando (los cuales tenían delante como referencia), de tal manera que, si en el acorde de tónica habíamos empezado por la nota del medio, luego habíamos hecho la nota de arriba y a continuación habíamos vuelto a la del medio, en los demás acordes debíamos hacer lo mismo. Repetíamos dos veces cada acorde para facilitar el control y la asimilación de la actividad y siempre terminábamos con el acorde de tónica, haciendo una nota larga en la segunda repetición para que, al frenar el ritmo, sonara más conclusivo. En todo momento, la profesora acompañaba las interpretaciones de los alumnos tocando los acordes en el piano, pero no la melodía del motivo con el que estuviéramos trabajando.

Desde el primer momento, explicamos también a los niños que el acorde de dominante es un poco especial y que, en vez de tres notas, puede tener cuatro para crear más tensión (la $7^{\mathrm{a}}$, aunque esa información no se la proporcionamos). Por esta razón, poder adaptar bien los motivos había que quitar una de ellas y, cada vez, eliminaban la que veían más conveniente.

Esta actividad la hacíamos de forma oral, lo cual exigía concentración por parte de los alumnos y permitía desarrollar la memoria musical. No obstante, a veces escribíamos algunos de los motivos que habían propuesto para trabajar su reflejo en la grafía musical.

A continuación, mostraremos cómo se adaptaría el motivo anterior a los acordes de tónica, subdominante y dominante para formar frases musicales de 8 compases, de dos maneras distintas:

- Utilizando los acordes en posición fundamental (colocados o transportados).

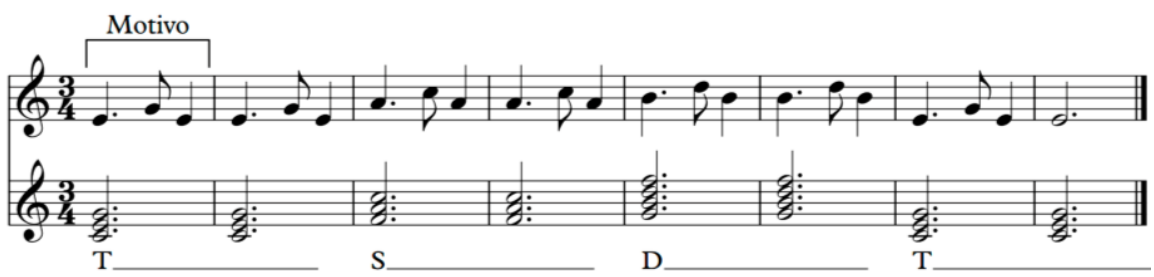

Figura 23. Adaptación de un motivo con notas reales a acordes en posición fundamental 
- Invirtiendo la posición de algunos acordes para que las notas estén más próximas entre sí (descolocados o enlazados).

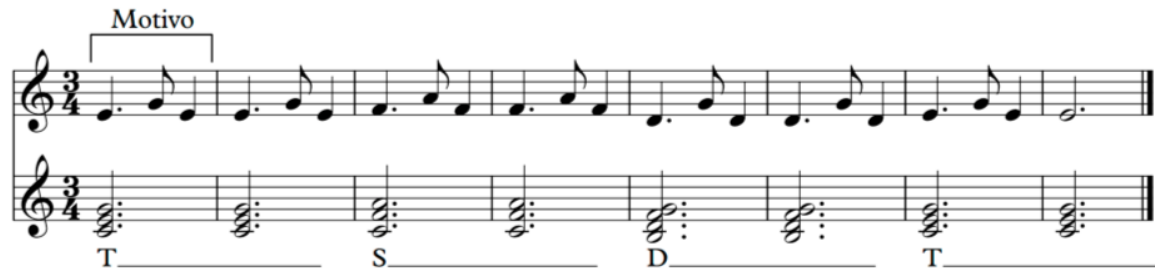

Figura 24. Adaptación de un motivo con notas reales a acordes enlazados armónicamente

Al principio, utilizamos únicamente notas reales presentes en los acordes, pero, progresivamente, fuimos añadiendo también notas de adorno: notas de paso, floreos y apoyaturas.

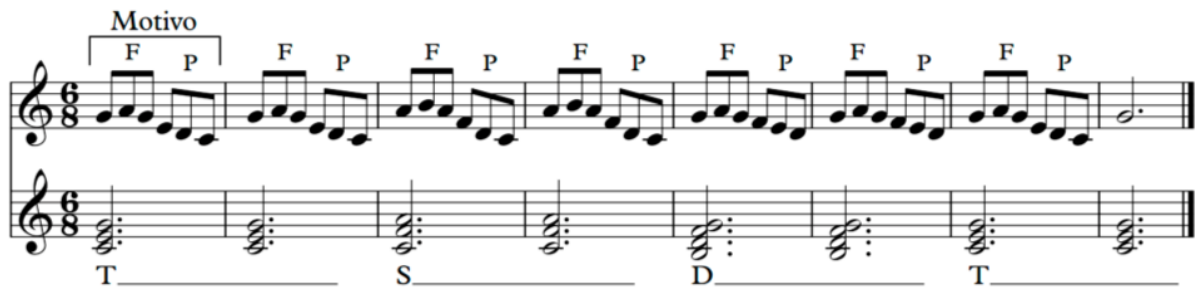

Figura 25. Adaptación de un motivo con notas de paso y floreos a acordes enlazados

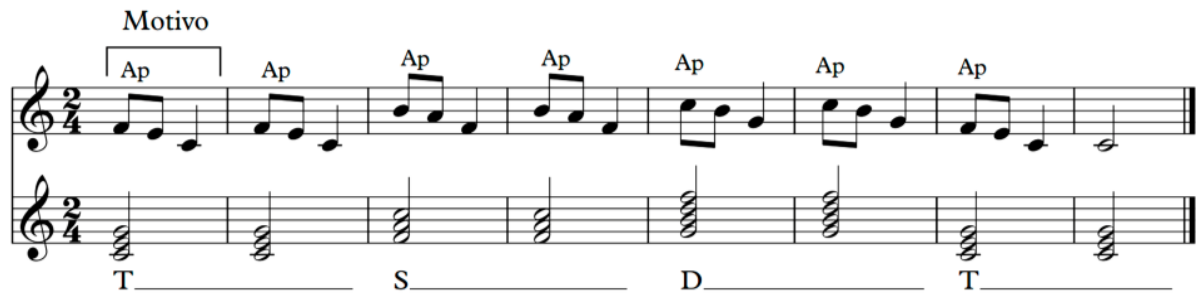

Figura 26. Adaptación de un motivo con apoyaturas a acordes en posición fundamental

\subsubsection{Aprendizaje, análisis y transcripción de canciones}

La transcripción de canciones son dictados musicales "encubiertos" y resultan muy útiles para trabajar e interiorizar las estrategias de resolución de 
los dictados, ya que a los niños les resulta mucho más sencillo memorizar una canción con letra (la cual aprenden por imitación de la profesora) que una melodía que acaban de escuchar y que tienen que retener casi al mismo tiempo que tratan de escribirla. De esta manera, al facilitar la memorización, pueden prestar más atención a dichas estrategias de decodificación musical, ya que la realidad nos muestra que el motivo por el que los alumnos fallan muchas veces los dictados no es que no sepan escribir el fragmento musical que tienen en su cabeza, sino que no han memorizado bien lo que han escuchado e inventan lo que no han retenido correctamente.

Eliminada la dificultad memorística, las estrategias que hemos utilizado para transcribir las siete canciones con las que hemos trabajado en cada curso, todas las cuales son aplicables a la resolución de dictados tradicionales, son las siguientes:

- Para comenzar, presentamos los aspectos generales de la canción:

- Comentamos las pautas de escritura: nota inicial, tipo de comienzo (tético, si no se comentaba nada, ya que es lo más frecuente, acéfalo o anacrúsico), tonalidad (a lo cual nosotros añadimos, como novedad metodológica, los acordes empleados), notas posibles de la melodía (se daba por hecho que siempre debían aparecer notas reales, por lo que solo se indicaba si, además, aparecía alguna nota de adorno), compás y figuras o agrupaciones rítmicas que se utilizaban.

- Identificamos auditivamente los acordes presentes en cada compás y los escribimos para que nos sirvieran de referencia. Además, en los grupos del primer curso, como las notas se iban presentando poco a poco, coloreamos en dichos acordes solo las notas que nos podían aparecer en la melodía.

- Identificamos la estructura o forma de la canción formulando preguntas como: ¿Cuántas partes tiene? ¿Las partes se parecen o son diferentes? ¿En qué se parecen? ¿Qué las diferencia? ¿El final de cada parte es conclusivo o suspensivo? ¿Las partes musicales coinciden con las partes de la letra?

- Para adivinar el ritmo:

- Escribimos en la pizarra las figuras, grupos rítmicos y silencios que podían aparecer.

- Cantamos, primero con letra y luego utilizando únicamente la sílaba "ta", fragmentos de 4 compases mientras íbamos marcando 
el pulso con el brazo (para conseguir mayor precisión en la medida, simultáneamente se podían ir haciendo pitos).

- Íbamos identificando el ritmo de cada pulso formulando preguntas como: ¿Cuántas figuras entran en el primer pulso? ¿Duran lo mismo? ¿Cuál es más larga? ¿Cómo se escribe eso en el compás en el que nos encontramos?

(Aclaración: Consideramos que el pulso es la unidad de medida más útil para ir formulando este tipo de preguntas, aunque puntualmente, si aparecen puntillos o ligaduras que se prolonguen entre dos pulsos, puede ser más práctico utilizar el compás como referencia).

- Para adivinar las notas:

- Cantamos, primero con letra y luego utilizando únicamente la sílaba "ta", fragmentos de 4 compases mientras íbamos representando con la mano (extendida y con la palma hacia abajo) los ascensos y descensos de la melodía. Se advertía a los alumnos que debían concentrarse en sus propios gestos y que estaba prohibido mirar al compañero de al lado, porque se podía equivocar y confundirles.

- Íbamos formulando preguntas que ayudaban a la identificación de las distintas notas, tales como: ¿Cómo es la línea melódica que acabamos de cantar? (por ejemplo, primero sube, después se mantiene, luego vuelve a subir y al final baja). ¿La melodía empieza subiendo por escala o por arpegio? ¿La última nota de la canción tiene carácter conclusivo?, es decir, ¿me quedo tranquilo porque suena a final o se percibe tensión?

- Cuando entre dos notas se producía un salto que los alumnos no identifican directamente, cantábamos siguiendo una escala las notas que había entre la primera y la segunda para comprobar a cuál habíamos llegado.

- En todo momento, los alumnos debían tener presentes los acordes de cada compás para comprobar si lo que ponían tenía sentido. Si las notas que escribían no podían explicarse según las reglas de la armonía tonal que habíamos visto, debían borrarlas, ya que se trataba de un error, lo cual les obligaba a dotar de significado a la tarea que estaban realizando. 


\subsubsection{Nuestra principal aportación: la creación de canciones}

Todas las actividades que hemos presentado hasta ahora eran consideradas un trabajo previo encaminado hacia la educación del oído armónico y la creación de canciones por parte de los alumnos, actividad principal de nuestra propuesta metodológica, para la cual debían tener en cuenta aspectos rítmicos, melódicos, armónicos, teóricos y formales, además de cuidar el ajuste entre la música y el texto.

Para crear sus propias canciones (siete en total), los alumnos debían seguir las mismas pautas de la canción que hubieran aprendido, analizado y transcrito en clase durante esa semana, tal y como acabamos de describir. Asimismo, en todo momento debían tener presentes los acordes de cada compás para comprobar si lo que escribían tenía sentido, es decir, debían ir atribuyendo significado melódico y armónico a cada nota que utilizaran, de tal manera que las notas de cada compás debían formar parte del acorde que tuvieran debajo (notas reales) o reunir las características de las distintas notas de adorno (notas de paso, floreos o apoyaturas). Si las notas que escribían no se podían explicar según las reglas de la armonía tonal trabajadas en clase (que comentaremos en el siguiente apartado), debían sustituirlas por otras, ya que se trataba de un error, lo cual les obligaba a mantener una actitud reflexiva ante la tarea que estaban realizando.

Por otra parte, al crear la letra de la canción, los alumnos debían conseguir un buen ajuste entre la música y el texto, teniendo presentes tres aspectos:

1. Que los acentos lingüísticos coincidieran con los musicales, de tal manera que, si en un pulso del compás de $2 / 4$ tenían dos corcheas, cuya acentuación natural es fuerte-débil, debían utilizar palabras llanas como casa, hola, dime o Pedro y evitar palabras agudas como ratón, jamón, perdón o Madrid.

2. Que existiera una correspondencia entre la temática de la canción y el carácter de la música. Por ejemplo, debían evitar temas excesivamente alegres o festivos si la canción estaba en modo menor.

3. Que la letra y la melodía tuvieran las mismas partes desde un punto de vista formal. Esto quiere decir que, si en la melodía existían dos partes de cuatro compases cada una, la letra debía presentar también dicha característica.

La creación de canciones, por tanto, es una actividad que integra todos los contenidos trabajados en la asignatura de Lenguaje Musical, ofreciendo al alumnado una visión de conjunto y una mayor significación a sus aprendizajes. Asimismo, permite desarrollar una educación auditiva 
completa, puesto que los alumnos deben crear una imagen mental acústica de lo que quieren expresar con su canción, plasmarla por escrito e interpretarla posteriormente de memoria ante el resto de sus compañeros, tanto con notas como con letra. La exposición frecuente de sus propios trabajos, además de resultar altamente motivadora para los alumnos, les ayuda a perder el miedo escénico y a reducir la ansiedad que suele generar la realización de interpretaciones musicales en directo.

\subsection{Conocimiento teórico de los códigos del Lenguaje Musical}

Todos los temas teóricos trabajados tradicionalmente en la asignatura de Lenguaje Musical son importantes, especialmente los relativos al análisis de intervalos, la armadura correspondiente a cada tonalidad y la formación de distintos tipos de escalas, pero no nos vamos a detener en explicar cómo trabajamos cada uno de ellos, porque no son objeto de nuestra investigación.

No obstante, sí consideramos relevante exponer en esta tesis la forma en que explicamos a los alumnos los temas que hemos introducido como novedad en nuestra metodología, cuya presentación se suele posponer hasta las enseñanzas profesionales. Estos temas son los relacionados con los acordes tonales, las notas reales y las notas de adorno utilizadas en la configuración de las melodías, la adaptación de motivos melódicos y la realización de instrumentaciones sencillas.

Queremos destacar que todos los contenidos se trabajan a través de una práctica continuada que los dota de significado, ya que no concebimos los aprendizajes teóricos que no tengan una utilidad inmediata para los alumnos. Dicha práctica está caracterizada por la experimentación y la creación musical, ya que consideramos que el ensayo-error es lo que permite la interiorización sólida y, por tanto, el verdadero aprendizaje de los distintos contenidos teóricos que expondremos a continuación.

\subsubsection{Acordes tonales}

La armonía es la ciencia que estudia los acordes y sus relaciones. Un acorde es el conjunto de tres o más sonidos ordenados por terceras que suenan a la vez.

Los acordes tonales son los que se forman sobre los grados primero, cuarto y quinto de una escala.

- Acorde de tónica (T): Es el acorde que se forma sobre el primer grado de una escala. Su sonoridad provoca una sensación de relajación y estabilidad. 
- Acorde de dominante (D): Es el acorde que se forma sobre el quinto grado de una escala. Puede llevar cuatro sonidos diferentes por tener una tercera más. Su sonoridad provoca una sensación de tensión e inestabilidad.

- Acorde de subdominante $(S)$ : Es el acorde que se forma sobre el cuarto grado de una escala. Su sonoridad provoca una sensación a medio camino entre la relajación de la tónica y la tensión de la dominante.

Los acordes también se pueden nombrar o "cifrar" utilizando números romanos que nos indican el orden que ocupan en la tonalidad.

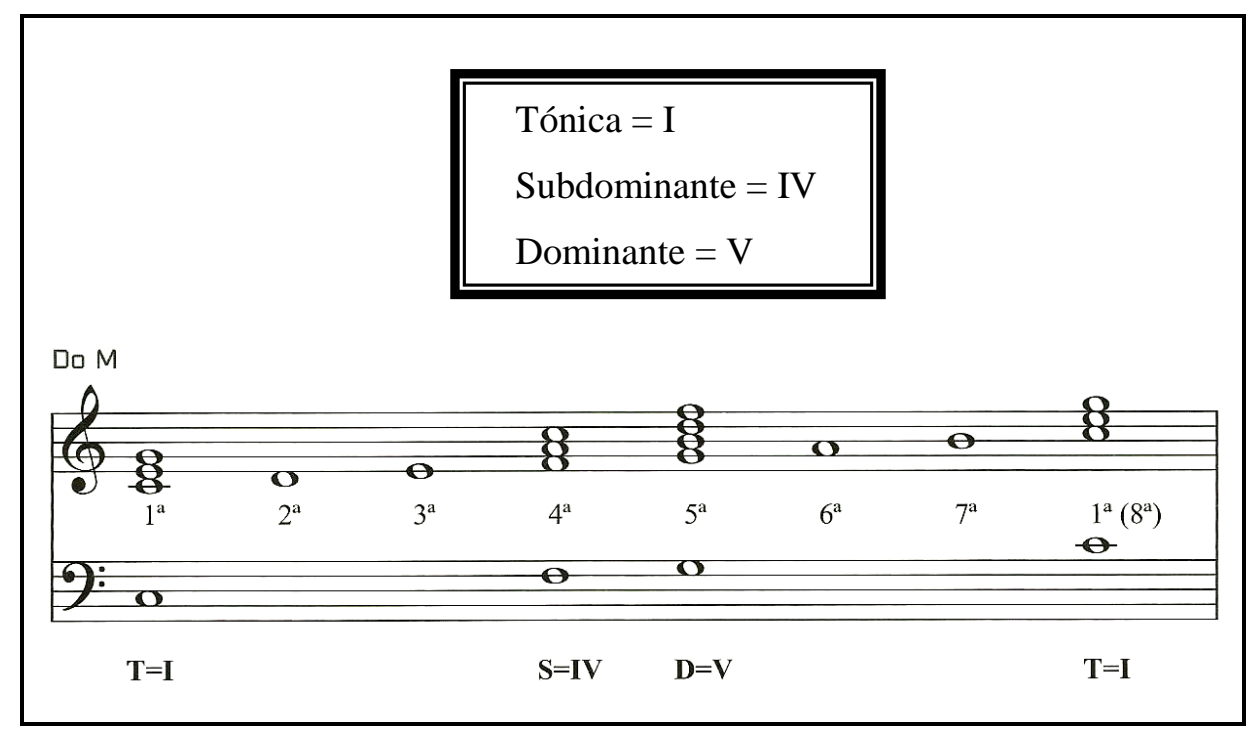

Figura 27. Construcción de los acordes de T, S y D a partir de las notas de la escala

Los acordes están colocados o transportados cuando sus notas están ordenadas por terceras. Visualmente es muy fácil reconocerlos porque todas sus notas están en espacios o en líneas consecutivas. 


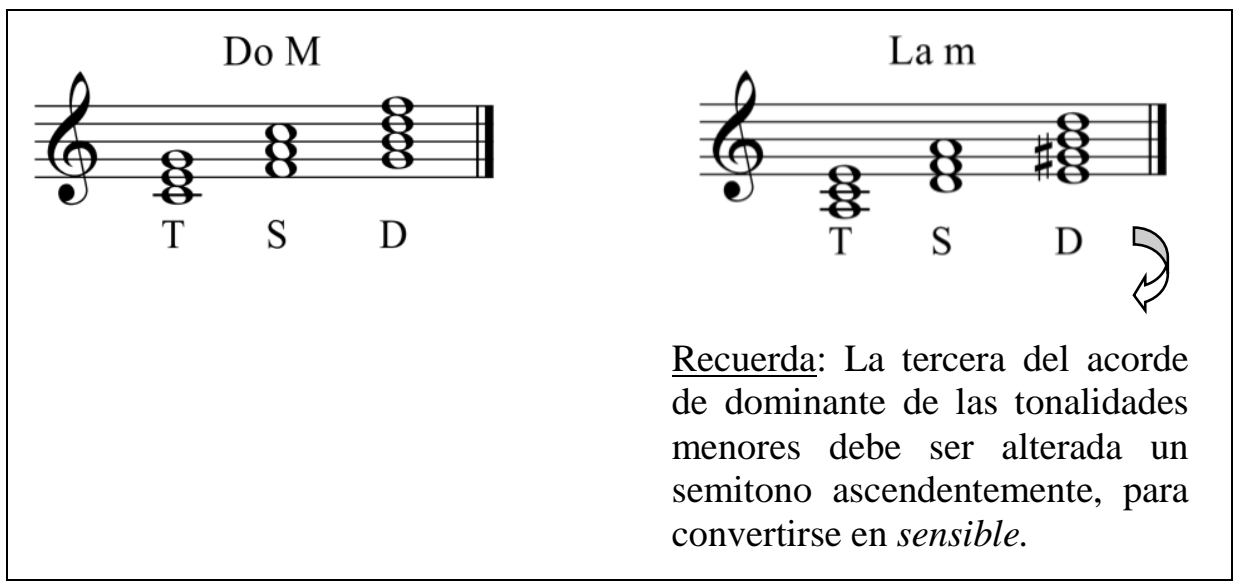

Figura 28. Acordes transportados o colocados

Los acordes están enlazados armónicamente cuando sus notas están descolocadas (no todas van por terceras) para que se encuentren unas más cerca de las otras. Esto se hace para que puedan cantarse o tocarse con mayor facilidad, sin dar tantos saltos.

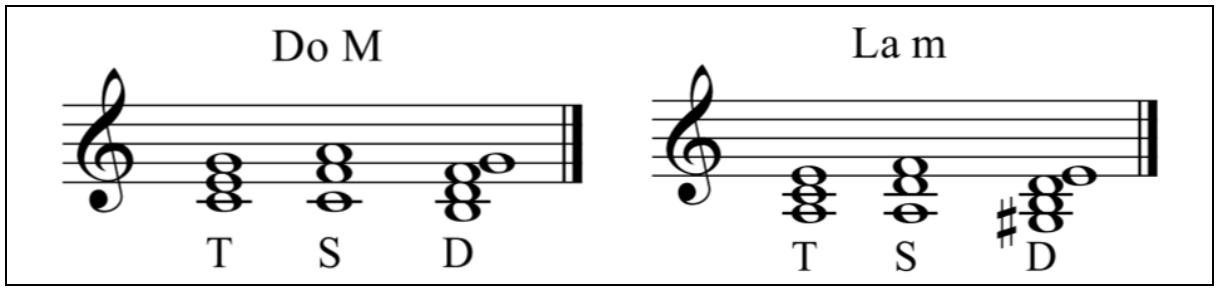

Figura 29. Acordes enlazados o descolocados

\subsubsection{Melodía: notas reales y notas de adorno}

Las notas que forman parte del acorde se llaman notas reales.

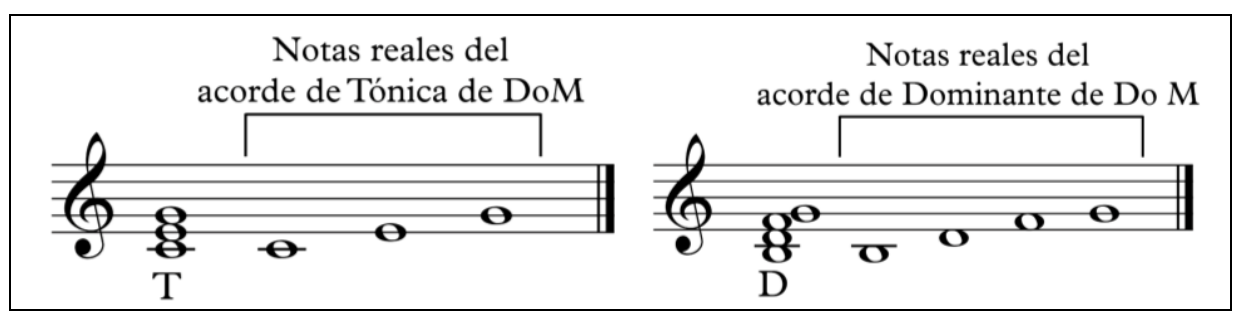

Figura 30. Notas reales de un acorde 


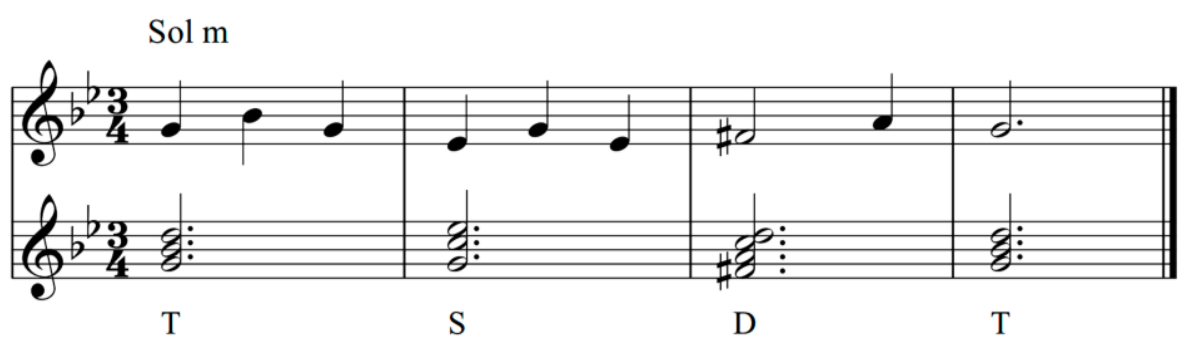

Figura 31. Fragmento musical formado por notas reales de los acordes

Las notas que no forman parte del acorde y que cumplen ciertas condiciones se llaman notas de adorno y nos permiten crear melodías más bonitas. Nosotros veremos tres tipos:

- Floreo $(F)$ : Es una nota de adorno que se coloca entre dos notas reales iguales, a distancia de $2^{\text {a }}$. Está situado en parte o fracción débil. Puede ser superior o inferior.

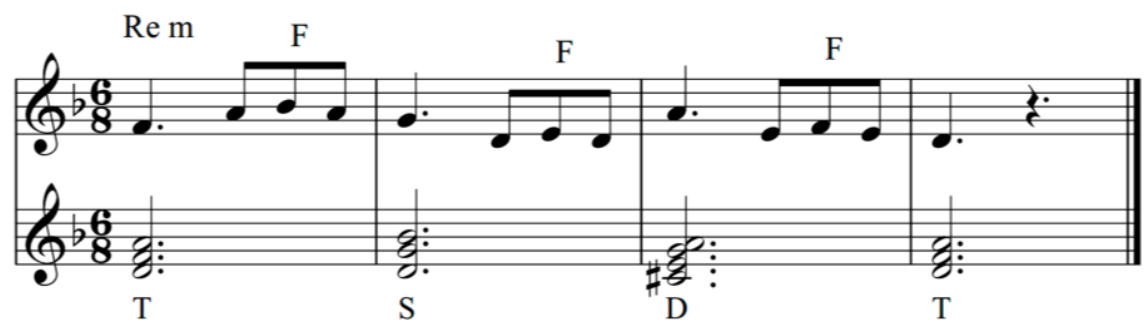

Figura 32. Fragmento musical con floreos

- Nota de paso (P): Es una nota de adorno que se coloca entre dos notas reales próximas. Está situada en parte o fracción débil. Cuando las notas reales están a distancia de tercera, la nota de paso es la que queda en medio. Cuando la distancia entre dos notas reales consecutivas no es de tercera, la nota de paso es la más cercana a la nota real hacia la que se dirige la música.

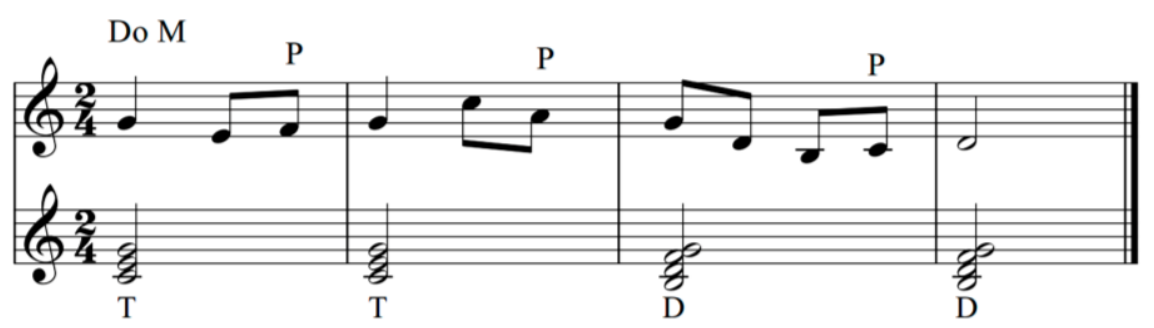

Figura 33. Fragmento musical con notas de paso 
- Apoyatura (Ap): Es una nota de adorno que se coloca delante de una nota real a distancia de segunda superior o inferior. Está situada en parte o fracción fuerte. Su sonoridad produce la "necesidad" de escuchar la nota real.

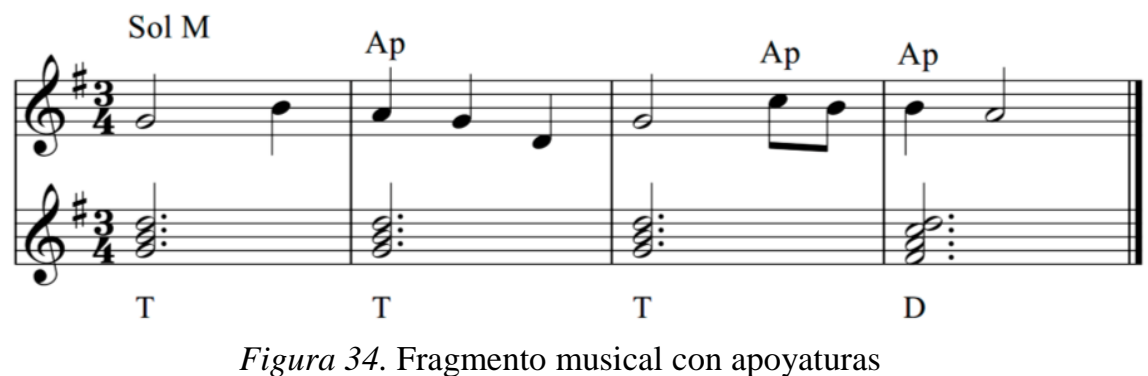

La siguiente tabla muestra la distribución de las partes y fracciones fuertes y débiles dentro de cada compás o pulso.

Tabla 10:

Distribución de las partes y fracciones fuertes y débiles en función de cada compás o pulso

\begin{tabular}{cc}
\hline $\begin{array}{c}\text { Unidades } \\
\text { (Compás o pulso) }\end{array}$ & $\begin{array}{c}\text { Distribución de acentos } \\
\text { (Partes o fracciones) }\end{array}$ \\
\hline Binario & F-D \\
Ternario & F-D-D \\
Cuaternario & F-D-SF-SD $^{(*)}$ \\
& \\
\hline (*) $\mathrm{SF}=$ Semifuerte y $\mathrm{SD}=$ Semidébil &
\end{tabular}

\subsubsection{Desarrollo de motivos melódicos}

Un motivo melódico es un conjunto de sonidos con cierto sentido musical. Al desarrollarse da lugar a la frase.

Un motivo se puede desarrollar de diferentes maneras. Aquí veremos cuatro: 
- Repitiéndolo.

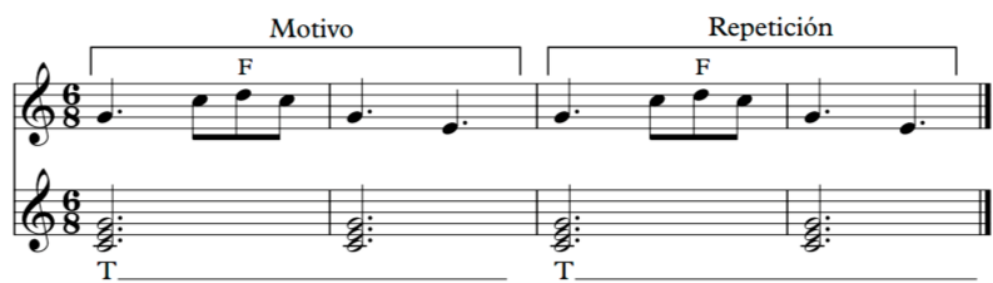

Figura 35. Desarrollo melódico por la repetición de un motivo

- Adaptándolo por transporte a otros acordes.

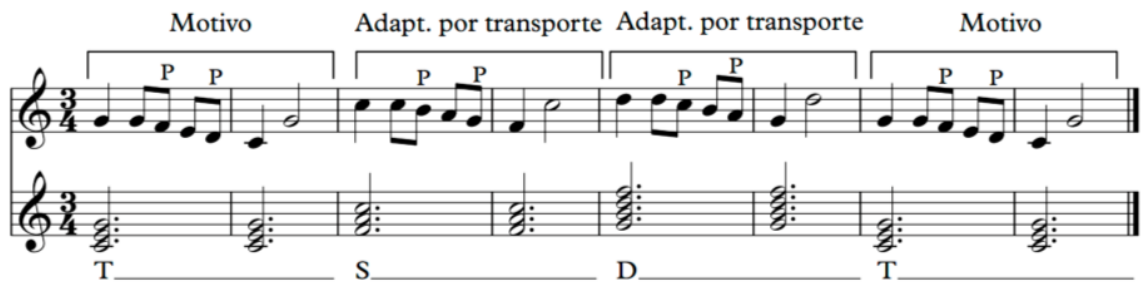

Figura 36. Desarrollo melódico mediante la adaptación de un motivo por transporte

- Adaptándolo por enlace armónico a otros acordes.

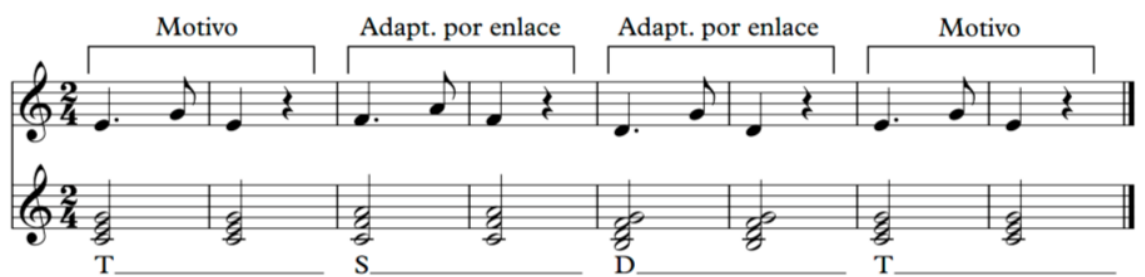

Figura 37. Desarrollo melódico mediante la adaptación de un motivo por enlace armónico

- Cambiándolo de nivel dentro del mismo acorde.

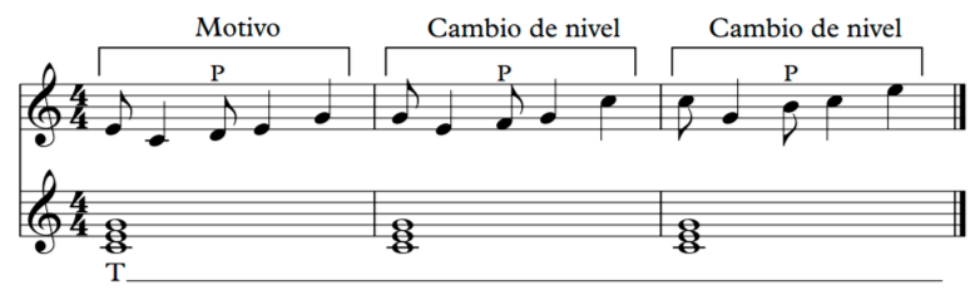

Figura 38. Desarrollo melódico mediante cambio de nivel de un motivo sobre un acorde 


\subsubsection{Nociones básicas de instrumentación}

Instrumentar es la forma de distribuir la música entre varias voces y/o instrumentos. Las canciones tienen melodía y acompañamiento:

- La melodía se interpreta con la voz o con instrumentos melódicos como la flauta, el violín, etc.

- El acompañamiento puede ser rítmico y/o armónico:

- El acompañamiento armónico consta de "bajos" y acordes, cuyas notas pueden estar arpegiadas de diferentes formas.

- Los bajos se interpretan con los instrumentos de sonido grave como el violonchelo, el piano (mano izquierda), la tuba, etc.

- Los acordes se interpretan con instrumentos polifónicos como el piano (mano derecha), la guitarra, etc.

- El acompañamiento rítmico suele ser a base de ostinatos interpretados por los instrumentos de percusión.

Observa todo lo dicho en esta instrumentación.
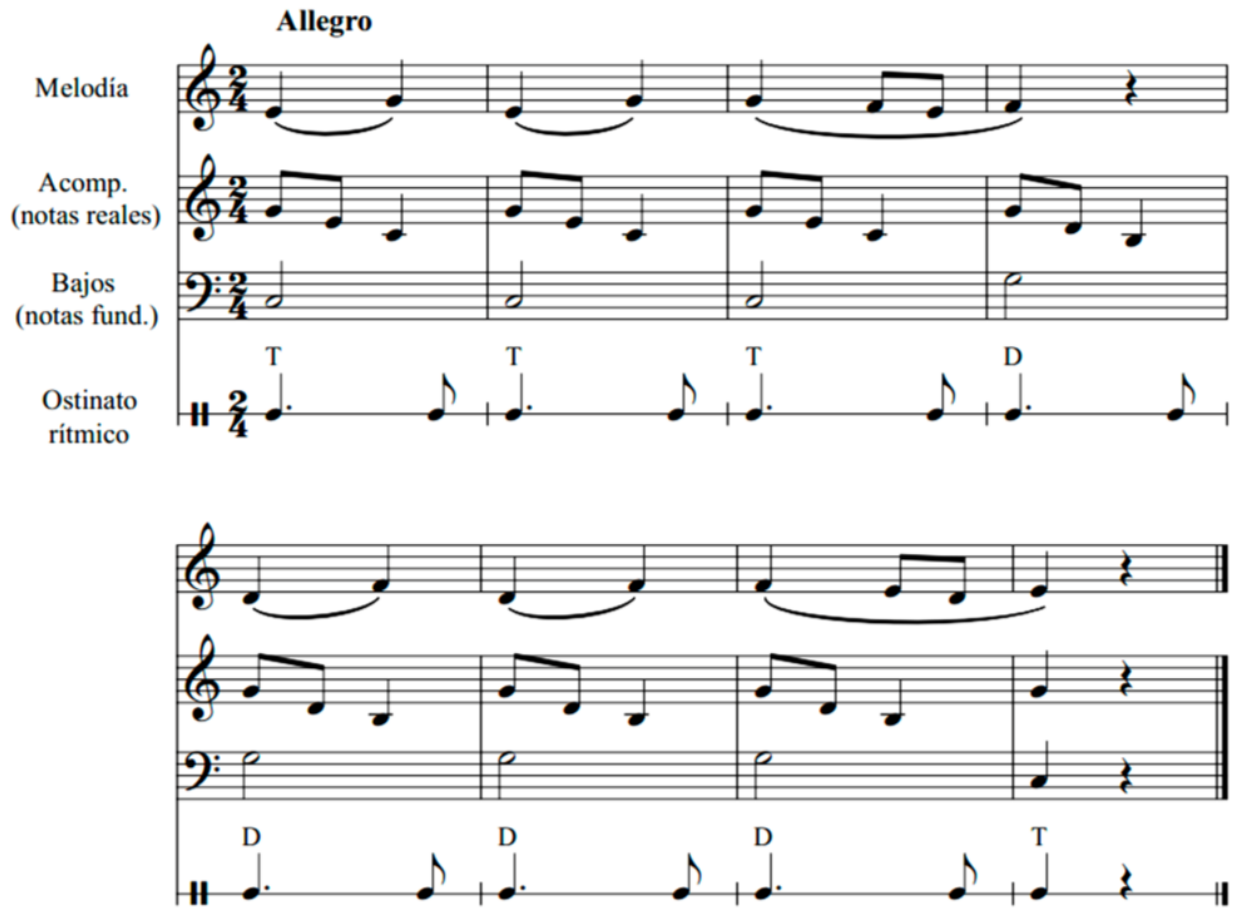

Figura 39. Instrumentación de una melodía 


\subsection{Ejercicios para el desarrollo de la memoria auditiva}

La memoria auditiva es fundamental para el aprendizaje, ya que si no se retiene adecuadamente el material musical con el que estamos trabajando y se relaciona con las imágenes sonoras almacenadas en la memoria a largo plazo es imposible dotar de significado al discurso musical. Por ello, es necesario potenciar su desarrollo mediante una adecuada intervención educativa.

Nuestras propuestas han sido fundamentalmente tres: utilización de la fononimia de Kodály, interpretación de distintas melodías de memoria y realización de notas, ritmos y secuencias rítmico-melódicas encadenadas. Veamos en qué consistían.

\subsubsection{Utilización de la fononimia de Kodály}

Antes de interpretar cualquier lección de entonación, transcribir canciones o realizar dictados musicales, presentábamos las notas que iban a aparecer y hacíamos ejercicios de calentamiento para facilitar el recuerdo de cómo sonaban. Para ello, la profesora cantaba series de notas, completando dos compases de 2/4 y apoyándose en los gestos fononímicos que propone Kodály, y los alumnos las repetían. Por ejemplo:

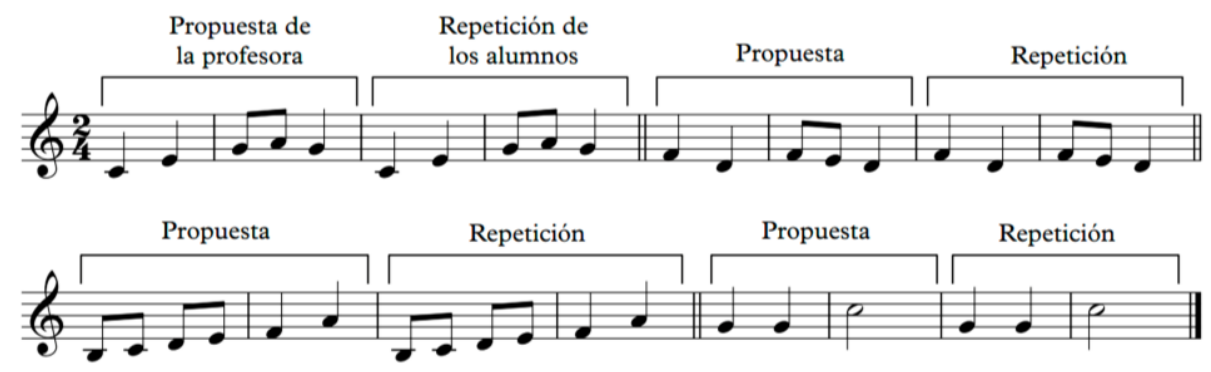

Figura 40. Práctica de notas utilizando la fononimia de Kodály

Después, la profesora iba indicando con los gestos de su mano distintas notas (ya no las cantaba) y los alumnos las entonaban directamente, realizando también simultáneamente esos mismos gestos.

\subsubsection{Interpretación de melodías y fragmentos de memoria}

La interpretación memorística de melodías o fragmentos musicales ayuda a fijar los sonidos en la mente para, posteriormente, poder reconocerlos o acudir a ellos de forma consciente. 
Por ello, durante todo el año los alumnos han cantado de memoria distintas melodías o secuencias sonoras, entre las cuales destacan:

- Las canciones que creaban en casa, tanto con notas como con letra.

- Algunas de las lecciones de entonación que trabajábamos en clase.

- Cada uno de los fragmentos en que dividíamos las canciones que transcribían de oído (descritas anteriormente) y los dictados musicales, como paso previo a su escritura, ya que consideramos que para poder escribir adecuadamente un fragmento musical debíamos asegurarnos primero de que lo habían memorizado bien.

- Ejercicios diseñados específicamente para el calentamiento de la voz y la preparación del oído que cantaban de memoria antes de la interpretación de canciones o lecciones de entonación y de la escritura de canciones o dictados musicales. Dichos ejercicios estaban dirigidos únicamente a los alumnos de segundo (con los de primero utilizamos solo la fononimia de Kodály) y se basaban en las escalas y arpegios de las tonalidades trabajadas, es decir, do mayor, la menor y sol mayor, incluyendo notas de adorno en los dos últimos. Para poder trabajarlos en casa hasta conseguir memorizarlos, los alumnos disponían de una plantilla con los ejercicios y unos audios con su interpretación. La figura 41 muestra los ejercicios diseñados para la tonalidad de do mayor. Las plantillas de las demás tonalidades están recogidas en el anexo II, junto con los audios de todas ellas. 


\section{TONALIDAD DE DO MAYOR}

Escala de Do M
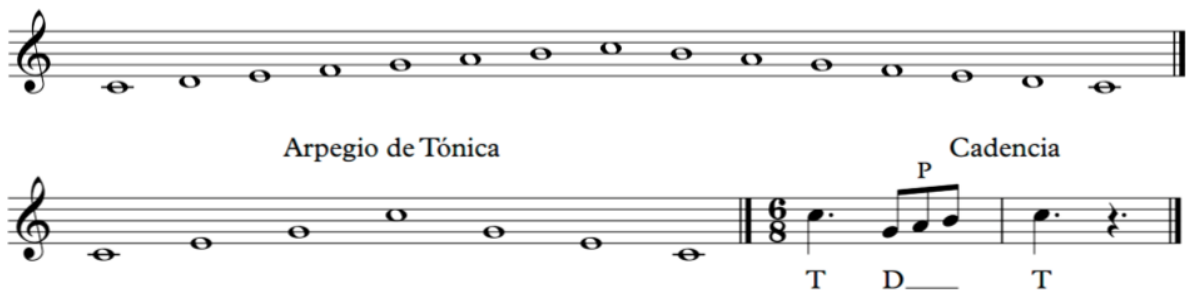

Acordes transportados (colocados)

Acordes enlazados
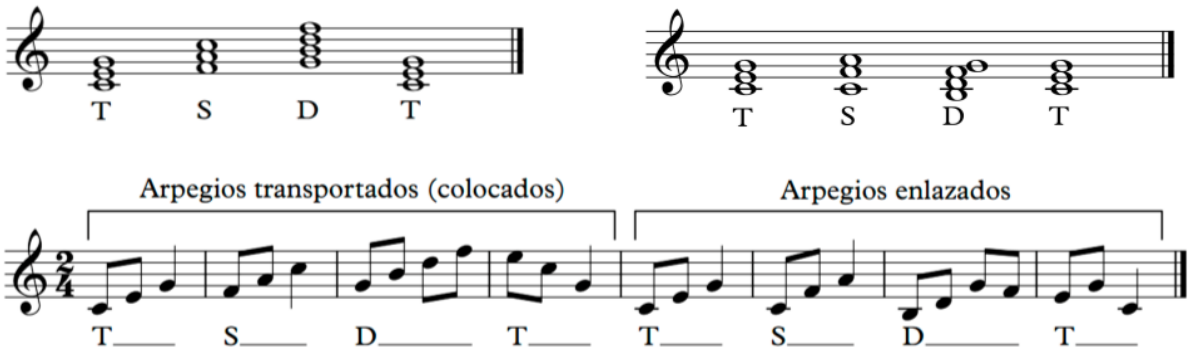

Escala con pedal de Tónica

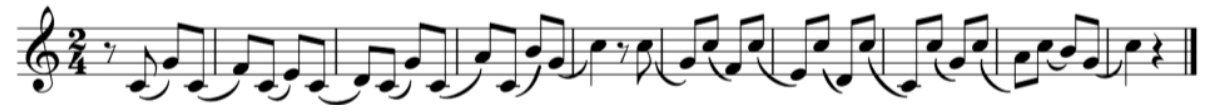

Despliegue de arpegios
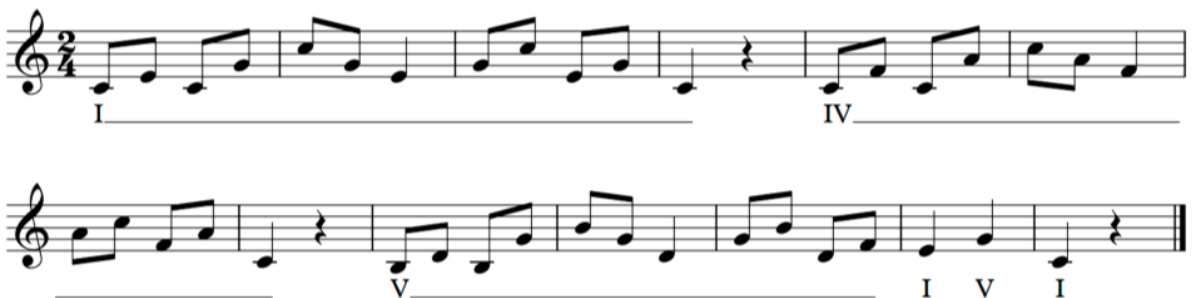

Arpegios con notas de adorno (floreos y notas de paso)
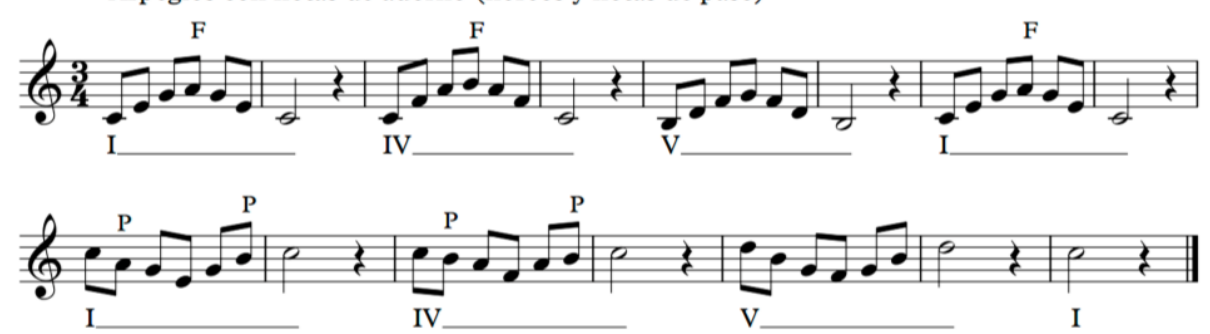

Figura 41. Ejercicios de calentamiento de la voz y de preparación del oído para Do Mayor 


\subsubsection{Notas, ritmos y secuencias rítmico-melódicas encadenadas}

Se trataba de ir haciendo propuestas de notas, de ritmos o de ambas cosas a la vez que se iban sumando. Vamos a explicarlos por separado:

- Notas encadenadas: Un alumno cantaba una nota, el alumno de al lado cantaba esa nota y otra más, el siguiente cantaba las notas de los dos compañeros anteriores y añadía una tercera, y así sucesivamente. La duración de cada nota era de una negra en un compás de 2/4. Cuando un alumno olvidaba alguna nota, volvíamos a empezar. El reto consistía en intentar hacer la serie más larga posible. Por ejemplo:

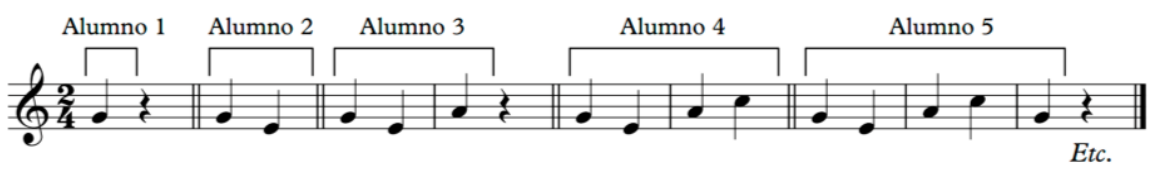

Figura 42. Ejemplo de notas encadenadas

- Ritmos encadenados: Un alumno proponía el ritmo de un compás elegido por él mismo $(2 / 4,3 / 4 \ldots)$ y lo percutía con palmas al mismo tiempo que lo solfeaba utilizando la sílaba "ta". Después, el compañero de al lado repetía ese mismo ritmo y añadía un compás más. A continuación, el siguiente alumno repetía los dos compases anteriores e inventaba otro, y así sucesivamente. Al igual que en la actividad anterior, se trataba de memorizar el mayor número de compases posible. Por ejemplo:

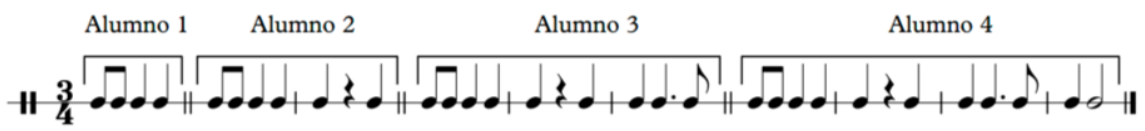

Figura 43. Ejemplo de ritmos encadenados

- Secuencias rítmico-melódicas encadenadas: Era la suma de las dos actividades que acabamos de describir, de tal manera que los alumnos debían ir proponiendo y memorizando compases en los que se combinaban tanto ritmos como notas. Por ejemplo:

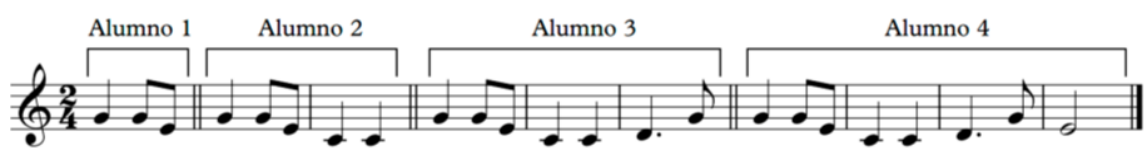

Figura 44. Ejemplo de secuencias rítmico-melódicas encadenadas 


\subsection{Otros aspectos claves: motivación, creatividad y ansiedad}

Además de todos los contenidos curriculares descritos, hay tres aspectos fundamentales que hemos tenido en cuenta en nuestro planteamiento metodológico desde el principio y que han estado presentes tanto en las actividades desarrolladas dentro del aula como en las tareas que los alumnos debían realizar en casa: la motivación hacia los aprendizajes, el desarrollo de la creatividad y la reducción de la ansiedad generada por la puesta en escena y por el alto nivel de exigencia que requieren los estudios musicales en los conservatorios.

En este sentido, hemos cuidado la motivación del alumnado partiendo de sus intereses y planteando las distintas actividades como "juegos musicales" con los que aprender disfrutando, hemos potenciado la creatividad haciendo hincapié en el aprendizaje por descubrimiento a través de la manipulación de los elementos musicales y su utilización como medio de expresión de sus propias ideas y sentimientos, y hemos controlado la ansiedad de los alumnos manteniendo una actitud flexible y aceptando los errores como parte natural de todo proceso de aprendizaje. 



\section{CAPÍTULO VI: DISEÑO Y DESARROLLO DE LA INVESTIGACIÓN}

\section{Introducción}

En este capítulo delimitaremos con precisión el trabajo de investigación que hemos llevado a cabo, el cual presenta un conjunto diverso de actividades íntimamente relacionadas, formando un todo interdependiente que ha de ser previsto, dentro de lo posible, desde el inicio, dado que las decisiones que se toman en cada fase tienen repercusiones en las siguientes.

El punto de partida de todo trabajo científico es la delimitación del tema de estudio, a partir del cual se establecen las principales características definidoras de la investigación, es decir, los objetivos, el enfoque metodológico, la fijación de la muestra, la aproximación a las fuentes, el plan de trabajo, las técnicas para la recogida de datos, el proceso de análisis de los mismos y cualquier otra cuestión referida al plan de trabajo que conduce a la obtención y exploración de la información requerida de acuerdo al tema estudiado.

\section{Definición del objeto de estudio}

En cualquier trabajo de investigación es importante utilizar temas destacados que sirvan de guía para su desarrollo, ya que "los temas nos llevan a observar, incluso a sonsacar los problemas del caso" (Stake, 1998, p. 26). El tema en torno al cual se articula esta tesis, formulado como un interrogante a resolver, es:

¿Es posible mejorar la educación auditiva a través de una metodología integradora basada en el sistema tonal-armónico desde el inicio de los estudios en la asignatura de Lenguaje Musical? 
De forma más específica, a partir de la pregunta general que acabamos de exponer, los objetivos que nos proponemos alcanzar en esta investigación pueden sintetizarse en los siguientes:

- Conocer las dificultades del alumnado en el ámbito de la audición musical desde la asignatura de Lenguaje Musical y cómo reducirlas.

- Determinar la utilidad de iniciar a los alumnos en el conocimiento de las bases de la armonía tonal para mejorar su desarrollo auditivo.

- Valorar la eficacia de nuestras estrategias metodológicas para ofrecer una educación auditiva integradora, significativa y motivadora.

- Analizar la respuesta de la comunidad educativa hacia las actividades propuestas durante el proceso de enseñanza-aprendizaje.

- Identificar las barreras encontradas a lo largo del proceso educativo y las estrategias desarrolladas para superarlas.

Una vez concretados los objetivos de la tesis, debemos plantear cómo conseguirlos, lo cual detallamos en el siguiente apartado.

\section{Diseño general de la investigación}

\subsection{Investigación cualitativa}

El elemento básico que define una investigación es su diseño, del cual se desprende el plan de acción a llevar a cabo. Para ello, en primer lugar debemos considerar qué enfoque es el más idóneo, respecto a lo cual Husén (1988) indica que depende en gran medida del objeto de estudio. En la misma línea, Buendía, Colás y Hernández (1999) defienden que:

[...] debemos entender el problema, decidir qué preguntas deseamos formular y, a partir de aquí, decidir qué modo de "indagación disciplinada" es más apropiado para responder a tales preguntas. (p. 5)

Dicho enfoque o paradigma de investigación es definido por Del Río (2003) como:

Esquema o modelo teórico adoptado por un grupo de científicos que comparten una percepción y comprensión de la realidad y que actúan teniendo en común una serie de pautas y normas de comportamiento de acuerdo con una escala de valores y creencias. (p.18)

Hasta hace relativamente poco tiempo, a la hora de realizar investigaciones en el aula solo se tenían en cuenta las conductas directamente observables, 
que eran interpretadas de forma aislada sin ser ubicadas correctamente en el ámbito en el que se originaban. Todo ello estaba enormemente influenciado por los planteamientos de la investigación cuantitativa.

Frente a ello, surgió la investigación cualitativa (también denominada interpretativa), que no se preocupa únicamente de las conductas aisladas en categorías, sino que pretende comprender lo que sucede en el aula desde diversos puntos de vista (profesores, alumnos, familiares, etc.), descansando sobre el supuesto de la existencia de múltiples realidades, considerando que las generalizaciones no son posibles, ya que lo máximo que uno puede esperar son hipótesis de trabajo referidas a un contexto particular, y sosteniendo que el investigador y las personas investigadas están interrelacionados, influyéndose mutuamente, por lo que los investigadores cualitativos procuran mantenerse a una distancia óptima del fenómeno.

Taylor y Bogdan (1986) definen la investigación cualitativa como "aquella investigación que produce datos descriptivos por medio de las palabras y la conducta observable" (p. 20). En la misma línea, Barba, González-Calvo y Barba-Martín (2014) afirman que "se trata de una propuesta para comprender o transformar los acontecimientos, las normas y los contextos desde la propia perspectiva de los participantes" (p. 3).

Por su parte, Flick (2004) señala que se interesa por "analizar casos concretos a partir de las expresiones y actividades de las personas que participan en sus contextos locales" (p. 27), lo cual supone que se trata de una investigación donde predomina la palabra y que pretende analizar las sensaciones vividas. Igualmente, Grundy (1991) considera que esta perspectiva metodológica está ampliamente relacionada con la palabra y la verbalización de sensaciones, una cuestión incompatible con la perspectiva técnica, pero que resulta ser compatible con la práctica interpretativa.

El carácter interpretativo propio de la metodología cualitativa precisa concebir la investigación de forma reflexiva y colectiva, permitiendo que todos y cada uno de los participantes puedan involucrarse activamente en el proceso (Imbernón, 2002). Por ello, el proceso investigador no concluye con la elaboración de un informe relacionado con el problema, sino que este enfoque busca comprender para conseguir el cambio y la transformación. En este sentido, cuando la investigación tiene como objetivo transformar la realidad, la participación ha de estar presente desde el primer momento (Stringer, 2007).

Nosotros en esta tesis hemos optado por llevar a cabo una investigación cualitativa porque lo que pretendemos es comprender a las personas dentro de su marco de referencia (Taylor \& Bodgan, 1986); el investigador se 
convierte en el principal instrumento de recogida de datos (Anguera et al., 1998); la investigación se orienta a comprender e interpretar lo singular de los fenómenos sociales, dejando las explicaciones de las leyes generales a las ciencias nomotéticas (Albert Gómez, 2006); hay una preocupación directa por la experiencia tal y como es vivida, sentida o experimentada (Sherman \& Webb, 1988); el foco de la investigación tiene carácter exploratorio y descriptivo (Maykut \& Morehouse, 1994); se prefiere la teoría nacida de los datos sobre sí mismos (Gimeno \& Pérez, 1985); se utiliza un lenguaje expresivo que recoja los matices específicos de cada fenómeno analizado (Eisner, 1991); y se recurre a distintas técnicas de recogida de datos para aumentar la validez de las conclusiones (Goetz \& LeCompte, 1988).

Asimismo, consideramos importante destacar que Parlett y Hamilton (1976, citados por Stake, 1998) consideran que en los estudios cualitativos se debe mantener un enfoque progresivo, ya que el curso que va a seguir el estudio no se puede trazar completamente de antemano. En este sentido, defienden que los investigadores empiezan con una base de datos extensiva y reducen sistemáticamente la amplitud de la indagación, para prestar una atención más detallada a los nuevos temas que surgen.

Finalmente, siguiendo a Barba (2013), hemos considerado relevante señalar otros principios propios de la investigación cualitativa que hemos tenido en cuenta al realizar nuestro estudio:

- El problema a investigar es una cuestión de la realidad, no de las limitaciones del marco teórico.

- La búsqueda bibliográfica supone un proceso qué se desarrolla antes o después de la práctica del estudio.

- Se pretende comprender o transformar la realidad.

- La selección muestral se realiza por el interés del caso a estudiar.

- Enunciar el problema a partir de preguntas que se deben responder.

- Las personas con las que se investiga son participantes, no sujetos pasivos.

- La planificación de la investigación se realiza en fases y se modifica según los avances de la investigación.

- La ética se basa en la toma de decisiones conjuntas y democráticas.

- El rigor se basa en la triangulación o en la cristalización.

- La investigación es válida si transforma el entorno. 


\subsection{Métodos de investigación utilizados}

Una vez establecido el marco conceptual de referencia que permite describir y justificar el camino que va a recorrer un proyecto de investigación, es necesario escoger el método más adecuado para llevarlo a cabo. Para Sabariego (2004):

El método constituye el camino para alcanzar los objetivos de la investigación. Son formas estables de trabajar por parte de un grupo o una comunidad de investigadores, para escoger y configurar la recogida de datos y el análisis de estos, en vistas a unas conclusiones. (p. 79)

Por su parte, Barba (2013) define el método como "el conjunto de técnicas e instrumentos que configuran una forma de investigar y que van a permitir el acceso al campo para conocer e interpretar su realidad con detalle" (p. 27).

Puesto que la investigación cualitativa es multidimensional, se puede afirmar que dentro de la misma existe una gran variedad de métodos que permiten estudiar la realidad vivida (Latorre, 2003), pero resulta difícil encuadrar la investigación de esta tesis dentro de un solo método.

Siguiendo a Fernández Pérez (1988), podemos afirmar que estamos ante "un polinomio cruzable: investigación en la acción/estudio de casos/investigación cualitativa" (p. 154). Estas aproximaciones metodológicas a la investigación de los hechos educativos pueden coincidir perfectamente en un único proceso, ya que nos encontramos ante un proyecto de investigación-acción realizado por una profesora en su aula, que se centra en el estudio de la intervención sobre casos concretos de alumnos, utilizando básicamente métodos cualitativos.

Consideramos oportuno señalar también que estas aproximaciones metodológicas a la investigación educativa no son anti-cuantitativistas, sino que, por el contrario, varios de sus instrumentos requieren, en algunas de sus versiones, cuantificaciones precisas, sin perjuicio del carácter cualitativo del acceso a los datos que se recogen y a la descripción, preferentemente verbal, tanto de sus diagnósticos, como de sus pronósticos y evaluaciones.

De este modo, podemos decir que hemos elaborado un proceso metodológico peculiar, adaptado a los objetivos de la investigación, a la estructura de la misma y a la propia situación de la investigadora. Todo esto nos sugiere el carácter versátil, flexible, creativo y adaptable del método de investigación al objeto de estudio que, en nuestro caso concreto, se trata de un problema o caso educativo específico, en su contexto multivariable e imprevisible. 
No obstante, los dos métodos principales de investigación que hemos utilizado son la investigación-acción, entendida como investigación en el aula, y el estudio de casos. A continuación, describiremos las características esenciales de ambos que nos han resultado de utilidad.

\subsubsection{Investigación-acción entendida como investigación en el aula}

Dentro de la investigación cualitativa, encontramos estudios participativos o transformativos en los que los investigadores buscan transformar la realidad mientras investigan (Barba, González-Calvo, \& Barba-Martín, 2014). No se pretende conocer ni describir la realidad, sino que el propio proceso de investigación consiste en mejorar la realidad educativa desde dos perspectivas: 1) emancipatoria, si el investigador no se incluye en el grupo, y 2) transformativa, si investigador y participantes se consideran en la misma realidad (Mertens, Sullivan, \& Stace, 2011). Al respecto, Freire (2007) afirmaba que la clave en este tipo de investigación es transformar la realidad, no obtener datos para narrar lo que sucede. La investigación, por tanto, es el propio proceso de transformación de un grupo concreto.

En educación, esta perspectiva se ha seguido desde: a) la investigaciónacción (Barba \& González-Calvo, 2013; Contreras-Domingo, 1994; Elliot, 1990; McKernan, 1999; Stringer, 2007), en la que expertos colaboran con docentes para mejorar las prácticas, y b) la investigación de los propios docentes sobre sus prácticas (González-Calvo \& Barba, 2014; Kincheloe, 2012; Schön, 1998; Stenhouse, 1987; Zeichner, 1993).

McKernan (1996) entiende la investigación-acción como "el proceso que llevan a cabo diversos profesionales en ejercicio, tratando de mejorar la comprensión de los acontecimientos, las situaciones y los problemas para aumentar la efectividad de su práctica" (p. 24). Tal y como señala Caín (2013), "las expresiones investigación docente o investigación sobre el profesor se utilizan algunas veces como sinónimo de investigación-acción y, en general, para referirse a cualquier forma de investigación realizada por los docentes" (p. 57).

La investigación-acción, entendida como investigación en el aula, es realizada por profesionales dentro de su propia práctica para mejorarla y comienza con preguntas tales como: ¿cómo puedo mejorar lo que estoy haciendo? (Whitehead, 1999). Este proceso se describe generalmente como un ciclo recurrente (Caín, 2013):

[...] después de examinar una situación existente, los investigadores planifican y llevan a cabo intervenciones, monitorizan las consecuencias esperadas y no esperadas de dichas intervenciones y reflexionan sobre ellas. 
Esas reflexiones son utilizadas para programar nuevas intervenciones, comenzando de este modo un nuevo ciclo. (p. 58)

La investigación-acción realizada por los profesores en su propia aula es diferente a otras formas tradicionales de investigación. Las principales diferencias pueden resumirse de la siguiente manera (Cain, 2013):

- La investigación educativa tradicional es realizada a menudo por investigadores que se posicionan ellos mismos como observadores no involucrados. En cambio, los profesores que analizan su propia práctica están involucrados subjetivamente en la situación sobre la que están investigando. A menudo, y como parte del proceso de investigación, esperan llegar a ser más conscientes de sus propios valores y más autocríticos.

- La investigación tradicional se realiza sobre las personas, mientras que la investigación en el aula se hace con las personas, es colaborativa y apunta a relaciones más éticas entre los profesores y los estudiantes, que trabajan juntos para mejorar el aprendizaje.

- En la investigación tradicional los hallazgos son asumidos como "válidos" cuando son verdaderos y como "confiables" cuando cualquier investigador, adoptando los mismos métodos, puede obtener los mismos resultados. Tales conceptos resultan útiles para los científicos, pero en la investigación-acción son problemáticos. La validez es un concepto problemático porque la "verdad" se vincula con los valores de quienes la proclaman. La confiabilidad es problemática porque cada situación educativa es una composición única de múltiples interacciones e interpretaciones de dichas interacciones. Puesto que no hay dos situaciones iguales, los profesores investigadores no pueden replicar entre sí sus investigaciones de una manera exacta.

- La investigación tradicional a menudo involucra un proceso de muestreo (elegir individuos que sean representativos de una población más amplia). En cambio, la investigación en el aula no trabaja con muestras representativas: los profesores investigadores trabajan con sus estudiantes, a pesar de que puedan ser representativos de otros grupos.

- La investigación tradicional algunas veces comienza con un tipo de hipótesis de causa y efecto que el investigador espera comprobar o rechazar. En cambio, la investigación-acción busca la evidencia del cambio y las influencias que contribuyen a tal cambio. 
- Los enfoques de la investigación tradicional involucran comparaciones entre grupos (normalmente, un grupo experimental y un grupo de control). La investigación-acción no lo hace, aunque a menudo compara situaciones posteriores con otras previas, reconociendo que las acciones del investigador son solo algunos de los factores que promueven el cambio.

- La investigación tradicional monta algunas veces situaciones artificiales en las cuales se eliminan las variables, mientras que la investigación-acción en el aula se realiza en el mundo "real", por lo que las variables no pueden ser apartadas de la situación estudiada.

Así pues, queda claro que en esta metodología de investigación el objetivo esencial no es formular teorías generalizables, sino mejorar la práctica profesional que se tiene entre manos, pero ello no implica ceguera teórica, todo lo contrario. Por un lado, el profesional investigador, en nuestro caso, la profesora-investigadora, se incorpora a la investigación en el aula con los conocimientos teóricos explícitos que posee en el momento de su iniciación. En segundo lugar, cada profesor aporta, además, el bagaje de sus teorías tácitas, implícitas o "teorías en acción". Finalmente, el proceso de la investigación en la acción torna explícitas, precisamente, las teorías implícitas de los docentes, de forma que puede afirmarse que genera teoría, al verificar la validez en la práctica (no hay otro lugar para la verificación empírica de los enunciados teóricos) de las teorías, siguiendo en esto, como se apreciará, el recorrido inverso de la investigación convencional científiconaturalista, que venía a las aplicaciones tecnológicas con teorías, leyes y principios generales previamente establecidos con solidez.

Terminaremos este apartado destacando que, de forma específica, las características principales de la investigación en el aula (Elliot, 1990; McKernan, 1996) en nuestro trabajo se concretan en tres: (a) la profesora ha sido la investigadora de su propia práctica; (b) el estudio de campo ha mantenido una perspectiva práctica, ya que la acción ha sido guiada por la recogida de datos; y (c) la unidad entre la práctica y el proceso de investigación se ha mantenido constante.

\subsubsection{Estudio de casos}

Hemos considerado que el estudio de casos era muy apropiado para nuestra investigación porque tiende a configurar un campo privilegiado para el estudio en profundidad de determinados fenómenos educativos.

En líneas generales, tal y como señala García Llamas (2003): 
El estudio de casos consiste en buscar soluciones a partir de la discusión y el análisis de un problema determinado, dentro de un grupo y situación real, extraída de la propia experiencia de los sujetos que lo componen. (p. 93)

Yin (1984) define el estudio de casos como "la descripción y el análisis detallado de unidades sociales que a priori son únicas" (p. 20). Este mismo autor, entiende que este método intenta responder de forma organizada y equilibrada los interrogantes del "cómo" y "por qué" se produce lo que se produce en el contexto estudiado. En esta misma línea, Stake (1998) añade que en el estudio de casos se analizan las particularidades y las complejidades para llegar a comprender la actividad en circunstancias concretas, y señala que es habitual que el trabajo de campo "oriente la investigación en sentidos imprevistos, por eso resultan problemáticos unos esquemas previos excesivos" (p. 35). Asimismo, Goetz y LeCompte (1988) consideran que este método es valioso para "mostrar los datos del contexto, las actividades y las creencias de los participantes en los escenarios educativos" (p. 41).

Por su parte, Albert (2006) señala las siguientes características del estudio de casos:

- Es eficaz como forma de acercamiento a la realidad.

- Permite su identificación-reconocimiento-comprensión.

- Opera a través de la descomposición y análisis de la realidad en sus variables más significativas.

- Se trata de un método apropiado para el estudio de los fenómenos complejos, caracterizados por la interacción entre sus variables.

- Es adecuado para el examen de las realidades susceptibles de tratarse como sistemas abiertos que interactúan en su entorno.

- Supone una descripción densa del problema a estudiar.

- El diseño es flexible.

- Supone una descripción de las partes interesadas y los motivos.

- Es inductivo, descriptivo, específico, heurístico, longitudinal.

- Se construye sobre el conocimiento tácito.

En el acercamiento al conocimiento del caso hay múltiples estrategias implicadas, ya que pretendemos conocer la realidad desde múltiples perspectivas. Por este motivo, se suelen utilizar diversos instrumentos que se 
aplican con diferentes participantes, aspecto en el que es clave la habilidad y la experiencia del investigador (Stake, 1998). A modo de ejemplo, Barba (2013) señala que para conocer el funcionamiento de un centro educativo habría que entrevistar al equipo directivo, a algunos profesores, a familias, a niños; observar algunas clases y reuniones; y analizar los diferentes documentos oficiales y actas, lo cual nos ha resultado de gran utilidad para nuestro estudio. A partir de la múltiple información recogida, se podría ir analizando qué aspectos se repiten, con qué frecuencia y qué fenómenos únicos deben estudiarse.

Existen distintas clasificaciones del método de estudio de casos. Al respecto, Stake (1998) considera que puede ser de dos tipos: intrínseco, que hace referencia a conocer un caso que nos interesa por alguna razón específica y que genera un informe totalmente descriptivo; e instrumental, el cual busca generar un conocimiento que va más allá de la realidad específica estudiada, obteniendo una mayor claridad y profundización sobre el tema. Por su parte, Yin (1984) ofrece una clasificación diferente, considerando que puede ser: exploratorio, cuando pretende conocer el caso; descriptivo, cuando tiene la intención de contar lo que sucede; y explicativo, cuando pretende buscar los porqués de lo que sucede. Asimismo, tanto Yin como Stake elaboran una clasificación en función del número de casos analizados, distinguiendo entre estudio de caso único y estudio de caso colectivo o múltiple.

Puesto que en esta tesis nos planteamos analizar la eficacia de nuevas estrategias metodológicas para llevar a cabo la educación auditiva de los alumnos, consideramos fundamental recoger también la aportación de Simons (1996), quien señala que el método de casos es particularmente apto para el estudio de la innovación por tres razones:

- Permite comprender la especificidad del caso en su particular contexto cultural y político. Mediante las técnicas frecuentemente adoptadas en el estudio de casos (entrevista, observación y análisis documental), el investigador de casos puede contar la historia de cómo fue experimentada e interpretada sobre el terreno la innovación, desde la perspectiva y con las palabras de los participantes clave.

- Por la propia relación, ricamente descrita e interpretada, los estudios de casos pueden servir de base para análisis e interpretaciones posteriores.

- Una tercera gran ventaja del método de casos sobre otras metodologías para el estudio de la innovación es la ausencia de categorías predeterminadas e hipótesis precisas. Este es un enfoque particularmente idóneo para estudiar la innovación por cuanto no siempre está claro, al principio de la implantación, lo que sucederá 
exactamente. A veces hay contrariedades hasta en los planes mejor atados, pero la flexibilidad del enfoque del estudio de casos permite seguir y documentar los cambios que se van originando.

Todo lo expuesto en este apartado nos permite concluir que, junto con la investigación en el aula, el estudio de casos constituye un método válido para nuestro trabajo de investigación porque nos permite llevar a cabo un análisis en profundidad sobre una serie de unidades muestrales (en nuestro caso, determinados grupos de alumnos) con la finalidad de resolver el caso (la iniciación a la educación auditiva desde un marco tonal) dentro de su contexto educativo (la asignatura de Lenguaje Musical).

\subsection{Configuración de la muestra}

En primer lugar, consideramos conveniente partir de la matización que hace Stake (1998): "El estudio de casos no es una investigación de muestras. El objetivo primordial del estudio de un caso no es la comprensión de otros. La primera obligación es comprender este caso". (p. 17)

Por tanto, cuando hablamos de muestra no nos estamos refiriendo a que pretendamos generalizar los resultados de nuestra investigación a toda la población de estudiantes de los dos primeros cursos de Lenguaje Musical de los conservatorios españoles, ya que somos conscientes de que no hemos utilizado una muestra representativa para ello, sino comprender lo que pasa en las aulas concretas que estamos estudiando.

Hecha esta aclaración, señalaremos que el estudio que presentamos se ha llevado a cabo fundamentalmente en el Conservatorio Profesional de Música de Segovia, durante el curso académico 2012-2013, con una muestra de 79 alumnos pertenecientes a siete grupos de Lenguaje Musical de los dos primeros cursos de las enseñanzas elementales (41 alumnos de primero distribuidos en cuatro grupos y 38 alumnos de segundo distribuidos en tres), a los que impartía clase la propia profesora-investigadora y con los cuales se ha puesto en práctica la nueva propuesta metodológica. Las edades de los alumnos estaban comprendidas mayoritariamente entre los 8 y 10 años, aunque contábamos también con tres adultos.

No obstante, para la obtención de los distintos datos necesarios para la investigación, los cuales describiremos más adelante, hemos contado también con la colaboración de:

- 1.635 alumnos, estudiantes de cualquiera de los seis cursos de Lenguaje Musical en conservatorios españoles de distintas provincias: 
Ávila, Segovia, Zaragoza, Huesca, Cantabria, Córdoba, Madrid y Murcia.

- Tres expertos de pedagogía musical con publicaciones específicas para el trabajo de la educación auditiva en la asignatura de Lenguaje Musical impartida en los conservatorios españoles.

- Padres y madres (en adelante utilizaremos la palabra genérica "padres" para referirnos a ambos) de los alumnos de la profesorainvestigadora. Todos han participado en la investigación aportando datos a través de las tutorías y los correos electrónicos que dirigían a la profesora durante el curso académico. No obstante, algunos han participado también de forma más directa a través de entrevistas individuales (cuatro familiares de primero y tres de segundo) y grupales (seis familiares de primero y siete de segundo).

- Cinco profesores de instrumento que eran tutores de los alumnos de la profesora-investigadora, entre los cuales se encontraban dos miembros del equipo directivo del centro.

\subsection{Acceso al campo}

Stake (1998, p. 17) señala que "si es posible, debemos escoger casos que sean fáciles de abordar y donde nuestras indagaciones sean bien acogidas". En este sentido, al tratarse de una investigación basada en la aplicación de una nueva metodología con los propios alumnos de la investigadora, el acceso al campo fue sencillo, ya que no interfería en el desarrollo ordinario de las clases de Lenguaje Musical. No obstante, a principio de curso se mantuvo una reunión con el equipo directivo para informarles del estudio y con los padres de los alumnos para pedir su autorización, mediante la cumplimentación del escrito recogido en el anexo III.

Asimismo, conviene señalar que, para la recogida de determinados datos de la investigación, tuvimos que acceder a otros miembros de la comunidad educativa.

- Para acceder a los alumnos de otros conservatorios españoles, contactamos vía telefónica y por e-mail con los directores de los centros, utilizando una carta de presentación en la que solicitábamos su colaboración, y, una vez aceptada, se procedió al envío de cuestionarios por correo postal.

- Para poder entrevistar a expertos, padres y profesores-tutores de los alumnos, en primer lugar les informamos de nuestros propósitos y nos ganamos su confianza utilizando el correo electrónico (aunque en 
algunos casos pudimos hablar personalmente) y, una vez que accedieron a colaborar, concertamos el día, hora y lugar adecuado para llevar a cabo las entrevistas.

\subsection{Plan de trabajo y temporalización}

El punto de partida del trabajo que presentamos lo constituye el deseo de la profesora e investigadora, que coinciden en la misma persona, por ayudar a sus alumnos a superar las dificultades manifestadas habitualmente en la realización de dictados musicales, unido al convencimiento de que el concepto de educación auditiva ha de ser más amplio que el asociado a la simple resolución de dictados tradicionales.

Para comprobar si dichas dificultades eran específicas de nuestros alumnos $y$, por tanto, se trataba de una circunstancia puntual, o si se manifestaban en el alumnado de más conservatorios españoles, convirtiéndose en una situación general, diseñamos unos cuestionarios que fueron administrados a estudiantes de ocho conservatorios de nuestro país, los cuales describiremos más adelante. Los resultados de dichos cuestionarios revelaron varios datos de interés que decidimos tratar con mayor profundidad en nuestro trabajo, sobre todo los relativos a las expectativas de los alumnos al iniciar sus estudios musicales, la motivación mostrada hacia el Lenguaje Musical y las dificultades que encuentran en dicha asignatura, que están relacionadas fundamentalmente con la realización de dictados, lo cual les genera gran ansiedad, confirmándose nuestra sospecha inicial de que, en general, no se trabajan adecuadamente.

Todo ello unido a las carencias que acusó la propia profesora como alumna durante sus primeros años de formación en el conservatorio (comentadas al inicio de esta tesis) nos motivó a emprender la búsqueda de un buen método que permitiera llevar a cabo una educación auditiva contextualizada en el sistema tonal-armónico propio de nuestra cultura y que, al mismo tiempo, facilitara a los alumnos la resolución de los dictados tradicionales, ayudándoles a comprender y a aplicar las "reglas del juego" para que no se convirtieran en jeroglíficos torturadores para ellos.

Siguiendo a Kerlinger (1981, p. 83), definimos el diseño como "el plan y estructura de la investigación concebido para obtener respuesta a los interrogantes de estudio”. Plan, estructura y estrategia no están reñidos con un proceso no lineal de investigación que nos aporta seguridad, por un lado, y flexibilidad, por el otro.

Partiendo de dicho concepto, decidimos iniciar la búsqueda de nuestro nuevo planteamiento metodológico revisando distintos libros y materiales 
utilizados en nuestro país para trabajar los dictados (en particular) y la educación auditiva (en sentido más amplio) y entrevistando a expertos que hubieran realizado publicaciones didácticas específicas para la asignatura de Lenguaje Musical de nuestros conservatorios. Ambas fuentes nos permitieron concluir que actualmente, al menos en su planteamiento teórico, aunque después la realización práctica dentro de las aulas sea otra, el énfasis puesto en el dictado está siendo desplazado por la búsqueda de una educación auditiva más completa, lo cual nos resultó muy interesante y nos sugirió dirigir nuestra atención pedagógica al desarrollo de distintas capacidades de los alumnos, independientemente de que luego fueran evaluadas también mediante la realización de dictados. De esta manera, la correcta resolución de dictados dejaría de ser un fin pedagógico en sí mismo para convertirse en un elemento que serviría para medir la calidad de la educación auditiva alcanzada en los alumnos a través de otras muchas actividades dirigidas a desarrollar aspectos tales como la percepción rítmica, la identificación de alturas sonoras, la memoria musical, el reconocimiento de estructuras formales o la discriminación de acordes que presentan distintos grados de tensión y reposo.

Este primer momento de la investigación se completó con una intensa búsqueda bibliográfica que nos permitió configurar el cuerpo teórico de la tesis con una sólida fundamentación, consultando distintas bases de datos en las que se recogían las aportaciones precedentes de autores de reconocido prestigio.

Todo el trabajo de revisión bibliográfica, fundamentación teórica, entrevistas a expertos y análisis de cuestionarios cumplimentados por los alumnos de distintos conservatorios españoles nos ha servido de base para realizar nuevas propuestas, tal y como hemos descrito en el capítulo anterior dedicado a la descripción de nuestra nueva metodología para el trabajo de la educación auditiva desde un contexto tonal.

Dicha propuesta metodológica la hemos puesto en práctica en el aula durante el curso académico 2012-2013, abordando simultáneamente un trabajo sistemático de investigación que nos permitiera ir comprobando su validez pedagógica. Para ello, hemos recogido datos a través de distintas técnicas y los hemos analizado con rigor científico del modo que describiremos en los próximos apartados.

La figura 45 muestra un esquema del plan de trabajo de la investigación. 


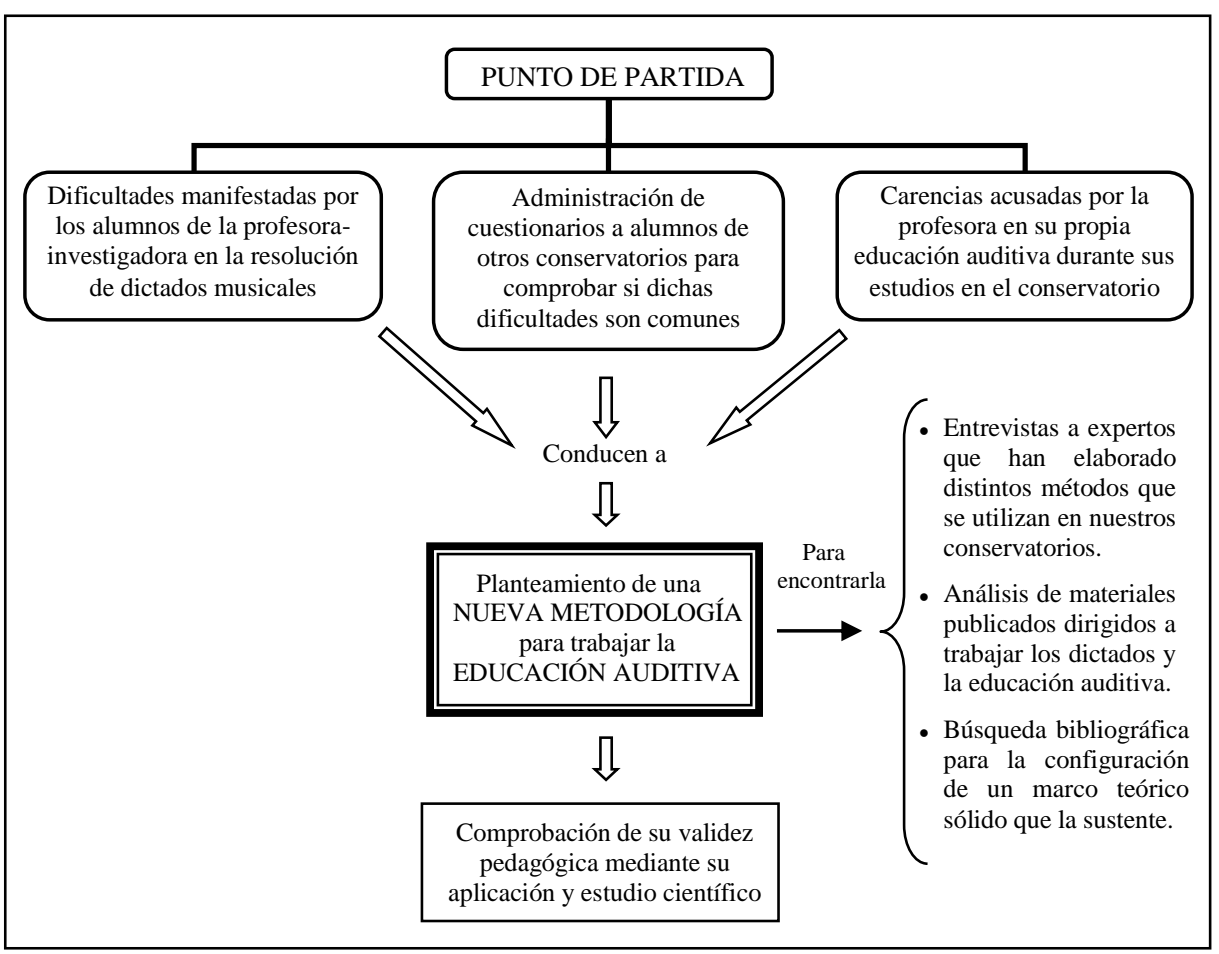

Figura 45. Plan de trabajo de la investigación

En cuanto a la temporalización del trabajo que presentamos, hemos seguido el siguiente cronograma.

Tabla 11:

Cronograma del proceso seguido en la investigación

\begin{tabular}{|c|c|c|c|c|c|c|c|c|c|c|c|c|c|c|}
\hline \multirow{2}{*}{ Cronograma de la investigación } & \multicolumn{2}{|c|}{2012} & \multicolumn{4}{|c|}{2013} & \multicolumn{4}{|c|}{2014} & \multicolumn{4}{|c|}{2015} \\
\hline & 3 & 4 & 1 & 2 & 3 & 4 & 1 & 2 & 3 & 4 & 1 & 2 & 3 & 4 \\
\hline Elección y concreción del objeto de estudio & & & & & & & & & & & & & & \\
\hline Elaboración del marco teórico & & & & & & & & & & & & & & \\
\hline Operativización del estudio y recogida de d & & & & & & & & & & & & & & \\
\hline Organización y análisis de los datos & & & & & & & & & & & & & & \\
\hline Elaboración del informe de la investigación & & & & & & & & & & & & & & \\
\hline Entrega y difusión & & & & & & & & & & & & & & \\
\hline
\end{tabular}




\section{Técnicas e instrumentos para la recogida de datos}

Para la obtención de los distintos datos que, posteriormente, serían analizados, utilizamos diversas técnicas e instrumenteos que nos permitieron llevar a cabo una triangulación y aportar, así, mayor validez y credibilidad a los resultados. Dichas técnicas e instrumentos han sido los siguientes:

- Diario de la profesora-investigadora (anexo IV).

- Entrevistas individuales y grupales (anexo V).

- Cuestionarios cerrados y abiertos (anexos VI y VII). Cabe señalar que, a pesar de que la utilización de cuestionarios es más característica del enfoque cuantitativo, en nuestra investigación le hemos dado un enfoque cualitativo.

- Análisis de documentos (anexos VIII, IX, X, XI y XVI):

- Publicaciones didácticas para la enseñanza del Lenguaje Musical

- Documentos oficiales

- Correos electrónicos

- Trabajos y exámenes de los alumnos

- Videos y fotografías

A continuación, describiremos con detalle cada uno de ellos.

\subsection{Diario de la profesora-investigadora}

A partir de la implantación del paradigma cualitativo-interpretativo, en el campo de la enseñanza se incrementa la utilización de documentos personales como instrumentos de investigación. El documento personal más utilizado es el diario del profesor, ya que suministra información respecto a la evolución de su propio pensamiento (Del Villar, 1994), constituyendo uno de los instrumentos básicos de evaluación que debe elaborar cualquier docente que mantenga una actitud reflexiva y crítica.

Según Zabala (2004) el diario es "el documento en el que los profesores y profesoras recogen sus impresiones sobre lo que está sucediendo en sus clases" (p. 15), aunque, un poco más adelante, también añade que "nada impide que otros ámbitos de la actividad docente puedan ser igualmente reflejados en el diario" (p. 16). Por su parte, Porlán (1987) lo define como "una herramienta para la reflexión significativa y vivencial de los enseñantes" (p. 27). 
No es un método objetivo de observación, ni una catalogación exhaustiva de las actividades de la clase, sino que recoge observaciones de hechos calificados como relevantes que permitirán conocer, a raíz de su descripción e interpretación, parte de la realidad escolar. En este sentido, es conveniente redactarlo lo más tempranamente posible con el fin de no olvidar ningún detalle relevante. $\mathrm{Al}$ respecto, no solo resulta fundamental la descripción de lo ocurrido, sino también las interpretaciones y las impresiones del propio profesor-observador, ya que constituyen la única forma de conocer las razones de su comportamiento.

El valor del diario como instrumento potenciador del desarrollo profesional se manifiesta en la posibilidad que brinda al sujeto de realizar una reflexión sistemática de su propia práctica, permitiéndole identificar problemas y plantear soluciones dirigidas a la mejora educativa. El diario invita al sujeto a expresar libremente sus impresiones, ideas y experiencias, haciendo explícitos los motivos que orientan su actuación profesional y ayudando a comprender cómo vivencia y resuelve los conflictos que se le plantean. Zabalza (2004) lo expresa de la siguiente manera:

Con los diarios se racionaliza la vivencia al escribirla (lo que tenía una naturaleza emocional o afectiva pasa a tener, además, naturaleza cognitiva con lo cual se hace más manejable), y se reconstruye la experiencia, lo cual posibilita descentrarse de ella y analizarla. (p. 21)

Porlán y Martín (1991) señalan que su utilización periódica permite reflejar el punto de vista del autor sobre los procesos más significativos de la dinámica en la que está inmerso. Dicha periodicidad no tiene por qué ser diaria, puede ser válido con realizarlo un par de veces por semana (Zabalza, 2004). El diario resulta muy útil para identificar los componentes más relevantes de la dinámica de la clase, analizarlos y, en caso necesario, plantear mejoras, pero no es un simple instrumento descriptivo, sino que constituye un conjunto de reflexiones y deliberaciones críticas que forman parte de un auténtico proceso de investigación, contribuyendo a compensar desequilibrios e introducir cambios.

Por todo ello, Torres (1986) considera que el diario no es solo un elemento primordial para conocer lo que sucede en las aulas, sino que también es un instrumento adecuado para la investigación del propio profesor. En su misma línea, Latorre (1996) defiende que:

El diario docente es un instrumento de formación que facilita la implicación y desarrolla la introspección, y es una herramienta de investigación, puesto que desarrolla la observación y la auto-observación, posibilitando registros de diferente naturaleza. (p. 9) 
Los diversos tipos de registros de los que se nutre el diario son, entre otros, los siguientes:

- Descriptivos: Anotaciones que nos ofrecen una perspectiva global de lo que está sucediendo, adentrándonos en el ambiente propio del aula y de lo que en ella acontece. Es un ejercicio de observación.

- Analíticos: Anotaciones en las que intentamos comprender la situación, encontrar un sentido a las acciones y reflexionar sobre las mismas. Es un ejercicio de comprensión, de análisis de la situación del aula.

- Críticos: Reflexionamos sobre el ideal y lo que está sucediendo en el aula. Es un acto de valoración que nos lleva a emprender cambios y revisar nuestras acciones.

- Expresivos: En el diario plasmamos nuestro sentir, se esclarecen los sentimientos, intereses, expectativas y motivaciones en torno a la educación. A través de una estructura dialógica nos planteamos interrogantes para avanzar: ¿Qué puedo hacer para mejorar? ¿Me siento satisfecho con los resultados? ¿Lo que hago es coherente con mi modelo pedagógico? ¿Me gustaría que fuese de otra manera?

- Práctico-organizativos: Nos ayudan en la toma de decisiones para afrontar nuevas acciones que afecten a la organización y al desarrollo curricular en la práctica.

Centrándonos de forma específica en el diario utilizado en esta tesis, cabe señalar que fue escrito durante los meses lectivos correspondientes al curso académico 2012-2013 (de septiembre de 2012 a junio de 2013), que es cuando tuvo lugar el trabajo de campo de la investigación. Para ello, en el aula tenía un cuaderno donde iba anotando de forma muy escueta los aspectos más relevantes que acontecían en las distintas clases, aprovechando los cambios entre un grupo y otro. Al finalizar la jornada laboral, antes de abandonar el centro de trabajo, completaba las anotaciones para ser más fiel a lo ocurrido sin perder detalles importantes. Todos los aspectos recogidos a lo largo de cada semana los aglutinaba y organizaba, de tal manera que el diario presenta una estructuración semanal.

En cuanto a los contenidos recogidos en el mismo, podemos afirmar que todos los tipos de registros señalados anteriormente confluyen en nuestro diario de forma interrelacionada, mostrando la riqueza del aula y favoreciendo su posterior interpretación. Fundamentalmente, encontramos contenidos que hacen referencia a aspectos curriculares: cómo dar clase, la forma de trabajar los contenidos, cómo respondían los alumnos a las 
distintas actividades propuestas, las dificultades que surgían, cómo potenciar su creatividad, hábito de estudio, progresión en los aprendizajes, etc., pero también tenían cabida otros aspectos más emocionales y relacionales: mis preocupaciones, reflexiones personales sobre lo observado, la evolución en las relaciones establecidas entre la profesora, los alumnos, los compañeros y los padres, comentarios o situaciones surgidas con distintos miembros de la comunidad educativa, la motivación hacia los aprendizajes, la colaboración dentro del grupo o cambios actitudinales producidos en los alumnos.

Por tanto, como puede apreciarse, el diario ha sido un instrumento muy vivo que se ha utilizado de manera flexible y abierta, adaptándose a las necesidades e inquietudes que iban surgiendo a lo largo del curso.

\subsection{Entrevistas}

La entrevista es una de las principales técnicas para la recogida de datos en la investigación cualitativa. La entrevista cualitativa consiste en una conversación intencionada entre, al menos, dos personas, en la cual una de las partes actúa como receptora (el entrevistador) y la otra como suministradora de información (los entrevistados), permitiendo recoger una gran cantidad y variedad de datos de una manera cercana y directa (Galindo, 1998). Estas personas dialogan con arreglo a ciertos esquemas o pautas acerca de cuestiones determinadas por los objetivos de la investigación, por lo que la entrevista posee un propósito profesional. En este sentido, Sierra (1998) destaca que:

Se trata de una conversación con un alto grado de institucionalización y artificiosidad, debido a que su fin o intencionalidad planeada determina el curso de la interacción en términos de un objetivo externamente prefijado. No obstante, al permitir la expansión narrativa de los sujetos, se desenvuelve como una conversación cotidiana. (p. 297)

La entrevista proporciona un acceso único al mundo vivido de las personas, que describen en sus propias palabras sus actividades, experiencias y opiniones. Su utilización en esta tesis viene justificada porque pretendíamos conocer la realidad desde la perspectiva de los propios sujetos, concediéndoles el protagonismo de la investigación. Al respecto, Del Rincón et al. (1995) señalan lo siguiente:

Las entrevistas constituyen una fuente de significado y complemento para el proceso de observación. Gracias a la entrevista podemos describir e interpretar aspectos de la realidad que no son directamente observables: sentimientos, impresiones, emociones, intenciones o pensamientos, así como acontecimientos que ya ocurrieron con anterioridad. (p. 334) 
Las entrevistas pueden presentar diversas formas. Se optó por la modalidad semiestructurada, ya que pretendíamos minimizar la variedad de información aportada por cada entrevistado y facilitar el posterior análisis de datos, y semidirigida, que permite una cierta sistematización en la información que la hace comparable y favorece su comprensión, pero, a su vez, admite informaciones fuera de las preguntas que pueden provocar nuevos interrogantes.

Asimismo, al realizar las entrevistas fuimos muy cuidadosos en crear un clima agradable y neutral, para que las personas entrevistadas estuvieran cómodas y contestaran a las preguntas con sinceridad, sin sentir presión por ningún tipo de juicio. Existe consenso entre Gurdián (2010), Hernández, Fernández y Baptista (2006) y Lucca y Berríos (2003) al realizar las siguientes recomendaciones a los entrevistadores: ayudar a que la persona entrevistada se sienta segura y tranquila, utilizar preguntas fáciles de comprender y no embarazosas, escuchar con paciencia dejándola concluir su relato, saber respetar las pausas y los silencios del entrevistado, evitar los roles de autoridad, no dar consejos ni valoraciones, ser empáticos, no discutir ni rebatir a la persona entrevistada, demostrar al entrevistado la legitimidad, seriedad e importancia de la entrevista, ser comprensivo y buscar que las respuestas a las preguntas abarquen los propósitos de la investigación.

Todas las entrevistas se grabaron en audio y, además, las entrevistas grupales se grabaron en video, siempre con el consentimiento de las personas entrevistadas, para poder estar más atentos durante su desarrollo y recoger fielmente todas las aportaciones. Posteriormente, se transcribieron y se ofrecieron a los entrevistados para garantizar su fidelidad y facilitarles la propuesta de enmiendas o aclaraciones, aunque ninguno optó por hacerlo.

La realización de entrevistas ha tenido lugar en varios momentos de nuestra investigación, buscando distintos propósitos:

- Al principio de la investigación, para indagar y obtener datos que nos ayudaran a centrar el problema planteado.

- A mitad de la investigación, para comprender la evolución de nuestras propuestas e introducir los cambios necesarios en la metodología que estábamos aplicando.

- Al final de la investigación, para profundizar en los datos recogidos a través de las demás técnicas (triangulación) y clarificar las contradicciones que han ido apareciendo a lo largo del estudio. 
A continuación, explicaremos con más detalle la planificación y el desarrollo de cada una de ellas.

\subsubsection{Entrevistas individuales}

Las entrevistas individuales son aquellas en las que se dedica una sesión para entrevistar a una sola persona. Realizamos un total de 15 entrevistas individuales dirigidas a distintos sujetos relevantes para recoger información relativa a los objetivos de la investigación.

En todas ellas, "el entrevistador guía hábilmente la conversación, pero estimula al entrevistado a hablar libre y largamente sobre temas pertinentes" (Fear, 1979, p. 31). De esta forma, el entrevistador mantenía el control, pero la información se obtenía de manera no directiva, y solo intervino para conseguir una mayor precisión o especificación en la misma.

\subsubsection{Entrevistas a expertos}

Uno de los puntos de partida de nuestro trabajo fue la realización de entrevistas a expertos. Las entrevistas, cuando se utilizan al principio de un estudio, nos ayudan a tomar decisiones sobre aspectos centrales del problema a investigar y nos guían en la selección de escenarios y en la recogida de documentos antes de entrar en el campo de estudio. La finalidad de las mismas es recoger datos generales a partir de personas que tienen información sobre el problema, por lo que se trata de conversaciones del investigador con una serie de informantes seleccionados con anterioridad por su conocimiento del tema.

En el trabajo que presentamos, seleccionamos a tres expertos que reunieran las siguientes características:

- Que fueran personas destacadas en el campo de la pedagogía musical, en general, y que mostraran preocupación por la educación auditiva, en particular.

- Que conocieran la forma en que se trabaja la educación auditiva en los conservatorios de nuestro país.

- Que tuvieran publicaciones y hubieran elaborado material didáctico específico para el trabajo de la educación auditiva y que dichos materiales se estuvieran utilizando en la asignatura de Lenguaje Musical impartida en los conservatorios españoles.

Los expertos entrevistados fueron los siguientes: 
- D. Emilio Molina, Ex-Catedrático de Repentización, Transposición Instrumental y Acompañamiento del Real Conservatorio Superior de Música de Madrid, concertista especializado en el conciertoimprovisación al piano, compositor, pedagogo pionero e investigador especializado en la introducción de la improvisación y el desarrollo de la creatividad en la enseñanza de las distintas especialidades musicales, y creador del Instituto de Educación Musical que lleva su nombre.

- Dña. Berenice Gómez Briones, profesora de Lenguaje Musical que actualmente desempeña su labor docente en el Conservatorio Profesional de Música de Torrelavega (Cantabria) y creadora, junto con otras dos autoras, de un nuevo e integrador método para la enseñanza y el aprendizaje del Lenguaje Musical titulado Cantabile.

- Dña. Encarnación López de Arenosa, Ex-Catedrática numeraria de Solfeo y Teoría de la Música del Real Conservatorio Superior de Música de Madrid, especializada en la Didáctica de la Música y, de forma más específica, en el Lenguaje Musical, con múltiples publicaciones de artículos, trabajos de investigación y libros para la educación auditiva, vocal y rítmica, entre otros.

En estas entrevistas buscábamos fundamentalmente adquirir un conocimiento más profundo sobre la importancia concedida a la educación auditiva en los conservatorios españoles, las dificultades que manifiestan los alumnos y los métodos que se utilizan para trabajarla desde la asignatura de Lenguaje Musical, con el fin de obtener información que nos ayudara a plantear nuestra nueva propuesta metodológica. Para ello, organizamos un pequeño guión con los bloques que queríamos abordar, pero los tratamos de una forma muy flexible y abierta, adaptándonos a las respuestas que iba ofreciendo cada informante:

a). Importancia concedida al bloque auditivo dentro de la asignatura de Lenguaje Musical

b). Metodología

c). Dificultades vocales y auditivas apreciadas en sus alumnos

d). Conocimiento de otras metodologías

e). Importancia concedida al entrenamiento auditivo en otras asignaturas de las enseñanzas de música

f). Otros aspectos 
Cabe señalar que, por limitaciones de tiempo, la experta número dos prefirió responder a las preguntas por escrito y mandárselas a la investigadora por correo electrónico, por lo que no tenemos una grabación en audio de dicha entrevista.

\subsubsection{Entrevistas a padres y profesores-tutores}

A mediados del curso académico, en el mes de febrero, consideramos que, aparte de los datos que iban aportando las anotaciones recogidas en el diario de la profesora, los trabajos y exámenes realizados por los alumnos hasta ese momento y los correos electrónicos intercambiados entre la profesora, los alumnos y sus padres, resultaba conveniente analizar con más profundidad cómo se estaba desarrollando el mismo, por si había que hacer alguna modificación en la metodología que estábamos empleando. Para ello, decidimos realizar entrevistas individuales a padres y profesores de instrumento que fueran tutores de los alumnos con los que se estaba realizando el estudio, entre los cuales estimamos conveniente que estuviera también algún miembro del equipo directivo. Por su parte, para recoger las opiniones de los alumnos optamos por utilizar unos cuestionarios abiertos y anónimos que describiremos más adelante.

En la selección de los padres y profesores entrevistados buscamos utilizar una muestra representativa que nos ofreciera una visión global desde distintos puntos de vista.

En este sentido, para la selección de los padres seguimos tres criterios:

- Seleccionar una familia de cada grupo de alumnos, es decir, cuatro de primero y tres de segundo (siete en total).

- Que hubiera tanto padres como madres.

- Que hubiera familias tanto de alumnos que tuvieran dificultades como de alumnos que fueran bien o muy bien.

En cuanto a la selección de los profesores de instrumento, nos basamos también en tres criterios:

- Que impartieran clase a mis alumnos de primero o de segundo y que conocieran el sistema de trabajo que estaba llevando a cabo con ellos.

- Que fueran representativos de las tres familias instrumentales (viento, cuerda y percusión) y de los dos instrumentos que tienen más demanda en el conservatorio, que son piano y guitarra (cinco profesores en total). 
- Que hubiera algún miembro del equipo directivo, ya que así podría ofrecernos una visión más general de su percepción y de los comentarios que le hubieran llegado a nivel de centro.

Para contactar con los padres utilizamos el correo electrónico y todos mostraron interés por colaborar en el estudio. La forma de contactar con los compañeros fue más directa, ya que la profesora-investigadora habló personalmente con ellos, y mostraron igualmente buena predisposición.

Las entrevistas tuvieron lugar en distintos espacios: aulas del conservatorio, despachos y cafeterías. En todas ellas, la investigadora planteó una serie de cuestiones (figuras 46 y 47) partiendo de los interrogantes aparecidos en el análisis de los demás datos. No obstante, las entrevistas estaban abiertas a otras aportaciones no determinadas previamente y las respuestas dadas por las personas entrevistadas provocaban nuevas preguntas por parte de la investigadora para clarificar los temas tratados.

\section{GUIÓN DE LA ENTREVISTA INDIVIDUAL A PADRES}

Buenas tardes y muchas gracias por venir. El motivo de esta reunión es comentar cómo percibes que está yendo el desarrollo del curso para valorar mejor el proceso de enseñanza-aprendizaje que estamos llevando a cabo, por si es necesario reconducirlo o introducir modificaciones.

1. En general, ¿piensas que tu hijo viene contento a clase de Lenguaje Musical?

2. El Lenguaje Musical consta de tres bloques: el ritmo, la teoría y el bloque auditivo, que incluye la entonación y el dictado. ¿Quieres comentar algo acerca de alguno de ellos?

3. ¿Estuviste en la audición que hicimos de Lenguaje Musical? ¿Eras consciente de que realizábamos en clase este tipo de actividades?

4. ¿Has visto la exposición que hemos hecho por los pasillos? ¿Comenta algo tu hijo/a sobre el trabajo que hacemos en clase con los refranes, o sobre la transcripción de canciones que aprendemos en clase?

5. ¿Qué opinas sobre las canciones que componen con el ordenador y que luego cantan de memoria delante de sus compañeros, con la posibilidad de enriquecer la puesta en escena con dibujos, carteles, disfraces?

6. ¿Cuando tu hijo estudia o tiene que realizar las tareas de Lenguaje Musical, se queja o encuentra dificultades?

7. En general, ¿cómo valoras el aprendizaje que está realizando tu hijo?

8. ¿Hay alguna cosa más que tu hijo comente acerca de la asignatura o que quieras añadir?

Muchas gracias por tu colaboración

Figura 46. Guión de la entrevista individual a padres 


\section{GUIÓN DE LA ENTREVISTA A PROFESORES DE INSTRUMENTO CON LOS QUE COMPARTO ALUMNOS}

Buenas tardes y muchas gracias por venir. El motivo de esta reunión es comentar cómo percibes que está yendo el desarrollo del curso para valorar mejor el proceso de enseñanza-aprendizaje que estamos llevando a cabo, por si es necesario reconducirlo o introducir modificaciones.

1. En general, ¿piensas que tus alumnos vienen contentos a clase de Lenguaje Musical?

2. Como sabes, la asignatura de Lenguaje Musical se divide en tres apartados: el ritmo, la teoría y el bloque auditivo, ¿consideras que todos son igual de importantes? ¿Debería emplearse el mismo tiempo de trabajo para cada uno de ellos?

3. Teniendo en cuenta el curso en el que se encuentran tus alumnos de $1^{\circ}$ y $2^{\circ}$ de las enseñanzas elementales, ¿hay algún aspecto que consideres que esté poco trabajado o en el que haya que incidir más desde la clase de Lenguaje Musical?

4. ¿Los padres o los alumnos te han hecho algún comentario acerca de la asignatura?

5. ¿Consideras que tus alumnos han adquirido un buen hábito de estudio?

6. En la exposición que hemos puesto por los pasillos se muestran algunos de los trabajos realizados por los niños. ¿Qué opinas del trabajo que hacemos con los refranes adivinando su ritmo e inventando nuevas letras?

7. También hemos expuesto canciones que han cantado, analizado y transcrito los niños en clase, así como otras que han creado ellos mismos, basándose en los acordes tonales básicos y ciertos aspectos formales ¿Qué opinas al respecto?

8. ¿Hay alguna cosa más que quieras comentar acerca de la asignatura?

Muchas gracias por tu colaboración

Figura 47. Guión de la entrevista individual a profesores-tutores

En todo momento, la profesora-investigadora intentó hablar lo justo y no hacer ningún comentario ante las palabras de los entrevistados para no condicionarles y dejar que se expresaran con total libertad. Todas las entrevistas se desarrollaron de forma adecuada con un clima de naturalidad, respeto y confianza.

\subsubsection{Entrevistas grupales a padres y alumnos}

En toda investigación educativa es necesario hacer una valoración final que nos permita extraer conclusiones de los resultados obtenidos. Por ello, consideramos necesario realizar nuevas entrevistas a los alumnos y a los padres para que nos proporcionaran información sobre cómo había sido el curso, una vez finalizado el mismo, es decir, en el mes de junio. No consideramos necesario realizar nuevas entrevistas a los profesores de 
instrumento, ya que la información proporcionada por los mismos en el mes de febrero era suficientemente relevante y clarificadora.

En esta ocasión, decidimos que las entrevistas serían grupales, para tener una perspectiva más global y comprobar en qué aspectos se ponían de acuerdo y en cuáles se corregían entre ellos. De esta manera, buscábamos clarificar lagunas que requerían una mayor profundización para comprender cierto tipo de acciones y algunas contradicciones surgidas en la información recogida por otras fuentes (entrevistas anteriores, documentos, cuestionarios, etc.), que pudieran haber creado problemas de relación si los hubiéramos tratado de esclarecer durante el curso. Así pues, hemos utilizado las entrevistas grupales para recoger información más delicada, pero que resultaba necesaria para la investigación.

En la entrevista grupal, uno o varios entrevistadores reúnen a varios entrevistados para que hablen de sus percepciones, experiencias y vivencias. Como acabamos de justificar, no es una entrevista alternativa a la individual, sino una modalidad de entrevista que aporta una información distinta a la que se obtiene en la entrevista individual.

Se suelen abordar cuestiones abiertas sobre uno o varios temas previamente elegidos. La guía de la entrevista que utiliza el investigador sirve para tener en cuenta todos los temas que son relevantes y, por tanto, sobre los que se quiere indagar, aunque no es necesario mantener un orden en su desarrollo. En nuestro estudio, elaboramos un guión (tabla 12) que agrupaba por temas los aspectos fundamentales de los que queríamos obtener información e indicamos la pregunta con la que podía iniciarse cada uno de ellos, así como otras posibles cuestiones que nos podían servir para una mayor profundización. 


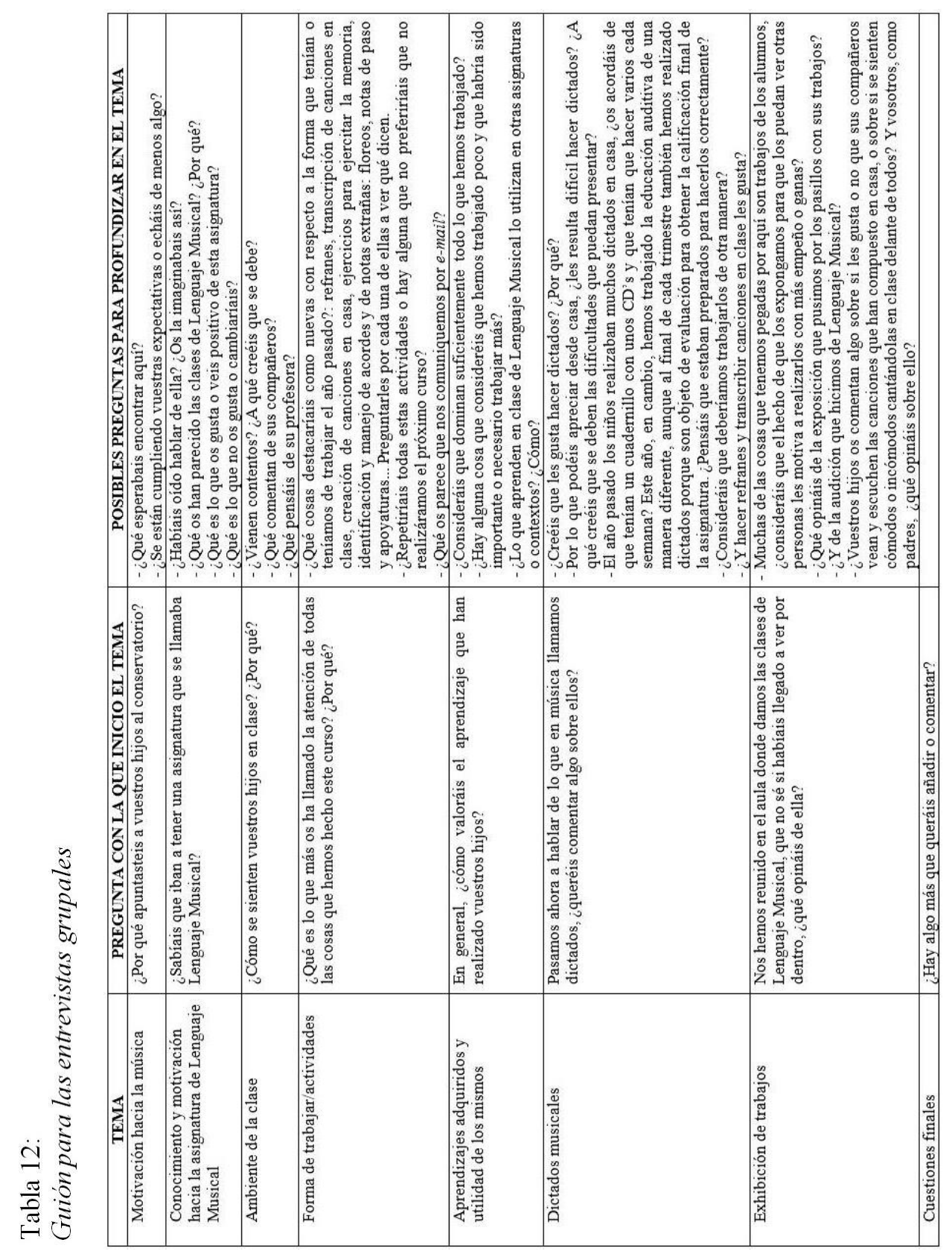


Desde el punto de vista metodológico, todas las entrevistas realizadas se fundamentaban "en la producción de un discurso continuo dotado de una cierta línea argumental, aunque esencialmente fragmentario" (Sierra, 1998, p. 311), es decir, se fueron adecuando a las respuestas que iban proporcionando los sujetos entrevistados.

El número de entrevistas realizadas fue nueve en total: dos entrevistas grupales a los padres (una para padres de los alumnos de primero y otra para los de segundo) y siete entrevistas grupales a los alumnos (una por cada grupo, cuatro de primero y tres de segundo, abarcando la totalidad del alumnado). Para conseguir una muestra significativa, los criterios de selección de los padres fueron los mismos que los utilizados en las entrevistas de febrero, siendo un total de seis padres de primero y siete de segundo. La vía para ponerme en contacto con ellos y solicitar su colaboración fue, igualmente, el correo electrónico y todos mostraron buena disposición.

La investigadora era la encargada de dirigir la interacción del grupo, creando un clima de confianza, dejando que los entrevistados se expresaran libremente $\mathrm{y}$, cuando se desviaban mucho de los objetivos de la investigación, reorientando la entrevista con pericia. Todas se desarrollaron de forma adecuada.

\subsection{Cuestionarios}

El cuestionario consiste en un conjunto de preguntas, preparadas sistemática $\mathrm{y}$ cuidadosamente, sobre los hechos y aspectos que interesan en una investigación, y puede ser aplicado en formas variadas, entre las que destacan dos: su administración a grupos estando presente el responsable de recoger la información o su envío por correo (Pérez Juste, 1991).

El empleo del cuestionario como técnica de recogida de datos suele asociarse a enfoques y diseños de investigación cuantitativos. No obstante, también puede prestar un importante servicio en la investigación cualitativa, permitiendo el acceso a una población amplia, e incluso dispersa, de una manera rápida y económica.

La principal diferencia con la entrevista reside en la poca relación directa que existe entre los sujetos y la persona que los aplica, ya que esta última se limita a presentarlo al grupo, a dar ciertas normas generales y a crear un clima que disponga favorablemente a la contestación sincera. Cuando se envía por correo, la relación se limita a una carta de presentación solicitando su cumplimentación e indicando la importancia y utilidad de los datos recogidos. 
Fox (1981) señala que, al utilizar esta técnica, el investigador tiene que considerar dos caminos metodológicos generales: estar plenamente convencido de que las preguntas se pueden formular con la claridad suficiente para que funcionen en la interacción personal que supone el cuestionario y dar todos los pasos posibles para maximizar la probabilidad de que el sujeto conteste y devuelva las preguntas.

Las etapas básicas que suelen seguirse en la preparación y validación un cuestionario son las siguientes (Marín Ibáñez, 1985):

- Determinar con precisión qué tipo de información necesitamos.

- Seleccionar los aspectos más relevantes para obtenerla.

- Decidir la modalidad de cuestionario más adecuada.

- Efectuar una primera versión del cuestionario, cuidando la redacción de las preguntas y los aspectos formales. En este sentido, cabe destacar que el cuestionario debe llevar un título que aluda, en forma abreviada, al tema central sobre el que se busca información y que deben especificarse claramente las instrucciones para su correcta cumplimentación.

- Someter el cuestionario a crítica por algunos expertos.

- Ponerlo a prueba con un grupo experimental.

- Elaborar el cuestionario definitivo teniendo en cuenta las observaciones de los expertos y de la prueba piloto y establecer los procedimientos para su aplicación.

La elección de las preguntas está condicionada por diversos factores, tales como la naturaleza de la información que se desea obtener o el nivel sociocultural, las características, las costumbres y los hábitos de las personas a las que se va a preguntar, por lo que es evidente que no existen reglas generales útiles para todos los cuestionarios. No obstante, siguiendo a Pérez Juste (1991), entre los principios a tener en cuenta al formular los ítems destacamos los siguientes:

a). No se debe recoger más información que la necesaria para el problema que se investiga, es decir, ha de haber una relación clara entre cada ítem y el problema a evaluar.

b). Cada cuestión debe incluir únicamente un aspecto, para no inducir a equívocos. 
c). Las cuestiones se han de redactar de forma clara, comprensible, precisa e inequívoca, utilizando un lenguaje sencillo, frases de estructura elemental y expresión clara.

d). Los ítems que impliquen determinados conocimientos técnicos deben ir precedidos de otros que permitan establecer si se poseen o no; así se evitará que los sujetos contesten al azar dando la impresión de que los conocen. Conviene, en estos casos, comenzar el ítem ofreciendo la información necesaria sobre tales conocimientos.

e). Las cuestiones que conlleven "deseabilidad social" deben hacerse de manera que posibiliten recoger la respuesta sincera, evitando preguntas directas que impliquen juicios de valor.

Según el modo en que se formulen, las preguntas pueden ser cerradas y abiertas.

- Las preguntas cerradas son aquellas que permiten a la persona que elija una o varias respuestas de una lista de opciones, poniendo una señal convenida: una cruz, rodear con un círculo, subrayar..., entre las que se suele incluir la posibilidad de responder no sé/sin opinión.

- Las preguntas abiertas no ofrecen ningún tipo de respuesta predefinida, dejando esta a la consideración del sujeto que completa el cuestionario, quien la expresará con sus propias palabras.

Normalmente es la clase de contenido y la tipología de sujetos quien impone el tipo de preguntas a incluir (Pérez Juste, 1991). Al respecto, Selltiz et al. (1976) señalan que:

Las preguntas cerradas o categorizadas son más eficaces donde las posibles respuestas alternativas son conocidas, limitadas en número y claramente definidas. [...] Las preguntas abiertas son adecuadas cuando el tema es complejo, cuando las dimensiones relevantes no son conocidas o cuando el interés de la investigación reside en la exploración de un proceso o en la formulación de un asunto. (p. 101)

En cuanto al número de ítems que debe contener un cuestionario, Hernández, Fernández y Baptista (2006) indican que es "recomendable hacer solamente las preguntas necesarias para obtener la información deseada o medir la variable" (p. 282) y que "si es muy corto se pierde información, pero si resulta largo puede resultar tedioso" (p. 289). De forma general, suele recomendarse que sea inferior a treinta, pero dependerá del tipo de cuestionario y de sus destinatarios. 
Para conseguir la máxima sinceridad en las respuestas, se plantean dos soluciones: garantizar el completo anonimato de los participantes o lograr una situación de total confianza entre la persona o institución que pretende aplicar el cuestionario y los sujetos que lo responden.

\subsubsection{Cuestionarios cerrados sobre motivación y dificultades en Lenguaje Musical}

Al principio de nuestra investigación, realizamos unos cuestionarios con el propósito de conocer la motivación de los alumnos hacia la asignatura de Lenguaje Musical, tal y como se imparte en los conservatorios de nuestro país, y las dificultades que encuentran en los distintos contenidos que se trabajan en la misma. Asimismo, desde un punto de vista pedagógico, nos interesaba identificar las causas de dichas dificultades para, posteriormente, planificar una adecuada intervención educativa que les ayudara a superarlas.

A continuación, describiremos cuál ha sido su proceso de elaboración y validación hasta obtener la versión definitiva, así como el modo en que hemos llevado a cabo su difusión y aplicación.

\subsubsection{Elaboración y validación del cuestionario}

La elaboración del cuestionario implicó, en primer lugar, diseñar un conjunto de preguntas y posibles respuestas que permitieran concretar las ideas, creencias o supuestos de los encuestados en relación con el objeto de estudio, priorizando dos aspectos:

- Relevancia de los ítems, formulando únicamente aquellos que respondían de forma directa a nuestros intereses, ya que buscábamos que fueran reducidos en número y evitar, de esta forma, la imagen de pesadez.

- Claridad y sencillez en la formulación de las preguntas y las respuestas, para facilitar su comprensión y que pudieran cumplimentarlos sin dificultad incluso los alumnos del primer curso.

A continuación, presentamos el cuestionario a dos expertos, que en nuestro caso fueron los tutores de la tesis, para que emitieran un juicio crítico sobre el mismo basándose en los siguientes aspectos:

- Adecuación de las preguntas a los objetivos marcados.

- Estructura general equilibrada y armónica.

- Falta de ninguna pregunta o elemento clave. 
- Longitud adecuada.

- Lenguaje sencillo y pautas claras.

- Comprobación de cada ítem por separado.

Tuvimos que realizar varios borradores hasta obtener una versión provisional del cuestionario, el cual aplicamos a un grupo reducido (piloto) de características semejantes a las personas a las que se iba a encuestar posteriormente, constituido por doce alumnos de distintos cursos de Lenguaje Musical del conservatorio de Segovia (dos por cada uno de los seis cursos en los que se imparte la asignatura), con objeto de comprobar la reactividad ante la prueba y subsanar todos los errores observables en la aplicación: facilidad, fatiga, dudas, incomprensión de instrucciones o de preguntas, etc.

A partir de los datos obtenidos en la aplicación a esta submuestra pequeña, optimizamos la redacción del cuestionario definitivo, quedando configurado tal y como describiremos en el próximo apartado.

\subsubsection{Descripción del cuestionario}

El cuestionario quedó constituido de la siguiente manera:

- Un encabezado con el sello de la institución desde la que se realiza el estudio: la Universidad de Valladolid.

- Un título que indica a quién va dirigido: "Cuestionario para alumnos de Lenguaje Musical".

- Nota de presentación donde se explica el objetivo que se persigue, se recogen las instrucciones generales para cumplimentarlo (en todas las preguntas se ofrecían varias opciones de respuesta para que rodearan aquella con la que estuviesen más de acuerdo, excepto en las cuatro últimas, donde se podían rodear hasta cuatro opciones e, incluso, ofrecer una respuesta propia) y se invita a responder con sinceridad garantizando el anonimato del mismo.

- Datos personales del alumno encuestado: edad, género, especialidad instrumental, curso de Lenguaje Musical que se está estudiando y provincia a la que pertenece el conservatorio. Cabe señalar que, aunque ninguna de estas informaciones ha sido utilizada como criterio discriminatorio al realizar el análisis de los datos de esta tesis, consideramos necesario recogerlas para poder utilizarlas en posteriores investigaciones. 
- Trece preguntas relacionadas con dos grandes bloques: motivaciones e intereses musicales de los alumnos (preguntas 1, 2, 3, 4, 7 y 8) y dificultades encontradas en la asignatura de Lenguaje Musical (preguntas 5, 6, 9, 10, 11, 12 y 13).

El tiempo estimado para responder el cuestionario era de 10 minutos.

\subsubsection{Difusión y aplicación del cuestionario}

Una vez elaborado el cuestionario, tuvo lugar su difusión. Para ello, contactamos vía telefónica y por e-mail con los directores de los conservatorios de ocho provincias españolas, utilizando una carta de presentación en la que explicábamos la finalidad de la investigación y la institución desde la cual se realizaba, al mismo tiempo que agradecíamos su colaboración. Una vez aceptada la propuesta de participación, se procedió al envío de los cuestionarios necesarios para cada centro utilizando el correo postal, incluyendo unos sobres franqueados con la dirección de retorno para su posterior reenvío al investigador, una vez cumplimentados.

La muestra invitada, es decir, el conjunto de personas a las que se les envió el cuestionario, estaba formada por estudiantes de los seis cursos de Lenguaje Musical de conservatorios pertenecientes a las provincias de: Ávila, Segovia, Zaragoza, Huesca, Cantabria, Córdoba, Madrid y Murcia. La selección de los conservatorios se realizó al azar, utilizando como criterio la facilidad para contactar con ellos, ya que conocíamos a músicos que trabajaban en dichos centros. Por tanto, el tipo de muestreo utilizado ha sido no probabilístico, al suponer un procedimiento de selección informal de la muestra, en función del investigador y, dentro de los no probabilísticos, es considerado de tipo casual, porque se utiliza como muestra a un grupo de individuos a los que se tiene facilidad de acceso.

La comunicación relativa a la correcta recepción de los cuestionarios por parte de los centros y a su posterior reenvío al equipo de investigación se mantuvo, igualmente, por teléfono y por $e$-mail. Este método se ha mostrado eficaz a la vista de los resultados obtenidos.

La muestra aceptante, es decir, el número de personas que respondieron a dicho cuestionario, fue de 1.635 alumnos. El índice de respuesta es considerado como muy generoso, ya que los cuestionarios recibidos representan más del $70 \%$ de los enviados.

El número concreto de cuestionarios recibidos de cada conservatorio aparece recogido en la tabla 13 . 
Tabla 13:

Cuestionarios recibidos de cada conservatorio

\begin{tabular}{cc}
\hline $\begin{array}{c}\text { Provincia a la que pertenece el } \\
\text { conservatorio }\end{array}$ & $\begin{array}{c}\text { Número de cuestionarios } \\
\text { recibidos }\end{array}$ \\
\hline Ávila & 236 \\
Segovia & 186 \\
Zaragoza & 246 \\
Huesca & 138 \\
Cantabria & 200 \\
Córdoba & 290 \\
Madrid & 112 \\
Murcia & 227 \\
\hline Total & 1.635
\end{tabular}

Al finalizar el curso académico, consideramos conveniente pasar también el cuestionario a los 79 alumnos de la profesora-investigadora con los que se había llevado a cabo el nuevo enfoque metodológico presentado en esta tesis, con el propósito de comparar si se apreciaban diferencias significativas en las respuestas ofrecidas respecto al alumnado de los demás conservatorios. En este caso, el índice de respuesta fue del 100\%.

Todos los cuestionarios recibidos están recogidos en el anexo VI de la tesis.

\subsubsection{Cuestionarios abiertos de autoevaluación sobre el desarrollo y aplicación de la nueva metodología}

Como hemos comentado con anterioridad, en el mes de febrero nos pareció pertinente realizar una revisión más profunda de la metodología que estábamos aplicando en el aula, preguntando a los alumnos su opinión sobre el desarrollo de las clases y los aprendizajes que estaban adquiriendo, y ofreciéndoles la posibilidad de responder utilizando sus propias palabras. Para ello, optamos por utilizar unos cuestionarios abiertos y anónimos, que les permitieran expresarse con mayor libertad.

Para Schuman y Presser (1981) las preguntas abiertas son esenciales para conocer el contexto del sujeto que contesta el cuestionario, especialmente cuando no se pueden presumir con antelación las posibles opiniones y reacciones de la población a la que va dirigida. 
Las preguntas abiertas son más fáciles de formular, puesto que no hay que prever ningún tipo de respuesta ni investigar acerca de la exhaustividad y exclusión de las categorías propuestas. Sin embargo, la dificultad aparece a la hora de tratar la información obtenida, ya que es muy difícil reducir contestaciones dispares a unas categorías significativas que permitan recoger la información más relevante.

En cualquier caso, nuestro interés radicaba en conseguir información de los propios alumnos que nos proporcionara una visión más completa del proceso educativo que estábamos desarrollando $\mathrm{y}$, para conseguirlo, al formular las preguntas cuidamos que fueran sencillas y fáciles de comprender, no embarazosas y que estuvieran redactadas de forma personal y directa.

El cuestionario constaba de 12 ítems breves dirigidos a conocer sus intereses, aprendizajes, grado de satisfacción, integración en el aula y dificultades, y de otra pregunta final en la que se brindaba a los alumnos la posibilidad de añadir algo más que no se les hubiese preguntado y les apeteciera comentar. Para su validación, lo sometimos al juicio crítico de los dos tutores de la tesis, que no consideraron necesaria la aplicación de una prueba piloto. Los alumnos cumplimentaron los cuestionarios durante una de sus clases de Lenguaje Musical (ver anexo VII), tardando alrededor de 15 minutos. La profesora-investigadora les motivó a ser sinceros y críticos, haciéndoles comprender la importancia de sus respuestas para poder mejorar.

\subsection{Análisis de documentos}

Entre las técnicas de análisis de la enseñanza, diversos autores reconocen la importancia del análisis de documentos para la recogida de datos cualitativos (Elliot, 1986 y 1987; Hopkins, 1987; Latorre \& González, 1987; Marcelo, 1987; Walker, 1985).

Tal y como señalan Goetz y LeCompte (1988), esto es debido a que "además de hablar e interactuar, los seres humanos fabrican y utilizan cosas" (p. 162) y "los artefactos resultantes constituyen datos que indican las sensaciones, experiencias y conocimiento de las personas, y también connotan opiniones, valores y sentimientos" (p. 163).

El análisis documental nos ha servido como punto de partida para sentar las bases de nuestro nuevo planteamiento metodológico en el aula $\mathrm{y}$, posteriormente, como procedimiento para contrastar y triangular las informaciones obtenidas a través de las demás técnicas de recogida de datos. A pesar de que, como veremos más adelante, tanto el análisis de los documentos oficiales que constituyen el marco legislativo de nuestras 
propuestas como el de distintas publicaciones didácticas para la enseñanza del Lenguaje Musical se realizó previamente a la intervención en el aula, la mayor parte de los documentos analizados se fueron recogiendo a lo largo del curso académico en paralelo a la elaboración del diario.

\subsubsection{Publicaciones didácticas para la enseñanza del Lenguaje Musical}

Uno de los puntos de partida de la tesis fue el análisis de distintos libros y materiales didácticos publicados en España para la enseñanza del Lenguaje Musical en los conservatorios y, de forma más específica, para el trabajo de la educación auditiva desde dicha asignatura. Asimismo, también analizamos algunos materiales franceses, ingleses, norteamericanos y alemanes destinados a la educación musical, para familiarizarnos con otras perspectivas didácticas.

Consideramos que realizar un muestreo de diversas publicaciones era muy necesario para conocer los planteamientos metodológicos subyacentes $\mathrm{y}$, de esta forma, poder hacer nuestra propia propuesta aprovechando los puntos fuertes y cubriendo las carencias apreciadas en las mismas.

\subsubsection{Documentos oficiales}

Toda propuesta educativa debe estar fundamentada en un marco legislativo que justifique su pertinencia. En este sentido, los documentos oficiales que nos han servido de referencia para realizar nuestro planteamiento metodológico han sido fundamentalmente los siguientes:

- Ley Orgánica 2/2006, de 3 de mayo, de Educación.

- Real Decreto 1577/2006, de 22 de diciembre, por el que se fijan los aspectos básicos del currículo de las enseñanzas profesionales de música reguladas por la Ley Orgánica 2/2006, de 3 de mayo, de Educación.

- Decreto 60/2007, de 7 de junio, por el que se establece el currículo de las enseñanzas elementales y profesionales de música en Castilla y León.

- Proyecto educativo del Conservatorio Profesional de Música de Segovia del curso 2012-2013.

- Programación didáctica de Lenguaje Musical del Conservatorio Profesional de Música de Segovia del curso 2012-2013. 
Todos estos documentos oficiales resultaban de gran interés y utilidad para la investigación, ya que nos permitían asegurarnos de que nuestros planteamientos tenían un respaldo legal.

\subsubsection{Correos electrónicos}

Los múltiples correos electrónicos intercambiados entre en la profesora, los alumnos, sus padres y algunos profesores durante todo el curso (anexo VIII) han sido muy útiles en este estudio, ya que nos han permitido verificar que la información recogida a través de otros instrumentos, especialmente la procedente del diario de la profesora-investigadora, había ocurrido realmente.

Para su selección hemos seguido un criterio de utilidad, en función de los objetivos perseguidos en la tesis.

\subsubsection{Trabajos y exámenes del alumnado}

A lo largo de todo el curso académico en el que tuvo lugar el trabajo de campo, llevamos a cabo una recopilación sistemática de distintos trabajos y exámenes de los alumnos. Previamente, realizamos una selección de las áreas y temas que queríamos que estuvieran representados en los mismos, en función de tres criterios:

1. Mostrar las innovaciones de la metodología que presentamos.

2. Conocer el nivel de asimilación de los nuevos contenidos trabajados por parte de los alumnos.

3. Comprobar la eficacia de la nueva metodología para resolver también tareas específicas de la enseñanza tradicional.

Para cubrir los dos primeros criterios, recogimos fichas de refranes, canciones transcritas de oído tomando como base los acordes tonales, canciones creadas a partir del análisis de las canciones anteriores, exámenes trimestrales de teoría musical y pruebas específicas para medir la memoria auditiva (a principio y a final de curso, para comprobar la evolución) de los 79 alumnos que constituyen la muestra de nuestro trabajo. Para poder valorar el tercer criterio, recogimos dictados musicales realizados por los alumnos al modo tradicional a final de cada trimestre (dos en el primero, dos en el segundo y uno en el tercero) y grabamos videos en los que se muestran sus interpretaciones de lectura rítmica y de lecciones de entonación. 
Todos estos documentos pueden consultarse en los anexos IX, X y XI de esta tesis $\mathrm{y}$, para poder utilizarlos, solicitamos previamente una autorización de las familias por escrito.

\subsubsection{Videos y fotografías}

Para facilitar la comprensión de las actividades realizadas y poder analizarlas mejor, hicimos varias fotos y videos que permitían visualizar tanto su desarrollo como su resultado final (anexos IX y XVII). Al igual que hicimos con los trabajos de los alumnos, solicitamos por escrito la autorización de los padres para poder realizarlos e incorporarlos a la tesis con este propósito.

\subsection{Temporalización para la recogida de datos}

El proceso de recogida de datos ha tenido lugar desde julio de 2012 hasta junio de 2013, de acuerdo con el cronograma que presentamos en la siguiente página.

Cabe destacar que los datos obtenidos durante los meses de julio, agosto y septiembre de 2012 a partir de entrevistas a expertos (pedagogos musicales de reconocido prestigio en España), cuestionarios dirigidos a alumnos de Lenguaje Musical de distintos conservatorios españoles, publicaciones didácticas utilizadas para la enseñanza del Lenguaje Musical y los documentos oficiales que han configurado nuestro marco legislativo fueron analizados durante estos mismos meses, ya que las conclusiones obtenidas a partir de dicho análisis resultaban fundamentales para poder plantear nuestro nuevo enfoque metodológico y ponerlo en práctica desde el inicio del curso académico. 


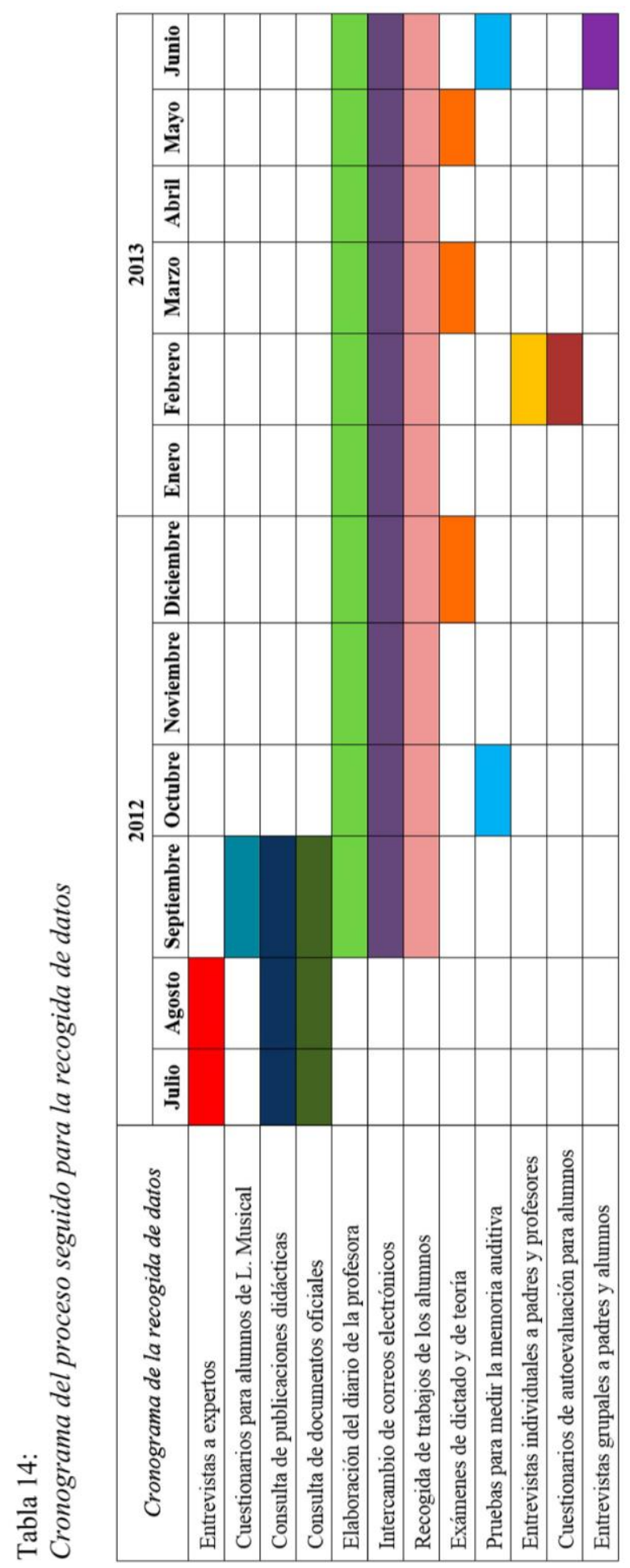




\section{Análisis de los datos}

Utilizando las palabras de Kerlinger (1982, p. 96), consideramos que "analizar significa establecer categorías, ordenar, manipular y resumir los datos", con el fin de obtener una visión lo más completa posible de la realidad objeto de estudio.

No obstante, el término análisis se mueve entre unos márgenes muy amplios, existiendo cierta ambigüedad al respecto. Así, en ocasiones es entendido como el proceso de codificar, de agrupar según significados, adquiriendo matices propios de tareas de procesamiento y organización de los datos y estando relativamente aislado del ejercicio de interpretación. En otros casos, es considerado exclusivamente como el trabajo imaginativo y creativo de interpretación, relegando las tareas de categorización, organización y clasificación de los datos a una fase preeliminar al análisis propiamente dicho. Nosotros nos inclinamos por adoptar una postura integradora, entendiendo que los trabajos de organización e interpretación de los datos están intrínsecamente relacionados y que se realizan de forma paralela, no teniendo sentido uno sin el otro (Coffey \& Atkinson, 2005; Miles \& Huberman, 1994).

El análisis de datos cualitativos no corresponde a una fase determinada de la investigación aislada en el tiempo, sino que es una actividad dinámica que se realiza a lo largo de todo el proceso de la misma (Hammersley \& Atkinson, 2001; Taylor \& Bogdan, 1986). Obviamente, las inferencias analíticas no son igual de profundas y ricas al comienzo del proceso que al final, sin embargo, todas ellas contribuyen al entendimiento del fenómeno de estudio. El proceso de análisis, por tanto, evoluciona en la medida en que lo hace el propio proceso de investigación, siendo más descriptivo y general al inicio y más focalizado e interpretativo en las fases más avanzadas (Field \& Morse, 1994).

El análisis es un proceso creativo y sagaz donde la sensibilidad del investigador toma especial importancia, entendiendo por sensibilidad la capacidad crítica y analítica de ver más allá de los datos, de identificar la esencia de los mismos (Hammersley \& Atkinson, 2001). En este sentido, Stake (1998, p. 68) señala que "en la búsqueda de significado hay mucho de arte y de proceso intuitivo". Esto es lo que permite hacer obvio lo invisible, ver más allá de los datos. Evidentemente, la capacidad interpretativa se adquiere con la experiencia y se ve influida por nuestras experiencias vitales, conocimientos previos, actitudes y aptitudes personales.

Asimismo, cabe destacar que el análisis constituye un proceso metódico, riguroso y cognitivamente complejo que implica la puesta en marcha de 
complicados procesos de comprensión, síntesis, teorización y recontextualización (Morse, 2005). Es decir, exige un conocimiento metodológico profundo a partir del cual el investigador puede trabajar su sensibilidad teórica y su creatividad desde la reflexividad y el rigor, garantizando la calidad interpretativa.

\subsection{El análisis de datos en la tesis}

El proceso de análisis que hemos llevado a cabo pone el acento en la construcción y generación inductiva de categorías para poder clasificar los datos recogidos, y en el posterior análisis cualitativo de la información asignada a cada una de ellas.

La utilización de diversas técnicas e instrumentos para la obtención de datos ha hecho necesario el empleo de distintos procedimientos para su análisis. A continuación, describiremos cómo hemos organizado y analizado los variados datos obtenidos.

\subsubsection{Organización de los datos procedentes de las distintas técnicas e instrumentos}

\section{- Diario, entrevistas y correos electrónicos}

El diario de la profesora-investigadora, las entrevistas (que fueron transcritas en papel) y los correos electrónicos constituían documentos escritos que recogían discursos verbales de considerable extensión.

A partir de los mismos intentamos analizar, de forma sistemática, la naturaleza del discurso con la finalidad de contestar a los objetivos que nos habíamos propuesto en esta investigación. En este sentido, seguimos a Fox (1981) al afirmar que estábamos ante un procedimiento para la categorización de datos verbales y de conducta con fines de clasificación, resumen y tabulación. Dicho autor señala que:

Es un proceso complejo, seguramente el que más esfuerzo requiere de todas las técnicas de análisis de datos. Es uno de los pocos campos comprendidos en las etapas finales del proceso de investigación en el que el investigador desempeña un papel importante, original y creativo. (p. 709)

Con tal fin, establecimos las categorías que presentaremos más adelante (apartado 5.1.2.) y fuimos asignando los datos recogidos a cada una de ellas. Ante el gran volumen de documentos y de información que estábamos manejando, consideramos conveniente el uso de un soporte informático que facilitara su codificación. Para ello, nos decantamos por utilizar el programa 
Atlas-ti (versión 6.2), diseñado específicamente para el análisis de datos cualitativos.

\section{- Cuestionarios}

- Cuestionarios cerrados de Lenguaje Musical: En general, los datos obtenidos a través de cuestionarios cerrados son fácilmente analizables e interpretables, más que los procedentes de respuestas orales $\mathrm{y}$, por ende, abiertas. El análisis de los datos se ha llevado a cabo mediante el registro de las respuestas ofrecidas en cada ítem con el programa informático Excel y la elaboración de unas gráficas con dichos resultados (anexo VI), los cuales hemos interpretado después de forma cualitativa.

- Cuestionarios abiertos de autoevaluación: El análisis de cuestionarios abiertos es más complejo que el que se realiza a partir de cuestionarios cerrados, ya que la categorización de las respuestas siempre tiene un riesgo de deformación. En este sentido, resulta interesante la aportación de Hernández, Fernández y Baptista (2006), que proponen un método concreto de codificación de las preguntas abiertas. Los cuestionarios eran anónimos, pero sí realizamos una agrupación de los mismos diferenciando los cursos y los grupos a los que pertenecían los alumnos, por si resultaba interesante utilizar estos criterios para profundizar en un estudio posterior. Para el análisis de estos cuestionarios no utilizamos ningún soporte informático, sino que hicimos una selección de las respuestas que consideramos más relevantes en relación a los objetivos de la investigación y las asignamos a las categorías establecidas en el apartado 5.1.2.

\section{- Documentos oficiales}

Todos los documentos oficiales que configuraban el marco legislativo de nuestra propuesta de trabajo en el aula se analizaron sin la ayuda de ningún programa informático, prestando especial atención a los objetivos, contenidos y criterios de evaluación recogidos en los mismos.

\section{- Publicaciones didácticas de Lenguaje Musical}

En el análisis de los libros y materiales didácticos para la enseñanza del Lenguaje Musical que consultamos como punto de partida y a partir de los cuales realizamos nuestro propio planteamiento metodológico hemos tenido en cuenta tres aspectos: enfoque metodológico, estrategias utilizadas y proyección/evolución a lo largo de los seis cursos de la asignatura, ya que 
nos interesaba mucho conocer hacia donde conducían las distintas propuestas y los pasos que iban dando para conseguirlo. En este caso, tampoco fue necesaria la utilización de un software específico.

\section{- Prueba de memoria auditiva}

La prueba de memoria auditiva que pasamos a los alumnos a principio y a final de curso para comprobar si se había producido mejoría, cuyos ejercicios específicos se encuentran recogidos en el anexo XI, consistía en la memorización de secuencias rítmicas, sonidos y secuencias rítmicomelódicas y en su posterior reconocimiento al escucharlas mezcladas con otras de características similares. La función de los alumnos consistía en rodear aquellos números en los que se escuchaba el sonido o la secuencia que habían memorizado, utilizando la siguiente plantilla.

\section{EJERCICIOS DE MEMORIA AUDITIVA (1 ${ }^{\circ}$ Lenguaje Musical)}

Vas a escuchar dos veces un ritmo, un sonido o una secuencia rítmico-melódica. Deberás memorizarlo porque, a continuación, los escucharás mezclados junto con otros de características similares. Rodea aquellos números en los que se escuche el sonido o la secuencia que has memorizado.

\begin{tabular}{|llllll|lllllll|}
\hline \multicolumn{11}{|c|}{ SECUENCIAS RITMICAS } \\
\hline 1 & 2 & 3 & 4 & 5 & 6 & 6 & $(1)$ & 2 & 3 & 4 & 5 & 6 \\
\hline 1 & 2 & 3 & 4 & 5 & 6 & 1 & 2 & 3 & 4 & 5 & 6 \\
\hline
\end{tabular}

\begin{tabular}{|llllll|lllllll|}
\hline \multicolumn{11}{|c|}{ SONIDOS } \\
\hline 1 & 2 & 3 & 4 & 5 & 6 & 1 & 2 & 3 & 4 & 5 & 6 \\
\hline 1 & 2 & 3 & 4 & 5 & 6 & 1 & 2 & 3 & 4 & 8 & 6 \\
\hline
\end{tabular}

\begin{tabular}{|llllll|lllllll|}
\hline \multicolumn{11}{|c|}{ SECUENCIAS RITMICO-MELÓdICAS } \\
\hline 1 & 2 & 3 & 4 & 5 & 6 & B. & 1 & 2 & 3 & 4 & 5 & 6 \\
\hline (2) & 2 & 3 & 4 & 5 & 6 & 1 & 2 & 3 & 4 & 5 & 6 \\
\hline
\end{tabular}

Figura 48. Plantilla con las respuestas ofrecidas por un alumno en la prueba de memoria auditiva 
Dicha plantilla era igual tanto para los alumnos de primero como para los de segundo, pero las secuencias y los sonidos a memorizar eran diferentes, siendo de mayor dificultad para los alumnos del curso superior.

Para el análisis de los resultados obtenidos realizamos un recuento de las respuestas ofrecidas en cada una de las preguntas que configuraban la prueba: secuencias rítmicas, sonidos y secuencias rítmico-melódicas.

Al contabilizar los errores tuvimos en cuenta los siguientes criterios:

- Las respuestas correctas eran consideradas aciertos.

- Las respuestas que habían rodeado y que no eran correctas eran consideradas errores.

- Las respuestas que no habían sido rodeadas pero que sí eran correctas eran consideradas no identificadas.

A continuación, mostramos los resultados a través de unas gráficas (anexo XI) y los asignamos a la categoría memoria musical para su posterior interpretación junto con el resto de los datos procedentes de los demás instrumentos y técnicas.

\section{- Exámenes y trabajos de los alumnos}

A lo largo de todo el curso, la profesora fue recogiendo y corrigiendo simultáneamente distintos trabajos y exámenes de los alumnos, lo cual permitía comprobar si se producían progresos en la dirección deseada o había que introducir modificaciones.

Los resultados obtenidos en dichos trabajos y exámenes quedan reflejados en la nota global obtenida por los alumnos en Lenguaje Musical y, de forma más específica, en cada uno de los apartados de la asignatura: ritmo, entonación, dictado y teoría.

Para contabilizar dichas calificaciones utilizamos el programa Excel (versión 2003) y mostramos los resultados a través de gráficas (anexo XII), asignándolos posteriormente a la categoría calidad y utilidad de los aprendizajes para su interpretación cualitativa.

\section{- Fotografías y videos}

El visionado de fotografías y videos que recogían las actividades realizadas en clase nos ha permitido analizar más objetivamente la actitud de los alumnos ante las mismas, proporcionando datos que facilitaban la 
interpretación y la extracción de conclusiones y aportando, asimismo, mayor veracidad y validez a los resultados.

\subsubsection{Definición de categorías para el registro y la reducción de los datos}

Como ya hemos comentado, en esta tesis el proceso de análisis de datos se desarrolla esencialmente a partir de la categorización. Ante el gran volumen de documentos y de información que estábamos manejando, consideramos conveniente el uso del programa informático Atlas-ti (versión 6.2) para facilitar la asignación de los datos a las distintas categorías, lo cual nos permitió reducirlos y organizarlos (anexo XIII).

La elección y la definición de las categorías que permitieran organizar la información fue un proceso vivo durante toda la fase de análisis, quedando establecidas, finalmente, tal y como recogemos a continuación.

a). Ansiedad: Grado de tensión que sienten los distintos miembros de la comunidad educativa hacia los estudios musicales debido a aspectos como la carga lectiva, la falta de comprensión, las interpretaciones en público, la necesidad de una adecuada planificación y organización del tiempo de estudio o la compaginación con otras actividades.

b). Calidad y utilidad de los aprendizajes: Aspectos relacionados con la adquisición de un buen o mal hábito de estudio, la comparación con los estudios realizados en otros centros o con otros profesores, la construcción de aprendizajes significativos y el grado de transferibilidad de lo aprendido a otros contextos.

c). Creatividad: Todo lo relacionado con la experimentación, el desarrollo de la imaginación y el dominio de las tareas para poder realizar nuevas creaciones musicales.

d). Dictado tradicional: Actitud de los alumnos ante la realización de dictados tradicionales, dificultades que manifiestan a la hora de resolverlos y relaciones entre los dictados musicales y otro tipo de actividades (refranes, canciones y lecciones de entonación).

e). Exhibición de trabajos: Implicación y actitud de los alumnos ante la puesta en escena o la exposición de trabajos, tanto dentro del aula como en otros contextos (paredes y pasillos del centro, auditorio, etc.).

f). Importancia de los contenidos: Concepción de las enseñanzas musicales y valor otorgado a su capacidad formativa y educativa, relevancia de la asignatura de Lenguaje Musical en comparación con 
las asignaturas instrumentales e importancia concedida a cada uno de los contenidos que se trabajan dentro del Lenguaje Musical.

g). Innovación y coordinación docente: Dada la amplitud y diversidad de datos que obtuvimos en esta categoría, decidimos dividirla en dos: innovación educativa, por un lado, y coordinación docente, por otro. La primera recoge los aspectos relacionados con la importancia de emprender iniciativas novedosas para conseguir avances en la educación musical, las dificultades e inseguridades que surgen en su puesta en práctica y el apoyo y oposición que generan entre la comunidad educativa. Por su parte, la segunda hace referencia a la necesidad de llevar a cabo acciones coordinadas entre el profesorado para obtener unos resultados educativos óptimos y a la comprobación de si existe o no dicha colaboración docente.

h). Melodía-armonía: Engloba los aspectos relacionados con la entonación y el manejo de los contenidos melódicos y armónicos, tanto a nivel vocal como en lo referente al reconocimiento auditivo. Esta categoría también recoge los aspectos formales de la música.

i). Memoria musical: Importancia concedida a la memoria auditiva y desarrollo de estrategias para la memorización de secuencias sonoras.

j). Motivación: Actitud mostrada por la comunidad educativa hacia las enseñanzas musicales, en general, y hacia la asignatura de Lenguaje Musical, en particular. Asimismo, incluye los datos que ayuden a clarificar qué hace que los aprendizajes resulten atractivos o desmotivadores para los alumnos.

k). Relaciones: Ambiente generado dentro del aula, relaciones establecidas entre los distintos sectores de la comunidad educativa, eficacia de la comunicación presencial y por e-mail e implicación de las familias en el proceso de aprendizaje de sus hijos.

1). Ritmo: Estrategias didácticas empleadas para el aprendizaje de los contenidos rítmicos (especialmente, el trabajo desarrollado a partir de refranes), grado de eficacia de las mimas, motivación generada en los alumnos y dificultades encontradas.

m).Teoría musical: Conocimiento teórico de los códigos del Lenguaje Musical y su relación con la práctica. 


\subsubsection{Análisis descriptivo e interpretativo de los datos}

Una vez organizados los datos y asignados a las distintas categorías, llevamos a cabo un análisis descriptivo e interpretativo de todos ellos dentro del marco de la investigación cualitativa que hemos expuesto. Los resultados se recogen con detalle en los capítulos VII, VIII y IX de esta tesis, organizados en tres bloques temáticos según su contenido:

Tabla 15:

Organización de las categorías de análisis en bloques de contenido

\begin{tabular}{ccc}
\hline $\begin{array}{c}\text { Contenidos trabajados } \\
\text { con nuestra metodología }\end{array}$ & $\begin{array}{c}\text { Innovación y calidad } \\
\text { educativa }\end{array}$ & $\begin{array}{c}\text { Aspectos emocionales y } \\
\text { socio-afectivos }\end{array}$ \\
\hline Ritmo & $\begin{array}{c}\text { Importancia de los } \\
\text { contenidos }\end{array}$ & Motivación \\
Melodía y armonía & Innovación educativa & Ansiedad \\
Teoría musical & $\begin{array}{c}\text { Calidad y utilidad de los } \\
\text { aprendizajes }\end{array}$ & Relaciones \\
Dictado tradicional & Coordinación docente & Exhibición de trabajos \\
Memoria musical & & \\
Creatividad & &
\end{tabular}

\subsection{Proceso de anonimato y confidencialidad}

Al ser una tesis sobre una nueva metodología en la que la propia profesora que la propone y la pone en práctica es, al mismo tiempo, la investigadora, era inevitable revelar su identidad.

Igualmente, consideramos relevante identificar a los expertos entrevistados dada su trascendencia en la educación musical impartida en los conservatorios de nuestro país, para lo cual pedimos su consentimiento.

No obstante, Stake (2006) defiende que es fundamental que el investigador muestre un elevado nivel de sensibilidad ante las repercusiones que su investigación puede conllevar a las personas, por lo que consideramos fundamental garantizar el anonimato de todos los demás participantes en este estudio para que pudieran expresarse con libertad sin miedo a ser reconocidos y señalados, lo cual podría perjudicar también las futuras relaciones de los mismos con la profesora-investigadora en su puesto de trabajo. 
Además, consideramos que lo importante de los informantes eran los datos que nos podían proporcionar como miembros del sector educativo al que representaban, por lo que incluir sus datos personales resultaba totalmente innecesario.

A continuación, presentamos el sistema de codificación que utilizamos para proteger a los participantes del estudio.

El profesorado se codifica con una letra que indica el sector educativo al que pertenece $(\mathrm{P})$, seguida de la especialidad que imparte y, si existen varios informantes de la misma asignatura, se añade un número personal. En ocasiones, después de este código aparecen otras letras que indican los órganos de gobierno unipersonal.

Tabla 16:

Resumen de codificación del profesorado

\begin{tabular}{|c|c|c|c|c|c|}
\hline $\begin{array}{c}\text { Profesor } \\
\text { Prof.-tutor }\end{array}$ & Especialidad & $\begin{array}{l}\text { Código } \\
\text { personal }\end{array}$ & $\begin{array}{l}\text { Equipo } \\
\text { directivo }\end{array}$ & $\begin{array}{l}\text { Ejemplo } \\
\text { de código }\end{array}$ & $\begin{array}{l}\text { Significado } \\
\text { del código }\end{array}$ \\
\hline $\mathrm{P}^{(*)}$ & & & & & Prof.-investigadora \\
\hline $\mathrm{P}$ & Tcas & 2 & & PTcas2 & $\begin{array}{l}\text { Prof. de asignaturas } \\
\text { teóricas } 2\end{array}$ \\
\hline $\mathrm{T}$ & V & & & TV & Prof.-tutor de violín \\
\hline $\mathrm{T}$ & Per & & & $\mathrm{T}$ & $\begin{array}{l}\text { Prof.-tutor de } \\
\text { percusión }\end{array}$ \\
\hline $\mathrm{T}$ & G & & D & TGD & $\begin{array}{l}\text { Prof.-tutor de } \\
\text { guitarra y director }\end{array}$ \\
\hline $\mathrm{T}$ & $\mathrm{Pi}$ & & $\mathrm{JE}$ & TPiJE & $\begin{array}{l}\text { Prof.-tutor de piano } \\
\text { y jefe de estudios }\end{array}$ \\
\hline $\mathrm{T}$ & $\mathrm{O}$ & & & TO & Prof.-tutor de oboe \\
\hline
\end{tabular}

(*) La "P" se utiliza de forma individual para hacer referencia a la propia profesorainvestigadora de esta tesis. Si se trata de cualquier otro profesor que no sea tutor, la "P" debe ir acompañada del código de la especialidad que imparte.

En el caso del alumnado, se comienza señalando el curso al que pertenece: primer curso (1C) o segundo curso (2C). Después, le sigue la letra que indica que se trata de un alumno (A) y, por último, aparece un número personal de una o dos cifras. 
Tabla 17:

Resumen de codificación del alumnado (alumnos individuales)

\begin{tabular}{ccccc}
\hline Curso & Alumno & $\begin{array}{c}\text { Código } \\
\text { personal }\end{array}$ & $\begin{array}{c}\text { Ejemplo de } \\
\text { código }\end{array}$ & $\begin{array}{c}\text { Significado del } \\
\text { código }\end{array}$ \\
\hline $1 \mathrm{C}$ & $\mathrm{A}$ & 24 & $1 \mathrm{CA} 24$ & $\begin{array}{c}\text { Alumno 24 del } \\
\text { primer curso }\end{array}$ \\
$2 \mathrm{C}$ & $\mathrm{A}$ & 6 & $2 \mathrm{CA} 6$ & $\begin{array}{l}\text { Alumno 6 del } \\
\text { segundo curso }\end{array}$ \\
\hline
\end{tabular}

En ocasiones, el informante es un grupo de alumnos considerado en su conjunto por lo que, tras señalar el curso al que pertenece, se añaden las letras que indican que son varios alumnos (As), seguidas de la letra que indica el grupo al que pertenecen (A, B, C...).

Tabla 18:

Resumen de codificación del alumnado (grupos de alumnos)

\begin{tabular}{ccccl}
\hline Curso & Alumnos & Grupo & $\begin{array}{c}\text { Ejemplo de } \\
\text { código }\end{array}$ & Significado del código \\
\hline $1 \mathrm{C}$ & As & $\mathrm{C}$ & 1CAsC & $\begin{array}{l}\text { Alumnos del grupo C } \\
\text { del primer curso }\end{array}$ \\
$2 \mathrm{C}$ & As & B & 2CAsB & $\begin{array}{l}\text { Alumnos del grupo B } \\
\text { del segundo curso }\end{array}$ \\
\hline
\end{tabular}

Los familiares, independientemente de que se trate del padre o de la madre, siguen la misma codificación que el hijo que estudia en el conservatorio, solo cambia la letra que indica el sector educativo al que representa, es decir, en vez de aparecer la letra correspondiente a los alumnos (A) aparece la letra asignada a los familiares $(\mathrm{F})$.

Tabla 19:

Resumen de codificación de las familias de los alumnos (familiares individuales)

\begin{tabular}{ccccl}
\hline Curso & $\begin{array}{c}\text { Familiar } \\
\text { padre/madre })\end{array}$ & $\begin{array}{c}\text { Código } \\
\text { personal }\end{array}$ & $\begin{array}{c}\text { Ejemplo de } \\
\text { código }\end{array}$ & Significado del código \\
\hline $2 \mathrm{C}$ & $\mathrm{F}$ & 49 & $2 \mathrm{CF} 49$ & $\begin{array}{l}\text { Familiar del alumno 49 } \\
\text { del segundo curso }\end{array}$ \\
$1 \mathrm{C}$ & $\mathrm{F}$ & 15 & $1 \mathrm{CF} 15$ & $\begin{array}{l}\text { Familiar del alumno 15 } \\
\text { del primer curso }\end{array}$ \\
\hline
\end{tabular}


Si los informantes son grupos de familiares, se señala el curso de los alumnos de quienes son padres y madres (1C o 2C), seguido de las letras que indican que se trata de varios familiares (Fs).

Tabla 20:

Codificación de las familias de los alumnos (grupos de familiares)

\begin{tabular}{cccl}
\hline Curso & Familiares & $\begin{array}{c}\text { Ejemplo de } \\
\text { código }\end{array}$ & Significado del código \\
\hline 1C & Fs & 1CFs & $\begin{array}{l}\text { Familiares de los alumnos } \\
\text { del primer curso }\end{array}$ \\
2C & Fs & $2 \mathrm{CFs}$ & $\begin{array}{l}\text { Familiares de los alumnos } \\
\text { del segundo curso }\end{array}$ \\
\hline
\end{tabular}

Finalmente señalaremos que, aunque los expertos no son anónimos, por tratarse de personas destacadas en el campo de la pedagogía musical de nuestro país cuya identidad considerábamos importante revelar, también utilizamos una codificación para facilitar la citación de los mismos a lo largo de la tesis. En este caso, utilizamos dos letras que indican que se trata de un experto (Ex) seguidas de un número personal.

Tabla 21:

Codificación de los expertos

\begin{tabular}{cccc}
\hline Experto & $\begin{array}{c}\text { Código } \\
\text { personal }\end{array}$ & $\begin{array}{c}\text { Ejemplo de } \\
\text { código }\end{array}$ & $\begin{array}{c}\text { Significado del } \\
\text { código }\end{array}$ \\
\hline Ex & 1 & Ex1 & Experto 1 \\
Ex & 3 & Ex3 & Experto 3 \\
\hline
\end{tabular}

\subsection{Proceso de codificación de los documentos}

Para identificar la procedencia documental de los distintos datos aportados en esta tesis, utilizamos también un sistema de codificación que describimos a continuación.

El diario de clase de la profesora utiliza las letras (DP), seguidas de la inicial del mes al que hace referencia, a excepción del mes de mayo, que se indica con una $(\mathrm{Y})$ para diferenciarlo de marzo. 
Tabla 22:

Ejemplo de codificación del diario de clase

\begin{tabular}{cccl}
\hline $\begin{array}{c}\text { Diario de la } \\
\text { profesora }\end{array}$ & Mes & $\begin{array}{c}\text { Ejemplo de } \\
\text { código }\end{array}$ & Significado del código \\
\hline DP & M & DPM & $\begin{array}{l}\text { Diario de la profesora } \\
\text { de marzo }\end{array}$ \\
DP & Y & DPY & $\begin{array}{l}\text { Diario de la profesora } \\
\text { de mayo }\end{array}$ \\
\hline
\end{tabular}

Los cuestionarios cerrados de Lenguaje Musical respondidos por alumnos de distintos conservatorios españoles se nombran con las siglas (CLM).

Tabla 23:

Codificación de los cuestionarios cerrados de Lenguaje Musical

\begin{tabular}{cc}
\hline $\begin{array}{c}\text { Cuestionarios de } \\
\text { Lenguaje Musical }\end{array}$ & Significado del código \\
\hline CLM & $\begin{array}{c}\text { Cuestionarios de Lenguaje Musical respondidos por } \\
\text { alumnos de distintos conservatorios españoles }\end{array}$ \\
\hline
\end{tabular}

En cambio, los cuestionarios abiertos de autoevaluación dirigidos a los alumnos de Lenguaje Musical con quienes se ha aplicado la nueva metodología presentada en esta tesis se codifican con las letras (CA), seguidas del curso del alumno que lo ha cumplimentado (1C o 2C) y del número de pregunta a la que hace referencia la respuesta.

Tabla 24:

Ejemplo de codificación de los cuestionarios de autoevaluación dirigidos a los alumnos

\begin{tabular}{ccccc}
\hline $\begin{array}{c}\text { Cuestionario de } \\
\text { autoevaluación }\end{array}$ & Curso & $\begin{array}{c}\mathrm{N}^{\mathrm{o}} \text { de } \\
\text { pregunta }\end{array}$ & $\begin{array}{c}\text { Ejemplo de } \\
\text { código }\end{array}$ & Significado del código \\
\hline $\mathrm{CA}$ & $1 \mathrm{C}$ & pre. 3 & CA1C, pre. 3 & $\begin{array}{l}\text { Respuesta del cuestionario } \\
\text { de autoevaluación ofrecida } \\
\text { por un alumno de primero } \\
\text { en la pregunta 3 }\end{array}$ \\
CA & 2C & pre. 6 & CA2C, pre. 6 & $\begin{array}{l}\text { Respuesta del cuestionario } \\
\text { de autoevaluación ofrecida } \\
\text { por un alumno de segundo } \\
\text { en la pregunta 6 }\end{array}$ \\
\hline
\end{tabular}


La codificación de las entrevistas consiste en utilizar la letra (E) seguida de las letras y números que indican las personas o grupos a los que se ha realizado la entrevista, que se identifican del modo descrito en el apartado anterior relativo al proceso de anonimato.

Tabla 25:

Ejemplo de codificación de las entrevistas individuales

\begin{tabular}{|c|c|c|c|}
\hline $\begin{array}{l}\text { Entrevista } \\
\text { individual }\end{array}$ & Entrevistado & $\begin{array}{l}\text { Ejemplo de } \\
\text { código }\end{array}$ & Significado del código \\
\hline $\mathrm{E}$ & Ex3 & EEx3 & $\begin{array}{l}\text { Entrevista al experto } \\
\text { número } 3\end{array}$ \\
\hline $\mathrm{E}$ & 1CF6 & E1CF6 & $\begin{array}{l}\text { Entrevista a un familiar } \\
\text { del alumno } 6 \text { del primer } \\
\text { curso }\end{array}$ \\
\hline E & 2CF59 & E2CF59 & $\begin{array}{l}\text { Entrevista a un familiar } \\
\text { del alumno } 59 \text { del } \\
\text { segundo curso }\end{array}$ \\
\hline $\mathrm{E}$ & TPer & ETPer & $\begin{array}{l}\text { Entrevista a un profesor- } \\
\text { tutor de percusión }\end{array}$ \\
\hline $\mathrm{E}$ & TGD & ETGD & $\begin{array}{l}\text { Entrevista al profesor- } \\
\text { tutor de guitarra y } \\
\text { director }\end{array}$ \\
\hline
\end{tabular}

Tabla 26:

Ejemplo de codificación de las entrevistas grupales

\begin{tabular}{cccl}
\hline $\begin{array}{c}\text { Entrevista } \\
\text { grupal }\end{array}$ & Entrevistado & $\begin{array}{c}\text { Ejemplo de } \\
\text { código }\end{array}$ & Significado del código \\
\hline EG & $1 \mathrm{CAsA}$ & EG1CAsA & $\begin{array}{l}\text { Entrevista grupal a los } \\
\text { alumnos del grupo A del } \\
\text { primer curso }\end{array}$ \\
EG & $2 \mathrm{CAsB}$ & EG2CAsB & $\begin{array}{l}\text { Entrevista grupal a los } \\
\text { alumnos del grupo B del } \\
\text { segundo curso }\end{array}$ \\
& $1 \mathrm{CFs}$ & EG1CFs & $\begin{array}{l}\text { Entrevista grupal a } \\
\text { familiares de los alumnos } \\
\text { del primer curso }\end{array}$ \\
& EG & EG2CFs & $\begin{array}{l}\text { Entrevista grupal a } \\
\text { familiares de los alumnos } \\
\text { del segundo curso }\end{array}$ \\
\hline
\end{tabular}


Por lo que respecta a los correos electrónicos, se nombran con las siglas (CE) seguidas del código del remitente que lo ha emitido, según las pautas descritas para preservar su anonimato. Si el remitente es la profesorainvestigadora $(\mathrm{P})$, se indica, además, quién es el destinatario, siguiendo esas mismas pautas. No obstante, si el remitente es cualquier otra persona (alumno, profesor-tutor o familiar), no se indica el destinatario porque se sobreentiende que siempre irán dirigidos a la propia profesora. A continuación, se utiliza la inicial del mes en que fue emitido el correo electrónico (mayo se indica con "Y", como hemos señalado anteriormente).

Dada su relevancia, se incluyen algunos correos electrónicos escritos por nuestros alumnos y sus padres tras realizar, en junio de 2015, la prueba de acceso a las enseñanzas profesionales, dos años después del curso académico 2012-13 durante el cual recogimos los datos para la realización de este estudio. En estos casos, no se incluye el curso, ya que se da por hecho que se trata de alumnos o de familiares que han trabajado con nosotros hasta finalizar los estudios de $4^{\circ}$ de las enseñanzas elementales. Tras la indicación del mes, se señala tal situación con las siglas de la prueba de acceso (PA).

Tabla 27:

Ejemplo de codificación de los correos electrónicos

\begin{tabular}{|c|c|c|c|c|c|}
\hline $\begin{array}{c}\text { Correo } \\
\text { electrónico }\end{array}$ & Remitente & Destinatario & Mes & $\begin{array}{l}\text { Ejemplo de } \\
\text { código }\end{array}$ & Significado del código \\
\hline CE & $1 \mathrm{CF} 12$ & (*) & E & CE1CF12E & $\begin{array}{l}\text { Correo electrónico de un } \\
\text { familiar del alumno } 12 \text { del } \\
\text { primer curso, de enero }\end{array}$ \\
\hline $\mathrm{CE}$ & 2CA53 & (*) & $\mathrm{J}$ & CE2CA53J & $\begin{array}{l}\text { Correo electrónico del } \\
\text { alumno } 53 \text { del segundo } \\
\text { curso, de junio }\end{array}$ \\
\hline $\mathrm{CE}$ & A46 & $(*)$ & JPA & CEA46JPA & $\begin{array}{l}\text { Correo electrónico del } \\
\text { alumno } 46 \text { tras la prueba } \\
\text { de acceso a profesional }\end{array}$ \\
\hline $\mathrm{CE}$ & $\mathrm{P}$ & $1 \mathrm{CA} 3$ & $\mathrm{~J}$ & CEP1CA3J & $\begin{array}{l}\text { Correo electrónico de la } \\
\text { profesora para el alumno3 } \\
\text { del primer curso de junio }\end{array}$ \\
\hline $\mathrm{CE}$ & $P$ & As & D & CEPAsD & $\begin{array}{l}\text { Correo electrónico de la } \\
\text { profesora para todos los } \\
\text { alumnos, de diciembre }\end{array}$ \\
\hline $\mathrm{CE}$ & TV & $(*)$ & $\mathrm{F}$ & CEP1CA5F & $\begin{array}{l}\text { Correo electrónico del } \\
\text { profesor-tutor de violín, } \\
\text { de febrero }\end{array}$ \\
\hline
\end{tabular}

(*) Los correos van siempre dirigidos a la profesora investigadora. 
Por último, los trabajos y los exámenes de los alumnos se indican con el curso del alumno al que pertenece dicho trabajo o examen (1C o $2 \mathrm{C})$ y un código que especifica de qué tipo de documento se trata: refrán $(\mathrm{R})$, canción escrita de oído (C), canción creada por los alumnos $(\mathrm{Cr})$, prueba de memoria auditiva realizada a principio de curso $(\mathrm{Ma})$, prueba de memoria auditiva repetida a final de curso (MaRep), dictado (Dct) y examen de teoría (T). Cuando existen varios modelos de un mismo tipo de documento (por ejemplo, distintos refranes o canciones realizadas a lo largo del curso o diferentes exámenes de teoría para cada trimestre) se indica, además, un número para identificar de cuál se trata.

Tabla 28:

Ejemplo de codificación de los trabajos y los exámenes de los alumnos

\begin{tabular}{|c|c|c|c|c|c|}
\hline Curso & Documento & $\begin{array}{l}\text { Significado } \\
\text { documento }\end{array}$ & $\begin{array}{c}\mathrm{N}^{\mathrm{o}} \text { del } \\
\text { documento }\end{array}$ & $\begin{array}{l}\text { Ejemplo } \\
\text { de } \\
\text { código }\end{array}$ & $\begin{array}{l}\text { Significado del } \\
\text { código }\end{array}$ \\
\hline $1 \mathrm{C}$ & $\mathrm{R}$ & Refrán & 6 & 1CR6 & $\begin{array}{l}\text { Refrán } 6 \text { del } \\
\text { primer curso }\end{array}$ \\
\hline $2 \mathrm{C}$ & $\mathrm{C}$ & $\begin{array}{l}\text { Canción } \\
\text { escrita de } \\
\text { oído }\end{array}$ & 4 & $2 \mathrm{CC} 4$ & $\begin{array}{l}\text { Canción escrita de } \\
\text { oído } 4 \text { del segundo } \\
\text { curso }\end{array}$ \\
\hline $2 \mathrm{C}$ & $\mathrm{Cr}$ & $\begin{array}{l}\text { Canción } \\
\text { creada }\end{array}$ & 7 & $2 \mathrm{CCr} 7$ & $\begin{array}{l}\text { Canción creada } 7 \\
\text { del segundo curso }\end{array}$ \\
\hline $1 \mathrm{C}$ & $\mathrm{Ma}$ & $\begin{array}{l}\text { Memoria } \\
\text { auditiva }\end{array}$ & & $1 \mathrm{CMa}$ & $\begin{array}{l}\text { Pruebas de memoria } \\
\text { auditiva del primer } \\
\text { curso }\end{array}$ \\
\hline $1 \mathrm{C}$ & MaRep & $\begin{array}{l}\text { Memoria } \\
\text { auditiva } \\
\text { repetida }\end{array}$ & & 1CMaRep & $\begin{array}{l}\text { Pruebas de memoria } \\
\text { auditiva repetidas } \\
\text { del primer curso }\end{array}$ \\
\hline $2 \mathrm{C}$ & Dct & Dictados & & $2 \mathrm{CDct}$ & $\begin{array}{l}\text { Dictados del } \\
\text { segundo curso }\end{array}$ \\
\hline $1 \mathrm{C}$ & $\mathrm{T}$ & Teoría & 3 & 1CT3 & $\begin{array}{l}\text { Teoría del tercer } \\
\text { trimestre del primer } \\
\text { curso }\end{array}$ \\
\hline
\end{tabular}

\section{Análisis del rigor metodológico de la investigación}

De acuerdo a Castillo y Vásquez (2003) una de las preguntas que el investigador se hace durante toda la investigación es cómo garantizar el rigor del trabajo científico. 
Los criterios que comúnmente se utilizan para evaluar la calidad científica de un estudio cualitativo y, por ende, su rigor metodológico son: la credibilidad, la confirmabilidad, la transferibilidad y la dependencia (Guba \& Lincoln, 1989; Ruiz e Ispizua, 1989; Franklin \& Ballau, 2005; Mertens, 2005). A continuación describiremos de qué manera los hemos tenido en cuenta en nuestro trabajo.

\subsection{Credibilidad}

La credibilidad es el criterio que nos permite confiar en la veracidad de los resultados y conclusiones de la investigación, asegurando que el objeto de estudio fue exhaustivamente identificado y descrito, contrastando la información obtenida a través de las diferentes fuentes de las que se han obtenido los datos.

Para aportar credibilidad a nuestro estudio, hemos utilizado la triangulación, la cual, utilizando las palabras de Stake (1998, p. 98) se realiza "para aumentar el crédito de la interpretación, para demostrar lo común en un aserto".

El término se tomó de la topografía y consiste en determinar ciertas intersecciones o coincidencias a partir de diferentes fuentes informativas o varios puntos de vista del mismo fenómeno. Según Okuna y Gómez (2005, p. 120) se puede hacer uso de diferentes estrategias que evalúan el objeto de estudio "desde una perspectiva diferente, cada una de las cuales muestra una de las facetas de la totalidad de la realidad en estudio, motivo por el cual la triangulación termina siendo una herramienta enriquecedora". Se trata, por tanto, de una herramienta heurística muy eficiente y su uso requiere habilidad por parte del investigador para garantizar que el contraste de las diversas percepciones conduce a interpretaciones consistentes y válidas.

Denzin (1970) es uno de los autores que mayor atención ha prestado al fenómeno de la triangulación e identificó cuatro tipos: de métodos, de datos, de investigadores y de teorías. Basándonos en dicho autor, hemos llevado a cabo las siguientes estrategias de triangulación:

a). Triangulación de métodos: La triangulación metodológica la conseguimos utilizando varias técnicas para dar respuesta a las preguntas de investigación. Concretamente, combinamos la observación participante, recogida a través de las anotaciones del diario, con las entrevistas, los cuestionarios y la revisión documental.

b). Triangulación de datos: Hemos utilizado una gran variedad de datos procedentes de diversas fuentes de información, tanto documentales 
como personales (expertos, alumnado, profesorado y familias), y tomados en contextos muy diferentes, ya que no es igual el contexto de una entrevista individual que el que envuelve una entrevista grupal o la administración de un cuestionario.

c). Triangulación de investigadores: A lo largo del proceso de investigación, hemos ido exponiendo nuestros resultados al juicio de dos compañeros de trabajo, de dos de los expertos entrevistados y de los directores de la tesis para que nos diesen su opinión, nos formulasen las dudas que les surgían, nos hiciesen críticas constructivas y nos propusiesen mejoras.

d). Triangulación de teorías: Algunos de los compañeros y de los expertos a los que consultamos mantenían puntos de vista teóricos diferentes a los nuestros a la hora de estructurar, analizar e interpretar un mismo conjunto de datos, por lo que podemos afirmar que se ha llevado a cabo una triangulación de teorías.

Además, la credibilidad de nuestro trabajo queda avalada por el hecho de que mantuvimos un trabajo prolongado en el campo a investigar (se comenzó en 2012), por la realización de comprobaciones con los participantes del estudio, que reconocían como reales o verdaderos los hallazgos encontrados, y porque llevamos a cabo una revisión bibliográfica consistente, fundamentada en publicaciones de distinta índole (libros, artículos científicos publicados en revistas, actas de congresos, leyes educativas, documentación sobre proyectos, etc.), sobre la que se sustenta el marco teórico.

Finalmente, señalaremos que hemos tratado de aportar credibilidad a la investigación mediante la adecuación referencial, comprobando el análisis y las interpretaciones de cada una de las partes del trabajo de campo, y mediante la coherencia estructural del informe, buscando alcanzar una conexión, consistencia y sincronización al interpretar posibles datos atípicos.

\subsection{Confirmabilidad}

La confirmabilidad se refiere a la neutralidad de la interpretación o análisis de la información, es decir, la certeza de la existencia de datos para cada interpretación. Este criterio trata de demostrar la independencia de los datos e informaciones respecto al investigador que las obtiene $\mathrm{y}$, por tanto, que pueden ser confirmadas por otras vías y personas. Por tanto, la confirmabilidad se logra cuando otros investigadores pueden seguir "la pista" al investigador original y llegar a hallazgos similares (Guba \& Lincoln, 1981). Para ello es necesario un registro detallado y toda la 
documentación de las decisiones e ideas que el investigador haya tenido en relación con el estudio.

La confirmabilidad de nuestro trabajo queda garantizada a través de varios procedimientos. En primer lugar, mediante la triangulación de datos, de métodos, de investigadores y de teorías, de la manera que hemos indicado anteriormente. En segundo lugar, mediante el ejercicio de reflexión, que hemos llevado a cabo de dos formas: por un lado, revelando de manera intencionada nuestra forma de entender el objeto de estudio y nuestro posicionamiento metodológico y, por otro, elaborando un diario de clase o de investigación (Blaxter, Hughes, \& Tight, 2008) donde íbamos anotando los progresos, sentimientos, pensamientos, inseguridades e intuiciones que nos iban surgiendo. En tercer y último lugar, hemos redactado el informe con los resultados de manera que el lector pueda revisar la confirmabilidad por sí mismo, ya que cada interpretación va acompañada de los datos que la sustentan: tablas, gráficas, documentos o citas textuales. En los anexos de la tesis se encuentran las grabaciones y transcripciones de las entrevistas, los cuestionarios cumplimentados, el diario y todo el material documental de donde hemos extraído los datos necesarios para realizar la investigación, de modo que cualquier persona interesada puede reconstruir el proceso que hemos llevado a cabo y llegar a nuestras mismas conclusiones, siempre y cuando comparta nuestras mismas perspectivas de partida.

\subsection{Transferibilidad}

La transferibilidad consiste en la posibilidad de extender los resultados de una investigación a otros contextos o grupos. Guba y Lincoln (1981) señalan que se trata de examinar cuánto se pueden ajustar los resultados a otros contextos, existiendo mayor transferibilidad cuanto mayor sea la similitud entre los mismos.

Goetz y LeCompte (1988) consideran que, para transferir los hallazgos, es necesario realizar una descripción precisa del contexto, especificando de forma minuciosa las características de las instituciones, de los materiales y de los participantes, así como de las relaciones que se establecen entre ellos, para poder construir de esta manera juicios de correspondencia.

Para favorecer la transferibilidad hemos descrito con detalle tanto el lugar como las características de las personas con quienes se ha llevado a cabo el estudio, es decir, hemos incluido descripciones minuciosas del contexto físico y personal. Esto permite que las propuestas que planteamos puedan ser aplicables más fácilmente en otros conservatorios o centros de educación musical de características similares. 
Asimismo, hemos recogido abundantes datos descriptivos, consiguiendo la saturación de la información, que se alcanza cuando se obtiene una misma información a partir de distintas fuentes. Al respecto, consideramos que hemos realizado una selección apropiada de las técnicas e instrumentos utilizados para la recogida de datos y de los sujetos informantes, ya que hemos acudido a quienes tenían un mejor conocimiento del fenómeno a investigar, lo cual garantiza una saturación efectiva y eficiente de las categorías, con información de óptima calidad. Especialmente queremos destacar el caso de las entrevistas, con las que hemos favorecido la transferibilidad al realizar un muestreo estructural, buscando la representatividad de los informantes, ya que hemos tenido en cuenta los diferentes discursos que existen en torno al objeto de estudio (de expertos, profesorado, alumnado y familias) y cómo se articulan estos.

\subsection{Dependencia}

La dependencia o consistencia lógica vela porque los resultados de una investigación sean estables y se define como el grado en que diferentes investigadores generan resultados equivalentes al recolectar datos similares en el campo y efectuar los mismos análisis. De acuerdo a Franklin y Ballau (2005) existen dos clases de dependencia: la interna (grado en el cual diversos investigadores, al menos dos, generan temas similares con los mismos datos) y la externa (grado en que diversos investigadores generan temas similares en el mismo ambiente y período, pero cada quien recaba sus propios datos). En ambos casos, ese grado no se expresa por medio de un coeficiente, solo se verifica la sistematización en la recolección y el análisis cualitativo (Hernández, Fernández, \& Baptista, 2006).

Las amenazas a la dependencia son, básicamente, tres: los sesgos que pueda introducir el investigador en la sistematización del trabajo de campo y durante el análisis, el que se disponga de una sola fuente de datos y la inexperiencia del investigador para codificar.

Siguiendo a Gurdián-Fernández (2007), hemos prestado atención a las influencias del sesgo y los valores mediante un proceso continuo de reflexión y análisis acerca de los registros descriptivos, el proceso investigativo, del contexto, de los datos y de sus interpretaciones.

Para garantizar la dependencia también hemos utilizado lo que Guba (2008) define como métodos solapados. Se trata de una especie de triangulación donde se pueden utilizar diferentes métodos a la vez, de manera que en caso de que uno de los métodos fuera más débil, se vería compensado con la fuerza de otro. En nuestro trabajo, como se ha indicado, nos hemos servido 
de la observación participante reflejada en el diario de clase, de cuestionarios, de entrevistas y del análisis documental.

Por otra parte, en la investigación hemos tratado de facilitar la réplica paso a paso (Guba, 2008), que consiste en posibilitar que un auditor externo pueda seguir el transcurso del trabajo. Para ello, hemos sido minuciosos al detallar el proceso de recogida de datos y de análisis de los mismos. Además, como ya hemos señalado anteriormente, hemos contado con el apoyo y la revisión de figuras externas a la tesis (compañeros, expertos y los propios directores de la tesis) que nos han hecho sus aportaciones y valoraciones para codificar, analizar e interpretar adecuadamente los datos. 



\section{CAPÍTULO VII: ANÁLISIS DE LOS CONTENIDOS TRABAJADOS A PARTIR DE NUESTRA PROPUESTA METODOLÓGICA}

\section{Introducción}

En este capítulo, analizaremos el desarrollo de los contenidos curriculares de la asignatura de Lenguaje Musical a través de nuestras propuestas y las repercusiones que han tenido en el proceso de enseñanza y aprendizaje de los alumnos.

En primer lugar, trataremos los apartados que, habitualmente, se distinguen en esta asignatura: el ritmo, la entonación-audición (recogidos en esta tesis bajo la denominación de contenidos melódicos y armónicos) y la teoría musical, dedicando un cuarto apartado al dictado en su concepción tradicional. A continuación, dada su relevancia en nuestro nuevo planteamiento metodológico, abordaremos los contenidos relativos al entrenamiento de la memoria musical y al fomento de la creatividad de los alumnos.

\section{El ritmo musical}

Uno de los elementos que configuran la música y, sin duda, uno de los más importantes es el ritmo. Muchos pedagogos musicales coinciden en la idea de que el ritmo debe ser el primer elemento experimentado en la educación musical, debido a que es un elemento innato en el ser humano y a que nuestra vida está rodeada de ritmo: el pulso cardiaco, la respiración, el lenguaje oral, el caminar, las estaciones del año, el día y la noche, etc. (Jaques-Dalcroze, 1965; Kodály, 1911, citado por Szönyi, 1976; Orff, 1930, citado por Sanuy \& González, 1969; Willems, 1984). 
Este apartado, dedicado al ritmo musical, nos permitirá comprender el desarrollo de nuestras nuevas propuestas y su utilidad para la formación musical.

\subsection{La importancia de la experimentación rítmica}

La experimentación es fundamental para todo aprendizaje y debe preceder a la conceptualización, especialmente cuando se trabaja con niños.

E- Yo he trabajado mucho con los niños bailando, he tratado de trabajar mucho el movimiento, porque integras la sensación a través de tu propio movimiento, sin racionalizarla. Te digo, por ejemplo, ¿qué es el movimiento del compás sino una facilitación para nosotros de las sensaciones musicales? (EEx3, p. 61)

E- He utilizado muchísimo la percusión diferenciada: palmadas huecas, palmadas planas, [...] en el pupitre o donde hay algo de metal, todo ese tipo de cosas. Yo he trabajado muchísimo las diferentes líneas rítmicas, porque, si tú quieres enterarte, tienes que hacer diferentes sonidos, diferentes ruidos, porque si no, claro, todo es una masa. (EEx3, p. 64)

Al respecto, destacados autores (Jaques-Dalcroze, 1965; Willems, 1984) defienden la importancia de experimentar el ritmo libre para poder comprender el ritmo métrico y hacen hincapié en que el niño deduce el concepto de duración a partir del concepto de movimiento.

Por ello, desde el primer día de clase, fui introduciendo los elementos rítmicos de la música haciendo que los niños jugaran con ellos y los vivenciaran para, posteriormente, mostrarles su grafía y dotarlos de significado.

Durante esta primera semana, en los grupos de primero he estado introduciendo los elementos básicos de la música a través de distintos juegos de experimentación del pulso y del acento o la lectura rítmica de palabras. [...] Hemos jugado con todos estos elementos marcando el pulso a distintas velocidades y percutiendo ritmos con diversas partes del cuerpo. [...] En la segunda clase he podido mostrarles, sin ninguna dificultad, la representación musical del ritmo a través de negras y corcheas. (DPS, p. 4)

Así, poco a poco y con una adecuada secuenciación, fui presentando los distintos contenidos rítmicos, consiguiendo que los niños los interiorizaran y que sintieran, en todo momento, la seguridad que proporciona el dominio de la tarea.

Mientras hacían la actividad, yo iba pasando entre las mesas y, cuando veía que algún alumno tenía algo incorrecto, simplemente le decía: "Marca el 
pulso y lee este compás despacio", y él mismo se daba cuenta del error. Si aún así no se daba cuenta, se lo hacía solfear aún más despacio y, entonces, lo comprendía y lo corregía sin necesidad de tener que explicarle nada más. Esto me demuestra que los niños, cuando tienen las pautas claras, entienden perfectamente lo que tienen que hacer y cómo, por lo que, si cometen errores, es por una falta de atención o por querer terminar rápido, ya que las únicas palabras que han salido de mi boca para ayudarles a solucionarlos han sido del tipo: "Fíjate bien" o "Marca el pulso despacio y piensa en lo que estás haciendo". (DPN, p. 1)

\subsection{El ritmo musical estudiado como métrica}

La métrica en música es la estructura subyacente que se basa en la aparición periódica, normalmente a intervalos regulares, de sonidos u otros elementos acentuados. A pesar de que existe una relación especial, intrínseca e íntima entre métrica y ritmo y que a menudo se confunden, en esencia son diferentes. Mientras que el ritmo hace referencia a las duraciones de los sonidos, la métrica tiene su razón de ser en los acentos. De hecho, aunque es habitual que la estructura métrica de acentos se explicite en una estructura rítmica de duraciones, esto no siempre es así. La métrica se expresa gráficamente por medio de las indicaciones de compás.

El problema surge cuando los docentes, en un intento por facilitar el aprendizaje rítmico, enseñan al alumnado a exagerar los acentos naturales de los distintos compases o combinaciones rítmicas, distorsionando, a nuestro modo de ver, la naturalidad del discurso musical. Así lo reconocían los expertos entrevistados.

E- No entiendo la manía de muchos profesores de metrificar el ritmo, exagerando acentos que surgen de manera natural. (EEx2, p. 4)

E- El ritmo fluye de manera natural, no hay que forzar los acentos con el falso propósito de facilitar su ejecución. (EEx1, p. 7)

El estudio métrico del ritmo en las aulas de Lenguaje Musical nos generaba polémica en dos aspectos: el primero de ellos estaba relacionado con la prioridad común de formar lectores de partituras frente al desarrollo de una formación musical integral, y el segundo hacía referencia a la lectura rítmica tal y como se ha venido practicando desde el solfeo tradicional. Veamos el análisis que hemos realizado de ambos. 


\subsubsection{Formación de lectores de partituras versus formación de músicos integrales}

La buena ejecución rítmica no implica únicamente la comprensión de las relaciones entre figuras y silencios y las diversas combinaciones entre ambos, sino que exige también conseguir fluidez en la lectura. Así lo demandaba una madre, mostrando preocupación porque consideraba que, después de casi tres meses de clase, su hija no tenía la suficiente soltura.

La mayor preocupación que mostraba la madre es que dedicar tanto tiempo a estos contenidos o forma de trabajar impidiera no dedicarle el tiempo suficiente a leer con fluidez. Dicho de otra forma, me pedía que practicara más lectura rítmica, porque, desde su punto de vista, eso era lo prioritario. (DPD, p. 11)

Este comentario manifiesta que el modelo actual de aprendizaje de la música en los conservatorios españoles sigue demandando fundamentalmente la formación de "músicos lectores de partituras", mientras que nosotros buscábamos una formación más integral, comprensiva, vivencial, manipulativa, intuitiva y completa, lo cual supone un nivel de comprensión de la música mucho mayor que la simple lectura de notas y ritmos.

Molina (2003) presenta una interesante comparación entre la lectura de un texto literario y la lectura musical para demostrar que, si conocemos las palabras y la relación entre las mismas, comprenderemos fácilmente el sentido de las frases, de igual forma que, si comprendemos las relaciones entre las figuras, las notas y los demás elementos musicales, podremos leer la música con rapidez.

La pregunta que deberíamos hacernos es: ¿Qué queremos conseguir, lectores de partituras o músicos integrales que conozcan y manejen los elementos de la música de forma creativa porque los han integrado y hecho suyos? Los comentarios de la madre apuntaban en la primera dirección, mientras que nuestra concepción de la enseñanza se basa en la segunda, ya que estamos convencidos de que la práctica consistente en leer notas y figuras sin conocer el entramado interno que las relaciona, es decir, el "rezar" las notas de una lección de solfeo sin buscar su comprensión, no es un procedimiento adecuado para agilizar la lectura. Además, aunque en un primer momento pudiera parecer que se avanzaba más despacio, a medio plazo ya se observaban las ventajas de nuestra forma de trabajar y los progresos eran mucho más notables. Se trataba simplemente de una priorización de contenidos, es decir, aunque todos ellos se trabajaban, había que valorar cuáles eran más importantes, para concederles un mayor peso. 
Por otra parte, tal y como pasa en el lenguaje verbal, hay que tener en cuenta que unos niños tardan más que otros en aprender a leer pero, si el trabajo de base está bien hecho, llega un momento en que se produce un "click" y todo empieza a cobrar sentido.

F- Llegó un momento en diciembre que pensaba: "Este niño no lee, o no..." Se equivocaba mucho con las notas, con el ritmo... y fue como si, en un momento dado, de repente, apretaras un botón y empezó a leerlo. [...] Eso es lo que más me impresiona: lo de coger de repente así, casi de una semana para otra, y empezar a leerlo.

P- ¿Y ahora ves que lo comprende bien? ¿Lo sigue bien?

F- Sí. (E1CF24, p. 2)

Fue entonces cuando comenzaron a manifestarse los rápidos progresos, lo cual sorprendió tanto a los niños como a sus padres, porque la agilidad en la lectura aumentaba con facilidad.

A31- A mí lo que más me ha llamado la atención ha sido lo de ritmo, porque he aprendido a marcar y a hacerlo con velocidad. (EG1CAsC, p. 12)

F25- Me sorprendía, porque es verdad que lo hacen muy bien y muy rápido. F5- Canciones muy difíciles.

F25- Iba viendo cómo avanzaban y, cada vez, era más fácil para ellos.

F5- Y tú lo leías y decías: “¡Madre mía!” (EG1CFs, p. 16)

Su coordinación al marcar el pulso y su fluidez en la lectura me han demostrado que están interiorizando muy bien los contenidos y que se sienten seguros para enfrentarse ante nuevas partituras. (DPM, p. 1)

Tal y como muestran los respuestas ofrecidas por los alumnos de distintos conservatorios en los cuestionarios de Lenguaje Musical, los contenidos rítmicos resultan más sencillos de trabajar si no se mezclan con la lectura de notas, ya que esto último es una dificultad añadida que provoca con frecuencia errores en la ejecución, y es que muchas veces los alumnos están más pendientes de descifrar las notas que del valor de las figuras, ya que les cuesta atender a los dos aspectos a la vez.

A28- Cuando lo hacías con "ta" era más fácil que cuando lo hacías con notas. (EG1CAsC, p. 24) 


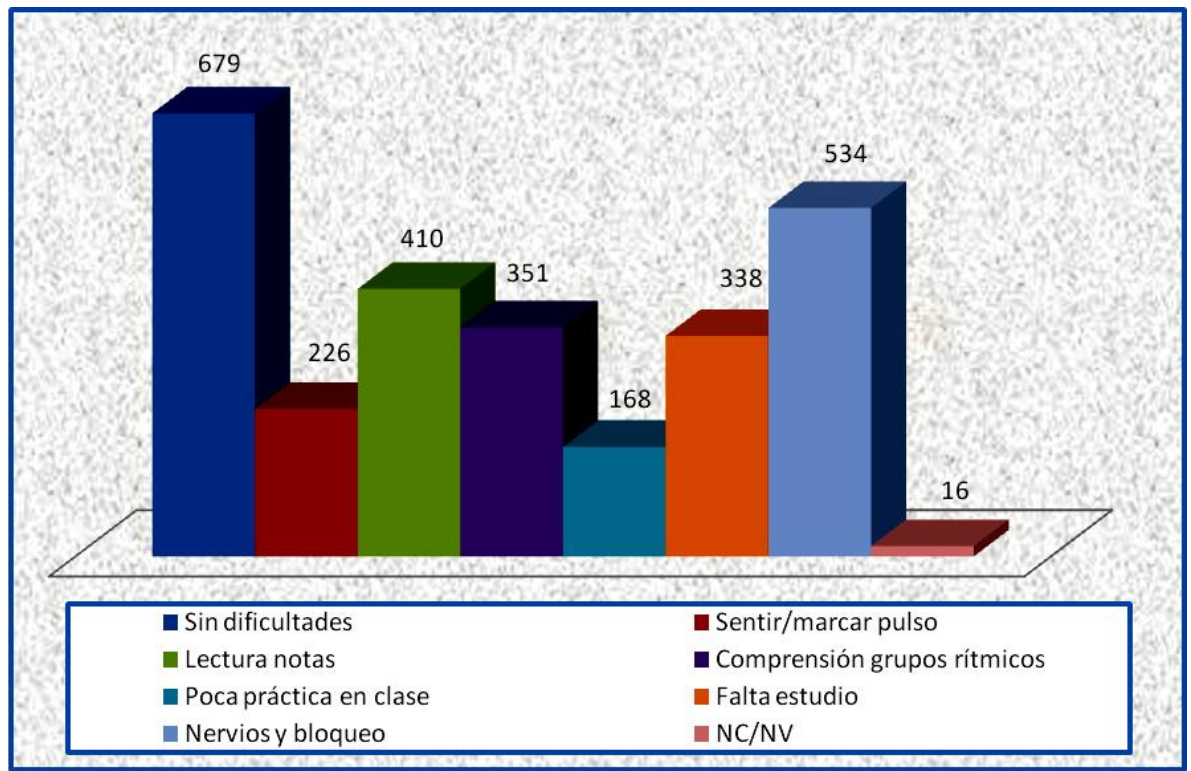

Gráfica 1. Respuestas de los alumnos a la pregunta 10 de los cuestionarios: Considero que mis dificultades en ritmo se deben a:

No obstante, considerábamos importante trabajar los dos aspectos (ritmo y notas) de forma integrada, porque es como cobran su verdadero sentido, aunque los separásemos puntualmente en momentos de mayor complejidad para ayudar a los alumnos a asimilar nuevos contenidos. Además, comprobamos que la seguridad en la lectura de notas se adquiere fácilmente con la práctica y era muy gratificante ver cómo disfrutaban los alumnos al sentir que controlaban los ejercicios.

Lo que he aprendido es muchísimo y no me cabe, así que te diré la mitad de las cosas: solfear, el tiempo que duran las notas y lo que más pero más me sorprende es la rapidez de pasar de una nota a otra. (CA1C, pre. 2)

A63 y A55 se han ofrecido voluntarios para leer la nueva lección de ritmo y la han hecho muy bien. Cuando han terminado, sus compañeros les han aplaudido de forma espontánea y ellos se han levantado a saludar orgullosos mientras decían: "¡Gracias, gracias!”. La verdad es que han mejorado muchísimo y muestran una gran seguridad y motivación. (DPE, p. 5)

\subsubsection{La lectura rítmica en el solfeo tradicional}

Resulta interesante comprobar cómo a muchos niños les resulta artificial y aburrido leer las notas sin entonarlas, práctica muy extendida en los conservatorios españoles, heredada del solfeo tradicional. De hecho, es 
frecuente evaluar la capacidad rítmica del alumnado mediante la interpretación recitada de partituras que recogen todos los contenidos del curso, independientemente de su musicalidad.

A41- El ritmo a mí no me gusta porque es solo marcar el pulso y decir las notas, y para mí es un poco soso.

P- Eso te parece un poco aburrido.

A41- Sí. (EG1CAsF, p. 6)

$\mathrm{P}-$ ¿Y por qué te parece difícil el ritmo?

A11- Pues porque yo no sé hacer las notas sin cantar.

P- ¿Que no sabes hacer las notas sin cantarlas? [...]

A11- Que no sé, que tengo que cantar las notas, que no sé decir las notas como si fuesen ritmo solo.

P- Muy bien. Te parece que tiene más sentido si las cantas, ¿es eso?

A11- (Asiente). (EG1CAsB, p. 4)

A64- A mí no me gusta ritmo.

$\mathrm{P}$ - ¿Por qué no te gusta el ritmo?

A64- Porque no entonas las notas y no sale una melodía bonita.

$\mathrm{P}-i$ Te resulta aburrido hacer ritmo?

A64- Pues sí.

$\mathrm{P}-\mathrm{Al}$ decir "ritmo", ¿te refieres a la lectura rítmica, cuando solfeamos?

A64- Sí. (EG2CAsD, p. 6)

Esta realidad debería hacernos reflexionar sobre la búsqueda de una nueva fórmula que permita a los niños coger agilidad en la lectura sin parecer "papagayos" que recitan notas rítmicamente, careciendo de significación y motivación para ellos. Afortunadamente, cada vez hay más docentes convencidos de ello.

E- Yo no concibo leer música sin entonarla. Eso de poner al alumno con un libro hecho específicamente para eso, para: "Esta no la entones, solamente lee", y hace el alumno: “Do, re, mi, fa sol, la, si, do, si, la, sol, fa, mi, mi, la, sol, fa" (sin entonar). Bueno, primero, no sé si has visto nuestros libros, que se llaman "Ritmo, Entonación y Lectura", no se llaman "Ritmo y Lectura". $[\ldots]$

P- ¡Anda!, o sea, ¿que están concebidos para cantarlos también, no es ritmo puro y duro?

E- No es ritmo, es que no creo que eso lleve a nada. Eso se hace con el instrumento, leyendo lo que tenga que leer a primera vista. (EEx1, p. 9)

E- Hice unos libros muy sencillos y muy progresivos que, en mi opinión, tenían la ventaja de que también iban integrando todas las notas que me interesaban, partiendo de do-sol y siguiendo con do-mi-sol, do-re-mi-sol, do-re-mi-sol-la..., con la sana intención de que el ritmo pudiera ser cantado, ¿sabes?, entonado. Y, encima, tratando de frasear, de que haya frases 
asumibles a la respiración, también pidiéndole al profesor que ponga las respiraciones donde crea conveniente, pero que se cuide ese tema de la emisión y del fraseo. Entonces, aquellos libros de ritmo integran los sonidos en el mismo orden en que a mí me interesaba presentarlos, para que pudieran cantarlos. (EEx3, p. 16)

E- El niño tiene que ser capaz de leer entonando una canción, si esa canción tiene lógica y no está hecha para matar a alguien; es decir, tú, cuando haces una canción para entonar, es como si cogieras un trozo de una sonata de Beethoven o un tiempo lento de una sonata de Mozart, y tú dices: "Canta eso". Eso no se puede rezar, eso es para cantarlo, y el niño tiene que estar preparado para cantar eso. (EEx1, p. 11)

Resulta aún más clarificador si se compara con el aprendizaje de un idioma.

E- No se debería rezar ninguna nota, hay que cantarlas. [...] Es como si estás aprendiendo italiano y te dicen: "Te voy a poner unas lecciones especiales para que leas muchas letras", y te ponen todas las letras cambiadas de sitio y todo muy... que no es italiano, que es el alfabeto, pero todo mezclado como quiere, $;$ a ver si eres capaz de leerlo! Y luego, por otra parte: "Ahora ya vamos a hablar italiano", y te ponen las lecciones con mensaje italiano que de verdad sean eso. ¿Cómo se pueden mezclar las letras de una forma que no sea italiano si estás aprendiendo italiano?, es decir, ¿cómo puedes hacer una lección que sea para leer, por la dificultad, cambiando las claves así a lo bestia?, pero... ¿dónde se cambia de claves? Vamos a ver, un violinista no cambia de clave nunca, un pianista lee clave de sol y clave de fa, y las lee las dos juntas como una clave; los dos leen y no tienen que hacer cambios de claves diferentes de esas. Una persona que toca la viola lee la clave de do en tercera, a veces clave de sol también; un violonchelista... O sea, según qué instrumento, podrías tener un tipo de partitura, pero hay partituras hechas. Cuando veo una partitura de esos libros que hay publicados mezclando muchas claves, digo: “¿Eso de dónde ha salido?", de la mente rebuscada de un señor que se preocupa de que alguien se maree la cabeza haciendo algo inútil. Eso es una inutilidad. (EEx1, p. 10)

E- Claro y, encima, dices: "Vamos a ver, vamos a analizar las claves, ¿dónde te encuentras tú en una partitura de instrumento que te estén cambiando de claves cada compás?" Eso lo hacían también mucho los ritmos y los solfeos franceses.

P- Y hay métodos aquí en España que todavía hacen eso.

E- Claro y dices, bueno ¿y a dónde vamos con eso?, ¿al artificio más puro? Porque, claro, encima el chico está cambiando de clave, en el mejor de los supuestos da con el nombre de la nota, pero la importancia de la clave, que es la tesitura, no la identifica para nada. ¿No será mejor hacer una escritura de claves situándola en sus tesituras y, en cambio, cantar como cantan los cantantes en una única, bien sea sol o fa, la más frecuente, pero en una única clave? (EEx3, pp. 30-31) 
¿Por qué se hace entonces?, es decir, ¿por qué la lectura rítmica, sin entonación, es una práctica tan extendida en nuestro país? Seguramente encuentre su justificación en el entrenamiento de los alumnos para que puedan leer las partituras rápidamente cuando las interpretan con sus instrumentos, pero no podemos olvidar tampoco que la representación mental de las distintas notas musicales es fundamental para que puedan saber si lo que está sonando cuando tocan es lo que tiene que sonar. Por tanto, si lo que pretendemos es que los alumnos realicen aprendizajes significativos, debemos tener presente que para ellos no tiene sentido nombrar las notas sin más, ya que, si las notas musicales representan sonidos, necesariamente deben sonar a diferentes alturas.

E- Yo creo que es muy artificial y, por eso, a mí me ha gustado que los ritmos puedan ser cantados, básicamente porque me parece que todo lo que sea hacer demasiada separación... (niega con la cabeza). Hombre, la lectura tiene un poco la justificación de que tú en el instrumento tienes que leer mucho más de lo que eres capaz de cantar y, además, leer en tesituras que muchas veces naturalmente el instrumento las tiene y tú no las tienes en tu registro para nada, ¿no?

P- O sea, que una lectura sin entonar la justificación que tendría es coger agilidad en leer notas, ¿no?

E- Claro, en que luego te va a dar facilidad en el instrumento. (EEx3, p. 25)

En este sentido, la agilidad en la lectura de partituras aumentará si hay una adecuada coordinación con el profesor de instrumento.

E- La agilidad de lectura la tendrá el alumno con su instrumento cuando tenga que leer sus partituras. Por ejemplo, tú le estás enseñando a tu alumno en primero la clave de sol y el profesor de viola dice: "Enséñale la clave de do en tercera", y tú le dices: "Hombre, estoy trabajando en primero, no puedo enseñarle la clave de do en tercera, enséñasela tú”, ¿no? ¿Quién se la va a enseñar si no es el profesor de viola? Y te puedo decir lo mismo del violonchelo o del fagot. (EEx1, p. 10)

Además, hay que tener en cuenta que también existen demandas de lectura específicas de cada especialidad instrumental.

T- Al principio, las cuerdas rítmicamente casi nunca están potentes. [...] Hay problemas inherentes a cada instrumento, no solo físicos, sino que cada instrumento tiene unas peculiaridades de forma de estudio y posibilidades. Por ejemplo, un instrumentista de cuerda aprende a leer mucho más tarde que uno de piano. El de piano enseguida se centra en las dos claves y la lectura ha de ser más ágil, pero el aprendizaje del instrumentista de cuerda es más lento, porque al principio se enfrenta solo con dos o tres notas. (ETV, p. 2) 
Por ello, es frecuente que los tutores nos reclamen a los profesores de Lenguaje Musical que dediquemos más tiempo a sentar buenas bases, en vez de avanzar rápidamente para enseñar contenidos rítmicos complicados que rara vez encontrarán en su repertorio.

T- Rítmicamente, hay unas dificultades que se van trabajando, a lo mejor, en una clase de Lenguaje Musical, que nunca llegan a alcanzarse en..., por ejemplo, cuando tocan unas obras. Posiblemente, un alumno en piano no llegue a ver un cambio de compás hasta que no está en cuarto o quinto de profesional, iy si lo ve!, pero, a lo mejor, sería necesario insistir más en que sean capaces de mantener un ritmo, vamos, un pulso, en que sean capaces de medir bien en un tres por cuatro, en un dos por cuatro, un tresillo, cosas de esas que son mucho más sencillas que, a lo mejor, se necesita incidir más, porque parece que se pasa demasiado rápido hacia adelante, cuando eso otro no se llega a ver en el instrumento. (ETPiJE, p. 1)

Finalmente, cabe destacar que comprender la utilidad de los aprendizajes es fundamental para potenciar la motivación ante su estudio. Por este motivo, aunque había momentos en los que trabajábamos los contenidos rítmicos de forma aislada para ganar fluidez, procuramos hacer ver a los alumnos en todo momento su relación con los demás parámetros musicales.

A37- El ritmo tiene, por ejemplo, las semicorcheas, síncopas... y es algo que te sirve, por ejemplo, para tocar el instrumento, te sirve para marcar el pulso y queda muy bonito. (EG1CAsF, p. 6)

P- ¿Por qué es importante para ti?

A41- Pues es importante porque si tú no supieses ritmo no podrías hacer las canciones de entonación y, sin eso, no sería nada de lenguaje musical. (EG1CAsF, p. 7)

\subsection{Utilidad del lenguaje verbal para el aprendizaje rítmico}

Como hemos apuntado anteriormente, existen múltiples semejanzas entre el lenguaje verbal y el musical. Ambos permiten a los seres humanos comunicarse entre ellos, por medio de la palabra o de la música, y poder transmitir tanto pensamientos como sentimientos. Al respecto, McAdams (2006) encuentra determinadas similitudes entre el procesamiento de la sintaxis musical y el de la lingüística, en el sentido de que "la primera se relaciona con la psicología cognitiva musical de misma manera que la segunda lo hace con la psicolingüística” (p. 303).

Numerosos pedagogos musicales reconocen la importancia del lenguaje verbal como recurso para favorecer la educación musical, a través de la utilización de sílabas rítmicas o palabras (Kodály, 1911, citado por Szönyi, 1976; Martenot, 1993; Ward, 1964) o de la identificación del ritmo interno 
de distintos dichos, trabalenguas, rimas... (Orff, 1930, citado por Sanuy \& González, 1969).

E- La palabra tiene la ventaja de que da la acentuación correcta. Entonces, fíjate, jugabas con el sol, la luna, el pájaro o el carromato hasta la exageración. Y, por ejemplo, para el dictado rítmico tú hacías una frase y, enseguida, te cantaban sol-carromato-luna-pájaro... (EEx3, p. 15)

Partiendo de esta idea, desde principio de curso jugamos a adivinar el ritmo de distintas palabras y frases. Trabajar con texto dotaba de mayor significado a las actividades, resultando mucho más cercanas a la realidad de los niños. Para facilitar la identificación del ritmo, primero decían las palabras o las frases varias veces con letra para interiorizar cómo sonaban, pero luego las repetían utilizando solo la sílaba "ta", tal y como expresaba en mi diario.

Hemos estado escribiendo el ritmo de frases sencillitas, utilizando solo negra y dos corcheas, en primero, y negra, dos corcheas y silencio de negra, en segundo. Por ejemplo:

En primero:

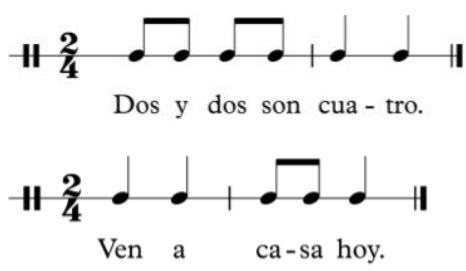

En segundo:
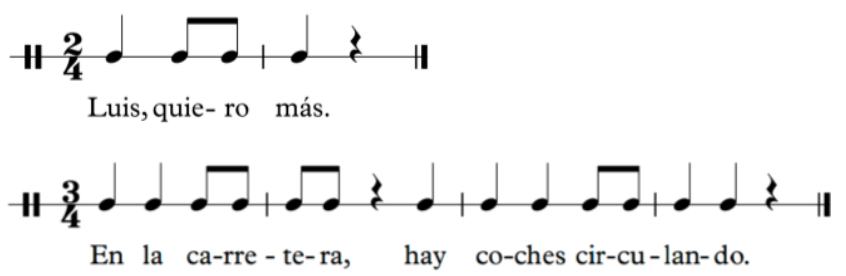

Para ello, primero hemos dicho la frase rítmicamente mientras marcábamos el pulso con palmadas o con el brazo y, después, hemos prescindido de la letra y hemos repetido solo el ritmo con la sílaba "ta", para percibir si en cada pulso entraba un "ta", dos "ta-ta" o si había un silencio. Esta actividad ha implicado explicar a los alumnos de primero el compás de $2 / 4$ como vagones de un tren en los que se podían meter solo dos pulsos de negra, cada uno de los cuales podía estar formado por una negra o dos corcheas "dadas de la mano". (DPO, p. 3)

Estas actividades previas sirvieron de introducción para el desarrollo posterior de un trabajo rítmico a partir de refranes, centrado en la 
discriminación y en la creación, el cual explicaremos en el siguiente apartado.

\subsection{Nuestra propuesta de trabajo rítmico discriminativo y creativo a partir de refranes}

A lo largo de todo el curso académico en el que pusimos en práctica nuestra nueva propuesta metodológica, desarrollamos en el aula un trabajo a partir de refranes que resultó de gran ayuda para que los alumnos mejoraran la discriminación rítmica y establecieran una relación entre el lenguaje verbal y el musical, comprendiendo la correspondencia entre las sílabas y las figuras, así como entre los acentos lingüísticos y los musicales. El análisis de dicho trabajo se presenta a continuación.

\subsubsection{Descripción de la propuesta}

Para pautar mejor el trabajo a seguir cuando se quiere identificar el ritmo de un texto, diseñamos unas fichas en las que, a partir de un refrán, había que completar una serie de pasos hasta llegar a escribirlo rítmicamente con la letra debajo; al final de las fichas se incluía también un último paso consistente en la creación de una nueva letra. Los siete refranes trabajados a lo largo del curso con los alumnos de primero tenían ritmos propios del compás de $2 / 4$ y un comienzo tético, y las fichas diseñadas para ellos constaban de cuatro pasos: identificación de las figuras y los silencios que aparecían en el refrán, separación del texto en sílabas, escritura del ritmo con el texto e invención de una nueva letra. 


\section{ESCRITURA RÍTMICA DE REFRANES ( $1^{\circ}$ Lenguaje Musical)}

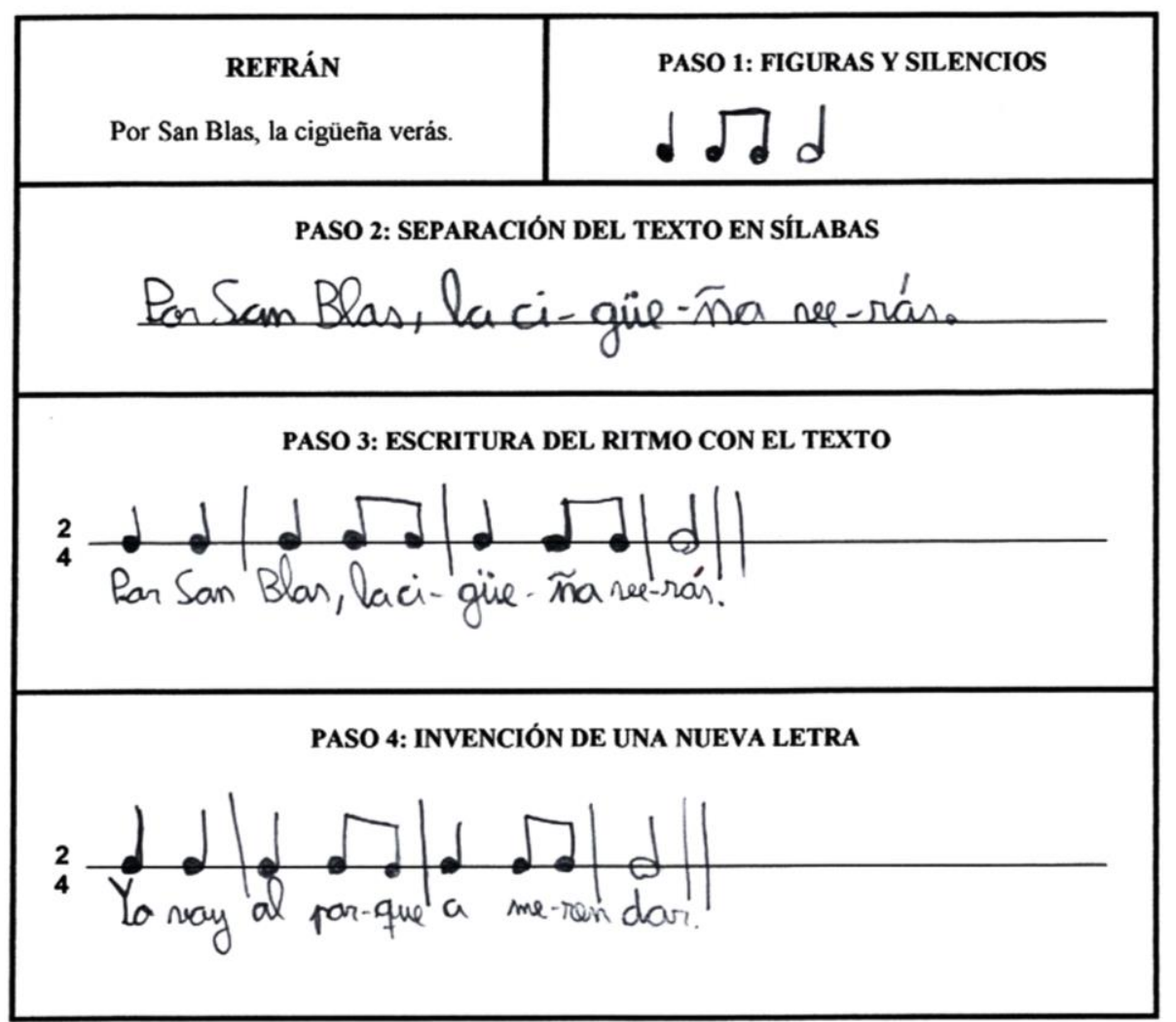

Figura 49. Refrán resuelto por un alumno de primero

Por su parte, los refranes trabajados con los alumnos de segundo podían estar en $2 / 4,3 / 4$ o $6 / 8$ y empezar de distintas formas, por lo que en sus fichas había dos pasos previos: identificación del compás (teniendo en cuenta el número de pulsos y la subdivisión binaria o ternaria) y el tipo de comienzo (tético, acéfalo o anacrúsico). 
ESCRITURA RÍTMICA DE REFRANES ( $2^{\circ}$ Lenguaje Musical)

\section{REFRÁN}

Fíate de la Virgen y no corras.

\section{PASO 1: IDENTIFICACIÓN DEL COMPÁS}

S Número de pulsos: 2 (3) 4

s Subdivisión: Binaria Ternaria

PASO 2: COMIENZO

Tético Acéfalo Anacrúsico

\section{PASO 3: FIGURAS Y SILENCIOS}

J. $\int, \square, d \cdot d$

\section{PASO 4: SEPARACIÓN DEL TEXTO EN SÍLABAS}

Fi.a-te de la vir-gen y 00 co-rorase

PASO 5: ESCRITURA DEL RITMO CON EL TEXTO

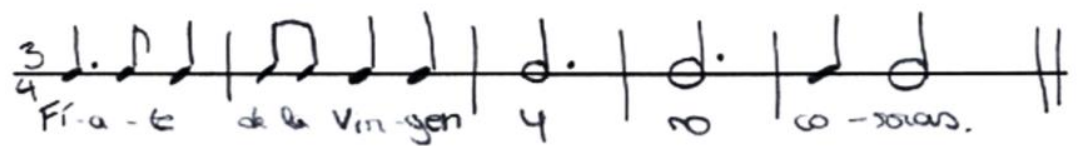

PASO 6: INVENCIÓN DE UNA NUEVA LETRA

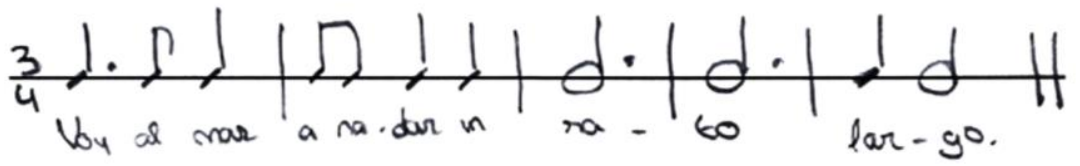

Figura 50. Refrán resuelto por un alumno de segundo 
La dinámica de trabajo para completar estas fichas era la misma que la descrita anteriormente para la escritura del ritmo de distintas frases, aunque se añadía un paso más: la creación de nuevas letras que respetaran la misma distribución de sus acentos musicales.

\subsubsection{Motivación de los alumnos hacia los refranes}

Las transcripciones de refranes eran, realmente, dictados rítmicos "encubiertos", pero resultaban más motivadores para los alumnos que la simple escritura de unos ritmos escuchados previamente.

P- ¿Hacer los refranes te gusta?

A20- (Asiente).

P- ¿Por qué?

A20- Porque aprendemos ritmos y letras para poner. (EG1CAsB, p. 5)

P- ¿Y qué es lo que más os ha llamado la atención de todas las cosas que hemos hecho este año?

A74- Los refranes.

$\mathrm{P}$ - Los refranes.

A74- Sí, hacer un ritmo y luego poner la letra, cantar los refranes, decir lo que pueden significar..., me ha impresionado. (EG2CAsD, p. 9)

Cuando les he dicho que era el último refrán que íbamos a hacer, varios han respondido: “¡Jo, qué pena!”, lo cual demuestra que les ha gustado mucho realizarlos. (DPA, p. 1)

$\mathrm{P}-\mathrm{Y}$ de los refranes, ¿qué me podéis decir?

A63- ¡Uy, a mí me encantan los refranes! (EG2CAsB, p. 14)

A70- Yo nunca me he imaginado que los refranes tuvieran un ritmo propio $\mathrm{y}$, poder escribir el ritmo y la letra y luego inventarte una, me ha parecido muy divertido. (EG2CAsD, p. 10)

Les llamaban tanto la atención y les resultaban tan divertidos que incluso jugaban con ellos en casa con sus padres y hermanos.

F- Lo de los refranes, más bien, lo que sí hace mucho es jugar con su hermana pequeña. Su hermana tiene seis años, entonces ellos ya lo han tomado como un juego, el hacer los refranes, pues en plan lo que hicisteis en la audición: "Perro ladrador..." (Lo dice rítmicamente mientras marca el pulso con palmadas). Pues a este tipo de cosas, le ha dado mucho por jugar con la hermana, más que contármelo a mí. Entonces ahora juegan, pues... a cualquier frase que se les ocurra, por ejemplo: "Qué difícil ha sido montar el Lego". "Qué difícil ha sido..." (lo dice rítmicamente mientras palmea). “¡No! Qué difícil... ¡No!” (lo dice con un ritmo diferente mientras palmea), 
y van probando. O sea, eso sí lo veo. Más que contármelo, lo repite y juega a ello con la hermana.

P- Juega a la clase de Lenguaje Musical (ríe).

F- Sí (ríe). (E1CF24, p. 4)

F- Y nos hemos visto hablándonos cantando, con el ritmo ese que tú les enseñas en clase y me dice: "Mamá, tráeme esto" (lo dice rítmicamente). Nosotros somos polacos, entonces lo hacemos en polaco, me habla en polaco cantando y yo le respondo, ¡y es un juego! Es un juego, sí.

$\mathrm{P}$ - ¿Es como el juego que hacemos con los refranes, lo que estás diciendo?

F- Sí, sí, sí, sí (ríe). (E1CF19, p. 2)

Lo que más les gustaba del trabajo con refranes era el último paso: poder inventar una nueva letra. Esto demuestra que lo que un niño crea por sí mismo es lo que le produce mayor satisfacción.

P- Los refranes también son ritmo, ¿no?

A64- Sí.

$\mathrm{P}-$ ¿Y los refranes te gustan?

A64- Un poco más porque, al final, tienes que crear la letra para el ritmo.

$\mathrm{P}-$ ¿Y eso te gusta?

A64- Sí. (EG2CAsD, p. 6).

A63- Pues a mí me gustan mucho porque esto es como una adivinanza: tienes que adivinar todo, con lo que has aprendido en todo el curso, vamos. Y te lo pasas muy bien haciendo los refranes, sobre todo el último ejercicio de poner la letra que tú quieres.

A63- ¡El inventar me mola mucho, a mí me encanta! (EG2CAsB, p. 15)

\subsubsection{Dificultades del alumnado para inventar nuevas letras}

Al principio a algunos alumnos les costaba encajar bien una nueva letra en el ritmo del refrán propuesto, porque no tenían en cuenta cómo sonaba el fragmento rítmico para escoger palabras que tuvieran esos mismos acentos, pero tampoco eran muy conscientes de ello.

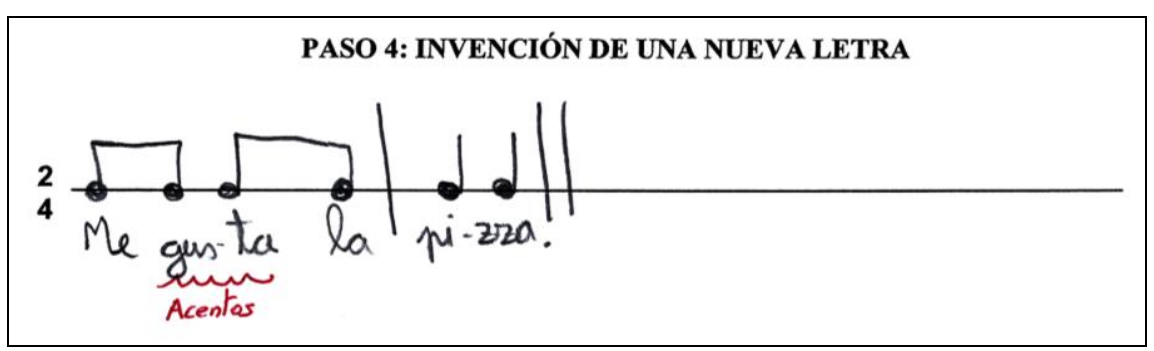

Figura 51. Errores cometidos por un alumno de primero al inventar una nueva letra 


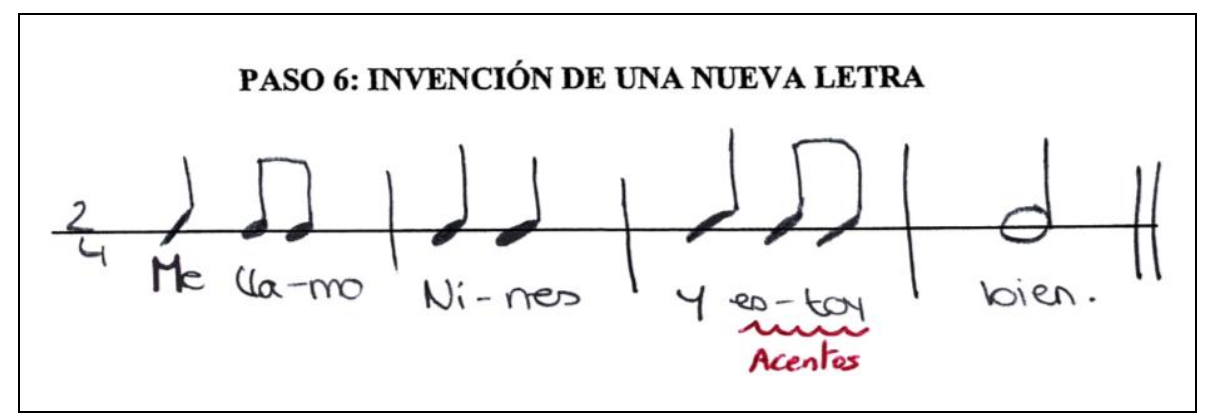

Figura 52. Errores cometidos por un alumno de segundo al inventar una nueva letra

Esta semana hemos trabajado con la primera ficha de refranes que les había preparado. [...] Debían inventarse una nueva letra que "sonara bien" con el mismo ritmo que habían escrito para el refrán y parece que a algunos les está costando entender cómo van los acentos musicales, a pesar de que los exageramos mucho para que los percibieran más claramente. No obstante, los alumnos han disfrutado con la tarea y no han sido conscientes de sus errores con los acentos ya que, cuando les he preguntado qué les ha parecido la actividad, me han respondido: "muy fácil", "bien", "divertida". (DPO, p. 6)

Para hacerles comprender sus errores, hacíamos varias veces el fragmento rítmico con la sílaba "ta" hasta que interiorizaban su sonoridad y luego lo decían con su letra para comprobar si había alguna palabra que sonara mal. De esta manera, fueron mejorando hasta conseguir un ajuste perfecto entre los acentos lingüísticos y los musicales.

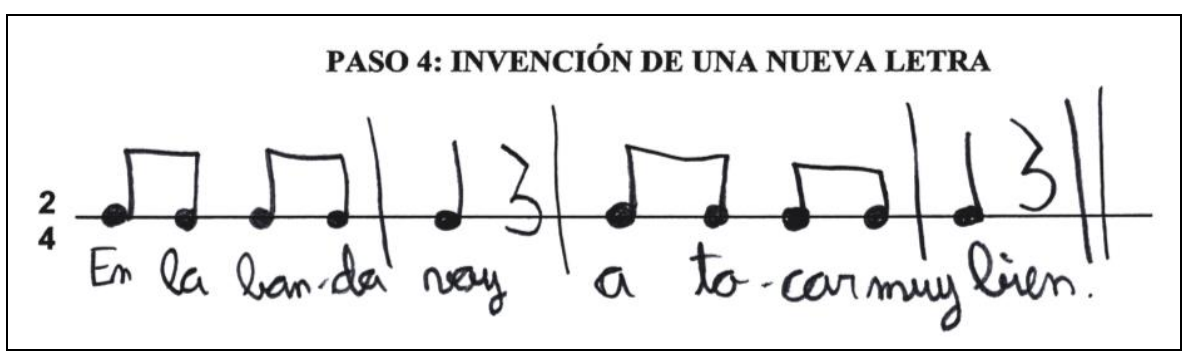

Figura 53. Letra correcta inventada por un alumno de primero 


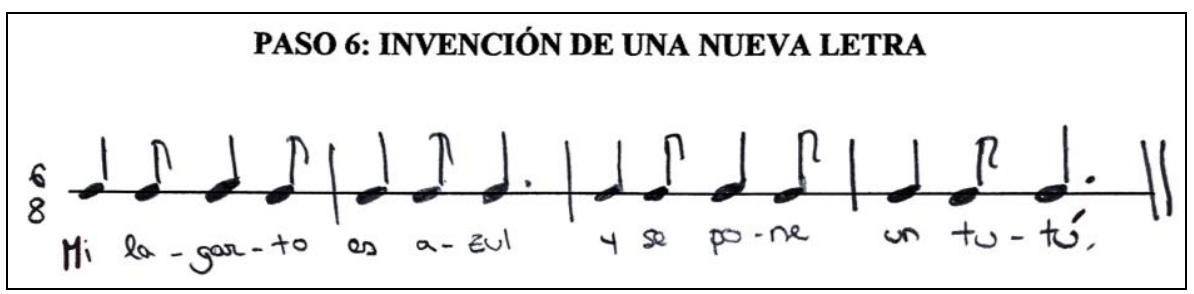

Figura 54. Letra correcta inventada por un alumno de segundo

P- Inventarte tú otra nueva letra no te resultaba fácil.

A41- No.

P- Hemos hecho muchos refranes, ¿te resultaba igual de difícil al principio que al final?

A41- Eh... (niega con la cabeza).

P- ¿No? ¿Cuándo te resultaba más fácil?

A41- Pues al final.

P- Al final. ¿Ya te salían mejor las letras?

A41- Sí. (EG1CAsF, p. 10)

Resultaba curioso comprobar que en sus invenciones había temas muy recurrentes, especialmente los relacionados con animales.

F50- Sí, el comentario era: “Tienes que ver la exposición” y estuvimos viendo todos los carteles con todos los refranes. ¡El perro y el gato aparecían por un montón de sitios!, ¡con los animales era increíble! No sé si es que lo ven tan próximo o no sé si es que la televisión les influye a nivel de dibujos animados, donde los animales perro y gato son los protagonistas en gran parte de esas series. ¡Y era curioso, era simpático!

P- A mitad de curso tuve que prohibirlo: “ $¡ Y$ Ya no hay más perros!, porque ya me lo habéis puesto azul, me lo habéis matado, me lo habéis dado de comer, lo habéis sacado a pasear..."

Fs- (Ríen). (EG2CFs, p. 21)

\subsubsection{Utilidad del trabajo realizado a partir de refranes}

Además de servir como elemento motivador, el trabajo con refranes ha resultado de gran utilidad para:

- El desarrollo del sentido rítmico de los alumnos.

A6- Yo creo que aprendemos un poco a mejorar el ritmo. Haciéndolo con "ta" y con frases, yo creo que se mejora en ritmo. (EG1CAsA, p. 16).

$\mathrm{P}-$ ¿Y a nivel musical crees que los refranes te han ayudado en algo?

A28- Sí, a saber sacar el ritmo de una canción o de alguna cosa que tenga ritmo. (EG1CAsC, p. 16) 
- El establecimiento de vínculos de unión entre el lenguaje verbal y el musical.

P- Quería preguntarte qué opinas del trabajo que hacemos con los refranes, en los cuales tienen que ir adivinando el ritmo y luego jugar con el lenguaje. $\mathrm{T}$ - Me parece genial, me parece una idea muy acertada que ellos se vayan familiarizando con el lenguaje musical a través del lenguaje común, que es el que aprendemos todos desde pequeños, ¿no? Me parece que establecer ese paralelismo es estupendo y les puede facilitar mucho el aprendizaje. De hecho, creo que es así: con algo que ya tienen muy interiorizado y con lo que están muy familiarizados, les enseñas otro lenguaje, o les aplicas otro lenguaje y así van aprendiendo dos lenguas a la vez, por así decirlo, la lengua común y la lengua musical. (ETO, p. 3)

- La conexión con otras artes y la cultura popular de su entorno.

P- Ahí tenemos algunos de los trabajos que han estado realizando los niños. ¿Qué opinas del trabajo que hacen con los refranes?

T- Genial. A mí me parece que si podemos aunarlo con otro tipo de artes, por así decirlo, ¿no? (ríe), a mí me parece estupendo. (ETPiJE, p. 3)

A28- Que a mí los refranes me han gustado porque aprendes dichos y luego te gusta decirlos cuando sabes lo que significan. (EG1CAsC, p. 16)

Asimismo, señalaremos que el trabajo con refranes ha servido para preparar el camino hacia la actividad principal de nuestra propuesta metodológica: la creación de sus propias canciones. Realizar las fichas de los refranes les resultaba más sencillo que crear canciones porque en estas últimas, además del ritmo y del ajuste entre música y texto, debían tener en cuenta los aspectos melódicos, armónicos y formales, de todo lo cual hablaremos en el siguiente apartado.

P- ¿Y cuántos errores cometéis en los refranes, muchos o pocos?

As- Pocos.

A63- Menos que en las otras cosas.

As- Pocos.

A63- Es que son más fáciles.

A58-Sí.

P- ¿Por qué crees que es más fácil hacer refranes que hacer canciones?

A54- Porque no hay que escribir las notas. (EG2CAsB, p. 15).

\section{Los contenidos melódicos y armónicos}

La música se compone de tres elementos básicos: el ritmo, la melodía y la armonía, los cuales Willems (1984a) distribuye en tres niveles, de tal manera 
que cada uno de ellos implica los anteriores, es decir, la melodía implica el ritmo y la armonía implica tanto el ritmo como la melodía.

En este apartado nos ocuparemos del análisis de los contenidos melódicos y armónicos trabajados en el aula a partir de nuestra propuesta metodológica.

\subsection{Entonación y discriminación auditiva: relaciones y dificultades}

Existe una relación clara entre la entonación y la discriminación auditiva, ya que la calidad de ambas depende, entre otros factores, de un buen desarrollo del oído interior (Berrón, 2012).

E- El oído interior no puede existir si no hay unas imágenes producidas por sensaciones porque, si tú no has oído e identificado una serie de elementos musicales, no puedes luego verlos escritos e imaginarlos sonando .Para tener una entonación correcta, tú tienes que tener un oído interior hecho a base de muchas experiencias exteriores que te dejan un sedimento de modelos de los que tú echas mano cuando te hacen falta. (EEx3, p. 47)

E- Evidentemente, si tú vas fraguando en el alumno una imagen de un acorde o de un conjunto de notas, cuando los oiga va a poder reconocerlos y, cuando los vea, los podrá entonar: es un proceso que va así. (EEx1, p. 12)

Esta estrecha relación provoca que las dificultades de un campo también se puedan manifestar en el otro, aunque haya alumnos que tengan más facilidad en uno de ellos.

E- Las dificultades de entonación y de percepción auditiva son paralelas, es decir, que la una acarrea a la otra porque están muy relacionadas entre sí, de forma que, quien no es capaz de oír de una forma discriminada, también tiene dificultades para entonar, y lo contrario. Es verdad que hay personas que son mejores en un campo que en otro, pero hay una clara relación y paralelismo entre ambas. (EEx1, p. 25)

P- Según su propia experiencia en las aulas, ¿podría afirmar que los alumnos que tienen dificultades en entonación también las manifiestan en dictado, y viceversa, o no se da necesariamente esta relación?

E- En algunos casos, sí. Es evidente que el alumno que suele tener problemas con el dictado también lo tiene en la afinación o entonación musical. Lo que también se da alguna vez es un alumno que hace muy bien los dictados, pero luego presenta más dificultades en la entonación. En este último caso, suele ser una cuestión de timidez la que determina la interpretación. (EEx2, P. 8)

E- Están relacionadas, pero puede haber problemas de fonación, como los problemas típicos de los cambios de voz, o problemas de inhibición que 
interfieren en la entonación, aunque es verdad que, en general, el niño que oye bien reproduce suficientemente bien, aunque su voz no esté especialmente educada. (EEx3, p. 32)

Para desarrollar la educación vocal en el aula, los expertos proponen distintas estrategias metodológicas, como las que se recogen a continuación:

E- Yo, personalmente, empiezo trabajando con dos sonidos, después tres, luego hago lo que yo llamo la "pentafonía vía heptafonía", porque la pentafonía tiene la ventaja de facilidad la improvisación con ella, ¿no? Yo siempre he escrito mucho en la pizarra los sonidos que vamos integrando, por ejemplo, do, re, mi, sol, la, do', y hacemos melodías simplemente con eso. (EEx3, p. 35)

E- En primer lugar, la educación vocal la trabajo preparando la voz con diferentes ejercicios de relajación, respiración y vocalización. En segundo lugar, trabajo el repertorio propuesto en cada curso atendiendo especialmente al ritmo musical y a la afinación. Como estrategias metodológicas, intento variar la forma de trabajar cada canción y ofrecer al alumno múltiples recursos: análisis previo de la pieza, aprender la canción por imitación sin saber aún qué estamos cantando en relación a los contenidos (rítmicos y melódicos) para después extraer y trabajar conscientemente dichos contenidos, o viceversa, estudiar la pieza separando los contenidos rítmicos y los contenidos melódicos, etc. (EEx2, p. 4)

E- Si quieres llegar a una visión del intervalo muy rápida y de cualquier tipo de entonación, hay una serie de pasos que tú tienes que dar resueltos. Uno, por supuesto, es que la lectura no te cueste trabajo, que tú puedas llevar una anticipación, anticipación que te permite no solamente saber qué sonidos son, sino en qué relación interválica están y, además, echar mano de tus recursos de cómo suena ese intervalo. [...] Aparte, estoy trabajando el intervalo de tercera, o de quinta, o de cuarta aislado, como tal, pero luego, además, lo hacemos a partir de sonidos determinados, con lo cual juega también el concepto de si hay alteración o no la hay. (EEx3, pp. 20-22)

Por su parte, para llevar a cabo la educación auditiva también proponen actividades como las siguientes:

E- Tú tocas una canción bien estructurada en los primeros momentos y dices: “¿Cuántas frases tiene?” Y te dicen: "Dos, tres...” "Avisadme dónde termina la primera". "Cuando vas ahí". Esto es importantísimo, porque estás dando también unas bases formales de estructura. (EEx3, p. 18).

E- La educación auditiva la trabajamos a través de diferentes actividades que tienen como finalidad escuchar y reconocer los elementos del lenguaje musical. En nuestro método aparecen estructurados ejercicios de audición, atendiendo a diferentes aspectos del lenguaje (ritmo, melodía, armonía, 
forma, expresión, etc.). Los ejercicios son variados: reconocer, discriminar, completar, etc. (EEx2, p. 5)

E- Un niño entra en clase el primer o el segundo día y le dices: "Voy a tocar una cosa”, y te paras y dices: “¿Pregunta o respuesta?” Estás en una dominante y te dice: "Pregunta" Y sigues preguntando: " $\mathrm{Y}$ ahora como terminaríamos?", te paras y te canta la tónica, sin ponerle nombre. ¿Qué es esa aculturación? Ellos tienen toda una serie de modelos metidos de los que no son conscientes y que tienen que aflorar, eso a mí me parece vital.

$\mathrm{P}$ - Entonces, lo que tienen es el contexto tonal ya metido.

E- Por supuesto, pero lo tienen metido porque están oyendo música muy tonal constantemente porque, claro, toda la música moderna, desde el punto de vista armónico, es muy simple y tiene unas cadencias muy determinadas. (EEx3, p. 7).

Pero el recurso fudamental para el desarrollo auditivo es la propia voz, tal y como señalan la mayoría de los autores (Ballesteros \& García, 2010; Raya, 2011; Tafuri, 2008). Así lo reconocen también los expertos entrevistados:

P- ¿Y qué recursos son más convenientes para favorecer el desarrollo auditivo: la voz, el instrumento que está estudiando el alumno, el piano del profesor, instrumental Orff, gestos corporales, cualquier otro...?

E- Todos son buenos, pero el más importante es la voz. Yo no concibo a un alumno de ningún instrumento al que le diga: "Canta" y que me diga que no sabe cantar. Yo siempre les digo a mis alumnos que canten, muchas veces. En la clase, como tú sabes, de alumnos de piano, de violines... se juntan todos y tienen su instrumento $\mathrm{y}$, a lo mejor, tienen un nivel alto, pero les digo: "Esto vamos a cantarlo antes de tocarlo ahí", porque la sensación sonora del instrumento natural que tenemos aquí cada uno de nosotros (se señala la garganta), es la que sirve para asociar realmente y para comprender la esencia de lo que después tocamos. (EEx1, p. 16)

E- La voz es un recurso imprescindible para trabajar la audición. Intentamos cantar siempre todos los ejercicios que realizamos. Además, por ejemplo, se utiliza como recurso para ver cómo suena lo que han escrito en un momento dado y compararlo con lo que ha sonado en realidad. Los gestos corporales asociados al sonido los utilizamos especialmente en el primer curso. Utilizamos el piano, a veces otros instrumentos (así ellos participan directamente en el desarrollo de esta actividad, tocando un ejercicio concreto) y también utilizamos audios o el blog, en el que ofrecemos diferentes dictados musicales. (EEx2, p. 5)

En el campo musical, es más importante tener un buen desarrollo a nivel auditivo que a nivel vocal, es decir, es mejor tener un buen oído que una buena voz, ya que lo segundo es más fácilmente educable (López de Arenosa, 2008b). 
P- ¿Qué considera más importante, tener una buena voz o tener un buen oído?

E- Oído, mejor. A veces hay niños que no entonan una cosa, pero porque no se les ha educado adecuadamente para entonar una cosa, pero, cuando la escuchan, la reconocen y eso es muy importante. Si lo reconocen escuchando, lo otro es menor. (EEx1, pp. 12-13)

El desarrollo del oído musical tiene lugar durante los primeros años de vida (Tafuri, 2006; Willems, 2001) y pueden surgir dificultades si la exposición a los estímulos sonoros no es la adecuada.

T- Nuestro principal problema y el principal problema de mis alumnos, no solo en este primer ciclo de elemental, sino cuando llegan a profesional, es que nuestros instrumentos están afinados o desafinados.

$\mathrm{P}-\mathrm{O}$ desafinados.

T- Eso, que es el problema. Si estuvieran afinados no tendríamos ningún problema, pero nuestros instrumentos están desafinados y eres capaz de escuchar un concierto de marimba, o eres capaz de estudiar diez años en este conservatorio, cuando sabemos que tenemos una marimba que tiene el si bemol y el $f a$ desafinados. Pues este alumno solo escucha esta marimba y realmente es un problema tener un instrumento desafinado. (ETPer, p. 3)

Los expertos consideran importante desarrollar los dos tipos de oído musical que existen: el relativo y el absoluto (Alborés, 2008; Malbrán, 2007a; Miranda, 2003), pero inciden mucho más sobre el primero, ya que es mucho más útil y práctico. Además, a nivel educativo es en el que más se puede intervenir.

E- Hablábamos del oído relativo y del absoluto, y te digo que el relativo por encima de cualquier otra cosa. Ten en cuenta que puedes tener un alumno que toque un saxo o un clarinete y, para ellos, lo absoluto no tiene que ver nada con lo tuyo. Tú tocas con el piano un sol y ellos tocan con su instrumento un sol y no suenan igual, ¿por qué le vas a crear un trauma a este hombre diciéndole que tu sol no es el sol? Bueno, puede ser que no sea el sol, pero es el suyo. No, relativo, siempre relativo. (EEx1, p. 17)

P- En el entrenamiento auditivo, ¿da más importancia al oído absoluto o al oído relativo?

E- Es importante desarrollar ambos tipos de audición, aunque incido más en el oído relativo, es decir, me interesa sobre todo que el alumno aprenda a entonar correctamente la distancia entre las notas (intervalos) a partir de una referencia dada. [...] Hay ejercicios que favorecen el desarrollo del oído absoluto como, por ejemplo, hacer dictados de notas fuera de cualquier tonalidad aunque, evidentemente, este tipo de ejercicios se hacen en cursos más avanzados. En general, escuchar mucha música y situar la tonalidad de cada obra puede afianzar el desarrollo del oído absoluto. (EEx2, p. 6) 
E- Yo te voy a decir una cosa, a riesgo de que haya quien lo discuta: el oído absoluto, en sí, no existe, en mi opinión. Lo que existe es una gran memoria del sonido. [...] El la del diapasón es una convención que ha estado más alta o más baja. Entonces, lo que es convencional no puede ser innato. Otra cosa es que la memoria sea muy buena y, al identificar un sonido, luego lo pueda reproducir siempre. En mi opinión, es que es de cajón, nadie tiene de innato lo que es convencional. (EEx3, p. 46)

Por otro lado, las principales dificultades que encuentran los alumnos en el campo de la entonación están relacionadas mayoritariamente con un desarrollo deficiente del oído interior, ya que, al preguntarles directamente a qué creen que se deben, destacan la falta de conocimiento del sonido asociado a cada nota musical y la falta de estrategias para adivinar cómo suena una nota que no tienen interiorizada. Asimismo, reconocen que entonar les genera nerviosismo y bloqueos, seguramente debido a una falta de dominio de la propia actividad (gráfica 2).

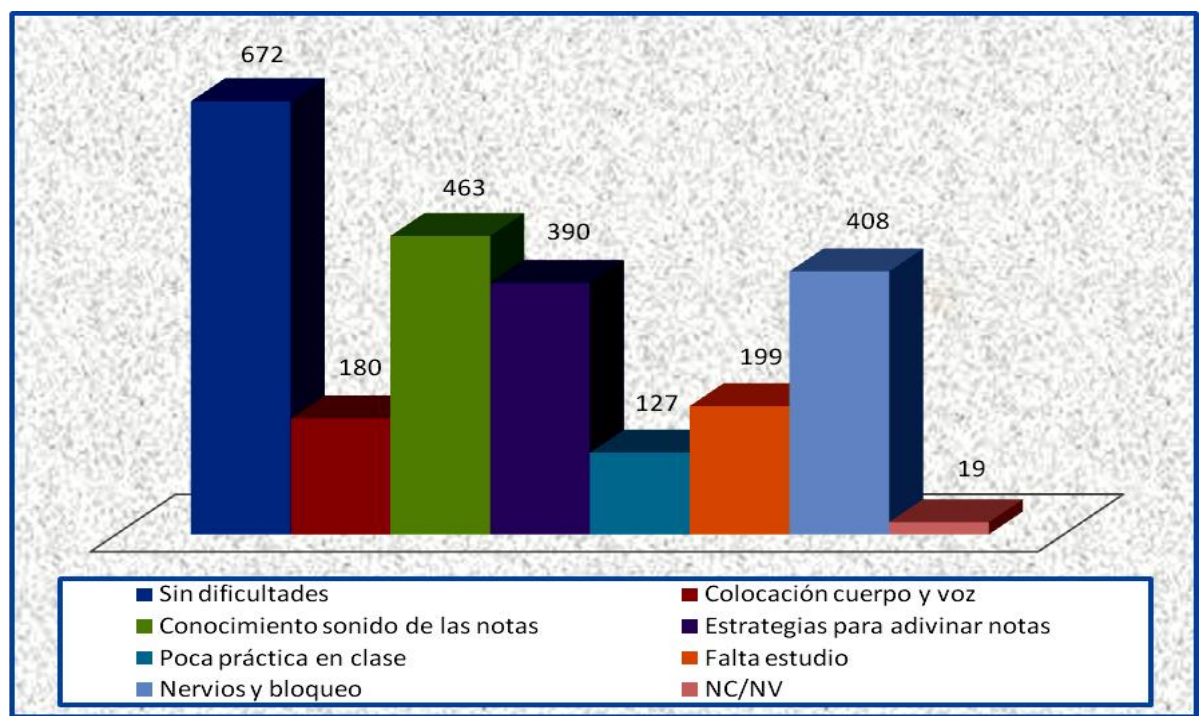

Gráfica 2. Respuestas de los alumnos a la pregunta 11 de los cuestionarios: Considero que mis dificultades en entonación se deben a:

En este sentido, las dificultades de entonación que han encontrado los expertos y los tutores en sus alumnos, así como los motivos que las justifican, son las siguientes:

E- El primer problema que existe para la entonación está relacionado con la sociedad en que vive cada uno. Es decir, aquí en España, en los colegios, sobre todo en el sur, no se canta, se canta muy poquito. [...] Tú vas al norte 
y, cuanto más al norte vayas, mejor canta la gente. Y tú vas a Alemania y la gente se reúne para cantar a dos voces, tres voces... La cosa es la siguiente: el niño que no tiene desde pequeño un entorno familiar de cantar, cuando va a un colegio y le dicen que cante le da vergüenza, porque piensa que eso es de niñas $\mathrm{y}$, a lo mejor, las niñas cantan, pero los niños no, los niños son muy machos y no cantan, porque eso de "la la la" (entonando), cantar con gusto y todo eso, parece de tontos; ser bruto está mejor visto. (EEx1, p. 23)

E- Los problemas que me he encontrado mayoritariamente son el cambio de voz de los chicos en la pre-adolescencia. (EEx2, p. 8)

T- Mis alumnos tienen que cantar todo lo que hacen, tienen que solfear todo lo que hacen, esto antes de tocar, o sea, yo antes de coger la partitura tienen un trabajo previo que es ineludible.

$\mathrm{P}-i \mathrm{Y}$ no te encuentras a ninguno que lo cante mal pero lo escuche bien?

T- ¿Que lo cante mal pero...? Sí, a veces, claro, sí pasa, que la voz no responde a sus pensamientos, el instrumento no le responde, sí, sí pasa. Sí tengo varios casos de esos, pero van mejorando poco a poco. [...] Es gente que normalmente nunca ha cantado. [...] Si lo oyen bien, es que tienen oído, pero cuando no lo saben manifestar, no lo saben reproducir, es que no han trabajado esto (se señala la garganta) y se puede trabajar. (ETV, p. 6)

Como hemos comentado anteriormente, si el oído funciona bien, los problemas de entonación se pueden corregir fácilmente con una buena educación vocal (Berrón, 2012), aunque para ello es fundamental que el profesor tenga la capacidad de adaptarse al alumno para transmitirle seguridad y poder guiarle poco a poco.

E- Hay que guiarlos poco a poco. Esos son problemas que hay que resolver. Primero, el profesor debe saber tocar en cualquier tono y buscar el acompañamiento en el tono en que el alumno está cantando para atender a ese alumno. La canción esta en do mayor, ¿vale?, pero puede llegar a tocar en si bemol, en la, en sol, en el tono que haga falta para atender al alumno. Eso es complicado, pero es la misión del profesor. Busca al alumno, busca el tono y acompaña y, entonces, el alumno sabe que es capaz de cantar, se valora a sí mismo. (EEx1, p. 17)

E- Al alumno hay que transmitirle confianza. Es una fase complicada para ellos, ya que se encuentran bastante desorientados. En este caso, adapto el registro de las piezas que trabajamos a sus posibilidades. (EEx2, p. 8)

E- Yo te voy a dar una posible solución para cantar en grupo. Cuando todos cantan a una altura y otro canta a otra, haz que todos canten a la altura del que no puede ir a la altura de los demás, no al contrario. O sea, no hagas que canten todos aquí arriba, no hagas que cante este que no puede, porque si no puede es porque no puede. Pero, si los otros cantan bien, seguramente sí pueden cantar más bajo, porque eso lo hacen bien y te siguen tu voz; entonces, tú baja la voz donde está este. [...] Al principio, consigues más 
bajando a los demás para que se lo suban todos, o sea, los demás se lo suben, tú no. Pero cuando él sepa que no tiene ningún problema. (EEx1, pp. 24-25)

Los alumnos y sus padres también reconocen fácilmente cuándo presentan dificultades para colocar la voz y entonar con afinación.

A31- En lo que más dificultad he tenido era en lo de la entonación, que al principio no entonaba bien, no llegaba a las notas. (EG1CAsC, p. 23)

P- ¿Le ves dificultad en algún apartado?

F- En la parte, a lo mejor, de entonación le noto que no coge, a veces, bien las notas, el tono de las notas. Rítmicamente, yo creo que no tiene ningún problema, pero el apartado de la entonación quizá sí le cuesta. A lo mejor, oyendo la música una o dos veces, ya él se coloca o coloca el tono en la posición. (E2CF45, p. 3)

Generalmente, los alumnos a los que les cuesta cantar lo pasan mal, especialmente si son adultos, porque las dificultades son mucho más difíciles de solucionar que cuando son pequeños y los avances son muy lentos (Tafuri, 2006).

A36- [...] canto muy mal, y entono muy mal. Me cuesta mucho entonar. (El alumno 36 es adulto y ha empezado sus estudios musicales este curso). [...] P- ¿Pero consideras importante que cantemos?

A36- Sí, sí, para identificar las notas y todo, pero cuesta. (EG1CAsF, p. 20)

E- Estos padres que van a llevar a sus hijos y, después, se apuntan ellos y ellos no han cantado nunca, ese padre nunca cantará. Es imposible. Esto es muy fácil corregir a los cuatro o cinco años, es también fácil a los siete $u$ ocho, es muy complicado a los trece o catorce y es imposible a los veinte. (EEx1, p. 23)

Pero con un buen trabajo pedagógico y constancia siempre se consigue mejoría, lo cual les anima a continuar esforzándose.

F- Al principio, entonar no le gustaba nada. Pensaba que lo hacía muy mal, le daba mucha vergüenza. [...] De repente, ha mejorado un poco de golpe. No llega a entonar muy bien, pero también ha mejorado y yo creo que él se da cuenta. Entonces, ahora le gusta ponerse en casa con las canciones e intentarlo. (E1CF24, p. 6)

A36- El enfrentarte a ello, pues te ayuda. Si no lo haces, pues... como que te quedas trabado. Yo canto muy poco y ya estoy adelantando a base de... (hace con las manos el gesto de repetir).

$\mathrm{P}-$ ¿Vas notando progresos poco a poco?

A36- Sí, pero muy poquito a poco. Me cuesta entonar e identificar los sonidos, aunque he notado mucha mejoría. (EG1CAsF, p. 20) 
Por su parte, los niños que disfrutan cantando se divierten mucho interpretando canciones y ejercicios de entonación.

F14- Bueno, ella lo de la entonación... Ella tiene su reproductor y se pone su CD y se puede tirar horas, empieza el libro y acaba con la canción veinte o con la veinticinco ¡y le da igual! ¡Ya me las sabía de memoria!, ¡fíjate que eran notas y yo me las sabía de memoria! "A14, siempre cantas lo mismo", y decía: "No, mamá, es que parece igual, pero no lo es". Ella, cuando tenía que estudiar la entonación, era feliz. (EG1CFs, p. 20)

F5- Se ha notado mucho toda tu asignatura porque ha seguido cantando y cada vez más, o sea, ella está constantemente cantando, le tenemos que decir que se calle, porque es que no podemos con ella. (EG1CFs, p. 7)

F25- Mi hija pequeña le dice: “A25, ¿te quieres callar ya?, ¡que es que ya me tienes harta, que no puedo ya escucharte más, que siempre cantas lo mismo!", y le dice muy serio: "Los niños que vamos al conservatorio tenemos que cantar mucho, o sea que...” (ríe). (EG1CFs, p. 20)

Terminaremos este apartado sobre el desarrollo vocal y auditivo señalando que, si la intervención educativa es adecuada desde que los alumnos son pequeños, sus progresos en los dos ámbitos pueden ser brillantes, sorprendiendo tanto a los niños como a sus padres.

He aprendido a afinarme. (CA1C, pre. 2)

Estoy aprendiendo a identificar las notas y los sonidos, cosa que no tenía ni idea. (CA1C, pre. 2)

F- Me sorprende también mucho que su padre toca la guitarra cifrada, pero, a lo mejor, le dice: "Mira, voy a cifrarme esta partitura", iy se la entona perfectamente!, o sea, ¡nos deja impresionados!, porque la coge y ella, perfectamente, te entona ya las notas, sin haberla escuchado nunca antes. No creas que primero lo mide sin entonarlo, ¡no, no!, ¡es que lo entona directamente! Entonces eso me sorprende mucho, porque a mí me parece difícil. (E1CF2, pp. 3-4)

\subsection{Trabajo de la entonación y la educación auditiva desde el marco tonal-armónico}

En la educación musical hay muchos aspectos que damos por supuestos, quizá porque los aprendimos así de pequeños y están muy generalizados en nuestro entorno, pero, si echamos un vistazo a nuevas tendencias o a lo que se hace en otros países, comprenderemos que no tienen por qué ser así necesariamente. Por ejemplo, nos encontramos con que no se canta diciendo el nombre de las notas en todos los lugares. 
E- Los ingleses y los americanos no saben cantar con: do, re, $m i, f a, s o l, l a$, si... (entonando). Eso se lo das a un inglés y ellos no cantan así, no saben cantar así.

P- ¿No cantan con notas?

E- No, no, no.

$\mathrm{P}-$ ¿Y cómo cantan?

E- (Tararea entonando). La, la, la, la... Es decir, saben entonar lo que hay que entonar, pero no lo identifican con un nombre. Lo identifican con su sonido y con su sitio en el piano.

P- (Con sorpresa) ¡Fíjate! [...]

E- No te sorprendas, no existe eso de cantar: $d o$, re, $m i$, fa, sol... nada más que en los países latinos, es decir, en: Italia, Portugal, España, creo, no estoy seguro, si en Grecia, y en parte de Francia, pero en los países nórdicos no existe,

$\mathrm{P}$ - Es interesante.

E- ¡Y viven muy bien! (EEx1, pp. 7-8)

Además, estamos acostumbrados a ver que tanto la educación vocal como la auditiva se trabajan combinando múltiples recursos motivadores y estimulantes, pero partiendo de las escalas y de los intervalos, dejando para las enseñanzas profesionales el estudio de los aspectos armónicos que los sustentan y dotan de significado en nuestro contexto tonal.

E- Intentamos variar siempre las dinámicas del grupo. Hacemos muchas actividades grupales, pero también individuales o en pequeños grupos. Trabajamos sentados o de pie, según la actividad, con acompañamiento y sin él. Una manera de trabajar que utilizo bastante y que está favorecida por la disposición de la clase (sillas colocadas en forma de U) es hacer determinados ejercicios en rueda, lo cual favorece mucho la concentración y atención del grupo, entre otras cosas.

P- En casa, ¿cómo trabajan la entonación?, ¿cantan a capela?, ¿utilizan su instrumento, un CD u otro tipo de apoyo?

E- Tienen las canciones en el CD para reforzar y mejorar lo ya trabajado en cada clase. También se ayudan de su instrumento, ya que hay muy buena relación entre ambas asignaturas, de tal manera que el alumno acaba tocando las canciones de Lenguaje Musical con el instrumento que está estudiando en el conservatorio. También, si disponen de ello, se ayudan del teclado. Otro recurso interesante para darse cuenta de qué están haciendo y cómo lo están haciendo es grabarse a sí mismos cantando. Al final, el objetivo es que entonen correctamente a capela. (EEx2, p. 5)

No obstante, el planteamiento pedagógico desarrollado en esta tesis consiste en basar la educación vocal y auditiva, ya desde los primeros niveles, en la música tonal (Cañada, López, \& Molina, 2005; Molina, 2004), partiendo del acorde y de las funciones armónicas básicas de tónica, dominante y subdominante para, desde ahí, comprender todo el desarrollo melódico, teniendo en cuenta, asimismo, aspectos formales que den coherencia a las 
composiciones musicales, por sencillas que sean. La idea surgió de las conversaciones mantenidas con los expertos entrevistados.

E- Yo recuerdo, manejando entonces todos los métodos que había por todas partes, algún francés que partía del acorde perfecto y a mí eso me pareció verdaderamente interesante porque, claro, nuestra música es básicamente tonal. Entonces, yo también he partido del acorde perfecto. (EEx3, p. 11)

E- El alumno no tiene referencias de todo hasta que no las escucha. Entonces, si tú te sientas al piano y haces un acompañamiento sencillo para la canción aquella y le enseñas a cantar, el alumno la escucha con toda su plenitud y es capaz de cantarla mejor. [...] Tú acompañas al piano o a la guitarra, o con el instrumento que sepas; si sabes tocar un clarinete, pues acompaña con un clarinete; acompaña, ¿eh?, no toques la misma melodía. (EEx1, p. 15)

E- Cuando la melodía tiene carácter de final y, sin embargo, tú haces una armonización que no se corresponde, te dicen: “¡No, no, eso está mal!” Y la cambias y preguntas: “ ¿Te gusta esta otra?” Entonces, estás aflorando toda una serie de conceptos que tienen integrados y que luego, naturalmente, te van a servir para denominar y para utilizar ya como herramienta, pero herramienta que ellos también saben que manejan. Hasta el punto que ellos, en realidad, enseguida te pueden hacer una armonización de una canción. (EEx3, p. 9)

E- Yo hago muchos tipos de ejercicios. En principio, el trabajar con un acorde; con "trabajar" quiero decir cantar o tocar el instrumento con un acorde, diciendo notas o sin decir notas. Después, pasamos a estructuras armónicas de cuatro compases sencillas: I-V-V-I, I-IV-V-I. Esas estructuras se cantan con notas, se crean motivos, se tocan al piano o con el instrumento de cada uno siguiendo los acordes y se inventan melodías en base a los motivos dados. (EEx1, p. 25)

Tal y como señala Lasuén (2014, p. 351), en los últimos años han aparecido varios libros de texto de Music Theory que utilizan ejemplos de muy diversa procedencia -músicas populares, urbanas, folclore, etc.- para explicar conceptos de armonía tonal. Uno de los más consolidados es The Musician's Guide to Theory and Analysis (Clendinning \& Marvin, 2011), pero se podrían citar otros como los propuestos por Roig-Francolí (2011) o Laitz (2012).

En este sentido, algunas de las estrategias metodológicas que hemos llevado a cabo en el aula experimentalmente utilizando como eje vertebrador las bases de la armonía tonal han sido las siguientes, descritas en mi diario de clase: 
Durante esta semana, al mismo tiempo que reforzábamos los contenidos vistos en las clases anteriores, en todos los grupos he introducido el concepto de acorde, como conjunto de notas que suenan a la vez y que nos producen una determinada sensación (sin entrar en más detalles). Tanto en primero como en segundo he presentado directamente los acordes de dominante y de tónica, para que sientan el contraste entre la tensión del primero y el reposo del segundo. Hemos jugado con ambos, levantando los brazos cuando lo que escuchaban les producía sensación de tensión y bajándolos cuando sentían reposo. Al principio les ha resultado muy fácil, porque yo tocaba los acordes en el piano en una única posición, pero luego he ido cambiándolos de posición y de octava y me he dado cuenta de que así ya no lo tienen tan claro, lo cual era de esperar, pero confío en que es solo cuestión de práctica. De momento no me interesa explicarles cómo se forman ni enlazan los acordes, sino que aprendan a reconocerlos auditivamente y a utilizarlos, entendiendo la relación que tienen con las notas de la melodía. Por tanto, después de jugar a representar dichos acordes con movimientos corporales, les he pedido que fueran escribiendo una $\mathrm{D}$ (dominante) o una $\mathrm{T}$ (tónica) en el cuaderno, en función de lo que fueran escuchando. Esta actividad también les ha resultado muy sencilla, porque, nuevamente, he utilizado una única posición para cada acorde y los niños han reconocido fácilmente cuando se producía un cambio. Después les he presentado en la pizarra cómo se escribían dichos acordes, sin pretender que lo comprendieran, sino que lo aprendieran como una imagen: primero en posición fundamental, diciéndoles que era como hacer muñecos de nieve o helados con varias bolas, y después invirtiendo el acorde de dominante ("descolocándolo", como les he explicado yo a los niños), para que las notas estuvieran más cerca unas de otras. A continuación, los alumnos de primero han dibujado los acordes y han coloreado en ellos las notas sol (de rojo) y $m i$ (de azul). Era un simple ejercicio de reconocimiento de notas; de momento, no buscaba nada más. (DPO, p. 1)

Hemos estado jugando con los acordes haciendo melodías, lo cual considero que es una de las actividades más significativas para que los niños comprendan la relación entre una melodía y los acordes que la sustentan. La actividad consistía en que un alumno tenía que escoger las notas que quisiera del acorde de tónica (por ejemplo, do-mi-mi) y cantarlas con un ritmo también escogido por él (por ejemplo, negra y dos corcheas), y después había que adaptar ese motivo rítmico-melódico a las notas del acorde de dominante, de tal manera que, si en el acorde de tónica habíamos empezado por la nota de abajo y luego habíamos hecho dos veces la nota del medio, en el de dominante teníamos que hacer lo mismo. Hacíamos el motivo dos veces en el acorde de tónica, otras dos veces en el de dominante y, para terminar, otra vez en el acorde de tónica, repitiendo la primera nota y haciéndola más larga para que sonara a final. En todo momento, les acompañaba tocando los acordes en el piano, pero no la melodía del motivo con el que estuviéramos trabajando. También he explicado a los niños que el acorde de dominante es un poco especial y que, en vez de tres notas, puede tener cuatro (la $7^{\mathrm{a}}$, aunque eso, lógicamente, no se lo he explicado aún), por lo que teníamos que decidir cuál queríamos quitar para poder 
adaptar bien los motivos que iban sugiriendo; cada vez escogían quitar una diferente, lo cual resultaba más enriquecedor. A continuación, hemos escrito dos de los motivos que habían propuesto. Transcribo uno de ellos.

- Primero lo hicimos con los acordes en posición fundamental (colocados o transportados).

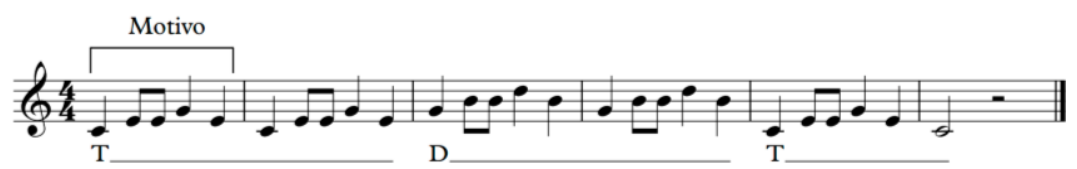

- Y después invirtiendo la posición del acorde de dominante (descolocados o enlazados).

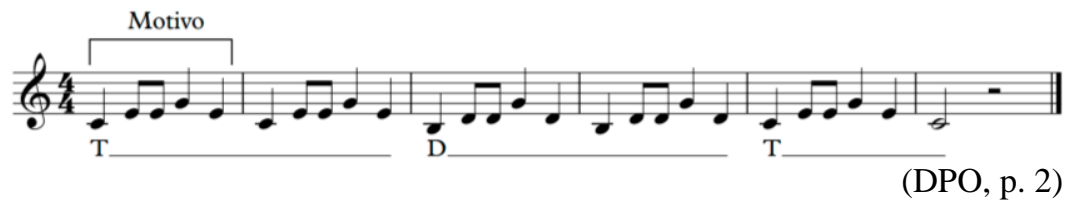

A los alumnos de primero les he presentado el acorde de subdominante diciendo que es un acorde que no produce tanta sensación de tensión como el de dominante ni tanto reposo como el de tónica. Lo representamos corporalmente con los brazos cruzados delante del pecho y hemos estado jugando a reconocer los tres acordes auditivamente: yo los iba tocando en el piano y ellos los iban representando con gestos (brazos abajo para la tónica, levantados para la dominante y en cruz para la subdominante). En todos los grupos lo han hecho fenomenal, jes increíble lo bien que identifican ya los acordes, tanto en posición fundamental como invertida y en distintas octavas! Después, hemos jugado con la creación y adaptación de motivos como otras veces, pero en esta ocasión el motivo debía adaptarse también al acorde de subdominante y obteníamos frases musicales de ocho compases.

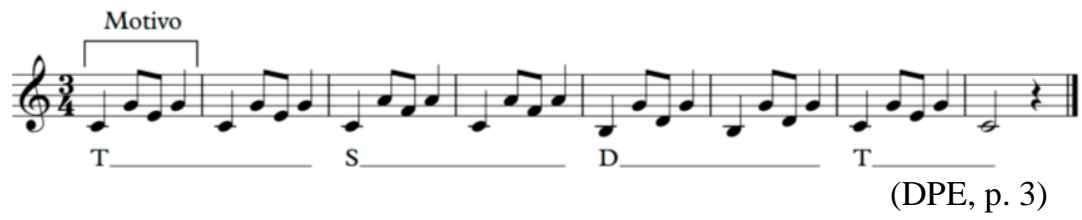

Este trabajo vivencial desarrollado con frecuencia a lo largo de todo el curso ha servido para educar armónicamente el oído de los alumnos y como base para la transcripción y la creación de canciones que comentaremos más adelante. 
Por otra parte, el hecho de basar nuestra metodología en los acordes y no en la melodía no significa que rechazáramos recursos de probada utilidad, como la fononimia de Kodály (1911, citado por Szönyi, 1976), que empleamos con frecuencia en los primeros niveles como estrategia para materializar el sonido y representarlo corporalmente, lo cual ayudaba a los niños a su correcta afinación. Eso sí, dichos recursos estaban siempre supeditados a su utilización dentro del marco tonal-armónico.

Les he enseñando las posiciones que propone Kodály para la representación de las notas sol (mano a la altura de la boca con la palma extendida y los dedos separados) y mi (mano a la altura del pecho con la palma hacia abajo) y su escritura en el pentagrama. (DPS, p. 4)

F- Un día le preguntamos no sé qué y nos dijo: "No, mamá, mira, que es que esto tiene que ir asî" (hace gestos con la mano), y me sorprendió, o sea, como que sí que les está ayudando eso a asimilarlo. Además, iba con esto, iba con algo de entonación, que le pregunté alguna nota, o cómo suena esta nota, o se la intenté cantar yo y me dijo: "No, no, no la estás cantando bien, porque estás cantando esto (hace el gesto fononímico del $\mathrm{fa}$ ) y tiene que ser esto (hace el gesto del la). No es así”. (E1CF2, p. 4)

Partiendo de los principios armónicos expuestos, consideramos que nuestra principal aportación metodológica en esta tesis ha sido la composición creativa de canciones, a partir de la transcripción al dictado y el análisis de otras canciones previas que servían como modelo, como veremos a continuación.

\subsection{Transcripción, análisis y creación de canciones desde el contexto tonal-armónico}

Nuestra concepción acerca de la manera de interactuar con la música en las primeras edades tiene una fundamentación eminentemente práctica: se aprende música haciendo música, partiendo de prácticas musicales holísticas, globales. La escucha, la interpretación y la creación son los tres ejes que articulan nuestras propuestas (Malagarriga, Gómez, \& Viladot, 2013; Pérez, 2011). Plantear prácticas musicales al alcance de los pequeños y guiarles adecuadamente para que puedan resolverlas satisfactoriamente constituye, a nuestro entender, uno de los retos principales de la tarea del docente.

Seguidamente, describiremos cómo han tenido lugar nuestras experiencias educativas de transcripción, análisis y composición de canciones y expondremos los excelentes resultados conseguidos con las mismas. 


\subsubsection{Descripción de la experiencia}

Actualmente, encontramos algunos artículos que describen experiencias pedagógicas en las que se utilizan ejemplos tonales de músicas populares, como el de MacLachlan (2011). No obstante, es previsible que aparezcan cada vez más y desable que algunos de ellos sean en español o, al menos, se traduzcan. Veamos en qué ha consistido nuestra experiencia educativa.

\subsubsection{Canciones transcritas y analizadas en clase}

Una vez al mes, trabajamos en clase con canciones que los alumnos debían transcribir al dictado, al mismo tiempo que realizábamos un análisis de las mismas. Dichas canciones eran, generalmente, populares, aunque también había algunas de creación propia adaptadas a los contenidos rítmicomelódicos que buscábamos en cada momento, para que hubiera una adecuada progresión en la dificultad de los mismos.

Esta actividad no era novedosa, ya que ha sido utilizada en el pasado y aún se emplea en la actualidad.

P- ¿Invita a sus alumnos a transcribir, de oído, la melodía de canciones que ya conocen o que han aprendido en clase?

E- Sí, por supuesto, es un ejercicio que realizamos también. (EEx2, p. 6)

P- ¿Analizáis en clase las piezas que cantáis? ¿Desde qué edad o nivel? ¿En qué aspectos se centra el análisis?

E- Sí, me parece importante. Procuramos que sea desde primero. El análisis se va complicando según los contenidos que se van trabajando, pero ya desde el primer curso introducimos el análisis de las canciones que vamos a trabajar: empezamos identificando qué elementos aparecen para ir, poco a poco, profundizando en cada uno de ellos. (EEx2, p. 4)

La novedad que aportábamos en nuestra propuesta era cultivar la capacidad analítica de los alumnos y la atribución de sentido a lo que estaban haciendo dentro del marco de la armonía tonal, tomando como base los acordes de T, $S$ y D. En este sentido, al realizar esta actividad, se insistía a los alumnos en que debían dotar de significado a todo lo que escribieran, lo cual significa que todas las notas que pusieran tenían que encontrarse en el acorde de debajo y, si alguna no lo estaba, debían poder explicarla como floreo, nota de paso o apoyatura porque, de no ser así, se trataba de un error; ello les ayudaba a realizar la tarea con más seguridad.

P- ¿Y escribir la melodía teniendo debajo el acorde os resulta más fácil o más difícil que sin tenerlo?

As- Más fácil. (EG1CAsF, p. 14) 
E- Tienes que partir primero de un concepto armónico y luego interválico, porque las sensaciones de tónica-dominante y, luego, la subdominante son muchísimo más fáciles de identificar que los intervalos. Además, eso te da pistas sobre la melodía, porque la melodía, en realidad, es un producto de lo armónico, cuando estamos trabajando en lo tonal. (EEx3, p.7)

Los pasos a seguir para llevar a cabo esta actividad, los explicaba en mi diario de la siguiente manera:

En la segunda sesión de esta semana les he enseñado una canción (Luna lunera a los de primero y La uva a los de segundo) y, después, la han transcrito siguiendo los siguientes pasos:

- Aprendizaje de la canción por imitación de la profesora.

- Escritura de las líneas divisorias de los compases (en todas las canciones con las que vamos a trabajar este curso habrá 8 compases).

- Reconocimiento auditivo de los acordes que sonaban en cada compás. Los niños iban apuntando una $\mathrm{T}$ (tónica) o una $\mathrm{D}$ (dominante), según lo que fueran escuchando.

- Escritura de los acordes por imitación. En la pizarra estaban escritos los acordes de tónica y de dominante y los alumnos han tenido que copiarlos encima de donde hubieran escrito anteriormente una $\mathrm{T}$ o una D. Los alumnos de primero aún no conocen las notas que están copiando, pero las han escrito igualmente y, después, han pintado de rojo la nota sol y de azul la nota mi en dichos acordes, que son las que, de momento, hemos visto.

- Transcripción de la canción por fragmentos de dos en dos compases. Mientras marcábamos el pulso, cantábamos un fragmento. Primero lo hacíamos con letra y luego con la sílaba "ta" para que sintieran que, si en un pulso entraba solo un "ta", debían escribir negra, si entraban dos "ta-ta", debían escribir dos corcheas, y si no sonaba nada, debían escribir un silencio (esto último solo para los de segundo). Para reconocer las notas, debían fijarse en los acordes que tenían debajo, ya que solo podían utilizar notas que estuvieran en los mismos (o que estuvieran coloreadas, en el caso de los alumnos de primero). Por tanto, si sentían que la melodía subía un poco, ponían la siguiente nota del acorde en orden ascendente y, si subía mucho, ponían otra que estuviera más arriba; así, la posibilidad de error era menor, al mismo tiempo que iban aprendiendo las normas de construcción de melodías basadas en la armonía. Debajo de las notas y figuras, iban escribiendo también el texto de la canción.

- Comprobación final de la canción, para asegurarse de que todo lo que han escrito se ajusta a las pautas y de que no hay errores de escritura musical como: posición de las plicas, colocación de la letra, etc.

(DPO, pp. 3-4) 
A modo de ejemplo, mostramos la canción popular Cuando mi barco navega transcrita de oído por un alumno de segundo.

\section{CUANDO MI BARCO NAVEGA}
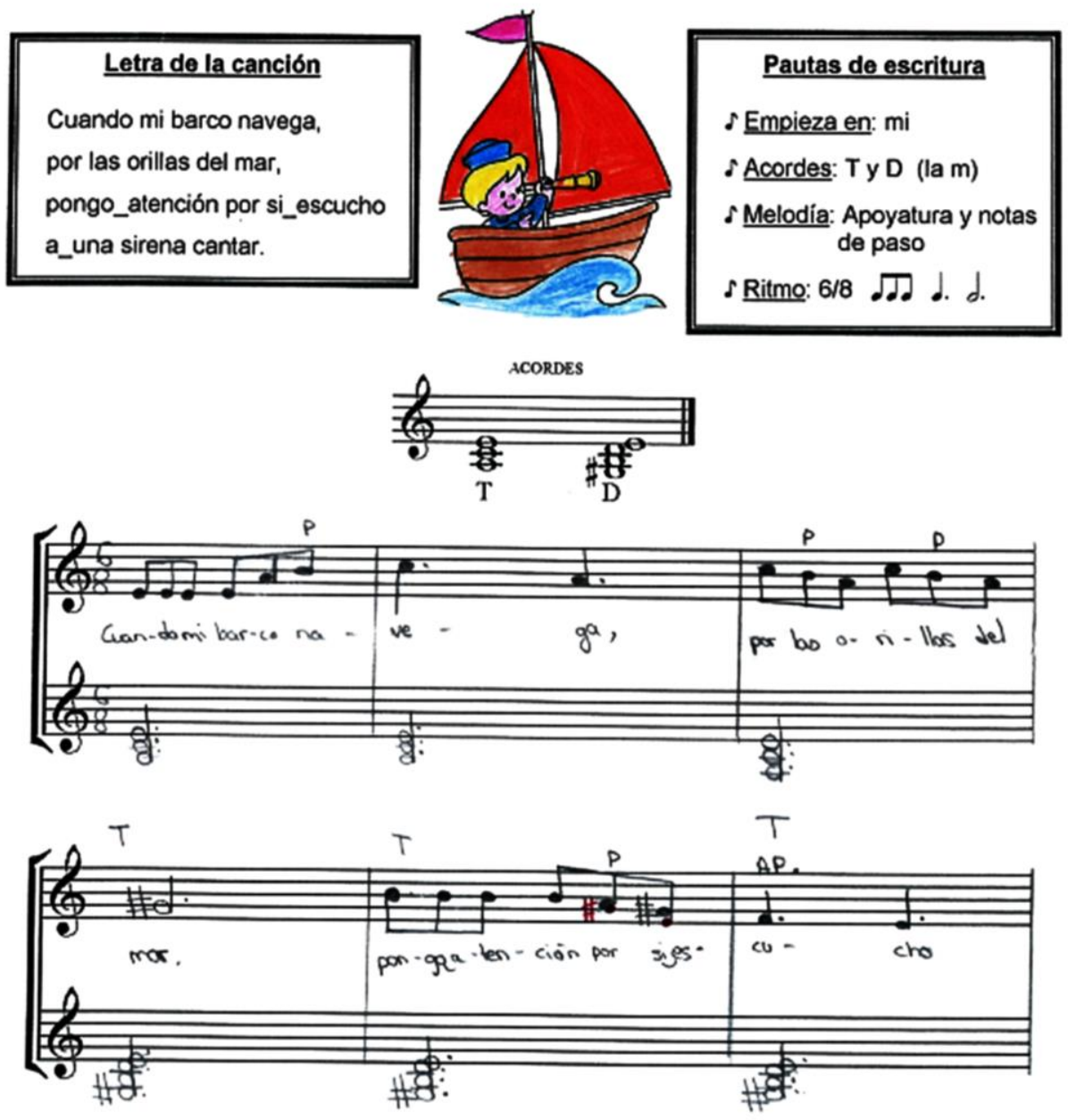

D

D D

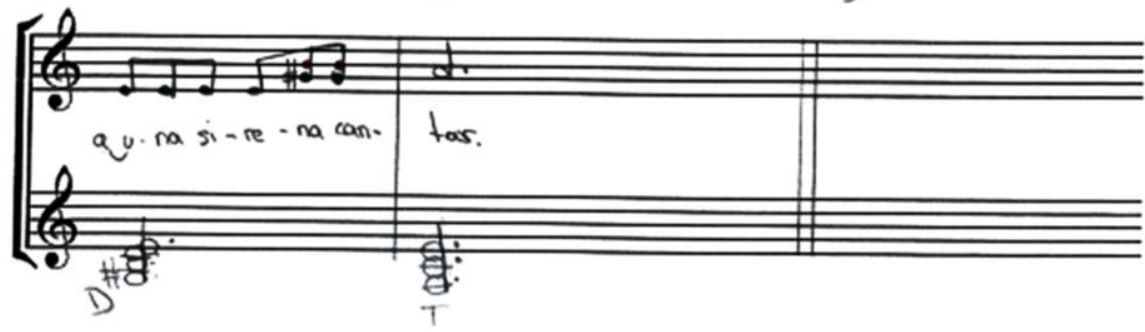

Figura 55. Canción transcrita de oído por un alumno de segundo 


\subsubsection{Canciones creadas por los propios alumnos}

A partir del trabajo que acabamos de describir, los alumnos debían componer sus propias canciones en casa, siguiendo las mismas pautas y utilizando el programa informático de edición de partituras MuseScore, como puede observarse en el siguiente ejemplo.

\section{LA TARDE NUBLADA}

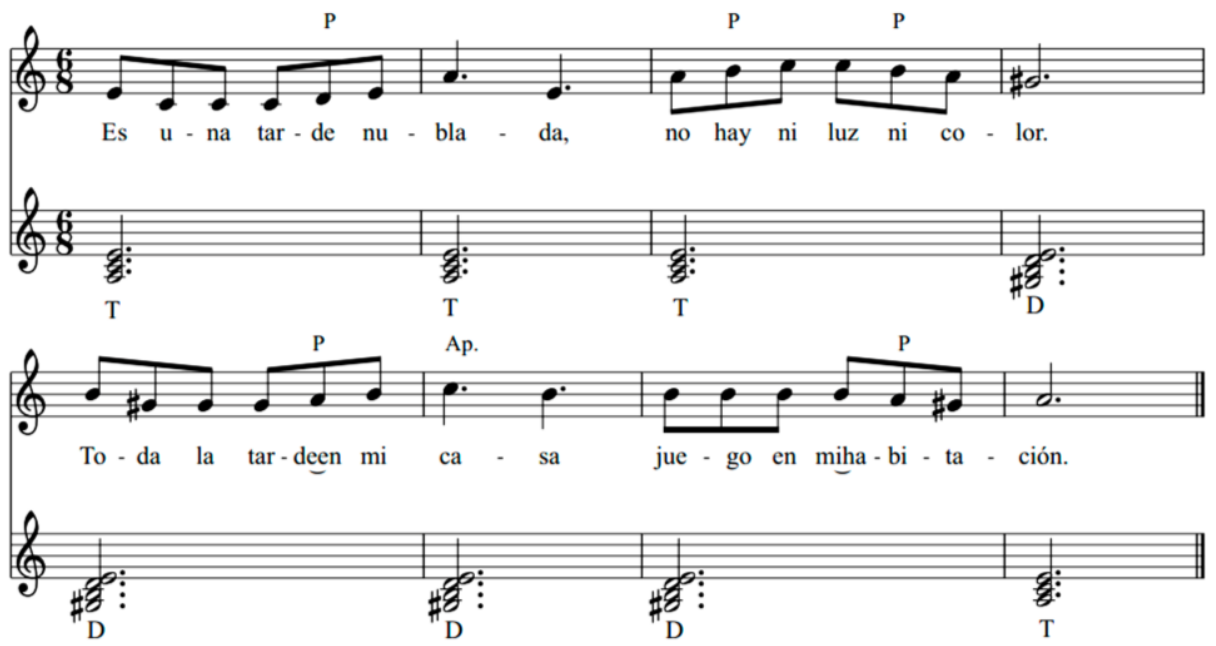

PAUTAS DE ESCRITURA: Las mismas que para la canción de "Cuando mi barco navega".

Figura 56. Canción compuesta por un alumno de segundo siguiendo las pautas de la canción anterior

Asimismo, debían cuidar mucho los aspectos formales tanto en la música como en la letra.

Formalmente, les insisto mucho en que, al componer, la letra que inventen debe tener las mismas partes que la música. Esto significa que, si la melodía tiene dos partes, el texto debe tener dos partes y que, si la canción tiene cuatro partes, la letra debe presentar también esa característica, de tal manera que no pueden dejar palabras incompletas al final de un fragmento musical y terminarlas al comienzo de una nueva parte, ya que buscamos orden y naturalidad. (DPF, p. 3)

Una vez realizadas, enviaban las canciones a la profesora por correo electrónico para su corrección. Los errores cometidos se indicaban de la siguiente manera: 
- Las notas que no se encontraban en el acorde y no se podían explicar como notas de adorno se marcaban en rojo.

- Las palabras que sonaban mal porque los acentos lingüísticos no coincidían con los musicales se marcaban en negrita.

- Si no se había respetado alguna pauta (partes, compases con la misma línea melódica, notas a utilizar, etc.), se indicaba debajo en forma de observaciones.

\section{LOS PLANETAS}
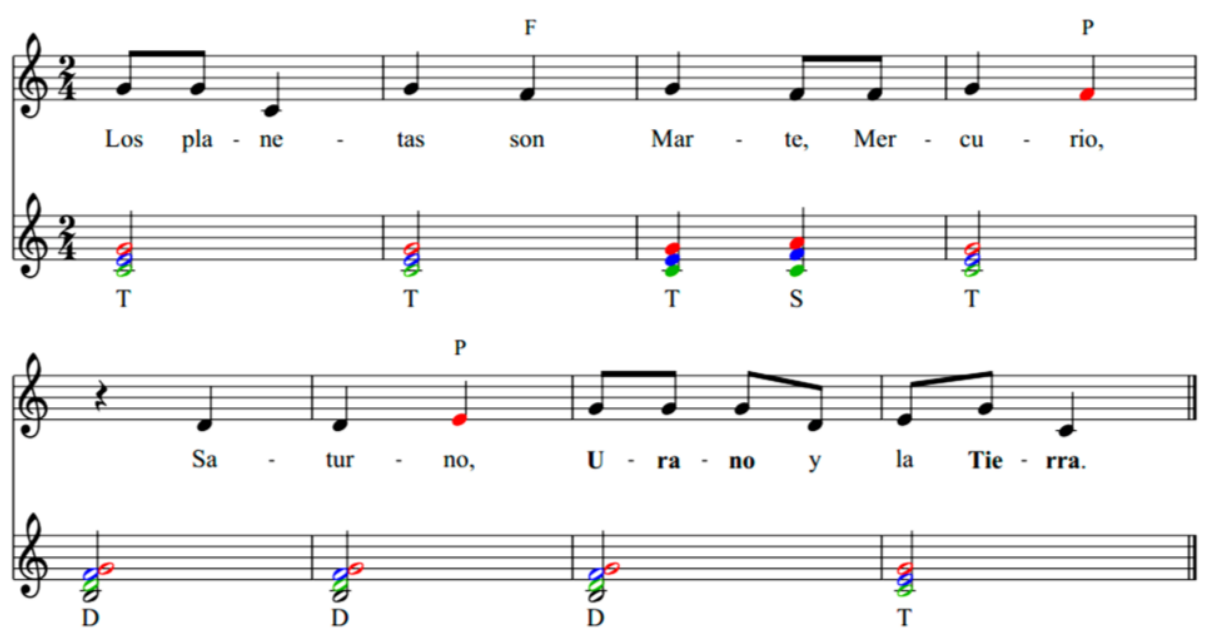

OBSERVACIONES: Los compases 5 y 6 no tienen el mismo ritmo y línea melódica que el 1 y el 2.

Falta la nota "La".

PAUTAS DE ESCRITURA: Las mismas que para la canción de "Tengo una muñeca".

Figura 57. Canción compuesta por un alumno de primero con la indicación de los errores cometidos

En estos casos, debían corregirla y enviar una nueva versión, tal y como se muestra a continuación. 


\section{LOS PLANETAS}
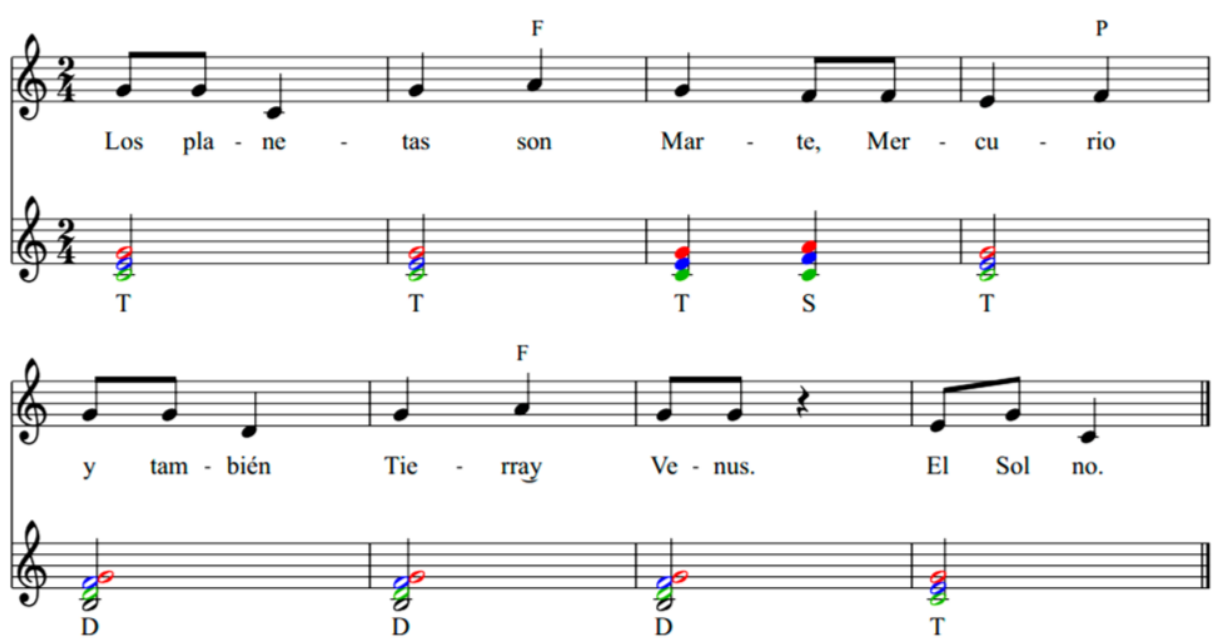

PAUTAS DE ESCRITURA: Las mismas que para la canción de "Tengo una muñeca".

Figura 58. Versión corregida de la canción anterior

Cuando la canción se daba por correcta, debían aprendérsela de memoria para cantarla en clase, tanto con notas, lo cual ayudaba a que fueran fijando los sonidos en su mente, como con letra.

E- Es un recurso muy bueno saber las canciones, aparte de con su letra, con la letra de la música, con sol, $f a, m i . .$. , porque de esta forma se va quedando en la cabeza el sonido asociado a un nombre. (EEx1, p. 15)

Asimismo, podían acompañar su actuación con instrumentos, dibujos, disfraces o todo aquello que consideraran conveniente para enriquecer la puesta en escena. Durante la interpretación, las canciones se proyectaban en la pared para poder comentarlas posteriormente.

\subsubsection{Resultados obtenidos}

Para la exposición de los resultados obtenidos, hemos establecido cuatro categorías: motivación hacia la actividad, dificultades encontradas, utilidad de la actividad y tiempo invertido.

\subsubsection{Motivación hacia la actividad}

Al principio, los alumnos no acababan de entender la dinámica de trabajo y parecía que la creación de canciones y su representación en clase no les atraían demasiado. 
Cuando cantaron su canción en clase me decepcioné bastante. Habíamos acordado que debían sabérsela de memoria y cantarla sin mirar, pero casi ninguno se la había aprendido. (DPO, p. 9)

Pero en cuanto empezaron a dominar las pautas y el programa informático, se convirtió en una actividad altamente motivadora para ellos.

A37- Las canciones me han gustado mucho porque nos has dado la oportunidad de utilizar nuestra imaginación. (EG1CAsF, p. 11)

F70- Vas con unos cuantos compañeros en el coche y se ponen a cantar las tareas y me parece estupendo. (EG2CFs, p. 20)

Me ha gustado mucho componerla y estoy deseando que la veas. (CE1CA4E, p. 2)

F- Le gusta mucho ponerse en el programa e ir viendo cómo suena: eso le ayuda mucho. (E1CF2, p. 6)

T- Hay algunas veces que después de tu clase vienen a la mía y vienen como ilusionados: quieren cantarme su canción, enseñarme su canción que han compuesto. (ETPer, p. 5)

F1- Él después se siente muy orgulloso o satisfecho de su trabajo y lo ve como algo que él ha elaborado. (EG1CFs, p. 14)

La puesta en escena para presentar su trabajo era fundamental para ellos, por lo que había que prepararla bien.

A37- Estoy deseosa de cantar la canción, de enseñar a mis compañeros el trabajo y de hacerlo con un acompañamiento y con nuestros trabajos, nuestros dibujos (EG1CAsF, p. 24).

F- La puesta en escena para ella es vital y dice: “¡Me tienes que preparar algo!”. Tiene mucha emoción por esa representación. El que se reconozca su trabajo para ella es importante. (EF6, p. 9)

A7- Me gusta venir a cantarlas porque sé que luego mis compañeros me van a aplaudir. (EG1CAsA, p. 8)

El hecho de utilizar un programa informático para realizar sus canciones constituyó otro aliciente, de tal manera que había alumnos que incluso dedicaban su tiempo libre a componer sin que se lo hubiéramos mandado como tarea para clase.

A24- A mí me gusta más hacerlas por el ordenador y luego las saco, porque, ya de paso, va sonando mientras escribo. (EG1CAsC, p. 14) 
F70- Lo del ordenador para mí es un acierto, porque hay veces que ella se pone a componer sin tareas. Me parece que eso de tener que hacer una partitura como antaño, en papel, no les motiva, pero esto sí.

$\mathrm{P}$ - Lo de componer sin tareas, no sé qué quiere decir.

F70- Pues que se pone con el programa y empieza a poner sus notas y a ver cómo suena y a ver qué ha hecho.

P- ¡Ah!, ¿sin habérselo mandado yo?

F70- Sí, por eso de que: "A ver cómo funciona el programa. Pues pongo esta nota aquí y luego le doy a ver cómo suena y... ¡Ah, pues está bien!” (EG2CFs, pp. 17-18)

\subsubsection{Dificultades encontradas}

Al principio, crear canciones les costaba bastante, porque les surgían muchas dudas acerca de las pautas a seguir y de cómo utilizar el programa, olvidando la musicalidad:

A6- Al principio, las canciones del ordenador me parecían un poco difíciles, pero luego ya cogí cómo se hacían y ahora me gusta mucho crear canciones, porque me divierto haciéndolas. (EG1CAsA, p. 8)

Para ser la primera canción que se inventan, no les ha salido muy mal, pero han cometido bastantes errores por despistes: utilizaban notas o figuras que no aparecían en las pautas, olvidaban poner el compositor o las funciones de los acordes, nombraban mal el archivo que me tenían que mandar, utilizaban palabras que no sonaban bien por los acentos... Considero que todos estos errores no son síntoma de que la tarea no se haya entendido o sea complicada para ellos, sino que se deben a una falta de atención o rigurosidad a la hora de seguir las pautas. (DPO, p. 8)

Parecía que habían ido rellenando los compases siguiendo las pautas de una forma artificial, sin tener en cuenta si aquello sonaba bien y era fácilmente cantable. Por tanto, para la próxima canción, trabajaremos más en clase los aspectos formales $\mathrm{y}$ las estrategias para componer con sencillez y musicalidad. (DPO, p. 10)

No obstante, pronto se familiarizaron con la actividad y desaparecieron las dificultades.

F- Ahora le veo suelto. El programa lo maneja muy bien. (E2CF45, p. 5)

F- Me ha sorprendido mucho la facilidad y la rapidez con la que lo hace. (E1CF2, p. 6)

Esta vez han seguido mejor las pautas y la verdad es que, en general, estaban bastante bien, ¡he notado mucha mejoría y me he alegrado muchísimo! Se aprecia mucha más musicalidad. (DPN, p. 3) 
$\mathrm{P}-$ ¿Entre las primeras composiciones y las últimas notas diferencia? F50- ¡Sí, sí!, ¡años luz, muchísima diferencia! Las primeras no eran composiciones (ríe); estas ya sí tienen pinta de composiciones, simples, pero tienen pinta de composiciones. (EG2CFs, p. 15)

A2- Antes me liaba un poco, porque no sabía ni los nombres ni cómo sonaban, pero ahora ya lo llevo muy bien y ya sé diferenciarlos y lo que son. (EG1CAsA, p. 11)

\subsubsection{Utilidad de la actividad}

Al transcribir de oído o componer canciones, los alumnos debían justificar cada una de las notas que escribían, bien como notas reales del acorde o como alguna de las notas de adorno estudiadas. Con esto se ha conseguido aumentar su concentración y su capacidad reflexiva, al tiempo que iban interiorizando las reglas de la armonía tonal. A modo de ejemplo, en la canción de la figura 55 puede observarse que los errores cometidos en los compases 5 y 7 tienen una justificación válida, lo cual demuestra que el alumno está dotando de significado a la tarea realizada.

F- Lo tiene superclaro: “¡No, no!, es que aquí esta nota no puede ir, mamá, porque fíjate aquí abajo lo que tienes puesto, y aquí no puede ir esta otra nota, aunque tú la quieras meter. (E1CF2, p. 6)

Para ello, muchos padres han tenido que implicarse en mayor o menor medida, lo cual era otro de los objetivos de este trabajo, ya que buscábamos hacerles partícipes del proceso de aprendizaje de sus hijos.

F1- Yo creo que un niño no puede tener en su cabeza todos esos ítems: tengo que hacer todas estas notas, todas estas figuras, la nota de floreo, la nota de paso, repetir este compás con éste. Necesita un padre al lado. (EG1CFs, p. 14)

F5- ¡Hemos aprendido todos a hacer canciones! (EG1CFs, p. 16)

En todo momento, la metodología de trabajo estaba adaptada a la psicología y capacidades de los alumnos.

T- El sistema que tienes no es fácil, porque tienes que aprenderlo: si es tónica, dominante, si está enlazado... pero son capaces de reconocerlos. Es como un juego de niños, para niños. (ETPer, p. 4)

F- Yo veo que aprende, que saca conclusiones, que saca beneficio. Veo, además, que va progresando y, sobre todo, la facilidad con que incorpora las cosas nuevas. (E2CF45, p. 3) 
La actividad ha sido muy útil también para reducir la ansiedad escénica.

A7- Yo, cuando me equivoco, pienso que mis compañeros no se van a reír de mí y que, como son muy majos, no van a decir nada, van a pensar que todos nos equivocamos. (EG1CAsA, p. 6)

Con lo que más he aprendido es componiendo, porque así aprendes a reconocer tus errores y también a cantar en público, porque soy un poco tímida. (CA2C, pre. 7)

Y para que los niños sean más tolerantes al error, perdiendo el miedo a equivocarse.

A2- A mí me gusta que me corrijas, porque así aprendo de mis errores y luego, la siguiente vez, sé que eso está mal y me corrijo también a mí misma cuando pongo las cosas. (EG1CAsA, p. 11)

A1- Si te equivocas, no pasa nada, porque todo el mundo se equivoca, nadie es perfecto. (EG1CAsA, p. 10)

Además, les ha ayudado a ejercitar la memoria.

A38- Aprendérmelas de memoria me ha gustado mucho, porque luego se las puedo enseñar a otros niños en el colegio para que ellos también se las sepan. (EG1CAsF, p. 11)

Y, sobre todo, a comprender mejor la música y a desarrollar su creatividad.

T- Es genial, porque luego llegan a una obra y pueden ver las mismas cosas que en las que ellos componen. [...] Creo que es estupendo que compongan y que sean creativos. (ETPiJE, p. 3)

A75- A mí me resulta más fácil con acordes porque con acordes, si tienes notas reales, pues, si sabes los acordes que son, tienes que poner las notas de esos acordes, no te las puedes inventar.

$\mathrm{P}-i \mathrm{Y}$ si no son notas reales?

A75- Pues tiene que ser un floreo, una nota de paso o alguna de esas y entonces tienes que fijarte bien en los acordes porque si tú pones otra nota que no es ni floreo, ni nota de paso, ni apoyatura, pues, como dice A71, si le das al play suena mal y, entonces, lo tienes que cambiar, porque suena mal. P- Eso en las canciones de casa, ¿y cuando estamos haciéndolo con las canciones de clase?, como aquí no tenemos play para darle a ver qué tal suena..., ¿os ayuda tener los acordes debajo o no?

As- Sí.

P- ¿Por qué?

A69- Porque sabes las notas que pueden entrar por los acordes. (EG2CAsD, p. 13) 
T- Me parece increíble que dominen o aprendan a dominar cosas que nosotros hemos trabajado en cursos ya muy avanzados de nuestras carreras $\mathrm{y}$ de nuestros planes antiguos, y que lo tengan interiorizado a edades tan tempranas y que sepan reconocer, por ejemplo, lo que son las funciones tonales, lo que representa cada una, el orden, y que ellos sean capaces, además, de poder utilizar eso para desarrollar su propia creatividad, sus propias canciones. Me parece increíble, muy interesante. (ETO, pp. 3-4)

Finalmente, cabe destacar que el contacto por e-mail ha contribuido a mejorar las relaciones de la profesora con los alumnos y los padres, apreciándose complicidad y gratitud.

Buenas tardes Elena, lo primero agradecerte enormemente el interés y el tiempo que nos dedicas, esperamos esta vez haberlo hecho un poquito mejor. (CE2CF44E, p. 2)

Aquí le mando el trabajo del artista, jespero que se estrene en Viena! (CE1CF14N, p. 6)

Te envío la canción que me he inventado, jespero que te guste mucho! (CE2CA49F, p. 2)

\subsubsection{Tiempo invertido}

Al principio, transcribir canciones en clase resultaba demasiado lento. Por tanto, tuve que modificar la planificación inicial.

Me estoy dando cuenta de que lleva demasiado tiempo, así que he decidido reducir las canciones a 7 , en vez de realizar las 10 que tenía programadas inicialmente. (DPN, p. 5)

Los alumnos no empleaban mucho tiempo en crear sus canciones en casa, aunque en las primeras tardaron un poco más.

F- Más de quince o veinte minutos no echa. (E2CF79, p. 3)

F- Del tiempo que dedicaba al principio al que dedica ahora hay una disminución, se le nota mayor agilidad a la hora de hacer la tarea. Yo creo que tiene más centrado cuál es el mecanismo. (E2CF45, p. 7)

No obstante, la corrección constructiva de las canciones por parte de la profesora sí ha sido lenta, y es algo que el docente interesado en aplicar esta actividad tiene que estar dispuesto a asumir, pero los resultados demuestran que merece la pena.

Tengo que reconocer que he tenido que echar muchísimas horas, porque cada día me encontraba unos 20 correos nuevos en mi bandeja de entrada y 
responder de forma constructiva a cada uno de ellos es muy lento, pero considero que es la única manera de que lo aprendan bien. (DPO, p. 9)

\subsubsection{Consideraciones finales}

Los resultados han sido muy satisfactorios, como se ha comprobado al cruzar los datos obtenidos a través de distintas técnicas e instrumentos.

Cabe destacar que las primeras canciones les costaron un poco, pero, progresivamente, los alumnos fueron adquiriendo un mayor dominio, convirtiéndose en una actividad altamente motivadora para ellos, tanto en su fase de creación, como por la puesta en escena.

Asimismo, a nivel educativo han demostrado su utilidad para que los alumnos comprendan las reglas básicas del sistema tonal-armónico, pierdan el miedo a equivocarse, actúen en público sin ansiedad, trabajen de forma reflexiva, desarrollen el oído, aumenten su creatividad, mejoren la colocación de la voz y se sientan acompañados por sus padres en el proceso de aprendizaje.

Para terminar, señalaremos que las temáticas empleadas por los alumnos para la creación de sus canciones nos informan sobre sus inquietudes e intereses, abriendo nuevas vía a la investigación.

\section{La teoría musical}

La asignatura de Lenguaje Musical recibe dicha denominación a partir de la reforma educativa planteada por la Ley Orgánica 1/1990, de 3 de octubre, de Ordenación General del Sistema Educativo, ya que anteriormente se llamaba Solfeo y Teoría de la Música.

Aunque en el nombre antiguo se refleja más explícitamente la importancia de trabajar contenidos teórico-musicales, en la actualidad dicha asignatura se ocupa igualmente de la enseñanza de los elementos y fundamentos de la música como lenguaje, lo cual exige su explicación teórica junto a su utilización en la práctica.

\subsection{Importancia de la teoría para el aprendizaje musical}

En los estudios musicales, el aprendizaje se basa sobre todo en la práctica continuada. Ello provoca que, a veces, no se conceda la suficiente importancia a los contenidos teóricos, lo cual consideramos un gran error, ya que son fundamentales para comprender el entramado musical en su plenitud. Así lo justificaba uno de los tutores entrevistados: 
T- Como músico, tienes que entender el lenguaje, tienes que entender la obra de un compositor, porque si tú quieres contar la obra de ese compositor tienes que entenderla. Yo, si quiero contar una poesía de Goethe, tengo que entender el alemán y luego saber una serie de cosas. Entonces, si quiero transmitir el mensaje que hizo Bach, tendré que entender eso, y eso implica una serie de conocimientos como la partitura, la forma, la armonía...; también es importantísima la historia, porque cada compositor está actuando en una época, con una serie de valores, de necesidades y de intenciones. De ahí deriva ese producto artístico, tú no puedes desvincularlo. Tiene su porqué: por qué uno compuso para un instrumento, por qué otro compuso para otros... También está el plano personal; por ejemplo, Chopin solo compuso para piano, no hizo sinfonías o cuartetos, y luego, también, en esa época, ¿por qué hizo nocturnos y no hizo fugas? O sea, que el conocimiento histórico, por un lado, es algo que se tiene que dar sin discusiones y se tiene que entender no como algo ajeno a la obra, sino como algo que debes conocer para entender la obra. Y, luego, otra serie de conocimientos, como el teórico y el armónico. El problema es que se potencia toda la técnica, pero no se potencia todo lo demás. [...] Tú, cuando alguien está tocando, tienes que saber lo que está tocando para entenderlo. Si estás escuchando un concierto o la música de alguien, lo que toca tiene una serie de recursos para generar interés, modulaciones, juegos tímbricos, determinados ritmos... Es decir, si no entiendes eso o si no escuchas las armonías que utiliza para generar lo que él persigue, no lo comprenderás; tienes que tener un oído formado que sepa discriminar todo eso. [...] Y, normalmente, eso no se estudia, no se trabaja cómo escuchar musicalmente. Lo bueno de escuchar musicalmente es que le da utilidad a todo lo que has aprendido, porque una de las cosas que provoca que la gente tenga desidia a la hora de estudiar ciertas cosas es el ¿para qué? Si a ti te digo: "Te vas a estudiar, por ejemplo, las constelaciones, pero nunca vas a ver un cielo", ¿qué motivación vas a tener o qué ilusión? Pero, sin embargo, si un día te enseño el cielo y te digo: "¿Ves aquello, ves la Osa Mayor?" Pues ya tienes un porqué y a lo mejor te provoca curiosidad. (ETV, pp. 3-5)

Todo músico debe entender todos los aspectos de la partitura que tiene delante para poder interpretarla adecuadamente (Hernández, Hernández, \& Milán, 2010, Michels, 2009).

E- Nada que no se entienda se debe hacer. Bueno, es muy exagerada la expresión, puede haber matices, pero yo trabajo el análisis desde el principio, entendiendo el análisis con la familiaridad que se debe entender, es decir, no estoy hablando del análisis típicamente de tesis doctoral cuando estoy hablando con un niño de 8 años para explicarle una canción. Conocer que esto es una frase y esto es una semifrase, eso es un análisis, vivenciado, pero es un análisis. (EEx1, p. 13)

El dominio de los aspectos teóricos también permite realizar una escucha analítica y reflexiva que facilita la comprensión de la música que se está oyendo (Copland, 2008). 
Las dos canciones tienen ocho compases $\mathrm{y}$, formalmente, tienen dos semifrases de cuatro compases cada una, de tal manera que ambas semifrases comienzan igual, aunque tienen una terminación diferente. Les he enseñado la canción por imitación y, después, les he hecho conscientes de esta circunstancia a través de preguntas como: “¿Cuántas partes creéis que tiene esta canción?". Algunos respondían que cuatro ya que, en las pautas de la canción, el texto aparece fragmentado en cuatro partes para que vayan transcribiéndola de dos en dos compases y les resulte más sencillo. Entonces, les dije que se olvidaran de la letra y que volvieran a cantar la canción tarareándola con la sílaba "ta". De esta forma, todos han coincidido en que tenía dos partes y que esas dos partes empezaban igual. (DPN, p. 2)

De esta manera, los contenidos teóricos se convierten en pilares sólidos que ayudan a comprender cómo se construye y utiliza la música, facilitando la adquisición de aprendizajes significativos.

E- Si la capacidad de análisis la tienes desde tus lecciones de solfeo, desde la música que oyes, desde la pequeña música que tú estás tocando y todo eso, aquello se convierte en una práctica muy natural. (EEx3, p. 27)

\subsection{Contenidos teóricos a trabajar en Lenguaje Musical}

Los contenidos que deben trabajarse en la asignatura de Lenguaje Musical aparecen recogidos en las disposiciones legales comentadas en el marco teórico de esta tesis (capítulo IV). Partiendo de dicho marco legislativo, y dentro de las enseñanzas elementales, en nuestro departamento de Asignaturas Teóricas se priorizan los contenidos relacionados con las tonalidades, los intervalos y las escalas.

A pesar de que compartimos la importancia de dichos contenidos, también consideramos que hay otros aspectos fundamentales que se deben trabajar de forma tanto teórica como práctica desde el inicio de los estudios musicales en el conservatorio.

Tradicionalmente, en los exámenes de teoría para el acceso a los distintos cursos de las enseñanzas elementales solo aparecen preguntas sobre intervalos, tonalidades y escalas, lo cual yo considero que debería ser diferente, ya que se dan otras muchas cosas que, desde mi punto de vista, también tienen mucha importancia, pero estos son los aspectos básicos en los que coincidimos todo el departamento, independientemente de que trabajemos además otros contenidos, de los cuales yo también examino a mis alumnos en los exámenes trimestrales. (DPD, p. 5)

Por ello, en nuestro estudio, apostamos por presentar a los alumnos de los dos primeros cursos de las enseñanzas elementales los contenidos teóricos necesarios para comprender, a un nivel adaptado a su psicología infantil y a 
sus capacidades, el funcionamiento del sistema tonal-armónico propio de nuestra cultura, De dichos contenidos hablaremos un poco más adelante (apartado 4.3.).

\subsubsection{Conexión entre la teoría y la práctica}

Hay que seleccionar bien el "qué" se enseña, teniendo siempre presente el "para qué", es decir, pensando qué queremos conseguir, porque hay contenidos teóricos que no son nada útiles ni prácticos, por lo que no tiene sentido emplear tiempo en ellos.

E- Que todo esto, cuando lo ves en la teoría (los grupos de valoración especial, los intervalos, el número de tonos y semitonos, las claves...), dices: "Bueno, vamos a ver, aplicación musical y, en función de la aplicación musical, vamos a trabajarlas. Y, desde la música, te voy a explicar la teoría porque, claro, me da igual que te explique lo que es una estrella si nunca has mirado al cielo". Aquí realmente el gran descubrimiento es la lógica. (EEx3, p. 58-59)

T- Se estudia armonía, pero no aplicada; se estudia historia, pero no aplicada; se estudia, por ejemplo, a veces el solfeo, pero no aplicado; se estudia técnica de violín, pero no aplicada y, al final, lo que no se hace es música. (ETV, p. 4)

E- Hay claves que no sirven absolutamente para nada; nadie lee en clave de do en primera o de fa en tercera.

P- Eso es cierto.

E- Eso es una barbaridad, es perder el tiempo, hay muchas cosas que hacer. Entonces, eso no me parece nada convincente. Ningún libro mío va a llevar una clave así, ¡me parece una barbaridad! (EEx1, p. 11)

López de Arenosa (2004) defiende que la información que recibimos al escuchar música se comprende y retiene buscando relaciones. Por ello, consideramos fundamental hacer aflorar este lenguaje musical pasando de las sensaciones a la intuición y a la práctica para, finalmente, llegar a la conceptualización.

Lo que se aprende de memoria sin una aplicación práctica no resulta motivador y no se comprende bien, por lo que se olvida fácilmente. En este sentido, resultan relevantes las respuestas de los alumnos en los cuestionarios al indicar que sus mayores dificultades en teoría se deben a factores como la falta de comprensión y a que les resulta aburrida, lo cual puede explicar también por qué la estudian con poca dedicación (gráfica 3). 


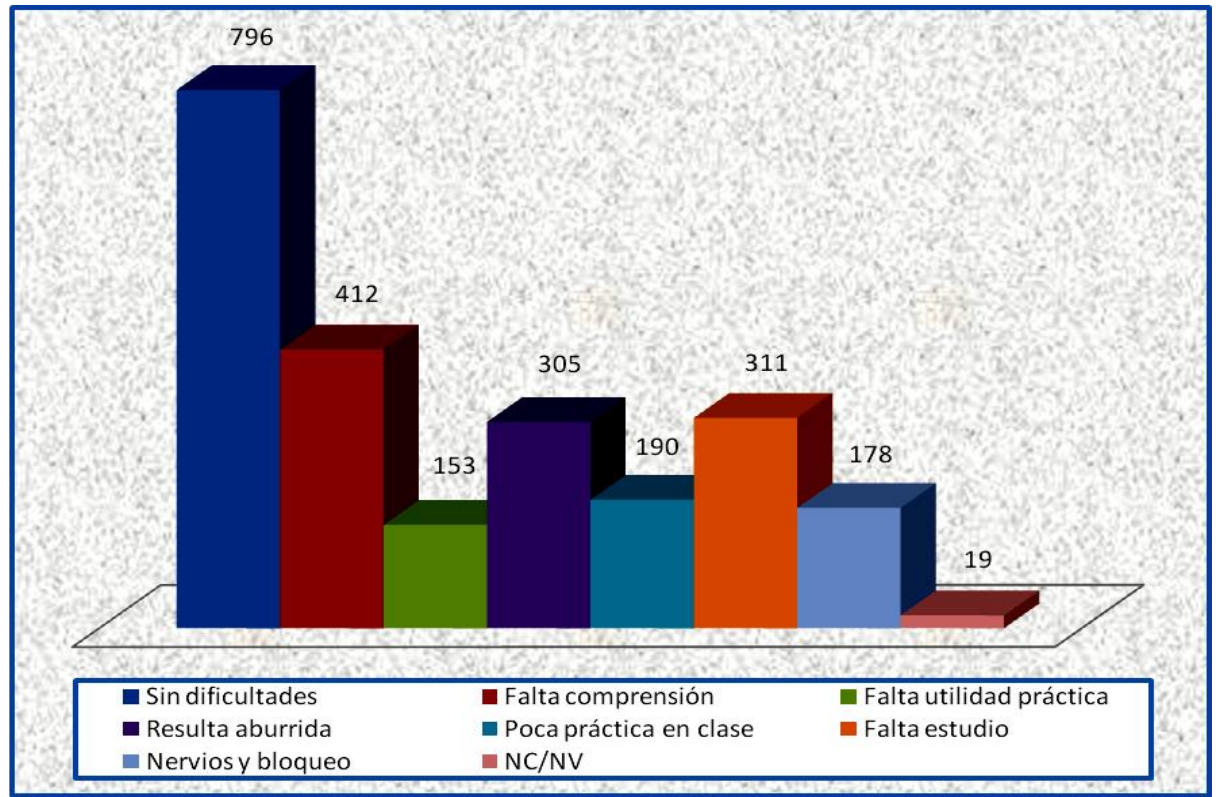

Gráfica 3. Respuestas de los alumnos a la pregunta 13 de los cuestionarios: Considero que mis dificultades en teoría se deben a:

Por este motivo, en nuestra propuesta metodológica insistimos mucho en que los contenidos teóricos estuvieran totalmente integrados con la práctica musical.

T-Se trata de que todo lo que se haga se asimile. Por eso lo que hablábamos de la relación con las otras partes, que no tienen que estar separadas.

P- Sí que, si están integrados en el ritmo, en la entonación, en la audición y en todo, los conceptos teóricos se asimilan bien.

T- Claro, se integran, es que no se viven como teoría. O sea, en el momento en que son elementos que tú puedes cambiar, ordenar, crear a partir de ellos, ya no se ven como teoría, porque no lo son. (ETGD, pp. 8-9)

\subsection{Priorización de contenidos teóricos en nuestra propuesta metodológica}

En la selección y priorización de los contenidos educativos es fundamental tener presente la meta hacia la que nos dirigimos. Dicho de otra forma, en función de dónde queramos llegar, así trabajaremos desde los primeros cursos para crear una buena base.

Como ya hemos destacado en varias ocasiones, en el estudio que presentamos apostamos por trabajar la educación auditiva, en particular, y la educación musical, en su conjunto, dentro del contexto tonal-armónico, lo 
cual implicaba abordar también aspectos teóricos sobre la construcción y función de los acordes tonales básicos desde el principio, así como su relación con la elaboración de melodías, utilizando notas reales presentes en dichos acordes y notas de adorno que las embellecieran. Dichas propuestas se apoyan en experiencias realizadas en trabajos previos (Cañada, López, \& Molina, 2004; López de Arenosa, 2004).

No consideramos más difícil para un niño aprender a construir los acordes y su relación con la melodía que comprender otros contenidos teóricos basados en escalas $y$ en tonalidades que, como hemos señalado, sí se trabajan tradicionalmente en estos niveles y que, incluso, les generan más dudas.

Las altas calificaciones obtenidas en los exámenes de teoría indican que los alumnos comprenden y manejan de forma práctica todos los contenidos trabajados, demostrando incluso un mayor dominio de los contenidos relacionados con los aspectos armónicos, que son los que se suelen enseñar en estudios posteriores, que en los contenidos que sí se suelen enseñar tradicionalmente en estos niveles, relativos al análisis de intervalos, la construcción de escalas y la correspondencia entre las armaduras y las distintas tonalidades. (DPM, p. 1)

F61- Bueno, el tema de las alteraciones... Yo, sinceramente, creo que eso es como dividir. Yo creo que hay que hacer muchas cuentas para aprender a dividir, entonces...

P- ¿Me estás hablando de teoría?

F61- De teoría, sí.

P- ¿De las tonalidades con las armaduras?

F61- Sí, eso que era..., es que yo no entiendo, no te sé decir..., de contar cinco parar arriba, tres para abajo..., no sé cómo es eso.

P-Sí, de las tonalidades.

F61- Lo que sea, que yo no lo sé, y es que es todo igual y se diferencia en una cosa de nada, y, o pillas esa diferencia, o subo y bajo, o bajo y subo... Digo: "Mira, tú haz lo que puedas y ya está". (EG2CFs, p. 4)

P-¿Qué es lo que más os ha llamado la atención de todas las cosas que hemos hecho este año?

A79- Teoría, que es lo que peor se me da.

P- Teoría es lo que más te ha llamado la atención y es lo que peor se te da. A79- (Asiente).

P- Explícalo un poco, ¿qué es lo que se te da mal?

A79- Sobre todo el examen que hiciste de la segunda evaluación, que me costó mucho lo de adivinar las tonalidades y eso.

P- ¡Ah!, lo de adivinar las armaduras de las tonalidades.

A79- Mi madre es que ya lo entendía hasta ella, y yo no.

$\mathrm{P}-i$ Os cuesta entender lo de las tonalidades?

A79- A mí ya no, pero antes sí. (EG2CAsA, p. 21) 


\subsubsection{Adquisición y dominio de los contenidos teóricos}

Como ocurre siempre que se inicia un nuevo aprendizaje, algunos alumnos tuvieron más dificultad que otros en entender y asimilar ciertos contenidos teóricos, pero conseguir su dominio fue solo cuestión de tiempo.

No tengo muy claro si he sabido utilizar bien las notas de paso, ¿me lo puedes volver a explicar? (CE2CA43N, p. 5)

F62- Quizás, yo creo que por timidez, hay cosas que, en algún momento dado, no ha entendido correctamente. Luego, yo creo que ha superado ese bache y bien. (EG2CFs, p. 20)

A9- Antes no sabía qué eran, no me sonaba el nombre y no sabía para qué servían, pero he aprendido y ya lo he cogido. (EG1CAsA, p. 11)

P- Y de los acordes, notas de paso, floreos..., todas estas cosas que hemos estado viendo este año, o tonalidades, ¿qué me decís?

A71- Que, al principio, son un poco liosas.

$\mathrm{P}-i \mathrm{~A}$ ti al principio te costaba entenderlas?

A71- (Asiente).

$\mathrm{P}-$ ¿Sí? ¿Y al final?

A71- No. (EG2CAsD, p. 11)

Eso sí, para que pudieran interiorizar todo de forma adecuada, siempre íbamos relacionando la teoría con la práctica, analizando y trabajando de forma creativa cada nuevo contenido. Lo expresaba en mi diario de esta manera:

He estado trabajando otra nota de adorno de la melodía: el floreo. Se lo he presentado teniendo delante los acordes y diciéndoles que consiste en coger una nota del acorde y luego subir o bajar a la que esté justo encima o debajo y volver a la nota de partida. Hemos estado realizando la adaptación de motivos en los que salían floreos, tanto de forma oral como por escrito, y parece que lo han comprendido bien. Al trabajarlos por escrito, les he explicado que, al igual que las notas de paso, los floreos deben estar siempre en parte o fracción débil y, cada vez que veían o escribían uno, debían señalarlo con una "F". Con ello pretendo que, cuando escriban notas, lo hagan de una forma ordenada y consciente, sabiendo que la mayor parte de las veces usarán notas reales del acorde pero que, si alguna vez escriben alguna nota que no aparezca en el acorde que tienen debajo, deben poder explicarla con una "P" o una " $F$ "; si no pueden explicarla porque no cumpla las condiciones, no la pueden poner. (DPN, p. 7)

En los grupos de primero hemos estado viendo el concepto de intervalo, como distancia entre dos notas, y hemos analizado intervalos en función de su distancia (intervalos de $2^{\mathrm{a}}, 3^{\mathrm{a}}, 4^{\mathrm{a}}, 5^{\mathrm{a}}, 6^{\mathrm{a}} \ldots$ ) y su sentido 
(ascendente/descendente). Después de realizar esta actividad, A15 me ha dicho: "Supongo que más adelante nos explicarás para qué sirven, ¿no?, porque mis compañeros de dulzaina están todo el día hablando de los intervalos y yo no entiendo por qué son tan importantes. Es más, les pregunto y tampoco me saben responder, pero dicen que hay que sabérselos muy bien porque te los preguntan siempre en los exámenes". Este comentario me parece muy interesante porque demuestra que mis alumnos están acostumbrados a que todo lo que aprenden en teoría tiene una aplicación práctica y están esperando que les muestre su utilidad, la cual han comprendido rápidamente cuando hemos jugado a identificar auditivamente intervalos de segunda mayor, de tercera mayor y de quinta justa (aunque en ningún momento he hecho referencia a la especie del intervalo). Las referencias que han utilizado los alumnos para reconocer de qué intervalo se trataba eran las siguientes: si sonaba como una escala, estábamos ante un intervalo de segunda y, si sonaba como un arpegio, podían ser terceras (si eran las dos primeras notas) o quintas (si eran la primera nota y la tercera). (DPY, p. 1)

Así lo reconocían también mis compañeros:

T- El otro día, con uno de los alumnos en concreto, en clase vimos una obra con forma $\mathrm{ABA}$, que conocen porque han trabajado ellos mismos. Entonces: "¡Ah!, ¡yo el otro día hice una canción que tenía la misma forma!” O: "¡Mira el final de esta canción, yo hacía lo mismo: dominantetónica!" Son cosas que reconocen y se dan cuenta de que ellos son capaces de usarlas y de que se usan también en la música que tocan. Entonces, esa relación entre la práctica y la teoría es que es fundamental, si no, ¿qué les estamos enseñando?, ¿algo que luego no pueden llevar a la práctica? [...] Para mí la música debe ser eminentemente práctica; todo, incluso la teoría que trabajemos, tiene que, inmediatamente, irse a la práctica para entenderse. (ETPiJE, p. 3)

El hecho de que los contenidos musicales que se trabajan en el conservatorio sean tan específicos y especializados hacía que los padres no pudieran ayudar a sus hijos cuando algo no lo habían comprendido bien, pero tampoco fue necesario, porque en el aula había un clima de gran confianza y, tanto en casa como en clase, les insistíamos en que me preguntaran las dudas que tuvieran todas las veces que hiciera falta.

F- No, no he tenido que ayudarle. Si lo que me preguntas es si los padres tienen que saber música para que el niño vaya mejor, yo creo que no. (E1CF24, p. 3)

P-¿Habéis notado que les haya costado alguna de las cosas de teoría?

F62- Yo, no. Yo, mi insistencia era: “LLo entiendes bien?” Yo claro, no puedo explicarle y mi marido, desgraciadamente, tampoco. Sí que es verdad que, a mediados de curso, yo creo que ha estado más floja en ese sentido: 
“Pero lo estás entendiendo? Si no lo entiendes, pregunta a Elena, que te lo vuelva a explicar" (EG2CFs, p. 19)

Le pondría un 10, porque nos explica muy bien y 1.000 veces si hace falta. (CA1C, pre. 11)

Al contrario, eran los hijos quienes disfrutaban explicándoles la teoría a sus padres, haciéndoles partícipes de su propio aprendizaje.

F- Yo no sabía la norma y él me dice: "No, es que te lo tienes que saber". Lo del fa mayor me parece que decía que era una excepción, y yo, como de memoria no me gustan las cosas, porque yo necesito razonarlas y tal, pues me costaba un poco de trabajo, y recordé un poco aquello. Y yo veía a él como: "No, no, que es así, es así".

P- (Asiente). Te lo explicó él a ti (ríe).

F- Sí. (E2CF45, p. 2)

Yo hice seis años en el conservatorio hace muchísimo tiempo. Entonces, a mí me llega y me dice: el floreo, y es que me explica él lo que es. (E1CF24, p. 3)

\subsubsection{El papel de la metodología en el aprendizaje teórico}

Estamos convencidos de que, para que los alumnos puedan realizar buenos aprendizajes, lo importante no es solo lo que se enseña, sino el cómo se enseña (Alberich, 2010; Balo, Lago, \& Ponce de León, 2014; Romero, 2008).

Si se tienen en cuenta sus características y se presentan los contenidos a su nivel, adaptándolos a su psicología infantil e invitándoles a manipularlos y a experimentar con ellos, los alumnos pueden aprender todo lo que, como docentes, nos propongamos.

He explicado a los niños que el acorde de dominante es un poco especial y que, en vez de tres notas, puede tener cuatro (la $7^{\mathrm{a}}$, aunque eso, lógicamente, no se lo he dicho), por lo que teníamos que decidir cuál queríamos quitar para poder adaptar bien los motivos que iban sugiriendo (DPO, pp. 2)

En cuanto a los alumnos de primero, para escribir la canción esta vez contaban con tres notas: do, $m i$ y sol, que han coloreado en todos los acordes de tónica y dominante donde aparecían, lo cual les resulta muy útil a la hora de adivinar las notas de la melodía, ya que, por ejemplo, cuando tienen un acorde de dominante, saben que únicamente pueden utilizar la nota sol y eso les ayuda a ir teniendo referencias. (DPN, p. 3) 
En esta semana, he empezado a improvisar y adaptar motivos rítmicomelódicos con los alumnos de primero basándonos en los acordes de tónica y dominante, al igual que he estado haciendo con los alumnos de segundo desde principio de curso. [...] La experiencia ha sido positiva y parece que han entendido bien la dinámica. Sin duda, pienso que les ayuda mucho el hecho de que las notas estén pintadas con distintos colores, porque así ven claro que, por ejemplo, el motivo empieza en la nota verde, luego va a la roja y, después, a la azul, independientemente del acorde en el que estemos. Vuelve a convertirse en un juego para ellos, dejando al margen conceptos teóricos vacíos de significado para su edad. (DPD, p. 3)

Dicha adaptación metodológica la reconocían tanto los propios alumnos como sus profesores de instrumento.

Nos explica las cosas de manera que las entendamos. (CA1C, pre. 11)

T- Les estás dando herramientas para trabajar a su nivel, evidentemente en unos niveles muy tempranos, pero, vamos, son cosas que yo, por lo que veo, están asumiendo perfectamente y que se pueden abordar desde un punto de vista más teórico, que es como lo hemos trabajado nosotros en nuestra carrera, o desde un punto de vista, en este caso, más experimental o, incluso, más lúdico, ¿no?, porque ellos van trabajando con ello, van jugando con la música y, al final, lo único que están haciendo en esos juegos es ponerle ese nombre, esa etiqueta a eso que ellos oyen y lo asocian con: "Bueno, pues esto me produce reposo, esto me produce tensión y tal". Me parece muy interesante. (ETO, P. 5)

De esta manera, avanzando poco a poco y poniendo el énfasis en una práctica continuada, todos los alumnos consiguieron asimilar perfectamente los contenidos teóricos, interiorizándolos no solo a nivel conceptual sino, sobre todo, mostrando un gran dominio a la hora de reconocerlos y de utilizarlos. Así lo recogía en mi diario:

Esta semana hemos realizado solo los exámenes de teoría y de dictado, reservando los de ritmo y entonación para la siguiente. Ambos exámenes se han desarrollado con normalidad y los alumnos los han defendido con gran soltura, demostrando tener los contenidos muy interiorizados y agilidad en la realización del dictado. Con respecto a esto último, quisiera destacar el hecho de que, durante el mismo, dos alumnos de segundo me han preguntado si tenían que señalar los floreos y las notas de paso que aparecían, ante lo cual yo he dicho en voz alta: "¿Es que habéis encontrado alguno?", y varios a la vez me han respondido que sí, lo cual era cierto. Les he respondido que no, que puesto que en estos dictados no tenían los acordes debajo no era necesario que fueran indicando floreos ni notas de paso pero que, no obstante, si a alguno le ayudaba para ser más consciente del dictado que estaba realizando y buscarle más lógica, podía ponerlo. ¡Me 
ha encantado que me lo dijeran, porque es una prueba de que transfieren los contenidos a nuevas situaciones! (DPD, pp. 1-2)

Por su parte, los alumnos expresaban dicho dominio de los conceptos teóricos de esta manera:

P- ¿Tú crees que ahora dominas suficientemente bien todo el tema de acordes, notas de paso, floreos, apoyaturas...?

A71- (Asiente).

$\mathrm{P}-$ ¿Eso qué significa?

A71- Que sí.

P- Que sí. ¿Y los demás?

A64- También.

A75- También. (EG2CAsD, p. 12)

A51- Yo creo que está fácil de aprender. Si, por ejemplo, el si está entre un $l a$ y otro la, pues sabes que es un floreo; y si es un sol y está entre un $f a$ abajo y un la arriba, o al revés, pues es una nota de paso; y si no suena bien la nota con el acorde que hay debajo, pues es una apoyatura, no es tan difícil de recordar.

$\mathrm{P}-\mathrm{A}$ ti te resulta fácil.

A51- (Asiente). (EG2CAsA, p. 27)

Con teoría, porque he aprendido acordes, tonalidades, buscar alteraciones... (CA2C, pre. 7)

A37- Cuando tengo el acorde me parece más fácil porque sé qué notas me pueden entrar y qué notas no me pueden entrar. Por ejemplo, en el de tónica me pueden entrar do, mi y sol, y no re, y en el de dominante me pueden entrar si, re, fa y sol. Luego, por otra parte, están las notas de paso, las apoyaturas y los floreos, pero para eso hay unas pautas. Las apoyaturas tienen que estar en parte o fracción fuerte y los demás en parte o fracción débil, y tienen que ir con unas notas determinadas: un floreo tiene que ir de una nota a otra y volver a la de partida, una nota de paso tiene que ir como un trozo musical que es una escala y las apoyaturas tienen que ir de una nota a otra..., bueno, puede ser... A ver, que me explico. Si, por ejemplo, hay un si, puedo ir al do y tiene que estar delante el $d o: d o-s i$, y eso sería una apoyatura superior. Y si quiero hacer...

P- ¿Quieres decir que, si quieres ir al si, primero te apoyas en el do para luego ir al si?

A37- Sí, sí.

P- Vale.

A37- Y siempre tiene que ir en escala. Inferior sería la-si.

P- Que te puedes apoyar también en el la para ir al si.

A37- Sí. (EG1CAsF, pp. 14-15)

A71- También con los acordes puedes saber la tonalidad que es: si es mayor, menor, o es la, re... (EG2CAsD, p. 14) 
Dicho dominio lo percibían también claramente los padres.

F- Y tiene muy cogido, que para eso sí que le ha ayudado mucho lo que hacéis en clase, cómo tiene que acabar una pregunta y cómo tiene que acabar una respuesta. Entonces, eso lo tiene muy metido en la cabeza.

P- De los acordes.

F- Sí. Y, luego, también me ha sorprendido lo de dominante y esto, que yo no tenía ni idea e, igualmente, lo tiene superclaro. (E1CF2, p. 6)

\subsubsection{Críticas y apoyos a nuestras propuestas teóricas}

En el campo educativo, todo cambio metodológico hace que surjan seguidores y detractores (Acaso, 2013). En este sentido, algunos compañeros no comprendían ni apoyaban que trabajara los contenidos teóricos relativos a la construcción de acordes y su relación con la creación de melodías a edades tan tempranas y cuestionaban que niños tan pequeños pudieran entenderlos.

Me decían que no entendían por qué dedicaba tanto tiempo a la comprensión y manipulación de elementos del lenguaje musical que ellos, como músicos, consideran innecesarios para estas edades y que podrían aprender más adelante. En este sentido, insistían mucho en que les explicara para qué necesitaba saber un niño de segundo lo que era un acorde, un floreo o una nota de paso. Yo intentaba explicarles que, al igual que los niños aprenden el lenguaje verbal hablando, leyendo y escribiendo, deben aprender el lenguaje musical cantando, escuchando, leyendo y componiendo (de forma espontánea o por escrito) y que, para ello, es fundamental que analicen canciones y aprendan a crearlas ellos mismos conociendo las "reglas del juego". (DPD, p. 10)

Sin embargo, varios de los profesores de instrumento con los que compartía alumnos reconocieron los beneficios de esta forma de trabajo y me mostraron su apoyo, ya que eran conscientes de que estaban aprendiendo sin problema y de que les abría el camino a una educación musical más integral.

T- Sí, yo creo que sí que los están asimilando perfectamente, pero porque, también, se los estás haciendo ver de una manera..., no como nos lo enseñaron a nosotros, como: "esta función conlleva este tipo de cosas, esta función tal...", sino que tú se lo estás transmitiendo a través, primero, de la percepción auditiva, ¿no?, de lo que ellos oyen y de lo que ellos reproducen. Tú a eso les estás diciendo: "Este acorde, por ejemplo, implica tensión, este acorde implica menos tensión y este acorde implica relajación". Entonces, es bueno que vayan jugando, simplemente, con asociar un nombre a una idea que, para ellos, ahora mismo es más accesible por su madurez. Me parece que lo están asimilando muy bien, y, vamos, no me parece para nada descabellado. (ETO, p. 4) 


\begin{abstract}
¡Hola, Elena!
Te quería decir que tus escalas, acordes y arpegios funcionan de maravilla con A74. Estaba ya un poco desesperada con ella porque no había manera de que afinara bien las notas agudas en el violín y le dije que practicara con una de tus hojas de acordes y arpegios y ahora los afina fenomenal, tanto con el violín como cantándolo, se lo sabe muy bien, ¡así que enhorabuena! (CETVM, p. 2)
\end{abstract}

\title{
5. El dictado tradicional
}

Cuando hablamos de dictados musicales tradicionales nos referimos a la tarea consistente en que el alumno escucha una serie de sonidos musicales medidos y debe plasmarlos en un papel, utilizando los códigos propios de la lecto-escritura musical. Es una tarea a la que deben enfrentarse todos los estudiantes de música dentro de la asignatura de Lenguaje Musical y que pretende medir su capacidad auditiva para discriminar una secuencia musical a una voz, en las enseñanzas elementales, y también a dos voces, en las enseñanzas profesionales.

E- Lo que me llama la atención, y lo hago notar muchas veces en mis intervenciones, es que, siendo la audición el punto de partida del músico, es algo que se ha considerado como un adorno y se ha hecho a través de lo que llamamos dictado. (EEx3, p. 6)

La educación auditiva aún sigue trabajándose y evaluándose con los tradicionales dictados a una o dos voces que realizaba yo en mis estudios hace casi treinta años. (DPS, p. 2)

Las características de esta tarea difieren ligeramente de unos centros a otros pero, a modo de ejemplo, citaremos en qué consistía el examen de dictado en la prueba extraordinaria de septiembre del segundo curso de las enseñanzas elementales en el Conservatorio Profesional de Música de Segovia, tal y como aparecía recogido en la programación de la asignatura para el curso académico 2012-2013.

El dictado tendrá una extensión de 8 compases en Do $M$, con las dificultades propias del curso. Como referencia se dirá al alumno el compás y la nota inicial. Se escuchará dos veces entero y luego se dividirá en dos fragmentos que se escucharán cinco veces cada uno. El enlace de los dos se escuchará dos veces y finalmente dos veces entero. (p. 48)

En este apartado comenzaremos analizando la actitud y las dificultades de los alumnos ante los dictados musicales tradicionales, lo cual nos llevará a reflexionar sobre la importancia de reducir la ansiedad y el miedo al bloqueo en su realización. Después, señalaremos distintas estrategias para trabajar los dictados, sugeridas tanto por expertos como por los propios alumnos, y 
presentaremos nuestras alternativas al dictado tradicional que, como comprobaremos a continuación, también capacitan a los alumnos para poder resolverlos adecuadamente, resultándoles notablemente más motivadoras.

\subsection{Actitud y dificultades de los alumnos ante los dictados musicales tradicionales}

El dictado es, por lo general, lo que más cuesta y menos gusta a los alumnos de Lenguaje Musical (Malbrán, 1996). Es una tarea compleja que, de alguna forma, engloba lo trabajado en los demás ámbitos: ritmo, entonación y teoría (Martínez, 2007).

A29- Yo creo que lo que no domino es el dictado.

$\mathrm{P}-\succsim$ Crees que no lo dominas?

A29- No.

P- Y cuando te he devuelto los dictados corregidos, ¿tú los has visto muy mal hechos?

A29- Hombre, muy mal hechos no, pero bastantes fallos sí que he tenido.

$\mathrm{P}-\mathrm{O}$ sea, que te gustaría hacerlos mejor.

A29- Sí.

P- Vale. ¿Que te gustaría hacerlos mejor o que los haces demasiado mal?

A29- Que me gustaría hacerlos mejor. (EG1CAsC, p. 23)

P- ¿Hay alguna cosa de las que hacemos en clase que no os guste o que quisierais cambiar?

A23- Los dictados.

P- ¿Por qué no te gustan?

A23- Porque son difíciles de hacer.

$\mathrm{P}-\mathrm{A}$ ti te parecen difíciles de hacer.

A23-Sí. (EG1CAsB, p. 6)

Analizando las respuestas ofrecidas en la pregunta 6: ¿Qué es lo que te resulta más difícil? de los cuestionarios de Lenguaje Musical administrados a distintos conservatorios observamos que el mayor número de respuestas se corresponden con el bloque auditivo, llegando a triplicar las puntuaciones ofrecidas en ritmo. Como dicho bloque auditivo integra tanto la entonación como el dictado, debemos seguir profundizando en él para llegar a comprender a qué se deben estos resultados; a ello nos ayudarán las respuestas del ítem número nueve. 


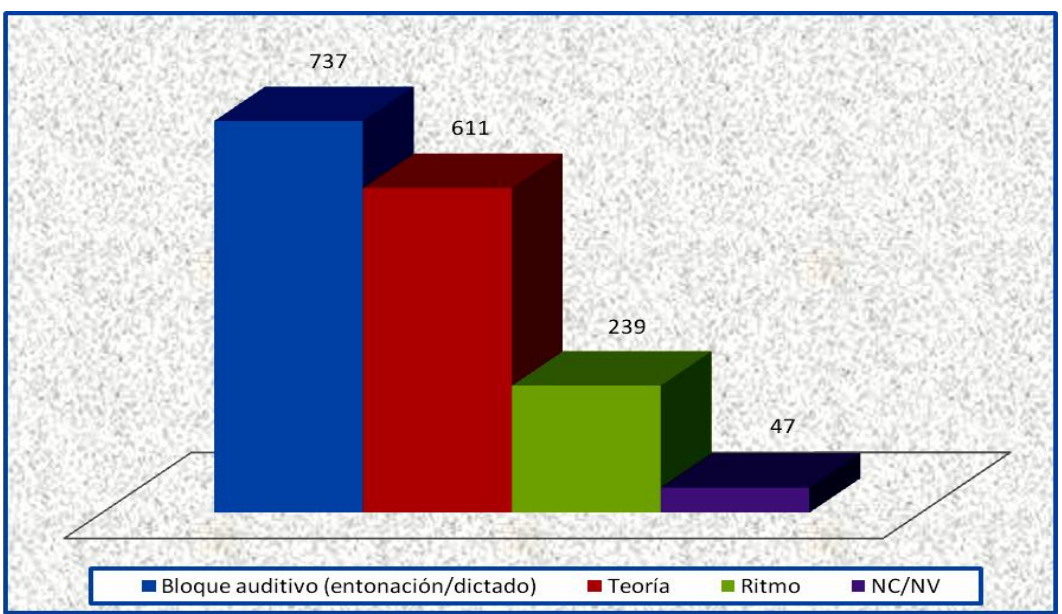

Gráfica 4. Respuestas de los alumnos a la pregunta 6 de los cuestionarios: ¿Qué es lo que te resulta más difícil?

El gráfico que muestra las respuestas a la pregunta 9: Dentro del bloque auditivo, ¿qué es lo que te resulta más difícil? de dichos cuestionarios nos permite afirmar que lo que más cuesta a los alumnos es la realización de dictados.

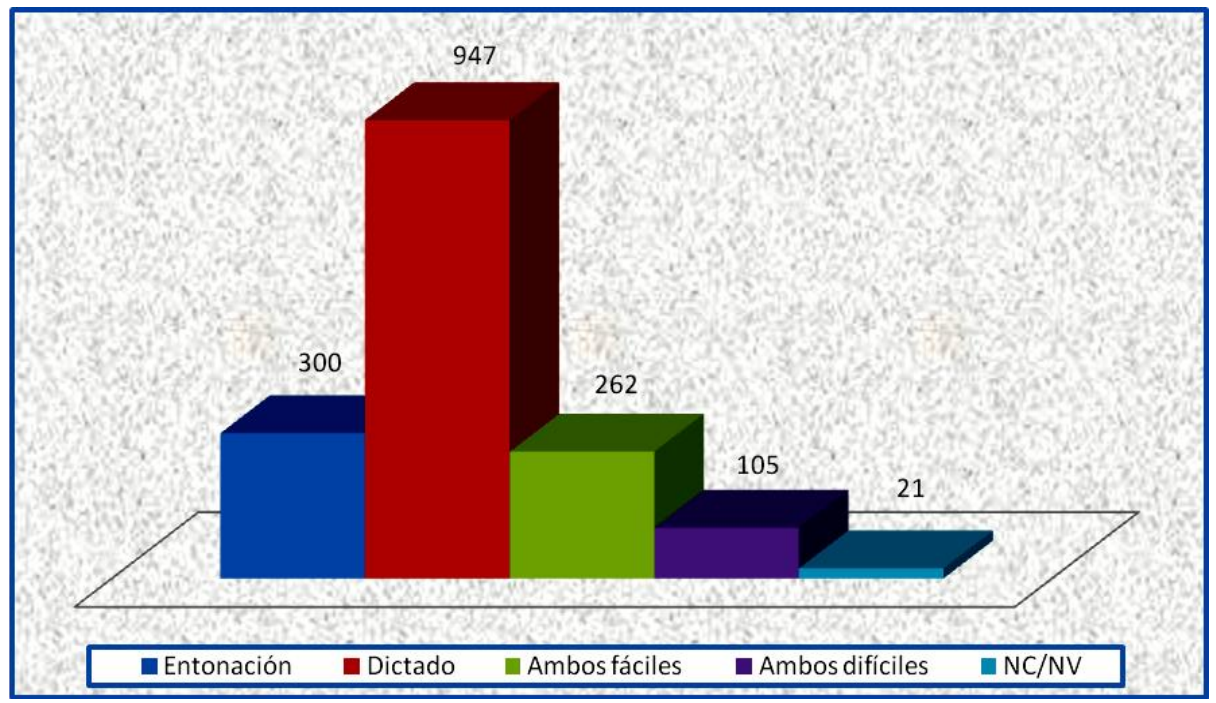

Gráfica 5. Respuestas de los alumnos a la pregunta 9 de los cuestionarios: Dentro del bloque auditivo, ¿qué es lo que te resulta más difícil? 
Por otra parte, en la pregunta 8: Dentro del bloque auditivo, ¿qué es lo que más te gusta? podemos ver que lo más motivador para los alumnos es la entonación, quedando el dictado muy por debajo en puntuaciones (casi una cuarta parte). Asimismo, comprendemos que, proporcionalmente, tampoco es muy elevado el número de alumnos que disfrutan con ambas tareas.

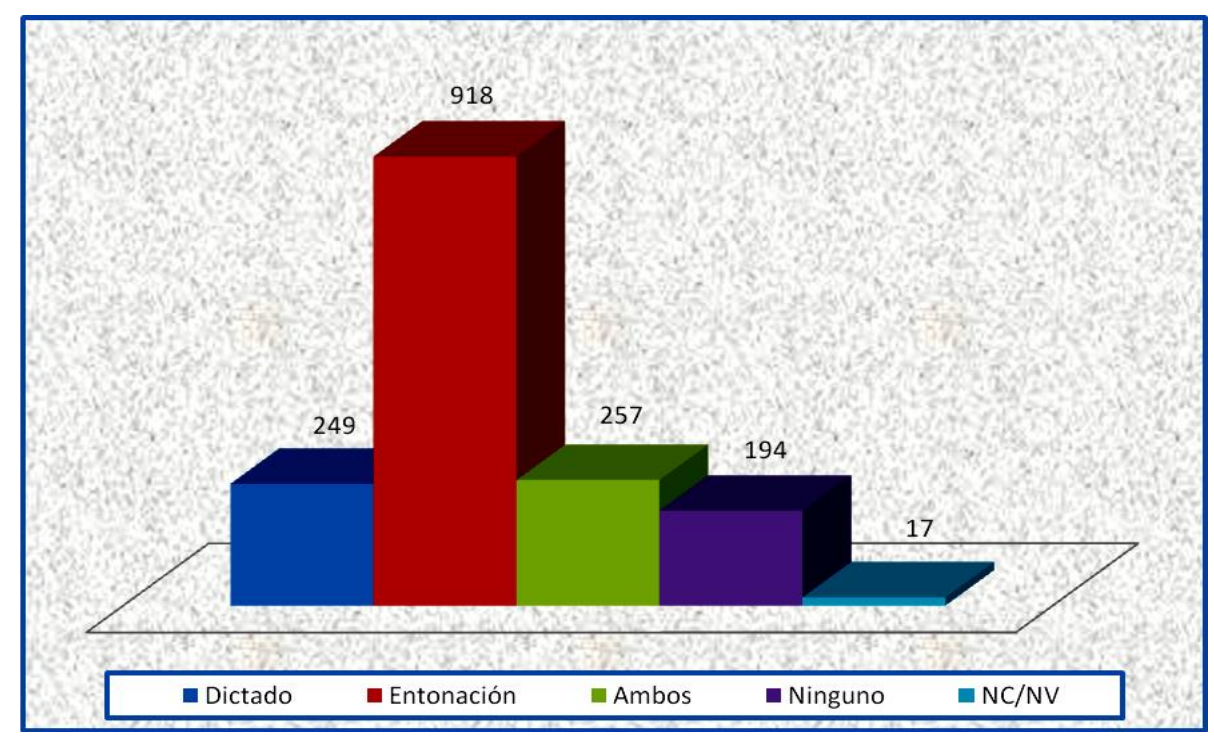

Gráfica 6. Respuestas de los alumnos a la pregunta 8 de los cuestionarios: Dentro del bloque auditivo, ¿qué es lo que más te gusta?

Es tan poco común encontrar algún alumno al que le motive la realización de dictados que, cuando esto ocurre, sus propios compañeros se sorprenden.

A79- Que a mí lo que más me gusta de Lenguaje Musical es el dictado. A45- ¿Es?

A51- ¿Dictado? (EG2CAsA, p. 6)

Dicha falta de motivación puede deberse a que es una tarea que consideran compleja, como acabamos de ver. Pero, $i$ a qué se deben estas dificultades en la realización de dictados? En este sentido, las respuestas de la pregunta 12: Considero que mis dificultades en dictado se deben a resultan de gran ayuda, ya que nos aclaran que lo más complicado para los alumnos es la identificación auditiva de las notas. Además, aunque en mucha menor medida, reconocen tener dificultades en la memorización de los dictados y en la identificación de contenidos rítmicos (pulso, compás y/o ritmo). 


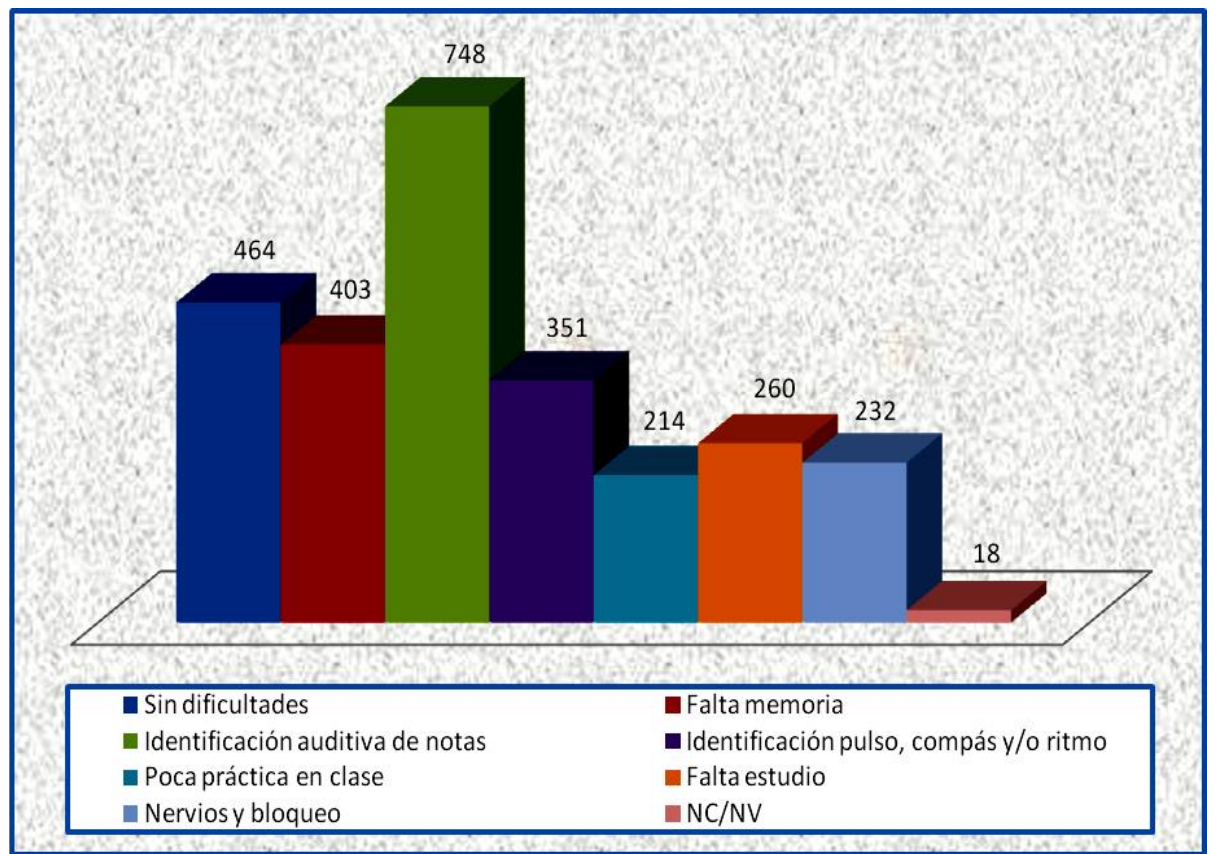

Gráfica 7. Respuestas de los alumnos a la pregunta 12 de los cuestionarios: Considero que mis dificultades en dictado se deben a:

Así lo expresaban algunos alumnos en las entrevistas realizadas en este estudio.

A47- Yo los errores que más tuve fueron los puntillos. [...] No había que ponerlos y puse todos.

P- ¿Que no había que ponerlos en un compás de seis por ocho, por ejemplo? A47- Sí.

P- ¡Ah! O sea, que ponías negra con puntillo-corchea, en vez de negracorchea.

A47- (Asiente). (EG2CAsA, p. 20)

A40- Identificar las notas puede que sea lo más difícil de todo. (EG1CAsC, p. 17)

A17- Las notas, que para mí es difícil encontrarlas, saber si es un do, un re, un $m i . .$. (EG1CAsB, p. 7)

A45- A mí me resulta difícil distinguir entre negra-silencio y blanca. (EG2CAsA, p. 20)

A63- A mí las notas me cuestan un poquito más. Si subes y bajas, eso está fácil, y el ritmo, pero las notas me cuestan. (EG2CAsB, p. 9) 
A algunos alumnos les crea tanta inseguridad hacer dictados que, a pesar de que los tengan bastante bien, tienen la sensación de haberlos hecho mal.

$\mathrm{P}-$ ¿Y cuando te lo he dado corregido tenías muchos errores?

A9- No, la verdad es que no.

$\mathrm{P}-\mathrm{O}$ sea que, aunque te parecieran difíciles, ¿consideras que lo has hecho bien o no?

A9- Sí.

P- ¿Sí? O sea, que es más sensación tuya que lo que realmente era, ¿es así?

A9- Sí. (EG1CAsA, p. 12)

Aunque a veces pasa lo contrario: creen haberlo hecho bien y luego se sorprenden al ver que habían cometido bastantes errores, lo cual demuestra que tienen una percepción errónea sobre su dominio de la tarea.

A64- Cuando los hago sin que me hayas puesto lo que hayas corregido, pues parece que lo he hecho bien, pero luego lo veo y lo he hecho regular. (EG2CAsD, p. 19)

El hecho de que para ejecutar los dictados se utilice normalmente un piano es un factor que también influye en su resolución, ya que suelen resultarles más sencillos a los pianistas, acostumbrados a su timbre, que a los alumnos que estudian otros instrumentos, especialmente si estos son transpositores (Balo, 2014).

P- ¿A ti te resultan difíciles?

A21- No, porque como yo toco el piano, pues lo escucho más. Yo suelo tocar todos los días el piano y, entonces, me sé cómo suena cada nota y me resulta fácil.

$\mathrm{P}-$ ¡Ah! porque, como lo toco en el piano, tú reconoces bien el piano.

A21- Sí. (EG1CAsB, p. 6)

De ahí la conveniencia de utilizar distintas fuentes para la realización de los mismos, aunque los alumnos que están acostumbrados al piano también encuentran dificultades al utilizar otro instrumento.

A46- No, que yo, particularmente, hubiese hecho más dictados en el piano.

P- ¿Más dictados tipo los que hemos hecho en el examen?

A46- En el piano, sí, tocando en el piano.

$\mathrm{P}$ - ¿Por qué?

A46- Porque identifico mejor los sonidos. (EG2CAsA, p. 19)

\subsection{Importancia de reducir la ansiedad y el miedo al bloqueo en los dictados}

Es frecuente que la realización de dictados genere ansiedad en los alumnos. 
Me ha resultado muy relevante el hecho de que, cuando he comentado que íbamos a hacer un pequeño examen de dictado, varios alumnos han dicho: "¡Noooo!" y, cuando les he preguntado por qué les asustaba me han respondido: “Porque es muy difícil!” Ante esta reacción, les he vuelto a preguntar: "¿Y cómo sabéis que es muy difícil si todavía no hemos hecho ninguno?" A lo cual me han dado respuestas como: "Porque a mi hermano mayor se le dan muy mal y dice que es muy difícil" o "Porque yo iba a una escuela de música en la que hacíamos dictados y no me salían". Estas respuestas manifiestan una vez más las reacciones negativas que despierta el "temido dictado", que predisponen a los alumnos al fracaso en su realización. (DPN, p. 6)

El miedo a quedarse bloqueados y dejar los compases en blanco es un factor que provoca una mayor disminución de la concentración y un aumento de los errores (Kenny, 2008; Louvier, 1996).

P- ¿De qué me hablas tú ahora?

A61- De los dictados, que sí que es verdad que algunas veces te cuesta. Es que te quedas en un compás parado y...

A57- ¡Y no te sale, no te sale...!

A61- Eso mismo.

A57- Es que le tienes que pedir que te lo repita.

$\mathrm{P}-\mathrm{Vale}$ ¿Os ponéis nerviosos cuando hacéis los dictados?

A57- Un poco.

A63- Un poco no, iyo exploto! (EG2CAsB, p. 25)

Por eso era muy importante tranquilizar a los alumnos, para que lo vieran como una actividad más y no tuvieran miedo a equivocarse, planteándolo como un taller (López de Arenosa, 2004) y no como una prueba de su capacidad auditiva.

Para reducir la ansiedad de los alumnos, he decidido reformular mi planteamiento y les he preguntado si adivinar el ritmo de los refranes y transcribir las canciones que aprendemos en clase les parecía difícil, a lo cual han respondido que no. Entonces, les he dicho que esto se hacía exactamente igual y que, en vez de llamarle dictado, le íbamos a llamar "adivinanza sonora", y que se trataba de un juego en el que yo iba a tocar algo que ellos tenían que descubrir cómo escribir. La idea les ha gustado y ha cambiado su actitud ante la actividad. (DPN, p. 6)

E- Yo soy partidaria de que, cuando llegan a la escritura, deben escribir lo que tienen archi-superado, de manera que la escritura de lo musical nunca plantee tensión, que es uno de los graves problemas del dictado.

P- Bloqueos, claro.

E- Claro y, además, convertirlo en taller; no es una prueba de: "Aquí te voy a poner un rojo porque te has equivocado", sino que yo siempre eso lo he hecho paseándome por la clase y corrigiéndoles con comentarios como: 
"Vuelve a oír eso. Vamos a ver si...", ¿sabes? Entonces, nada de calificaciones ni descalificaciones, ni nada por el estilo y corregimos cantando. Luego lo vemos en la pizarra y tú sabes lo que han hecho porque lo ves y lo retienes. Ellos también lo saben y lo corrigen. (EEx3, p. 14)

Además, al aumentar la tolerancia de los alumnos al error, concienciándoles de que es un elemento normal del proceso de aprendizaje (Eloise Ristad, 1997, citada por Maxwell, 2000), conseguimos que se relajaran y que aumentara su concentración y sensación de control, por lo que mejoró su eficacia en la resolución de los dictados.

A71- Me di cuenta de que no se me daba mal y me empezó a gustar. (EG2CAsD, p. 20)

A29- A mí me parece que los fallos que he tenido han sido normales porque, después de todo, estamos en el primer año, y, bueno, hay que tener fallos, no estás apuntado en el conservatorio para ya tenerlo todo aprendido. $\mathrm{P}-\mathrm{Si}$ ves fallos en tu dictado, ¿te molesta?

A29- Hombre... no, no mucho. Hombre, si veo toda la hoja ahí llena de fallos, sí, pero...

As- (Ríen).

P- ¿Y tú has visto alguna vez toda la hoja llena de fallos?

A29- No. (EG1CAsC, p. 19)

P- ¿Tú crees que los dominas?

A61- Pues parte sí y parte no. A mí el ritmo me sale bien, las notas un poco peor.

A54- Igual que a mí.

P- Vale. ¿"Un poco peor" significa que tú crees que se te dan bastante mal, o que te gustaría que se te dieran mejor aunque no se te dan muy mal?

A61- Pues que no se me dan mal, mal, mal del todo, pero me gustaría que se me dieran mejor.

A63- Hombre, a todos.

A61- Por ejemplo, que suena $m i$ y pongo $f a$, cosas así. (EG2CAsB, p. 28)

Indudablemente, la práctica también les hizo ganar seguridad.

A7- A mí, al principio, me parecían difíciles, pero luego ya, como vamos aprendiendo más cosas y todo se nos va quedando mejor en la cabeza, ya me iban saliendo mejor todos.

P- ¿Aunque fueran más difíciles los últimos?

A7- Sí. (EG1CAsA, p. 12)

P- ¿Tú sientes que has mejorado?

A63- Sí.

P- ¿De como los hacías al principio a como los hacías al final? 
A63-Sí, porque he visto la hoja que nos diste para poner las pegatinas y he visto que he mejorado mucho: antes tenía muchos errores y ahora tengo unos pocos menos. (EG2CAsB, p. 9)

A6- Pues a mí, al principio, me parecían un poco difíciles, pero, más o menos, ahora ya me van saliendo mejor. (EG1CAsA, p. 12)

A31- Al principio me ha parecido difícil porque no sabía... vamos, no lo entendía muy bien y, cuando tocabas algo, no captaba bien las notas, y ahora las capto mejor y los hago mejor. Y ahora me gustan más que antes.

$\mathrm{P}$ - ¿Te gustan más porque los dominas más?

A31- Sí. (EG1CAsC, p. 18)

A medida que los fueron controlando, aumentó su motivación y empezaron a disfrutar haciendo dictados, dejando de suponer un trauma para ellos.

P- ¿Algún tipo de comentario cuando tiene que trabajar?

F- Las de ritmo, las que tiene que poner las figuras.

$\mathrm{P}-$ ¿Los ejercicios de audición donde tiene que escribir?

F- Sí.

P-Sí.

F- Que hay unos que son... vienen las figuras y tiene que poner el ritmo, pues si son corcheas, blancas..., esa le encanta. (E1CF24, p. 6)

A2- A mí me parecen fáciles porque, como tengo muy buen oído para la música, pues entonces cojo bastante rápido las notas y me suena bien el dictado. Entonces, me cuadra y, normalmente, lo tengo bien y no tengo ningún fallo. (EG1CAsA, p. 12)

\subsection{Estrategias para trabajar los dictados}

Cuando un alumno tiene dificultades en la realización de dictados, es frecuente escuchar entre los docentes que es que "tiene mal oído". No obstante, nosotros estamos convencidos de que el problema que hay detrás es una metodología deficiente a la hora de enseñarles cómo resolverlos, aunque lógicamente haya alumnos que tengan más facilidad que otros (Musumeci, 2007). En este sentido, el análisis continuado y la atribución de significado a cada una de las notas que escriben resultan fundamentales.

E- He visto chiquillas, cuando yo todavía no tenía mucha experiencia, que te cogen el dictado perfecto, pero con una voz en una tonalidad y otra en otra. Es decir, que el concepto tonal... Eso es lo que te va haciendo pensar que no puede ser porque oyen muy bien cada una, aunque la cogen confundida del principio, pero, claro, lo que no piensan es que esa una es el resultado de la otra. Pues es que hay que hacérselo pensar, ¿no?

P- ¿Podríamos decir entonces de esto que los errores que tú veías eran de una metodología mal aprendida más que de un problema físico o de oído? 
E- Para mí absolutamente. Fíjate, yo creo que es que, como nosotros lo hemos aprendido tarde y mal, trasladamos nuestra dificultad a los chicos. (EEx3, p. 57)

Por ello, dentro de este apartado, presentaremos distintas propuestas utilizadas por los expertos para trabajar los dictados, recogeremos algunas sugerencias de los propios alumnos y, finalmente, describiremos cuáles han sido las estrategias metodológicas específicas que hemos utilizado en este estudio para facilitarles su realización.

\subsubsection{Estrategias y recursos utilizados por los expertos}

Ya hemos comentado en varias ocasiones que lo más importante para un músico es el desarrollo del oído (Kühn, 2003; Malbrán, 2007a) y que una buena escucha implica dotar de significado a lo que se está oyendo.

E- Vamos a ver si nos enteramos de que lo primero es el oído. [...] Tienen que oír desde el primer día y, además, saber lo que oyen. (EEx3, p. 18)

E- La audición debe estar siempre presente. El músico no se puede permitir el lujo de no tener el oído absolutamente despierto para todo lo que hace, porque la música, si no suena, no es música. (EEx3, p. 29)

Un dictado no puede convertirse en un jeroglífico o un acertijo aleatorio, sino que debe ser el resultado de una serie de contenidos que ya se han trabajado previamente y que, por tanto, los alumnos controlan y sabrán identificar.

E- Yo, como alumna, nunca hice dictado, se empezó a hacer el dictado siendo yo ya profesora, dictado a una voz que, por otra parte, me parece dificilísimo porque, claro, la armonía centra muchísimo, y encima sin ningún tipo de secuencia: "Al que Dios se la dé, San Pedro se la bendiga", ¿sabes? Esto es: ¡allá va lo que se me ha ocurrido sobre la marcha! En fin, ¡aquello era terrible! (EEx3, p.6)

E- La lección del dictado tiene que estar pensada de acuerdo a lo que los alumnos han estudiado, no es una lección cualquiera, porque si tú la dictas y ellos no son capaces de seguir los elementos que tú les has enseñado antes, no lo van a hacer. (EEx1, p. 19)

E- Los alumnos realizan un dictado rítmico-melódico semanal en casa, para reforzar los contenidos trabajados en las clases. [...] Estos dictados siempre están basados en motivos rítmico-melódicos ya trabajados. (EEx2, p. 6)

Puesto que la música tonal-armónica es la más característica de nuestro contexto socio-cultural, es importante plantear el trabajo de la audición 
tomando como base el acorde y los tópicos tonales: sucesión de tensión y reposo mediante la dominante y la tónica, cadencias típicas, estructuras formales que buscan la unidad y el contraste o construidas a modo de pregunta-respuesta, etc.

E- Te encuentras con que hay mucha gente cuya capacidad de identificación de lo sonoro es cero, ¡es cero!, tanto en lo concreto como en lo global. Por eso, mi manía en las clases era: "Vamos a oír sin tomar ninguna nota y sin nada y luego vamos a ver los salientes que nos han llamado la atención. Vamos a ver qué se nos ha quedado de esto y luego vamos al papel". Porque, claro, si vamos al papel lo primero, el análisis, en realidad, es un análisis totalmente a la violenta. (EEx3, p. 28)

P- ¿Qué tipo de contenidos trabaja en los dictados: rítmicos, melódicos, armónicos, formales, tímbricos...?

E- Trabajamos todos los que se plantean en la pregunta, aprendiendo a escuchar e identificar todos los elementos del Lenguaje Musical. (EEx2, p. 6)

E- Jugamos con el acorde de tónica y el acorde de dominante y, luego, aparece el de subdominante, que es diferente. $\mathrm{Y}$ ahora vamos a hacer un juego en el que, mientras suena el de tónica, hacemos tal movimiento, mientras suena el de dominante, otro y, cuando suena el de subdominante, otro diferente, de manera que haya una identificación. También hacemos improvisación sobre esos tres acordes, armonización sobre melodías que estén hechas nada más que sobre las notas del acorde, etc. (EEx3, p. 36)

Todo ello manteniendo a los alumnos en una actitud activa, manipulando los sonidos constantemente, creando motivos o melodías con ellos, identificando auditivamente los distintos elementos de la música, sacando conclusiones $\mathrm{y}$, en definitiva, haciendo del lenguaje musical un lenguaje propio con el que se puedan comunicar.

E- Vamos a improvisar sobre los acordes básicos. Si tú haces un proceso armónico muy sencillo de tónica-subdominante-dominante-tónica, por ejemplo, y dices: "A cada uno de estos acordes le vamos a dar un valor de tres pulsos en tres por cuatro, por ejemplo. Entonces, yo sostengo el acorde y vosotros improvisáis utilizando solo notas del acorde". Y pueden improvisar lo que quieran. Ya sabemos que al siguiente compás cambiamos de acorde, con lo cual tienen que imaginar el acorde en el que están. Y luego, a veces, lo que hacemos es que eso lo mantengan ellos mismos, ¿no?: hay un coro que mantiene los acordes y un solista. Entonces, el solista ya se puede permitir el lujo de meter unas notas de paso o lo que quiera, depende del nivel que estés buscando. $\mathrm{O}$ al revés, haces una melodía muy clara y, sobre la marcha, dices: "Armonizádmela. Dadme la nota base del acorde de esta melodía”. (EEx3, p. 24) 
E- Muchas veces digo: "Canta con el acorde de la mayor pero no digas los nombres de las notas" y dice: "La la la la" (entonando notas de dicho acorde) y digo a los demás: "Ahora repetid eso, pero ponedle nombre", aunque primero digo: "Repetidlo igual: la-la-la-la" para que sepan cómo es y recordarlo. (EEx1, p. 18)

E- Vamos a cantar la escala de sol por activa y por pasiva ¿no? Y, entonces: "Pues haced una melodía, hazme una melodía tipo pregunta y tu hazle la respuesta". Improvisando constantemente, sobre todo sobre los básicos significativos. (EEx3, p. 23)

Los dictados orales son mucho más rápidos y generan menos ansiedad a los alumnos que los dictados escritos, por lo que resultan de gran utilidad, especialmente si se plantean a partir de canciones y con un sentido lúdico.

E- Yo estoy en la clase haciendo dictados continuamente, pero no escritos. [...] Yo de vez en cuando diré a los alumnos: "A ver, dime tu motivo". Y dirá alguno: "La, la, la, la" (entonado). Y les diré: "Cantadlo todos". "La la la la" (entonado). “QQué notas son?”. "Sol, do, mi, do" (entonado). Te diría que puedes hacer veinte dictados en cinco minutos con este sistema. Y en algún momento diré: “¿Cómo se escriben?” [...], pero no lo hago mucho porque se va mucho tiempo. Tú tendrás la experiencia de que escribirlo es muy pesado para los chavales. Hay que hacerlo, pero es pesado y se te va la clase. (EEx1, p. 18)

E- Primero aprendemos una canción de memoria y luego decimos: "Vamos a descubrir con qué sonidos está hecha" Y entonces: "Pues esta no tiene nada más que do-mi-sol o do-re-mi-sol". Y seguimos: "Pues ahora vamos a esta frase. Vamos a cantarla con el texto. Vamos a cantarla con 'la-las'. Y ahora vamos a cantarla con los sonidos, a ver qué sale en conjunto". Y te cantan con los sonidos. Claro, el que, indistintamente, tú cantes con texto, con "la-las" o con los sonidos específicos supone que están integrando unos modelos con mucha facilidad. Entonces tú, al margen de la canción, estás trabajando muchos dictados orales en los que haces una melodía y ellos te la repiten y, luego, te la cantan con los sonidos, siempre sabiendo de qué sonidos partimos. (EEx3, p. 14)

En cualquier caso, estemos trabajando con dictados orales o escritos, el análisis continuado sobre lo que se está haciendo resulta fundamental para que el alumno adquiera el control de la tarea.

E- Una cosa que a mí me ha interesado mucho en los dictados es que identifiquen puntos básicos. Por ejemplo: “¿La cadencia es una cadencia perfecta? ¿Termina sobre la tónica? ¿Es una semicadencia? ¿Termina sobre la dominante o sobre otro grado?" Vamos a oír y a analizar los puntos básicos, de manera que luego el error sea mínimo. (EEx3, p. 37)

P- ¿Qué estrategias utiliza para facilitarles su comprensión y realización? 
E- Corregimos los dictados en clase y hacemos ver dónde están los errores. Me parece importante hacer pensar al alumno constantemente, que sea consciente de cómo suena lo que va escribiendo, que utilice todos los recursos que ya conoce, que relacione continuamente, etc. (EEx2, p. 8)

Finalmente, señalaremos que los expertos también consideran muy importante trabajar la memoria musical para la correcta realización de los dictados (Louvier, 1996).

E- Los dictados los corrijo sobre la marcha en la clase, poniéndolos luego en la pizarra y haciendo, además, un ejercicio de memoria: lo tengo en la pizarra, vamos a aprendernos la primera voz, la segunda voz, vamos a cantar vosotros la primera voz, vosotros la segunda, ahora viceversa, ahora voy a borrar un fragmento, y ahora lo voy a borrar todo y lo cantamos de memoria, pero, además, lo transportamos. Entonces, estás jugando a muchas cosas al tiempo: la memoria, por supuesto, pero también el análisis. (EEx3, p. 52)

\subsubsection{Sugerencias de los alumnos acerca de los dictados}

Preguntar a los alumnos cómo deberían ser los dictados para que les gustaran más y les resultasen más fáciles resulta interesante para conocer mejor sus dificultades y diseñar una intervención educativa adecuada.

A28- Pues los dictados yo creo que, para empezar, se deberían hacer con pocas notas y ritmo más fácil, con menos compases. Y, cuando ya vas avanzando y sabiendo más cosas, se deberían hacer con más notas y más compases para aprender más. (EG1CAsC, p. 22)

P- ¿Cómo crees tú que podrías mejorar los dictados, o qué podríamos hacer aquí para que te resultara más fácil hacerlos?

A23- Pues que fuera un poco más corto: en vez de una línea y un poco, de una línea.

P- ¿En vez de ocho compases, de cinco, por ejemplo?

A23- ¡Sí! (EG1CAsB, p. 8)

P- ¡Ah! O sea, que tú quieres decir que, en vez de hacer un dictado largo de ocho compases en el que hacemos dos partes de cuatro y cuatro...

A55- Cinco, todos de una, y ya está.

P- Tú prefieres hacer uno de cinco, donde estés escuchando todo el rato los cinco, para que no se te mezcle lo que has escuchado en la primera parte con lo que has escuchado en la segunda.

A55- Sí.

$\mathrm{P}-$ ¿Es eso?

A55- Sí. (EG2CAsB, p. 16) 
Cabe señalar también que los alumnos de segundo que estuvieron conmigo el curso anterior hacían dictados en casa, porque ahora hay muchas editoriales que los elaboran con tal propósito, pero les resultaban muy pesados y, realmente, este curso comprobamos que el trabajo desarrollado en clase había sido suficiente para resolverlos correctamente.

A79- A mí esos dictados no me gustaban nada, nada.

P- Esos dictados no te gustaban nada, los que hacías en casa con los CD's. ¿Por qué?

A79- No lo sé, es que eran muy rollo.

A47- Yo me ponía nervioso, no podía.

$\mathrm{P}$ - ¿Con los CD's, dices?

A47- No podía (negando con la cabeza).

P- Pero te refieres a los que hacías en casa con los CD's.

A47- Sí. (EG2CAsA, p. 16)

P- ¿Tú no los has echado de menos?

A69- Yo no.

$\mathrm{P}$ - ¿Y con lo que hacemos en clase tú consideras que estás preparada para saber hacer los dictados?

A69- Sí. (EG2CAsD, p. 17)

F61- En casa los dictados... (niega con la cabeza, como dando a entender que no los ha trabajado), los hacíais aquí, no como el año pasado que, a lo mejor, teníamos que poner el disco y tal. El examen de dictado ya lo ha hecho, pero en casa no ha estudiado, yo no sé, pero me decía: "No, si lo hacemos todos los días, no hay que estudiar”. Digo: “ $¡$ Ah, vale, pues tira para adelante!" (EG2CFs, p. 3)

Debido a ello, opté por utilizarlos únicamente con casos excepcionales en los que fuera necesario un mayor refuerzo educativo.

T- Lo que veo es que, con alumnos que tenían muchas dificultades en los dictados, la solución que has encontrado con los libros que les has dado para recuperar estaba bien, el nivel era progresivo. (ETPer, pp. 4-5)

\subsubsection{Nuestras alternativas al dictado tradicional y actitud de los alumnos ante las mismas}

Desde que empecé a trabajar como profesora de Lenguaje Musical hace cuatro años he utilizado distintas estrategias para facilitar a mis alumnos la realización de los dictados, dándoles distintas pautas que aumentaran su concentración y asegurándome de que las ponían en práctica.

E- La mayor dificultad en este ejercicio es, quizá, la falta de concentración. (EEx2, p. 8) 
Lo primero que me propuse conseguir fue que se acostumbraran a escuchar con atención y a memorizar la secuencia que acababan de oír antes de ponerse a escribir. El hecho de que el dictado tenga un número de repeticiones limitado provoca que la mayoría de los alumnos se lancen a escribir según lo están escuchando para "no perder tiempo", de tal manera que muchas veces no llegan a memorizarlo correctamente e inventan lo que no consiguen recordar.

Para evitar esta tendencia generalizada, una de las estrategias que puse en práctica consistía en que, mientras estuviera sonando el dictado, ningún alumno podía escribir nada, solo concentrarse en escuchar. Pero, claro, es difícil saber lo que un alumno está pensando mientras escucha el dictado y, por ello, les pedía que repitieran cantando en voz alta lo que acababan de oír, lo cual les forzaba a estar atentos. Memorizar fragmentos de cuatro compases (que es lo que se les exige en estos niveles en nuestro conservatorio, ya que se realizan dictados de 8 compases divididos en dos partes) es costoso si no se tiene un buen entrenamiento, pero acordarse, al menos, del principio sí que es sencillo. Por ello, insistía a los alumnos en que lo importante era escuchar con atención y repetir cantando solo hasta donde recordaran, porque en sucesivas repeticiones la memoria iría aumentando hasta poder reproducir los cuatro compases en su totalidad. Si cuando lo estaban cantando empezaban a inventar la melodía, les cortaba con un gesto y se callaban al instante; era entonces el momento de ponerse a escribir el fragmento que habían escuchado y entonado correctamente. Esta dinámica de trabajo ha dado muy buenos resultados y permitía saber si las dificultades que mostraban los alumnos se encontraban en la representación musical de lo escuchado mediante notas y figuras o, por el contrario, se debían a una falta de memoria.

El apoyo de la voz resultaba muy positivo para ayudar a los alumnos a memorizar mejor y adivinar las notas que habían sonado (Campbell, 1998; Kühn, 2003), al mismo tiempo que servía como medida de control sobre la retención de lo escuchado.

$\mathrm{P}-\succsim$ Os ayuda cantarlo para escribirlo mejor?

As- ¡Sí!

A16- Pero en alto me resulta más fácil.

P- Cantarlo en voz alta te resulta más fácil que cantarlo por lo bajo.

A16- Sí.

P- ¿Por qué?

A16- Porque hay veces que, cuando lo cantas en bajo, se te olvidan cosas, porque estás pensando en otras cosas.

A21- O, cuando lo haces en bajo, como lo estás haciendo más bajo, a lo mejor te sale un poco más grave y te sale otra nota. (EG1CAsB, p. 9) 
E- Cuando realizamos un dictado musical, utilizamos la entonación como recurso esencial para sentir las diferentes alturas del sonido. (EEx2, p. 4)

Algunos alumnos, especialmente los adultos, se descentraban un poco al escuchar cantar a otros y necesitaban silencio absoluto para concentrarse mejor. Y es que, al ser grupos numerosos, el hecho de que todos repitieran en voz alta lo que acababan de escuchar a veces les confundía, pero considerábamos importante insistir en ello para que cogieran bien la dinámica de trabajo.

A13- Estar en silencio, en silencio absoluto, todo el mundo en silencio, es como te concentras un poco, porque en nada que uno dice algo o canta una nota que no es la que has tocado tú, a los de al lado... (niega con la cabeza). A mí, por lo menos, me pasa, que me descontrola "to"”.

A23- Y te dices: "¡Ya me he perdido!"

A13- Sí. Yo creo que habría que estar en silencio absoluto, cada uno pensando en lo que has tocado. Claro, es muy difícil. (EG1CAsB, p. 8)

A38- Es que con los compañeros, si uno se equivoca, el otro se equivoca, porque hay muchos que están atentos al otro compañero y entonces los que lo están haciendo bien se fían también de los que lo están haciendo mal.

$\mathrm{P}-¡$ ¡Ah!, con eso quieres decir entonces que, cuando repetimos de memoria todos en voz alta, si uno se equivoca, confunde a otros, ¿quieres decir eso?

A38- (Asiente). (EG1CAsF, p. 19)

Además, insistimos mucho a los alumnos en la aplicación de distintas estrategias o "trucos" para mejorar los dictados, convencidos de que la correcta realización de los mismos dependía de seguir un buen método.

A54- Yo creo que sí, los trucos que tú nos decías.

P- ¿Qué trucos?

A63- Lo de...

A54- Así (va subiendo y bajando la mano a distintas alturas, utilizando la fononimia de Kodály).

A63- Cantábamos la escala.

P- Espera, espera, que lo explique ella primero.

A54- Lo de las manos (haciendo gestos fononímicos).

P- ¿Lo de ir subiendo y bajando la mano en función de lo que escuchabas?

A54- Sí, y lo de seis por ocho, pues lo de: si entran aquí dos (marca el pulso de abajo con el brazo), sería negra-corchea; si entra una que dura, pues sería negra con puntillo; y, si entran tres, pues tres corcheas.

A63- También ayudaba mucho lo de la escala, que tú cantabas la nota e ibas cantando la escala hasta la nota que era.

A57- Sí.

A58- Y el arpegio.

P- ¿Cuando tenéis saltos entre las notas y no sabéis qué nota es?

A63-Sí. (EG2CAsB, p. 11) 


\begin{abstract}
A partir del segundo curso, como ya sí que vemos la especie de los intervalos, utilizamos canciones que comienzan con cada uno de ellos como recurso para reconocerlos. Por ejemplo, asociamos el intervalo de cuarta justa con el comienzo de la canción Pinocho fue a pescar, el de tercera mayor con la canción Soy la reina de los mares y el de quinta justa con la banda sonora de Supermán. (DPY, p. 1)
\end{abstract}

Aparte de enseñarles estrategias metodológicas que les ayudaran a mejorar, el tema de la motivación seguía siendo importante. Por ello, para tratar de conseguir que la realización de dictados se convirtiera en una tarea más atrayente para los alumnos, consideramos necesario replantear la forma de trabajarlos, utilizando otras actividades. En este sentido, tanto en clase como en casa empezaron a realizar ejercicios de audición que no eran dictados tradicionales y que les ejercitaban el oído, como descubrir errores de notas o de ritmo en un fragmento dado, identificar figuras y motivos rítmicos presentes en una pieza musical escuchada, reconocer auditivamente la presencia de notas de adorno (notas de paso, apoyaturas o floreos), averiguar la secuencia armónica y la estructura formal de una melodía, o inventar motivos melódico-rítmicos de uno o dos compases, adaptarlos de oído a distintos acordes y escribir la frase musical resultante de alguno de ellos.

F- Esos le gustan mucho, los que tiene que ver la nota que está mal.

P- Los ejercicios de audición.

F- (Asiente). Esos ya los hace sola. O sea, ella ya se pone sola y luego me dice: "Ven a comprobar, a ver si te parece que está mal esto". Y, a veces, yo no lo noto y ella lo nota a la primera. (E1CF2, p. 2)

A continuación, hemos escuchado un minueto de Bach y han estado adivinando el compás, el tipo de comienzo, las frases musicales y los motivos rítmicos que aparecían. Después, han escrito los acordes y la melodía de la primera frase, indicando la presencia de notas de adorno con una P (nota de paso), F (floreo) o Ap (apoyatura). (DPA, p. 2)

No obstante, sin lugar a dudas, las dos estrategias fundamentales de esta tesis que han permitido aumentar la motivación de los alumnos hacia los dictados, reducir la ansiedad que les generaban y mejorar la realización y comprensión de los mismos han sido los trabajos a partir de refranes y canciones que hemos descrito en apartados anteriores. El propósito principal que buscábamos con ellos era llevar a cabo una educación auditiva integral aunque, como ya hemos visto, han cubierto otros muchos objetivos.

P- ¿Y qué te gusta más, hacer dictados o hacer las canciones?

A4- Las canciones, porque luego nos inventamos una en casa. (EG1CAsA, p. 13) 
Al cambiar el nombre de "dictado" por el de "refrán" o "canción" y enfocar el trabajo de los mismos como una tarea lúdica o, dicho de otra forma, como un taller de creación musical, algunos alumnos no tienen conciencia de haber estado trabajando los dictados durante todo el curso.

Refuerzas mucho la teoría, la entonación y el ritmo, pero no hacemos casi nada de dictado y a mí me gustaría hacer dictado. (CA2C, pre. 11)

A50- Quitar dictado.

P- Quitar dictado, ¿por qué?

A50- Pues porque no hacemos casi nunca, no hacemos casi ninguno y, luego, en el examen, entra muchísimo. (EG2CAsA, p. 9)

Pero casi todos los alumnos han percibido la clara relación que había entre las distintas tareas y tienen muy claro que sí que hemos hecho muchos dictados de forma "encubierta", a través de actividades menos pesadas, arduas y tensas.

A4- Pues a mí los dictados me recuerdan un poco a las canciones que tocas en clase, porque tocas un trozo y lo repetimos y vamos viendo cómo va. (EG1CAsA, p. 13)

Con lo que más he aprendido es con los refranes, que son como dictados. (CA2C, pre. 7)

P- ¿Hay alguna otra actividad que creáis que os ha ayudado a mejorar a la hora de escribir esas notas y esos ritmos?

A61- Las canciones que hacíamos en clase.

A54- Sí.

A61- La de La uva, El juez...

$\mathrm{P}$ - ¿Tú ves alguna relación entre esas canciones y los dictados?

A61- Pues sí, porque tú las tocas y tienes que adivinar el ritmo y las notas, y en los dictados es lo mismo. (EG2CAsB, pp. 11-12)

A51- Que yo creo que sí que hacemos bastantes dictados porque, para empezar, las canciones y los refranes ya son dictados y, luego, lo que hacemos en el cuaderno de audición, que ahí o es adivinar ritmo, o es adivinar sonidos, o las dos cosas. Entonces, nos preparamos más para los exámenes y sabemos más para hacerlos bien. (EG2CAsA, p. 20)

Al combinar ritmo y melodía, la relación de los dictados con las canciones era aún más directa que con los refranes, pero, de las tres actividades, los dictados seguían siendo los considerados como más complicados y menos atrayentes para los alumnos. 
A65- A mí me parecen más fáciles los refranes porque, como dice A69, solo hay que adivinar el ritmo, y en los dictados hay que adivinar las notas también.

P- ¿Y comparándolo con las canciones, que también tienen notas?

A65- Pues..., no sé..., igual. Aunque un poco más fáciles las canciones porque, como ya tienes los acordes, sabes qué notas puedes poner y, si hay alguna nota que no está en el acorde y la piensas poner, tienes que explicar por qué: si es una nota de paso, un floreo, una apoyatura...

$\mathrm{P}$ - ¿Y qué os gusta más, hacer las canciones y los refranes o hacer los dictados?

A75- A mí me gustan más las canciones y los refranes porque son más divertidos. (EG2CAsD, p. 21)

Uno de los motivos que explican por qué les parecían más divertidas y fáciles las canciones que los dictados, aún cuando ambos tenían la misma dificultad de escritura, es que las primeras les resultaban más bonitas y más pegadizas. De ahí la importancia de hacer dictados que sean atractivos y lógicos desde el punto de vista musical y no, como ocurre en muchos casos, dictados académicos elaborados con el propósito de trabajar determinados contenidos al margen de su sonoridad.

A7- A mí me ha pasado lo mismo que a A4.

$\mathrm{P}$ - ¿También te parecen más fáciles las canciones que los dictados?

A7- Sí.

$\mathrm{P}-$ ¿Y a ti por qué te parecen más fáciles?

A7- Por lo mismo.

P- ¿Porque son más pegadizas?

A7- Claro. (EG1CAsA, p. 14)

A9- A mí me parecen más fáciles las canciones, porque son más bonitas y tienen más ritmo. Por ejemplo, la de Los esqueletos tiene mucho ritmo y mola mucho. (EG1CAsA, p. 15)

P- Más fácil en las canciones, ¿por qué?

A20- Porque algunas canciones las has oído más veces y ya te salen mejor las notas y los dictados no los has oído nunca. (EG1CAsB, p. 19)

E- Y un dictado también debe ser lógico, no del tipo: "A ver si me acierta la nota que toco"; tiene que tener una lógica, lógica tonal; el dictado podría ser una pieza de Mozart. (EEx1, p. 11)

Además, el hecho de que las canciones tuvieran los acordes debajo también les ha ayudado mucho, lo cual debería hacernos reflexionar sobre la conveniencia de acompañar armónicamente los dictados tradicionales, aunque después, si lo preferimos, solo les pidamos que escriban la melodía. Ello dotaría a la tarea de mayor significado para los alumnos, ya que la 
música que ellos escuchan suele tener siempre un acompañamiento armónico, por lo que la situación sería más real.

A28- En las canciones reconocía mejor los sonidos ayudándome de los acordes que tocabas con el piano.

$\mathrm{P}-$ ¿O sea, que los acordes os ayudaban a sacar el dictado mejor?

As- Sí.

$\mathrm{P}-$ ¿Y, por eso, las canciones eran más fáciles de hacer que los dictados?

As- Sí. (EG1CAsC, p. 21)

P- Y el hecho de tener debajo acordes, ¿crees que te ayuda o no te ayuda?

A29- Sí, ayuda muchísimo.

P- ¿Por qué?

A29- Porque en los acordes te salen las notas que hay y que puedes tener. Bueno y, luego ya, contando las notas de paso, los floreos y todo. (EG1CAsC, p. 15)

A36- Para mí son más difíciles los dictados, porque no tienes la guía de los acordes. Entonces tienes que identificar las notas sin tener ninguna guía que te diga algo, de si es una u otra. (EG1CAsF, p. 19)

Consideramos que a estas alturas del análisis ya ha quedado muy justificada la utilidad, a varios niveles, de las estrategias que acabamos de describir, pero, por si fuera poco, también han demostrado que capacitan perfectamente a los alumnos para resolver los dictados musicales tradicionales, como veremos a continuación.

\subsection{Dictados tradicionales realizados en este estudio}

A lo largo del curso realizamos cinco dictados tradicionales a modo de examen o control, los cuales nos ayudaron a valorar las capacidades que iban desarrollando los alumnos y la conveniencia de la metodología que estábamos llevando a cabo para resolver adecuadamente esta tarea.

Aunque no soy partidaria de la forma "tradicional" en la que se hacen los dictados musicales en los conservatorios españoles y, por ello, este año estoy apostando por llevar a cabo la educación auditiva de una forma más global y entrenar la práctica de transcribir ritmos y melodías a través de refranes y canciones, también soy consciente de que debo asegurarme de que mi forma de trabajar permitirá a mis alumnos poder realizar dichos dictados. Por ello, el primer día de esta semana he realizado un primer examen de dictado al "estilo tradicional", siguiendo las instrucciones recogidas en la programación de Lenguaje Musical. (DPN, pp. 5-6)

La situación para resolverlos era muy academicista (con las mesas separadas, se escucha dos veces entero, cinco veces la primera parte, dos veces entero, 
cinco veces la segunda parte y otras dos veces entero), pero los dictados eran muy musicales y estaban construidos con los contenidos rítmicos, melódicos, armónicos y formales trabajados en el aula, ya que no concebimos que pudieran realizarse de otra manera. Dichos dictados fueron los siguientes:

\section{DICTADOS $-1^{\circ}$ Enseñanzas Elementales}

(1)
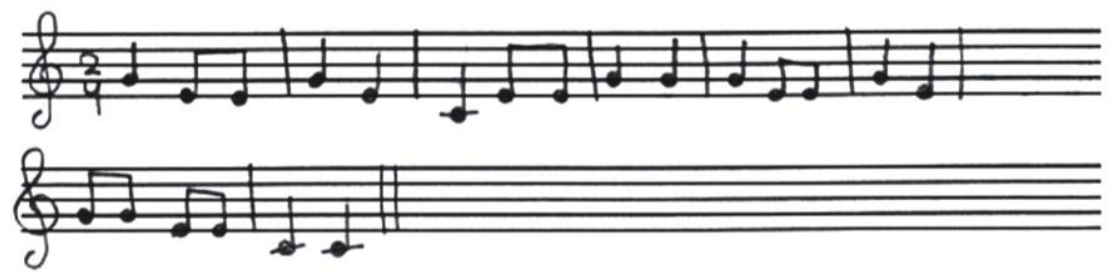

(2)
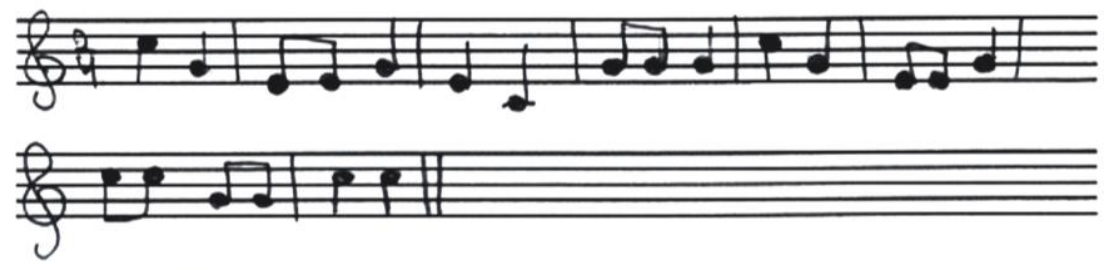

(3)
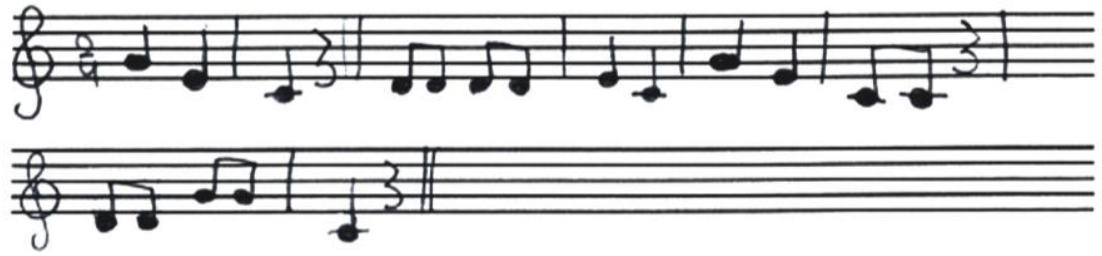

(4)
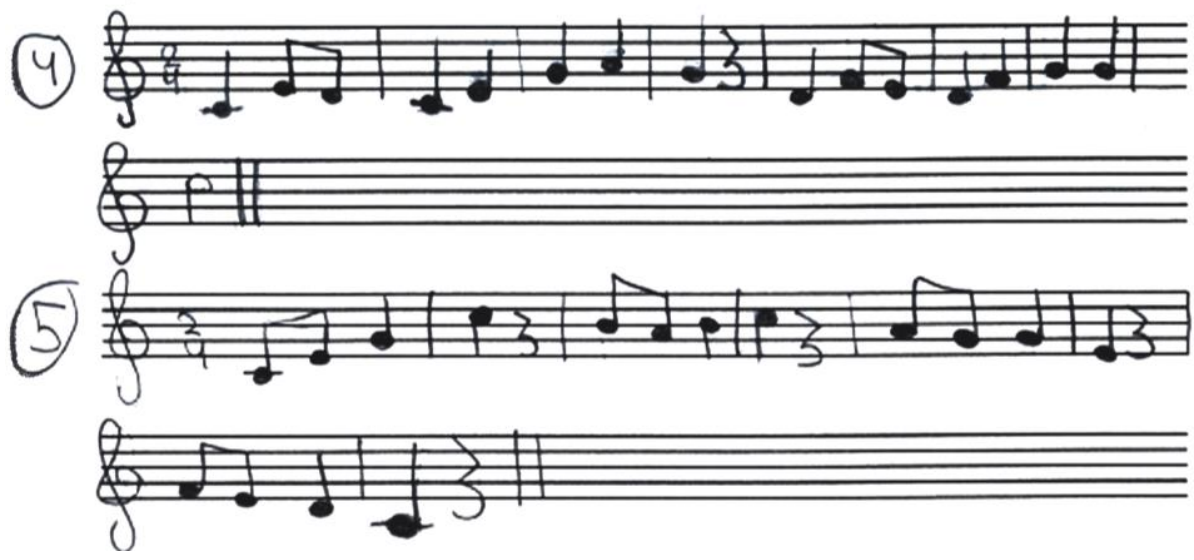

Figura 59. Dictados hechos por un alumno de primero de las enseñanzas elementales a lo largo del curso 


\section{DICTADOS - $2^{\circ}$ Enseñanzas Elementales}

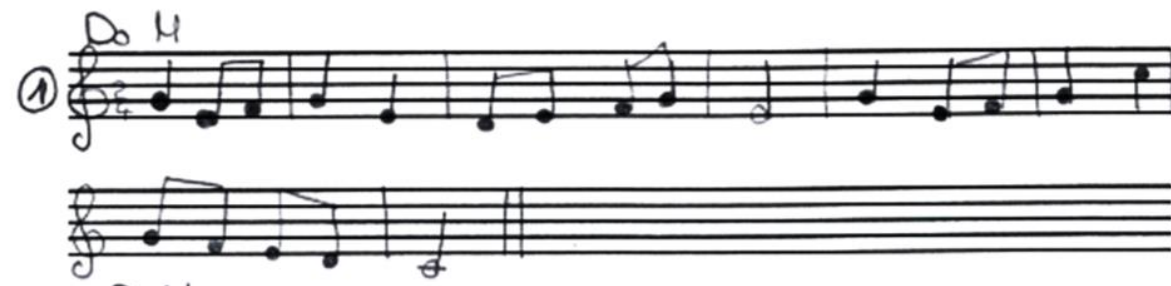

(2)
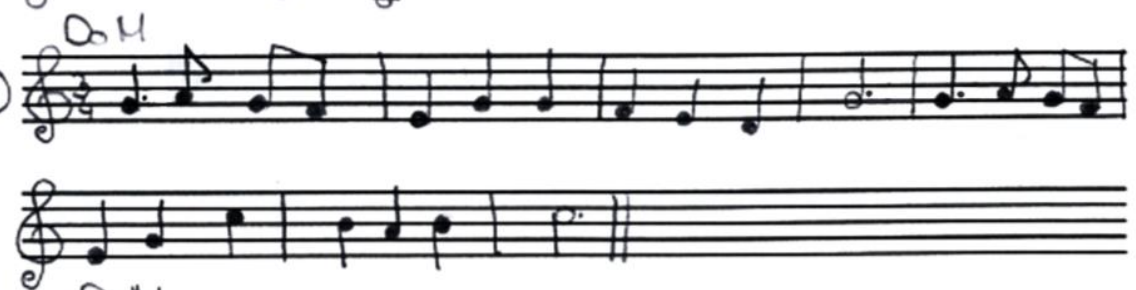

(3)
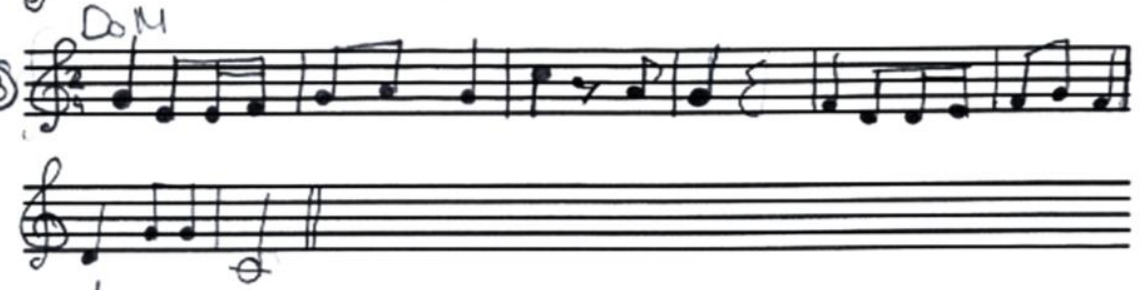

(4)

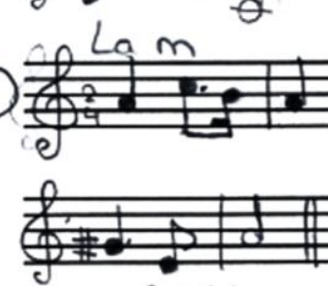

(5)
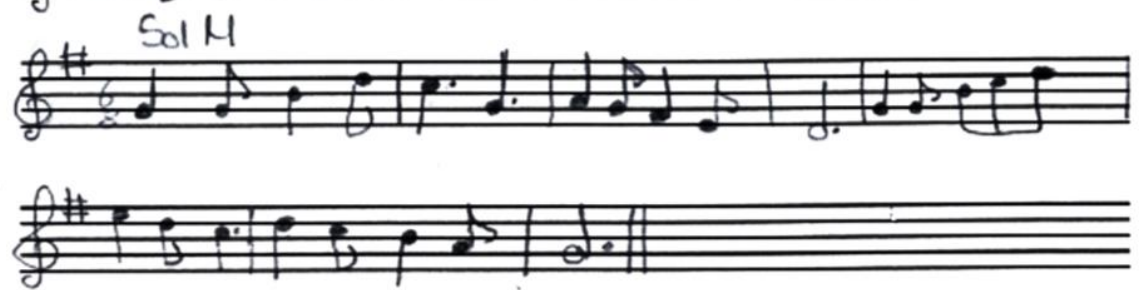

Figura 60. Dictados hechos por un alumno de $2^{\circ}$ de las enseñanzas elementales a lo largo del curso

A pesar de haber hecho únicamente cinco dictados al estilo tradicional, los alumnos se sentían preparados para resolverlos bien.

P- Entonces, ¿os sentís preparados para hacer los dictados bien?

As- Sí. (EG1CAsA, p. 13) 
Pero, además, resultaba interesante comprobar cómo lo que aprendían en las canciones lo aplicaban también en los dictados, y es que, cuando se comprenden los fundamentos que justifican la construcción de melodías dentro de nuestro contexto tonal-armónico, se reconocen los elementos constituyentes aunque no estén los acordes escritos debajo.

A69- En los dictados, si te resulta más fácil, puedes averiguar un poco el acorde y saber si la nota te entra en el compás o qué nota te puede entrar.

P- ¡Ah!, o sea que, cuando estamos haciendo los dictados, tú, de alguna manera, intentas intuir qué acorde hay para que te ayude a hacer el dictado, ¿es eso?

A69- Sí. (EG2CAsD, p. 21)

Yo les insistía en lo gratificante que había sido para mí realizar un dictado tradicional con ellos y preguntarles: “ ¿Os ha salido algún floreo o nota de paso?", y que dijeran rápidamente: "Sí,, lo cual manifiesta que, incluso sin tener los acordes dibujados debajo, empiezan a reconocer la armonía presente en cada compás y los elementos que configuran la melodía, dotándoles de significado, lo cual supone un nivel de comprensión de la música mucho mayor que la simple lectura de notas y ritmos. (DPD, p. 11)

Asimismo, como en todo aprendizaje, comprender la utilidad de los dictados les sirvió de motivación para querer hacerlos bien y, cuando hay interés, también disminuye la ansiedad.

A24- Para saberte de memoria una partitura y tocarla bien, tienes que hacer dictados para acostumbrarte ya a saber las notas sin verlas. (EG1CAsC, p. 17)

A8- A mí los dictados me parecen bonitos, porque así aprendemos a escuchar bien y a poner las notas en su sitio. A mí me encantan los dictados porque, así, funciona tu oído mejor y vas mejorando en Lenguaje Musical. (EG1CAsA, p. 13)

A64- Porque aprendes mucho y te ayuda a componer las canciones que luego tenemos que interpretar.

P- ¿Por qué crees que te ayuda hacer el dictado a eso?

A64- Porque me ayuda con el ritmo y con la entonación. (EG2CAsD, p. 18)

Todo lo expuesto en este apartado demuestra que las estrategias y actividades propuestas son buenas alternativas al dictado tradicional porque han motivado a los alumnos y han reducido su ansiedad, ya que han aprendido a ver la transcripción de ritmos y melodías (dictados) como un juego o taller, no como una tarea evaluable donde no tiene cabida el error. Además, les ha preparado para resolver muy satisfactoriamente dictados tradicionales cuyos contenidos se ajustaban a lo establecido en la programación de Lenguaje Musical para estos cursos e, incluso, los buenos 
resultados obtenidos nos han permitido subir el nivel de los mismos. Así lo iba recogiendo en mi diario en distintos momentos del curso académico.

El resultado ha sido que, tanto los alumnos de primero como los de segundo, han realizado los dictados bastante bien y, cuando les he preguntado si les ha parecido fácil o difícil, han respondido que "muy fácil". Realizar este dictado me ha servido para dos cosas: por un lado, para verificar una vez más las reacciones negativas que provoca la realización de dictados y ser consciente de la importancia de reducir la ansiedad ante dicha tarea para conseguir buenos resultados y, por otro lado, para comprobar que la metodología que estoy empleando permite resolverlos muy satisfactoriamente a pesar de que no esté trabajándolos de la forma tradicional. (DPN, p. 6)

El lunes, al finalizar las clases, me quedé en el aula pasando a mi fichero las notas de los dictados que realicé a los alumnos de segundo y entró PTcas1. Entonces, quise aprovechar para enseñarle los dictados que tenía encima de la mesa y preguntarle qué tal los veía de nivel para el primer trimestre del segundo curso, a lo cual me respondió que bien, pero que quizá el último era un poco difícil por utilizar negras con puntillo, porque eso se suele dejar para más adelante, ante lo cual me alegré muchísimo porque yo pensaba que, quizá, había hecho unos dictados demasiado fáciles, ya que, en general, los habían resuelto muy bien. Pienso que este comentario y los resultados obtenidos por mis alumnos demuestran que su evolución en la realización de dictados está siendo muy favorable, lo cual me permite, incluso, subir el nivel. (DPD, p. 4)

Cuando he enseñado el dictado de la prueba extraordinaria de septiembre que había preparado para los alumnos de segundo de elemental, me han pedido que lo simplificara más, a pesar de que estaba en do mayor y que melódicamente era muy sencillo: me han pedido que quitara notas y que eliminara el ritmo de corchea con puntillo-semicorchea porque era difícil de identificar, el cual la mayoría de mis alumnos reconocieron sin problema en el examen que les realicé en la segunda evaluación en la tonalidad de la menor, que es más complicada. Entiendo que los exámenes de septiembre recogen los mínimos exigibles para superar la asignatura, por lo que me anima comprobar que, si alguno de mis alumnos suspende el curso en junio, estará bien preparado para sacar adelante el dictado en la convocatoria de septiembre, ya que la buena preparación que están manifestando me ha permitido subir la dificultad de los dictados realizados en clase, siendo mayor que la exigida para estos niveles. (DPA, p. 2)

\section{La memoria musical}

La memoria es fundamental para el aprendizaje porque nos permite adquirir conocimientos y establecer relaciones entre los mismos. 
A37- Me gusta hacer ejercicios de memoria para recordar cosas, [...] porque en la vida y en la música te va a afectar. (EG1CAsF, p. 20)

$\mathrm{P}-$ ¿Te cuesta retener cosas?

A75- Un poco.

P- ¿Y crees que es importante ejercitar la memoria?

A75- Sí.

P- ¿Por qué?

A75- Pues no sé, porque luego, más adelante, te tienes que aprender una cosa muy grande y primero tienes que calentar.

$\mathrm{P}-i$ Calentar aprendiendo cosas pequeñas, quieres decir?

A75- Sí.

P- Para luego poder aprender cosas más grandes, memorizar cosas más grandes.

A75- Sí. (EG2CAsD, p. 11)

En la educación musical también tiene una gran relevancia y presenta unas particularidades específicas, como veremos a continuación.

\subsection{Importancia de la memoria en la educación musical}

En el campo de la música, la memoria es fundamental para asociar cada sonido a una nota, cada duración a una figura y cada sensación a un tipo de acorde, así como para comprender la forma de una obra musical, reconociendo fragmentos que se repiten, procesos modulatorios, cadencias, etc. (Ibarra, 2009; Jude \& Rickard, 2010; Rickard, Wing, \& Velik, 2012).

E- La memoria es la herramienta que permite comprender una obra que escuchas porque, si tú no eres capaz de tener memoria musical, oyes el tema uno de la sonata y, cuando lo vas a desarrollar o cuando lo lees, no te enteras de que va.

$\mathrm{P}$ - Es verdad, porque no lo relacionas con lo primero que has escuchado.

E- O aún más, si tú oyes una frase y, según vas oyendo, vas olvidando, la frase no tiene sentido. Imagínate que yo te estuviera diciendo una frase muy larga en la que tuvieras que estar pendiente de cuál es la pregunta que te voy a hacer [...] Si tú olvidas las palabras, no eres capaz de darle sentido a la frase. La música se desarrolla igual, en horizontal, es una cuestión temporal, no te dan el objeto como en la escultura, que te lo dan de golpe, esto va poco a poco. Por tanto, si tú no eres capaz de memorizar de una forma un poco coherente elementos, pues ni siquiera una frase podrías entenderla. (EEx1, p. 20)

Gracias, Elena. Ahora me aprenderé bien la canción para cantarla en clase. Me gusta mucho sabérmela de memoria, porque así aprendo cómo suenan las notas. (CE1CA8E, p. 2) 
E- En el lenguaje hablado, te dicen los lingüistas que lo importante es comprender y hablar, pero el lenguaje lo recibes de fuera, del ambiente que te rodea, mediante la reiteración de hechos. Fíjate que el niño es muy pequeño $y$, sin embargo, cuando empieza a construir sabe muy bien la función del verbo y la función del sujeto, aunque sea: "Yo querer", pero sabe muy bien de qué está hablando, es decir, quién quiere, lo que supone querer y qué es lo que quiere, que es el objeto, ¿no? Digamos que esas bases el niño las aprende de la reiteración, de las frases que está oyendo, en las que se producen unas construcciones similares. Pues esto trasladado a la música es exactamente igual. El niño, inconscientemente, está oyendo unas cosas que producen unas reiteraciones de las que él extrae, sin conciencia ninguna, toda una serie de conclusiones $\mathrm{y}$, efectivamente, puede hablar de pregunta y respuesta por la sencilla razón de que sabe que aquello no puede terminar ahí. (EEx3, p. 7)

Pero para que la memoria musical sea útil y conduzca al aprendizaje, hay que hacerla "inteligente", es decir, hay que apoyarla en la reflexión, lo cual permite una mejor retención (Justel \& Rubinstein, 2013).

P- Y en cuanto a la memoria musical, ¿qué importancia tiene en todo esto? ¿Hay que trabajarla mucho?

E- iiiVital!!!

P- ¿Sale sola? ¿Qué opina de todo...?

E- No, no, no, no... No sale sola. Además, fíjate, la memoria musical que hemos trabajado en general los músicos es la de la repetición, que eso nos llevaría también a otro camino, que es la forma de estudio que se ha hecho, por ejemplo, instrumental. [...] Esa memoria hay que hacerla inteligente. Yo he trabajado mucho con fragmentos similares: primero un fragmento de poca dimensión, de dos o tres compases, lo repetimos con "la" y luego lo repetimos con sonidos; pasamos al segundo fragmento, con muchos elementos comunes, lo repetimos con "la, la, la" y con notas; un tercer fragmento, y, dependiendo del grupo, hasta un cuarto fragmento. Pero ya en el segundo fragmento digo: "¿Os acordáis del primero? Vamos a cantar el primero". Lo mismo después del tercero y después del cuarto. Entonces, ¿qué pasa?, que hay que tomar datos: "Sí, son parecidos, pero este empieza saltando de no sé qué a no sé cuantos y luego bajando por grados conjuntos". O sea, que la memoria hay que apoyarla. Es importante que ellos vayan tomando notas mentales que ayuden a la memoria de repetición, que es una memoria que, efectivamente, es utilísima, pero que tiene que ser una memoria que tú apoyas, no se trata solo de repetir continuamente. (EEx3, p. 48)

\subsubsection{El papel de la memoria en la reproducción musical}

Gracias a la memoria auditiva y al oído interno, una persona musicalmente educada puede imaginar cómo suena la música con tan solo ver una partitura. Por tanto, no necesita escucharla previamente desde una fuente 
externa, porque ya la oye dentro de sí mismo antes de cantarla o interpretarla con un instrumento (Gordon, 1997; Martenot, 1993; Willems, 2001).

E- Un ejercicio que planteamos es reconocer una canción popular o clásica ya conocida, que el alumno ve escrita pero que no escucha previamente. Tiene que imaginarse cómo suena. (EEx2, p. 6)

E- Una prueba que yo hacía mucho al entrar en clase es: “¿Cómo suena el sol?" y, efectivamente, te cantaban el sol o te cantaban el do porque, claro, lo estábamos trabajando por activa y por pasiva y lo tenían muy asimilado. No es que tuvieran oído absoluto, es que yo les había trabajado hasta la saciedad este tema y lo que tenían era una gran memoria, aunque unos más que otros, por supuesto. (EEx3, p. 63)

\subsubsection{Utilidad de la memoria para la creación musical}

Tanto la representación mental de las distintas notas y acordes musicales como la relación existente en la duración de las figuras son retenidas en la memoria, de tal manera que todo músico puede combinarlas en su pensamiento para crear su propia música. Ello le permite, posteriormente, poder interpretarla directamente con su voz o su instrumento, así como plasmarla en un papel o en algún soporte informático (Cañada, López, \& Molina, 2005).

$\mathrm{P}-$ ¿Y tú te imaginas la canción que quieres hacer antes de escribirla en el ordenador?

A7- Sí.

P- ¿Sí? ¿Tú eres capaz de imaginarte cómo es lo que quieres escribir antes de escribirlo?

A7- Sí.

P- ¿Y luego lo compruebas dando al play, o cómo lo haces?

A7- Luego, yo me imagino el ritmo que quiero y una letra y, luego, veo a ver si me cuadra eso con las notas y, si no, pues o cambio la letra o el ritmo y ya, al final, acabo la canción. (EG1CAsA, p. 15)

\subsubsection{La memoria en la realización de dictados musicales}

En el campo de la educación auditiva, objeto de esta tesis, resulta muy relevante comprobar que la falta de memoria es uno de los motivos principales de las dificultades que presentan los alumnos para resolver los dictados tradicionales.

Realizar correctamente los dictados requiere el desarrollo de dos capacidades: memorizar lo escuchado y escribirlo en un papel utilizando los códigos propios de la lecto-escritura musical (Balo, 2014; López de Arenosa, 2008a), pero es muy frecuente entre los docentes potenciar la segunda 
olvidando la primera, lo cual provoca errores en la resolución de los mismos. Dicho de otra forma: muchas veces, no es que los alumnos no sepan codificar correctamente lo que tienen en la cabeza, es que no han memorizado bien lo que han escuchado e inventan lo que no han retenido.

No me gusta el dictado, porque hay que estar muy atento y no lo memorizo bien. (CA2C, pre. 5)

A33- A mí los dictados porque, mientras que tú los tocabas, los teníamos que memorizar y costaba un poco memorizar las notas. (EG1CAsC, p. 17)

Durante el curso trabajaremos la memoria auditiva a través de distintas actividades y espero que se observe mejoría, ya que, para poder realizar bien un dictado, el primer paso es retenerlo bien. (DPO, p. 11)

A28- Porque te las tienes que aprender de memoria.

$\mathrm{P}-i \mathrm{Y}$ eso te cuesta, aprenderlas de memoria?

A28- (Asiente). (EG1CAsC, p. 6)

\subsection{El juego y las actividades creativas como estrategias para desarrollar la memoria}

Con lo expuesto hasta este momento, queda justificada la importancia de ejercitar la memoria musical. Para ello, planteamos desarrollar estrategias educativas de la forma más lúdica posible, ya que el juego resulta muy motivador y permite que los alumnos disfruten mientras conseguimos nuestro propósito. Dicho de otra forma, la memoria funciona mucho más eficazmente cuando algo se aprende en un ambiente agradable y relajado (Cabrera, 2010; Puente-Ferreras, 2003).

E- Una vez que tú escuchas, y que te he dicho lo importante que es la escucha, el siguiente proceso es recordar lo que has escuchado. [...] Cada improvisación tiene que ser repetida, y eso obliga a concentrarse y a memorizar. Conforme avanza la historia, los motivos son cada vez más complicados y más largos. (EEx1, p. 19)

E- Los alumnos trabajan la memoria auditiva semanalmente. Memorizan una canción que recoge todos los contenidos que luego se van trabajando de forma secuenciada (ritmo, melodía, audición, etc.). (EEx2, p. 7)

Además, cuando se plantean actividades entretenidas y atrayentes para los alumnos, la sensación de dificultad desaparece, a pesar de que exijan un elevado nivel de concentración y memorización.

P- Bueno, y de las actividades que hacemos para ejercitar la memoria: por ejemplo, cuando yo toco algo y lo tenemos que intentar repetir, o en vez de 
hacerlo al derecho lo hacemos al revés, o cuando os habéis inventado algún motivo y, después, teníais que irlo pasando de memoria a los distintos acordes, ¿de eso qué me decís?

A21- ¿Cómo que ir pasándolo a los distintos acordes?

P- Pues cuando os decía: "Venga, invéntate un motivo en el acorde de tónica". "Pues empiezo en la nota de arriba..."

A21- ¡Ah, ya!

P- "... paso a la de abajo".

A21- Eso es fácil.

A18- Sí, es fácil.

A16- Eso es fácil.

$\mathrm{P}-$ ¿Eso os resulta fácil?

As- Sí. (EG1CAsB, p. 21)

A75- Una vez que te has escuchado las canciones, ya las tienes en la memoria y las puedes escribir fácilmente.

P- ¿Los demás pensáis lo mismo?

As- Sí. (EG2CAsD, p. 4)

Si realizábamos el trabajo memorístico a través de actividades creativas, las ventajas eran aún mayores porque, lo que los alumnos creaban y manipulaban por sí mismos, lo aprendían y memorizaban mejor.

A34- A mí los motivos me han parecido divertidos, porque todos teníamos la oportunidad de inventarnos nuestra propia canción, solo que más pequeño, y así aprendíamos más y mejor. (EG1CAsC, p. 16)

A61- Es que, lo que te inventas tú, como que...

As- (Hablan varios a la vez).

P- ¿Lo que te inventas tú, qué?

A61- Pues que lo que te inventas tú, como que se te queda mejor en la cabeza. (EG2CAsB, p. 23)

Por todo lo expuesto, los alumnos consideran que las actividades para trabajar la memoria que hemos hecho en clase han sido necesarias y, al mismo tiempo, positivas.

P- Y acerca de las actividades que hemos estado haciendo durante el año para mejorar la memoria, ¿qué pensáis?

A54- Que son buenas. A mí sí que creo que me refuerzan la memoria y me ayudan.

P- ¿Tú sientes que te han ayudado a mejorar la memoria?

A54- Yo creo que sí. (EG2CAsB, p. 18) 


\subsection{Prueba de memoria auditiva}

Como acabamos de exponer, la memoria auditiva es fundamental para conseguir una correcta educación musical (Nagy, 2014; Palacios, 2001). Por ello, además de realizar actividades encaminadas a su desarrollo, nos interesaba comprobar si a lo largo del curso se había producido mejoría en dicho campo, para lo cual diseñamos la prueba de reconocimiento auditivo de secuencias rítmicas, sonidos y secuencias rítmico-melódicas descrita en el apartado de metodología de esta tesis, que fue administrada en dos momentos: en octubre y en mayo.

He aprovechado para pasar a los alumnos una prueba que he elaborado para medir su memoria auditiva, consistente en tres partes: una rítmica, otra de sonidos y una tercera de secuencias rítmico-melódicas. Las instrucciones eran claras: debían memorizar lo que habían escuchado porque, a continuación, aparecía mezclado junto con otras notas o secuencias de características similares, y tenían que rodear los números en los que se escuchaba exactamente aquello que habían memorizado inicialmente. (DPO, p. 10)

\subsubsection{Análisis de los resultados obtenidos}

La prueba que diseñamos para medir la memoria auditiva, aunque estaba planteada según pautas y contenidos recogidos en la programación de Lenguaje Musical para los niveles de primero y de segundo de las enseñanzas elementales a los que pertenecían los alumnos, era bastante difícil de realizar, de lo cual éramos conscientes al diseñarla. Por ello, no nos sorprendió que cometieran bastantes errores.

Aunque las instrucciones eran sencillas, reconozco que el nivel de dificultad de los ejercicios propuestos para memorizar era bastante elevado por su longitud, porque quería evitar que les resultase demasiado fácil, ya que mi propósito es volver a hacerles la misma prueba dentro de unos meses para comprobar si ha habido mejoría en su memoria auditiva. No obstante, dicho nivel de dificultad es acorde a lo que está establecido en la programación de la asignatura, donde se indica que los dictados musicales deben dividirse en dos partes de cuatro compases cada una, por lo que se supone que los niños deben tener la capacidad suficiente para retener esos cuatro compases en su memoria. La única dificultad que he añadido al respecto es que yo el modelo se lo he repetido únicamente dos veces, mientras que en los exámenes de dictado se repiten cinco veces, pero como no tenían que estar pendientes de decodificarlo, sino solo de escuchar y tratar de memorizar, he considerado que con dos repeticiones era suficiente para el objetivo que perseguía. (DPO, p. 10) 
De las tres partes que formaban el ejercicio, la que les resultó más difícil era la de secuencias rítmicas, lo cual demuestra que la presencia de notas musicales ayuda a la memoria, al conseguirse melodías más pegadizas.

P- ¿Qué quieres decir de la prueba auditiva?

A58- Que en el último recuadrito, que era más difícil. Bueno, no sé si era el último.

A63- Ése era el más fácil, el último.

P- El último recuadrito era el que tenía secuencias rítmico-melódicas.

A58- ¡Ah, no, era el primero, el primero!

$\mathrm{P}$ - El de secuencias rítmicas.

A58- Sí, que era más largo y costaba memorizar.

P- Era igual de largo.

A63- Sí, ése era difícil.

A54- Es verdad. (EG2CAsB, p. 7)

Tras la intervención educativa llevada a cabo en el aula, tanto los alumnos de primero como los de segundo mejoraron su memoria auditiva, como puede comprobarse al analizar sus comentarios y al comparar los resultados obtenidos en las pruebas realizadas a principio y a final de curso.

P- Al ver la prueba que os he hecho para comprobar si la memoria había mejorado o no había mejorado, ¿qué pensáis, había mejorado o no había mejorado la memoria?

As- Sí, sí. (EG2CAsB, p. 17)

P- Las actividades que hemos hecho para que la memoria mejorara.

A34- Bueno, eso me ha parecido difícil, pero con este tiempo que hemos pasado todos aprendiendo eso, pues ya se me va dando mejor.

P- ¿Tú crees que has mejorado la memoria? ¿Retienes mejor las cosas que escuchas que al principio?

A34- Sí. (EG1CAsC, p. 16) 


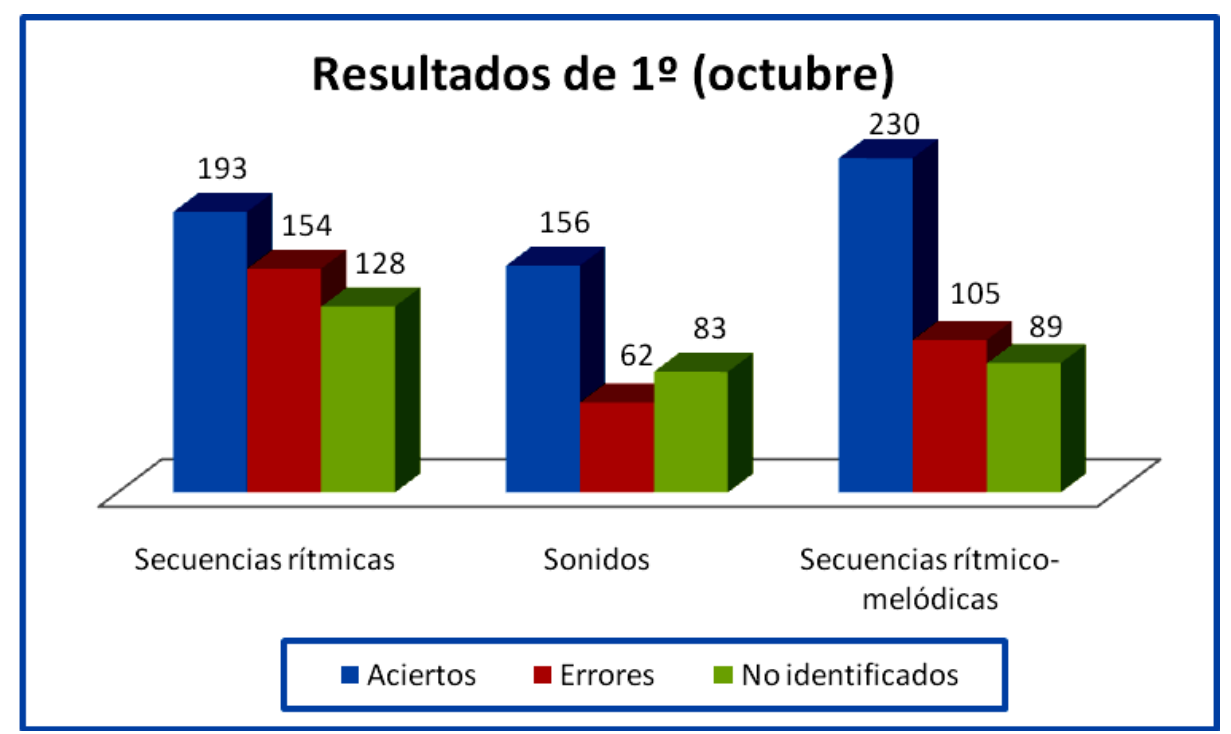

Gráfica 8. Resultados de la prueba de memoria auditiva realizada en octubre por los alumnos del primer curso

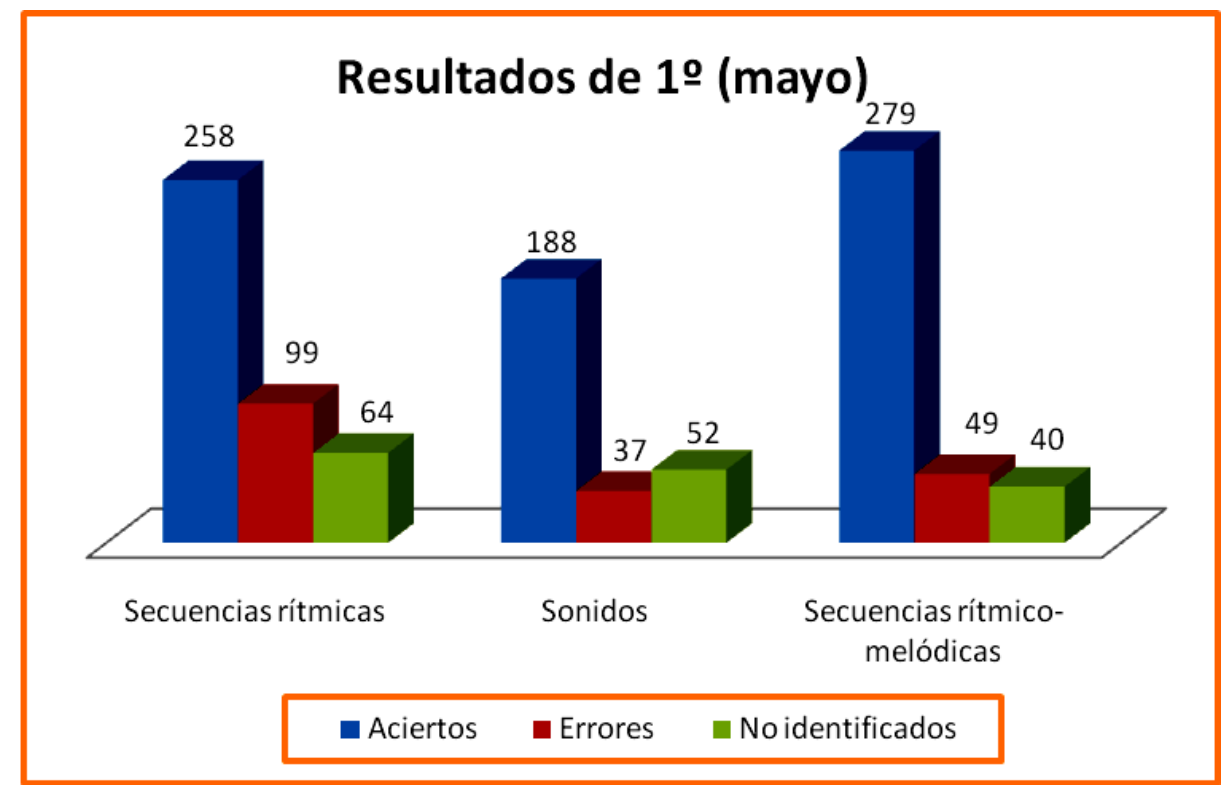

Gráfica 9. Resultados de la prueba de memoria auditiva realizada en mayo por los alumnos del primer curso 


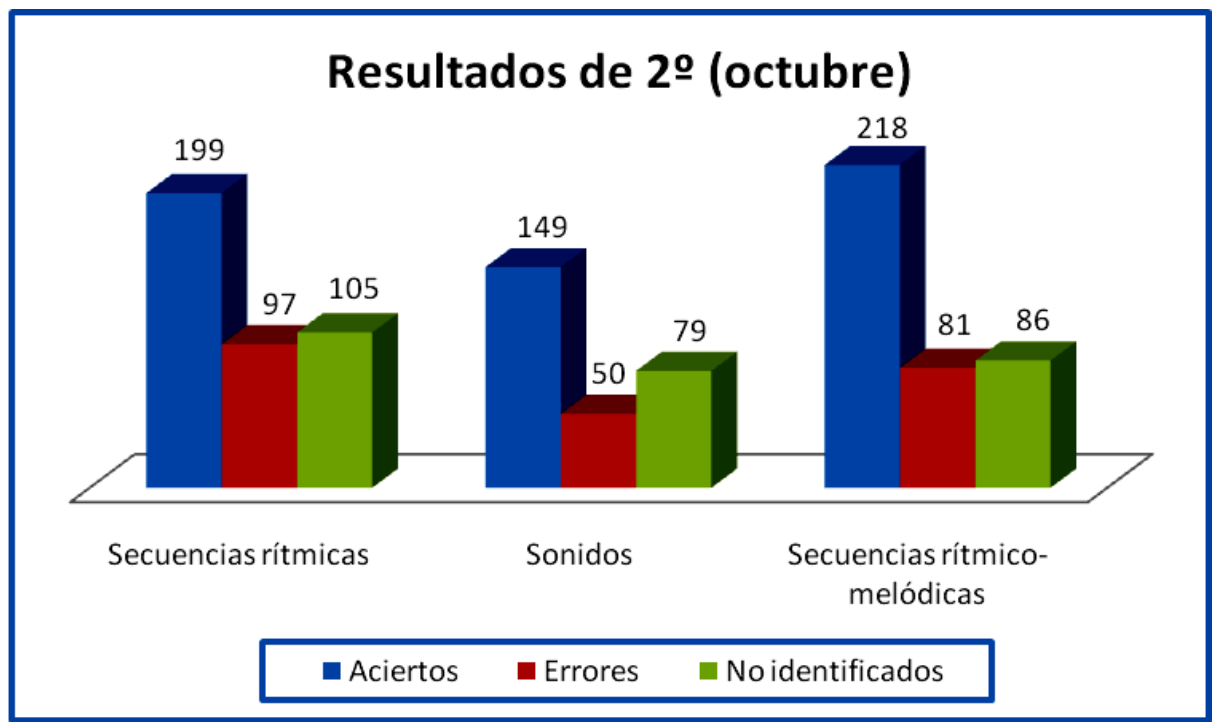

Gráfica 10. Resultados de la prueba de memoria auditiva realizada en octubre por los alumnos del segundo curso

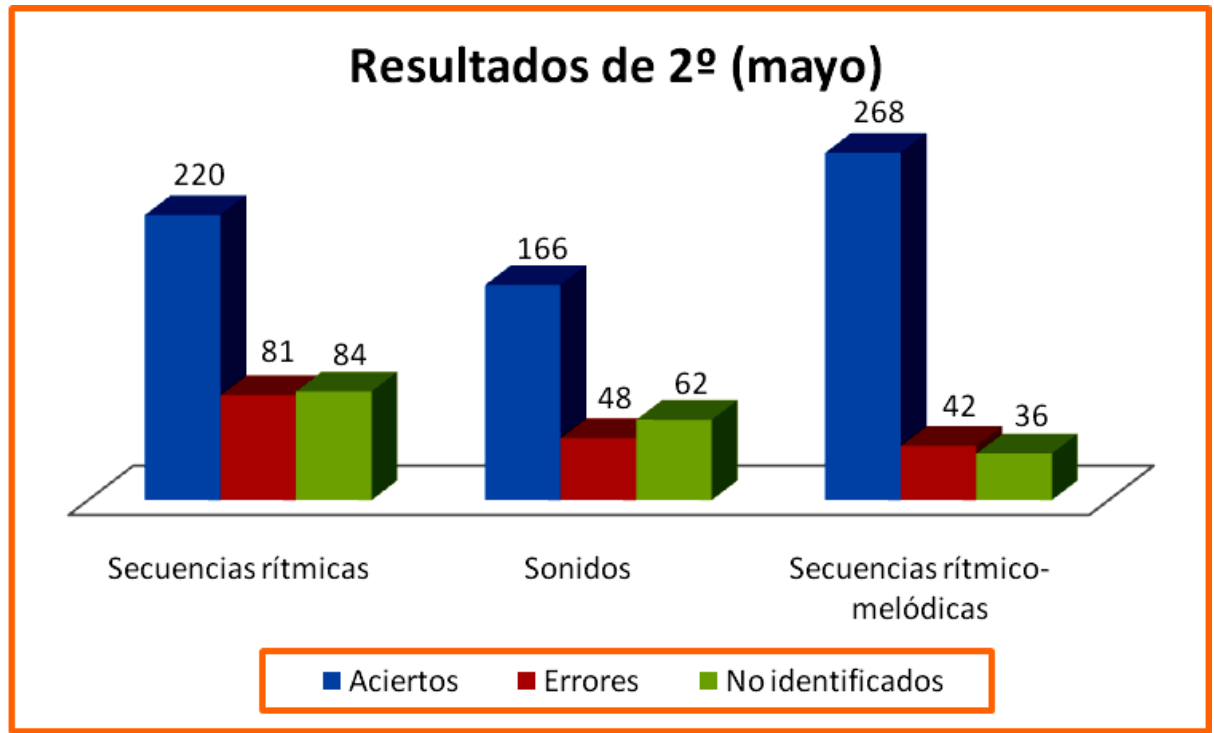

Gráfica 11. Resultados de la prueba de memoria auditiva realizada en mayo por los alumnos del segundo curso 


\section{La creatividad}

La necesidad de expresarse y de crear cosas nuevas es innata al ser humano y está presente en cualquier ámbito de la vida.

T- La creatividad es algo innato al ser humano, porque tú creas tus propias oportunidades, tú creas tu ambiente, tú creas tu entorno, tú creas tus amistades, tú creas las relaciones, porque tú eliges cómo te vas a relacionar conmigo: si te vas a relacionar de forma más hostil, más empática, más distante, menos distante... Tú lo creas todo, te creas tu mundo. (ETV, p. 12)

E- Yo creo que la creatividad está en todas y en cada una de las actividades humanas, cuando tú buscas el darle una mayor utilidad a aquello que tenía una utilidad menor o buscas una vía de atajo para enseñar una cosa. Esa vía, efectivamente, tú la has creado a partir de tus experiencias anteriores y asumes el riesgo de hacer algo nuevo, pero algo nuevo útil, no la tontería. ¡Oye, muchas veces confundimos la creatividad con la locura que se me ha ocurrido! (EEx3, pp. 49-50)

En este apartado veremos la importancia que tiene la creatividad en la sociedad actual y, de forma específica, en la educación musical de nuestros alumnos, analizando los beneficios que presenta la composición como estrategia didáctica para potenciar su desarrollo.

\subsection{Importancia de la creatividad en la sociedad actual}

Las nuevas generaciones deben vivir en una época en la que la sociedad tiene unas exigencias muy distintas a las del pasado, demandando personas activas y creativas capaces de dar una respuesta rápida y eficiente a los problemas (Martínez-Salanova, 2005).

T- Por ejemplo, ¿a mí con quién me gustaría trabajar?, ¿con quién me gustaría tocar al lado? Pues con un tipo que, cuando haya algún problema o que cuando hagamos una cosa y cambie algo, se dé cuenta y se adapte, no que le tengas que decir: "No, no, que aquí hacemos esto", y tenga que apuntarlo, ¿no?, o sea, un tío que esté activo o un tío que tenga iniciativa. Si toca en un grupo, que tenga iniciativa de hacer algo; si trabaja en una academia, que tenga la iniciativa de crear o de hacer un taller o alguna actividad para que los padres estén contentos. O sea, me interesa gente activa, gente con iniciativa, gente que tenga recursos y gente que se desenvuelva de forma espabilada con el medio. Entonces, hay que crear ese tipo de alumnos, porque a mí es lo que me gustaría tener al lado y lo que creo que demanda la sociedad de hoy y del futuro. (ETV, p. 17) 
Por ello, docentes y expertos reconocen que el sistema educativo debe potenciar el desarrollo de la creatividad, enfatizando su valor formativo y motivador.

E- Es necesario que la creatividad y la improvisación formen parte de la vida y de la enseñanza musical. [...] A los alumnos, desde pequeños, les sirve para disfrutar de la música, para entenderla mucho mejor, para aprender mejor su repertorio, memorizarlo mejor cuando llegue el caso y para disfrutar de tocar canciones y de inventar. Pero al profesor, además de para todo eso que he dicho, le va a servir para poner en marcha su propia capacidad pedagógica. (EEx1, pp. 28-29)

T- Te puedo decir que los chavales sí que están contentos, que están más animados y más ilusionados, y que todo lo que sea un trabajo de desinhibirse, de encontrar un marco de expresión, de hacer sus cosas y de que tengan iniciativa, que es luego lo que les vamos a exigir en el día de mañana, es lo más importante, porque un tío pasivo no te sirve para nada, es una mala inversión. (ETV, p. 16)

T- Que ellos sean capaces de poder utilizar eso para desarrollar su propia creatividad, sus propias canciones, me parece increíble y muy interesante. (ETO, p. 4)

\subsection{La creatividad en las enseñanzas musicales}

Diversos autores comparten la idea de que la música juega un papel fundamental en el terreno de la expresión de emociones (Juslin \& Västfjäll, 2008; Koelsch, 2014; Koelsch, Kilches, Steinbeis, \& Schelinski, 2008; Meyer, 2005).

Por este motivo, las enseñanzas musicales deben aprovechar su potencial para contribuir a la canalización de la expresión creativa del alumnado (Hernández, Hernández, \& Milán, 2007; Molina, 2008).

T- Ya de entrada, desde el punto de vista personal, hay que ser creativo y crearte tu mundo, generarte oportunidades, hacer cosas. Y luego, desde el punto de vista artístico, ipues ya me dirás tú!, si no creas... Lo más interesante que puedes aportar es tu visión propia, porque para hacer lo que hizo Mozart ya está Mozart. Los tiempos pasan y no puedes estar siempre anclado en el pasado, tienes que tirar para delante. (ETV, p. 13)

Lamentablemente, la realidad nos muestra que, en la mayoría de los casos, esto no está ocurriendo en nuestras aulas, como veremos a continuación. 


\subsubsection{La falta de creatividad en nuestros conservatorios}

Todas las personas poseen cierto potencial creativo, pero necesitan de unos procesos formativos adecuados para poder desarrollarlo (Bravo \& De Moya, 2006). En este sentido, distintas investigaciones (Bautista, Pérez-Echeverría, \& Pozo, 2011; López-Íñiguez, Pozo, \& De Dios, 2014; Torrado \& Pozo, 2006) muestran que, con frecuencia, los profesores están más centrados en lograr resultados o productos musicales, así como en la técnica para llegar a producirlos, que en desarrollar las capacidades creativas de sus alumnos.

E- Yo hice un artículo hablando de la falta de creatividad de las enseñanzas aparentemente muy creativas, como las artísticas, porque el conductismo en la música ha sido feroz: "Tú aprendes una obra, tú aquí pones el tercer dedo..." [...] Yo es que pienso que, efectivamente, si en algún centro docente el conductismo ha sido feroz ha sido en los conservatorios: te han señalado la digitación, no te han enseñado a digitar; te han dicho fuerte o piano, no te han dicho por qué; no te han contextualizado la obra, ni el autor, ni el estilo, ni la armonía, ni la forma y además tú, como no sabes nada de eso ni tienes herramientas, al final te dicen "bien o mal", pero ¿"bien” por qué o "mal” por qué? Entonces, ¿dónde está la creatividad? ¿En el producto? En el producto del autor que tú reproduces como puedes. (EEx3, p. 49)

En este sentido, no es de extrañar que en las enseñanzas musicales de nuestro país los alumnos dependan demasiado de las directrices de su profesor y no cuenten con un espacio para su propia toma de decisiones.

E- Cuando un chico toca una obra y la hace muy bien de arriba a abajo sin equivocarse a lo mejor no es nada creativo, ha sido conducido desde el primer momento. [...] Esto se demuestra fácilmente también en el hecho de que los instrumentistas nunca ven el momento de soltarse de su maestro. Si te das cuenta, siempre buscan otro maestro que les conduzca porque ellos, en realidad, no saben lo que saben.

P- Y es cierto, fíjate.

E- Sí. Y siempre tienen que escuchar el espaldarazo de: "Esto está bien", pero tampoco saben por qué está bien. Hablo en general, por supuesto. [...] Tú nunca sabes lo que vale porque te están tasando los otros: "Esto lo haces bien, lo otro lo haces mal. No te digo por qué lo haces bien, ni por qué lo haces mal, pero ya te lo he dicho". Entonces, el alumno instrumentista está siempre buscando un apoyo y yo digo: toda la vida esperas que otros te ayuden, coges ideas de otros, pero también tienes que asumir tu propia responsabilidad, ¿no? Y, fíjate, a nuestros instrumentistas les cuesta mucho trabajo. (EEx3, p. 51)

Esto no quiere decir que la creatividad no sea algo deseado e implícito en los docentes y alumnos (Laukka, 2004), sino que no se llega a explicitar ni a implementar en la práctica del aula, ya que se asume que es algo personal y 
surgirá motu proprio una vez que se haya alcanzado el dominio técnico y conceptual adecuado de la música. El trabajo se centra solo en cómo mejorar la técnica, indudablemente importante, pero no suficiente. Estudios con alumnos de diferentes niveles educativos musicales muestran esta tendencia (Bautista, Pérez-Echeverría, Pozo, \& Brizuela, 2012; Marín, PérezEcheverría, \& Hallam, 2012; Marín, Pérez-Echeverría, \& Scheuer, 2013).

\subsubsection{La necesidad de potenciar la creatividad musical}

Si un alumno no manipula los elementos del lenguaje de la música utilizándolos como medio de expresión de sus propias ideas y sentimientos, no los interiorizará bien y no servirá de nada, o tendrá poca utilidad, lo que ha estado estudiando y, aparentemente, aprendiendo (López de Arenosa, 2009).

T- Si tú quieres ser músico, tienes que hacer música; si quieres ser cocinero, tienes que cocinar. Desde el primer momento, tienes que hacer cosas. ¿En los talleres de cocina para niños pequeños qué hacen? Cocinar. Pero, ¿qué hacen?, ¿un cocido? No, hacen algo acorde a su nivel. Pues un músico tendrá que hacer su concierto, ¿pero con qué?, ¿con la sonata de Brahms? No, con su piececilla. Entonces, será un músico desde el principio. Lo que no puedes esperar es enseñarle cosas aisladamente y luego decir: "Bueno, ya será músico". (ETV, p. 12)

E- Improvisar es como hablar; tú ahora estás hablando y, cuando te enseñaron a hablar y a leer y a escribir, te enseñaron a hacer cosas juntas. Bueno, hablar significa controlar ciertas palabras, ciertos enlaces de...

P- Bueno, no, aprendes a hablar antes que a escribir de niño.

E- Claro, encima eso. Pero nunca dejas de hablar, o sea, el objetivo no es escribir ni es leer. Que los alumnos de música conviertan su objetivo en leer una partitura, ipues vaya gracia! Como mucho, memorizarla y tocarla así, pero en el momento en que la olvides porque dejes de tocarla tres meses, ya no sabes nada. ¿De qué te sirve estudiar 10 horas el piano durante 8 años si después te tomas unas vacaciones de 4 meses y resulta que te olvidas de las obras que tocas y no puedes tocarlas? Entonces, ¿de qué te sirve haber estudiado? Imagínate que, después de diez años de inglés, estuvieras tres meses sin hablar inglés y te digan: "Venga, vamos a hablar" y digas: "No, es que ya no me acuerdo de nada". Claro, si tu enseñanza de inglés ha sido aprenderte de memoria las obras de Shakespeare, pues puedes haberlas olvidado, porque eso se puede olvidar. (EEx1, p. 21)

Por lo tanto, es fundamental que, desde el principio, los estudiantes de los conservatorios se expresen musicalmente, utilizando libremente los elementos del lenguaje musical.

E- Es importante que el alumno sepa utilizar libremente los elementos del lenguaje que se van trabajando, que sea capaz de relacionar lo que aprende 
con otras asignaturas, que comprenda, en definitiva, el lenguaje de la música. Improvisar es crear y es una herramienta necesaria para ver el dominio que tienen los alumnos del lenguaje musical. (EEx2, p. 7)

La mejor manera de aprender un nuevo lenguaje es utilizarlo para expresar lo que pensamos y sentimos. (DPO, p. 8)

Además, lo novedoso y creativo despierta un mayor interés y potencia el aprendizaje (Molina, 2008).

T- Desde el punto de vista práctico, lo que a mí me interesa de la creatividad es el interés que despierta, la motivación para aprender. (ETV, p. 13)

Por otra parte, compartimos con Palmer y Muñoz (2008) el convencimiento de que existe un azar creador y generador de novedades que opera en la música a través de la práctica de la improvisación y que, posteriormente, estas innovaciones serán plasmadas y conservadas en las composiciones. En este sentido, las personas que están habituadas a analizar y a hacer sus propias creaciones musicales desarrollan una mejor capacidad crítica ante las composiciones propias y ajenas.

T- ¿La creatividad de qué te sirve? Primero, como elemento motivador para manejar un material, conocerlo, darle uso y asimilarlo, [...] pero luego, también, para entender el lenguaje de otra gente. Luego, en las composiciones dices: "A ver, venga, en esta composición la primera frase, ¿cuál es?". "Pues esta es la pregunta y esta es la respuesta”. Si ellos hacen preguntas y hacen respuestas, pues luego te entienden y saben leerte. Hay muchos chavales que en el grado medio les preguntas cuál es la pregunta o la respuesta o la frase, o qué es una frase... iy no saben! ¿Pero por qué?, porque no lo trabajan. [...] Si tú nunca compones, ¿cómo miras la composición de un tío? En cambio, si tú compones, la ves con otros ojos, con sentido crítico, y ya solo piensas en comparar y en aprender qué cosas te pueden aportar, y todo lo ves de otra forma, y eso solo lo puede hacer quien está en el plano creativo. Por eso el que es más crítico, claro, es más crítico con su trabajo, para valorar qué es lo que está bien y qué es lo que está mal y qué se puede mejorar, y eso también provoca un mayor ritmo de aprendizaje, porque el que es pasivo se limita a repetir, porque no persigue ningún ideal, no persigue nada, pero el que es crítico tiene más claro lo que quiere. (ETV, pp. 13-14)

\subsubsection{Deseo del alumnado por expresarse de forma creativa}

Muñoz y Bonastre (2013) sugieren que la expresividad debería mejorarse en los procesos de enseñanza-aprendizaje de la música y que la inclusión de elementos explícitos de entrenamiento de la expresividad emocional en el 
currículo de los conservatorios podría ser una idea positiva que completaría la formación de los alumnos.

$\mathrm{Al}$ respecto, la respuesta ofrecida a la primera pregunta del cuestionario de Lenguaje Musical administrado a distintos conservatorios, relativa a "¿Para qué quieres aprender música en el conservatorio?”, nos muestra que los estudiantes no solo disfrutan interpretando música escrita por compositores de diferentes épocas y estilos artísticos, sino que también existe en ellos un gran deseo por expresarse a través de su propia música.

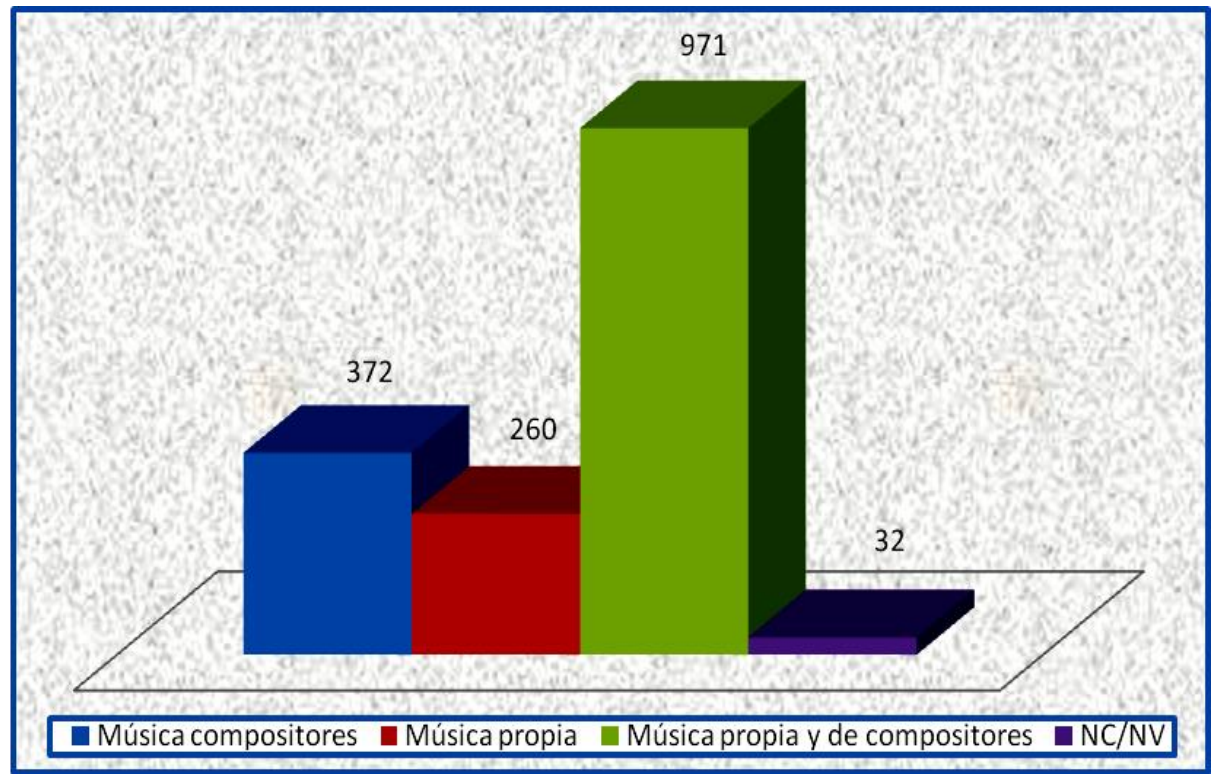

Gráfica 12. Respuestas de los alumnos a la pregunta 1 de los cuestionarios: ¿Para qué quieres aprender música en el conservatorio?

Así lo demostraban también sus comentarios, ya que las actividades mejor valoradas por los alumnos eran aquellas que implicaban creación y desarrollo de su imaginación.

A63- ¡Inventar me mola mucho, a mí me encanta! (EG2CAsB, p. 15)

A5- Que a mí me parecen muy fáciles los refranes y, además, muy divertidos, porque luego nos tenemos que inventar una nueva letra y eso me mola mucho. (EG1CAsA, p. 16) 
Me he inventado una canción con el MuseScore para hacerla con viola y cantando, se la enviare también a mi profesor de instrumento. Espero que te guste. (CE2CA56M, p. 2)

Los han realizado con mucha soltura y en varios grupos me han pedido que lea en voz alta las nuevas letras que se han inventado, porque la parte creativa es lo que más les gusta del trabajo con los refranes. (DPF, p. 2)

Me gusta mucho hacer composiciones y luego cantarlas en clase, y también los refranes. (CA2C, pre. 4)

\subsection{La composición musical como estrategia creativa}

Consideramos lamentable que, en general, se tenga poco presente en las aulas el deseo expresivo y creativo de los alumnos y que rara vez se les dé la oportunidad de iniciarse en la composición desde el principio, posponiéndolo hasta los estudios de armonía de las enseñanzas profesionales.

Desde nuestro punto de vista, esta tardanza en los inicios de la creación musical es un grave error ya que, si un alumno no se acostumbra a crear desde pequeño, irá perdiendo frescura y naturalidad y le costará mucho más expresarse artísticamente de adulto. De ahí la importancia concedida al desarrollo de la creatividad en la metodología que presentamos en este estudio.

T- El conocimiento es vital, porque si tú no tienes conocimiento no tienes recursos, pero también la actitud activa mediante la creación. Lo de que empiecen ya a hacer cosas, eso implica iniciativa y esas cosas hay que hacerlas desde el principio, porque yo lo que tengo claro es que hay ciertas cosas que, o las haces al principio, o nunca las haces, y eso es así. [...] Si a un chaval no le pides que cree desde el primer momento, que se involucre, que asocie que hacer música es: "Vengo al conservatorio y esto es lo que hacemos, en esto consiste la música", eso no lo va a asociar dentro de tres años, porque ya ha cogido una dinámica, está en su carril y ya tira para allá con sus esquemas mentales. Entonces, esas cosas son vitales. Desde el primer momento tiene que haber participación activa, creación y todo eso, yo lo veo necesario. (ETV, p. 19)

F37- Lo sorprendente es que tengan interiorizado eso con ocho años, de verdad, que yo tengo hasta sexto de piano y es que no me pongas a improvisar, porque yo era una "tricotosa" auténtica. Me refiero a que hacía "tu-cu, tu-cu, tu-cu, $t u$ ", tocaba la sonata y punto y final.

F1- Pero es que yo creo que hay gente que es capaz de improvisar y gente que no, aunque acabe el conservatorio. 
F37- ¡Ufff!, yo creo que a todo el mundo le cuesta y, de verdad, pienso que, cuanto más pequeños empiecen, mejor, como cuando estudias dos idiomas. (EG1CFs, p. 19)

Además, hemos comprobado que la creación de sus propias canciones se convirtió en una actividad altamente motivadora para los alumnos y les hacía sentirse importantes, lo cual resultaba muy beneficioso para su implicación en el proceso educativo.

A51- Yo creo que lo que más me ha llamado la atención de lo que hemos hecho en el curso ha sido lo de componer las canciones a partir de otras, porque nunca había hecho eso, no nos lo habían enseñado, y digo: “¡Ahí va, pero si esto es nuevo!’. Y luego, también, ves a los demás cantándolas y dices: “¡Bueno, esto ya es lo máximo!”. (EG2CAsA, p. 21)

Aquí te mando mi canción para que me la corrijas, se llama El dinosaurio feroz. A lo mejor tengo algo mal, pero mola componer. (CE1CA23N, p. 5)

A54- A mí me gustan las canciones con las letras, porque hay que echarle imaginación. (EG2CAsB, p. 22)

F37- El tema de la composición es lo que a ella le ha enganchado porque es como, desde muy pequeña, sentirse muy importante con el hecho de decir: "¡Esto lo he hecho yo y encima sé cómo!”

F25- Sí, "¡lo he hecho yo, le he puesto mis palabras y he puesto yo mi nombre a la partitura!".

F37- "Me ha costado trabajo, pero encima veo cómo los demás también lo hacen". Es una parte creativa, original.

P5- Disfrutan. (EG1CFs, p. 11)

\subsubsection{El análisis como punto de partida de la composición}

En nuestro planteamiento didáctico, consideramos que toda improvisación o creación musical debía partir de un análisis previo (en nuestro caso de refranes, canciones y piezas musicales breves), para que los alumnos pudieran conocer los elementos constituyentes de la música que luego iban a manipular. Así lo reconocían también los expertos:

E- Lo que yo entiendo por improvisación, y hay muchas formas de entenderla, es el desarrollo del control de los elementos musicales, es decir, la improvisación consiste en que tú puedes hacer algo nuevo en base a saber cosas de la teoría, de la armonía, de la entonación... Hay un montón de cosas que tú sabes y esas cosas que sabes, a la vez, las estás poniendo en marcha con la improvisación y, el hecho de improvisar con ellas, lo que hace es que las puedas asimilar mejor. Yo confío en una enseñanza musical, que es parecida a una enseñanza con un lenguaje cualquiera, que esté basada en que yo cojo una canción cualquiera, siempre popular o clásica, 
esa canción la canta el alumno, la canta conmigo, se la enseño a cantar, con su letra, le enseño a que se divierta con ella, a que se motive con esa canción... Digo canción en el sentido genérico, una pieza cualquiera, ¿no? Y, a partir de ahí, le hago un análisis: le doy los elementos rítmicos y le digo que puede jugar con ellos, le doy los elementos melódicos y le digo que puede jugar con ellos, le doy los elementos armónicos y le digo que puede jugar con ellos, le doy los elementos formales y le digo que puede jugar con ellos. Es decir, que el análisis me proporciona cuatro tipos de elementos: rítmicos, armónicos, melódicos y formales, y esos cuatro elementos se los voy dando al alumno, o a veces el propio alumno los analiza conmigo, y, a partir de ahí, jugamos a hacer algo nuevo basándonos en eso. [...] Dependiendo del nivel del alumno, lo que cambiará será el punto de partida, la obra en cuestión que cogemos y el análisis y los ejercicios que se derivan de ahí, pero, en cualquier caso, esa es la unidad didáctica "tipo", y todo eso se basa en la improvisación entendida como control. Control significa análisis y cada elemento de la partitura, separado y junto con otros, proporciona materiales inmensos para trabajar con el alumno. (EEx1, pp. 3-4)

Muchos de mis compañeros o "colegas" docentes, profesores de instrumento de mis alumnos, aprobaban igualmente esta forma de proceder.

T- Me parece muy adecuada la forma de: "Bueno, este es el sistema de existir de la música, ahora lo vas a hacer tú”. (ETPer, p. 3)

T- La creatividad implica, primero, tener un conocimiento amplio del campo, o sea, tú no puedes innovar en algo si no conoces el lenguaje. Yo no puedo innovar, por ejemplo, en la literatura o en la poesía japonesa, si no conozco el japonés ni conozco las formas básicas; es imposible que aporte algo nuevo. (ETV, p. 13)

\subsubsection{Pautas para organizar el trabajo compositivo}

Como hemos señalado anteriormente, siempre que se demanda a los alumnos realizar algún tipo de actividad creativa es necesario proporcionarles una serie de pautas que les permitan mantener el control sobre lo que están haciendo, especialmente en los primeros cursos (Hernández, Hernández, \& Milán, 2007).

Para casa les he mandado inventar su propia canción siguiendo las mismas pautas recogidas en las canciones que habíamos aprendido en clase: notas, figuras, acordes, etc. (DPO, p. 8)

La necesidad de proporcionar unas pautas claras como punto de referencia para la creación musical era defendida por los expertos.

E- No hay ninguna dificultad si se les da las herramientas. (EEx1, p. 19) 
E- Si les presentas cada uno de los sonidos caracterizándolos, su capacidad de improvisación es mucho mayor, porque les das unos puntos de apoyo muy fuertes. (EEx3, p. 36)

E- Siempre que me oigas decir la palabra improvisación tienes que definirla como un control del lenguaje, como una creatividad derivada del control del lenguaje. (EEx1, p. 25)

E- Intentamos crear desde el primer curso. Lo que varía es el nivel de contenidos, que va acorde al curso correspondiente. En los cursos iniciales, les damos pautas para su creación pero, según van avanzando en el conocimiento de los elementos del lenguaje musical, las creaciones a veces son guiadas y otras veces son libres. (EEx2, p. 7)

La importancia de dichas pautas también era reconocida por los distintos miembros de la comunidad educativa.

T- Lo de trabajar con moldes está superbien. Además, es superlógico, porque la ambientación te da un marco del que partir y luego, sobre eso, ya puedes aplicar la variación. Es un punto superinteresante porque si le dices: "Crea de la nada", no saben, no tienen referencias. Tener un molde como punto de partida me parece que es muy interesante y práctico. (ETV, p. 10)

A51- Yo creo que las pautas se han puesto para que sigamos como unas normas cuando vayamos a hacer la música. [...]

A43- Supongo que las pautas se inventarían por lo mismo que se inventa un idioma: para que las personas se entiendan entre ellas. (EG2CAsA, p. 14)

F- Tener que componer canciones cortitas, pero con unas pautas determinadas, les encauza mucho el trabajo y les da una sistematicidad en la forma de trabajar. A mí me parece bien, me gusta. (E2CF45, p. 6)

T- No lo veo complejo. Veo que ellos entienden lo que tienen que hacer. (ETPer, p. 7)

No obstante, se trata de pautas que organizan el trabajo sin coartar la creatividad del niño.

La canción está bastante bien, pero habíamos acordado que los compases 5 y 6 tenían que ser casi iguales a los compases 1 y 2. ¡Ánimo, a ver cómo lo arreglas! (CEP1CA27E, p. 1)

F37- La parte de la creatividad, habiendo pasado yo también por el conservatorio, a mí me daba un poco de miedo, porque a veces es un poco castrante. Sin embargo, me llevo la grata sorpresa de dar con Elena. (EG1CFs, p. 11) 
E- Todo lo que sea darles a los niños herramientas para que las utilicen, pues es fomentar su creatividad, no dárselas resueltas para que las repitan. Incluso, dar disyuntivas: "Esto podría ser así, o como lo plantea fulanito, o como lo plantea menganito...” “Por qué nos gusta más esto?, ¿por qué nos gusta más lo otro?" Darles la posibilidad de tener unas herramientas con las que van a hacer su propio uso y su propio descubrimiento. (EEx3, p. 50)

En resumen, consideramos fundamental que los alumnos puedan expresarse libremente para fomentar su imaginación y capacidad creativa, pero siempre dentro de un orden que dé coherencia al trabajo realizado.

T- Me parece que es un buen trabajo y que, aunque hay correcciones por tu parte de palabras, de notas o de figuraciones que no son correctas, respetas mucho las ideas de los niños. La verdad es que me parece muy atractivo para los chicos de esta edad $\mathrm{y}$, desde fuera, se ve un trabajo con un fundamento y bien hecho. (ETPer, p. 7)

A44- Después de haber seguido unas pautas y de saber lo que tienes que hacer, cada uno puede escribir la música que le dé la gana. (EG2CAsA, p. 12)

E- Ellos pueden hacer un ritmo y escribirlo con su grafía inventada: unos son más fantásticos y escriben pájaros y huevos de pájaro o lo que sea y otros... Te quiero decir que das lugar a que ellos relacionen más largo o más gordo y más alto o más agudo, y luego lo vas centrando. (EEx3, p. 35)

El arte se lleva en las venas y cada uno lo manifiesta a su manera, ipor lo que todos sois tan buenos artistas como el resto! (CEP2CA46E, p. 6) 



\section{CAPÍTULO VIII: ANÁLISIS DE LA INNOVACIÓN Y LA CALIDAD EDUCATIVA}

\section{Introducción}

Durante los últimos años, se han multiplicado las reflexiones en torno a la calidad y la innovación educativa entre los profesionales de la educación y los responsables políticos, preocupados por su medición y su potenciación (Egido, 2005; Miralles et al., 2012; Torre, Pujol, Lorenzo, \& Rajadell, 2011).

En el trabajo que presentamos, también hemos considerado fundamental dedicar un capítulo a analizar la calidad de nuestras propuestas educativas en la asignatura de Lenguaje Musical. Para ello, partiremos de la reflexión sobre la importancia concedida a los diferentes contenidos curriculares de dicha asignatura. Después, nos centraremos en los aspectos relacionados con la innovación didáctica, destacando las dificultades que surgen al ponerla en práctica y la necesidad de perseverar para la obtención de resultados, a pesar de que no se cuente con todo el apoyo de la comunidad educativa. Todo ello nos llevará al análisis de la calidad de nuestras nuevas propuestas metodológicas y a señalar la utilidad de los aprendizajes adquiridos por los alumnos para su desarrollo musical e integral. Por último, veremos la importancia de fomentar una mayor coordinación docente para romper la tendencia autosuficiente e individualista predominante entre el profesorado de los conservatorios, lo que, sin lugar a dudas, repercutirá en una mayor calidad educativa.

\section{Importancia concedida a los distintos contenidos de la asignatura}

Los ámbitos en los que se considera conveniente realizar cambios e innovar para mejorar la calidad educativa se determinan en función de la importancia 
concedida a los diversos contenidos curriculares. En función de nuestras prioridades educativas, emprenderemos acciones en una o en otra dirección.

Por ello, consideramos necesario analizar la importancia concedida a los estudios musicales y, más concretametne, al Lenguaje Musical y a los distintos contenidos de esta asignatura.

\subsection{Importancia de los estudios musicales}

Los estudios musicales son vistos por algunos padres como una actividad extraescolar que complementa la formación de sus hijos, pero no les conceden demasiada importancia. Por ello, dejan en sus manos la decisión de realizarlos o abandonarlos libremente y no dudan en desapuntarlos si no obtienen buenos resultados en el colegio o en el instituto.

F- El conservatorio es una cosa más, pero tiene claro que primero es el cole. Desgraciadamente, la vida es así. Y yo le dije: "Si el cole va mal, pues ya sabes..." (E1CF6, p. 2)

F61- Me ha dicho que hasta cuarto sigue, que luego no, y yo no le voy a obligar. [...] Es lo que él diga, no puedo obligar a nadie a hacer lo que no quiera. (EG2CFs, p. 4)

F75- Tengo muy claro que, en principio, para mí no es lo fundamental de su formación académica, porque para mí lo fundamental son las clases que está recibiendo en el colegio y que luego reciba en el instituto, incluso la formación universitaria. (EG2CFs, p. 7)

No obstante, la mayoría reconocen su gran valor formativo para el desarrollo integral de la persona (Jauset, 2011; Torres, 2011; Willems, 1981), priorizándolos frente a otras enseñanzas y actividades extraescolares. Incluso, los elevan al mismo nivel que los estudios impartidos en la enseñanza obligatoria.

F50- Si echas un vistazo a todos los países de nuestro entorno, sobre todo a los países de Centroeuropa, es inconcebible que una persona no sepa tocar un instrumento. [...] A mi hija, igual que le obligo a ir a inglés, a clases de matemáticas y a literatura, le obligo a que tenga una formación musical, porque creo que esa formación musical va a ser complementaria con su formación académica. [...] Yo sé que ella no va a llegar a concertista, no va a vivir de la música, pero estoy convencido de que, cuando sea adulta, va a decir: “¡Qué bien que sé tocar el piano, qué maravilla!”. Por eso te decía que era innegociable, porque para mí la música tiene la misma categoría docente que puedan tener las matemáticas, el inglés o la literatura. (EG2CFs, p. 5) 
F75- En principio, nos llevó a apuntarla el hecho de que la consideramos una actividad primordial y muy beneficiosa, que la compatibilizamos también con el aprendizaje del inglés. Entonces, está estudiando tanto inglés como música, y estamos encantados. (EG2CFs, P. 7)

F51- A mí me llama la atención que ninguno tenemos formación musical, pero a todos nos ha interesado que nuestros hijos la tengan. Yo comparto la idea de establecer, al mismo nivel, el resto de las enseñanzas con el tema de la enseñanza musical, porque la enseñanza musical en el colegio me parece muy escasa. (EG2CFs, p. 9)

\subsection{Importancia de la asignatura de Lenguaje Musical}

En cada país, los estudios musicales tienen una organización propia que va cambiando en sucesivas reformas educativas. A continuación, veremos cómo se aborda la enseñanza del Lenguaje Musical en otros países y lo compararemos con el planteamiento de dicha asignatura en España.

\subsubsection{La enseñanza del Lenguaje Musical en otros países}

El Lenguaje Musical se imparte en más o menos cursos, según el desarrollo normativo de las enseñanzas musicales de cada país.

E- En los conservatorios franceses, el Lenguaje está presente en todos los niveles y, además, con unos niveles de exigencia muy altos. (EEx3, p. 29)

Sin embargo, en algunos países ni siquiera existe la asignatura de Lenguaje Musical, de tal forma que sus contenidos se imparten de forma integrada en otras asignaturas (Díaz \& Giráldez, 2007).

E- En Inglaterra no existe.

P- ¿No hay asignatura de Lenguaje Musical?

E- No hay asignatura de Lenguaje Musical, y en Alemania tampoco, y se hacen muchos músicos allí.

P- (Con sorpresa) ¡Fíjate!

E- Eso no significa que no se dé, no lo pienses mal, porque no significa que no se dé el contenido de esa asignatura.

P- Ya, que no se da aparte.

E- Que no se da aparte, efectivamente, o sea, el profesor de piano sabe que es un profesor de música antes que de piano, y el profesor de trombón igual. (EEx1, p. 6)

E- Es una buena asignatura, pero los ingleses y los americanos la entienden como teoría musical, es decir, consideran que es "el sitio donde te enseñan teoría musical", y es como la armonía y todas esas cosas juntas, pero no está el Lenguaje Musical entendido al estilo español. (EEx1, p. 7) 


\subsubsection{El Lenguaje Musical en España}

En nuestro país, la tendencia en los últimos años ha sido la de ampliar el tiempo dedicado al Lenguaje Musical (Ley Orgánica 1/1990, de 3 de octubre, de Ordenación General del Sistema Educativo), conocido como Solfeo y Teoría de la Música en anteriores planes de estudio.

E- La enseñanza del Lenguaje Musical en España ha evolucionado en cuanto a tiempo de dedicación y también en cuanto a número de cursos.

P- Sí, antes eran cinco y ahora seis.

E- Sí, y antes cuatro. Incluso, ya no sé hasta dónde remontarme, pero posiblemente menos. Es decir, que la evolución del Lenguaje Musical ha sido ampliar el número de cursos. En la última versión que yo conocí, alguien habló de poner catorce cursos, igual que en las demás cosas, pero eso es en España. (EEx1, p. 6)

Lamentablemente, a veces no se reconoce su importancia, siendo considerada una asignatura de segunda categoría respecto a las clases de instrumento (Perandones, 2005).

Consideran que su hija tiene que dedicar demasiado tiempo al estudio del Lenguaje Musical en casa, un tiempo del que no dispone y que se lo tiene que quitar del estudio del instrumento, que es lo importante. (DPD, p. 10)

El instrumento sí que lo estudia todos los días en casa, pero reconozco que hay semanas que no abre el libro de Lenguaje Musical. (CE1CF35N, p. 2)

Asimismo, el hecho de que en España el Lenguaje Musical exista como una asignatura separada de la clase de instrumento genera algunas polémicas a la hora de distribuir responsabilidades entre los profesores implicados en la formación musical de un mismo alumno. Así lo expresaba uno de los expertos entrevistados:

E- Cuando aquí al profesor de piano le preguntas de qué da clase te dice que de piano, y eso se puede entender de muchas maneras: unas buenas y otras malas. Seguramente, el profesor español lo entiende como que tiene que dar clase de técnica del piano, porque sabe que hay un profesor aparte que le va a dar al niño el Lenguaje Musical, con lo cual, si su alumno viene a clase y no sabe los tresillos de corcheas o el compás de $6 / 8$, su primera reacción es: "Vete a clase de Lenguaje y que te lo enseñen, porque yo no te lo puedo enseñar aquí".

P- Como que no es responsabilidad suya.

E- Sí, y esa es una actuación fatal, producto posiblemente de que existe la asignatura. La asignatura no es mala en sí misma, pero podría no existir. (EEx1, p. 7) 
Por otra parte, los resultados del estudio realizado por Perandones (2005) muestran que, en general, los alumnos no se sienten satisfechos con el tipo de educación que reciben en Lenguaje Musical, debido a que, al impartir dicha asignatura, muchas veces no se sigue un procedimiento didácticamente lógico y se da tanta importancia a contenidos secundarios como a los principales. De ahí la necesidad de establecer una adecuada priorización en los contenidos para crear una buena base, tal y como veremos a continuación.

\subsection{Priorización de contenidos para crear una buena base musical}

Como no se puede enseñar ni aprender todo, hay que hacer una selección de los contenidos a trabajar en cada curso.

T- Lo que tenemos que hacer es ver qué es lo importante y ponerlo en su momento y trabajar para que sea asimilado. (ETGD, p. 8)

En función de lo queramos conseguir, priorizaremos unos u otros, poniendo especial énfasis en crear una buena base sobre la que cimentar posteriores conocimientos (Torrado, 2011).

T- El problema principal es también que nosotros no podemos enseñar todo, igual que no podemos aprender todo, y eso es una cosa que realmente no tenemos asimilada. [...] Depende de lo que enseñes, el niño sabrá unas cosas u otras. [...] En función de cómo se enseña, lo que se saca, lo que se sacrifica y lo que no se sacrifica, es cuando se puede evaluar a nivel global si compensa o no compensa, pero, de entrada, todo lo que sea que el niño se divierta y que haga música es interesante. (ETV, pp. 11-12)

E- Los grandes parámetros musicales vamos a ponerlos como base muy sencillamente. (EEx3, p. 12)

Hay que tener en cuenta que la atención es limitada y no se pueden resolver varias dificultades al mismo tiempo.

T- La atención es limitada. La atención la puedes fijar en una cosa o dos. Entonces, los instrumentistas de cuerda cuando cogen el violín están: que si la mano está tensa, que si se me cae el violín, que si coge el arco, que si pasa el arco, pero esta cantidad de arco, que qué nota es ésta... ¿Tú crees que tienen tiempo para pensar en la afinación? (ETV, p. 2)

Igualmente, es fundamental garantizar que todo lo que se dé en clase tenga utilidad y significado para los alumnos (Torrado \& Pozo, 2006), evitando impartir contenidos aislados que se estudien para un examen y que luego se olviden por no tener un desarrollo posterior. 
Bastantes aspectos que desconocía ahora me son familiares y los considero importantes para aprender a leer música con fluidez y saber su justificación. (CA2C, pre. 2)

T- Hay cuestiones teóricas que se abordan tradicionalmente en Lenguaje Musical y que nunca van a ser utilizadas por los alumnos, porque no sirven para nada en la práctica. (ETGD, p. 4)

Se refuerzan mucho las cosas que damos para que se nos queden bien. (CA2C, pre. 1)

Y es que, si no se tienen los objetivos claros, es muy fácil caer en el error de atender a lo urgente en vez de a lo importante.

T- Al final te tienes que limitar muchas veces, sobre todo en grado medio, al aspecto técnico porque tienen un programa tan vasto, tantas cosas que solventar, que vas con el agua al cuello y, a veces, lo importante no lo atiendes, atiendes lo urgente. (ETV, p. 20)

\subsubsection{Equilibrio en la atención educativa de los contenidos}

Siempre hay que buscar un equilibrio para poder atender con la calidad deseada los contenidos impartidos en la asignatura de Lenguaje Musical. En este sentido, los alumnos admiten que todos los contenidos se han trabajado suficientemente en las clases, a pesar de los límites de tiempo con los que contábamos.

A46- Lo que se practica es equilibrado: se toca la entonación, el dictado, el ritmo y la teoría. Lo que ocurre es que a cada uno se nos da mejor una cosa u otra y, para unos, será suficiente lo que se da en clase y, para otros, pues habrá que reforzar en casa. (EG2CAsA, p. 11)

F50- Me parece bien. Además, es una evaluación homogénea, está bien. (EG2CFs, p. 19)

A46- Hay que decir que no puedes dar más de lo que das; una hora no da más de sí. Yo entiendo que algunas veces queremos hacer más, y más, y más, pero sería en detrimento de otras actividades, y una hora no da para más. [...] O sea que creo que está todo bien equilibrado.

A44- Sí, yo pienso que también. (EG2CAsA, p. 30)

Por su parte, los padres también reconocen que los contenidos se han trabajado de forma equilibrada.

F70- Dentro de nuestra ignorancia, yo me fijo más en las calificaciones, en que pienso que todas sean más o menos homogéneas; si hay algo que destaque respecto a las otras es que algo falla. Yo, como las veo todas 
homogéneas, independientemente de que sean un cinco, un ocho, un siete.. Si todas son homogéneas, es que ninguna de las partes anda coja, entiendo. (EG2CFs, p. 20)

Además, nos parece relevante destacar que la mayoría de los alumnos conceden la misma importancia a todos los contenidos de la asignatura, tal y como puede observarse en las respuestas ofrecidas a la pregunta 7 de los cuestionarios administrados a distintos conservatorios españoles.

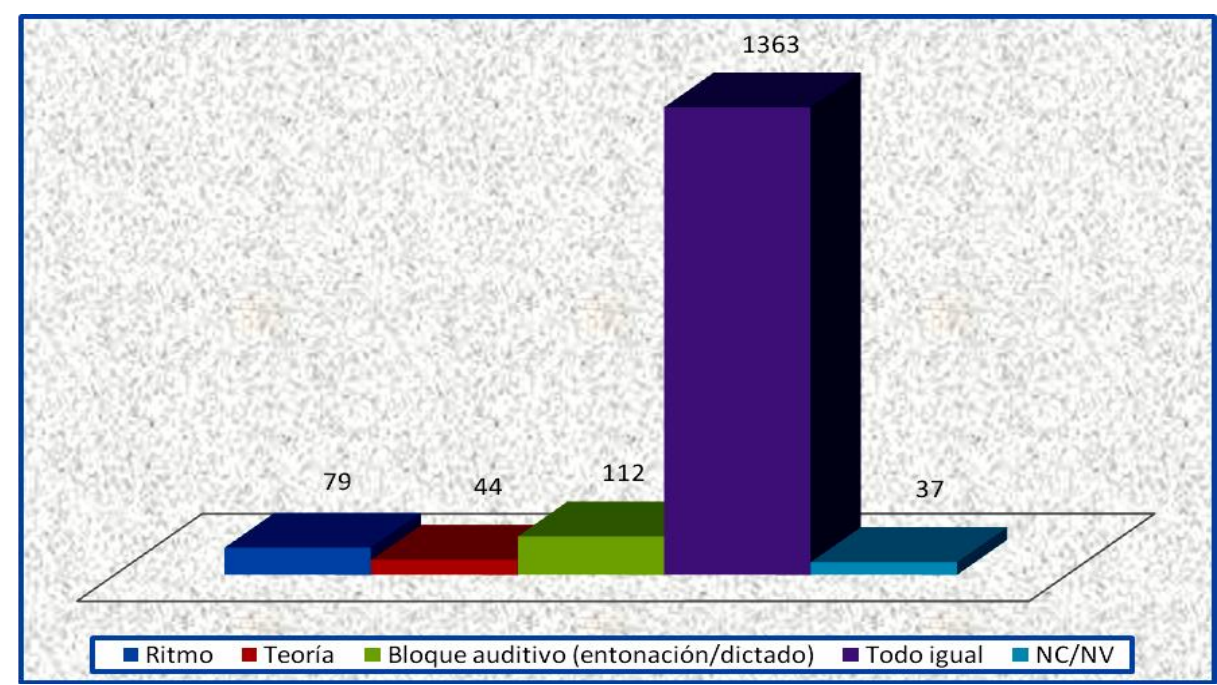

Gráfica 13. Respuestas de los alumnos a la pregunta 7 de los cuestionarios: ¿Qué te parece más importante para ser un buen músico?

Esta opinión de los alumnos es compartida por algunos profesores.

T- A mí me parece que todos son fundamentales, porque podría decirte ¿la práctica?, es decir, ¿lo que es el solfeo? No, porque el solfeo no se puede llegar a entender si no tienes una parte teórica detrás. ¿El dictado?, pues el dictado sin tener el solfeo... (niega con la cabeza). Entonces, me parece que están un poco complementados. (ETPer, p. 2)

T- En principio, vistos de una forma integral, son todos igual de importantes, no veo que haya algo que sea más importante. (ETGD, p. 4)

T- Es como los cinco dedos de la mano, que cada uno tiene una función: son diferentes y todos son importantes. (ETV, P. 1)

Y también hay expertos que admiten que los diferentes bloques de contenidos poseen la misma importancia. 
E- Me parecen todos igual de importantes: es igual de importante cantar, escuchar, escribir o medir, ya que todo está relacionado.

P- ¿Trabaja todos los aspectos del Lenguaje Musical, es decir, ritmo, entonación, dictado y teoría en todas las sesiones?

E- De forma general, trabajamos en una sesión ritmo y entonación y en otra sesión dictado y teoría. Intentamos que cada semana se hayan trabajado los cuatro bloques (ritmo, entonación, dictado y teoría), que son independientes y cuentan un $25 \%$ cada uno en la prueba final del trimestre y en las pruebas de acceso a las enseñanzas profesionales. (EEx2, pp. 2-3)

No obstante, nuestra opinión como docentes es diferente, tal y como veremos en el siguiente apartado.

\subsubsection{Priorización de los contenidos de desarrollo auditivo}

Desde nuestro planteamiento, aunque todos los contenidos que se trabajan en Lenguaje Musical estén interrelacionados y sean importantes, lo más relevante para garantizar una buena formación musical es el desarrollo auditivo.

Todo ello ha hecho que me replantee mi manera de enseñar y que empiece a ver claro el camino que quiero emprender para ofrecer una mejor educación auditiva a mis alumnos, ya que considero que es el pilar para garantizar una buena formación musical. (DPS, p. 1)

Nuestro punto de vista es compartido por varios profesores.

T- Si yo tuviese que enfatizar alguno, supongo que lo haría en función de cada curso, pero al principio, sobre todo, cantar, porque todo tiene su momento y cuando tienen que desarrollar la voz, cantar y ejercitar el oído es, sobre todo, al principio. (ETV, P. 1)

T- En principio, puesto que hablamos de música y la música es algo que se percibe a través del oído, le daría importancia al bloque auditivo: la entonación y el dictado. Luego, en el siguiente escalón de importancia estaría el ritmo, porque es lo que organiza lo que se percibe a través del oído, lo que organiza el material auditivo, por así decirlo. Y luego, por último, la teoría. La teoría, en definitiva, no es más que una serie de conceptos que sirven para poner nombre a aquello que se está escuchando, es decir, a aquello que se percibe por el oído. Así, en cuanto al tiempo que se debería emplear para cada uno de los apartados, yo considero lo mismo que antes: primero el bloque auditivo, luego el apartado rítmico y, lo último, la teoría. (ETO, pp. 1-2)

T- Un alumno que no escucha es un alumno que jamás va a poder tocar bien, porque no va a poder mejorarse. Entonces, para mí, está arriba. Considero que es más importante que cualquiera de las otras cosas, porque 
un músico que no escucha no puede llegar a ser un buen músico. Muchos de los alumnos con los que te encuentras no son capaces de escuchar. En cambio, lo que sí que noto con tus alumnos es que escuchan y eso para mí es importantísimo a la hora de darles clase. (ETPiJE, p. 2)

Y también está apoyado por la opinión de expertos.

E- La música, si no se escucha, no es nada, por lo que la audición es primordial. No es que sea más o menos importante, es que es primordial. No te la quiero comparar con el ritmo o con otros aspectos, porque todos son necesarios, pero conozco a muchos músicos que saben mucha teoría, rítmica y armonía, pero que son incapaces de escuchar, y eso es fatal para ser intérprete. La audición es algo primordial, esencial en la formación. No debería haber un músico sin formación auditiva, porque todo se escucha, todo se lleva al oído. (EEx1, pp. 5-6)

P- ¿Qué sería más importante para garantizar un buen desarrollo musical del alumno?

E- Para mí, por supuesto, la audición. Yo no creo mucho en el buen oído, creo en el oído educado o no educado. [...] Le doy muchísima importancia a la audición y, concretamente en las clases de solfeo, a los dictados, porque el ejercicio del oído es algo que el músico tiene que hacer siempre: mientras que un pianista no va a necesitar cantar, si necesita oir. ¿A qué le doy más importancia? Por supuesto, al oído. (EEx3, p. 32)

La priorización del desarrollo auditivo frente a todos los demás contenidos es defendida, incluso, por grandes pedagogos (Suzuki, 2007; Kodály, 1911, citado por Szönyi, 1976; Willems, 2001), tal y como expone uno de nuestros expertos, al presentarnos una visión global de los planteamientos de importantes pedagogos musicales reconocidos a nivel mundial.

E- Cualquiera de las metodologías de más extensión por el mundo están muy preocupadas por el desarrollo de la audición. Por ejemplo, Kodály tiene una relación directa con la creación de coros y con el desarrollo del instrumento vocal como el instrumento de formación musical preferido; Orff trabaja mucho desde niños en la formación de conciertos, con elementos pequeños tanto instrumentales como vocales para la formación del oído; Willems es muy conocido por los instrumentos que utiliza microtonales para desarrollar el oído; Dalcroze utiliza la audición del alumno para seguir ciertas consignas, tanto si es música grave como aguda, como picado, como cierto tipo de compás, todo está relacionado con la audición. Aunque ahora el que más me viene a la cabeza como formación del oído es Suzuki, porque empieza desde muy pequeño a basar su formación en la escucha, es decir, que el alumno, que en este caso era un violinista, escucha la obra que quiere aprender y la escucha reiteradamente con sus padres en su casa, de forma que esta se convierte en un objetivo a tocar y, cuando toca el violín, lo que trata de hacer es escuchar en su interior la pieza que quiere tocar de forma que, al tocar, está reconociendo 
los sonidos que ha escuchado muchas veces. Este sistema podría simplificarse diciendo que la música hay que vivirla y hay que escucharla antes de tocarla, y eso viene muy bien para todo tipo de formación. Me parece que es una forma ideal que debería ser tomada, no como modelo exclusivo, pero si como un gran elemento de ayuda de trabajo. (EEx1, p. 26)

\subsubsection{Contenidos específicos demandados por los profesores de instrumento}

Además de lo dicho hasta ahora, consideramos relevante destacar que cada tutor, en función del instrumento que imparte, demanda de forma prioritaria a los profesores de Lenguaje Musical el trabajo de determinados contenidos.

T- En el piano, quizá por ser un instrumento polifónico, para nosotros es muy importante el reconocimiento armónico, porque yo puedo trabajar mucho mejor en el momento en el que ellos reconocen acordes, relaciones entre acordes, relaciones entre notas. El contenido armónico para mí, como pianista, es fundamental. (ETPiJE, p. 1)

T- En la especialidad que yo imparto, que es percusión, tenemos una base rítmica que es imprescindible, es decir, no pueden fallar el ritmo. A lo mejor el de clarinete te va a decir que no pueden tocar con tres bemoles cuando la tonalidad es de dos. Nosotros eso no lo tenemos tan presente porque la marimba representa un $20 \%$ de nuestro instrumento. (ETPer, p. 2)

Concluiremos este apartado reiterando que, independientemente de que se conceda más importancia a unos aspectos o a otros, defendemos que lo más importante no es dar muchos contenidos, sino crear una buena base sobre la que cimentar posteriores conocimientos (Tafuri, 2006), para que los alumnos puedan realizar aprendizajes significativos.

T- Una formación más integral lo que hace es reforzar la base, que es partir de que todo lo que se hace se tiene que asimilar, y eso se puede hacer aunque, al final, haya menos contenidos, pero se ven mucho mejor. Esa es la base para que luego esos contenidos puedan ampliarse más adelante mucho más. (ETGD, p. 7)

\section{Innovación educativa}

Tal y como señala Pastor (2014), uno de los rasgos que adquiere mayor relevancia en el profesorado es tener competencia para innovar, ya que "la mente se nutre del cambio, la anorexia mental viene por desnutrición de cambio" (p. 328). 
El poder de la imaginación innovadora radica en su capacidad de crear alternativas de mejora a la realidad dada, de resistencia al anquilosamiento. En el marco de un centro (escuela, instituto, universidad, conservatorio...) no se trata tanto de dar grandes saltos, cambiando todo de arriba a abajo, como pretenden infructuosamente las leyes orgánicas educativas imponiendo un gran cambio "desde arriba". Se trata más bien de una ambición más duradera: la de acumular prácticas tangibles y esfuerzos continuados en todo aquello que es susceptible de mejora. Dicho de otra forma, se debe potenciar la innovación derivada de algo tan básico como es sumar y multiplicar las mejores prácticas de cada colega del centro pues, a menudo, unos hacen algo valioso y útil, se produce un traslado a otro sitio $\mathrm{y}$, cuando han salido por la puerta, ya se ha volatilizado toda su herencia.

En este apartado veremos cómo la sociedad actual demanda cambios en el sistema educativo y cómo se manifiestan en la realidad específica de la enseñanza musical. También reflexionaremos sobre las dificultades y resistencias que surgen en torno a las prácticas innovadoras y, a pesar de ello, sobre la importancia de arriesgarse para mejorar la educación, aunque no siempre los esfuerzos realizados tengan un reflejo visible. A continuación, señalaremos la necesidad de que los cambios planteados se adapten a las características de los alumnos y respeten el marco legislativo regulador de nuestras prácticas educativas, utilizando para ello los recursos pertinentes y prestando especial atención a la incorporación de las TICs. Finalmente, haremos hincapié en la paciencia y la perseverancia del docente como cualidades esenciales para la obtención de resultados y en la importancia de que la comunidad educativa apoye la innovación.

\subsection{La educación musical en el siglo XXI}

En el siglo XXI, la sociedad demanda cambios en la educación a nivel general para adaptarse a las nuevas necesidades.

T- Cada plan de educación o cada forma de educar tiene que responder a unos retos. En la que nosotros nos educamos se forjó para responder a una serie de retos, pero esos retos ya han quedado obsoletos. La sociedad en la que vivimos es diferente, los niños están expuestos a una serie de necesidades, de formas de expresarse, de formas de aprender que nosotros jamás hubiésemos pensado. Entonces, tenemos que enfocar las cosas de otra manera. [...] Las cosas son diferentes, esa es la única certeza [...] y tú tienes que tener recursos para enfrentarte a esos cambios. (ETV, pp.17-18)

Las investigaciones en Eduación Artística confoman un espacio específico y muy heterogéneo con su propia identidad distintiva, situado justo en la intersección entre los problemas de las artes y los problemas educativos (Viadel, 2011). Dichas investigaciones revelan que, como parte del sistema 
educativo, la sociedad actual también pide una renovación de los métodos de enseñanza utilizados en los conservatorios de música.

F1- Sigo pensando que el conservatorio es demasiado académico y yo me temo que, a veces, no saben que trabajan con niños; es la percepción que tengo. (EG1CFs, p. 5)

F- Yo a veces pienso que el sistema en vez de hacer amar la música, lo que consigue es que la aborrezcan. (E2CF59, p. 4)

F- Los estudios de música son muy tradicionales y, además, muy competitivos: aquí el que vale, vale, y el que no, a la calle. Son muy selectivos. (E1CF6, p. 8)

Afortunadamente, la educación musical que se ofrece hoy en día en los conservatorios españoles es más completa que en épocas anteriores, consiguiéndose que los nuevos profesores estén cada vez mejor formados.

E- La formación de los profesores de ahora, sobre todo de los que salen del grado superior, contiene muchos elementos de suficiente garantía como para pensar que son profesores estupendos y eso hace que cambie, a su vez, el centro donde ellos educan. (EEx1, p. 32)

Aunque los cambios son muy lentos y hay que reconocer que aún estamos demasiado anclados en el pasado (Aróstegui, 2006).

T- No me parece bien que se siga teniendo una metodología antigua en la que yo enseño y tú aprendes. Me parece que actualmente se ha visto que eso está descartado. (ETPer, p. 4)

T- El solfeo puro y duro tiene cincuenta años de vida y sobrevive como un diplodocus. (ETGD, p. 2)

\subsubsection{Revisión de planteamientos pedagógicos y de materiales didácticos}

La investigadora y pedagoga musical Hemsy de Gainza (2003) señala que es esencial que nuestros docentes puedan "recuperar cuanto antes su autonomía intelectual y preguntarse en relación a sus respectivos quehaceres: ¿Dónde estamos? ¿Qué hacemos? ¿Por qué y para qué lo hacemos?” (p. 18)

En este sentido, cuando los profesores están comprometidos con su actividad docente, les nace espontáneamente el deseo de mejorar la enseñanza que ofrecen, lo cual nos llevó a revisar los materiales y los planteamientos metodológicos del pasado y del presente para poder dirigir la mirada hacia un futuro de mayor calidad. 
Ya estamos en septiembre y recibo con ilusión el comienzo de un nuevo curso. A pesar de que los profesores tenemos la fama de contar con muchas vacaciones, tengo la sensación de que no he tenido apenas días de desconexión, ya que he dedicado la mayor parte del verano a reflexionar sobre cómo mejorar mi práctica docente en el campo de la educación auditiva. Esta reflexión me ha llevado a leer múltiples libros, artículos y trabajos de investigación llevados a cabo no solo en España, donde resultan muy escasos, sino también en otros países. Asimismo, me he puesto en contacto con distintos "expertos" que han editado libros específicos para utilizar en las clases de Lenguaje Musical, con el fin de conocer de primera mano los planteamientos metodológicos subyacentes en los mismos. Todo ello ha hecho que me replantee mi manera de enseñar y que empiece a ver claro el camino que quiero emprender para ofrecer una mejor educación auditiva a mis alumnos. (DPS, P. 1)

En dicha revisión, resultaron muy útiles las aportaciones de los expertos entrevistados, que nos informaron sobre nuevos planteamientos metodológicos utilizados para la educación musical en España, derivados de las carencias observadas en metodologías anteriores:

E- El IEM es una institución que yo he creado y que parte de mi propia formación intuitiva y autodidacta. La verdad es que he aprendido más de la propia experiencia que de haber conocido gente aparte, porque mi formación ha sido quizá más autodidacta de lo que debería, muy apartado de corrientes exteriores. En España, la formación musical era muy escasa en los tiempos en los que a mí me tocó ser estudiante, allá por los años 60 y 70 , por lo que es prácticamente una creación propia basada en libros, naturalmente, aunque no en muchos, en ideas que recojo de aquí y de allá, y en la propia experiencia de ver que yo podía hacer cosas que mis alumnos no podían. Podía hacer cosas como, por ejemplo, tocar una canción como Noche de paz o Yesterday, pero veía que mis alumnos, que eran generalmente del plan superior y con una capacidad técnica muy importante, se sentían como inútiles, incapaces de llevar a cabo esa función, cuando era realmente mucho más fácil que aquello que tocaban ellos, pero había otro chip que ellos no habían puesto en marcha y que yo creo que les faltaba. Entonces, desde aquel momento, y estoy hablando de hace unos 30 años, yo empecé a trabajar con alumnos superiores y, después, me di cuenta de que lo que les faltaba era la base. (EEx1, p. 27)

Igualmente, los expertos nos informaron sobre planteamientos pedagógicos y metodologías para la educación musical presentes en otros países:

P- ¿Conoce algún tipo diferente de metodología para la educación vocal y auditiva utilizada en otros países, escuelas de música o diversos centros? E- Las metodologías que conozco son las heredadas de los grandes pedagogos: Willems, Dalcroze, Suzuki, Martenot, Orff, etc. Existen escuelas que se centran en una de ellas y otros centros que aplican una combinación de varias. Ningún método es perfecto, ni todos los alumnos o 
profesores somos iguales, así que, quizá, una buena opción sea coger lo que nos resulte interesante de cada uno de los métodos y, a través de la experiencia, seguir avanzando y creando. (EEx2, p. 9)

E- De todo lo que yo he conocido, musicalmente hablando, lo que me ha interesado más es Dalcroze, precisamente porque Dalcroze parte de la sensación. [...] A partir de la audición, tú extraes todos los parámetros: tiene un ritmo que tú estás percibiendo, que estás haciendo con tus movimientos pero, además, puedes hacer el parámetro de seguir la vía de la melodía, es decir, dibujar en el aire aquella melodía que estás escuchando, o identificar a través de la audición y representar a través del movimiento la forma, jugar muchísimo con los conceptos de distancia/tiempo, y a las armonías respondemos o bien con un movimiento determinado o bien con un color determinado. (EEx3, pp. 59-60)

\subsection{La innovación frente a la estabilidad de lo tradicional}

Cuando trabajas en un centro en el que, por tradición, las cosas se hacen de una determinada manera, resulta un poco incómodo emprender acciones innovadoras por el miedo al "qué dirán".

Soy consciente de que las novedades en mi metodología pueden dar de qué hablar, ya que todo lo nuevo parece que se percibe como una amenaza; estaré alerta, pero no quiero negarme la posibilidad de innovar, ya que estoy convencida de que las cosas pueden aprenderse de otra manera iy mejor! (DPO, p. 8)

En este apartado, veremos lo duro que resulta introducir cambios sin garantías de éxito y la fortaleza anímica que ha de mantener el docente para llevar a cabo iniciativas innovadoras que permitan adaptarse a los nuevos tiempos.

\subsubsection{Las dificultades y el cuestionamiento de la novedad}

La innovación requiere un proceso de cambio voluntario, planificado y creativo, pero los cambios resultan complicados y requieren tiempo, ya que las resistencias son múltiples y diversas (Miralles, Maquilón, Hernández, \& García, 2012).

Además, hay que tener presente que, cuando se pretende un cambio, suelen surgir imprevistos dentro y fuera del aula que hay que ir solventando o reconduciendo.

Como estoy llevando a cabo esta actividad con más de 90 alumnos, atender tantas dificultades en horas de tutoría me parece una locura, y tengo que solucionarlas cuanto antes para que la metodología que pretendo llevar a 
cabo tenga sentido y no se convierta en un obstáculo que eclipse su valor formativo. (DPO, p. 6)

No obstante, lo que más suele limitar o condicionar al docente que se plantea llevar a cabo iniciativas innovadoras no son las dificultades surgidas en su desarrollo, sino los comentarios de la comunidad educativa cuestionando la validez de su nueva forma de trabajar (García-Retamero, 2010).

T- Noté a principio de curso que los padres mostraban un poco de pesar con el tipo de metodología empleada, por el tema de que los niños usaran las nuevas tecnologías para hacer determinadas cosas de la asignatura, pero porque, como nunca lo habían hecho, supongo que les asustó un poco. (ETO, p. 2)

A pesar de mis intentos porque comprendieran mi forma de trabajar, parecía no convencerles, ya que me insistían en cómo y cuándo aprendieron ellos estos contenidos durante sus estudios musicales, y les costaba entender que en clase los estuviéramos trabajando de una manera más vivencial y experimental, adaptada a la psicología y las capacidades de los niños. (DPD, p. 11)

Por ello, a pesar del convencimiento de que "quien no arriesga, no gana", a veces no resulta cómodo probar nuevas estrategias metodológicas, lo cual obliga al docence a armarse de valor y paciencia para no caer en el desánimo que le lleve a desistir en su empeño.

Estoy desmotivada. Nada más empezar la reunión de departamento, PTcas1 se ha dirigido a mí pidiéndome explicaciones sobre los contenidos armónicos que estoy trabajando en el aula. (DPD, p. 4)

Me entran ganas de desistir y volver al modelo tradicional. Cuando no te sales de "la norma", nadie te mira, ni te cuestiona... (DPD, p. 11)

Por lo que nos has contado, pienso que es una iniciativa muy interesante y que puede resultar muy beneficiosa para la educación de nuestros hijos, pero también sé que, cuando uno se arriesga por mejorar, a veces el camino se vuelve muy tortuoso, por eso te deseo mucha suerte y mucho ánimo. (CE1CF6S, p. 1)

Y es que, cuando alguien innova, está en el punto de mira, sintiendo la presión añadida de tener que garantizar unos buenos resultados.

Cuando alguien intenta hacer algo diferente, no solo tiene que soportar la presión de estar en el punto de mira, cuestionada por todo su entorno, sino que además tiene la responsabilidad de que le debe salir bien, ¿¿por qué esto es así?! ¡Los científicos experimentan continuamente con el "ensayo-error" 
y nadie cuestiona si trabajan bien o no porque no consigan a la primera los resultados que pretenden! (DPD, p. 4)

Sigo adelante con mis propuestas porque estoy muy contenta con los resultados que se van obteniendo, pero anímicamente me está costando mucho. (DPE, p. 4)

\subsubsection{Importancia de arriesgarse para mejorar la educación}

Con lo expuesto hasta ahora, resulta evidente que el deseo de mejorar la educación debe ir acompañado de valentía para arriesgar.

Innovar implica tiempos de desierto, en el sentido de que te encuentras solo caminando por tierras arenosas en las que es difícil avanzar, encontrar apoyo y tener claro hacia dónde caminas. (DPD, p. 11)

E- Una de las características, naturalmente, es la tolerancia a la incertidumbre, porque muchas veces tú arriesgas cuando estás opinando algo que no es lo común, cuando estas experimentando algo que no es lo común y tú tienes que ser lo bastante fuerte como para saber que, aunque este dice no sé qué y el otro dice no sé cuántos, yo tengo que tener mi propia experiencia fundamentada. (EEx3, p. 50)

No obstante, consideramos que siempre merece la pena poner en práctica algo en lo que crees, aunque no tengas muy claro si saldrá bien o no.

[...] en esta incertidumbre se descubre lo bonito que es tratar de mejorar y abrir nuevos horizontes: quien no se adentra en estos caminos, trabajará tranquilo, sin duda, y es posible que obtenga resultados aceptables, pero está condenado a reproducir modelos que, hoy en día, ya están obsoletos, porque ni los niños ni la educación actual son iguales a los del siglo pasado. (DPD, p. 11)

$\mathrm{Y}$ es que, independientemente del resultado, toda innovación nos lleva a sacar conclusiones que nos permiten seguir avanzando en una $\mathrm{u}$ otra dirección, evitando el estancamiento educativo (Miralles, Maquilón, Hernández, \& García, 2012).

T- Evidentemente, cuando intentas hacerlo cada vez mejor, te mueves hacia adelante. Tendrás momentos de decir: "Bueno, ahora voy para un lado, ahora voy para el otro", pero, claro, que el que no hace nada, no se mueve de donde está desde hace un montón de años. (ETGD, p. 10)

E- Efectivamente, esto funciona y esto no, y me hago mis cálculos de por qué funciona y por qué no funciona, y de lo que ha funcionado aprendo y de lo que no ha funcionado también, y tomo mis notas y experimento, y veo los resultados finales. (EEx3, p. 43) 


\subsection{Lo invisible y lo visible de la innovación}

A veces las innovaciones pueden pasar desapercibidas, especialmente cuando trabajas con alumnos que no han recibido clases de Lenguaje Musical con anterioridad, y algunos de ellos y sus padres no sabían si lo que estábamos haciendo en clase era innovador o era lo normal.

T- Si nunca han tenido clase de Lenguaje Musical con otra gente, no saben si lo que estás haciendo es peor, es mejor, es más lento o es más rápido. [...] A veces haces cosas con las que te estás dejando la vida, pero la gente no sabe hasta qué punto eso es normal, es lo que se espera de ti y lo que tienes que hacer o si, realmente, es algo extra. (ETV, pp. 7-8)

Pero lo frecuente es que las novedades llamen la atención (Pastor, 2014) y que se perciba el cambio.

F37- Tenemos familiares que estudiaron en el conservatorio y la opinión de generaciones anteriores es: “iQué bien, cómo ha cambiado esto!”, porque antes era mucho más rígido y más académico. (EG1CFs, p. 10)

F26- Yo he estudiado música de manera particular, pero los que han ido al conservatorio dicen: "Bueno, esto no tiene nada que ver con lo que era antes", se ve que la cosa va mejor.

F37- Es cierto que ha cambiado, pero también es muy importante el profesor que te toque. (EG1CFs, p. 10)

En este sentido, la mayoría de la comunidad educativa era consciente de que estábamos poniendo en práctica una metodología diferente.

F- La forma de trabajar que se ve no es una enseñanza tradicional como la que estudié yo. (E1CF6, p. 7)

A7- Yo no iba a clases en otros sitios aunque sí había oído hablar del Lenguaje Musical y esas cosas, pero no me lo imaginaba así, me lo imaginaba de otra manera.

P- ¿Cómo te lo imaginabas, o qué es lo que te ha sorprendido de lo que hemos hecho aquí que sea diferente?

A7- Pues lo de crear canciones, lo de los refranes, grabarnos con las canciones, traer cosas que hemos hecho para las canciones y ponerlas por la clase... Vamos, que es mejor de lo que me imaginaba.

$\mathrm{P}$ - ¿Hacer esas cosas te gusta?

A7- Sí. (EG1CAsA, p. 5) 


\subsection{El fin justifica los medios, pero adaptándose a la realidad}

A priori, en educación no hay nada que esté bien ni que esté mal, todo depende de con qué fin se lleve a cabo, con qué medios y con qué metodología.

T- Algo no está ni bien ni mal de entrada. Todo lo que sea aprender y, sobre todo, potenciar que haya conexión con el mundo real, me parece bien, me parece que es positivo y correcto. (ETV, p. 12)

T- ¿Eso quiere decir que hay que dejarlo todo para más adelante? No. Lo que quiere decir es que hay que asegurarse de que, lo que se hace, se asimile.

P- O sea, que no es tan importante lo que se dé, sino cómo se dé.

T- Cómo se dé, claro. Elijamos lo que elijamos, ver el cómo y trabajar para que haya posibilidades de éxito y para que comprobemos luego que realmente eso se ha conseguido. [...] Tú introduces unos elementos armónicos muy elementales desde el primer momento, pero lo que tienes que hacer es examinarlos cantándolos, manipulándolos, sintiéndolos en el propio oído y utilizándolos con el instrumento y con la voz. Por eso, hay que hacerlo muchas veces y de muchas maneras para que sea asimilado.

(ETGD, pp. 8-9)

En cualquier caso, siempre que se plantea un cambio hay que tener presente la edad de los alumnos para adaptarlo a sus capacidades y a sus características psicológicas (Pozo, 2008). En este sentido, nos aseguramos de que era asequible para todos ellos.

F- Pienso que todo el mundo puede hacerlo, siempre y cuando trabaje y tenga una motivación, y eso se genera en las primeras edades. (E1CF6, p. 8)

Lo importante es la manera en que se enseña a los niños. Ellos son como esponjas y, si se pone a su nivel, lo entienden perfectamente. (DPD, p. 6)

Quiero agradecerte personalmente el proceso que has llevado a cabo en la enseñanza de la música de A6, aplicando otras formas de enseñanza que, aunque profesionales, están muy bien adaptadas a la psicología de estas edades. Enhorabuena por tu trabajo. (CE1CF6Y, p. 3)

Asimismo, necesitamos dotarnos de los recursos que nos permitieran llevar a cabo nuestras propuestas, pero no nos quedó más remedio que utilizar muchos materiales de creación propia, porque no existía en el mercado nada que se adaptara perfectamente a los objetivos que perseguíamos.

Tengo las ideas claras de lo que quiero conseguir, pero a veces no es fácil encontrar materiales que se adapten a lo que se busca o desea, por lo que 
utilizaré varios materiales de creación propia para poder poner en práctica mi nuevo planteamiento metodológico. (DPS, p. 2)

E- Nosotros hemos sido pedagogos absolutamente autodidactas y, claro, ahí había dos posibilidades: repetir lo que habían hecho contigo que, por cierto, en cuanto hacías un somero análisis no te parecía el ideal, o ver dónde buscar las guías. [...] Todas mis publicaciones pedagógicas vienen de la experiencia de utilización de materiales que, a mi juicio, estaban completamente desordenados, arbitrarios y muy lejos de tener una secuencia lógica que permitiera a los alumnos saber lo que estaban aprendiendo. (EEx3, pp. 1-2)

Por otra parte, siempre hay que asegurarse de que la realización de actividades novedosas no interfiere en modo alguno en el trabajo de los contenidos curriculares y en la consecución de los objetivos recogidos en la programación. Dicho de otra forma, una nueva metodología se considera válida cuando permite alcanzar los objetivos propuestos con calidad sin perjudicar los logros que ya se estaban consiguiendo con anterioridad.

T- Lo difícil, lo de siempre, la vieja escuela crítica: "Claro, pero es que al final se hacen esas cosas y no se hacen otras". [...] La gente que estamos entre dos generaciones, que eso nos pasa a todo el mundo, tenemos que conseguir equilibrar: coger lo bueno, lo básico y la base de lo nuestro e intentar adaptarlo al futuro. Hay cosas que se van a perder, porque es que no se puede aprender todo, porque el tiempo es limitado, entonces, si haces una cosa, no puedes hacer la otra. Lo difícil es eso: intentar renunciar a las menos cosas posibles e integralas de la mejor manera. Pero, vamos, que se necesita un cambio, sí, porque el modelo, que es como se enseña y se sigue enseñando, ese ya no responde. (ETV, p. 17)

En este sentido, los tutores no han notado que haya disminuido el rendimiento de sus alumnos en ningún ámbito del Lenguaje Musical con respecto a otros años.

T- Ella está repitiendo y hasta este año no estaba contigo. Está motivada y trabajando con mucho ahínco. ¿Dónde llegue o dónde no llegue?, no lo sabemos, pero está mejorando, no noto que haya perdido nivel por hacer cosas diferentes. (ETGD, p. 7)

$\mathrm{P}$ - $\mathrm{Y}$ teniendo en cuenta el curso en el que se encuentran tus alumnos, ¿consideras que hay algún aspecto que esté poco trabajado a la altura de curso en que estamos, o en el que pienses que hay que incidir más, tanto de primero o de segundo?

T- No. Tampoco creo que primero y segundo sean más que una toma de contacto y un asentar muy bien las bases. (ETPer, p. 3) 


\subsubsection{Utilización de las TICs en la educación musical actual}

En nuestro contexto sociocultural, desde hace años resulta fundamental potenciar el uso de las nuevas tecnologías en el aula (Gértrudix \& Gértrudix, 2010). Esta es una práctica generalizada en las distintas modalidades de enseñanza (obligatoria, universitaria, formación profesional, cursos formativos, etc.), pero no es tan frecuente en los conservatorios, ya que, tal y como señala Santapau (2014), "sigue prevaleciendo la idea de que música y tecnología no van parejas y menos en el estudio de música en un conservatorio" (p. 248).

Las tecnologías han supuesto una auténtica revolución en el mundo de la música y tienen el potencial de modificar sustancialmente la educación musical pero, aunque esto es evidente en algunas parcelas de la música moderna, no lo es tanto en la música clásica.

Afortunadamente, las cosas están cambiando y, poco a poco, las TICs van teniendo mayor presencia en la educación formal impartida en los conservatorios de música.

E- Utilizamos el blog http://laclavedeblog.blogspot.com.es/ y algunas páginas web de referencia, como http://www.teoria.com/ (EEx2, p. 6)

Consciente de las posibilidades que ofrecen las nuevas tecnologías (Galera, Tejada, \& Trigo, 2013; Giráldez, 2012), la comunidad educativa colaboró en nuestro trabajo apoyando la utilización del programa informático de edición de partituras MuseScore en las clases de Lenguaje Musical.

F50- La enseñanza que estáis impartiendo nos parece muy correcta. Además, habéis sabido utilizar las nuevas tecnologías al servicio de la música y eso para mí, para nosotros, es un acierto tremendo. (EG2CFs, p. 1)

T- Ahora mismo, las nuevas tecnologías creo que son algo vital, porque son el presente y son el futuro. $\mathrm{O}$ sea, los que estamos desfasados somos las personas como yo; yo estoy desfasado en ese plano. Entonces, tenemos que montarnos al carro. [...] Hoy en día cualquier chavalillo joven te maneja mil programas de grabación y de secuenciación; es el futuro y es el presente. (ETV, p. 17)

Su utilización era muy sencilla, pero fue necesario formar adecuadamente a los alumnos y aclarar bien las dudas que les iban surgiendo hasta que se familiarizaron con él.

Tal y como estaba previsto, esta semana he subido con cada uno de mis grupos de alumnos al aula de informática y hemos hecho prácticas con el 
programa MuseScore escribiendo nuevamente, paso por paso, la canción que tuvieron que hacer en casa, para solucionar las dudas que habían surgido al respecto. Contábamos con varios ordenadores (al menos uno por cada dos alumnos) en los que, previamente, había instalado el programa y copiado las plantillas que íbamos a utilizar; además, he utilizado la pizarra digital para que pudieran ir viendo más claramente lo que había que hacer en cada momento antes de realizarlo en sus ordenadores. Tenían delante las hojas con las instrucciones y las íbamos leyendo y haciendo al mismo tiempo. Han asistido todos los alumnos y bastantes padres y creo que se han solucionado todas las dudas. (DPO, p. 8)

De esta forma, de acuerdo con Sang (2010) y Webster (2011) conseguimos que los alumnos aumentaran su motivación hacia los aprendizajes y aprovecharan las ventajas que les ofrecían las TICs.

Lo que más me gusta es que utilicemos tecnología para la música. (CA2C, pre. 4)

P- ¿Veis alguna ventaja más entre que sea en el programa de ordenador o a mano?

A59- Que salen las notas más rectas.

A54- Sí.

As- (Ríen).

P- Que se ven mejor las notas (sonríe).

A59- (Asiente).

A54- Es verdad, porque no hacemos los chupa-chuses ni los coches, ya nos los hacen ellos.

$\mathrm{P}-\mathrm{Te}$ salen las plicas bien colocadas.

As- Sí.

P- No tenéis que estar pendientes de si las hacéis rectas o no.

As- No (ríen).

A63- Y también el sonido porque, si compusiéramos a mano una canción, no podríamos oír cómo quedaría. Entonces, si quedara mal, habría que corregirla y con el ordenador sí se oye. (EG2CAsB, p. 5)

P- Y, aparte de porque os guste más hacerlo a ordenador, ¿veis alguna ventaja entre hacerlo a ordenador y hacerlo a mano?

A57- ¡Sí!

A63- Sí, porque las canciones no íbamos a mandarlas por correo llevándolas a un sitio como una carta.

A57- ¡Claro!

As- (Ríen).

A63- En el ordenador tenemos el correo electrónico y es mucho más fácil. (EG2CAsB, p. 5) 


\title{
3.5. Paciencia y perseverancia para la obtención de resultados
}

Cuando una innovación educativa está bien fundamentada y planteada desde la base, la obtención de resultados positivos es solo cuestión de tiempo, por lo que pronto sentimos la satisfacción personal de comprobar que los alumnos iban disfrutando y asimilando el nuevo sistema de trabajo.

\begin{abstract}
Después del primer mes de trabajo, donde las tutorías con los padres y el intercambio de información por e-mail fueron continuos, parece que durante el mes de noviembre las cosas han ido mejor. Ya los niños comprenden la forma de trabajo, van asimilando los conceptos y empiezan a disfrutar con lo que hacen, y ello me ha dado esperanza para continuar por este camino. (DPD, p. 6)
\end{abstract}

Poco a poco, nuestro nuevo planteamiento metodológico permitió que los alumnos adquirieran una percepción más global de la música, dotándola de un mayor significado.

T- Yo creo que el principio básico es la enseñanza del Lenguaje Musical de una forma más integral. Se trata de que los alumnos no estudien ni vivan desde el primer momento esos apartados que se supone que tenemos. No es la teoría por un lado, el dictado por otro, la entonación por otro y el ritmo por otro, porque eso, en el fondo, en la música no existe. Eso es una división pedagógica desde la que se considera que, distribuyendo todos esos apartados, se puede profundizar mejor, pero es algo que está superado por todas las corrientes pedagógicas desde hace décadas, ipero muchas! Sobrevive en sitios como en éste. Entonces, cuando rompes esa separación, pues lo que tienes que hacer es enseñar a la vez todos los elementos. Por eso me parece lógico comenzar con elementos armónicos desde el primer momento, porque es que un porcentaje muy alto de la música que tocamos y que hacemos aquí está basada en conceptos armónicos. Pero no es que empieces con contenidos teóricos muy avanzados en un nivel muy elemental, ¡no!, es que están enlazados con la escritura, con los contenidos rítmicos, con la entonación... Se trata de unirlo todo. Entonces evidentemente, unirlo todo exige un trabajo de preparación mucho mayor que separarlo todo. Ese es el problema, o sea, no es que no se pueda hacer, sino que lo queramos hacer. (ETGD, pp. 2-3)

Por tanto, con la paciencia y la perseverancia como aliadas (GarcíaRetamero, 2010), podemos afirmar que los cambios han merecido la pena y han demostrado ser positivos para el proceso de enseñanza y aprendizaje.

He estado hablando con TGD y me ha dicho que está encantado con la nueva forma de trabajo que estoy utilizando y que ve a su alumna de guitarra más motivada y dotando de mayor significado a los aprendizajes que está realizando, los cuales aplica también en la clase de instrumento. (DPN, p. 7) 
T- Te animo a que sigas trabajando con esta metodología, que yo creo que es muy novedosa pero, a la par, muy eficaz y que, vamos, está produciendo, en principio, buenos resultados. Estás consiguiendo que los alumnos que tienes aprendan música desde otro punto de vista al que nos ha tocado aprender a nosotros, o sea, experimentando desde la propia música, no primero: "Vamos a aprender primero cómo se hace la música y luego ya hacemos música", sino: "Vamos a hacer música y luego ya le ponemos nombre a eso que estamos percibiendo y escuchando". Lo veo muy acertado y te animo a que sigas con ello con tu tenacidad. Me parece estupendo, de verdad, sí. (ETO, pp. 5-6)

Esta semana he pasado a los alumnos los cuestionarios de autoevaluación y de valoración de cómo va el curso y los han estado cumplimentando en clase de forma anónima. Les he insistido mucho en que se sintieran libres y que respondieran con total sinceridad, ya que iba a mezclar todos los cuestionarios y no iba a saber quién los había escrito, y que lo que me importaba era conocer su opinión para mejorar lo que hiciera falta. Cuando he leído sus respuestas, me he llevado la grata sorpresa de que decían cosas muy positivas. ¡Están encantados! (DPF, p. 3)

\subsection{La importancia del apoyo de la comunidad educativa}

La aplicación de cualquier propuesta innovadora resulta mucho más sencilla cuando se cuenta con el apoyo del entorno en el que se aplican los cambios que, en nuestro caso, era la comunidad educativa.

Al respecto, ya hemos señalado las críticas y el cuestionamiento de la validez de nuestra metodología por parte de algunos padres $y$, principalmente, por algunos profesores del centro (apartado 3.2.1).

No obstante, a lo largo de todo el proceso también hemos sentido el apoyo continuo de:

- Los alumnos:

A4- Yo creo que eres muy original para enseñar porque, en vez de estar ahí haciendo notas todo el rato, hacemos cosas muy divertidas y entonces se nos queda mejor todo.

P- ¿Tú sientes que aprendes mejor así, haciendo cosas distintas?

A4- Sí, yo creo que sí, porque es que haciendo ahí todo el rato (imita el gesto de solfear, pero poniendo cara de aburrimiento), pues es un poco...

A7- (Ríe) ¡Vaya cara!

A4- Y así, haciendo cosas divertidas y tal, pues es más divertido y se aprende mejor (EG1CAsA, p. 7) 
- Los padres y las madres:

Estoy recibiendo por los pasillos y vía e-mail comentarios de varios padres felicitándome por el trabajo que estoy realizando con sus hijos y agradeciéndome el interés y esfuerzo que estoy poniendo, lo cual me anima a continuar. (DPD, p. 7)

Me han seguido llegando e-mails de los padres felicitándome por la actuación y diciéndome que les había sorprendido y gustado mucho la manera que tenemos de trabajar en clase, lo cual me anima mucho a seguir por este camino. (DPF, p. 2)

Estoy segura de que no es fácil tener iniciativas tan innovadoras, por eso quiero felicitarte y darte todo mi apoyo. (CE1CF2F, p. 4)

- Y distintos compañeros:

T- Sorprende, pero me parece que es lógico el camino que llevas y me pareció que es una forma de sacar el lenguaje musical desde el lenguaje común, desde el lenguaje verbal. Entonces, me pareció que es como: "Tú ya sabes hacer esto, pues de esto vamos a sacar esto otro". Me pareció muy coherente. (ETPer, p. 6)

T- Mi postura, en general, como director del centro es apoyar a cualquiera que esté dispuesto a hacer un esfuerzo extra, que esté aportando una investigación o una novedad intentando mejorar. A cualquiera que en cualquier asignatura o nivel vaya a hacer algo en este sentido, nosotros lo intentamos apoyar; eso es en principio. Y luego ya, concretamente con lo que tú haces, por mis conocimientos de pedagogía musical, yo creo que estás siguiendo una línea mucho más acertada que lo que está haciendo la mayoría de la gente. (ETGD, p. 2)

Cuando la innovación va acompañada del proceso investigador desde una perspectiva científica (Lorenzo, Herrera, \& Hernández, 2007), las dificultades se multiplican y resulta aún más valioso el apoyo de las personas implicadas.

F- Cuando uno investiga sobre sus clases, pues dice mucho de una persona. (E1CF6, p. 8)

Soy profesora en la universidad y soy consciente de las dificultades que surgen al llevar a cabo un trabajo de investigación de esta envergadura, así que quería decirte que puedes contar conmigo para lo que puedas necesitar. Es alentador comprobar que hay docentes que aún se atreven a apostar por una educación de mayor calidad. (CE1CF6S, p. 1) 
En ambas reuniones les he comentado mi interés por mejorar mi propia práctica docente para tratar de solventar las dificultades que, en estos años, he observado en mis alumnos. También he compartido con ellos mi convencimiento de que todo docente es un continuo investigador que va reconduciendo el proceso de enseñanza-aprendizaje en función de los resultados que se van obteniendo, pero que, no obstante, mis inquietudes formativas me habían llevado a plantearme un estudio más riguroso o científico conducente a la elaboración de mi tesis doctoral. [...] He invertido bastante tiempo para que conocieran mis propósitos con detalle porque, al final de la reunión, les he pedido que aquellos que no tuvieran inconveniente en que realizara dicho estudio con sus hijos cumplimentaran una autorización. [...] Todos los padres han mostrado su apoyo, lo cual me ha animado mucho. (DPS, pp. 3-4)

\section{Calidad y utilidad de los aprendizajes}

Los estudios musicales en un conservatorio no son una actividad extraescolar comparable a otras, ya sea un deporte, taller de pintura, bailes, informática o, incluso, el aprendizaje de otro idioma, ya que exigen mucha más disciplina y esfuerzo por parte de los alumnos. Esto es debido a que, además de suponerles una carga lectiva importante (4 horas semanales en los primeros cursos, las cuales van aumentando al ascender a cursos superiores), exigen un estudio continuado en casa para poder aprovecharlos adecuadamente.

Ha sido un trimestre muy intenso, porque este año tengo a muchos alumnos nuevos y a algunos les costaba coger el ritmo de trabajo, entender la forma de abordar los estudios musicales y cambiar el "chip" de que aprender música no consiste solo en cantar, bailar y pasarlo bien, sino que exige mucho esfuerzo, organización y trabajo. Es muy bonito, pero también duro, por eso insistí a los padres en la primera reunión acerca de que el conservatorio no es una "actividad extraescolar más", sino que es bastante más intensa. (DPD, pp. 7-8)

Por ello, los docentes tenemos la responsabilidad de ofrecerles una enseñanza de calidad que haga que sus esfuerzos merezcan la pena, independientemente de que muestren "a priori" unas mayores o menores aptitudes musicales.

E- Muchas veces he discutido con profesores que dicen: "Yo, cuando un chico entra en el aula, ya sé si tiene condiciones o no". Y yo siempre contesto lo mismo: "Yo la bola de cristal me la dejo en casa, porque mis experiencias no son esas". Mi experiencia es que, si a chicos que empiezan muy flojos, de repente les das confianza, les das puntos de apoyo, saben lo que buscan, saben lo que se pretende, les das orientaciones, les dices: “¿Ves como así puedes?", empiezan a desarrollar aptitudes. ¿Dónde van a 
terminar? Eso ya se verá. Y, a lo mejor, te encuentras con chicos muy espontáneos en el principio y que funcionan muy bien, pero que pierden interés por lo que sea y no llegan a ninguna parte. O sea que, en mi opinión, nuestra obligación es desarrollarlos a todos en lo posible y nada más. (EEx3, pp. 47-48)

En este apartado analizaremos la calidad de los aprendizajes adquiridos a partir del trabajo desarrollado en esta tesis y la utilidad de los mismos para los alumnos.

\section{1. ¿Qué entendemos por una enseñanza de calidad?}

Hoy nadie dudaría acerca de que todos pretendemos unos resultados o productos del aprendizaje y que la calidad de estos tiene relación con la calidad de sus procesos (Pozo, 2008).

Ofrecer una enseñanza de calidad requiere sentar buenas bases desde el principio, haciendo a los alumnos conscientes de sus propios aprendizajes. Para ello, debemos proporcionarles una formación completa y no buscar un simple adiestramiento en la ejecución musical.

E- A mí me interesaba mucho la consciencia. En cada cosa que hagamos, que sepamos lo que hacemos. (EEx3, p. 12)

E- En realidad, las carreras musicales muchas veces se convierten en habilidades: "Tengo la habilidad de leer fusas en cuatro, veintisiete claves a toda velocidad..." Eso, al circo, porque eso no es música... "Y ahora he repetido hasta la saciedad esta obra y la toco muy deprisa y muy bien, aunque no tengo ni idea de todos los elementos que lleva implícito”, ¿no? Pues al circo. (EEx3, p. 69)

Y siempre contextualizando para ampliar el bagaje musical de nuestros alumnos más allá del repertorio que interpretan con su propio instrumento.

E- Vamos a descubrir, a través de sus características, la época, la forma, etc., con lo cual, vamos a ir entendiendo qué caracteriza a cada uno de los estilos, el contexto en que se escribe, el autor y el pensamiento filosófico y artístico que está rodeando toda esa producción creativa, porque es que el músico conoce muy poca música y, a veces, ni le gusta. Parece una tontería lo que te digo, pero no es tontería. Ha oído muy poca música, menos que muchos aficionados, se centra en su instrumento y en las obras que está trabajando y no ve más allá. Y yo creo que esa es una de las graves deformaciones de la formación musical. Si no conoces qué estás trabajando y no contextualizas y no lo ves en el panorama de la cultura en todos sus aspectos, creo que tienes grandes carencias. (EEx3, p. 68) 
Asimismo, debemos cuidar la motivación y cultivar en los alumnos el gusto por el trabajo bien hecho, para que se acostumbren a ser autoexigentes y a disfrutar haciendo las cosas correctamente, no a medias.

Considero muy importante que aprendan que no vale hacer las cosas a medias, por eso le estoy dedicando tanto tiempo a sentar buenas bases. (DPO, p. 9)

E- Están acostumbrados a que una calificación sea lo que a ellos les motive, en vez de tener una sensación propia de que sé que lo he hecho bien, o me podría haber salido mejor, o he fallado en esto o en lo otro, es decir, tengo mis propias herramientas de calibrar también lo que he hecho. (EEx3, pp. 51-52)

Soy muy meticulosa y quiero que se acostumbren a hacer las cosas bien y con gusto. Por eso, les insistía en que debían ser muy cuidadosos y "elegantes" al escribir, porque las partituras tenían que estar limpias, con la clave, las notas, los silencios, los puntillos, el texto y todos los símbolos bien colocados en el pentagrama, prestando atención también a que las plicas estuvieran rectas y en el lugar adecuado. (DPO, p. 4)

\subsubsection{Planificación adecuada del tiempo}

Consideramos que el tiempo del que disponemos para impartir la asignatura (dos horas semanales) es suficiente para proporcionar una enseñanza de calidad.

P- ¿Considera que el tiempo del que se dispone para impartir la asignatura es suficiente para trabajar bien todos los aspectos?

E- Dos horas semanales me parecen suficientes para desarrollar la materia de manera satisfactoria. Buscamos los mejores recursos para que el aprendizaje se desarrolle de la mejor manera posible. En este punto, es el trabajo que el alumno realice en casa el que determinará una adecuada y positiva evolución. (EEx2, p. 3)

Pero ello exige una planificación adecuada por parte del docente, presentando los contenidos de forma integrada y coordinada (Zabala, 2007) y potenciando que los alumnos adquieran un buen hábito de trabajo desde pequeños, tanto en clase como en casa.

E- Los alumnos saben qué trabajo tienen que hacer ya desde el primer curso de enseñanzas elementales y dedican un tiempo semanal a estas actividades; es un entrenamiento constante y progresivo en dificultad. Son capaces de relacionar todas las actividades con los contenidos que se pretenden interiorizar y, en definitiva, aprender. (EEx2, p. 7)

Bastante suelto, porque estudio en casa. (CA2C, pre. 9) 


\subsubsection{Adecuación de los materiales y recursos educativos}

La calidad educativa está condicionada por otros factores, como el tamaño y el mobiliario del aula, que en nuestro caso no eran los más adecuados.

P- ¿Qué opináis del aula en el que están vuestros hijos?

F62- Pues que es un poco engañosa, porque yo la creía con más fondo, siempre la dejaba aquí y veía las sillitas primeras, y me ha parecido un poco pequeña, pero muy bonita, muy colorida. (EG2CFs, p. 26)

P- ¿Qué pensáis de esta aula?

F1- Pues que es enana.

P- Qué no entramos ni nosotros ahora (ríe).

F1- Para eso que te planteaba yo al principio de hacer cosas diferentes, muchas veces la propia limitación es el espacio. Si yo quiero hacer un juego de las sillas, ¿cómo lo hago, si no cabemos? (EG1CFs, p. 26)

Las mesas son muy pequeñas y se escribe un poco mal. (CA1C, pre. 9)

Asimismo, deben seleccionarse adecuadamente los materiales didácticos que se utilizan, los cuales deben estar adaptados a los objetivos que perseguimos, presentar los contenidos con una secuenciación coherente y mantener una progresión paulatina en el aumento de las dificultades (Davini, 2010). Así lo expresaba una de las expertas:

E- Yo empecé a escribir los libros cuando vi la anarquía de los materiales. Yo recuerdo mi perplejidad, cuando empecé a dar clase, en los libros que entonces nos hacían utilizar. El director decía: "Ya sabe Vd. que tiene que utilizar estos libros" y entonces te encontrabas con que, por ejemplo, los compases de subdivisión ternaria aparecían en el segundo curso; aparecían en una lección pero, ya la primera vez que aquello aparecía, te encontrabas con ritmos como corchea con puntillo-semicorchea-corchea y, a la lección siguiente, aquello ya estaba con grupos de semicorcheas con silencios en diferentes puntos. ¿Cuál era la única solución a la mano? Pues subdividir porque, claro, el chico, de golpe, no podía asimilarlo, ni tú veías tampoco la manera de que aquello lo pudieran asimilar en aquella falta absoluta de progresión y de sentido didáctico diría yo. [...] Igualmente, estaban trabajando todo el primer curso en do mayor y, muy secundariamente, en la menor, pero sin saber lo que era eso, sin haber diferenciado mayor-menor para nada. Y, de repente, abrías el segundo curso y te encontrabas armaduras de clave, fusas en clave de fa iy es que tenías ganas de salir corriendo!..., tenías ganas de...

P- ¡Madre mía!, ¡ganas de llorar!

E- No, no de llorar. Decías: “¿Qué hago yo con esto?, ¿por dónde lo cojo?” Por otra parte, las lecciones había que repetirlas indefinidamente, con lo cual la gente se sabía, a lo mejor, de memoria la lección, pero era incapaz de leerla escrita. (EEx3, pp. 10-11) 


\subsubsection{La figura del docente como factor de calidad}

Indudablemente, el factor principal para ofrecer una enseñanza de calidad es el profesor (Luna, 2005; Robalino, 2005).

El profesor, en concreto, es fundamental para enganchar, tanto en Lenguaje Musical como en el instrumento. (EG1CFs, p. 7)

F5- Yo tengo la experiencia de profesores diferentes con métodos diferentes y resultados totalmente distintos. A mi hija mayor le ha tocado con otro profesor con el que no ha conseguido enganchar ni saber cómo afrontar la asignatura y le está amargando la vida. (EG1CFs, p. 7)

F70- A70 está muy contenta, muy contenta con todo. No sé si es que ha tenido suerte con los profesores, que también puede ser, porque, si te toca un mal profesor, a lo mejor esas expectativas que tienes se vienen abajo y no quieres seguir, pero está muy contenta (EG2CFs, p. 11)

$\mathrm{Al}$ respecto, cabe destacar que la función docente en las clases de Lenguaje Musical ha sido muy bien valorada en este estudio.

F- Yo estoy muy contenta con las clases de Lenguaje y él también. Me parece que lo haces muy bien. (E1CF24, p. 7)

F37- La pequeña ha tenido mucha suerte contigo. (EG1CFs, p. 9)

F- Vamos, que no es por hacerte la pelota ni nada, pero dije: “iJobar!, jse lo curra, pero muchísimo!" Me pareció, vamos, que me sorprendió muchísimo. (E2CF59, p. 5)

A79- Porque eres muy metódica.

P- ¿Qué significa que soy metódica?

A79- Eh... me lo ha dicho mi madre, yo no sé. ¡Ah!, espera, espera. ¡Ya lo sé! Que nos enseñas muchos procesos para llegar a una conclusión.

A45- ¿Qué?

P- ¿Tú lo sientes así, aunque te lo haya dicho tu madre?

A79- Se lo dije yo a ella, mejor dicho (ríe). (EG2CAsA, p. 32)

Es importante que el profesor utilice un lenguaje adaptado a sus alumnos, ya sean niños, adolescentes o adultos, y que explique los nuevos contenidos con claridad para que todos puedan entenderle, teniendo en cuenta sus características y su psicología.

Me siento muy bien, la profesora explica de maravilla. (CA2C, pre. 9)

A57- Que nos lo explica muy bien todo y que, si no lo entendemos, nos lo explica otra vez y las veces que no lo entendamos. 
P- ¿Tú te has ido alguna vez con alguna duda?

A57- No. (EG2CAsB, p. 20)

Un 10, porque explica muy bien las cosas y, si no las entiendes, tiene paciencia y te las vuelve a repetir. (CA2C, pre. 11)

Pero, sobre todo, es fundamental que tenga verdadera vocación docente y sepa motivar a sus alumnos, dedicándose con profesionalidad a su trabajo (Robalino, 2005).

Te queremos felicitar por la actuación del pasado miércoles, al tiempo que agradecer la dedicación y profesionalidad con la que trabajas con nuestros niños y niñas (CE1CF6F, p. 7)

Es increíble lo que has conseguido. Creo que estás haciendo un trabajo que va mucho más allá de tus obligaciones y no es fácil encontrar en estos tiempos a docentes realmente comprometidos que mantengan su profesionalidad por encima de recortes de sueldos y otros derechos. Te lo digo por mi propia experiencia. (CE2CF78F, p. 3)

Me gustaría transmitirte nuestro agradecimiento y satisfacción por tu labor y dedicación durante el curso. (CE2CF47Y, p. 4)

F- Tienes un método determinado y me parece bien. (E2CF45, p. 4)

Que la paz y la alegría de la Navidad colme tu corazón en atención a tu buen hacer en el trabajo, que como madre agradezco. (CE1CF11D, p. 4)

\subsection{Calidad de los aprendizajes adquiridos en Lenguaje Musical}

Tanto los alumnos como sus padres y sus profesores de instrumento consideran que nuestras clases de Lenguaje Musical han promovido la adquisición de aprendizajes de muy buena calidad, tal y como se deriva del análisis de los datos recogidos, como veremos a continuación.

\subsubsection{Valoración de la asignatura por parte de los alumnos}

En el caso de los alumnos, al preguntarles cómo valoran el aprendizaje realizado durante este curso, sus respuestas demuestran que lo consideran muy elevado.

P- ¿Cómo valoráis el aprendizaje que habéis hecho durante este año? Habéis prendido mucho, poco...

A63- ¡Mucho, mucho, mucho!

A57- ¡Muchísimo!

A58-Sí.

A57- ¡Y muy bien! (EG2CAsB, p. 25) 
P- Y, en general, ¿cómo valoráis el aprendizaje que habéis hecho?

A17- ¡Diez!

A20- Diez.

P- ¿Consideráis que habéis aprendido mucho, poco, regular?

A18- Diez sobre diez.

As- Mucho, mucho.

A19- ¡Muchísimo!

A20- Once.

A21- Mucho más de lo que esperaba. (EG1CAsB, p. 22)

A29- ¡Yo creo que he aprendido muchísimo! [...] Nunca había visto cosas que hemos visto aquí. (EG1CAsC, p. 23)

A8- Yo he aprendido muuucho (enfatizando). En este año he aprendido muchas cosas. (EG1CAsA, p. 17)

Se sienten bien preparados y con un gran dominio de todos los ámbitos de la asignatura (ritmo, entonación, teoría y dictado).

F- No veo que tenga grandes dificultades. Le veo como muy hábil. Ya te digo que se ponen a hablar los dos de cosas de las tareas y le veo con mucha soltura. (E2CF59, p. 8)

$\mathrm{P}$ - ¿Y hay alguna cosa que consideréis que hemos trabajado poco y que habría sido importante trabajar más?

As- (Ponen cara de pensar, pero negando con la cabeza).

$\mathrm{P}-$ ¿Esas caras qué significan?

As- ¡No, no! (sonriendo). (EG1CAsA, p. 18)

A41- Hemos trabajado todo mucho y es suficiente para saberlo bien.

A37- Para pasar a segundo.

A38- Sí, todo. (EG1CAsF, p. 22)

Además, los alumnos consideran que han aprendido mucho más en esta clase de Lenguaje Musical que en otros centros.

A33- Hemos aprendido muchas más cosas que las que aprendíamos en las academias y en el colegio. (EG1CAsC, p. 23)

A41- He aprendido más que en otras escuelas que he estado. Yo no me imaginaba que íbamos a aprender floreos, notas de paso, acordes, apoyaturas... Yo pensaba que solo íbamos a hacer notas y ritmo. (EG1CAsF, p. 4)

A74- Sí, que yo también estaba en la escuela de música y lo que no hacíamos allí era lo de hacer canciones en el ordenador e interpretarlas en clase, por ejemplo.

$\mathrm{P}-$ ¿Y alguna cosa más que hayamos hecho aquí y que no hicierais allí? 
A71- Yo también estuve en otra escuela de música y tampoco interpretábamos canciones ni aprendíamos canciones como esas de La uva o El cocherito leré, no las escribíamos.

$\mathrm{P}-$ ¡Ah, las que aprendíamos en clase y que luego escribíais dices!

A71- Sí.

P- Eso tampoco lo habíais hecho.

A71- No, casi siempre hacíamos dictados y eso.

A75- Tampoco hacíamos los refranes que nos dabas tú en una hoja.

$\mathrm{P}-$ ¿Y qué pensáis de esas actividades, de los refranes y de las canciones?

A71- Son muy divertidas.

$\mathrm{P}-i$ Te gusta hacerlas?

A71- (Asiente). (EG2CAsD, p. 3)

A63- Yo antes de venir al conservatorio iba con mis amigos a otras clases de Lenguaje Musical, pero de otra forma, mucho más fácil.

$\mathrm{P}$ - ¿Se parecían a las clases que estamos dando aquí?

A63- (Niega con la cabeza). No, era mucho más fácil y ahora es mucho mejor, y aquí se aprende más. En el otro te decían una cosa y se te olvidaba al momento y, aquí, para toda la vida se te queda. (EG2CAsB, p. 2)

Y también reconocen que han hecho actividades y han aprendido cosas que no se esperaban, lo cual les ha resultado muy motivador.

A52- Pues que yo pensaba, antes de venir aquí, que solo era como un poco de entonación y todo ritmo, que no era pues... hacer canciones y cosas así. Bueno, dictados..., alguno pensaba, pero no muchos. (EG2CAsA, p. 4)

A4- Cuando vine aquí, pues yo me alegré mucho porque empezamos a crear canciones y a hacer refranes y cosas muy divertidas, y me lo paso muy bien. (EG1CAsA, p. 4)

A37- ¡Yo no me imaginé que era esto!, ¡me imaginé que era mucho más aburrido! Me he sentido muy bien.

P- ¿Quieres decir que te lo has pasado mejor de lo que esperabas antes de apuntarte?

A37- ¡Sí!

$\mathrm{P}-i \mathrm{Y}$ por qué crees que te lo has pasado mejor?

A37- Porque he aprendido cosas que no aprenden otros niños, que son diferentes, y lo que es diferente me gusta.

$\mathrm{P}-$ ¿Y qué crees que es diferente y que no han aprendido otros niños?

A37- El floreo, las apoyaturas, las notas de paso, las cosas del libro de teoría sobre la célula...

P- ¿Tú has hablado con otros niños para saber que eso no lo han dado? ¿o por qué crees que no lo han dado?

A37- Porque he estado hablando con mi hermana y dice que eso es superraro, que ella no lo ha dado y que dice que eso en la música no entra. Y digo: "Que no, que es una parte de la música que tú tendrás que dar, por muy pequeña que seas, o muy mayor que seas". 
$\mathrm{P}-\succsim$ Tu hermana ha estudiado en el conservatorio?

A37- (Asiente).

P- ¿Qué curso hace?

A37- Tercero.

P- Tercero de elemental.

A37- (Asiente). (EG1CAsF, pp. 7-8)

\subsubsection{Perspectiva de las familias sobre el Lenguaje Musical}

Los padres han valorado muy positivamente los aprendizajes adquiridos por sus hijos, considerándolos de muy buena calidad.

F62- A mí me ha sorprendido, porque me parece que el conservatorio funciona muy bien, me parece que la formación es estupenda. (EG2CFs, p. 8)

P- De una forma global, ¿cómo valoráis el aprendizaje que han realizado vuestros hijos en esta asignatura?

F62- A mí, desde el desconocimiento de la música, me parece increíble la evolución que han tenido contigo, ¡increíble! (EG2CFs, p. 25)

F- En general, todo perfecto, muy contentos y, bueno, teníamos el miedo ese de: "A lo mejor no le gusta, a lo mejor...", ¿sabes?, pero de momento todo va viento en popa, todo perfecto. (E1CF19, p. 2)

F-Yo no me pensaba que iba a ser capaz de hacerlo tan rápido y que se le iba a educar el oído tan rápido, ¡es que no se le escapan las notas! A lo mejor dice: "No, no, esta es la nota, pero no mide lo mismo que tiene que medir", y eso me impresiona. Me parece que lo coge muy rápido. Y hay matices que, quizá, a mí me pasan desapercibidos y ella los percibe. (E1CF2, p. 2)

Y les ha sorprendido la rapidez con la que iban avanzando, ya que, una vez sentadas las bases, los progresos eran muy grandes.

F- Yo este año he notado que, en muy poco tiempo, me parece que ha pegado un salto enorme. (E1CF2, p. 1)

F25- A mí lo que más me llama la atención es ver en tan poco tiempo, en tan pocos meses, cómo progresan de rápido. [...] La verdad, en poco tiempo, es muy lucido, es muy agradable ver cómo progresan, estamos muy impactados este curso. (EG1CFs, p. 4)

F50- Yo lo que he observado ha sido que, cuando empezó el conservatorio, empezó pez y la progresión ha sido fantástica. En el mes de enero, que empezó casi en octubre, lo analicé y dije: “¡Es increíble, ha avanzado muchísimo! ¡De octubre a esta parte ha dado un paso gigante!”, y eso, 
naturalmente, ha sido gracias a vosotros, así que, por lo que respecta a nosotros, ¡felicidades y gracias! (EG2CFs, p. 20)

F- Yo me sorprendo mucho con la rapidez con la que aprende y asume ciertos conocimientos. (E1CF6, p. 4)

Al igual que a los niños, a los padres les ha impactado el alto nivel adquirido en comparación con otros centros de enseñanza musical (escuelas de música, academias o conservatorios).

F50- Yo tengo una amiga que es profesora en el conservatorio de Toledo, y viendo a A50 y echando un vistazo a lo que llevaban dijo: “ NNivelazo que lleva el conservatorio de Segovia! ¡Nivelazo!”, fueron sus palabras. “¡Un nivel muy, muy alto!", dice. El conservatorio Jacinto Guerrero es uno de los primeros conservatorios de España, junto con el Real de Madrid, y esta amiga lleva veintitantos años de profesora y le sorprendió el nivel alto que tenéis aquí en el conservatorio de Segovia. (EG2CFs, p. 26)

F- Sí que veo positivo, comparando con el hermano, el método que lleva ella, que si el hermano lo hubiera tenido igual, pues a lo mejor no tendría ahora los problemas que tiene. (E2CF79, p. 1)

F- Yo estoy muy contenta y ella está contentísima. Ya te digo que estoy sorprendida porque no pensaba que iban a aprender tanto. No sé, a lo mejor es por desconocimiento o porque, en los cuatro años de la escuela, a mí me pareció que iban muy despacio $\mathrm{y}$, hombre, me pensaba que aquí iban a ir más rápido, pero no tanto. (E1CF2, p. 7)

Asimismo, han reconocido la utilidad de todas las actividades planteadas y consideran que tanto el método como el ritmo de trabajo han sido adecuados.

P- Quería preguntaros si hay algunas de las actividades que hemos hecho con las que consideréis que sería mejor no continuar el próximo curso.

F14- Yo creo que no, que está todo bien. (EG1CFs, p. 20)

F- Me gusta el sistema y veo que, del principio a como está ahora, ha evolucionado bastante. (E2CF45, p. 6)

Muchas gracias por todo, Elena. Ya hemos visto las notas de A53 y estamos contentos con la evolución; esperamos comenzar el $2^{\circ}$ trimestre con este nivel de trabajo, que es el adecuado. Tan solo nos queda desearte una ;feliz Navidad! y que disfrutes de un merecido descanso. (CE2CF53D, p. 2)

Soy F47, la madre de A47. Solo quería agradecerte de corazón tu gran trabajo y desearte que pases un feliz verano y que disfrutes de estas merecidas vacaciones. Elena, iigracias por todo y hasta el curso que viene!! (CE2CF47J, p. 2) 
Incluso, les ha sorprendido que los niños fueran capaces de aprender el Lenguaje Musical sin que su estudio les resultara una carga.

F- Está aprendiendo sin que le cueste estudiar, sin que sea como..., pues eso, como siempre antes hablaban de... Yo no he estudiado música, pero el solfeo era como una cosa muy difícil, muy dura, lo que a ningún músico le gustaba, y ella no lo ve como eso. Entonces, pues si consigue aprender así, pues bien. (E2CF79, p. 4)

F- Me ha llamado la atención la forma en la que trabajas, porque le resulta fácil seguir el ritmo sin demasiado esfuerzo. O sea, no tiene que tirarse siete horas dale que te pego, sino que, con poco esfuerzo, veo que él sigue el ritmo bien. (E2CF59, p. 8)

Muchas gracias por todo lo que está aprendiendo mi hija A38 contigo y, sobre todo, por la manera que tienes de acercarle la música, ya que le está ayudando a amarla sin darse cuenta. (CE1CF38Y, p. 1)

\subsubsection{Calidad de la asignatura percibida por profesores}

Los tutores de los alumnos (profesores de los distintos instrumentos) también han considerado interesante la metodología empleada en nuestras clases de Lenguaje Musical.

T- Yo creo que esta metodología es muy positiva. Evidentemente, cuando vas a trabajar muchos más aspectos desde un nivel más elemental, a lo mejor, cuando pasen " $\mathrm{x}$ " años, no vas a llegar al mismo número de elementos de contenidos que llegas cuando todo lo das por "compartimentos estanco", pero vas a conseguir un nivel de asimilación mucho mayor. (ETGD, p. 7)

T- Me pareció muy sorprendente, primero, la puesta en escena de todo, cómo se fue hilando todo y todo era muy coherente, ¿no?, el ritmo que exponías de cómo trabajas en clase, cómo ellos van trabajando contigo y todo eso, la verdad, era muy interesante, me pareció genial y, a la par, novedoso. Y, luego, veía las caras de los alumnos, cómo estaban disfrutando implicados en el teatro que tuvisteis que hacer para presentar el trabajo y todo, y ellos como que lo tenían muy interiorizado, que estaban trabajando así, que les gustaba trabajar así, [...] en un ambiente muy distendido y, vamos, ¡que me pareció genial!, igenial! (ETO, p. 5)

T- Los alumnos, cuando me hacen comentarios acerca de la asignatura de Lenguaje Musical, es siempre para decir que están encantados con las clases, que trabajan muy a gusto en casa, que nunca han tenido problemas y que están encantados. Nunca he tenido un comentario negativo ni de padres ni de alumnos. [...]

$\mathrm{P}-$ ¿Consideras que tus alumnos han adquirido un buen hábito de estudio?

T- Pues sí. (ETPiJE, p. 2) 
Además, los profesores han valorado positivamente la calidad de los aprendizajes adquiridos por los alumnos.

T- El aprendizaje hecho desde la base es muy fundamental. Quiero decirte, con todo este "rollito", que hay muchos alumnos que en cuarto de elemental van a decidir no seguir, pero esto que han aprendido aquí, que es base de su experiencia y no de su: "Voy a clase a escuchar", porque lo han hecho ellos, esa composición siempre la van a tener ahí y estoy segura de que, cuando tengan muchos años, se acordarán de "El astronauta que toca la flauta", de "Mi padre que juega al mus" y de todas estas letras que han compuesto ellos y para ellos. (ETPer, p. 8)

T- Los resultados está claro que son positivos y que están aprendiendo muy bien, así que ya sabes que mi apoyo lo tienes. (ETPiJE, p. 4)

T- Todo lo que sea potenciar el oído es genial, y potenciar que conozcan la tensión, relajación, que conozcan las formas, que se vayan familiarizando, es interesantísimo. (ETV, p. 11)

Por otra parte, hemos comprobado que el hecho de realizar actividades novedosas no ha interferido negativamente en el rendimiento de los alumnos con respecto a otros cursos, ya que otros profesores no han detectado déficits en ningún campo del Lenguaje Musical.

P- ¿Hay algún aspecto que consideres que está poco trabajado o en el que haya que incidir más en mis clases de Lenguaje Musical?

T- No, yo no me encuentro con ningún problema específico. O sea, en general, están funcionando bien a todos los niveles. Siempre les pasa que con la lectura de notas tienes niños que son más rápidos que otros, o tienen una madurez distinta unos que otros y hay conceptos que, a lo mejor, entienden antes, pero creo que todo va bastante equilibrado. (ETPiJE, p. 2)

P- Yo creo que, en general, sí, van bastante preparados y saben lo que están haciendo en cada momento.

P- Teniendo en cuenta el nivel en el que se encuentran tus alumnos de primero y de segundo de enseñanzas elementales, ¿consideras que hay algún aspecto que esté poco trabajado o en el que deberíamos incidir más desde la clase de Lenguaje Musical?

T- En principio, yo creo que no. (ETO, pp. 2-3)

T- El nivel de los alumnos que comparto contigo, que son de primero y segundo, me parece que es suficiente como base. Es que es eso, es la base, es lo básico: tengo que aprender a escuchar, a encontrar el ritmo, a ritmar, a aprenderme las notas y a reconocerlas. Y, después, la teoría que hacéis en primero y segundo está muy basada en la lectura de las piezas que ellos tocan. Entonces me parece que para ser básico, para ser lo elemental, es el nivel que deben tener. (ETPer, p. 4) 


\subsubsection{Calificaciones obtenidas por los alumnos}

Todos estos datos se confirman, asimismo, con las calificaciones obtenidas por los alumnos a final de curso, ya que son mayoritariamente altas. Tal y como muestra la gráfica 14, en el primer curso de las enseñanzas elementales no ha habido ningún suspenso, el $29,3 \%$ ha obtenido aprobado-bien, el $31,7 \%$ notable y el $39 \%$ sobresaliente. Por su parte, en el segundo curso ha suspendido el $7,9 \%$ de los alumnos, el $21,1 \%$ ha conseguido aprobado-bien, el $50 \%$ notable y el $21,1 \%$ sobresaliente.

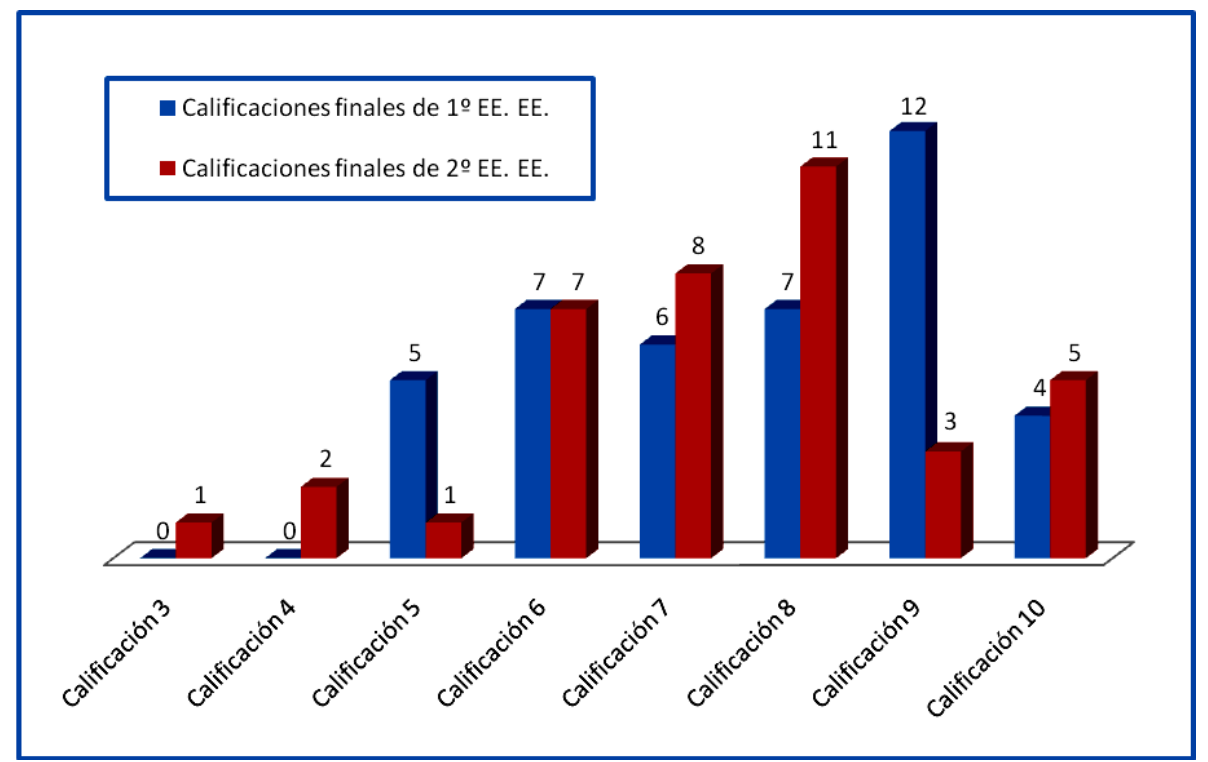

Gráfica 14. Calificaciones finales obtenidas por los alumnos en Lenguaje Musical

A continuación, las gráficas 15 y 16 muestran de forma más específica las calificaciones en los distintos apartados de Lenguaje Musical. Queremos llamar la atención fundamentalmente sobre las notas de dictado, por ser el apartado que más se ha visto influenciado por el trabajo desarrollado en esta tesis. El hecho de que no se registre ningún suspenso y de que las calificaciones sean muy altas demuestra que la metodología de trabajo que hemos presentado como alternativa al método tradicional es perfectamente válida para resolver los dictados musicales, al mismo tiempo que ha resultado muy positiva para la educación auditiva de los alumnos desde una perspectiva más amplia.

A pesar de que, tal y como aparece recogido en la programación del conservatorio donde hemos realizado el estudio, en el primer curso este 
apartado no se tiene en cuenta para calcular la nota final de la asignatura, observamos que el 17,1\% de los alumnos ha obtenido una calificación de aprobado-bien, el 19,5\% de notable y el $63,4 \%$ de sobresaliente. En el segundo curso también encontramos notas muy elevadas, ya que el 39,5\% son de aprobado-bien, el $23,7 \%$ de notable y el $36,8 \%$ de sobresaliente.

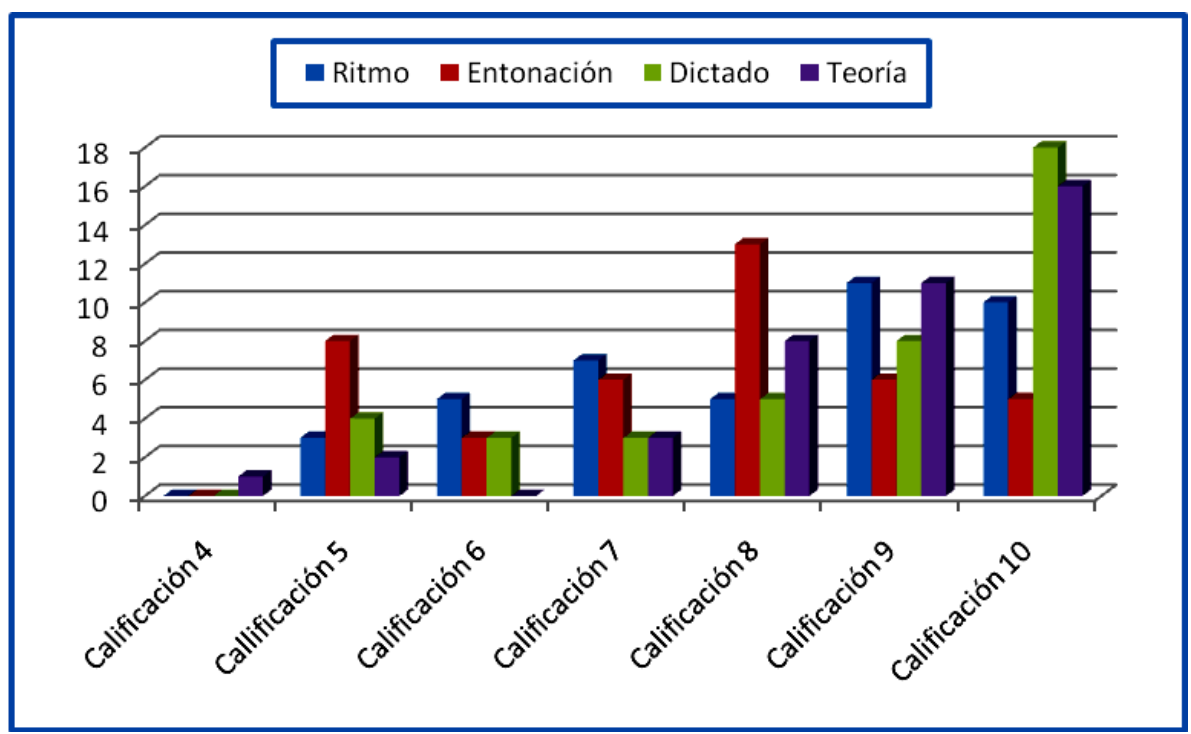

Gráfica 15. Calificaciones obtenidas por los alumnos de primero de las EE. EE. en cada uno de los apartados de Lenguaje Musical

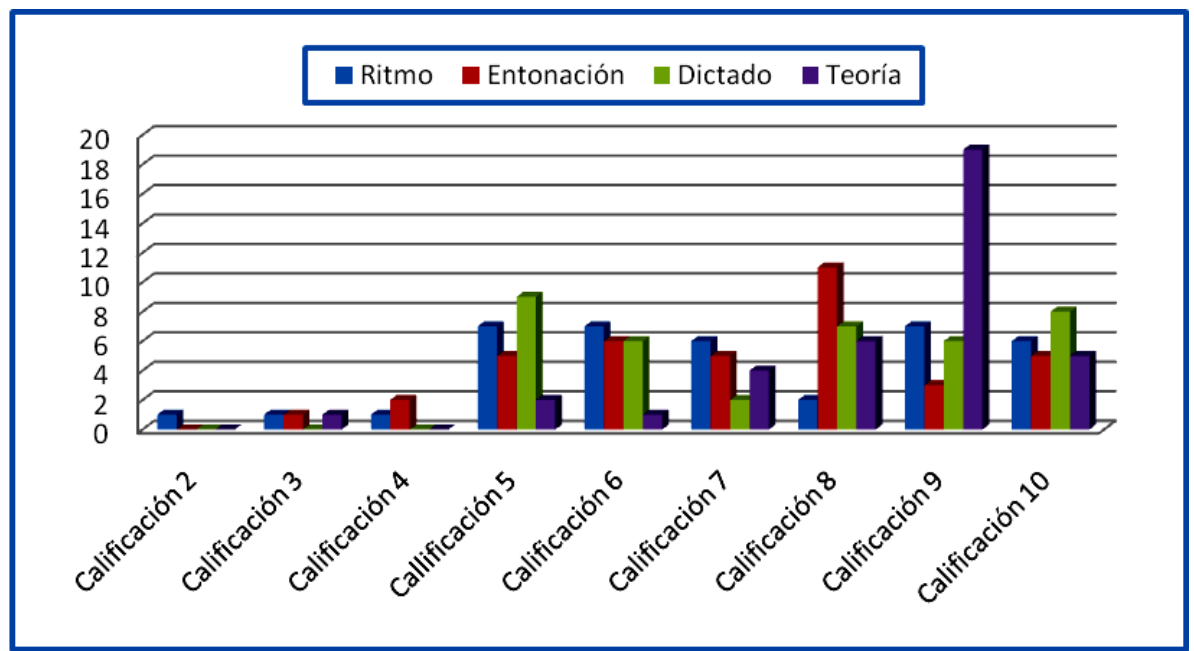

Gráfica 16. Calificaciones obtenidas por los alumnos de segundo de las EE. EE. en cada uno de los apartados de Lenguaje Musical 


\subsubsection{Calificaciones de la prueba de acceso a las enseñanzas profesionales dos años después}

Después de realizar el trabajo de campo en el aula (curso académico 201213), mientras llevábamos a cabo las fases correspondientes a la organización, análisis de los datos y elaboración del informe de la investigación, hemos continuado trabajando con nuestros alumnos en la misma línea descrita en esta tesis. Durante los dos años que hemos dedicado a dichas tareas investigadoras, los alumnos que estaban en el segundo curso han tenido tiempo de finalizar sus estudios de cuarto de las enseñanzas elementales. Llegado a este punto, es común que algunos abandonen sus estudios musicales, pero la mayoría de nuestros alumnos han decidido presentarse a la prueba de acceso a las enseñanzas profesionales.

Dada su relevancia para demostrar la validez del sistema de trabajo que hemos presentado, consideramos necesario recoger los resultados obtenidos por nuestros 32 alumnos en dicha prueba.

En la gráfica 17, podemos observar, por separado, las calificaciones de los exámenes correspondientes a la especialidad instrumental y a la asignatura de Lenguaje Musical. Hemos redondeado las puntuaciones a la unidad para facilitar su presentación, ya que todas ellas aparecían en las actas con un decimal. Así, podemos apreciar que en el examen de instrumento ha suspendido un único alumno, lo cual se corresponde con el 3,1\% del total, el $43,8 \%$ ha logrado aprobado-bien, el $28,1 \%$ notable y el $25 \%$ sobresaliente. Por su parte, en el examen de Lenguaje Musical ha suspendido también el $3,1 \%$ de los alumnos, pero las demás calificaciones son aún más altas que las alcanzadas en la parte instrumental, ya que el 6,3\% ha obtenido aprobadobien, el $56,3 \%$ notable y el $34,4 \%$ sobresaliente. 


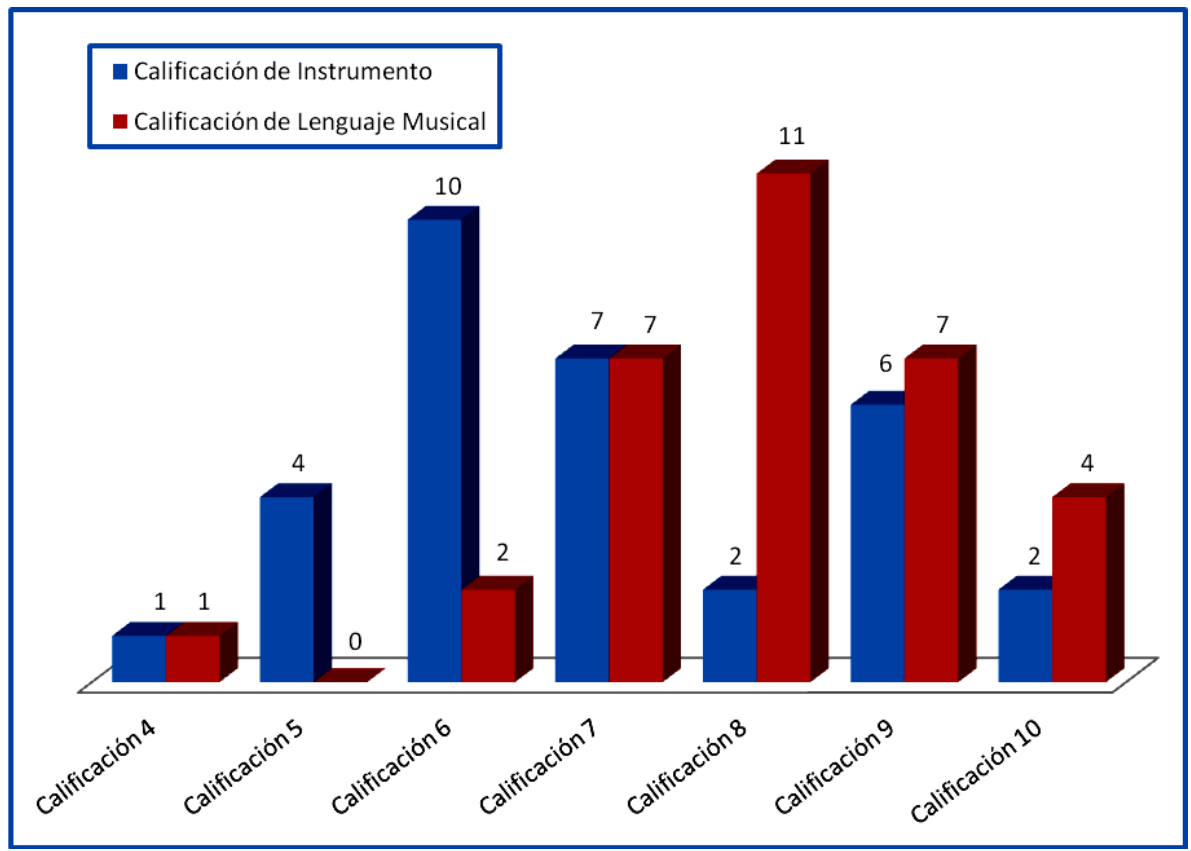

Gráfica 17. Calificaciones obtenidas por nuestros alumnos en la prueba de acceso a las enseñanzas profesionales dos años después

Consideramos que estos resultados garantizan, una vez más, la calidad de nuestras propuestas metodológicas y nos permiten intuir, asimismo, que la buena base adquirida en Lenguaje Musical ha podido repercutir favorablemente en sus calificaciones de instrumento, aunque para poder afirmar esto último necesitaríamos realizar un análisis más profundo.

Por otra parte, resulta muy gratificante comprobar que tanto los alumnos como sus padres están muy satisfechos con los resultados obtenidos, tal y como nos manifestaron personalmente muchos de ellos y pudimos constatar a través de distintos correos electrónicos recibidos tras la publicación de las notas en dichas pruebas de acceso.

Muchas gracias por todo, Elena, estamos muy contentos con los resultados. Te deseamos buen verano y, una vez más, reiterar tu gran trabajo para con nosotros, que va más allá de la simple rutina, donde pones el acento más en el "formato" que casi en el contenido de las enseñanzas. (CEA46JPA)

[...] la enseñanza es algo más que trasmitir conocimientos, hay otra parte que es tan importante como esa y es el saber entender a los chicos y empatizar con ellos. Por eso te vuelvo a dar las gracias, por saber hacer bien tu trabajo, ahí están los resultados. Creo que has demostrado sobradamente que tus métodos funcionan muuuucho más que los de otros. (CEF77JPA) 
Terminaremos este apartado recogiendo algunos fragmentos de una emotiva carta escrita a mano por la madre de uno de nuestros alumnos (la totalidad de la carta se encuentra en el anexo XVI). En ella se aprecia el valor que otorga a nuestra labor docente y la satisfacción que siente al comprobar que la constancia en el trabajo se ha visto debidamente recompensada.

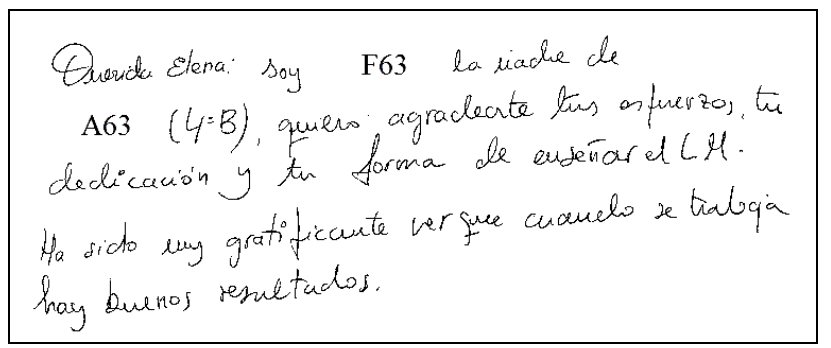

Y es que la alegría de obtener buenos resultados en una prueba determinante para poder continuar los estudios profesionales de música hace que todo esfuerzo les haya merecido la pena.

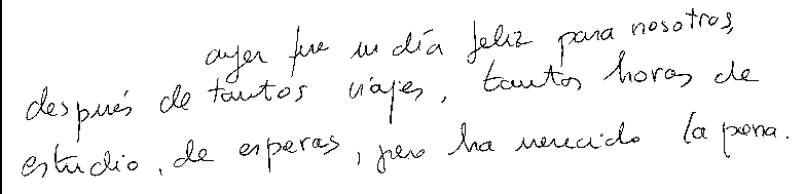

La madre recuerda que los inicios con el nuevo método no fueron fáciles, pero también reconoce que pronto empezaron a recogerse los frutos derivados del mismo.

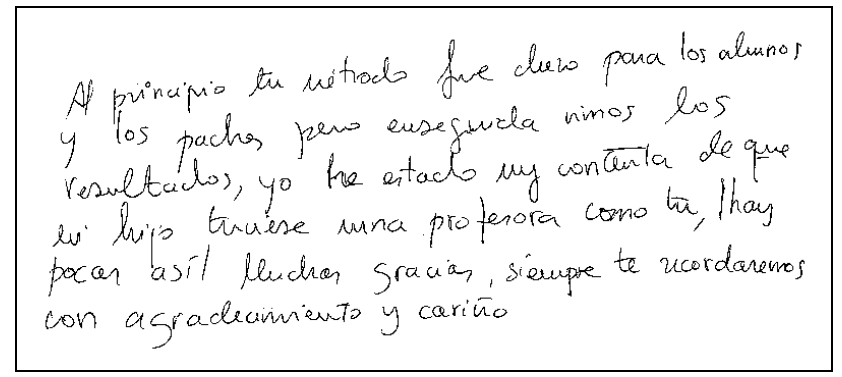


Aunque, fundamentalmente, valora que su hijo haya venido a clase contento y que haya estado motivado por aprender todos los contenidos trabajados en Lenguaje Musical.

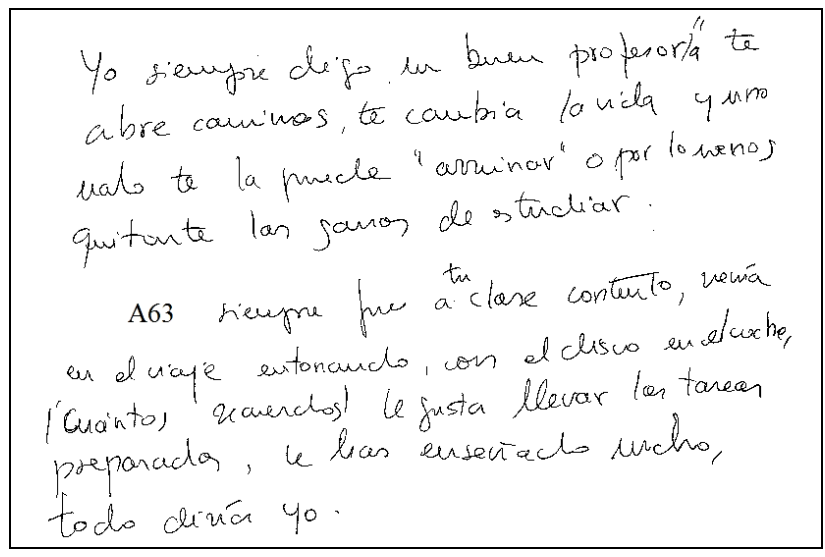

Por todo ello, se despide con mucho cariño y agradecimiento, ya que el próximo curso su hijo continuará sus estudios en otro centro.

$$
\begin{aligned}
& \text { ('hasta siempie Elena Berrín! } \\
& \text { Con unan que unclo carivis, una madre agratecida }
\end{aligned}
$$

\subsection{Utilidad de los aprendizajes para el desarrollo musical e integral}

El hecho de que la música forme parte del currículo de la enseñanza obligatoria permite que todos los alumnos accedan al conservatorio con algunos aprendizajes musicales, los cuales debemos conocer para seguir trabajando a partir de ellos.

Todo ello ha resultado muy sencillo porque los alumnos cuentan con ciertos conocimientos musicales, ya que la asignatura de música forma parte del currículo de la educación primaria. (DPS, p. 4)

No obstante, la música en la enseñanza obligatoria no pretende formar músicos, sino que persigue objetivos relacionados fundamentalmente con el desarrollo de la socialización, la creatividad, la coordinación y la 
sensibilidad (Díaz, 2004), por lo que los contenidos musicales que se trabajan son bastante escasos.

P- ¿Se parecen las clases del colegio a las que hacemos aquí?

A75- No, porque las clases del colegio son muchísimo más fáciles. Nosotros, por ejemplo, ahora estamos dando la nota la y la nota sol.

A69- Y nosotros hemos dado tres notas (ríe).

A75- Hemos dado cuatro notas solo, son muy fáciles las clases (sonríe). (EG2CAsD, p. 15)

Por su parte, los estudios de música impartidos en los conservatorios persiguen la formación de músicos profesionales (Decreto 60/2007) pero, además de proporcionar una formación musical, resultan muy útiles para el desarrollo de distintas capacidades y hábitos de los alumnos. Concretamente, al analizar los datos extraídos en este estudio, podemos afirmar que han demostrado su utilidad y eficacia para:

a). Aumentar la responsabilidad y la autonomía.

F25- Para ella ha sido muy importante el tema de la autonomía que les da el venir aquí. Yo, en el caso de A25, por su timidez, el venir aquí, el moverse ella sola, el contactar con otros niños que no conoce y en otros grupos, a mí me parece fantástico. Ella ha pegado un cambio de comportamiento y de actitud fabuloso. (EG1CFs, p. 8)

F- Es muy independiente, ella se sube a su habitación y se pone a estudiar, hace lo que tenga que hacer. Si tiene alguna duda, le pregunta al hermano, no me pregunta a mí, porque como sabe que yo de música no ando muy allá, pues tampoco se molesta en bajar a preguntarme. No se queja, ella hace lo que tiene que hacer, no hay que estar encima de ella. (E2CF79, p. 4)

$\mathrm{P}$ - ¿Le tenéis que recordar que haga tareas o es ella autónoma a la hora de decir: "Pues tengo que hacer esto", y me pongo y lo hago?

F- En general, ella sola. (E1CF19, p. 4)

b). Desarrollar la personalidad y las capacidades intelectuales.

F70- Yo creo que ha cambiado su forma de ser. Dentro de su personalidad, pues se abre, ve otra gente con otras inquietudes y, sobre todo, que la ayudan a desarrollar lo que, en el futuro, va a ser. (EG2CFs, p. 11)

F37- Pensamos que el lenguaje de la música es fundamental y que todo el mundo debería de saber expresarse a través de un instrumento porque, además, es algo que une muchas cosas: la parte artesana manual con la parte cerebral y, bueno, pues que te enseña o te ayuda a resolver problemas, te ayuda a pensar mejor. (EG1CFs, pp. 1-2) 
c). Organizar mejor el tiempo.

F14- El fomento de la música yo creo que es muy importante y que les ayuda en muchas áreas de su vida, y una de las áreas también muy importantes es a nivel de organización. A nivel organizativo, la amortización del tiempo que tienen es impresionante: ellos saben que cuentan con un horario determinado, y en ese horario se sientan y hacen lo que tengan que hacer. [...] Es increíble cómo se sienta y hace sus tareas y que le dé tiempo a todo: a hacer un deporte, a venir al conservatorio y a jugar, y yo creo que eso es muy importante. Yo es una de las facetas que no esperaba del conservatorio y ha sido una experiencia muy positiva ver el nivel de organización que han adquirido. (EG1CFs, pp. 3-4)

F26- Les comparo con otros niños que tienen toda la tarde libre y yo creo que no llegan a aprovechar tan bien su tiempo como ellas, aunque sí que entiendo que es un esfuerzo grande. [...] Me maravilla cómo ellas son capaces de organizarse y estructurarse y llevarlo todo, preparar los exámenes del colegio y hacer las tareas y preparar las cosas del conservatorio. Les da tiempo a todo. (EG1CFs, p. 9)

d). Aumentar la auto-exigencia y el gusto por el trabajo bien hecho.

F37- El nivel de auto-exigencia que ellos van adquiriendo es muy bueno.

F14- Eso es bueno.

F5- Y lo consiguen, y son capaces de conseguirlo.

F37- Claro. (EG1CFs, p. 18)

Perdona que te vuelva a enviar la canción 4 (no sé si bien o mal), pero A62 ha querido repetirla, se ve que le has picado en su orgullo. Ha querido hacerlo bien por sí misma. (CE2CF62E, p. 3)

e). Comprender mejor otras asignaturas del colegio.

A71- Yo, con el Lenguaje Musical, aprendí mejor las fracciones. Me fue más fácil aprenderlas porque, al poner el inicio del compás en 2/4 o 3/4, cuando en matemáticas, en tercero, nos pusieron esas fracciones, a A64 y a mí nos resultó más fácil aprenderlas, sabíamos en lo que consistían y fue más fácil para nosotros aprenderlo. (EG2CAsD, p. 15)

F50- Yo, gracias a la música, ¿sabes lo que sé?: inglés. A mí me gustaba mucho la música, pero quería saber qué decían los Rolling Stones, porque no me conformaba con cantarlas en inglés, quería saber la traducción. Yo decía: "¡Yo quiero saber lo que han dicho!" y, entonces, adquirí un vocabulario tremendo gracias a la música. (EG2CFs, p. 11)

P- ¿Lo que aprendéis aquí en clase lo utilizáis en otros lugares o en otras asignaturas?

A4- Sí, en música, en el colegio. 


\section{P- ¿Cómo?}

A4- Pues como aprendo más cosas aquí y allí son más fáciles, me lo sé mejor.

A7- Pues yo sí, lo utilizo en música y lo de las notas y eso. Mis amigas, como saben que vengo al conservatorio, me dicen que les chive las notas porque no se las saben (ríe). (EG1CAsA, p. 17)

f). Aplicar los aprendizajes adquiridos en Lenguaje Musical en otras asignaturas del conservatorio.

F- Es que ahora, ya te digo, te coge cualquier partitura y te la lee, no tiene ningún problema en la clase de instrumento, pero ninguno. Le entrega las partituras su profesor de violín y lo primero que hace es solfearla y ver cómo tiene que ir la canción, iy no ha oído la canción nunca! Y, a veces, las partituras son incluso más complicadas que lo que dais en clase, y le da igual. O sea que veo, no solo que lo hayan aprendido, sino que lo tienen asimilado y que lo trasladan a otras asignaturas, que a mí me parece eso un paso muy importante, ¿sabes?, que lo mismo que hace ella cuando compone una canción contigo, luego lo traslada cuando tiene que componer una canción para violín. O lo que está haciendo en clase cuando le pones la partitura de la canción, luego ella, cuando le viene una partitura nueva, sigue la misma metodología. Entonces, me parece que, además, ella se da cuenta de que no solo la clase de Lenguaje Musical es aprender por aprender, es que le ve la utilidad inmediatamente, y eso también es muy importante: que ella vea que lo que está dando ahí le está sirviendo ya. (E1CF2, p. 7)

A29- Yo no sabía que íbamos a tener Lenguaje Musical, porque pensaba que solo era tocar el instrumento y ya está, pero ya me he dado cuenta de que no se puede tocar un instrumento sin saber las notas, los ritmos y todo. Me parece bien que sí que haya. (EG1CAsC, p. 3)

A21- Sí, en colectiva.

A18- Yo aprendo más aquí.

P- ¿En clase de colectiva, dices? (dirigiéndose a la alumna 21).

A21- O en piano también, cuando es la hora de leer las notas, pues te lo enseñan aquí y luego te sirve para tocar canciones en otros sitios.

A18- Lo mismo digo.

A21- Y si tú quisieras sacar una canción, pues también te sirve.

P- ¿Tú lo has hecho alguna vez, intentar sacar alguna canción?

A21- Sí. En colectiva me han mandado sacar la de Cumpleaños feliz, la de Navidad... y me han salido bien. (EG1CAsB, p. 23)

P- ¿Lo que aprendéis aquí lo utilizáis en otras asignaturas o en otros contextos?

A65- Sí.

P- Dinos algo. 
A65- Pues en piano, por ejemplo, o cada uno en su instrumento. Yo, a veces, aplico la clave de fa que aprendemos en clase o las tonalidades. (EG2CAsD, p. 15)

g). Mejorar la socialización con alumnos de su edad o de edades diferentes.

Me siento a gusto y rodeada de amigos. (CA1C, pre. 9)

F5- Y todos juntos de diferentes clases, de diferentes edades, ¡haciendo cosas tan contentos!

F25- ¡Muy divertido! (EG1CFs, p. 28)

P- ¿Cómo os sentís en clase?

As- Muy bien.

P- Levantamos la mano.

A4- Muy bien, como si estuviéramos en casa.

P- ¿Sí? ¿Tú estás cómoda con todos?

A4- Sí.

$\mathrm{P}-$ ¿Y por qué crees que te sientes cómoda?

A4- Porque todos me tratan bien y me siento bien. (EG1CAsA, p. 5)

h). Ocupar el tiempo de ocio y el disfrute personal.

A37- Pues cuando me aburro y ya he estudiado Lenguaje Musical, he estudiado violín y he estudiado el colegio, pues yo lo que hago es cantar las lecciones de entonación y también cantar las nuevas canciones que me he inventado.

P- Para divertirte, entiendo.

A37- Sí. (EG1CAsF, p. 22)

F26- Tocar un instrumento es una cosa extraordinaria y ya, cuando tocas en grupo, ni te cuento; la sensación esa de estar en un grupo haciendo algo es muy agradable. (EG1CFs, p. 9)

F75- Pongo música en el coche cuando voy conduciendo y suena una canción normal de Amaral iy te van sacando ellas las notas!; te van diciendo: "Si, la, do, re, do, si..." (EG2CFs, p. 20)

P- ¿Y fuera del conservatorio y del colegio utilizáis algunas de las cosas que aprendemos aquí?

A64- Yo sí.

P- ¿Dónde y para qué?

A64- Pues yo toco con la trompa y, a veces, a mi hermano le gustan las canciones que yo toco y él las intenta modificar, y yo le ayudo con las notas que tiene la canción que toco yo con la trompa.

$\mathrm{P}$ - Me cuesta un poco entenderlo. O sea, ¿tú tocas con tu instrumento y tu hermano toca esa misma canción y la cambia? 
A64- Sí, cambia algunas cosas por otras que le gustan más, o compone otras cosas que no sean de esa canción.

P- ¿Y tú crees que alguna de las cosas que hacemos aquí en Lenguaje Musical te sirve para hacer eso?

A64- Sí.

P- ¿El qué, por ejemplo?

A64- Lo de poner los tresillos, negra-corchea, el floreo, la nota de paso, las apoyaturas...

P- O sea, que tú todo eso lo utilizas después para cambiar la obra que tú ya te sabías con tu instrumento.

A64- Sí. (EG2CAsD, p. 16)

F37- En las fiestas, como decís, se bajan el teclado y son los reyes de la fiesta. Hemos hecho una felicitación de Navidad tocando ellos, hay un cumpleaños y tocan el Cumpleaños feliz (hace el gesto de tocar) y sí que lo utilizan, sí que les gusta. (EG1CFs, p. 21)

A17- La música la podemos aplicar también en las fiestas del pueblo, como hago yo.

A21- ¡La fiesta del pueblo! (ríe).

P- ¿En las fiestas de tu pueblo la utilizas?

A17- Sí, en la peña.

$\mathrm{P}-$ ¿Y qué haces?

A17- Saco la caja o el bombo, mi hermano saca la trompeta..

A13- Mi hermano también la saca, y yo el trombón. (EG1CAsB, p. 23)

F75- Ayer estuvieron en casa unos primos mayores que ella y, entonces, hablaron de una canción que está ahora de moda, de un grupo que yo jamás he oído hablar. Y, entonces, la animaron a ver si podía tocar la canción, vamos, los compases de esa música. Entonces nos metimos en Internet, nos bajamos la partitura, la imprimimos y la cría se puso a tocarla y, entonces, sus primos, que ya tienen unos veinticinco años, decían: “¡Si suena igual!” Hombre, no perfecta, ¿no?, pero como diciendo... y era la primera vez que la tocaba, ¿eh?, no la había oído, y sus primos decían: “¡Anda, anda, sí que es la canción!"

F50- ¡Qué maravilla! (EG2CFs, pp. 25-26)

\section{Coordinación docente}

Para que una institución educativa pueda obtener unos resultados óptimos es imprescindible que exista una buena coordinación entre el profesorado que desarrolla su labor profesional en la misma.

Estoy convencida de que el diálogo y la coordinación son indispensables para ofrecer una buena calidad educativa. (DPS, p. 2)

F25- Hablando de las clases de Lenguaje Musical y de instrumento, posiblemente, si una de las asignaturas te gusta mucho o en ella vas muy 
bien pero en la otra vas muy cojo o tienes muchos déficits, a lo mejor no terminas de coger el ritmo. Yo creo que tienen que ir ambas un poco sincronizadas aunque, claro, esa parte me imagino que es complicada, cada instrumento será un mundo, pero yo creo que eso es muy importante. (EG1CFs, p. 20)

No obstante, conseguir una adecuada coordinación docente es una de las mayores urgencias educativas de los conservatorios, porque no se encuentra con facilidad, como veremos a continuación.

\subsection{La tendencia al trabajo individualista en los conservatorios}

En la enseñanza de la música, Pastor (2014) destaca que los profesores "ni estamos solos ni somos el centro" (p. 329). Consideramos relevante destacar este aspecto porque, siendo la música una experiencia eminentemente socializadora, grupal y cooperativa, la formación inicial de todo el profesorado ha sido radicalmente individual, centrada en cada sujeto y competitiva. Esta experiencia induce más de lo que reconocemos a ejercer de profesores desconectados de los otros colegas, incluso de los del mismo centro.

Por este motivo, en los conservatorios hay una tendencia bastante generalizada a trabajar de forma aislada e individualista, lo cual no sucede de una manera tan acusada en otros ámbitos y niveles del sistema educativo.

En los dos años que llevo ejerciendo docencia en el conservatorio he comprobado que la dinámica de trabajo es muy distinta a la que he vivido durante los ocho años anteriores como maestra y que los profesores trabajan de manera más individualista, por lo que los intentos de coordinación interdepartamental e, incluso, dentro de un mismo departamento, son complicados. (DPS, p. 1)

T- Aquí la dificultad importante es que acometemos un trabajo individual en el que cada uno en su aula hace lo que quiere. [...] Hay gente que ni siquiera se ha planteado la importancia de que el alumno reciba una formación en la misma línea en sus diferentes asignaturas. (ETGD, pp. 3-4)

La coordinación dentro de cada departamento es bastante limitada, ya que los profesores suelen trabajar encerrados en su aula y, prácticamente, solo se ponen en común los elementos curriculares fundamentales relativos a los objetivos, contenidos y criterios de evaluación de cada curso, pero los aspectos metodológicos a veces son muy dispares, existiendo grandes diferencias entre unos y otros.

F37- Hombre, a mí, teniendo la comparativa con las dos, me gustaría que hubiera un poco más de unidad entre vosotros. 
P- ¿De profesores de Lenguaje dices?

F37- Sí. Entiendo que es muy complicado y lo digo porque he sido maestra muchos años, muchísimos, y es algo muy importante. Yo he estado en educación especial y sé lo importante que es para esas familias la unidad entre los profesores y, aún así, es muy complicado. Y en el conservatorio más aún, porque yo veo mucha disparidad y de eso no tenéis la culpa, porque cada uno tiene su método, su idiosincrasia, pero bueno... No sé, de alguna forma, esa es mi crítica, y lo veo pues..., por eso, porque a mí me da pena de la mayor en comparación con la otra.

F5- Y con la mía.

F37- Sí, me da pena, porque no disfruta igual, y a mi hija mayor le gusta porque nosotros cantamos muchísimo en casa, pero no disfruta igual.

F1- Pero no entiendo por qué no hay unidad, debería haberla.

P- Sí, hombre, tenemos una programación común.

F1- Por eso.

P- Tenemos una programación común, pero luego la manera de llevarla a cabo ya puede ser un poco diferente en función, mismamente, de la personalidad de cada uno.

F25- Bueno, un poco no, es totalmente diferente. (EG1CFs, pp. 12-13)

Esta falta de coordinación es aún más acusada cuando se trata de departamentos distintos, lo cual genera desajustes a la hora de presentar a los alumnos los diversos contenidos musicales desde diferentes asignaturas.

T- Lo único que yo veo en los alumnos es que tenemos un poco de descoordinación entre los comienzos del instrumento y los comienzos del Lenguaje: que no empezamos con las mismas figuras, no empezamos con los mismos ritmos..., o sea, no está muy interrelacionada una cosa con otra, o no está bien coordinado lo que podemos enseñar nosotros y lo que puedes enseñar tú en tu clase de Lenguaje Musical. Por ejemplo, tú trabajas con ellos al principio en corcheas y yo tengo que trabajar en redondas, para que ellos trabajen un aspecto técnico del instrumento como es el control del aire. Entonces, igual ahí hay un poco de descoordinación, pero yo creo que sería cuestión de que intentáramos trabajar conjuntamente, para que no sea que yo les enseñe una cosa que en Lenguaje Musical no han visto y viceversa. Un poco de coordinación pienso que sería necesaria, porque las metodologías se pueden cambiar y se puede llegar a consensos. (ETO, p. 3)

La deficiente coordinación interdepartamental también genera discrepancias o descompensaciones en el nivel exigido en los contenidos desde las distintas asignaturas a las que asisten los alumnos en un mismo curso.

T- Lo que sí que veo es que, en el nivel que alcanzan los alumnos, hay una cierta descompensación al comparar los conocimientos que adquieren en Lenguaje con los que ellos necesitan para tocar el instrumento. $\mathrm{O}$ sea, no veo una buena coordinación entre los contenidos de Lenguaje y lo que necesitan para el instrumento. Por ejemplo, alcanzan ciertos niveles en la lectura rítmica que no necesitan para tocar el instrumento. 
P- ¿Por ser más elevados?

T- Por ser más elevados que lo que necesitan para el instrumento y, en cambio, suelen acabar con ciertas carencias en el apartado auditivo, aunque en mi instrumento no es importante, porque no es un instrumento en el que la afinación dependa del oído, pero los profesores de violín y de algún instrumento de viento siempre están reclamando que los alumnos deben tener un mayor nivel en ese sentido. (ETGD, p. 4)

Asimismo, la falta de coordinación provoca una ansiedad innecesaria entre el profesorado, generada por la sobrecarga de responsabilidades cuando, realmente, si se siguiera una línea común de trabajo, podrían repartirse y delimitarse más fácilmente las funciones de unos y de otros.

E- El profesor de Lenguaje piensa que el tiempo del que dispone siempre es poco y le falta tiempo para esto, esto y esto, porque se ha cargado de la responsabilidad de enseñarle todo al alumno. Pero ¡no!, existe la clase de instrumento y el profesor tiene mucha responsabilidad en eso, lo que pasa es que si no la toma, pues es un problema suyo. [...] Entonces, no es cuestión de tiempo, es de ver qué contenidos haces.

P- Claro, y de qué le corresponde a cada uno, que a veces es verdad que asumimos cada vez más cosas.

E- Claro, es que es la globalidad. Lo importante es que en el departamento, o como queráis llamarle a las reuniones de grupo, se sepa muy bien: "Oye, ¿y tú qué haces?, ¿y yo qué hago?, ¿y esto de aquí? Yo le enseño esto, y tú le enseñas esto, ¿te parece?”. (EEx1, p. 8)

\subsection{Búsqueda de una mayor coordinación entre el profesorado}

Los resultados obtenidos a partir de iniciativas individuales son valiosos, pero no tienen demasiada fuerza a nivel de centro. Por ello, es importante que trasciendan a otros profesores, para poder iniciar una línea de trabajo común bajo una misma concepción educativa.

T- Tenemos que darnos cuenta de que el trabajo individual de uno siempre va a tener efectos hasta cierto punto. Entonces, el salto que debemos dar es empezar a vivir y a pensar como organización, como centro. [...]

$\mathrm{P}$ - O sea, intentar buscar un poco más de coordinación.

T- Así es como lo veo yo, sí, sí. Entonces, si tú vas encontrando " $\mathrm{x}$ " personas con las que puedas decir: " $\mathrm{A}$ Ah, pues vamos a intentar hacer esto!" en una clase colectiva o de instrumento, por ejemplo, o con coro, que es una asignatura que afecta a muchos alumnos, tendríamos la posibilidad de ir mejorando. Tú puedes tener un nivel de excelencia en tu pequeño círculo, pero, por mucho que profundices y lo hagas mejor, si te quedas ahí, no se consiguen tantos resultados como si conseguimos extenderlo.

P-Sí, que trascienda a otras asignaturas.

T-Claro. (ETGD, pp. 10-11) 
Por otra parte, consideramos necesario reflexionar sobre el hecho de que, al hacer música, somos interdependientes y que esta interdependencia convierte la experiencia musical en una gran metáfora para la vida y para trabajar en un centro. El trabajo cooperativo puede ser una pieza clave para el desarrollo profesional docente, ya que compartimos con Pastor (2014) que "la autarquía docente no es una afección crónica, es curable" (p. 329). El trabajo en equipo es una inteligente vacuna que nos inmuniza del virus del aislamiento, de la rutina y del cansancio profesional.

En este sentido, la experiencia también nos demuestra que, cuando hay un interés común por mejorar algún aspecto, poco a poco se consigue llegar a acuerdos, lo cual nos debe invitar a reflexionar sobre qué ámbitos precisan de una mayor atención educativa para poder tratarlos de la forma más coordinada posible, aunando las distintas propuestas del profesorado.

En la reunión de departamento me he alegrado mucho, ya que me da la sensación de que están empezando a cambiar las cosas y que cada vez somos más conscientes de la necesidad de que exista una mayor coordinación entre nosotros. En la segunda evaluación, dos compañeros hicieron un examen conjunto a todos los alumnos de cuarto para que se fueran preparando para la prueba de acceso a las enseñanzas profesionales y los resultados fueron bastante diferentes en función de qué lección le tocara interpretar a cada alumno. Ello ha dado pie a reflexionar sobre la importancia de que acordemos con más precisión las pautas para elaborar las lecciones de ritmo y de entonación de las distintas pruebas de acceso, porque, a pesar de que en todas había los mismos contenidos, la manera de presentarlos cambiaba bastante de unas lecciones a otras, lo cual determinaba la mayor o menor dificultad. Donde más disparidad se encontraba era en las lecciones de entonación, porque en la programación tenemos fijadas las tonalidades que se pueden utilizar, pero no hemos especificado claramente a dónde se pueden hacer las distintas flexiones armónicas en cada curso, por lo que hemos visto necesario reflejarlo por escrito. La reunión ha sido muy provechosa y hemos acordado, por ejemplo, que en la prueba de acceso de tercero de elemental solo se pueden hacer flexiones a la dominante o al cuarto grado, que en la de cuarto se puede ir también al sexto, y así sucesivamente, de tal manera que en las enseñanzas elementales vayamos siempre a tonalidades cercanas y no compliquemos las lecciones en exceso. También hemos visto necesario concretar más los criterios de calificación de los exámenes de teoría, estableciendo el valor asignado a cada pregunta para que no haya dudas al corregirlos. (DPA, pp. 1-2)

\subsubsection{Dificultades para trabajar de forma coordinada}

El problema de la falta de coordinación en los centros se agrava cuando hay profesores que no la consideran necesaria. 
La compañera trataba de convencerme de que aquí se tiene mucha más flexibilidad para todo y que basta con que cada uno sepa lo que hace en su aula, pero que no hace falta que sepamos cómo se trabaja en la clase de al lado, a pesar de que estemos formando a los mismos alumnos. “QQué más da que dos profesores que dan clase a un mismo alumno le expliquen un contenido teórico, como las tonalidades o los intervalos, de maneras diferentes?, ¡así su aprendizaje será más rico!", me respondió. Comentario que yo no comparto porque, cuando un niño está aprendiendo (y más a estas edades), necesita que se le expliquen las cosas de una manera clara e insistir, a priori, en un mismo procedimiento para que lo afiance bien. Esto demuestra que la coordinación docente es deficitaria, pero, si no cambia la actitud del profesorado, será difícil mejorarla. (DPO, p. 7)

Pero también es cierto que, al margen de intentarlo y de tener una programación común, a veces es difícil coordinarse porque, dependiendo de nuestra concepción educativa, los profesores ponemos el énfasis en aspectos diferentes, en función de los cuales organizamos nuestra metodología.

F37- Es que yo creo que es verdad, que claro que hay una unidad y debe de haberla, porque es una enseñanza reglada, pero, ¿qué objetivo quiere conseguir cada profesor?, ¿eso está claro? O sea, yo veo que hay objetivos distintos. Esa es mi crítica hacia el centro, que yo desde casa no percibo que los objetivos sean los mismos, los que se persiguen con unos profesores que con otros.

F1- Yo es que es algo que juraría que no está publicado.

P- Sí, en Internet está la programación publicada.

F37- Sí, sí, sí, sí.

P- Está publicada la programación de todas las asignaturas.

F1- ¡Ah!, ¿sí?

F29- Pero los objetivos de la programación son comunes también, ¿no?

P- Claro: objetivos, contenidos, criterios de evaluación... son comunes.

F37- Pero el papel lo aguanta todo. Al final, lo que yo creo que vale es lo que traen a casa ellos.

F29- Yo creo que cada profesor quiere conseguir cosas diferentes, al margen de lo que esté programado.

F37- Yo creo que algunos, por mi experiencia, es que no quieren conseguir nada, quieren que haga el do, mi, fa, sol y ¡chin pun! (EG1CFs, pp. 13-14)

T- La verdad es que en el centro cada profesor tiene una metodología muy diferente y nosotros, como profesores de instrumento, tenemos acceso a su programación, pero nunca a su metodología. [...] Entonces, sí que es verdad que yo noto diferencia entre los alumnos que van con un profesor o con otro, sin conocer el profesor. (ETPer, p.1) 


\subsubsection{El profesorado de los conservatorios también puede coordinarse}

Un único profesor no puede acceder a saberlo todo, por eso necesitamos complementarnos interactuando. Además, la cooperación activa eleva exponencialmente la capacidad de un grupo para lograr metas profesionales ambiciosas (Torrado, 2011). Al respecto, consideramos que la interacción profesional constituye una vía de innovación educativa eficaz e insustituible para intercambiar información y experiencias, para coordinar las materias y, sobre todo, para emprender proyectos prácticos de mejoras concretas.

Afortunadamente, y a pesar de lo comentado en el apartado anterior, también encontramos en los conservatorios a docentes comprometidos con su función tutorial, que muestran mucho interés y preguntan a los compañeros y a sus propios alumnos sobre lo que hacen en el resto de las asignaturas para poder ayudarles cuando tienen dificultades.

T- Y, por lo menos con los alumnos de elemental, yo también soy muy pesada con: “¿Habéis hecho los deberes?, ¿tenéis los dictados?, ¿hay algo que no entendáis?, ¿queréis que hagamos algo?"

P- Estás muy pendiente de ellos.

T- Sí. [...]

P- ¿Conocías que trabajábamos de esa manera?

T- Algo sí que conocía porque mis alumnos siempre vienen y me cuentan, y yo les pregunto mucho: “QQué hacéis? ¿Cómo van los dictados? ¿Qué nota has sacado en el dictado? ¿Cómo van las lecciones? ¿Qué has compuesto esta semana? ¿Cómo se llama?”, un poco así. (ETPer, pp. 5-6)

P- ¿Con los padres hablas de la asignatura o, simplemente, si te comentan ellos algo?

T- Hablo, pero es que los alumnos que van contigo, en general, están muy controlados. Lo bueno es que la tutoría que hacen también contigo a mí me deja muy tranquila, porque yo sé que ellos están muy enterados de cómo van en la clase de Lenguaje. Entonces, no tengo esa necesidad de estar preguntándoles constantemente, porque sé que van muy bien y sé que los padres están informados, cosa que creo que es fundamental. (ETPiJE, p. 2)

E- En algunas clases instrumentales me consta que, si el alumno presenta dificultades en algún aspecto de Lenguaje Musical, se le refuerza con alguna actividad concreta. (EEx2, p. 10)

Yo, normalmente, con los alumnos que tienen ciertas dificultades sí que estoy un poco encima e intento que refuercen las asignaturas en las que no van bien. (ETGD, p. 7)

Asimismo, cuando hay motivaciones comunes, es relativamente sencillo llegar a acuerdos coordinados entre el profesorado. 
Hemos terminado de revisar los exámenes de la asignatura para las distintas pruebas de acceso que se realizarán en junio y para los alumnos suspensos que se presenten a la convocatoria extraordinaria de septiembre. La reunión ha sido bastante fluida y nos hemos puesto de acuerdo con facilidad en los criterios a seguir y en los cambios a realizar. (DPY, p. 2)

Pero el mayor salto que debemos dar es el de conseguir una buena coordinación interdepartamental. Solo de esta forma podremos ajustarnos adecuadamente al enfoque de educar en competencias recogido en la legislación actual (Pastor, 2014). Formar musicalmente en competencias no es sino profundizar en la compleja experiencia musical que abarca la escucha activa, la realización creativa (componer e improvisar), la comprensión linguiística y estética, y la interpretación, interconectando los aprendizajes de cada materia entre sí de manera muy funcional (Levitin, 2012). De ahí el sinsentido de que cada asignatura vaya a lo suyo, sin injertarse en el tronco vertebrador del desarrollo musical integrado y global.

\subsubsection{Beneficios educativos de la coordinación docente}

Ya hemos señalado que el esfuerzo individual es valioso pero, si se da de un modo aislado, resulta insuficiente como factor de cambio sustancial de un centro. Ello justifica que sea necesario implicar al conjunto del profesorado en el compromiso por un proyecto educativo común, ya que la interacción de todos es la mejor garantía para avanzar en propuestas de mejora didáctica a medio y largo plazo (Luna, 2005).

T- Yo, en general, como hacemos todos, como no hemos establecido un contacto muy cercano con las otras asignaturas, funcionamos de forma independiente, con lo cual, si el alumno va un poco por encima o un poco por debajo de lo que debía ser, resulta más o menos irrelevante, lo cual es un problema también porque, si nosotros controláramos eso, podríamos multiplicar el efecto positivo de los contenidos de todas las asignaturas para que fueran complementarias. (ETGD, p. 6)

El hecho de que los profesores tengan un conocimiento integral de sus alumnos y estén informados de lo que hacen con otros profesores aumenta los beneficios de sus acciones educativas.

T- Hay muchos profesores que no saben que su niño canta. Yo, por ejemplo, te puedo decir de todos mis alumnos quién tiene oído absoluto, ya en primero, quién es creativo, quién no es creativo, quién es tímido, quién no es tímido..., tengo que conocer a mis alumnos. Lo que no puede ser es que haya gente que acabe grado medio, incluso muchos el grado superior, $y$ que el profesor no sepa si su alumno canta bien o canta mal, cuando para un músico creo que eso es relevante, que sepa si su alumno es un tío con 
curiosidad, lee, sabe acerca de la música, no sabe, si crea, no crea, compone, no compone, si ensaya por su cuenta... (ETV, p. 12)

E- Independientemente del Lenguaje Musical, que es donde se lleva a cabo toda la educación del oído y que es un sitio donde muchos profesores lo hacen muy bien, pienso que el profesor de instrumento también debería preocuparse por la formación auditiva de sus alumnos, pero no me consta que lo haga. Digamos que tienen tanta preocupación por la formación instrumental y técnica que les queda poco tiempo, o piensan que les queda poco, para hacer otras cosas. (EEx1, p. 31)

Igualmente, la coordinación permite a los docentes trabajar en una misma línea, realizando actividades comunes o complementarias en distintas asignaturas, y facilita a los alumnos la adquisición de aprendizajes más funcionales y significativos.

T- Una posible mejora sería que consigamos utilizar el mismo lenguaje en los mismos momentos en todos los niveles, porque si lo que ellos están estudiando en las clases de Lenguaje, que les parece un rollo, lo están aplicando en las clases de instrumento y ven el sentido que tienen, les parecerá un poco menos rollo, lo van a aprender mejor y lo van a poder comprender y ver más natural. (ETGD, p. 6)

F- También compone en violín, su profesor también les manda hacer lo que llama frases pregunta-respuesta, de cuatro compases cada una. Y ahí sí que se complica un poco más porque, como no tiene las pautas tan fijadas como en Lenguaje Musical de que "este compás se tenga que parecer a este", pues hace lo que quiere. (E1CF2, p. 6)

T- Mi metodología está muy unida a los conceptos y los contenidos que tenéis en vuestra programación y también juego mucho con la improvisación, con: "Pues tú ahora haz este ejercicio tuyo, escribe tú una lección que tenga..." Entonces, veo que la metodología está muy cercana. P- ¿A la que aplico yo o la que tenemos en la programación del departamento?

T- No, a la tuya. (ETPer, p. 5)

\subsection{Intercambio de experiencias entre distintos profesionales}

No podemos cerrar este apartado dedicado a la coordinación sin señalar la conveniencia de propiciar el intercambio de información entre distintos profesionales de la música a través de cursos, seminarios, grupos de trabajo o congresos, para poner en común materiales y experiencias que enriquezcan nuestra labor docente.

Desafortunadamente, en nuestro país no hay muchas ofertas en este sentido, a pesar de que existe una gran demanda social. 
P- ¿Y podría citar algún otro tipo de asociación o institución que organice cursos o eventos en España y que faciliten el intercambio de información entre profesionales de la música? ¿O tiene conocimiento de congresos que se organicen en nuestro país?

E- Bueno, la única organización que yo conozco en España está relacionada con una organización a nivel mundial que es el ISME. En España se llama SEM-EE, que significa algo así como Sociedad para la Enseñanza de la Música del Estado Español o algo así; es SEM-EE. Es una organización con la que yo tengo mucha relación, con la que el IEM tiene relaciones habituales porque, realmente, yo soy socio de esa asociación, igual que la directora de la asociación es socia del IEM y nos ayudamos mutuamente y organizamos cosas. Por ejemplo, el último congreso que hemos organizado CEIMUS II que, como su nombre indica, es el segundo, es un congreso importante de educación musical en el que se han reunido trescientas y pico personas en la Universidad Rey Juan Carlos de Madrid y fue un punto de encuentro de muchísima formación, muchísima gente de universidad, de institutos, de conservatorios, de escuelas de música con un gran deseo de exponer sus ideas. Fue en marzo y el anterior había sido hace cuatro años, porque es muy difícil de organizar con demasiada frecuencia, ya que lleva consigo mucha infraestructura, pero sí lo hemos hecho y ha sido un gran éxito de público y de contenido. (EEx1, p. 30) 


\section{CAPÍTULO IX: ANÁLISIS DE LOS ASPECTOS EMOCIONALES Y SOCIO-AFECTIVOS}

\section{Introducción}

Los aspectos emocionales y socio-afectivos tienen un gran peso en todos los ámbitos educativos (Gallego et al.1999; Goleman, 2002). Su trascendencia para la educación musical no constituye una excepción (Balsera \& Gallego, 2010), lo cual justifica la importancia de analizar el tratamiento que hemos hecho de los mismos desde la asignatura de Lenguaje Musical.

El capítulo se organiza en cuatro grandes apartados. En los dos primeros, analizaremos los efectos que han tenido nuestras acciones educativas sobre la motivación y la reducción de la ansiedad de los alumnos hacia los estudios musicales y, más concretamente, hacia la asignatura de Lenguaje Musical. A continuación, comprobaremos su influencia para el establecimiento de relaciones afectivas y colaborativas, especialmente entre la profesora, los alumnos y sus familias. Por último, veremos la relevancia de mostrar los trabajos de los alumnos para impulsar el proceso de enseñanza-aprendizaje y crear vínculos de unión entre los distintos miembros de la comunidad educativa.

\section{Motivación}

La motivación es el motor de todas las acciones humanas, el empuje que necesitamos para poder realizar algo. Molino (2014) define la motivación como el impulso para lograr una meta necesaria o deseada y señala que, salvo en situaciones extremas de depresión o de problemas de sociabilidad, siempre está presente, porque es inherente a la persona. 
T- Yo creo que lo más importante es dar siempre un motivo para algo: si tú das un motivo, la gente está dispuesta a sacrificar. O sea, yo estoy dispuesto a sacrificar mi tiempo, estoy dispuesto a sacrificar mi esfuerzo, si para mí tiene interés, si para mí tiene una serie de alicientes, pero tú no me puedes pedir a mí que sacrifique algo, si no me das algo que me convenza. Yo te puedo esperar dos horas, pero si luego me vas a invitar a una mariscada, ¿no?

P- (Ríe). Claro.

T- Entonces sí te espero, y con una sonrisa (ríe). (ETV, p. 9)

En este apartado, veremos la importancia que tiene en el proceso de enseñanza y aprendizaje, analizaremos los motivos que mueven a los alumnos a iniciar los estudios de conservatorio y señalaremos cómo se puede fomentar la motivación desde la asignatura de Lenguaje Musical.

\subsection{La motivación como factor imprescindible en educación}

En cualquier ámbito educativo, cuidar la motivación es fundamental para favorecer el aprendizaje (Carretero, 2009; Stipek, 1996; Paoloni, 2011). Al respecto, Gértrudix y Gértrudix (2013) señalan que "la actividad motivadora funciona como resorte para continuar aprendiendo" (p. 123).

E- Que el alumno muestre motivación en lo que hace me parece esencial para conseguir buenos resultados. (EEx2, p. 7)

E- Por supuesto, la motivación hay que cuidarla y plantearles retos de aprendizaje cuando haya algo nuevo, pero siempre dándoles las herramientas para poder resolverlos. (EEx3, p. 54)

En el campo de la educación musical, también es importante prestar atención a los aspectos motivacionales porque, aunque la música tenga un elevado componente lúdico y se asocie al entretenimiento y a la diversión, su aprendizaje es largo y costoso, demandando gran constancia y esfuerzo. Ello provoca que, si en los estudios musicales de los conservatorios no se cuida la motivación interna de los alumnos, muchos terminen abandonándolos.

E- La música es sobre todo disfrute y el que no disfruta está siendo machacado. O sea, ningún músico que tenga que estar forzado a estar tres horas estudiando sin querer, aguanta con la música. El que aguanta es porque le gusta muchísimo, pero sé que tengo que motivar porque mis alumnos necesitan un poco de aliento. (EEx1, p. 20)

Pero la motivación no ha de considerarse únicamente desde la perspectiva de los alumnos que aprenden, sino también desde el punto de vista de los docentes que enseñan, ya que un profesor motivado se implica con más dedicación y empeño en el proceso educativo (Bonetto \& Calderón, 2014; 
Bono, 2010). A continuación, analizaremos la influencia de los aspectos motivacionales desde ambas perspectivas.

\subsubsection{Motivación y aprendizaje de los alumnos}

Como hemos apuntado anteriormente, los estudios musicales impartidos en los conservatorios exigen muchos años de dedicación y de esfuerzo continuo por parte del alumnado, por lo que resulta fundamental cuidar su motivación.

Esto es una carrera de fondo, donde la resistencia solo la proporciona la motivación. (CEP1CF2A, p. 8)

E- Sin motivación, sin disfrute, no hay posibilidad de nada. Yo creo que se puede decir de cualquier campo, pero es que en la música es muy ingrato ponerte seis horas a estudiar un domingo cuando están tus amigos en el parque tomando el sol. Si no estás muy motivado, te suicidas. (EEx1, p. 21)

La motivación potencia el esfuerzo por aprender y el deseo de hacer las cosas bien (González, 2007b; Järvelä, 2001). En otras palabras, cuando un alumno disfruta con lo que está haciendo, se esfuerza por sacarlo adelante y consigue superar las dificultades que le van surgiendo.

F- Yo creo que cuando una persona tiene motivación por lo que hace no tienes que decirle nada, porque ya se esfuerza por hacerlo bien. (E1CF6, p. 2)

T- Cuando te lo pasas bien haciendo cosas, eso siempre se contagia, y eso es una motivación para luego aprender más cosas, porque lo que es innato al hombre es querer mejorar. A la larga, lo que más compensa es captar su interés y hacer que para ellos tenga sentido. (ETV, p. 9)

Lamentablemente, en nuestro campo educativo, a veces caemos en el error de pensar que la música es motivadora por sí misma y olvidamos que estamos trabajando con niños a los que debemos animar y estimular adaptándonos a su psicología.

A veces da la sensación de que el conservatorio es demasiado "profesional" y se olvida de que en él también hay niños de 8 años a los que hay que enganchar y motivar para que disfruten de la música. (CE1CF2F, p. 4)

Yo creo que el conservatorio sigue en una postura demasiado académica y creo que, cuando empiezan con los chiquininos, sobre todo en grado elemental, no se dan cuenta de que son niños. (EG1CFs, p. 6)

E- Me acuerdo cuando empezamos a trabajar mucho con el ostinato, la percusión... que había profesores que decían: "Pero ¿esto?, jesto es de 
colegio!” Y, claro, mi tesis es: el niño que va al colegio de enfrente, ¿se convierte en un adulto cuando entra en tu clase? ¿Le cambia la psicología? ¿Le cambia la edad? ¿Le cambia...? ¡Qué le cambia al pobrecito mío! ¿No es tan niño ahí como aquí? Vamos a cogerle en su terreno, ¿no? (EEx3, p. 54)

Esta circunstancia, unida a la presión que soportan los alumnos, conduce a que muchos abandonen sus estudios musicales, ya que pierden la motivación que les condujo a iniciarse en ellos.

F1- Alguna vez he venido con él a instrumento, y ¡Dios mío de mi vida! A mí, que soy profesora de música, la hora se me hace pesadísima. Yo, perdonadme, pero es que es todo técnica: "El dedo, el dedo, el dedo...", y a mí me da miedo que mi hijo, que es un entusiasta, que no hace más que tocar en casa todo lo que se le pone por delante, lo coja manía. Pero bueno, es lo que hay. [...] Se queja y yo le entiendo, porque he venido a alguna clase con él y tengo que hacer verdaderos esfuerzos para no dormirme, porque, claro, mi hijo tiene ocho años, yo lo que quiero es que se entusiasme con la música, no que la empiece a coger manía, y en eso creo que las escuelas lo suplen mejor, hay una parte lúdica que consigue enganchar muchísimo mejor a los chavales. (EG1CFs, p. 5)

Esto ocurre tanto en los cursos bajos como en los altos, siendo frecuentes los casos de alumnos que, después de muchos años de esfuerzo, dejan de disfrutar con la música, produciéndose un rechazo hacia el propio instrumento.

E- ¿Cuánta gente conocerás tú que ha dejado el piano para siempre en quinto o en sexto en grado medio?

P- Pues yo misma lo he dejado al terminar el grado medio, que lo termine por cabezonería.

E- Vale y, después de terminarlo, lo dejaste ¿no?

P- Sí, sí, cerrado.

E- O sea, si ahora vuelves al piano, ¿qué tocarías?, pues intentarías tocar aquella pieza que tocabas, no te saldrá y te la tendrás que volver a estudiar, con lo cual, el poquito disfrute que podías tener tocando, pues resulta que acabas estudiando otra vez y dices: “¡Si yo no quiero estudiar! ¡Si yo quiero disfrutar de esto!" (EEx1, pp. 20-22)

\subsubsection{Motivación e implicación docente}

Una de las mayores inquietudes que tenemos los docentes es conseguir que los alumnos aprendan divirtiéndose, ya que somos conscientes de que la motivación impulsa el aprendizaje (D’Alessio, 2013; Pintrich, 2006).

T- El principal desafío que tenemos es mantener el equilibrio entre que un alumno se divierta y que, al mismo tiempo, aprenda. (ETV, p. 15) 
E- Las bases de la enseñanza y el aprendizaje del Lenguaje Musical las podemos concretar en que cada uno de los alumnos aprenda haciendo, aprenda de forma activa a través de diversas actividades y, por encima de todo, que aprenda disfrutando. (EEx2, p. 1)

No obstante, en el proceso educativo no solo es importante cuidar la motivación del alumnado, sino que también es necesario potenciarla en los docentes para que se impliquen con mayor dedicación e interés (Bonetto y Calderón, 2014; Bono, 2010).

En este sentido, en nuestro estudio, la satisfacción e ilusión mostrada tanto por los alumnos como por sus padres han sido fundamentales para alimentar la motivación de la propia profesora-investigadora, de igual modo que la implicación y el disfrute de esta última acrecentaban la motivación de los primeros, influyéndose mutuamente.

La motivación de los alumnos me ha animado mucho y me alegra comprobar cómo nos contagiamos mutuamente las ganas por trabajar y emprender proyectos. (DPE, p. 2)

No me deis las gracias por algo que hago encantada. Trabajar con niños en algo tan bonito como es la música es una bendición, y considero que tratar de transmitir esa alegría y motivación a cada uno de ellos es una responsabilidad inherente a todo docente. De otra forma, sería imposible resistir la presión de esta bonita pero dura carrera de fondo de los estudios musicales profesionales. ¡Gracias por vuestra motivación, significa mucho para mí! (CEP1CF5Y, p. 4)

\subsection{Motivaciones para iniciar los estudios de conservatorio}

Las edades más frecuentes a las que los alumnos acceden al conservatorio son los 8 y 9 años, por lo que la mayoría de las veces son los padres quienes apuntan a sus hijos sin que ellos lo hayan pedido, porque lo estiman positivo para su formación y desarrollo personal.

F70- Todo lo que tenga que ver con potenciar la sensibilidad, como es la música, como es el dibujo o como es la pintura, me parece estupendo, porque yo creo que a los chavales, desde pequeños, les abre la mente. (EG2CFs, p. 11)

F50- Para nosotros, al menos para mi mujer y para mí, la música es una enseñanza ineludible: no entendemos la vida sin la música. (EG2CFs, p. 1)

F26- En casa hay tradición larga de estudiar en el conservatorio, por lo menos tres generaciones. Todos hemos estudiado música en algún momento, nos parece una cosa muy interesante y muy bonita y que es muy buena para el desarrollo de los niños. (EG1CFs, p. 8) 
F62- Participo un poco de lo que han dicho mis compañeros aquí. ¿Por qué matriculamos a A62?, pues porque la música nos parece una formación complementaria, fenomenal, estupenda y casi ineludible. (EG2CFs, p. 8)

F37- Pensamos que la música ayuda a muchas cosas en el desarrollo del niño, del ser humano. Tenemos tres niñas y pensamos que tener conocimientos básicos de música es fundamental en su vida. (EG1CFs, pp. 1-2)

En otras ocasiones, los padres les apuntan porque ellos mismos deseaban haber aprendido a tocar un instrumento y quieren dar esa oportunidad a sus hijos.

F29- En mi caso quizá influyera también eso que dicen de que los padres no deben proyectar sus frustraciones en los hijos (ríe). Yo no sé tocar ningún instrumento, pero me encantaría saberlo y dije: "Voy a intentarlo con el mío". (EG1CFs, p. 3)

Por su parte, los motivos que empujan a los alumnos a querer iniciar sus estudios en el conservatorio son, generalmente, que les gusta la música y que quieren aprender a tocar un instrumento.

P- Me gustaría saber por qué os apuntasteis al conservatorio.

A7- Pues porque a mí me gusta mucho cantar y mi madre, como me veía que estaba cantando todo el día, me preguntó si quería venir al conservatorio y le dije que sí. También porque me gusta mucho el piano. (EG1CAsA, p. 3)

A5- Porque a mí me gusta mucho la música y siempre he querido tocar algún instrumento. (EG1CAsA, p. 1)

A71- Me gustaba mucho la guitarra y entonces, como mi madre se dio cuenta, pues dijo que podía ir al conservatorio, y primero no sabía lo que era y me dijo mi madre lo que era y me apunté. (EG2CAsD, p. 1)

A34- Porque me interesaba aprender la música y tocar instrumentos.

$\mathrm{P}$ - Y cuando dices que te interesaba aprender música, ¿a qué te refieres?, porque hay muchas cosas de la música.

A34- Pues que me gustaría aprenderla, que me gustaría tocarla, hacerla, cantarla...

P- O sea: cantar, tocar instrumentos y hacer tu propia música, ¿es eso?

A34- (Asiente). (EG1CAsC, p. 2)

Si los alumnos tienen hermanos mayores que han empezado a estudiar en el conservatorio antes que ellos, dicha motivación hacia la música les suele venir de haberles escuchado tocar su instrumento y del deseo de imitarles. 
A64- Yo quería entrar porque mi hermano entró y a mí me apetecía tocar algún instrumento de viento como él. (EG2CAsD, p. 1)

A74- Pues que mi hermana estaba muchísimo tiempo en el conservatorio y cuando la oía tocar me gustaba mucho porque, además, aprendía mucho y muy rápido, y me gustaba el violín y me quise apuntar al conservatorio. (EG2CAsD, p. 1)

Aunque también hay algunos alumnos, generalmente más mayores, que se apuntan motivados por otros aspectos.

P- ¿Qué es lo que te interesa a ti de la música?

A44- Pues saber el origen de la música y por qué en cada pueblo y en cada ciudad tienen un determinado tipo de música, cómo se formó y esas cosas.

$\mathrm{P}-i \mathrm{Y}$ crees que eso lo puedes aprender aquí?

A44- No sé (ríe). Sí, supongo que sí, es historia de la música, ¿no? (EG2CAsA, p. 3)

Existen otros centros de educación musical, como son las academias y las escuelas de música, pero hay varios motivos por los cuales tanto los padres como los alumnos prefieren la formación ofrecida en los conservatorios:

- Por motivos económicos:

P- Si estabas ya en la academia, ¿por qué querías venir aquí?

A35- Bueno..., es que así ahorraríamos un poco más.

$\mathrm{P}-i \mathrm{Ah} !$, ¿porque es más barato el conservatorio?

A35- Sí, supuestamente. (EG1CAsF, p. 1)

F- Por ejemplo, está la escuela municipal de música. Lo que pasa es que a nosotros, por la familia que somos, esto nos sale gratis y aquello no. Entonces, yo aquí puedo traerles con la libertad de que no tengo que pagar. Si tuvieran que ir a otro sitio, no iban, o podría ir uno, pero no los ocho. Entonces, bueno, yo veo que hay cosas que tenemos que aprovechar porque es una oportunidad que tenemos, que se nos brinda. (E2CF59, p. 5)

- Para conseguir una mayor formación musical:

F50- Lamentamos que en los colegios no haya una asignatura potente de música y creemos que el único camino que hay para que una persona adquiera una formación musical es el conservatorio, porque las escuelas municipales, con todo el respeto, llegan hasta donde llegan y se paran, ¿no? En el caso de A50, que entró en segundo directamente, las escuelas musicales le quedaban pequeñas. (EG2CFs, p. 1)

- Por el interés de obtener una titulación oficial y poder dedicarse profesionalmente a la música: 
A45- Yo antes estaba en otra escuela de música y el profesor de trompeta me dijo que allí, si acababa, no iba a tener ninguna titulación y me dijo que yo tocaba bastante bien y que me viniera aquí y, entonces, le hice caso. (EG2CAsA, p. 3)

A51- Yo empecé en una escuela de música y como quería, por así decirlo, triunfar, pues entonces decidí apuntarme al conservatorio.

P- Cuando decías que querías triunfar, ¿a qué te refieres?

A51- Pues que me gustaría hacer más cosas, más importantes, porque aquí se aprende bastante más y te meten más caña y, entonces, das más el empujón y puedes aprender más.

P- Porque te gustaría, en un futuro, dedicarte profesionalmente a la música, ¿es por eso?

A51- Sí. (EG2CAsA, p. 2)

\subsection{Motivación de los alumnos hacia el Lenguaje Musical}

El Lenguaje Musical es una asignatura obligatoria del currículo de las enseñanzas musicales impartidas en los conservatorios de nuestro país que proporciona la comprensión de los elementos y reglas que forman la música.

En este apartado veremos que, en general, dicha asignatura no resulta motivadora para los alumnos, llegando incluso a ser la causa del abandono de los estudios musicales para algunos de ellos.

T- Tenemos bastantes bajas que se deben al Lenguaje Musical, eso es tradicional. Está claro que es algo que debemos, en algún momento, trabajar sobre ello. (ETGD, p. 1)

Por otra parte, en educación es frecuente escuchar que los estudiantes tienen mal rendimiento porque no están motivados. Por ello, consideramos prioritario analizar por qué los estudiantes están desmotivados y descubrir cuáles serían las herramientas útiles para recuperar su motivación hacia la asignatura de Lenguaje Musical, teniendo en cuenta sus nuevos intereses en la sociedad actual, donde los cambios son continuos y vertiginosos. Al respecto, destacamos las palabras de Bono y Huertas (2006), quienes afirman que, en la mayoría de los casos, "los estudiantes no es que no estén motivados, sino que lo están por cosas distintas de las que les proponen sus profesores" (p. 6).

Esta realidad justifica la necesidad de preguntarles directamente por sus intereses, para poder plantear una adecuada intervención educativa acorde con los mismos y obtener unos óptimos resultados en el proceso de enseñanza-aprendizaje, como veremos a continuación. 


\subsubsection{El Lenguaje Musical frente a otras asignaturas del conservatorio}

Analizando las respuestas ofrecidas en la pregunta 2: De las asignaturas que estudias en el conservatorio, ¿cuál te gusta más? de los cuestionarios de Lenguaje Musical administrados en distintos conservatorios españoles (gráfica 18), vemos que existe una clara predilección por las clases de instrumento, ya sea individual o colectiva, frente a otras asignaturas. El hecho de que las asignaturas de coro, banda y orquesta sean menos votadas puede deberse a que son asignaturas que no se imparten desde el primer curso, por lo que muchos alumnos no han tenido la opción de escogerlas. No obstante, es importante resaltar que la asignatura de Lenguaje Musical, a la que asisten todos los alumnos que han cumplimentado los cuestionarios, ha sido escogida por una minoría.

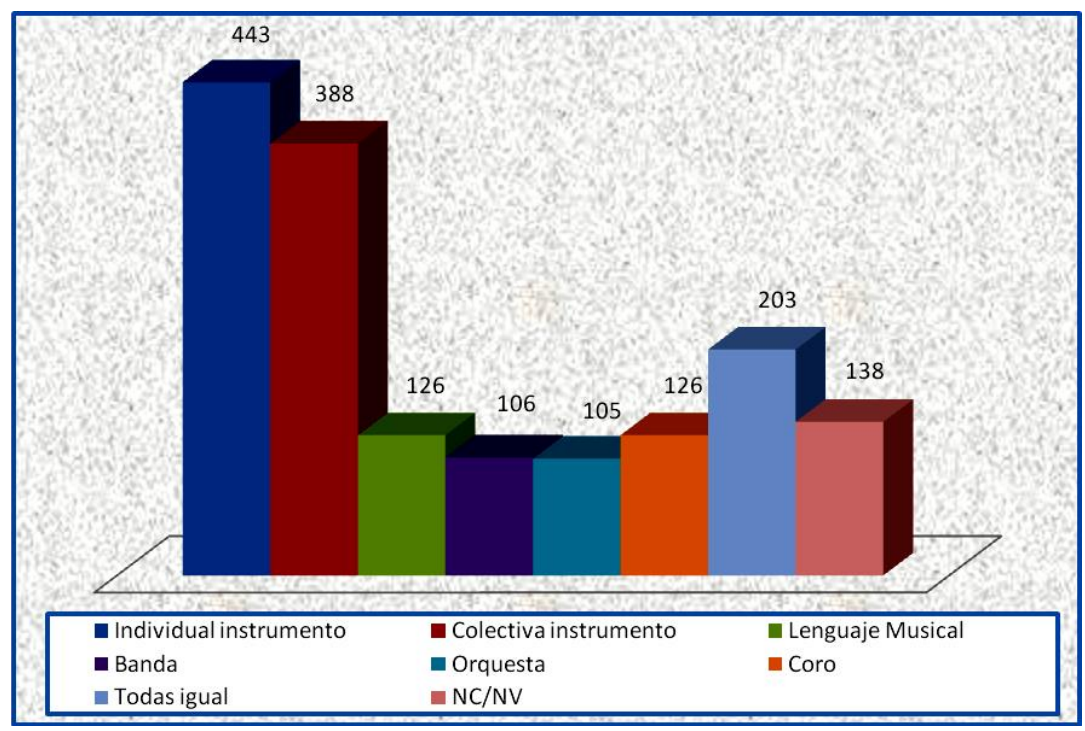

Gráfica 18. Respuestas de los alumnos a la pregunta 2 de los cuestionarios: De las asignaturas que estudias en el conservatorio, ¿cuál te gusta más?

Estas respuestas no nos han sorprendido demasiado porque, como ya hemos comentado, somos conscientes de que los alumnos se apuntan al conservatorio motivados por aprender a tocar un instrumento, pero también era necesario comprobar si, aunque el Lenguaje Musical les gustara menos, disfrutaban en clase, por lo que añadimos al cuestionario la pregunta 3: En general, ¿qué opinas de la asignatura de Lenguaje Musical? Camuflamos un poco el interés real de la pregunta añadiendo el texto de "se aprenden 
cosas importantes", para facilitar al alumnado responder con sinceridad la opción c (no me gusta demasiado) sin sentirse violentos. Los resultados de la gráfica 19 nos muestran que tan solo la mitad de los alumnos reconocen que disfrutan en la asignatura, mientras que existe también un porcentaje alto de alumnos que manifiestan que no les gusta demasiado.

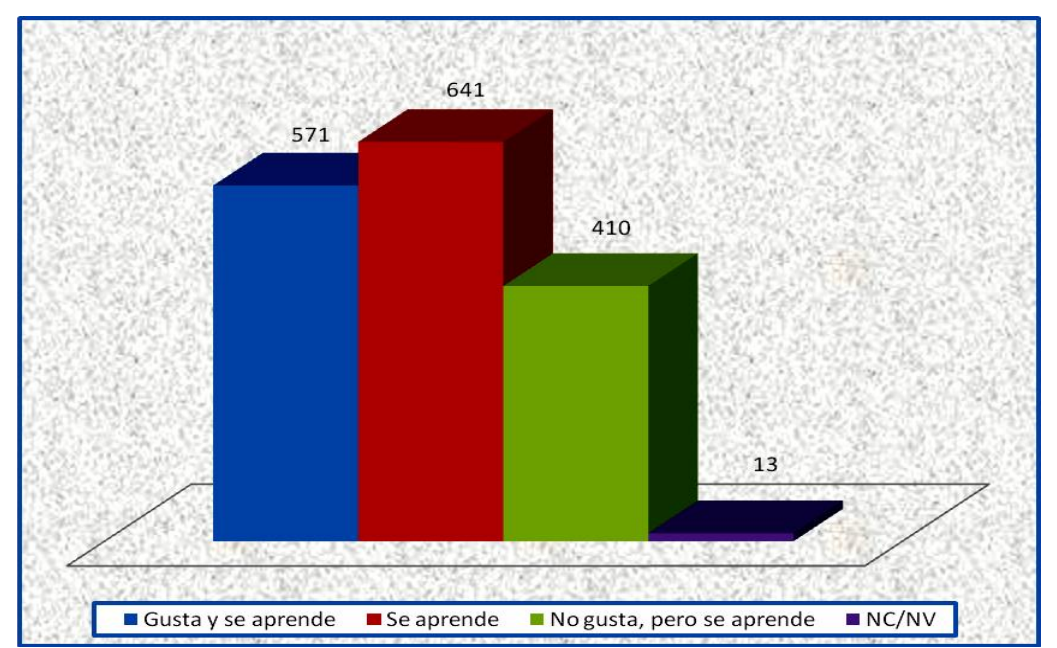

Gráfica 19. Respuestas de los alumnos a la pregunta 3 de los cuestionarios: En general, ¿qué opinas de la asignatura de Lenguaje Musical?

Estos datos coinciden con la opinión ofrecida por los alumnos, padres y profesores entrevistados y es que, en general, los alumnos no suelen ir motivados a la clase de Lenguaje Musical. Incluso antes de empezar las clases, ya imaginan que van a ser muy pesadas, porque hay un pensamiento colectivo bastante negativo hacia dicha asignatura.

T- Mi experiencia desde hace años me ha demostrado que el porcentaje de alumnos de Lenguaje Musical que no van contentos y que no la consideran una clase en la que aprenden a gusto es alto en general. (ETGD, p. 6)

F- Siempre parece que del Lenguaje Musical dices: “QQué arduo!, iqué difícil!" (E1CF2, p. 3)

T- Normalmente el Lenguaje Musical es como las Matemáticas en el colegio, ¿no?, no es que despierte pasiones. (ETV, p. 1)

P- ¿Os imaginabais así la clase de Lenguaje Musical?

As- No.

A63- A mí me gusta más ahora que como pensaba. (EG2CAsB, p. 3) 
T- Hay veces que el Lenguaje Musical, por desgracia, se toma como: "Voy porque tengo que ir, pero no me gusta". (ETPer, p. 5)

A18- Que yo me imaginaba que iba a ser más aburrida, y es muy divertida.

A16- Y que iba a ser más difícil.

P- Tú te imaginabas que iba a ser más difícil.

A16- (Asiente).

A23- ¡Muuucho más! (EG1CAsB, p. 3)

Aunque sabemos que es difícil competir con la motivación hacia la clase de instrumento, lo cual tampoco es nuestro propósito, ¿no podríamos cuidar más la motivación de nuestros alumnos hacia la asignatura de Lenguaje Musical para que también disfruten y aumenten, al menos, las respuestas de "me gustan todas por igual"? Este era uno de los objetivos que nos planteábamos en nuestro estudio y que conseguimos alcanzar con éxito, como puede comprobarse en las gráficas 20 y 21 , que recogen las respuestas ofrecidas por mis alumnos tras aplicar la metodología que hemos presentado.

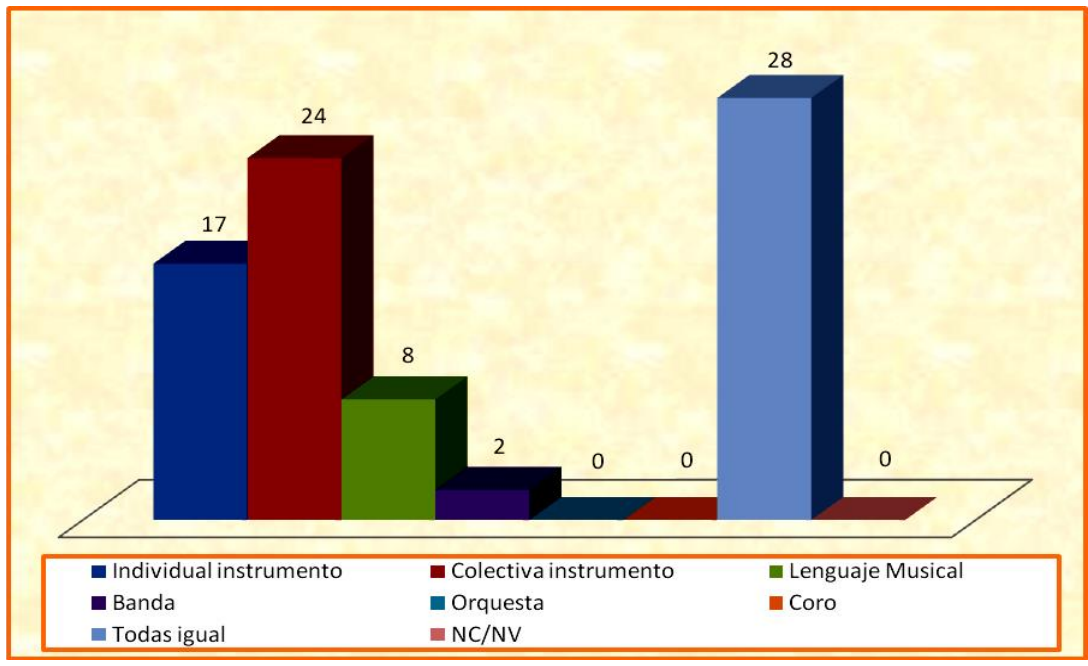

Gráfica 20. Respuestas de mis alumnos a la pregunta 2 de los cuestionarios: De las asignaturas que estudias en el conservatorio, ¿cuál te gusta más? 


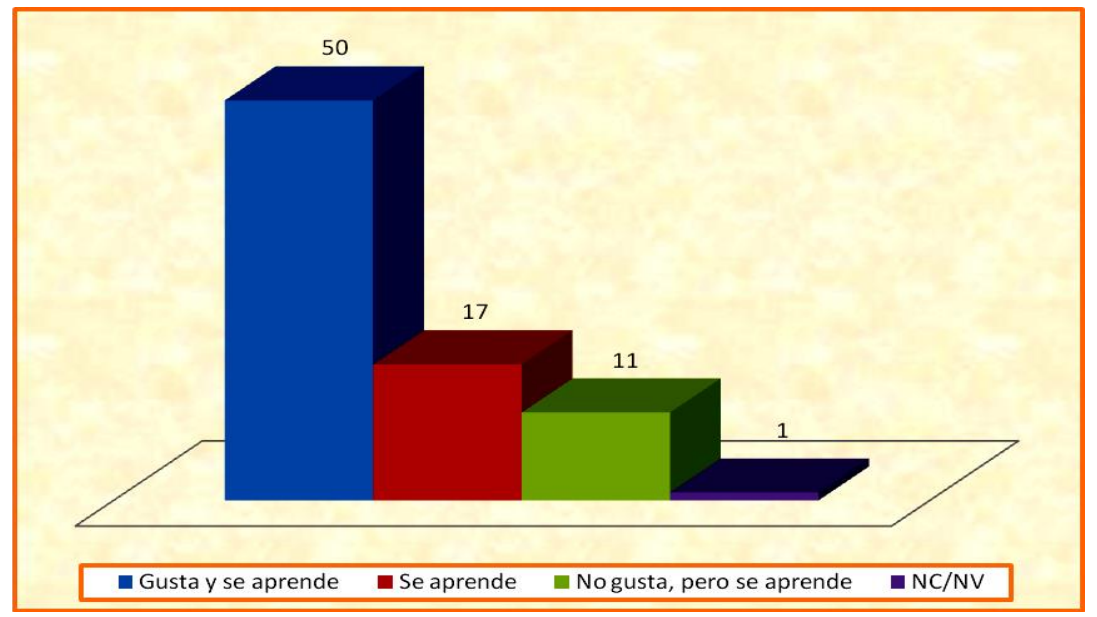

Gráfica 21. Respuestas de mis alumnos a la pregunta 3 de los cuestionarios: En general, ¿qué opinas de la asignatura de Lenguaje Musical?

La validez de estos datos queda muy ampliamente demostrada al cruzarlos con los recogidos a través de las demás técnicas e instrumentos utilizados en esta tesis (entrevistas, diario, cuestionarios de autoevaluación, correos electrónicos...), ya que todos ellos confirman que los alumnos con los que se ha llevado a cabo este estudio han estado a gusto y han disfrutado en clase. Así lo expresaban los distintos sectores de la comunidad educativa implicada:

- Los padres:

F1- El mío sale siempre encantado, ¡encantado! “Cómo te lo has pasado?” "¡Genial!"

F29- Sí. (EG1CFs, p. 25)

A A75 la veo encantada y que disfruta con la música. (EG2CFs, p. 20)

F- A2 viene feliz. De hecho, si hay alguna semana que, a lo mejor, tiene algo y le digo: "A lo mejor no podemos ir a clase", se pone a llorar (ríe). Viene muy contenta. Yo creo que le ha sorprendido, porque ya había estudiado algo de música antes y le ha sorprendido la forma en que se da aquí la clase. Bueno, de hecho, llegó a decir que va a ser profesora de Lenguaje Musical, o sea que ¡no te digo más!; está muy contenta. (E1CF2, p. 1)

Quería preguntarte si el viernes tendrán clase o si también es festivo en el conservatorio. A A43 le da mucha rabia cuando la clase de Lenguaje Musical coincide con un día de fiesta y la tiene que perder. (CE1CF43N, p. 5) 
F- Mis padres, que son más mayores y vinieron a ver la audición, luego nos comentaron que les había sorprendido lo bien que se lo tienen que pasar en clase. Si la audición es como las clases, pues no te piensas que en clase se lo vayan a pasar tan bien. Claro, así entiendes por qué vienen tan contentos, que yo nunca le he tenido que forzar a venir, ni nada, ni muchísimo menos. (E1CF2, P. 8)

F- Me he quedado muy sorprendida de que diera ese avance y de que venga tan contento, eso también lo agradezco mucho, que venga contento a clase, se divierte. (E1CF24, p. 7)

F51- Ella está muy contenta, en general, iy con Lenguaje Musical está encantada! (EG2CFs, P. 9)

F29- La asignatura de Lenguaje Musical a él le encanta, o sea que yo espero que sí continúe. (EG1CFs, p. 3)

F- Ella viene muy contenta. Yo no la tengo que obligar a nada. En casa, ella sola me pide: "Mamá, ¿me puedes encender el ordenador?, porque quiero practicar" Ella sola. No la veo obligada para nada, al revés, veo que le gusta, le encanta, me cuenta cosas... (E1CF19, p. 1)

F- La veo contenta, está motivada, está entusiasmada. (E1CF6, p. 5)

F- Todo ha sido perfecto, porque desde el primer día hemos notado que le gusta muchísimo. (E1CF19, p. 1)

F25- Ella hace lo que sea de Lenguaje Musical sin que nadie se lo diga; lo del instrumento le cuesta más, hay que insistir en que practique, pero de Lenguaje Musical está todo el día cantando ¡y más que estaría! (EG1CFs, p. 8)

- Los profesores:

T- Les gusta mucho, es decir, ellos acuden a las clases de Lenguaje Musical con motivación, con la alegría de compartir ese momento con sus compañeros y con lo que están aprendiendo y con lo que han trabajado en casa también. (ETPer, p. 1)

T- Yo creo que sí, ellos vienen muy contentos a clase. Cuando coincide que justo después de tu clase vienen a la mía, les pregunto siempre: "¿Qué tal la clase de Lenguaje Musical?" Y la respuesta es siempre: "Bien, bien, bien", como que se lo han pasado bien. Vamos, que son siempre afirmativas las respuestas. (ETO, p. 1)

T- Van contentos a clase, eso sin lugar a dudas. Están motivados, eso sí se nota. (ETV, p. 1) 
T- Yo creo que ella va bastante contenta, incluso cuando es una alumna que tiene bastantes dificultades y le lleva una carga de trabajo bastante importante intentar mantenerse al ritmo del curso. (ETGD, p. 1)

T- He preguntado a los alumnos y ellos, en general, están todos muy contentos. (ETPiJE, p. 1)

- Los alumnos:

Me lo paso genial y la clase es muy divertida. (CA2C, pre. 9)

$\mathrm{P}-$ ¿Y qué os han parecido las clases?

As- ¡Guay! ¡Muy buenas! (EG2CAsB, p. 3)

Me siento emocionado, con ganas de aprender. (CA1C, pre. 9)

A18- Que la profesora es muy buena y muy divertida, y las clases son muy divertidas y aprendemos mucho. (EG1CAsB, p. 5)

A4- ¡Que me han encantado todas las clases, que me lo he pasado muy bien y han sido muy divertidas! (EG1CAsA, p. 21)

Me siento estupendamente, es muy divertido. (CA2C, pre. 9)

Me parecen superdivertidas las clases que hacemos de Lenguaje Musical. (CA1C, pre. 1)

Me parecen geniales porque aprendemos mucho y también nos divertimos. (CA2C, pre. 1)

Me siento fenomenal. (CA1C, pre. 9)

A7- ¡Me ha encantado esta clase y este año ha sido el mejor! (con énfasis). (EG1CAsA, p. 21)

A2- ¡Que me lo he pasado genial, he estado muy contenta y he aprendido mucho! (EG1CAsA, p. 21)

- Y la propia profesora-investigadora:

Los niños han salido contentos de las clases. (DPS, p. 4)

La madre, en una tutoría anterior, me dijo: "Es la primera vez que veo a mi hijo tan interesado por las clases de Lenguaje Musical y con tantas ganas de hacer las tareas que les mandas. Además, juega con su hermana pequeña a explicarle las cosas que hacéis en clase, imitándote, lo cual para mí es muy significativo, porque le veo que disfruta y se siente cada vez más seguro". (DPD, pp. 8-9) 


\subsubsection{Motivación hacia los distintos contenidos de la asignatura}

Centrándonos de forma específica en los contenidos propios de nuestra asignatura, observamos que, en la pregunta 4: ¿Qué es lo que más te gusta del Lenguaje Musical? de los cuestionarios cumplimentados por los alumnos de varios conservatorios, el ritmo y el bloque auditivo son los aspectos más valorados, con puntuaciones muy próximas (gráfica 22), lo cual resulta lógico al encontrarnos frente a una asignatura eminentemente práctica. No obstante, al comparar estos resultados con los de la gráfica 6 de esta tesis, comprobamos que, dentro del bloque auditivo, lo que más les gusta es la entonación, ya que el dictado solo ha sido elegido aproximadamente por la cuarta parte de los alumnos. También llama la atención que exista un número relativamente elevado de alumnos que prefieren la teoría. La explicación puede ser que se sienten más seguros resolviendo ejercicios teóricos que interpretando música, pero, para comprenderlo mejor, vamos a analizar la siguiente pregunta del cuestionario.

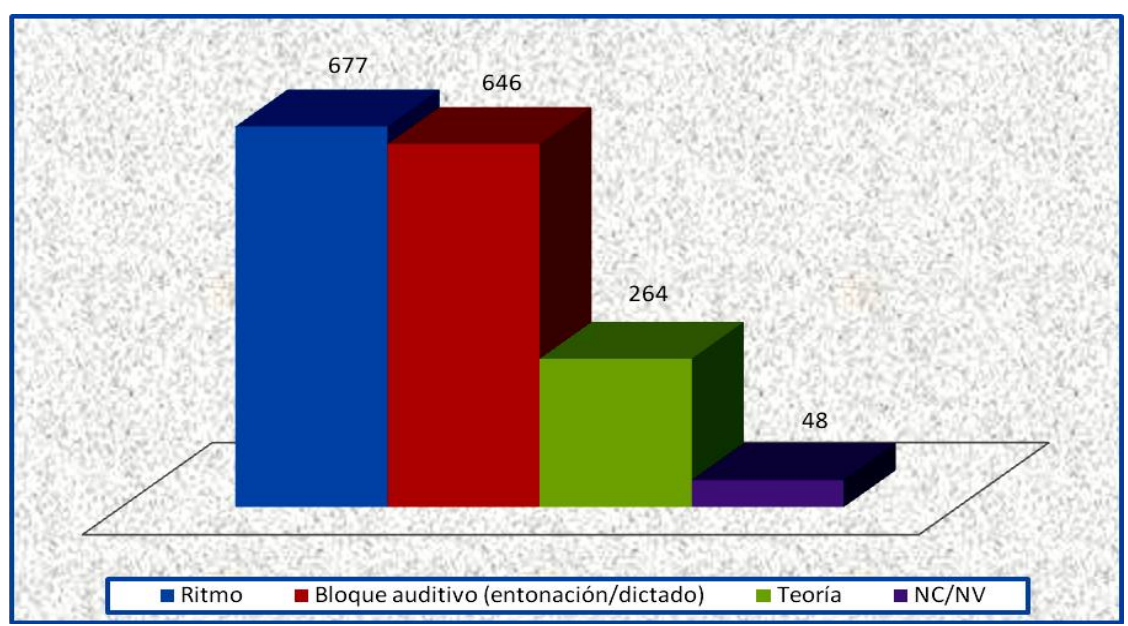

Gráfica 22. Respuestas de los alumnos a la pregunta 4 de los cuestionarios: ¿Qué es lo que más te gusta del Lenguaje Musical?

La comparación entre las respuestas de la pregunta 5: ¿Qué es lo que te resulta más fácil? (gráfica 23) y las del ítem anterior nos sugiere que lo que les resulta más fácil coincide en gran medida con lo que más les gusta o, dicho de otra manera, que el dominio de la tarea produce en muchos alumnos una mayor sensación de placer; dicho ajuste se percibe sobre todo en el apartado rítmico. No obstante, el número de alumnos que consideran que la teoría es lo más fácil es más elevado que el de los alumnos que consideran que es lo que más les gusta, mientras que ocurre a la inversa con 
los resultados en el bloque auditivo (entonación/dictado), lo cual indica que también se dan casos en los que los gustos no coinciden con su percepción de sencillez.

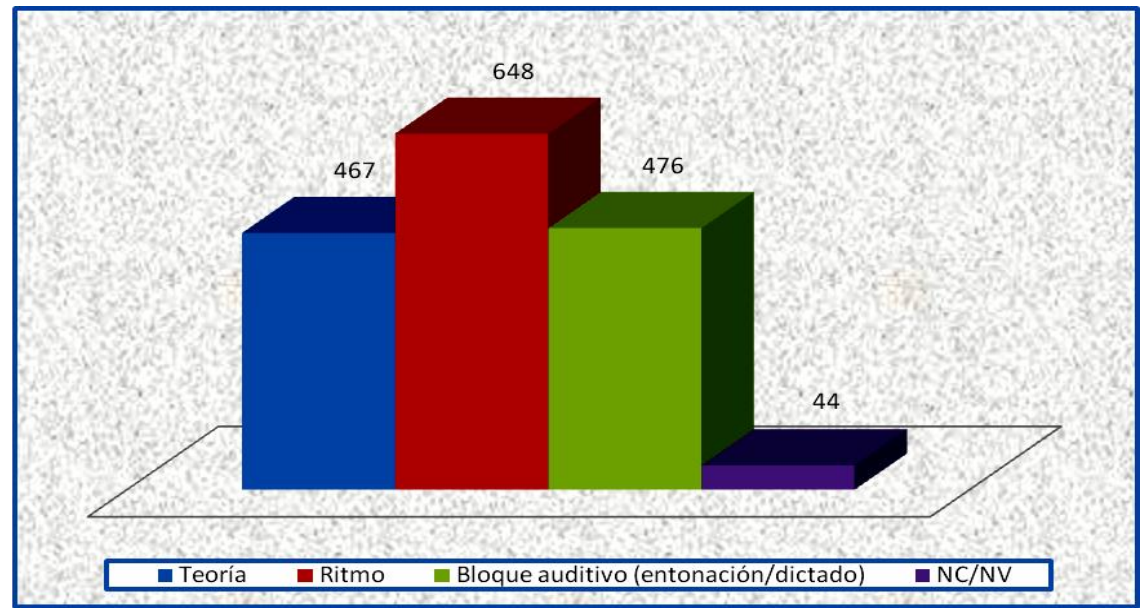

Gráfica 23. Respuestas de los alumnos a la pregunta 5 de los cuestionarios: ¿Qué es lo que te resulta más fácil?

\subsubsection{Otros aspectos motivadores de nuestras clases de Lenguaje Musical}

Dejando al margen la separación estándar de los contenidos en la asignatura, comprobamos que lo que más ha motivado a nuestros alumnos ha sido divertirse, sentirse valorados, aprender cosas nuevas, realizar actividades creativas (como la composición de canciones con el ordenador) y exponer sus trabajos ante los demás.

A19- Porque son muy chulas, aprendes cosas nuevas, te diviertes y no te aburres. (EG1CAsB, p. 5)

Componer, porque es donde practico lo aprendido y valoras mi esfuerzo. (CA1C, pre. 4)

P- ¿Hay alguna cosa más que queráis añadir?

A63- ¿El año que viene vamos a hacer canciones de esas del ordenador?

$\mathrm{P}-$ ¿A ti te gustaría?

A63- ¡Sí, sí, sí, sí!

A54- Que si el año que viene vamos a hacer otro teatro.

A63- ¡Eso, eso, eso, eso, eso!

A57- ¡Sí, otra audición!

P- ¿También os gustaría?

As- ¡Sí, sí! (EG2CAsB, p. 31) 
A54- Lo que más me ha gustado han sido las canciones, las lecciones de entonación, la audición que hicimos, que fue muy divertida, que la clase está muy adornada y que, cuando lo necesitamos, tú lo repites. También lo que hemos hecho con los refranes y componer en el ordenador. (EG2CAsB, p. 4)

Salir a cantar las canciones que nos inventamos y escuchar las canciones de los demás. (CA1C, pre. 4)

No hay nada de lo que hemos hecho en clase que no les haya gustado o parecido útil.

P- ¿Repetiríais todas las actividades que hemos hecho el próximo año o hay alguna que no haríais?

A4- Yo haría todas.

$\mathrm{P}-$ ¿A ti te han gustado todas?

A4- Sí. (EG1CAsA, p. 11)

P- ¿Repetiríais todas estas actividades el próximo año o hay alguna que no querríais volver a hacer?

A75- Que me gustaría hacer todas porque son muy divertidas.

$\mathrm{P}-$ ¿Y los demás?

A71- A mí también.

P- ¿A ti también?

A71- Sí.

A69- Y a mí también.

As- Y a mí.

$\mathrm{P}-$ ¿No quitamos ninguna?

As- No. (EG2CAsD, p. 14)

No, todo es muy chulo. (CA1C, pre. 5)

No hay ninguna actividad en la que no haya aprendido nada, todas han servido para algo. (CA2C, pre. 8 )

Tener un aula acogedora y decorada con los trabajos de los propios alumnos también les ha resultado motivador para el aprendizaje.

P- ¿Y de vuestra aula qué pensáis?

A18- ¡Es muy creativa!

A23- ¡Es la más decorada de todas las aulas del conservatorio! (EG1CAsB, P. 23)

P- ¿Y qué os parece que esté la clase así de decorada?

A58- ¡Muy bonito!

A63- Es más... ¿cómo se dice?

A54- ¡Más decorativa!

A61- ¡Es más guapa! 
A63- ¡Encantadora! ¡Es más encantadora! ¡Le coges cariño a la clase! A54- Mira, se me ha ocurrido una idea, en vez de aula de Lenguaje Musical, ¡es la mansión de Lenguaje Musical! (EG2CAsB, p. 21)

F5- Hombre, es bonita, por los colores, las formas... Yo creo que es agradable para ellos (EG1CFs, p. 26)

A52- Es bonita.

A53- ¡Muy bien decorada!

A51- ¡Muy bonita y muy bien decorada! (EG2CAsA, p. 30)

¡Tenemos el aula más decorada del conservatorio! (CA2C, pre. 1)

A5- Yo creo que es muy bonita, muy colorida y, además, como tiene todo de música, si hay algo que no nos acordamos, pues lo miramos y vemos si está bien o no. ¡Es muy chula! ¡Mola! (EG1CAsA, p. 18)

A21- Que es muy acogedora y se puede decir que casi no se ve la pared. Cuando tú miras, se ven más los muñecos esos o lo de la escala cromática o los dibujos que ponemos ahí en la pared. Es más divertida la clase que tener una clase amarilla y aburrida. (EG1CAsB, p. 24)

A4- Es muy bonita, porque está muy decorada con trabajos nuestros, notas y cosas que hacemos nosotros. (EG1CAsA, p. 18)

No obstante, la mayor motivación que hemos cultivado en el aula es la satisfacción personal de cada alumno por hacer las cosas bien, es decir, hemos fomentado que el propio aprendizaje sea motivador por sí mismo.

T- Sobre todo lo que veo yo es que se esfuerzan, porque ven una compensación por parte de los compañeros y tuya, una compensación que es la gratificación de hacer las cosas bien. (ETPer, p. 2)

A21- Que muy bien, porque cada día aprendemos una cosa nueva y se entiende muy bien cuando explicas. (EG1CAsB, p. 14)

F- Necesitaba coger una dinámica de trabajo, ¿sabes? Ahora, si no le sale como ella quiere que le salga, lo repite, pero antes tenía que ser yo quien le dijera: "Venga, vamos a hacerlo otra vez, a ver si conseguimos que salga mejor". (E1CF2, p. 2)

A63 y A55 se han ofrecido voluntarios para leer la nueva lección de ritmo y la han hecho muy bien. Cuando han terminado, sus compañeros les han aplaudido de forma espontánea y ellos se han levantado a saludar orgullosos mientras decían: “¡Gracias, gracias!”. La verdad es que han mejorado muchísimo en ritmo y muestran una gran seguridad y motivación. (DPE, p. 5) 


\begin{abstract}
Alegre, porque sé que voy a aprender algo más. (CA1C, pre. 9)
Me parecen muy bien porque aprendo muchas cosas. (CA1C, pre. 1)

Me alegra mucho que los niños se impliquen y se "piquen" por hacerlo cada vez mejor, eso es muy positivo. (CEP2CF62E, p. 3)
\end{abstract}

Finalmente, no podemos olvidar que a los padres también les gusta aprender con sus hijos, por lo que hemos propiciado la implicación de las familias en el proceso de enseñanza-aprendizaje.

F- He ido aprendiendo con ella y lo he ido estudiando con ella. [...] Cuando da una cosa que no me sé, me la explica. A ella también le hace mucha ilusión compartirlo conmigo porque, como sabe que me gusta mucho, se siente muy importante de poder enseñarme cosas de música. (E1CF2, p. 2)

F- Yo siento que quiero aprender también. (E1CF19, p. 1)

\title{
3. Ansiedad
}

La ansiedad es un estado emocional en el que las personas se sienten inquietas, aprensivas o temerosas frente a situaciones que no pueden controlar o predecir o sobre situaciones que parecen amenzantes o peligrosas (Virues, 2005). La ansiedad puede tener su origen en un déficit en las habilidades sociales y emocionales, una evaluación cognitiva errónea de su respuesta emocional y/o una exposición repetida a experiencias aversivas en situaciones sociales o personales (Gallego et al., 1999)

Si tenemos en cuenta que, en nuestra sociedad, son cada vez más las personas que padecen estrés y que manifiestan respuestas de ansiedad y dolencias psicosomáticas, no debemos esperar que sea menor el porcentaje de niños que comiencen a sufrirlo. En este sentido, los exámenes, una agenda escolar llena, desear estar a la altura de sus compañeros o un número elevado de actividades extraescolares son algunos de los factores que pueden provocar un exceso de ansiedad desde la infancia (Peralbo, 2011), lo cual debe ser tenido en cuenta tanto por los padres de los alumnos como por los docentes implicados en su educación, para proporcionarles un entorno adecuado que favorezca su desarrollo.

Por otra parte, la ansiedad escénica es uno de los aspectos más relevantes en la práctica y el estudio musical, pudiendo llegar a convertirse en un auténtico problema para poder realizar una carrera profesional con cierta garantía de éxito. 
Todo ello justifica la necesidad de dedicar este apartado a analizar la ansiedad de alumnos y docentes debido a la sensación de falta de tiempo y sus repercusiones en el ámbito educativo. A continuación, nos centraremos en los factores específicos que generan ansiedad en la asignatura de Lenguaje Musical y veremos cómo reducirlos. Finalmente, debido a su trascendencia para los estudiantes de música, analizaremos las causas de la ansiedad escénica y señalaremos una serie de pautas que nos han permitido atenuarla.

\subsection{Ansiedad generada por los límites de tiempo}

Actualmente, no solo los altos ejecutivos con una agenda a rebosar sufren ansiedad por la sensación de "falta de tiempo" para llevar a cabo todas las tareas del día a día. Como veremos en este apartado, este mal afecta también a los docentes y, más especialmente, a los niños, para quienes se torna aún más grave, ya que no saben cómo afrontarla.

\subsubsection{Ansiedad de los alumnos por el exceso de actividades}

El estudio de las enseñanzas musicales en un conservatorio exige un esfuerzo importante por parte de los alumnos, ya que dedican gran parte de su horario semanal a asistir a las clases y a estudiar las distintas asignaturas.

En el caso de A34, sale a las 17:30 todos los días del colegio, después va cuatro días al conservatorio y a las 20:00, cuando llega a casa, tiene que hacer la tarea del cole y el estudio de música. Eso sin contar cuando está de exámenes como esta semana, que tiene que repasar los temas. (CE1CF34F, p. 1)

Cuando en la enseñanza obligatoria tienen un horario de jornada partida, el cansancio de los alumnos es todavía mayor y aumenta su ansiedad por la sensación de falta de tiempo.

P- ¿Antes de ir al colegio se pone a tocar?

F- Sí, sí. Tú imagínate la carga que tiene. Se va al cole hasta las cinco y media, y mira qué hora es y todavía no ha llegado a casa, ¿eh? (ahora son las 20:30). [...] O sea, es que llega un momento en que no llegamos: ni ella, ni yo. (E1CF6, p. 3)

Los niños y sus familias se organizan dentro de sus posibilidades, pero a veces sienten frustración por no poder abarcarlo todo con la calidad que les gustaría.

F- El problema es que entre semana está muy limitado su tiempo. Los fines de semana sí que dedica más tiempo a hacer toda esa tarea. Y luego, bueno, 
las cosas pequeñas, pues antes de acostarse, se pone su música e intenta estudiar, pues lo que le da tiempo a la pobre, no lo que, a lo mejor, debería o lo que, a lo mejor, quisiera ella, pero es que no tiene tiempo para más. (E1CF6, p. 3)

Y sienten, incluso, que les impide hacer otras actividades que, como niños, reclaman (Peralbo, 2011).

F- Ella dice: “¿Cuándo juego?” Es que a mí me da mucha pena con ocho años, la pobre, pero bueno, es la vida, ¿no? (E1CF6, p. 3)

Realizar las tareas de Lenguaje Musical en casa no les exige mucho tiempo ni esfuerzo.

F- Son tareas que se hacen rápido. Por lo menos ella lo hace rápido. (E1CF6, pp. 3-4)

Es verdad que no tardan mucho, el problema es que hay días que nos faltan 10 minutos. (CE1CF34F, p. 2)

Asimismo, me resulta muy significativo que en el puente de todos los Santos, como tenían más días, les puse el doble de tareas para casa y, al preguntar a los alumnos si habían tardado mucho en hacerlas, solo se quejó una niña diciendo: "Yo sí, tardé mucho, casi media hora", por lo que los demás niños se rieron y dijeron: "¿Media hora en siete días te parece mucho?" Yo imagino que algunos niños le estarán dedicando más y otros menos, pero se trata de un tiempo de estudio que considero dentro de lo normal. (DPN, p. 2)

Pero la ansiedad les viene fundamentalmente al tener que sumarlas a las tareas del colegio y a otras actividades (Peralbo, 2011).

F- Tiene muchísimas tareas del cole. Esta semana, por ejemplo, tiene toda de exámenes. O sea, una semana sí, otra no, tiene exámenes. Entonces, bueno, pues quiero decir que ella hace lo que puede. (E1CF6, p. 4)

Lo que más me cuesta son las tareas de casa, porque tengo muchas actividades y en el colegio me mandan muchas tareas. (CA1C, pre. 6)

F50- Cuando salen después de seis, siete u ocho horas de un colegio, que salen a veces abrasados, yo lo digo por mi hija, con una cantidad de deberes impresionante, y eso que la niña tiene 10 años, y le dices que es que se tiene que pasar dos horas seguidas en el conservatorio, ¡la matas!, ¡hay días que la matas!, y ella llega aquí diciendo: “PPuffff!”. Y dices tú: “Esfuerzo, esfuerzo..." Y, cuando llega a casa, que llega a las seis y media de la tarde o siete, se tiene que poner a hacer los deberes una hora y media más, y, claro, tiene que cenar, ya son las nueve y media, y se tiene que ir a la cama, 
porque a las siete y media se tiene que levantar. Entonces, es posible que llegue un momento que diga: “¡Odio la música!” (EG2CFs, p. 12)

\subsubsection{La sensación de falta de tiempo en la práctica docente}

En un principio, la limitación temporal también me generaba ansiedad a mí, como profesora, porque no podía respetar en clase los tiempos planificados para las distintas actividades (Alemañy, 2009).

Esta actividad ha sido bastante laboriosa, nos ha llevado cuarenta minutos, cuando yo pretendía haber tardado veinte. (DPO, p. 4)

Ello nos hizo replantearnos aspectos metodológicos para reconducir la manera de abordar los contenidos y facilitar la adquisición de los mismos.

Me he alegrado porque he comprobado que "perder" un par de minutos al principio para hacer un análisis general de la canción facilita mucho su posterior escritura, ya que, en esta ocasión, los niños han tardado aproximadamente media hora, es decir, diez minutos menos que cuando realizaron la primera canción. (DPN, p. 3)

Además, durante el primer trimestre, tuve que dedicar muchas horas en casa a corregir los trabajos de los alumnos y a resolver por e-mail o en los tiempos de tutoría las dudas que les surgían, lo cual resultaba muy duro e, incluso, desconsolador.

Me he armado de paciencia y he vuelto a responder todos los correos diciendo lo que le faltaba a cada uno para completar la actividad. ¡Espero que cojan bien el hábito pronto, porque si no me dan ganas de desistir! (DPO, p. 9)

No obstante, a partir del segundo trimestre, con la dinámica de trabajo ya adquirida, se fueron reduciendo las horas de corrección, por lo que empezamos a relajarnos y a disfrutar de los resultados positivos derivados de las actividades.

Esta vez he tardado bastante menos en responder todos los correos de los alumnos. Se ve que tanto ellos como yo nos hemos acostumbrado a la dinámica de trabajo y todo fluye sin las dificultades del principio, ¡bravo! (DPF, p. 3)

\subsection{La ansiedad en la asignatura de Lenguaje Musical}

El Lenguaje Musical es una asignatura que, en muchas ocasiones, genera ansiedad a los alumnos. Así lo expresaba una madre, hablando de dos hijos suyos que estudiaron música hace unos años. 
F- Ellos no querían venir, resultó durísimo y, sobre todo, para su madre, que era la que estaba encargada de que vinieran y de que trabajaran. Entonces dije: “ßBasta ya de conservatorio!” (E2CF59, p. 3)

En ello también coinciden los profesores de instrumento y el equipo directivo, que ven en dicha asignatura un peligro para que los alumnos continúen estudiando su instrumento.

T- El Lenguaje Musical es una especie de penitencia que tienen que hacer, para luego tener el premio de poder tocar el instrumento. Es que se ve así, eso es una realidad. (ETGD, p. 6)

T- Hay veces que el Lenguaje Musical, por desgracia, se toma como un momento de: "Voy porque tengo que ir, esto no me gusta". Y después muchas veces hay: Lenguaje Musical valoración dos, instrumento ocho, cuando debería ser la misma nota, y eso se sabe ya. (ETPer, p. 5)

Esta situación conduce a que muchos alumnos abandonen sus estudios musicales.

T- Se dan bastantes casos de alumnos que dejan el centro porque el peso negativo de la enseñanza de la asignatura de Lenguaje Musical no compensa el peso positivo del instrumento, y eso ocurre regularmente, en general. (ETGD, p. 1)

Pero ¿qué es lo que provoca esta ansiedad y rechazo hacia la asignatura? Veámoslo con más detenimiento.

\subsubsection{Ansiedad por las relaciones entre profesores y alumnos}

El nivel de ansiedad en el aula se debe fundamentalmente a la relación que se establece entre cada alumno y el profesor (Moya, 2010). Cuando un niño no está a gusto con el profesor o con su forma de trabajar, aumenta su ansiedad y, por consiguiente, su rechazo hacia la asignatura.

Me he reunido en tutoría con la madre de A37 y me ha dicho que su otra hija, que es más mayor, quiere dejar el conservatorio porque su profesor se enfada mucho con ella cuando no le salen las cosas bien, así que se pone muy nerviosa y lo hace todavía peor. Me ha preguntado si podría venir conmigo el próximo curso, para ver si consigue ilusionarse como su hermana pequeña antes de tirar la toalla. (DPA, p. 3)

F25- A5 sabe lo que tiene que estudiar y de qué manera, o sea, sabe que tiene que estudiar de la lección 10 a la 19, por ejemplo. En cambio, su hermana, que va con otro profesor, sabe que llega el examen y le preguntarán lo que le pregunten, pero yo creo que no lo tiene muy claro y eso le agobia. (EG1CFs, p. 13) 
Aunque esta circunstancia no es exclusiva del Lenguaje Musical, sino que también se da en las clases de instrumento.

F14- El problema mío es que yo empecé a tocar la guitarra, pero fue... bueno, lo voy a decir: "El profesor me dio una bofetada el tercer o cuarto día de clase y, desde entonces, para mí la guitarra..." (niega con la cabeza). Fue totalmente frustrante. Desde ese momento, para mí la música se acabó, porque no quise seguir. (EG1CFs, p. 17)

Consciente de esta realidad, en clase hemos cuidado mucho las relaciones personales entre la profesora y los alumnos, generando confianza (Covarrubias \& Piña, 2004; Moya, 2010).

F24- Es un niño al que le cuesta mucho trabajo..., es muy tímido, le cuesta mucho trabajo adaptarse al profesor, a las clases, pero la verdad es que en esta de Lenguaje lo ha hecho muy bien, vamos, para lo que yo esperaba o para otras actividades que hace, que lo ha hecho rápido y ahora mismo está viniendo muy contento, mucho. (E1CF24, p. 1)

A57- Haces bromas con nosotros.

A58- Y nos reímos. (EG2CAsB, p. 22)

Si hace falta nos explica las cosas 50 veces y nos ayuda en todo. (CA1C, pre. 11)

Asimismo, hemos fomentado buenas relaciones entre los propios alumnos, para que se sintieran cómodos los unos con los otros y existiera un clima propicio para el aprendizaje (Llorent \& López, 2012).

$\mathrm{P}-$ ¿Y os lleváis bien con vuestros compañeros?

As- Sí, mucho.

P- ¿Cómo os sentís en clase?

As- Muy bien (varios a la vez).

P- Levantamos la mano.

A4- Muy bien, como si estuviéramos en casa.

P- ¿Sí? ¿Tú estás cómoda con todos?

A4- Sí.

$\mathrm{P}-$ ¿Y por qué crees que te sientes cómoda?

A4- Porque todos me tratan bien y me siento bien. (EG1CAsA, p. 5)

Me siento a gusto. Hay muy buen ambiente. (CA2C, pre. 9)

A7- Yo me siento como si fuésemos hermanos, como si fuera una familia, y me gusta mucho venir al conservatorio porque sé que me voy a encontrar con mis compañeros y que vamos a estar juntos contándonos cosas y cantando.(EG1CAsA, p. 6) 


\subsubsection{Ansiedad debida a los contenidos y al ritmo de trabajo}

Los contenidos de la asignatura de Lenguaje Musical y el ritmo de trabajo a veces resultan duros para algunos alumnos, creándoles tensión. Esto ocurre, sobre todo, al principio, porque los niños se apuntan al conservatorio pensando solo en disfrutar con la música, pero no cuentan con tener que esforzarse tanto. Por ello, durante el primer trimestre, que es cuando se establecen las bases y se marca el ritmo de estudio, algunos niños se agobiaron bastante.

Tendrías que verle cuando hace los ejercicios, hasta llora, se siente muy impotente al ver que no le sale, pero yo creo simplemente que es cuestión de ponerse al día y practicar más, porque en el momento que yo me pongo con él y lo repetimos varias veces empieza a tomar aliento. (CE1CF27N, p. 6)

A22 hoy no lo ha disfrutado, para nada se ha divertido, todo lo contrario, se ha agobiado un montón. Una de las cosas que más le gusta en estos momentos es la música. Sabe que necesita estudiar y dedicar tiempo si quiere aprender. Quizá sea un poco pronto, todavía están cogiendo el ritmo, adaptándose... Tú eres la profesora y la que marca el ritmo de trabajo, pero igual te ayuda saber cómo lo viven desde casa, una vez que tú no estás de refuerzo para ellos. No quiero que te lo tomes como una crítica a tu trabajo, todo lo contrario, pero creo que debes saber cómo es el trabajo desde el otro lado. (CE1CF22N, p. 3)

No obstante, a medida que avanzaba el curso, al ir adquiriendo un buen hábito de estudio y mayor control sobre los contenidos de la asignatura, la ansiedad fue desapareciendo.

De lo que hablamos a principio de curso, parece que lo lleva mejor. De momento le da tiempo a realizar todas las actividades y no está agobiada. Le gusta mucho. ¡Muchas gracias! (CE1CF22E, p. 5)

\subsubsection{1. Énfasis en la confianza y en la aceptación de los errores}

Una estrategia que ha resultado muy positiva para reducir la ansiedad de los alumnos ha consistido en que, cuando mostraban algo de tensión o preocupación ante alguna tarea, les animábamos quitando importancia a los errores y reforzando positivamente su esfuerzo.

Aquí te dejo mi composición. El cuarto compás le he repetido con "ta" y luego cantando, pero no sé yo si queda muy bien, lo he hecho lo mejor que he podido. (CE1CA32E, p. 1) 
Efectivamente, el cuarto compás sonaba mal y, además, tenías una nota (el re) que no podías utilizar, pero lo puedes arreglar muy fácilmente si tienes en cuenta que te falta por utilizar el silencio de negra. ¡Ánimo, a ver cómo lo arreglas! Y, la próxima vez, fíate de tu intuición, que era buena. (CEP1CA32E, p. 2)

A46, tu canción está muy bien, pero el do no es floreo, por lo que te expliqué ayer, ya que está en fracción fuerte, y la palabra "niñito" suena mal por los acentos. ¡Buen trabajo! ¿Te acuerdas de cuánto te costaban las primeras canciones? ¡Has mejorado un montón! (CE2CA46A, p. 10)

La aceptación de los errores como algo natural del proceso de aprendizaje y el hecho de aprovecharlos para mejorar han permitido que los alumnos se tomaran bien las correcciones a sus trabajos, considerándolas positivas y necesarias (De la Torre, 2004).

A2- A mí me gusta que me corrijas porque así aprendo de mis errores y luego, la siguiente vez, sé que eso está mal o que está bien y me corrijo también a mí misma cuando pongo las cosas. (EG1CAsA, p. 11)

A29- Yo creo que en esta clase te corrigen para ayudarte, pero es que, en la mía del colegio, cuando dices algo que no es te dicen: “¡Pero qué dices, que es otra cosa!". Y te empiezan a gritar.

$\mathrm{P}-$ ¿Y eso aquí no pasa?

As- No (varios).

A29- No, gracias a Dios.

A31- Para nada. (EG1CAsC, p. 11)

A34- Pues porque, a veces, tus compañeros te dicen: "Te has equivocado ahí”, y tú no lo has puesto y, entonces, pues dices: “¡Ah, pues la próxima vez ya lo corregiré bien!"

$\mathrm{P}-$ ¿Y eso te gusta?, ¿o no te gusta que te corrijan?

A34- Sí.

P- ¿Sí?

A34- Porque así aprendo más de los demás. (EG1CAsC, p. 26)

Además, sentían orgullo al comprobar que "El que la sigue, la consigue”, y que iban mejorando (Torre et al. 2011).

F26- Dice: "Lo he vuelto a repetir y me ha salido bien" (imitando al hijo).

F37- ¡Claro, claro!

F25- "He sido capaz" (imitando al hijo).

F37- Eso es muy importante. (EG1CFs, p. 26)

Quizá lo más relevante haya sido comprobar que la ansiedad no la genera la materia en sí o el nivel de exigencia, ya que, aunque se les exija mucho, si 
los contenidos están bien estructurados y los alumnos tienen claro qué se les va a pedir y cómo, no sienten tensión.

Yo creo que tú eres muy estructurada y que, aunque contigo trabajan mucho, ellos se acostumbran a ese ritmo y lo van llevando y saben lo que les vas a pedir. El problema es cuando, a lo mejor, no saben lo que tienen que hacer, ni les guían. (EG1CFs, p. 13)

No obstante, hay que reconocer que a veces el ritmo de trabajo es intenso y algunos niños, inevitablemente, se sienten presionados.

F61- Ha dicho que solo va a estar hasta cuarto, aunque le gusta, pero es que la asignatura de Lenguaje Musical se le hace bola, iy eso que ha sacado buenas notas!, pero es que se ha sentido muy presionado. (EG2CFs, p. 2)

También encontramos alumnos muy responsables y con gran sentido de la perfección que experimentan mucha ansiedad si no les sale todo como les gustaría (Peralbo, 2011). En estos casos es en los que más hay que insistir para conseguir que se relajen y sean tolerantes al error, porque un alto nivel de autocrítica puede provocar que dejen de disfrutar con la música.

A16 es una alumna de $1^{\circ}$ muy trabajadora y responsable, pero que manifiesta bastante ansiedad en clase porque le falta confianza en sí misma y tiene un gran sentido de la perfección. A16 hace todo bastante bien, pero es muy aprensiva y hace suyos todos los comentarios que lanzo en clase a algunos de sus compañeros. Por ejemplo, si están escribiendo y digo en voz alta dirigiéndome a un niño: "Hay que ser más limpio y cuidadoso, que en vez de negras parece que has dibujado chupa-chús", A16 borra sus negras y las vuelve a dibujar, aún cuando las tenía muy bien dibujadas, por si no estaban perfectas. Todo eso le genera ansiedad, y yo se lo noto también en clase e intento tranquilizarla y animarla con refuerzo positivo en todas las tareas que realiza, pero aún no es suficiente. La madre me reconoció que su hija era muy perfeccionista y que, si no tiene todo completamente controlado, lo pasa mal. Es una buena alumna que ha sacado un 8 en este trimestre y le insistí, tanto a ella como a la madre, que sus únicos deberes para estas vacaciones eran relajarse y disfrutar con la música, porque lo estaba haciendo muy bien. La actitud de esta niña muestra el afán de superación de los artistas y para mí es muy importante reducirle la ansiedad y hacerle ver que no importa equivocarse, que todos los artistas tienen fallos, porque si deja de disfrutar con lo que hace no avanzará favorablemente. (DPD, pp. 9-10)

Por último, cabe destacar que hay alumnos que no muestran interés por el Lenguaje Musical porque sienten mucha presión con su instrumento y, por tanto, rechazan todo lo que tenga que ver con los estudios musicales. 
Te envío lo que ha hecho A24, no he conseguido que lo acabase. Desde que sabe que tiene una audición de trombón en marzo está fuera de sí, totalmente agobiado y descentrado, lo cual se traduce en rechazo hacia todo. (CE1CF24F, p. 6)

\subsubsection{Atención a la ansiedad generada en los padres}

Con frecuencia, las demandas y los resultados del proceso educativo no solo generan ansiedad a los alumnos, sino también a sus padres (Benso \& Pereira, 2007; Forest \& García, 2006).

Soy la madre de $\mathrm{A} 63$ de $2^{\circ} \mathrm{B}$, acabo de ver las notas de Lenguaje Musical y, la verdad, me he quedado sorprendida, porque el niño ha estudiado y ha hecho las tareas con bastante constancia e ilusión. Está claro que siempre se puede estudiar más, pero no me esperaba que suspendiera. Me gustaría hablar contigo esta tarde. (CE2CF63D, p. 4)

Elena, perdóname, pero realmente tengo algún problema con el envío de las canciones. Desde el ordenador de mi casa no puedo enviarlas y el del trabajo está muy protegido y no me permite enviar los ficheros. Por eso, en casa hacemos las canciones y luego tengo que ir a otro ordenador con el pen-drive para enviártelas. Me dijo A16 que la última canción que te envié no estaba corregida del todo. No debí grabar la canción final corregida y, por eso, no se guardaron los cambios. Mil perdones de nuevo. A ver si ahora llega la canción correcta. (CE1CF16E, p. 8)

No resulta del todo clara la alusión a que ya no crees que tenga posibilidad de hacerlo, pues hasta donde yo sé como psicóloga y educadora, lo importante es que tu alumna aprenda y no se retrase en la adquisición de contenidos. Confío plenamente en que tal es tu objetivo. Por supuesto, todos entendemos que en el momento en que se supera una enfermedad es cuando un alumno puede iniciar el proceso de ponerse al día con tareas escolares, y no antes. En cualquier caso, y para otra vez, si nuestra hija vuelve a enfermar, nuestro sentido de la responsabilidad y nuestras posibilidades nos marcarán, sin duda, el momento en el que podamos ponernos en contacto contigo. (CE2CF77N, pp. 1-2)

Por eso, es necesario cuidar la relación con las familias y establecer buenos vínculos con ellas, atendiendo a sus dificultades e inquietudes, para orientarlas adecuadamente y que no sientan tensión (Comellas, 2009; Domínguez, 2010).

Acabo de ver tu correo. Espero que con lo que hablamos el otro día haya podido aclararos que estoy muy contenta con el trabajo que ha realizado A63 durante todo el trimestre y de, como comentas, la constancia e ilusión que ha mostrado. Tenía dificultades importantes que solventar y ya está mucho más seguro. Ahora solo le falta reforzar los dictados, pero con el 
nuevo cuadernillo que le he mandado y siguiendo las pautas que damos en clase confío en que los mejorará pronto. Hablé también con él en clase para que no se desanimara y le puse de ejemplo de constancia y esfuerzo ante sus compañeros. Creo que lo entendió y se lo tomó bien. (CEP2CF63D, p. 4)

No te preocupes, entiendo que la tecnología a veces da estos problemas. La canción ya es correcta. (CEP1CF16E, p. 8)

Está claro que ha habido una confusión con mi correo anterior. Lo que quería decir es que no le iba a dar tiempo a hacerlo antes de la clase que tuvimos ayer, que fue en la que corregimos y pregunté esas tareas, por lo tanto, ya no tenía sentido que las hiciera, porque las iba a hacer conmigo en clase al ponerlas en común. Por supuesto, si un alumno está enfermo y no puede hacerlas, no hay ningún problema. (CEP2CF77N, p. 2)

Además, los docentes debemos tener en cuenta que la función de los padres ayuda a reducir la ansiedad de los alumnos ante la presión de los estudios, por lo que debemos trabajar en estrecha colaboración con ellos (Benso \& Pereira, 2007).

F50- Ella sabe que ese es su trabajo y que tiene que cumplirlo, y que tiene que intentar hacerlo lo mejor posible. Nunca le decimos: “¡Oye, esto no puede ser, has sacado un 7 y tienes que sacar un 10!” ¡No!, ¡como si saca un 5 ! ¡No, jamás, nunca! Eso sí, con el suspenso ya tenemos que hablar, pero del 5 al 10, el que tú veas que tienes que sacar. (EG2CFs, p. 15)

Os comenté que el conservatorio no es una actividad extraescolar más, ya que conduce a una titulación oficial, cosa que no ocurre en otras alternativas, como academias o escuelas de música, por lo que el ritmo de trabajo es diferente. Os lo dije para que comprendierais a vuestros hijos si en algún momento se agobiaban un poco, para que no les presionéis, sino que les animéis. (CEP1CF22N, p. 4)

El padre de A60 me ha pedido que intente poner menos tareas del martes al jueves, porque solo tienen un día para realizarlas. Yo le he explicado que de martes a jueves mando siempre repasar las lecciones de ritmo y entonación que hemos visto en clase, pero que tampoco busco que salgan completamente bien al día siguiente (que es lo que siento que agobia al padre porque, al ser músico, sabe perfectamente si su hija las controla o no y, lógicamente, quiere que le salgan perfectas). De hecho, le he insistido en que dedicamos varias clases a trabajar la misma lección para que la asimilen con seguridad, así que le he pedido que se relajen, que no presione a la niña y que no le dediquen tanto tiempo la primera vez, ya que cuento con que no saldrá perfecta y me da pie a decirles: "Para el próximo día, estudiad otra vez la lección un poco más, porque aún no sale del todo bien". (DPD, p. 10) 


\subsection{Ansiedad debida a las interpretaciones musicales en público}

Cuando un nuevo alumno desea estudiar en un conservatorio, debe realizar una prueba de acceso que, por lo general, genera mucha ansiedad.

F5- Le costó muchísimo esfuerzo hacer la prueba de acceso porque ella es muy tímida y, entonces, al ver que se tenía que meter en una sala con diez niños que no conocía y con no sé cuántos profesores a cantar una canción que llevaba preparada, pero que no se atrevió a cantar por la presión, para ella fue complicado. (EG1CFs, p. 7)

F- Venía él con miedo y nosotros también, y no sabíamos cómo iba a resultar. [...] Le metieron en una habitación, le dieron el papelito rítmico y digo: “ßBueno!..." El rítmico no me preocupaba, pero lo otro sí, el de la entonación. Luego, la trompeta no me preocupaba tampoco, porque yo sabía que, más o menos, el nivel no iba a ser mucho y ese sí lo tenía medio dominado, y lo pasé fatal por él, porque se puso muy nervioso. Es que es una situación muy fuerte. [...] La prueba de acceso para él fue dura, lo pasó mal. (E2CF45, pp. 7-8)

Esta ansiedad no es consecuencia de no dominar los contenidos exigidos porque, la mayoría de las veces, los alumnos vienen muy preparados o tienen buenas aptitudes para las enseñanzas musicales, sino al hecho de que deben defender lo que saben ante un tribunal que desconocen y que va a juzgar su trabajo. Lo relevante de esta circunstancia es que no se trata de una situación puntual por la que ha de pasar el alumno, es decir, no consiste en experimentar un momento malo para superar una prueba de acceso y, a partir de ahí, se acabaron las tensiones de actuar en público, sino que será una situación que se repetirá continuamente durante la larga carrera de sus estudios musicales.

$\mathrm{Al}$ respecto, Balsera y Gallego (2010) señalan que "un elevado porcentaje del alumnado de los conservatorios se siente angustiado ante las presentaciones públicas" (p. 50), lo cual, en cierto modo, es normal, porque todas las personas tenemos miedo al fracaso y a dar una imagen poco favorecedora de nosotros mismos, ya que queremos ser aceptados y reconocidos por los demás.

Salmon (1990) define la ansiedad escénica como la experiencia de aprensión angustiosa sobre la disminución real de las habilidades interpretativas, en un contexto público, hasta un grado que no garantice la aptitud musical del individuo, el entrenamiento o el nivel de preparación de éste.

A pesar de que, actualmente, la definición de la ansiedad escénica sigue sin ser única (Studer et al., 2011), sí que existe un consenso bastante amplio al 
considerar que está caracterizada por una evidente y perceptible aprensión a la actuación (Kenny, 2008; Salmon, 1990; Studer et al., 2011; Wilson, 1997) y que presenta tres componentes diferenciados: cognitivo, fisiológico y conductual (Osborne, Kenny, \& Holsomback, 2005).

Es importante saber reconocer y combatir la ansiedad escénica porque impide que el músico disfrute de su interpretación, lo cual, utilizando las palabras de Balsera y Gallego (2010), "deteriora su ejecución musical, provocando en muchas ocasiones sentimientos de angustia y decepción”. (p. 50)

A continuación, veremos las causas que la generan y señalaremos algunas pautas que ayudan a reducirla.

\subsubsection{Causas de la ansiedad escénica}

Dalia (2004), psicólogo clínico y formador de terapeutas, ha realizado una extensa investigación y tratamiento de la ansiedad escénica en músicos. En la introducción de su libro Cómo superar la ansiedad escénica en músicos argumenta que las razones por las que una persona tiene ansiedad escénica pueden ser de distinta naturaleza, aunque uno de los principales motivos de esta patología viene dado por las características propias de la enseñanza musical en los conservatorios de música: a) clases individualizadas, b) presión sobre la búsqueda de una interpretación lo más perfecta posible, c) importancia de la crítica externa y d) escasas posibilidades de realizar audiciones o conciertos. Igualmente, comenta que este problema de ansiedad escénica puede llegar a interferir no solo en la vida profesional del joven músico sino también en su calidad de vida, ya que trae consigo otros problemas tales como baja autoestima o falta de comunicación, perjudicando las relaciones interpersonales.

En nuestro trabajo hemos comprobado que, en muchas ocasiones, la inseguridad y ansiedad a la hora de actuar delante de los compañeros se debe a una falta de estudio.

F- Cuando salió le pregunté: “¿Qué tal? ¿Has cantado?” Y me respondió: "Me ha dicho que tengo que estudiar más”. Y le insistí: "¿Nada más?" "Mmm..., bueno, nada". Porque, a ver, también es como decirme: "La profesora me ha dicho que no he estudiado" y por eso él me dice: "Me ha dicho que tengo que estudiar más" y ya está. Ese fue el comentario.

P- ¿Y esa última canción la traía trabajada?

F- Es lo que yo no sé, porque yo sé que estuvo estudiando con su hermana. Él tiene una hermana mayor pero, según él, la canción tenía que cantarla una semana después, entonces le llegó un poco de sorpresa y a mí me dio la impresión de que habían repasado poco la canción. (E1CF24, p. 5) 
Aunque también hay niños que, por su carácter, son más tímidos e introvertidos, por lo que les cuesta más exponerse delante de la gente, independientemente de que lo lleven bien preparado y de que el contexto sea la clase u otros ambientes.

F26- Las mías son muy tímidas y no hay manera de que toquen, aunque se lo pidas en casa. [...] Me llama la atención de que no hay manera de sacarles a...: "Anda, por favor" "No, que eso me da mucha vergüenza". (EG1CFs, p. 22)

F5- A5 lo pasaba realmente mal. Eso de venir con parafernalias y que se le notara mucho más, o sea, ser más el centro de atención porque traes... O sea, hay niños que yo creo que les sale, ¿no?, y otros que ese día preferirían que les tragara la tierra. Entonces es: "Yo voy, la hago y la canto, pero no..." Mira que yo insistía: "Pues llévate no sé qué". Pues creo que solo lo llevó en la última. (EG1CFs, p. 27)

P- No sé él cómo lleva el ponerse delante, como comentabas al principio que es un chico tímido, el ponerse delante de sus compañeros y cantar.

F- Muy mal, eso lo lleva muy mal. [...]

P- ¿Qué comenta al respecto? ¿No le apetece salir?

F- Que no, porque le da mucha vergüenza. Él lo dice muy claro: "Me da mucha vergüenza y me da mucha vergüenza", y eso... ahí se queda. (E1CF24, p. 5)

En este sentido, para Coso (1992) las razones de la ansiedad escénica hay que buscarlas no en aspectos musicales sino, más bien, en aspectos relacionados con el carácter del estudiante y su actividad interior, es decir, en aquellos pensamientos y sentimientos (positivos o negativos) que configuran su personalidad y que condicionan el éxito o fracaso de cualquier momento de su vida.

Por otra parte, parece ser que a los niños les cuesta menos equivocarse delante de personas que conocen que de las que no conocen.

A75- Que yo me siento muy a gusto porque a ellos ya les conozco muy bien y en el auditorio no conozco a mucha gente, entonces me da más vergüenza. $\mathrm{Y}$ aquí, como conozco a todos muy bien, pues ya no me siento nerviosa.

$\mathrm{P}$ - ¿Al principio te ponías nerviosa cuando no conocías a tus compañeros?

A75- Un poco.

P- Un poco. ¿Y ahora ya al final?

A75- Ahora ya los conozco muy bien, entonces ya estoy muy a gusto. (EG2CAsD, p. 23)

Además, resulta interesante comprobar que les incomoda menos confundirse en clases colectivas como la de Lenguaje Musical que en las clases individuales de instrumento, lo que se traduce en una disminución de la 
ansiedad. Esto es debido a que, a pesar de que se exponen ante más gente, ven que no son los únicos en fallar y que todos los alumnos, en un momento $\mathrm{u}$ otro, se equivocan, lo cual les da tranquilidad, al mismo tiempo que aprenden a respetar a su compañeros.

A21- Cuando estás en la clase de individual y te corrigen, pues es un poco incómodo, porque solo te corrigen a ti. Es mejor en otras clases, cuando estás con otras personas, que no solo escuchas mis errores, escuchas también los de todos y no te sientes tan mal.

A17- Y aprendes de ellos. (EG1CAsB, pp. 12-13)

F29- Bueno, y también entender que es una manera diferente, ¿no?, porque en clase, a veces, en clase normal del cole, pues uno tiene un 7 otro un 8 , tal, ¿no?, y aquí ellos saben que un poco también se autoexaminan, que yo salgo ahora, pero dentro de dos minutos saldrá la compañera que está al lado y tendrá que romper también sus miedos, y yo creo que eso, en mi caso, yo creo que mi hijo ha aprendido un poco a ser más respetuoso y a comprender que los demás también se equivocan. También saben que un día lo hacen bien y otro menos bien, pero al viernes siguiente hay que volver a salir y volver a intentarlo, ¿no?, y yo creo que esa actitud o esa manera de entender las actuaciones de los compañeros o el trabajo de los compañeros expuesto en clase es la primera vez que él lo ha vivido en primera persona como sujeto paciente, y también como agente cuando sale. (EG1CFs, p. 25)

Lo que más les costaba era actuar delante de una cámara, porque les preocupaba que sus errores quedaran recogidos en un video y, al ponerse más nerviosos, se ralentizaba el ritmo de la actividad y disfrutaban menos con ella. Por este motivo, solo lo hicimos una vez para guardar algunos de sus trabajos en directo, pero no queríamos causarles una tensión añadida.

A33- A mí sí y no. No, cuando nos ponías la cámara ahí delante porque nos poníamos más nerviosos. Y sí, porque ya los conozco bien y ya no me da vergüenza cantar.

P- O sea, que cantar delante de todos no te importa, pero que esté con la cámara grabándote... ¡ eso no!

A33- Sí (riendo). (EG1CAsC, p. 27)

A63- A mí cuando me da vergüenza es cuando pones la cámara ahí delante. (EG2CAsB, p. 24)

Para terminar, destacaremos que la vergüenza y la ansiedad asociada a la misma se acrecienta con la edad, por eso es importante conseguir controlarla lo antes posible.

F- Todavía yo creo que es pequeña; lo mismo dentro de un poco cambiamos la versión, pero ahora mismo todavía no tiene vergüenza. 
P- Hombre, intentaremos que no. Muchas veces, si cogemos rutina ahora...

F- Claro, lo que pasa es que, cuando se van haciendo mayores, pues las cosas ya van cambiando. Lo que no les da vergüenza de pequeños, de mayores sí. Y luego ya, de mayores, nada, ¡luego de mayores ya no les da vergüenza nada! (ríe). (E2CF79, p. 4)

Seguidamente, señalaremos algunas pautas que hemos utilizado con los alumnos en este estudio y que han demostrado su utilidad para reducir la ansiedad ante las interpretaciones musicales en público.

\subsubsection{Pautas para reducir la ansiedad escénica}

Muchos estudiantes de música en los momentos previos a una actuación tienen pensamientos del tipo: iSeguro que me sale mal!, ;Me voy a confundir!, ¿Qué sucederá si tengo un fallo de memoria?, ¡Me voy a poner nervioso!, ¡No voy a estar a la altura!, ¡No voy a ser capaz de controlar mi miedo!, etc. Estos pensamientos son ideas negativas que hay que aprender a gestionar (Balsera \& Gallego, 2010), ya que, como hemos comentado anteriormente, los alumnos que experimentan una ansiedad incontrolable en las actuaciones públicas suelen disminuir significativamente su rendimiento interpretativo.

Dalia (2004) utiliza diversos métodos para que sus pacientes dominen la ansiedad escénica, como la aplicación de técnicas de reestructuración cognitiva, ejercicios de relajación y las autoinstrucciones, además de exponer y observar a sus pacientes cuando interpretan ante el público.

En la misma línea, para perder el miedo a la situación de exponerse ante otros, en la clase de Lenguaje Musical los alumnos han cantado continuamente delante de sus compañeros, aunque, al principio, a muchos les costaba bastante.

A31- Al principio me ponía muy nerviosa por si me equivocaba, porque no sabía cómo eran de carácter ni nada, porque no les conocía. [...]

P- ¿Por ellos o por mí?, ¿quién te daba miedo?

A31- ¡Todos! (EG1CAsC, p. 27)

Acostumbrarse a la situación ha sido un proceso paulatino, porque la confianza se adquiere poco a poco. Pero, a medida que avanzaba el curso, todos fueron ganando seguridad y perdiendo la vergüenza a actuar delante de sus compañeros.

P- ¿Y no pasabas vergüenza cantando delante de todos?

A35- No.

$\mathrm{P}-\succsim \mathrm{Al}$ principio tampoco pasabas vergüenza? 
A35- Bueno, sí (sonriendo)...

$\mathrm{P}-$ ¿Y por qué al principio sí y después no?

A35- Porque al principio no estaba acostumbrado y luego sí.

P- ¿Y ahora ya te da un poquito de vergüenza o no te da nada de vergüenza?

A35- No.

$\mathrm{P}-$ ¿No, que significa?

A35- Que no me da vergüenza.

P- ¿Nada?

A35- No. (EG1CAsF, p. 10)

Estoy muy sorprendida de la evolución que han experimentado alumnos muy introvertidos como A26 y A38, ya que han cantado sus canciones con mucha seguridad y han sonreído al terminar mientras saludaban. Parece que, por fin, se sienten cómodos y están empezando a disfrutar al presentar sus trabajos en clase. (DPM, p. 3)

El clima de confianza generado en el aula permitió que los alumnos no sintieran tensión al cantar y que perdieran el miedo a equivocarse (Dalia, 2004).

P- ¿Tú te sientes cómoda equivocándote delante de tus compañeros?

A4- Me da un poco de vergüenza, pero... (se queda callada y sonríe).

$\mathrm{P}-$ ¿Pero te sientes mal?

A4- No.

P- ¿Por qué?

A4- Porque sé que solo es un fallo y que todos tenemos fallos. (EG1CAsA, p. 5)

A29- Pues yo me siento bien porque, si fallo, no me importa mucho porque, después de todo, estamos en el primer año y equivocándonos se aprende, y, bueno, cuanto más aprenda mejor. Equivocarse, casi que nos beneficia a todos. (EG1CAsC, p. 10)

A38- Me he sentido muy bien. Cuando ensayaba para salir ahí, yo siempre lo ensayaba bien a ver si me salía, pero, aunque me salga mal, sé que los compañeros me van a apoyar y que, si tengo algún fallo, me lo van a decir y no se van a reír. (EG1CAsF, p. 24)

Mi función como profesora también ha sido esencial para reducir la ansiedad y conseguir un clima propicio en clase, aceptando los errores de las actuaciones en directo como elementos inherentes al proceso de aprendizaje.

A4- Cuando tenemos fallos, tú nos ayudas para que no nos sintamos mal. (EG1CAsA, p. 7)

F1- Sí, yo creo que eso influye mucho, el que tu actitud, a lo mejor, es muy positiva, y entonces, aunque ellos se equivoquen: “Cómo te ha salido?” 
"Bueno, pues me equivoqué aquí, pero me ha dicho que fenomenal". Yo creo que el refuerzo positivo, sobre todo a estas edades, les influye mucho a pensar: "Bueno, me he equivocado, no pasa nada, ya está, el próximo día me saldrá mejor”. (EG1CFs, p. 25)

El nivel de seguridad alcanzado por los alumnos a mediados de curso era tan alto que ni siquiera tuvieron miedo de actuar delante de un auditorio completamente lleno.

$\mathrm{P}-$ ¿Y no te pusiste nerviosa actuando delante de un auditorio tan lleno de gente?

A2- No, no. Estaba muy contenta, no pensaba en los medios. (EG1CAsA, p. 19)

P- ¿Y os dio vergüenza actuar y cantar delante de un auditorio que estaba completamente lleno?

A40- Yo lo he hecho mogollón de veces y no da vergüenza.

A33- No mucho.

A40- Sabes que, si fallas, hombre, vas a hacer un poco el ridículo, pero no da vergüenza.

A33- No, porque no se dan cuenta, menos el profesor.

A40- Ninguno se da cuenta, menos el profesor. (EG1CAsC, p. 25)

Daba gusto ver cómo se desenvolvían en el escenario, ninguno parecía nervioso, al contrario, sonreían y me dijeron que se lo habían pasado muy bien. (DPF, p. 1)

A37- A mí me parece que mostrar lo que hacemos en clase a la gente es una idea muy bonita y que cantar delante de un montón de gente fue una experiencia muy buena.

$\mathrm{P}-$ ¿A ti te gustó cantar en el escenario?

A37- Sí.

P- ¿No te dio vergüenza cantar delante de todos?

A37- No. Bueno, un poco sí, me puse nerviosa, pero luego comprendí que, si me salía mal, tampoco pasaba nada. Yo sabía que me la sabía y que no me tenía que poner nerviosa. (EG1CAsF, pp. 23-24)

P- ¿A los niños les visteis que les gustara hacerla o que les diera vergüenza?, porque algunos cantaron solos, creo que A75 fue una de ellas, y, claro, es que cantar ahí delante de un auditorio no es lo común, con el instrumento parece que está uno un poco más protegido, ¿no?

F75- Yo la vi bien. (EG2CFs, p. 23)

Los niños disfrutan aún más cuando se reconoce su trabajo, lo cual aumenta su autoestima y les ayuda a acumular experiencias positivas que reducen sus miedos ante futuras actuaciones. 
P- Y tú que eras uno de los protagonistas, ¿no te dio vergüenza actuar ahí delante de un auditorio lleno?

A63- No, no.

A61- Fue el que mejor lo hizo, ¡vaya!

A63- ¡La gente luego aplaudía muchísimo! ¡Y parecía, así, el rey del mundo! ¡Olé, olé! (saludando) Iba mi madre de guardaespaldas (hace el gesto de apartar a la gente).

$\mathrm{P}-$ ¿Y tú te sentías famoso?

A63- (Asiente mientras ríe). (EG2CAsB, pp. 29-30)

Para ello, otra estrategia muy positiva consiste en realizar actuaciones en grupo, ya que se sienten más protegidos que cuando actúan individualmente.

P- ¿Os dio vergüenza actuar delante de un auditorio que estaba lleno?

A52- No, porque te veías tapado por los demás, no como, por ejemplo, en una audición de tu instrumento. Que no eras tú solo, porque tenías más compañeros y ellos, si se te olvidaba algo, te podían ayudar en la misma actuación. (EG2CAsA, p. 24)

De esta manera, se consigue que incluso niños muy tímidos e introvertidos venzan sus miedos y disfruten interpretando su música ante los demás, extendiendo esa seguridad a otros campos de su vida.

F25- Mi hijo era timidísimo, pero tímido, que en las actuaciones de Navidad del colegio si podía esconderse detrás de la cortina, pues ¡qué bien, que paso desapercibido!, y yo ahora le he visto que ha dado un paso para adelante, y es que en casa está todo el día cantando: "A25, por favor, cállate". " $i Q u e$ no, que no, que no!, porque es que luego tengo que llegar y dar bien el tono, y tengo que subir bien", y me llama mucho la atención. De hecho, en una audición en la que me dijiste (dirigiéndose a la profesora): "Cuento con A25", te dije: "Con A25 no, porque no se va a atrever", pero, para mi sorpresa, él quiso hacerlo. ¡Y es verdad!, jes que ha sufrido una transformación!, y en el cole ahora le resulta más fácil esa parte que tenía un poquito de introvertido.

F26- Pues es verdad que eso también es muy importante.

F25- Ahora va muy suelto por la vida, yo creo que ha tenido mucho que ver: o ha coincidido o, desde luego, ha sido a raíz de esto.

F37- Por supuesto. (EG1CFs, p. 11)

Por todo ello, las familias también reconocen la importancia de que los niños interpreten música en público con frecuencia para evitar la ansiedad escénica $\mathrm{y}$ han valorado muy positivamente las actuaciones realizadas por sus hijos en la asignatura de Lenguaje Musical.

F26- Yo creo que les da confianza en sí mismos.

F25- Sí, autoestima.

F26- Les da seguridad. (EG1CFs, p. 12) 
Incluso algunos padres, a su manera, también lo potencian desde casa.

F26- Entonces, ¿qué hemos hecho?, pues que, aprovechando que tenemos algunos amigos que son profesores de aquí, pues hemos reunido a varios niños y ellos han sido tan amables de tocar también, y yo me animé un día, y hemos hecho unos conciertos, unos brunch los domingos por la mañana, en los cuales ellos tocan. Entonces, se prepara cada uno su pieza y tal y cual, algunos dos, y tienen un sobrino que canta Los campanilleros, que es... ¡lo hace muy bien, pero es de risa, de verdad! Porque, cuando es un cumpleaños, a la hermana no la puedes convencer de que toque el Cumpleaños feliz. “¡No, no, no, no!”, ahí le entra toda la timidez, y a A26 lo mismo. Entonces, ha sido la manera que hemos hecho entre cuatro o una cosa así, ¿no?, cada vez en una casa, ha sido la manera de que se lancen a tocar delante de los amigos. Solo que es en petit comité, pues seremos como veinte personas. (EG1CFs, p. 22)

\section{Relaciones}

El establecimiento de unas relaciones adecuadas entre los distintos miembros de la comunidad educativa condiciona en gran medida la calidad del proceso de enseñanza-aprendizaje (Covarrubias \& Piña, 2004; Domínguez, 2010; Llorent \& López, 2012).

E- Yo siempre lo digo: primero educamos y luego enseñamos. Hay una frase muy bonita que yo la repito mucho y que no sé de quién es que dice que: "No se enseña lo que se sabe sino lo que se es".

P-Sí, es verdad, a mí también me gusta mucho.

E- Claro, es trasladar vocación, ilusión, respeto a los demás, respeto a ti mismo.

P- Y enseñamos más con lo que somos que con lo que...

E- .. que con lo que sabemos, no te quepa duda. Porque, además, cuando les has transmitido ese sentido de colaboración, de compañerismo, de afición a lo que hacemos, de vocación por tal, de respeto a la norma, de disciplina... en ese momento, todo lo que les enseñes vale y funciona. (EEx3, p. 55)

Para contactar con los padres utilicé el correo electrónico y todos mostraron interés por colaborar en mi estudio, lo cual demuestra que estamos estableciendo una buena relación. (DPF, p. 2)

A31- Me he sentido bien y he conocido a gente nueva que no conocía. Y cuando tenía alguna duda, a veces la profesora me ayudaba o, si no podía, me ayudaban los demás compañeros. (EG1CAsC, p. 9)

Por ello, es necesario cuidar el ambiente y los vínculos afectivos tanto dentro como fuera del aula. 
Muchísimas gracias por todo el trabajo, dedicación y cariño que has entregado a tus alumnos y familias en este curso. Esperamos que descanses y disfrutes plenamente de las merecidas vacaciones. (CE2CF50J, p. 3)

A70- Me siento cómoda y a gusto porque, cuando salgo del colegio, salgo muy nerviosa y aquí me relajo y me divierto.

$\mathrm{P}-$ ¿Sales nerviosa del colegio?

A70- Sí.

P- ¿Por qué?

A70- Porque mis compañeros arman barullo, no hacen caso al profesor, a veces nos castigan... y aquí no pasa eso, aquí estamos más tranquilos y me relajo y me divierto. (EG2CAsD, p. 7)

Muy bien. Me gustan mis amigos y la profesora. (CA2C, pre. 9)

En las siguientes páginas, destacaremos algunas particularidades de las enseñanzas impartidas en los conservatorios, las cuales influyen especialmente en el vínculo que se forma entre el profesor y el alumno en las clases individuales y en las relaciones que establecen los propios alumnos entre sí en las clases colectivas. A continuación, nos centraremos en el análisis de las relaciones establecidas por la profesora en este estudio, tanto con los alumnos como con las familias y con otros docentes del centro. Para terminar, señalaremos el papel que ha desempeñado el correo electrónico para facilitar la creación de vínculos afectivos.

\subsection{Relaciones particulares de las enseñanzas en conservatorios}

La estructura organizativa de los conservatorios presenta unas características peculiares que conduce al establecimiento de relaciones entre los profesores $\mathrm{y}$ los alumnos diferentes a las que tienen lugar en los colegios, institutos $\mathrm{u}$ otro tipo de enseñanzas (Moya, 2010).

Las clases individuales de instrumento, que tienen lugar durante una hora semanal, implican una relación directa entre el profesor (adulto) y el alumno (normalmente niño o adolescente), demandando al docente la posesión de grandes habilidades sociales para poder empatizar y conectar adecuadamente con cada alumno en particular, lo cual no siempre se consigue.

F- El otro día lo hablaba con la profesora de A59 y me comentaba que ellos lo que habían observado es que, a pesar de que los niños sean muy brillantes y que se les dé muy bien, la estructura que tiene, por ejemplo, la clase individual de instrumento, en la que está un adulto una hora entera con un niño, hace que haya niños que no sepan manejar muchas veces esa situación, porque si no te lo has preparado, estar una hora entera con un adulto... Y, bueno, si conectas, pues bien, pero si encima no hay feeling... 
La hermana de A59 tuvo cada año un profesor de individual y no terminaba de conectar con ellos, así que le resultó muy duro. (E2CF59, p. 4)

Por su parte, las clases colectivas como las de Lenguaje Musical están constituidas mayoritariamente por alumnos de edades próximas, pero esto no se produce de forma exclusiva, dándose el caso de que deben participar del mismo proceso educativo niños, adolescentes y adultos dentro de un mismo aula. Nuevamente, esta circunstancia exige al docente el dominio de amplias habilidades sociales para conseguir establecer un ambiente propicio para el aprendizaje.

F37- A A37 una de las cosas que más le ha gustado ha sido compartir con otras edades. (EG1CFs, p. 25)

El hecho de que alumnos de distintas edades compartan aula e interactúen en un mismo proceso educativo fomenta las relaciones interpersonales entre los mismos (Llorent \& López, 2012), lo cual resulta muy positivo para su desarrollo personal y social, ya que les prepara para vivir en la sociedad actual, caracterizada por la pluralidad, lo cual no se consigue en otros contextos educativos.

T- Yo me acuerdo, cuando era pequeño, que llamaba a gente para buscar a personas que ni conocía y les decía: "Oye, vamos a hacer esto". Te movías, tenías la iniciativa para buscar a un tío que no conocías y plantearle cosas, y seguramente esa actitud me haya sacado de muchos apuros. Pero hoy en día eso no existe, no se favorece la relación entre ellos y algo que es muy importante: la relación entre diferentes edades. Los niños de siete años siempre están con los niños de siete, los de ocho con los de ocho... y eso tiene muchas cosas que no convencen, porque cuando se relacionan con personas de otras edades aprenden muchas cosas: aprenden que hay mayores, que hay jerarquías, que hay gente que es de otra manera, a saber ocultar debilidades o a copiar cosas de los que saben más. (ETV, p. 18).

\subsection{Análisis de las relaciones establecidas en este estudio}

La importancia de cuidar las relaciones personales en el ámbito educativo es incuestionable (Benso \& Pereira, 2007; Forest \& García, 2006; Llorent \& López, 2012; Moya, 2010).

Para ello es fundamental la labor del profesor, aunque hay que tener presente que cada uno tiene una personalidad que determina su estilo de enseñanza, de tal manera que lo que a un profesor le funciona quizá a otro no le dé buen resultado.

T- Hay cosas que a mí me funcionan bien y a otro profesor no le funcionan bien, ¿por qué?, por el carisma. Por ejemplo, si yo soy un profesor 
superintrovertido, hay cosas que no me va a pegar hacer, y si mi contacto con el alumno es un contacto bastante distante o frío, aunque sea respetuoso $\mathrm{y}$ afectivo, hay cosas que no me van a funcionar. La manera de hablar que tú vas a tener y la manera de exigir van a ser diferentes. Hay un contacto físico más cercano, hay más empatía o afinidad, otro ambiente, ¿no? No todos pueden hacer lo que yo hago, ni yo puedo hacer lo que hacen otros profesores, porque no funcionaría en mí, porque yo no soy ellos ni tengo su forma de ser, igual que otros no hacen lo que yo hago. A mí me funciona porque soy yo y lo hago porque a mí me sale. (ETV, pp. 10-11)

A lo largo de este apartado, veremos cómo hemos conseguido crear buenos vínculos entre los distintos miembros de la comunidad educativa, lo cual ha sido uno de los pilares fundamentales para obtener unos buenos resultados.

A38- Los compañeros nos tratan bien y la profesora es muy maja y nos ayuda si tenemos algún fallo o si tenemos que hacer algo y no lo sabemos. (EG1CAsF, p. 7)

Muchísimas gracias por todo el trabajo, dedicación y cariño que has entregado a tus alumnos y familias en este curso. Esperamos que descanses y disfrutes plenamente de las merecidas vacaciones. (CE2CF50J, p. 3)

P- A nivel de ambiente de la clase, ¿dicen algo de los compañeros o de cómo están conmigo?

F37- ¡Fenomenal, fenomenal!

Fs- (Asienten).

F26- ¡Encantada!

F1- ¡A1 se lo ha pasado genial! Ha salido muy contento, ¡muy contento! (EG1CFs, p. 25)

Me siento bien en clase, me llevo bien con mis compañeros y con Elena. (CA2C, pre. 9)

\subsubsection{Relaciones entre la profesora y los alumnos}

El análisis de los datos recogidos en este estudio nos permite afirmar que la relación entre los alumnos y la profesora era muy buena y que el respeto hacia la asignatura se ha conseguido a base de cariño (Alcáraz, 2000; Moya, 2010; Sabbatella, 2000), estableciéndose la disciplina de trabajo sin mostrar dureza y desterrando el dicho de la vieja escuela: "la letra con sangre entra". Veamos con más detalle a qué se deben estos resultados.

En un primer momento, al preguntar a los alumnos qué opinaban sobre mí como profesora, destacaban mi simpatía y cercanía.

A57- Casi nunca nos regañas, siempre te portas bien con nosotros.

A58- ¡Sí! (EG2CAsB, p. 21) 
A24- Porque la profesora es muy maja y entonces las clases son más divertidas.

P- ¿Los demás también lo pensáis?

As- ¡Síiii! (EG1CAsC, p. 5)

$\mathrm{P}-$ ¿Y lo de que es muy maja qué significa?

A41- Pues que no regaña casi y es muy simpática.

A37- Que nos ayuda en todo, es muy comprensiva y muy divertida. (EG1CAsF, p. 8)

También valoraban el apoyo que les había prestado en su proceso de aprendizaje y lo amenas que resultaban las clases, proponiendo actividades variadas y motivadoras para ellos.

A6- Yo pienso que tú eres muy maja, nos has ayudado a saber mucho más las notas y nos has apoyado mucho.

A8- A mí me parece que eres muy maja porque, cuando nos equivocamos, nos ayudas y nos dices que hagamos tareas muy divertidas, como: estudiar canciones, hacer ritmos, las notas del libro..., y a mí me encantan. (EG1CAsA, p. 7)

Se preocupa por ayudarte y las clases son entretenidas. (CA1C, pre. 11)

Asimismo, señalaban todo lo que habían aprendido conmigo, mi implicación en el trabajo y el interés que había mostrado por explicarles las cosas las veces que hiciera falta, sin perder la paciencia.

A9- Eres muy maja y muy lista y nos has enseñado a saber música, a hacer canciones, a medir notas y a aprender nuevas figuras y notas. (EG1CAsA, p. 6)

A46- Que demuestras mucho interés y que trabajas mucho. Estamos muy agradecidos. Yo por lo menos.

A44- ¡Y que te lo curras! ¡Y que tienes una paciencia que tela! (EG2CAsA, p. 32)

A mi profesora le pondría un 10 , porque se curra mucho todo lo que hace y todo es para nosotros. (CA2C, pre. 11)

P- ¿Y de vuestra profesora qué pensáis?

A75- Que es muy maja porque nos explica las cosas si no lo entendemos y nos lo vuelve a explicar hasta que lo entendamos bien, nos lo puede repetir las veces que queramos. (EG2CAsD, p. 8)

La confianza creada entre nosotros ha sido tan estrecha que los alumnos se han sentido libres para expresarse con espontaneidad en todo momento. 
P- ¿Alguna cosa más?

A21- (Riendo y señalando al alumno 11). ¿Que ha dicho que eres muy guapa!

P- (Sonriendo) ¡Eso hay que decirlo especialmente fuerte para que me ponga yo contenta!

As- (Ríen todos). (EG1CAsB, p. 5)

A18- Que es muy buena gente, es muy moderna y muy guapa, y nos enseña muchas cosas.

As- (Ríen).

P- ¿Y lo de "muy moderna" por qué es?

A21- Porque con eso de ahí (señalando la ropa de la profesora)..

A18- Porque vas muy bien vestida.

P- ¡Ah, que voy muy moderna! (EG1CAsB, p. 14)

Los niños son muy trasparentes y he percibido el cariño que me tenían en todo momento.

Percibo continuamente el cariño de mis alumnos. Normalmente estoy en el aula bastante antes de que lleguen para recibirles, pero hoy me he retrasado tres minutos y, al verme aparecer, los alumnos de $1^{\circ} \mathrm{C}$ se han alegrado y han dicho: "¡Viva, sí que has venido! Ya pensábamos que no tendríamos clase”. (DPM, p. 2)

De la misma manera, les he mostrado continuamente mi aprecio, prestando especial atención a los momentos en los que sabía que estaban más preocupados y agobiados.

Os escribo este e-mail para mandaros muchos ánimos en esta recta final del curso, para que preparéis muy bien todos los exámenes y los hagáis tranquilos, demostrando todo lo que habéis trabajado y aprendido durante el año. (CEPAsY, p. 3)

Los padres también han sido conscientes de todo ello y han reconocido la buena relación establecida entre la profesora y los alumnos.

No puedo menos que mandarte un mensaje en nombre de mi pequeña A5 para agradecerte tus desvelos, tu presencia y todo el apoyo y cariño que les das día a día, que hacen que ellos vivan tu asignatura y todo lo que la rodea con tanta alegría y motivación. De verdad, de corazón, enhorabuena por tu labor y por la huella que dejas en ellos, es un placer tener docentes con tu nivel profesional y personal. (CE1CF5Y, p. 3)

Por todo lo expuesto, los alumnos no dudan al afirmar que les gustaría continuar teniendo la misma profesora en próximos cursos. 
P- ¿Os gustaría tener la misma profesora el próximo año?

As- ¡Śíii! (todos). ¡Muchísimo!

$\mathrm{P}-$ ¿No me voy a la clase de al lado?

As- ¡Nooo! (EG1CAsC, p. 5)

A54- ¡Ah!, que para todos los años estés tú de profesora.

A57- ¡Eso!

$\mathrm{P}$ - ¿También queréis que esté con vosotros?

As- ¡Sí!

$\mathrm{P}$ - Ya veremos qué se puede hacer.

A54- ¡Hasta que te jubiles aquí! (EG2CAsB, p. 31)

$\mathrm{E}$, incluso, que les gustaría seguir manteniendo contacto conmigo durante el verano.

Hemos visto el cartel que hay en la puerta anunciando un campamento de verano de música y me ha preguntado mi hijo si tú irías, porque dice que, si tú vas, se apunta, pero que si no, no. (DPY, p. 3)

\subsubsection{Relaciones entre los propios alumnos}

En el conjunto global de relaciones interpersonales que se producen en un centro educativo son de particular importancia las que establecen entre sí los propios alumnos (Llorent \& López, 2012). Somos conscientes de que cuidar dichas relaciones es prioritario para crear un clima propicio, por lo que hemos puesto especial énfasis en que los alumnos estuvieran a gusto con sus compañeros.

Muy a gusto, porque todos son muy majos. (CA1C, pre. 9)

A6- Yo me siento alegre porque todos mis compañeros me apoyan y a mí me gusta venir mucho al conservatorio porque mis compañeros juegan conmigo y me lo paso muy bien. (EG1CAsA, p. 6)

F62- Ella se siente a gusto en su clase y muy a gusto con su clase. [...] Yo veo que a mí que más me da ir con unos compañeros que con otros, pero ellos ya tienen sus relaciones y está a gusto. (EG2CFs, p. 22)

F75- Yo la observo que bien, nunca le he oído ninguna queja y, luego, cuando vengo a recogerla, me fijo si sale con alguna amiga y sí que la veo que se relaciona bien con otras niñas o niños que salen de aquí de la clase, y no se queja de nada en absoluto. (EG2CFs, p. 21)

Se han cogido tanto cariño que les gustaría seguir estudiando juntos, manteniendo el mismo grupo durante el próximo curso. 
$\mathrm{P}-$ ¿Os gustaría mantener la misma clase?

As- Sí.

P- ¿Con los mismos compañeros?

As- Sí.

P- ¿La misma profesora?

As- ¡Sí!

P- ¿No me voy a la clase de al lado?

As- No (sonriendo). (EG2CAsD, p. 23)

A33- Sí, seguir con el mismo grupo y con la misma profesora.

As- ¡Sí!

A34- ¡Sí, Elena, no nos cambies!

A40- ¡Eso molaría mogollón, macho! (EG1CAsC, p. 28)

Para conseguirlo, hemos ido fomentando en el aula, poco a poco, la amistad y el respeto entre todos los alumnos (Alcáraz, 2000).

P- ¿Qué creéis que os ha podido ayudar a sentiros a gusto con vuestros compañeros?

A74- Conocernos más, hacernos más amigos y estar más en clase juntos, que también afecta. (EG2CAsD, p. 7)

$\mathrm{P}-$ ¿Y a qué creéis que se debe que os llevéis bien entre vosotros?

A57- Pues no sé, porque nos hemos conocido.

As- (Hablan todos a la vez).

$\mathrm{P}-\mathrm{De}$ uno en uno, de uno en uno, por favor.

A55- Porque hay buena comunicación entre nosotros. (EG2CAsB, p. 19)

Para el establecimiento de unas buenas relaciones, también resulta fundamental la realización de actividades grupales y el fomento del compañerismo (Llorent \& López, 2012).

E- Lo individual es necesario, no cabe duda, pero, si no va precedido de mucho trabajo desinhibido de grupo, se hace difícil. (EEx3, p. 41)

F50- Influye mucho también el compañerismo que tengan, la persona que está a tu lado. (EG2CFs, p. 21)

E- Cuando el trabajo es muy de equipo, ellos te ven a ti como la persona que les está ayudando, que está trabajando con ellos y que está buscando la mejor manera para su aprendizaje. Que entre ellos también, en un momento dado, tú dices: "Oye, ayuda a Fulanito en este tema que a ti se te da muy bien y él está teniendo un problema. Ayúdale mientras yo hago no sé qué". (EEx3, p. 54)

Ello justifica que hayamos potenciado la colaboración y el trabajo en equipo, lo cual se ha conseguido con resultados óptimos. 
Me encanta ver cómo se apoyan y se ayudan los unos a los otros. Más que compañeros, son un grupo de amigos. No se aprecia competitividad entre ellos, sino colaboración. (DPA, p. 3)

A71- Cuando tú explicas algo u otro compañero corrige un ejercicio y a mí no me ha dado tiempo a corregirlo, si pido que lo vuelvan a repetir, no se enfadan y lo repiten. (EG2CAsD, p. 7)

A55- Si estás en grupo, tienes que pensar algo que a los demás también les guste, no a ti solo. (EG2CAsB, p. 19)

P- ¿Y por qué creéis que hay buena comunicación? ¿Hay alguna cosa que hagamos aquí que creáis que ayuda a eso?

A55- Sí, hacer cosas en grupo.

A58- Sí.

A57- Cariño. (EG2CAsB, p. 19)

Este clima de confianza ha permitido que perdieran el miedo a equivocarse delante de sus compañeros, considerando los errores como elementos naturales del proceso de aprendizaje (Ristad, 1997, citada por Maxwell, 2000).

P- ¿Y cómo os sentís aquí, en esta clase?

A75- Muy a gusto porque estás con todos tus compañeros y, si te equivocas, pues no te van a criticar, porque ellos saben que también alguna vez lo pueden hacer mal.

P- O sea, que tú te sientes cómoda con tus compañeros.

A75- Sí.

P- No sientes que se metan contigo.

A75- No.

P- ¿Y no te importa, entonces, equivocarte delante de ellos?

A75- No. (EG2CAsD, p. 6)

Incluso, las buenas relaciones establecidas han hecho posible que los alumnos se corrigieran los unos a los otros, realizándose críticas constructivas que eran bien aceptadas.

P- Cuando alguien se equivoca, ¿sentís que los compañeros se meten con vosotros o que os corrigen para que podáis aprender?, ¿cómo os sentís? Lo decimos con la mano levantada, que si no...

A31- Que nos corrigen para aprender, no bruscamente, porque son unos amigos que quieren que aprendamos lo mismo que ellos y que no nos estemos equivocando siempre.

P- ¿Pero tú no percibes que se metan contigo?

A31- No.

P- Tú sientes que te corrigen para que lo aprendas.

A31- Sí. (EG1CAsC, p. 11) 


\subsubsection{Relaciones con las familias y su implicación educativa}

La implicación y la colaboración de las familias es un pilar fundamental en el que debe apoyarse el proceso de aprendizaje de los alumnos (Domínguez, 2010; Forest \& García, 2006), de ahí que se convirtiera en otro de los objetivos de esta tesis.

Para conseguirla, resulta imprescindible establecer unas buenas relaciones y conocer su opinión (Comellas, 2009), la cual consideramos muy relevante en la mejora del proceso educativo. En este sentido, los padres han agradecido que les hayamos mantenido informados y que hayamos contado con ellos desde el principio.

A principio de curso, realizo siempre una reunión con los padres de mis alumnos para comentarles la organización de la asignatura, la forma de trabajo y los materiales que vamos a utilizar. El lunes cité a los padres de los alumnos de segundo de las enseñanzas elementales y el martes a los de primero. (DPS, p. 3)

Gracias por tus correos informativos y por mantenernos al tanto de las actividades y progresos de nuestros hijos en tu asignatura. De verdad que es un placer poder colaborar con profesores tan implicados y motivados en su trabajo. Consigues que a los niños les guste la asignatura, a pesar de la exigencia y dificultad. (CE1CF5J, p. 1)

Han valorado muy positivamente ser escuchados y tenidos en cuenta porque, desgraciadamente, no es algo común en las enseñanzas de régimen especial, como es el caso de los estudios musicales.

P- Muchísimas gracias por venir y por esta contribución.

Fs- A ti, a ti.

F37- Y a ti por preguntarnos, porque vuelvo a decir lo mismo: a mí es la primera vez que me preguntan.

F5- Para saber lo que piensas.

F37- Sí. (EG1CFs, p. 32)

Además, les tranquilizaba saber que la profesora era cercana y que estaba disponible en todo momento para aclarar sus dudas y compartir sus inquietudes (Benso \& Pereira, 2007; Comellas, 2009).

Escribí un e-mail a todos los padres comentándoles la importancia de que los niños hicieran esta actividad despacio y siguiendo uno a uno los pasos indicados, y ofreciendo mi ayuda para responder a todas las dudas que les fueran surgiendo al respecto. (DPO, p. 5) 
Me alegra haber hablado contigo y que me comentaras en primera persona cómo veías a A57. Como hemos hablado, se está enganchando y espero que siga así y progrese poco a poco durante el curso para poder superarlo. Por tus comentarios, he podido ver que has captado bien la personalidad de A57 y así poder ayudarlo en clase. Por mi parte, tienes mi apoyo en cualquier actividad que el niño tenga que realizar en casa. Estoy pendiente de su evolución y sus deberes. (CE2CF57D, p. 1)

Por otra parte, cuando un niño desarrolla una actividad es importante que trascienda a la familia, porque eso une y enriquece, hace más motivador el estudio y contribuye a establecer mejores relaciones entre los padres y los hijos (Domínguez, 2010; Forest \& García, 2006).

En este sentido, debemos tener presente que, aunque sean autónomos trabajando, a los niños les gusta compartir sus aprendizajes con sus padres y hermanos, ya que les ayuda a sentirse acompañados en sus dificultades y valorados en sus logros.

F- Pues, mira, él lo que hace más bien es aprovechar que yo sé, pero yo tener que explicarle... (niega con la cabeza), es decir, él ha aprovechado que yo me puedo sentar con él y tomarle la lección, pero lo que él ha ido aprendiendo lo ha aprendido en clase. O sea, yo no he tenido que estar sentándome con él y diciéndole: "A ver, ¿qué es un silencio?, ¿cuántos hay?" Es la otra parte, es: "Quiero que mi madre me tome la lección", digamos.

P- Que esté conmigo al lado.

F- Eso es, pero yo no he tenido que explicarle nada. (E1CF24, p. 3)

Al mismo tiempo, hay que considerar que los padres disfrutan conociendo lo que están estudiando sus hijos y aprendiendo con ellos.

F61- Estoy aprendiendo mucho yo también. Cuando él está entonando, yo voy leyendo y digo: “ $\mathrm{J}$ o, va a toda pastilla, no le sigo!”, y estoy aprendiendo este año. (EG2CFs, p. 10)

F- Es para nosotros algo nuevo y nos vemos aprendiendo también con ella. Nos ha ayudado a abrirnos también a escuchar diferentes estilos de música, a aprender nuevo vocabulario y no sé qué más. Que todo en positivo, todo en positivo. (E1CF19, p. 1)

P- ¿Tú trabajas con ella en casa?

F- Sí, lo hacemos las dos juntas todo. Bueno, si yo la dejo, ella se pone el CD y lo haría sola, pero a mí me gusta hacerlo con ella, así lo compartimos y luego puedes hablar, o viene de clase y dice: "Pues esto lo hemos hecho así". Y me parece que, aparte de tenerlo aquí, es un nexo de unión en casa. (E1CF2, p. 2) 
F- No siempre los niños aprenden de los padres, sino también nosotros de los niños y, en este caso, nos está pasando, ¡es muy bonito! (E1CF19, p. 3)

\subsubsection{Relaciones de la profesora y otros docentes del centro}

Cuando un docente emprende acciones educativas innovadoras pueden surgir discrepancias entre los propios compañeros (Miralles, Maquilón, Hernández, \& García, 2012). Tal ha sido nuestro caso, ya que se han generado situaciones incómodas que han complicado mis relaciones personales y profesionales con algunos profesores del centro.

No he sentido el apoyo de varios de mis compañeros y la situación me ha generado gran malestar. (DPD, p. 4)

Dada la ilusión manifestada por los alumnos, quizá me anime a preparar algo, pero necesito dejarlo reposar, porque los compañeros que no comparten mi método pueden aprovechar dicha circunstancia para seguir enjuiciando mi manera de trabajar. No me apetece seguir exponiéndome a sus comentarios, pero también reconozco que sería una actividad muy positiva para los alumnos. (DPD, p. 7)

No obstante, contábamos con el apoyo de varios compañeros, lo cual me ha ayudado a trabajar más tranquila y a seguir adelante con nuestras propuestas.

La forma de contactar con los compañeros fue más directa, ya que hablé personalmente con ellos, y todos mostraron también buena predisposición por colaborar conmigo. (DPF, p. 2)

Ya sabes que tienes todo nuestro apoyo, aunque sé que es difícil seguir adelante cuando te ponen obstáculos. Tú sigue dedicándote a los alumnos, que son los que importan. (CETPiJEF, p. 4)

T- Cuando dicen, a veces, con ciertas cosas, que eso está estudiado y que se ha visto que eso no funciona, pues que me demuestren a mí que el hecho de que el niño se divierta, que el niño empiece a componer... que me demuestren a mí dónde no funciona eso o por qué no, porque, a lo mejor, no te puede funcionar a ti, pero al de al lado sí. Entonces, no es que no funcione, es que a un profesor no le funciona y a otro sí. (ETV, p. 11)

T- Que tú ahora estés haciendo esto es muy importante, porque estás introduciendo una novedad y estás abriendo la posibilidad de que la gente abra los ojos hacia otras cosas o formas de hacer. (ETGD, p. 3)

\subsection{El correo electrónico como facilitador de vínculos afectivos}

Terminaremos este apartado señalando que un recurso clave para la mejora de las relaciones entre los alumnos, los padres y la profesora ha sido el 
contacto a través del correo electrónico durante todo el curso, ya que ha posibilitado mantener una comunicación continuada y fluida.

Agradecemos mucho la cercanía que nos has mostrado y la posibilidad que nos brindas de comunicarnos contigo a través del correo electrónico, aparte de las tutorías. (CE1CF16S, p. 1)

P- ¿Y os gusta que nos hayamos estado comunicando por correo electrónico?

As- ¡Sí, sí! ¡Mola mucho! (EG2CAsB, p. 5)

P- $¿$ Y cuando no lo entiendes mucho te vas a casa con la duda?

A69- No pero, si luego se me olvida, te lo pregunto por $e$-mail. (EG2CAsD, p. 8)

La inmediatez de las respuestas ofrecidas por la profesora para solucionar las dudas que les iban surgiendo ha sido muy bien valorada y agradecida.

A54- Yo pienso muy bien de ti porque si, por ejemplo, te mandamos un mensaje, lo miras enseguida.

A58- ¡Sí! (sonriendo).

A54- Me dijo un día la madre de A52: “¡Anda, pero si lo mira con el móvil! Ella tiene que estar todo el rato con el móvil, porque lo contesta muy rápido y te resuelve todas las dudas".

$\mathrm{P}$ - Cuando me escribes por correo electrónico, dices.

A54- Sí. (EG2CAsB, p. 21)

P- ¿Qué opináis de la comunicación que hemos tenido vía $e$-mail?

F1- ¡Ah, fantástico, fantástico!

F5- ¡Fantástico!

F29- ¡Y de una inmediatez...! Yo me preguntaba, ¿de dónde sacará tiempo

Elena para mandarnos inmediatamente la respuesta?

F25- Sí, demuestra una dedicación, por tu parte, grande. (EG1CFs, p. 33)

Y es que estamos convencidos de que un docente solo puede pedir esfuerzo y dedicación a los alumnos y a sus familias si él mismo está dispuesto a implicarse en la misma medida (Comellas, 2009).

F25- Los fines de semana yo estaba sorprendida: "Elena está conectada ¡¿a qué hora?!" Sí, es verdad.

F26- Sí, porque pone: "Hace nueve horas" en el mensaje, o sea, ¡sabemos a qué hora lo has mandado!

Fs- (Ríen). [...]

P- Es que, cuando se pide, yo creo que es obligación del docente responder, y yo sé que cuando uno hace un trabajo necesita ver la respuesta. Entonces, yo no puedo pediros que estéis, si yo no estoy, eso lo tengo muy claro. (EG1CFs, p. 33) 
Finalmente, podemos afirmar que el correo electrónico ha servido de cauce para estrechar lazos y establecer un trato más cercano, porque ha sido utilizado en varias ocasiones para enviar mensajes al margen de las tareas u obligaciones académicas.

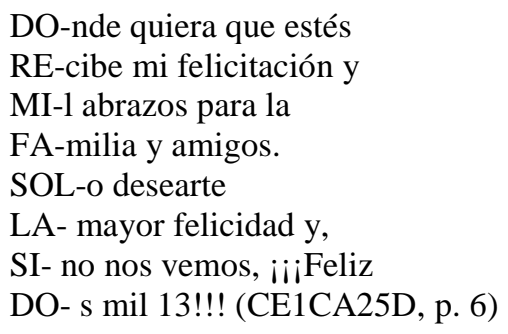

Gracias Elena, todo correcto, eres incansable, ¡qué suerte de "profe"! (CE2CA46M, p. 6)

\section{Exhibición de trabajos}

Todo músico debe aprender a dominar el escenario y disfrutar de sus interpretaciones, controlando la ansiedad que pueda generarle el hecho de exponerse ante un público que, inevitablemente, emitirá juicios sobre las mismas (Balsera \& Gallego, 2010; Dalia, 2004; Studer et al., 2011). Para ello, es necesario familiarizar a los alumnos con dicha situación desde pequeños, a lo cual contribuímos desde la clase de Lenguaje Musical realizando diariamente interpretaciones individuales y grupales de distinta índole.

En este último apartado del capítulo, veremos cómo la presentación contínua de las creaciones de los propios alumnos ante sus compañeros de clase les ha ayudado a ganar confianza, a interiorizar el protocolo artístico para la puesta en escena y a perder el miedo ante las críticas. Asimismo, comprobaremos lo motivador que les ha resultado decorar el aula con sus trabajos y mostrarlos al resto de la comunidad educativa a través de exposiciones y representaciones escénicas.

\subsection{Exposición en el aula de las creaciones de los alumnos}

La ansiedad escénica, a la que hemos dedicado el apartado 3.3 de este capítulo, es una forma de ansiedad social específica, pues ocurre solo en los "escenarios". No obstante, por escenario no entendemos solo el lugar físico del teatro o el auditorio del conservatorio, sino cualquier contexto en cual se nos pueda valorar o juzgar (Dalia, 2004). 
La ansiedad escénica en músicos es la que se sufre sobre todo encima del escenario ante una actuación, bien sea concierto, audición o exámenes, pero también se genera cuando se hacen interpretaciones en clase ante profesores y compañeros.

Dicha ansiedad puede observarse en los alumnos desde sus inicios en los estudios musicales y, si no se trata adecuadamente, irá aumentando a lo largo de los mismos.

$\mathrm{P}-$ ¿Y te dio vergüenza cantar delante de todos?

A17- Demasiada. Los cinco minutos de antes estaba sudando la gota gorda.

Tenía que estar así con la camiseta (hace el gesto de limpiarse la cara). Igual que en la audición de percusión, así, ¡qué calor!

P- ¿Sentiste los mismos nervios que cuando actúas solo en percusión?

A17- Sí.

P- ¿Sí? Esos son los nervios de antes pero, una vez que lo has hecho, ¿cómo te sientes?

A17- Ya me relajé.

$\mathrm{P}-$ ¿Y mientras lo hacías?

A17- Nervioso.

P- ¿También?

A17- Sí. (EG1CAsB, p. 26)

$\mathrm{P}-i \mathrm{Y}$ a ti te dio vergüenza cantar sola delante de todos?

A75- Un poco, estuve un poco nerviosa. (EG2CAsD, p. 22)

A23- Cuando no conoces a tus compañeros te da vergüenza.

A17- El primer día que cantas te da más corte. (EG1CAsB, p. 10)

Por lo tanto, es importante prestarle atención desde el primer momento, para que no suponga un problema más difícil de tratar a posteriori (Dalia, 2004; Kenny, 2008; Osborne, Kenny, \& Holsomback, 2005) y poder reducirla progresivamente.

F70- Sé que es muy tímida y que, a lo mejor, le cuesta, pero también es verdad que esto les ayuda a ponerse delante de la gente y a quitarse sus miedos. (EG2CFs, p. 18)

F62- Eso es terapia para los niños tímidos. [...] A mí me parece que es defender tu trabajo de compositor y, además, hacerlo delante de la gente, perder tu miedo y decir: “iPues esto lo he hecho yo!” (EG2CFs, p. 16)

Veamos cómo hemos conseguido reducirla en el aula mediante de la exhibición de los trabajos realizados por los alumnos. 


\subsubsection{Motivación hacia la presentación de trabajos en clase}

Como hemos señalado en anteriores capítulos, consideramos que nuestra mayor aportación en este estudio ha sido enseñar a los alumnos a crear sus propias canciones y que, el hecho de interpretarlas posteriormente ante sus compañeros, les ha ayudado a ganar confianza y seguridad en sí mismos, así como a perder el miedo a equivocarse al actuar en directo.

A41- Yo me siento bien. No tengo nada de vergüenza, porque estoy acostumbrado a que mis compañeros me oigan. (EG1CAsF, p. 24)

P- ¿Cantar delante de tus compañeros te gusta?

A18- Sí, ya sí. Al principio me daba un poco de vergüenza. (EG1CAsB, p. 10)

$\mathrm{P}_{-} \mathrm{Y}$ os da la misma vergüenza cantar ahora que a principio de curso, más o menos?

A40- Ahora menos, mucho menos.

As- Menos.

P- ¿Y por qué os da menos vergüenza?

A26- A mí menos porque ya los conoces mejor y ya te sientes... (se queda bloqueada).

P- ¿Más cómoda?

A26- Más cómoda.

A34- Sí, más encajada en el grupo. (EG1CAsC, p. 26)

Además de cumplir su objetivo de desinhibición, dicha actividad ha sido altamente motivadora para ellos, sirviendo de estímulo hacia el aprendizaje.

P- ¿Os gustan las canciones de vuestros compañeros?

As- Sí.

A63- ¡Te crees muy coqueto con la canción!

$[\ldots]$

P- Y cuando tenéis que salir aquí en clase a cantarlas delante de vuestros compañeros, ¿qué me decís de eso?

A63- ¡Es lo más chulo de la clase! (EG2CAsB, p. 23)

Dicha motivación estaba impulsada por el hecho de que, al cantar, podían enriquecer la puesta en escena con todo aquello que cada cual estimara conveniente, permitiéndoles hacer uso de su creatividad, como hemos visto a lo largo de la tesis.

P- ¿Qué es lo que te gustaba de hacer canciones en casa?

A35- Que podíamos ponerles nombre de animales y que también, además de inventarlas, podíamos traernos algo para representarlas.

P- ¿Te gustaba cantar así en clase con una puesta en escena diferente?

A35- Sí. (EG1CAsF, p. 10) 
A75- A mí también me gusta mucho componer las canciones en casa y luego salir aquí a cantarlas llevando algo o trayendo algo para cantar. P- O sea, que te gusta hacer algo para completar tu actuación. A75- Sí. (EG2CAsD, p. 5)

\subsubsection{Interiorización del protocolo artístico en escena}

En las interpretaciones escénicas ante un público, se debe seguir un cierto "protocolo artístico" que incluye: salir al escenario con calma, colocarse sin prisa, controlar los nervios durante la interpretación y saludar correctamente antes y después de cada actuación (Balsera \& Gallego, 2010). Todo ello constituye un aprendizaje necesario para los músicos.

Les he intentado hacer ver que todo artista tiene que lucirse en el escenario y que no sirve de nada hacer una canción muy bonita si luego la cantan mal y no tienen una buena presencia, así que hay que cuidar la puesta en escena. (DPO, p. 9)

En nuestro estudio, al actuar en clase con tanta frecuencia, hemos conseguido que los alumnos hayan interiorizado dichas pautas para la puesta en escena, a pesar de que, al principio, a algunos les daba vergüenza y no eran muy rigurosos en su seguimiento, por lo que su actuación perdía calidad.

P- ¿Y a vosotros os gusta, cuando estáis aplaudiendo a vuestros compañeros, que el compañero al que estáis aplaudiendo os salude?

A57- Sí.

A63- Hay veces que no lo hacen, ¡se van corriendo por ahí!

A58- ¡Sí! (riendo).

A63- ¡Será por vergüenza!

$\mathrm{P}-$ ¿Os da vergüenza saludar a vuestro público?

As- (Se levantan dos alumnos y se inclinan saludando).

A58- Es que da un poco... (sonriendo).

A57- ¡Da un poco de "yuyu”! (riendo).

A54- A mí ya no me da "yuyu”. (EG2CAsB, p. 24)

\subsubsection{Aceptación de críticas constructivas}

Una vez que se ha conseguido establecer un clima de confianza y de compañerismo en el aula, nos encontramos en una situación propicia para fomentar el pensamiento crítico ante las produciones musicales propias y ajenas (Bernardini, 2010).

$\mathrm{Al}$ respecto, comprobamos que a nuestros alumnos les gustaba que tanto su profesora como sus compañeros fueran sus jueces y valorasen sus interpretaciones. 
$\mathrm{P}-$ ¿Y te sientes cómoda cantando delante de ellos?

A34- Sí, porque luego dan su opinión de si lo he cantado bien o no.

P- ¿Cómo dan su opinión?

A34- Aplaudiendo. Si lo hemos hecho mal, un aplauso (da una sola palmada); si lo hemos hecho muy bien, muchos aplausos (aplaude mucho); $\mathrm{y}$, si lo hemos hecho regular, tres (da tres palmadas). (EG1CAsC, p. 26).

P- Y aquí, cuando cantáis delante de los compañeros, ¿cómo os sentís? A69- Yo me siento a gusto con los compañeros cuando canto, porque no se ríen y, si se ríen, es por una cosa graciosa, y te aplauden cuando terminas. $\mathrm{P}-i \mathrm{Y}$ eso te gusta?

A69- Sí. (EG2CAsD, p. 23)

Igualmente, a pesar de que algunas de sus canciones tuvieran errores, los alumnos disfrutaban mucho cuando se proyectaban en las paredes del aula para que todos pudieran verlas y comentarlas, ya que dichos errores y comentarios constructivos se interpretaban como una fuente de aprendizaje y no como una crítica a su trabajo.

P- Oye y, cuando hacéis las canciones de casa, ¿os gusta después que vuestros compañeros vean la canción proyectada en la pared, el trabajo que habéis hecho, y que os escuchen cantarla, a ver cómo la habéis hecho?

As- ¡Sí, sí! (sonriendo).

P- ¿Por qué os gusta?

A26- Porque así ven lo que has hecho.

A33- Sí, porque ven los errores que has tenido y que te has equivocado, y te gusta que la gente vea lo que has hecho y cómo te has esforzado en hacerlo. (EG1CAsC, p. 26)

P- ¿Y que proyectemos las canciones en la pared para que vean los errores que has tenido te gusta?

A74- También, porque así los puedo corregir.

$\mathrm{P}$ - ¿A ti no te importa que los compañeros vean en qué has fallado?

A74- No

P- ¿Por qué?

A74- Porque así puedo aprender de lo que me dicen. (EG2CAsD, p. 4)

\subsubsection{Decoración del aula con los trabajos realizados}

A medida que avanzaba el curso, el aula de Lenguaje Musical estaba cada vez más decorada, porque la íbamos adornando con los trabajos que realizaban los alumnos. De esta manera, conseguimos que les resultara más acogedora y que la sintieran más suya (Navarrete, 2009).

A74- Que es muy bonita porque está decorada con cosas que han hecho los compañeros, que son muy bonitas y tienen muchos colores. (EG2CAsD, p. 22) 
A2- A mí me parece muy bonita, porque está muy adornada, y muy divertida, porque tiene nuestros trabajos y cosas que hemos hecho, que nos hemos esforzado en hacerlas y que quedan muy bien y adornan muy bien la clase. (EG1CAsA, p. 18)

$\mathrm{P}-$ ¿Os gusta que estén vuestros trabajos o no los pongo?

As- ¡Sí!

A45- Esto es una clase abstracta. Sale un muñeco de nieve, un sol, unas gafas con un bigote que es el acueducto... (EG2CAsA, p. 31)

El hecho de que sus trabajos quedaran expuestos en el aula les animaba a hacer más y a esforzarse por realizarlos lo mejor posible.

P- ¿A ti el hecho de que estén los trabajos puestos te anima a hacer más?

A4- Sí. (EG1CAsA, p. 18)

P- ¿A ti te gusta que estén tus trabajos puestos por la clase?

A74- Sí.

$\mathrm{P}-$ ¿Y de tus compañeros?

A74- Sí.

P- ¿Te anima a hacer más?

A74- Sí. (EG2CAsD, p. 22)

$\mathrm{P}-i \mathrm{Y}$ eso te gusta, poder después completar tu actuación en clase?

A58- Sí, porque luego lo dejamos por la clase y queda decorado.

A63- Sí, dices: “¡Mira, ese es el mío! ¡Mira qué guay mi dibujo!, ¿a que sí?” (EG2CAsB, p. 23)

P- El hecho de que expongamos los trabajos de los alumnos, ¿creéis que les está motivando a hacer más?

F62- Sí.

F75- Sí, porque es lógico, ¿no?, ven lo que ellos han hecho y lo ven ahí puesto. Yo estoy viendo ahí algo que ha hecho la mía y, entonces, yo supongo que, cuando ella lo vea, le animará. (EG2CFs, p. 27)

Además de motivarles, los dibujos, fotografías, canciones, refranes, manualidades y demás trabajos de los alumnos repartidos por las paredes del aula les permitían recordar las actividades realizadas.

A21- Es como un recuerdo y queda bien porque tú dices: "Pues mira, eso lo hice yo". Me gusta recordar que hice eso y lo hice bien. (EG1CAsB, p. 24)

A16- Nos hemos esforzado en hacer esos dibujos y queda bien tener un recuerdo de cuando has estado con los compañeros y con tu profesora cantándola. (EG1CAsB, p. 24)

A75- Así decoramos más la clase y podemos enseñar todas las cosas que hemos hecho nosotros. (EG2CAsD, p. 5) 


\subsection{Presentación de trabajos a la comunidad educativa}

Consideramos que los trabajos de los alumnos eran tan bonitos y estaban tan bien hechos que no podían quedarse en el aula y vimos la necesidad de compartirlos con el resto de la comunidad educativa (Navarrete, 2009).

No sé cómo, pero tengo que plantearme la forma de presentar al público los trabajos de los niños, ya que están muy bien hechos y merece la pena que se conozcan. Además, la ilusión y la facilidad que tienen al realizarlos demuestran que la metodología que empleo es válida y de buena calidad. (DPD, p. 6)

Por ello, decidimos organizar una exposición por los pasillos del centro y preparar un teatro-audición que mostrara nuestra forma de trabajar.

\subsubsection{Exposición por los pasillos del centro}

A mitad de curso, realizamos una exposición por los pasillos del conservatorio con algunas de las composiciones creadas por los alumnos a partir de distintos refranes y canciones que les sirvieron de modelo.

Dicha exposición nos permitió mostrar los trabajos de los alumnos para que se conocieran, ya que todo el que pasaba por allí se acercaba a verla.

P- ¿Vosotros habéis visto a gente viendo las canciones?

A18- Sí, a muchísima.

A21- Hay gente que, por ejemplo, no sé, alguna profesora, que se ha parado ahí a verlo.

A17- Padres que estaban esperando a niños lo veían.

A16- Y niños que esperaban a padres, también. (EG1CAsB, p. 24)

A43- ¡La gente se ponía a cantarlos cuando pasaban! [...]

P- Entonces, ¿veíais a la gente cantarlas por los pasillos?

As- Sí.

A45- Mi hermano está todo el día cantando.

A43- ¡La mía ha tenido éxito! (EG2CAsA, p. 31)

A38- A mí me ha parecido que has tenido una buena idea porque los padres y los otros compañeros, los de las otras clases, han podido ver lo que han hecho los otros compañeros y los hijos.

P- ¿Tú veías a padres, o a profesores u otros niños viendo los trabajos?

A38- Sí.

A39- Yo a muchos. (EG1CAsF, p. 23)

A toda la comunidad educativa le sorprendió que hiciéramos una exposición de Lenguaje Musical, pero, en general, resultó interesante y gustó mucho. 
P- ¿La exposición la has visto?

T-Sí.

P- Y, de los trabajos que hemos puesto por ahí con los acordes, con la melodía, las notas de paso..., ¿qué opinas?

T- Muchos me sorprendieron. Por ejemplo, el de alguno de mis alumnos o el de El astronauta que toca la flauta. ¡Me encantan! (ETPer, p. 6)

Los trabajos que habéis expuesto por los pasillos son muy interesantes. A22 estaba encantada de buscar el suyo. (CE1CF22F, p. 8)

Sin duda, los que más disfrutaron con ella fueron los propios compositores, ya que consideraban que había quedado muy bien y se sentían orgullosos de que los padres, profesores y otros alumnos la vieran.

P- ¿Y qué opináis de la exposición que pusimos por los pasillos?

A21- ¡Ah!, ¡genial!

A17- ¡Muy bien!

A18- ¡Preciosa! Porque así la podían ver los padres y la podía ver mucha gente. (EG1CAsB, p. 24)

A63- La gente decía: “¡Qué canción más bonita! ¿La has escrito tú?”. Y yo respondía: "Sí”. Y decían: “QQué bien escribes!” Y te quedabas muy contento de que te dijeran eso. (EG2CAsB, p. 28)

A41- A mí lo que me gustó es cuando pusiste algunos de nuestros trabajos por las paredes para que los viera la gente y vieran cómo hemos trabajado, los trabajos que hemos hecho. (EG1CAsF, p. 23)

Además de mostrar sus trabajos, la exposición permitió a los alumnos conocer lo que habían hecho en otras clases y cursos.

P- ¿Qué pensáis de la exposición que hemos tenido puesta por los pasillos durante buena parte del curso?

A7- Me parece que has tenido muy buena idea porque son nuestros trabajos y también porque podemos ver cómo lo han hecho en otras clases y las canciones que han creado, y podemos cantarlas y mirar qué bien lo han hecho. (EG1CAsA, p. 18)

A71- A mí cuando has pegado las canciones y los refranes en las paredes del pasillo me ha interesado porque podías ver las canciones de los demás compañeros y de la demás gente de otras clases, porque no ha sido solo la gente de esta clase, sino que ha habido más gente de más clases que ha hecho también refranes y canciones, y es muy interesante ver las canciones de los demás. (EG2CAsD, p. 10)

F- Los primeros días, sobre todo, decían todos: "Mira, esta la ha hecho no sé quién, esta la he hecho yo, esta no sé cuántos..." Estaba muy contenta, les ha gustado. (E2CF79, p. 2) 
A28- Me ha gustado porque has visto el trabajo que han hecho otros que eran más mayores que tú y que tú lo vas a hacer el curso que viene y te gustaría aprenderlo. (EG1CAsC, p. 25)

Y, sobre todo, sirvió para demostrar que se pueden hacer actividades diferentes a las tradicionales en la asignatura de Lenguaje Musical.

A23- Niños que vienen nuevos dicen: “iHala!, ¿quién hizo eso?”

A16- Pues, por ejemplo, si tú vienes nuevo y piensas que en primero o en segundo no se aprende mucho, pues tú ves eso y te das cuenta de que se aprende más de lo que piensas. (EG1CAsB, p. 25)

\subsubsection{Teatro-audición sobre nuestra forma de trabajar}

Coincidiendo con la exposición de los pasillos, en el mes de febrero realizamos un teatro-audición para poder mostrar desde el escenario del auditorio cómo trabajamos en clase de Lenguaje Musical.

P- ¿Qué os pareció que hiciéramos una audición de Lenguaje Musical? A69- Me pareció muy bien y muy bonita para que la gente sepa lo que hacemos en clase, lo que trabajamos.

A75- A mí también me pareció muy divertida porque la gente aprendió lo que nosotros aprendemos y, además, nosotros fuimos los que enseñamos a los que nos veían las cosas que nosotros aprendemos en clase. (EG2CAsD, p. 22)

F- Me pareció bastante instructiva, que decía bastante claro cómo es la forma de trabajar de los chicos en clase y cómo participan en ella. A mí me gustó. (E2CF79, p. 2)

A38- A mí me ha parecido que has tenido una buena idea y que fue muy bonita. Que los compañeros vean lo que hacemos en clase es una buena idea. (EG1CAsF, p. 24)

A pesar de tener que mover y coordinar a alumnos de siete grupos distintos, organizar la representación fue bastante sencillo, porque se trataba de reproducir una clase ordinaria de Lenguaje Musical y los alumnos tenían muy cogida la dinámica de trabajo en el aula.

Además, a pesar de contar con muy pocos ensayos, está resultando muy fácil montarlo todo, porque tienen muy asimilada la dinámica de trabajo en el aula y dominan perfectamente los contenidos que hemos trabajado. (DPE, p. 4)

P- ¿Y de la audición que hicimos qué me contáis?

A18- ¡Preciosa!

A17- ¡Impresionante! 
P- ¿Por qué preciosa? (dirigiéndose a la alumna 18).

A18- Porque es como estar en una clase normal y así aprendía la demás gente que nos iba a ver. (EG1CAsB, p. 25)

La iniciativa resultó ser altamente motivadora y los alumnos estaban emocionados.

A63- ¡A mí me encantó esa audición!

A57- ¡Fue muy bonita! (EG2CAsB, p. 29)

A2 me dijo que estás preparando la audición y que estaba muy contenta, porque para la niña la audición es muy importante, que le hacía mucha ilusión. (ETV, p. 7)

Los niños están entusiasmados con la audición y eso me da mucha energía. (DPE, p. 4)

Y es que consideraban valioso lo que estaban haciendo en clase y sintieron orgullo al poder presentárselo al público.

A7- Tuviste una buena idea, porque así los padres saben lo que hacemos en Lenguaje Musical y se ponen orgullosos de nosotros. (EG1CAsA, p. 20)

F70- A nosotros nos ayuda a ver un poquito cómo trabajan, qué es lo que hacen, y yo creo que a ellos también les viene bien, porque hay un trabajo por su parte y se valora, o quieren que lo valoremos. Me parece interesante. (EG2CFs, p. 23)

Incluso, estaban convencidos de que podría servir para que más gente quisiera apuntarse al conservatorio.

A18- Que así nuestros hermanos pequeños o mayores o la gente que no se haya apuntado a alguna clase de música ven que aprendes mucho y les animas a que se apunten.

A20- Para animar a que se apunte al conservatorio mucha gente.

P- ¿Vosotros creéis que la gente se animaría a apuntarse viendo esa audición?

A18- Sí, mucha gente.

A21- Sí, se apuntarían a montones.

A18- Que una amiga me fue a ver y ahora se quiere apuntar, y quiere que la toque contigo para que lo haga. (EG1CAsB, p. 25)

F25- Mi hija, que tiene cuatro años, estaba en primera fila y dijo: “Mamá, yo quiero apuntarme a Lenguaje Musical!’. Bueno, pues sí, contagia un poco ver el ambiente ese.

F37- Sí, la mía pequeña también lo dijo; tiene cinco, pero también. (EG1CFs, p. 28) 
Por otra parte, la audición ayudó a los padres a conocer mejor el proceso de aprendizaje de sus hijos y a valorarlo más.

F70- Yo he tenido un conocimiento más próximo de lo que hacen en clase con lo que he visto en la audición. Si no la hubiese visto, bueno, pues lo poco que te cuenten, así es que me parece un punto a tu favor, en el sentido de que nos has ayudado a entender un poco qué es lo que hacéis y cómo lo hacéis. (EG2CFs, p. 23)

F29- Después de la actuación, todos tuvimos una idea diferente de lo que es la clase de Lenguaje Musical. (EG1CFs, p. 29)

La audición estuvo muy bien, nos quedamos maravillados del trabajo que realizas. (CE1CF17F, p. 6)

Asimismo, les ayudó a comprender que la exigencia del trabajo puede combinarse perfectamente con el entretenimiento y la diversión.

Queríamos darte la enhorabuena a ti y a todos tus alumnos por la actuación de esta tarde. Reconforta ver que el trabajo también llega a ser divertido. Nos ha gustado mucho. (CE2CF56F, p. 3)

He visto la audición y me ha gustado mucho. Haces fácil lo díficil. iiEnhorabuena!! (CE1CF29F, p. 2)

F- En la audición presentaste muchas cosas y creo que es una buena forma de trabajar. A mí también me gusta seguir un método, no me gusta la improvisación. A mí me gusta la forma porque veo que mi hijo aprende y que está motivado. (E2CF45, p. 4)

Gracias por ofrecernos la maravillosa oportunidad de comprobar cómo aprenden nuestros hijos en tu clase y ayudarnos a ver que la asignatura de Lenguaje Musical posee unos componentes de juego, destreza y autoexigencia que ayudan a nuestros hijos a adquirir los conceptos musicales. (CE1CF9F, p. 8)

En cuanto a la puesta en escena, los niños reconocen que se divirtieron mucho y que fue una actividad muy gratificante para ellos.

La audición fue genial, ¡me lo pasé muy bien! (CE2CA70F, p. 5)

A2- Me divertí muchísimo y me puse muy contenta, me encantó. Estuve ahí como si estuviera en mi casa en un momento muy importante y muy divertido. Me gustó mucho y estuve muy tranquila, la verdad. (EG1CAsA, p. 19) 
A4- A mí me pareció super-divertida porque fue como una clase de música para el público. A mí me gustó muchísimo. (EG1CAsA, p. 19)

A1- A mí me gustó mucho cuando salieron el floreo y la nota de paso.

$\mathrm{P}-i$ Te hizo gracia?

A1- Sí (sonriendo).

A7- Pues a mí me gustó mucho porque, además, tuviste la idea de que unos niños cantasen sus canciones y que otros pudiesen representar la canción, que yo hice de perro y a todos les hizo mucha gracia (sonríe).

A4- Cuando yo entré vestida de gato todo el mundo se rió (sonríe). (EG1CAsA, p. 20)

A21- Que a mí me hizo mucha gracia cuando la niña iba a apuntar lo de la pizarra y quitaron el papel y apareció ahí (ríe).

A13- (Ríe). Hicimos magia, ¿verdad?

A16- Muy bonita y muy divertida.

A18- ¡Y muy creativa! (EG1CAsB, p. 25)

Al público también le resultó una respresentación amena y entretenida.

P- ¿Estuvisteis en la audición que hicimos de Lenguaje Musical?

F- Sí, sí, estuvimos, estuvo muy bien. Nos ha gustado muchísimo. Vamos, como te estoy diciendo, algo nuevo para nosotros ¡y nos gusta muchísimo! (E1CF19, p. 2)

A4- Yo creo que al público también le gustó, porque mi hermano luego llegó a casa todo el rato cantando: "Perro ladrador..." (imitando la forma en que se hizo en la audición). (EG1CAsA, p. 20)

Enhorabuena también por la puesta en escena, que resultó extraordinariamente entretenida. (CE1CF9F, p. 8)

En la misma línea, la audición fue bien valorada por los profesores que asistieron a ella, quienes destacaron el buen trabajo realizado.

La actuación de tus alumnos fue muy original y se notaba que estaba muy bien preparada, eso es algo muy agradable de compartir. Yo te animo a que hagas más audiciones de Lenguaje Musical, me parece una idea genial y se te da muy bien. Prometo ir a verte con mis alumnos. (CETVF, p. 5)

Soy consciente de todas las felicitaciones que te están llegando. Están muy justificadas, ;enhorabuena por tu trabajo! (CETGDF, p. 5)

Quería felicitarte por tu gran trabajo. La verdad es que te lo curraste un motón y salió todo muy bien. ¡Hubo un lleno completo, cartel de no hay billetes! ¡Bravo! (CETPerF, p. 4) 
Enhorabuena por la actuación, disfruté mucho de la clase. ¡Ojalá a mí me hubiesen enseñado así el Lenguaje Musical! (CETOF, p. 6)

Finalmente, señalaremos que, al igual que pasó con la exposición, somos conscientes de que hacer teatros o audiciones en Lenguaje Musical no es habitual y que, posiblemente, ese sería otro motivo por el que llamó tanto la atención y fue tan bien recibida.

A44- Yo no pensé que en una clase así se hiciese un teatro y me llamó mucho la atención.

A52- A mí también. (EG2CAsA, p. 23)

F37- Yo he tratado mucho con músicos y trato mucho con músicos, y a una interpretación como la que hicisteis de Lenguaje Musical es la primera vez que asisto. Fue muy original y sorprendente porque nadie lo esperaba. (EG1CFs, p. 12)

Por ello, ante todos estos resultados positivos, deberíamos replantearnos la realización de más audiciones o actividades públicas desde nuestra asignatura, sabiendo que, además, contamos con la predisposición de los alumnos, a quienes les hubiera gustado hacer alguna más.

P- ¿La experiencia fue buena? ¿Os hubiera gustado hacer alguna más?

As- Sí.

A54- ¡Pero que yo sea la protagonista!

$\mathrm{P}-$ ¿Os gusta que la gente conozca las cosas que estamos haciendo en clase? As- Sí.

A61- Y que lo aprecien. (EG2CAsB, p. 30)

P- ¿Os hubiese gustado que hubiésemos hecho alguna audición más a lo largo del año?

As- ¡Síiii! (EG2CAsA, p. 23) 



\section{CAPÍTULO X: CONCLUSIONES}

\section{Introducción}

En esta tesis hemos partido del convencimiento de que la educación auditiva de los alumnos es el aspecto fundamental a la hora de formarles musicalmente, planteamiento en el que coincidimos con distintos autores y pedagogos consultados para la elaboración del marco teórico, pero también con varios de los expertos y docentes entrevistados. No obstante, tanto por parte del alumnado como del profesorado, es un proceso que resulta costoso.

Desde la asignatura de Lenguaje Musical, la formación auditiva se ha vinculado tradicionalmente a la realización de dictados musicales a una o dos voces que, en muchas ocasiones, carecen de sentido para los alumnos, por no ir acompañados de un análisis o reflexión que los dote de significado durante la escucha.

En nuestro contexto socio-cultural, la mayoría de la música que producimos y consumimos está basada en el sistema tonal-armónico, que organiza el discurso musical a partir de la combinación de acordes con distintos grados de tensión y de reposo.

Por todo ello, en un intento por mejorar la formación auditiva de los alumnos y facilitarles la significatividad de lo escuchado, hemos abordado, desde nuestro trabajo, la elaboración, puesta en práctica y evaluación de una propuesta metodológica para la iniciación a la educación auditiva desde un contexto tonal en la asignatura de Lenguaje Musical, dirigida a los alumnos de los dos primeros cursos de las enseñanzas elementales del Conservatorio Profesional de Música de Segovia.

En este último capítulo, a modo de síntesis y como colofón al trabajo realizado, recopilaremos las conclusiones más significativas derivadas de la 
investigación, desde una perspectiva rigurosa y determinada por los objetivos planteados en la misma. Asimismo, señalaremos las dificultades y limitaciones que hemos encontrado en su desarrollo y terminaremos realizando algunas sugerencias para futuras investigaciones.

\section{Conclusiones de la investigación}

La elaboración de las conclusiones supone la culminación de toda investigación. Es un proceso que permite alcanzar la comprensión de la totalidad del estudio, a través de la integración de todas sus partes y de la deducción de las ideas y las conclusiones principales.

En este sentido, a lo largo de esta última fase, hemos interpretado los resultados obtenidos en relación con los objetivos de investigación marcados, estudiando el grado de consecución de los mismos.

Con la intención de que la presentación de las conclusiones sea clara y mantenga una estructuración coherente con nuestro objeto de estudio, las organizaremos en dos apartados:

- Conclusiones respecto al tema central de la tesis.

- Conclusiones relativas a los objetivos específicos.

\subsection{Conclusiones respecto al tema central de la tesis}

A lo largo de este trabajo, tanto en la justificación que nos ha llevado a realizarlo como en el análisis de los datos extraídos durante su desarrollo, ha podido comprobarse nuestro interés como investigadores $\mathrm{y}$, sobre todo, como docentes comprometidos con nuestra labor educativa por detectar dificultades y carencias en el aprendizaje de los alumnos, para planificar cambios en el proceso educativo que permitan solventarlas o conseguir mejorías.

Las dificultades mostradas por los alumnos en el campo de la educación auditiva han quedado evidenciadas a través de los datos recogidos con diversos instrumentos y técnicas, a partir de distintos informantes. Como consecuencia de ello, nos planteamos trabajar la educación auditiva en la asignatura de Lenguaje Musical desde una perspectiva más amplia que la asociada al tradicional dictado, tomando como referencia las bases de la música tonal-armónica propia de nuestra cultura.

Desde el punto de vista investigador, nos interesaba comprobar la validez de dicha propuesta para la consecución de los fines perseguidos. Por ello, para extraer las conclusiones finales de esta tesis, vamos a partir de la pregunta 
inicial que nos planteamos, la cual constituye nuestro objeto de estudio o tema central:

¿Es posible mejorar la educación auditiva a través de una metodología integradora basada en el sistema tonal-armónico desde el inicio de los estudios en la asignatura de Lenguaje Musical?

Tras el trabajo desarrollado, los resultados obtenidos nos permiten responder con un rotundo sí. A pesar de que la respuesta pueda parecer corta y contundente, no se ha ofrecido a la ligera, ya que planificar una posible mejora también implica decidir qué tipo de evidencias podrían demostrarla, de modo que en la planificación de la investigación hemos incluído decisiones sobre cómo se podrían recolectar, examinar y analizar los datos para otorgarles el necesario rigor científico.

Sintetizar es recomponer lo que el análisis ha separado, es decir, integrar todas las conclusiones y análisis parciales en un conjunto coherente que cobra sentido pleno al integrarse como un todo único. La síntesis es, por tanto, la conclusión final, el resultado aparentemente simple pero que engloba dentro de sí a todo el cúmulo de apreciaciones que se han venido haciendo a lo largo del trabajo.

En este sentido, la utilidad de aplicar en el aula una metodología integradora basada en el sistema tonal-armónico ha quedado demostrada no solo en una notable mejoría de la educación auditiva de los alumnos, que ha permitido la eficaz resolución de dictados musicales tradicionales al mismo tiempo que desarrollaba de forma comprensiva su oído melódico y armónico, sino también en las calificaciones obtenidas en los distintos apartados de la asignatura de Lenguaje Musical. Asimismo, nuestras propuestas metodológicas han desarrollado en los alumnos otras competencias compositivas, creativas, deshinibitorias, críticas, relacionales y emocionales, potenciando su motivación hacia la música, el control sobre las tareas que emprenden y un mayor deseo de superación personal.

Todas estas afirmaciones están basadas en las conclusiones extraídas de los distintos objetivos de investigación que nos habíamos fijado, las cuales se recogen a continuación.

\subsection{Conclusiones relativas a los objetivos específicos}

En este apartado, expondremos las principales conclusiones de cada uno de los objetivos de investigación establecidos para dar respuesta a nuestro objeto de estudio, que están recogidos en el apartado 2 del capítulo VI de esta tesis. 


\subsubsection{Dificultades en el ámbito de la audición musical}

El primer objetivo de investigación que nos planteamos era:

Conocer las dificultades del alumnado en el ámbito de la audición musical desde la asignatura de Lenguaje Musical y cómo reducirlas.

Para cumplir dicho objetivo, inicialmente utilizamos las entrevistas a expertos, los cuestionarios de Lenguaje Musical administrados a alumnos de distintos conservatorios españoles y las referencias consultadas para la configuración del marco teórico. A partir de su análisis, pudimos comprobar que, actualmente, la educación auditiva sigue trabajándose y evaluándose mayoritariamente a través de la realización de dictados tradicionales y que dichos dictados crean serias dificultades en alumnos de todas las edades y niveles. La situación se agrava al comprobar que, después de sucesivos fracasos en los dictados musicales que figuran los programas de exámenes o distintas pruebas selectivas, gran número de jóvenes han tenido que abandonar su ilusión por una carrera profesional, aunque sus resultados en otras materias fueran satisfactorios. Tal realidad es percibida también por los profesores de instrumento entrevistados.

Es tal el miedo colectivo que hay en torno a los dictados tradicionales que, inicialmente, existía incluso en los alumnos de primero con los que hemos llevado a cabo este estudio, a pesar de que jamás hubieran realizado ninguno. Sus temores se debían a que habían oído hablar a sus hermanos y amigos acerca de su complejidad, poniéndoles en alerta sobre dicha actividad, tal y como hemos comprobado a través de las anotaciones recogidas en el diario de la profesora y de comentarios realizados por los propios alumnos y sus padres en entrevistas, cuestionarios o correos electrónicos.

Como en los estudios musicales todos los contenidos están íntimamente relacionados, vimos conveniente analizar las dificultades que presentaban los alumnos en los distintos ámbitos de la asignatura de Lenguaje Musical (ritmo, entonación, dictado y teoría), ya que podría ser que las limitaciones presentadas en otros aspectos estuvieran repercutiendo en la manifestación de mayores dificultades auditivas. Ello nos permitió determinar que existían dificultades comunes en la entonación y el dictado, relacionadas con la discriminación de las notas musicales y la falta de estrategias para identificarlas. Asimismo, constatamos el peso de la falta de memoria musical, así como los nervios y el bloqueo que sienten algunos alumnos hacia determinadas actividades musicales, siendo la realización de dictados 
la más costosa y menos motivadora para la mayoría, considerándola aburrida y difícil.

A la vista de los resultados, parece evidente que el trabajo auditivo en la asignatura de Lenguaje Musical requiere una revisión profunda y meditada. Las opiniones expresadas por los alumnos y sus comentarios en relación a las emociones que experimentan cuando realizan un dictado musical son aspectos a tener muy en cuenta a la hora de diseñar y realizar la intervención en el aula.

No obstante, hay que destacar que no todo es negativo. El alumnado, a pesar del malestar que demuestra realizando este trabajo, considera que es imprescindible para su formación, por lo que debemos tener en cuenta esta predisposición y buscar los medios necesarios para lograr que el ejercicio auditivo, además de proporcionar aprendizajes, resulte motivador y contribuya al disfrute personal, ya que, cuando el alumno disfruta con lo que hace, su aprendizaje es mucho más efectivo y duradero.

Al respecto, antes de realizar un ejercicio de audición cualquiera, resulta fundamental la creación en el aula de un clima relajado y de silencio, pero también distendido y en el que no se dramaticen los errores, convirtiéndolos en experiencia de aprendizaje. Todo ello contribuye a la serenidad interior $y$, como consecuencia, a una mayor sensibilidad auditiva y mental.

También es importante insistir en el papel de las asociaciones musculares para conseguir automatismos sensoriales. Gracias a la asociación de los movimientos de la laringe con los del cuerpo, un brazo o una mano que sube y baja, los niños adquieren la correcta sensación de la dirección ascendente o descendente de una sucesión de sonidos. De igual modo, cuanto más cante el alumno diciendo al mismo tiempo el nombre de las notas, mejor asociará en su memoria la relación entre dichos nombres y los sonidos correspondientes, lo cual facilitará el desarrollo del oído absoluto. Si además ha practicado la memorización y luego la reproducción vocal espontánea de un grupo melódico de sonidos con su entonación exacta, en el momento en que la laringe esboce los movimientos de los sonidos de un fragmento del dictado, los nombres de los sonidos correspondientes surgirán instintivamente en su interior.

Otro tipo de estrategias didácticas, como cantar los sonidos intermedios que existen entre una nota inicial y otra final, o asociar una determinada distancia interválica con el comienzo de distintas canciones o con patrones de escalas y arpegios interiorizados previamente mediante la práctica vocal, también han demostrado su eficacia para facilitar a los alumnos el control sobre la realización de dictados. Igualmente, las TIC constituyen aliadas valiosas, ya 
que nos han permitido confeccionar ejercicios variados que motivaban al alumnado y le permitían seguir entrenándose fuera del aula, a su ritmo y sin miedo a equivocarse.

Por otra parte, los autores referenciados en el marco teórico, los comentarios de los expertos y profesores entrevistados y la revisión documental de distintas publicaciones didácticas dirigidas a su utilización en las clases de Lenguaje Musical nos permiten concluir que, hoy en día, empieza a existir una cierta tendencia a trabajar la educación auditiva desde una perspectiva más amplia que la asociada a los dictados tradicionales, lo cual nos resulta alentador.

En este sentido, los resultados obtenidos en esta tesis a partir de nuestras propuestas metodológicas nos permiten avalar la importancia de abordar el tratamiento de las dificultades auditivas no solo de manera específica, sino también global, utilizando estrategias integradoras que permitan a los alumnos relacionar teoría y práctica y extrapolar conocimientos de unas situaciones a otras, lo cual les facilita, asimismo, la resolución de dictados. Como prueba de ello, cabe destacar que, a pesar de haber hecho únicamente cinco dictados tradicionales a lo largo de todo el curso, nuestros alumnos no tuvieron grandes dificultades para realizarlos y que, incluso, la buena resolución que iban demostrando en dichos dictados nos permitió subir el nivel respecto a las características de los mismos recogidas en la programación de Lenguaje Musical para los cursos en los que se encontraban.

\subsubsection{Utilidad del conocimiento armónico para la educación auditiva}

Iniciar a los alumnos en el conocimiento de las reglas básicas del sistema musical tonal-armónico desde los primeros cursos de Lenguaje Musical ha sido la apuesta más importante de la propuesta metodológica que hemos presentado. De ahí que uno de los objetivos ineludibles de nuestra investigación fuera:

Determinar la utilidad de iniciar a los alumnos en el conocimiento de las bases de la armonía tonal para mejorar su desarrollo auditivo.

La experiencia nos ha demostrado que es posible leer y escribir música a pesar de tener un desarrollo mediocre del oído musical y una falta total de creatividad, pero consideramos que este no es el aprendizaje óptimo que debemos buscar en nuestros alumnos. Así, en las clases de Lenguaje Musical es frecuente ver cómo se prioriza la lectura musical sobre otros contenidos y 
la situación que se produce en estos casos es que, en general, el alumno aprende a "sonorizar" una serie de signos que no tienen ningún significado para él, ya que el esfuerzo por descifrar o decodificar cada uno de ellos le impide advertir la relación entre los mismos y el efecto del conjunto.

Por este motivo, nuestro punto de partida fue replantear y esclarecer los objetivos que perseguíamos con la enseñanza, para poner el acento en aquellos contenidos que nos permitieran crear unas buenas bases sobre las que asentar futuros aprendizajes. Los cimientos de nuestra propuesta metodológica están formados por la adquisición de destrezas auditivas fundamentadas en el conocimiento global del discurso musical a nivel rítmico, melódico, armónico y formal. Ello exige presentar a los alumnos las reglas básicas del sistema tonal-armónico mucho antes de lo que suele hacerse en los actuales planes de estudio, que, en muchas ocasiones, posponen dichos aprendizajes hasta los estudios posteriores de armonía, ya en las enseñanzas profesionales. Dichas reglas armónicas son interiorizadas con naturalidad por los alumnos a través de:

- La interpretación y la escucha pautadas, que permiten dirigir la atención hacia los puntos de interés.

- El análisis, que ayuda a comprender cómo se construye la música.

- La creación, que es lo que posibilita realmente la adquisición significativa de todo nuevo lenguaje.

Con respecto a la interpretación y la escucha, cabe destacar que tanto la entonación como el dictado musical constituyen procesos mentales iguales que se producen en sentido inverso. En la lectura vocal se trata de que los signos escritos provoquen el pensamiento y la emisión de los sonidos, mientras que en el caso del dictado se trata de representar los sonidos escuchados por medio de los signos de escritura correspondientes. En este sentido, debemos destacar la importancia de cultivar automatismos en la relación sonido-nombre, ya que, al no intervenir reflexión, adquieren un valor práctico óptimo, alcanzando una rapidez casi similar a la de los reflejos. Para conseguir estos automatismos, ha resultado de gran utilidad la entonación memorística de escalas y arpegios, a partir del conocimiento de su relación con los acordes de tónica, subdominante y dominante.

En cuanto al análisis, es necesario dirigir la atención de los alumnos hacia aspectos relevantes del discurso musical que les ayuden a comprender su composición y estructura. La audición es algo más que la simple recepción de sonidos por el oído. Atender, interiorizar, memorizar, reproducir, identificar, comparar, caracterizar, organizar, evocar, etc., son habilidades que se interrelacionan y complementan en el aprendizaje de los distintos 
procedimientos relacionados con la percepción auditiva. No cabe duda de que a escuchar se aprende escuchando, pero la simple audición reiterada de una obra musical no garantiza la formación de un oyente comprensivo, hay que dotarla de significado.

En nuestro trabajo, hemos comprobado que el análisis ha proporcionado a los alumnos las herramientas para entender cómo estaba construida la música que escuchaban, cantaban o veían escrita. Al respecto, cabe destacar que conocer las bases del sistema tonal es lo que más les ha ayudado a la comprensión de dicha música, buscando las relaciones existentes entre la melodía y la armonía. Como consecuencia de ello, el alumnado ha manifestado sentirse más cómodo transcribiendo de oído canciones una vez que habían identificado su estructura armónica, la cual les servía de guía, que realizando dictados tradicionales en los que no había ninguna referencia de acordes.

Crear buenos oyentes es labor compleja que requiere de una reflexión y un análisis de los procedimientos, de la utilización de estrategias apropiadas y de una cuidada selección de los recursos a utilizar, ya que la percepción será más refinada y más profunda en la medida en que el alumnado pueda incorporar experiencias significativas, que dependerán no solo de la audición, sino también de la interpretación, la improvisación y la composición. Ello justifica que la intervención en el aula deba incluir procesos creativos, ya que contribuyen de forma decisiva al desarrollo del oído musical.

La creatividad en la composición musical supone un ejemplo claro de cómo se emplea la capacidad humana para resolver problemas e inventar situaciones variadas y ricas de forma imaginativa. A través de la improvisación, la adaptación de pequeños motivos rítmicos o melódicos y la composición de sus propias canciones, los alumnos han desarrollado su capacidad auditiva y su creatividad, al mismo tiempo que inteorizaban reglas básicas que dotaban de significado al discurso musical, desde el punto de vista melódico, armónico y formal. Asimismo, hemos podido comprobar que los alumnos aplicaban posteriormente dichas reglas de forma espontánea al realizar dictados tradicionales, donde también diferenciaban distintas partes y motivos melódicos y tenían el impulso de buscar la armonía subyacente a la melodía, identificando notas de paso, floreos y apoyaturas, lo cual indica que iban analizando internamente los acordes presentes en cada compás.

El papel que juega el docente en todo este proceso perceptivo, analítico y creativo es determinante, ofreciendo oportunidades a sus alumnos para que puedan expresarse musicalmente de forma individual y colectiva. Además, hay que tener presente que en las actividades creativas no solo interviene el 
intelecto, sino que hay que cuidar otras dimensiones de la persona, como son la motivación, la sensibilidad, la confianza en las propias producciones, el espíritu crítico y la curiosidad por descubrir cosas nuevas y aprender de ellas. De todos estos aspectos hablaremos en el siguiente apartado.

\subsubsection{Eficacia de nuestras estrategias metodológicas}

De todos los objetivos establecidos en esta tesis, el que consideramos más relevante para responder a la pregunta clave que nos habíamos planteado es:

Valorar la eficacia de nuestras estrategias metodológicas para ofrecer una educación auditiva integradora, significativa y motivadora.

Para sintetizar las principales conclusiones derivadas de dicho objetivo de investigación, nos basaremos en el grado de consecución alcanzado respecto a los objetivos didácticos que perseguíamos con nuestras nuevas propuestas metodológicas (recogidos en el apartado 4 del capítulo $\mathrm{V}$ de la tesis).

Durante los últimos años, dentro de la asignatura de Lenguaje musical la educación del oído ha venido tomando cada vez más importancia y, en los principales materiales para la enseñanza de esta asignatura, han ido apareciendo actividades de audición musical que propician el reconocimiento auditivo de elementos básicos (ritmos, alturas, escalas, acordes, etc.). De todos ellos, nosotros concedemos especial relevancia al trabajo realizado con los elementos armónicos, mediante la identificación auditiva de los acordes de tónica, subdominante y dominante, así como de las distintas notas que los constituyen, interés que queda reflejado en el objetivo didáctico relativo a mejorar el desarrollo auditivo mediante el conocimiento de las bases de la armonía tonal. A través de nuestra intervención en el aula, hemos comprobado que la interiorización y el manejo de dichos acordes tonales, así como la comprensión de la relación que guardan con la construcción de melodías, ha proporcionado a los alumnos el pilar sobre el que ir construyendo aprendizajes sólidos y significativos, contribuyendo de forma decisiva a la educación de su oído musical melódico y armónico.

A pesar de que los principios de intervención educativa postulan lo contrario, la práctica demuestra que, en la formación tradicional, a la hora de aprender los elementos musicales aún se parte demasiado de la conceptualización teórica. Además, en la mayor parte de los casos, todo este trabajo no suele ir asociado al desarrollo paralelo de una práctica auditiva sistemática de todos los contenidos musicales que han de ser asimilados. Sin embargo, en este estudio hemos defendido que todo proceso de educación 
musical debería partir necesariamente de la práctica, esto es, del desarrollo de capacidades relacionadas con la audición, la interpretación y la composición. Paralelamente, y como resultado del mismo proceso de aprendizaje, el alumno irá internalizando y construyendo un vocabulario que le permitirá expresarse musicalmente y comprender lo que escucha.

El proceso expuesto es similar al que sigue la adquisición y desarrollo del lenguaje verbal. La comparación entre el aprendizaje del lenguaje verbal y el musical no es nueva y, como hemos referenciado tanto en el marco teórico como a partir de los datos extraídos del trabajo de campo, en numerosas ocasiones se ha apelado a ella para poner en evidencia que la secuencia y metodología utilizadas en la educación musical no siempre respetan los principios básicos del aprendizaje.

Al respecto, hemos demostrado que la intelectualización o comprensión teórica de los distintos elementos musicales será el punto final de una destreza auditiva que, en realidad, demanda el desarrollo de otras destrezas previas. Solo contemplando los pasos previos necesarios y situando la formación auditiva en el centro del proceso educativo, los profesores conseguiremos que los alumnos lleguen a comprender un fragmento musical en tiempo real y puedan atribuir un significado pleno a la música que escuchan, ven escrita o interpretan.

El hecho de que el trabajo de todos los contenidos curriculares pase por el oído, es decir, por su comprensión y discriminación auditiva, relacionándolos con su significación dentro del sistema tonal en el que se ubican los diversos sonidos, ha permitido a los alumnos de este estudio adquirir una formación integral, que ha quedado demostrada no solo en su mayor desarrollo auditivo, tanto a nivel melódico como armónico, sino también en las calificaciones obtenidas en cada uno de los apartados de la asignatura de Lenguaje Musical.

Igualmente, destacaremos que se debe procurar siempre que el trabajo auditivo esté basado en la musicalidad, utilizando material estructurado y con sentido, es decir, melodías o canciones que se presentan, cuando es necesario, fraccionadas siguiendo la estructura natural de la frase y no por unidades de compás. Como procedimientos usaremos, en este orden, la audición, imitación, memorización y asociación con el nombre o símbolo. Posteriormente, podremos pasar a la escritura del fragmento musical escuchado. Este trabajo es fundamental cuando queremos desarrollar el oído relativo ya que, al ser la audición relativa más lenta que la absoluta, no puede proceder de forma automática a la asociación sonido-nombre. Por tanto, es imprescindible que el alumno memorice el fragmento y que, a 
través del canto y de la comparación de sonidos con puntos de referencia tonales, proceda a descubrir su nombre.

Tendremos cuidado en secuenciar tanto las dificultades auditivas rítmicas, que son menores, como las melódicas y armónicas. Practicaremos la memorización de fórmulas rítmicas de forma progresiva según su dificultad y, para el desarrollo melódico, usaremos series de 2, 3, 4, 5, etc. sonidos, ubicados en un contexto tonal, a partir de la observación de los giros melódicos característicos de nuestra cultura musical. Trabajaremos paralelamente la audición y entonación de dichas series de sonidos, mediante el dictado oral y escrito, la lectura, la improvisación y la composición. Igualmente, utilizaremos como referencia canciones que comiencen con distintos intervalos, ya que resultan de gran utilidad didáctica para el aprendizaje y el reconocimiento de los mismos. Desde un primer momento, paulatinamente, iremos introduciendo también la percepción de la simultaneidad sonora, con intervalos armónicos y acordes que, en estos primeros cursos, serán únicamente los de tónica, subdominante y dominante de las tonalidades estudiadas.

Otro de los objetivos didácticos que pretendíamos alcanzar con nuestra intervención en el aula era aumentar la motivación del alumnado hacia la asignatura de Lenguaje Musical. Por una parte, este objetivo se ha cubierto mediante el cuidado de los vínculos afectivos entre la profesora y los alumnos, así como de los propios alumnos entre sí. Dichos vínculos han tenido efectos positivos en ambas direcciones, contribuyendo a la formación de alumnos motivados para aprender, pero también de una profesora motivada para enseñar, lo cual ha aumentado la implicación de todos ellos en el proceso de enseñanza-aprendizaje. Por otra parte, ha sido decisiva la propuesta de actividades que, no solo despertaban el interés y cubrían las expectativas de aprendizaje, sino que las han superado, tal y como han manifestado tanto los propios alumnos como sus familias y profesores de instrumento, destacando especialmente aquellas relacionadas con aspectos creativos.

La creatividad es una dimensión compleja de la personalidad del individuo que implica la movilización de una serie de procesos mentales para la elaboración de productos nuevos y originales. Debido a esta peculiaridad, en el ámbito educativo, y más concretamente en educación musical, el trabajo creativo propiamente dicho se suele dejar al margen en detrimento de otras actividades menos complejas y más mecánicas, como son la práctica vocal o instrumental. Sin embargo, estamos convencidos de que la escuela del siglo XXI, sin dejar al margen la enseñanza de conceptos y destrezas musicales, debe desarrollar la creatividad de los alumnos si pretende que alcancen una 
formación integral. Por ello, otro de los objetivos que nos planteamos era el de contribuir al desarrollo de la creatividad del alumnado.

Las actividades creativas en nuestro campo educativo requieren un espacio de libertad donde se permita la experimentación sonora y la puesta en práctica de habilidades manipulativas en la interpretación, creación y expresión musical. En este sentido, en las actividades llevadas a cabo en el aula y que se recogen en esta tesis, se ha constatado que a los alumnos les gusta experimentar con la música y atreverse a realizar producciones novedosas, siempre que el entorno posibilite la autonomía creativa y que el docente les motive adecuadamente, mostrándoles confianza hacia sus elaboraciones. Son muchos los aspectos que se han potenciado a través de nuestras actividades creativas: incremento del interés y curiosidad por la música, aprendizaje activo, expresión de los sentimientos y las emociones, fomento y aceptación de críticas constructivas, disfrute y cohesión grupal, entre otros. De todas nuestras propuestas, la más valorada ha sido la composición y puesta en escena de sus propias canciones, que es una actividad creativo-intelectual que requiere un conocimiento y un dominio de su técnica e implica un proceso de elaboración en el que la originalidad, el oído y la reflexión tienen una gran trascendencia.

En cuanto al objetivo relativo a ejercitar la memoria musical cabe destacar que es un aspecto al que no se le suele conceder la importancia que merece, cuando, en realidad, es fundamental para el desarrollo de todas las capacidades musicales, especialmente las auditivas. Al respecto, resulta relevante comprobar que muchos de los errores cometidos por los alumnos en la resolución de dictados no se deben a la falta de identificación de los ritmos o las notas presentes en los mismos, sino a una mala memorización de lo escuchado. Por ello, en nuestra intervención educativa hemos priorizado su desarrollo mediante estrategias como la retención y repetición de ritmos, sonidos o motivos rítmico-melódicos cada vez más amplios, la interpretación memorística de lecciones de entonación y de canciones, tanto con letra como con notas, o la entonación de motivos y su adaptación a distintos acordes en tiempo real. Todas ellas han demostrado ser eficaces para el entrenamiento de la memoria musical.

Mejorar los hábitos de estudio y la capacidad de autocrítica de los alumnos ha sido tanto un objetivo didáctico como un requisito para poder alcanzar todos los demás. Acostumbrar a los alumnos a organizarse y a planificar adecuadamente el tiempo de estudio ha contribuido de forma decisiva al desarrollo adecuado de su proceso de aprendizaje, a pesar de que, al principio, a varios les costó seguir el ritmo marcado. Asimismo, el hecho de cultivar el gusto por el trabajo bien hecho ha aumentado su capacidad de 
autocrítica, buscando cada vez una mayor perfección en la realización de las tareas.

Para conseguir dicho hábito de estudio y ayudar al alumnado a sentirse apoyado en sus aprendizajes musicales, nos propusimos implicar a las familias en el proceso de aprendizaje de sus hijos. Los resultados obtenidos muestran cómo los alumnos agradecen compartir con sus padres las actividades que realizan y, al mismo tiempo, cómo los padres disfrutan aprendiendo con ellos. El contacto continuo que hemos mantenido con las familias, especialmente vía e-mail, ha contribuido de forma decisiva a su mayor implicación y ha potenciado las relaciones entre la profesora, los padres y los alumnos, ya que, en muchas ocasiones, los padres eran los encargados de transmitir a sus hijos la información que la profesora les enviaba por correo electrónico y de remitir los trabajos realizados para su corrección, una vez que los habían terminado.

Esta búsqueda de apoyo familiar también se justifica en la gran exigencia de los estudios musicales, la cual provoca, en numerosas ocasiones, que el alumnado se vea sometido a situaciones de tensión muy duras y que se encuentre sin herramientas propias para hacerlas frente. En esta misma linea, otro de nuestros objetivos didácticos era reducir la ansiedad ante las tareas musicales, especialmente las que implican una puesta en escena. Estamos convencidos de que aprender consiste en adquirir conocimientos a través del error, analizándolo y rehaciendo el aprendizaje, por lo que defendemos la necesidad de no condenar los fallos y aceptarlos como elementos inherentes al proceso educativo, convirtiéndolos en experiencias que ayuden a nuestro alumnado a crecer musicalmente.

Los errores que más acusan los músicos en formación son los cometidos durante sus interpretaciones públicas. El temor a equivocarse o quedarse bloqueados les genera, con frecuencia, ansiedad escénica, pudiendo llegar a convertirse en un auténtico problema para concluir con éxito sus estudios y dedicarse profesionalmente a la música. Para combatirla, hemos promovido las interpretaciones individuales en el aula, ayudándoles a familiarizarse con dicha situación y a interiorizar el protocolo artístico, perdiendo el miedo a subirse a un escenario. Los estudiantes de éxito son aquellos que cometen errores, los detectan y los superan. Como no todos tienen esa capacidad, es tarea del profesor promoverla, enseñando al alumnado a reconocer sus fallos, sin condenarse por ellos, y a analizarlos para poder corregirlos. Todo ello motivando al discente a que tome sus propias decisiones acerca de qué aspecto cambiar con el fin de mejorar, permitiéndose el derecho de disfrutar tanto con el proceso como con el resultado final. 
Por último, hemos de desterrar la idea de que los conservatorios están desfasados con respecto a centros educativos que ofrecen otro tipo de enseñanzas, ya que los profesores tenemos a nuestro alcance multitud de recursos tecnológicos para complementar todos aquellos conocimientos que transmitimos a los alumnos. Los ordenadores, sintetizadores, distintos dispositivos de grabación y reproducción musical, programas informáticos, tabletas, pizarras interactivas e, incluso, determinadas aplicaciones para los teléfonos móviles constituyen, en la actualidad, recursos muy valiosos en el campo educativo, lo cual nos hizo plantearnos la necesidad de aprovechar las posibilidades que ofrecen las TIC en la formación musical.

Los docentes no podemos dar la espalda a los beneficios didácticos y motivadores que proporcionan los nuevos medios que tenemos a nuestro alcance. En este sentido, tenemos la responsabilidad de formarnos para poder aprovecharlos y de difundirlos para que otros profesores también los puedan utilizar. En nuestro estudio, cabe destacar la utilización del programa de edición de partituras MuseScore, que ha demostrado ser muy útil para que los alumnos desarrollaran sus capacidades exprexivas, creativas, analíticas y auditivas, adquiriendo una comprensión global de la configuración del discurso musical. Asimismo, reiteramos las ventajas que nos ha proporcionado el uso del correo electrónico, tanto para el envío de trabajos como para dar avisos, realizar consultas y ofrecer soluciones rápidas a las dudas que iban surgiendo en el proceso de enseñanza-aprendizaje.

\subsubsection{Respuesta de la comunidad educativa}

Las novedades metodológicas introducidas en el aula no afectan únicamente al docente que las lleva a cabo, sino a todas las personas implicadas en el proceso educativo. Por ello, necesitábamos valorar la respuesta de la comunidad educativa ante nuestras nuevas propuestas, quedando el objetivo de investigación expresado de la siguiente manera:

Analizar la respuesta de la comunidad educativa hacia las actividades propuestas durante el proceso de enseñanza-aprendizaje.

Para exponer las conclusiones extraídas de dicho análisis, vamos a organizarlas en función de los distintos sectores implicados: profesores, alumnos y familias.

La realidad nos muestra que los conservatorios, como su propio nombre indica, tienden a ser conservadores y poco permeables a procesos de cambio. A pesar de que la opinión predominante entre el profesorado de nuestro centro es positiva a la necesidad de introducir modificaciones en el sistema 
educativo, en algunos docentes se constata una actitud de recelo ante la toma de medidas concretas, lo que impide que las reformas sean acogidas favorablemente. De alguna forma, parece existir una sutil y silenciosa conspiración para que las cosas continúen como están, para no alterar las formas de trabajo establecidas y asumidas como válidas por su permanencia a lo largo del tiempo.

No debemos olvidar que, habitualmente, todo proceso de reforma genera otro de contrarreforma de igual intensidad y en sentido contrario, y nuestro caso no iba a ser una excepción. Así, desde el momento en que iniciamos la puesta en práctica de nuestras nuevas propuestas metodológicas, se sucedieron una serie de reacciones entre el profesorado: algunos compañeros mostraron indiferencia; otros sintieron curiosidad y se interesaron por ellas; hubo algunos que, incluso, se sumaron a nuestras propuestas desde sus clases de instrumento; pero también se formó un sector, especialmente dentro del propio departamento al que pertenece nuestra asignatura, que mostró oposición hacia las mismas y rechazó inicialmente su validez, descalificándolas sin esperar a ver los resultados que se obtenían con ellas.

Estos últimos compañeros consideraban que nuestras aportaciones eran "iluminaciones erradas", fruto de mi "inexperiencia docente", porque, al haber estado trabajando con anterioridad como maestra en centros de educación primaria y ser nueva en el cuerpo de profesores de música, tendría una imagen tergiversada de lo que era un conservatorio y de la forma en que se debía trabajar allí, lo cual me habría llevado a especular sobre la realidad educativa sin conocerla. Dicha oposición tensó nuestras relaciones personales y docentes, generando situaciones muy incómodas para el ejercicio profesional. No obstante, a medida que avanzaba el curso y se demostraba que las novedades introducidas en el aula estaban siendo positivas para el proceso de enseñanza-aprendizaje, las críticas y el rechazo a nuestras propuestas se fueron suavizando.

En cuanto a la respuesta del alumnado, en general ha sido muy positiva desde el principio, aunque en los primeros meses algunos se agobiaron bastante hasta que comprendieron y adquirieron la dinámica de trabajo, lo cual nos exigió estar especialmente atentos y disponibles, incluso fuera del horario laboral, para solucionar las dudas que les iban surgiendo. Pasado el primer trimestre, todos los alumnos tenían bien asentadas las bases sobre las que ir construyendo aprendizajes significativos y fueron ganando seguridad y confianza.

El componente lúdico y creativo de las actividades, la interacción grupal y la valoración de sus trabajos, tanto a nivel de aula como a nivel de centro, han sido elementos claves para potenciar su implicación en las clases y en las 
tareas que debían realizar en casa. No obstante, en lo que más hemos insistido ha sido en favorecer que el aprendizaje fuera motivador por sí mismo, consiguiendo que los alumnos sintieran orgullo personal al notar sus progresos y que disfrutaran no solo de los resultados obtenidos, sido del proceso educativo seguido en todas las propuestas desarrolladas.

Por último, respecto a las familias, la acogida inicial de las innovaciones que íbamos a introducir en el aula fue buena. Éramos conscientes de que, si no existía una adecuada información y negociación previa, difícilmente se podría esperar una cooperación entusiasta por su parte. Por ello, les presentamos nuestras propuestas en una reunión anterior al inicio de curso, en la que solicitamos su colaboración y consentimiento para que sus hijos participaran en la investigación. Todos se mostraron receptivos e interesados por los cambios que planteábamos, justificando su coherencia en las necesidades del propio sistema y en la búsqueda de una mayor calidad educativa.

No obstante, al igual que pasó con algunos alumnos, hubo familias que en los primeros momentos mostraron preocupación ante las dificultades que les surgían en su puesta en práctica. Ante tal circunstancia, la cercanía de la profesora y su predisposición para atenderlas y solucionar todas sus dudas fue determinante para recuperar su confianza. De esta forma, según avanzaban los meses e iban comprobando que las nuevas propuestas resultaban beneficiosas para la educación musical de sus hijos, las familias se fueron relajando e implicando con mayor motivación, terminando el curso muy agradecidas con el trabajo desarrollado.

\subsubsection{Barreras encontradas y estrategias para superarlas}

Existe una conciencia generalizada acerca de la necesidad de adecuar el sistema educativo a las demandas y exigencias sociales, para lo cual resulta inevitable introducir periódicamente procesos de reforma e innovación educativa. De hecho, actualmente nos encontramos ante un momento de cambio importante, no solo en la organización y funcionamiento general de nuestro sistema educativo, sino también en la renovación de los contenidos en todos los niveles de la enseñanza.

No obstante, los cambios no suelen ser sencillos y mucho menos cuando se aplican en centros donde, por tradición, las cosas se hacen de una determinada manera. Por este motivo, consideramos necesario mantenernos alerta ante las barreras que nos encontrábamos, para poder resolverlas y continuar con el desarrollo de nuestras propuestas, quedando el objetivo de investigación expresado de la siguiente manera: 
Identificar las barreras encontradas a lo largo del proceso educativo y las estrategias desarrolladas para superarlas.

La primera barrera a la que nos enfrentamos fue la relativa a la falta de apoyo inicial por parte de varios compañeros del departamento de Asignaturas Teóricas al que pertenece la asignatura de Lenguaje Musical, tal y como hemos señalado en el apartado anterior. Esta situación ha incomodado nuestra labor docente y ha tensado mucho las relaciones, pero hemos conseguido resolverla justificando que todas las propuestas sugeridas tenían cabida en el marco legislativo vigente y eran acordes tanto con la programación didáctica de la asignatura como con las características de los alumnos. El tiempo y la eficacia demostrada por las mismas para la consecución de los objetivos curriculares, así como la constancia en el cuidado de las relaciones profesionales y personales con los compañeros, posibilitaron, poco a poco, superar dicha barrera, hasta recuperar la confianza del departamento.

Otro obstáculo que nos encontarmos fue la falta de una dotación tecnológica adecuada para que los alumnos pudieran realizar sus composiciones con el ordenador en clase y aprender el manejo del programa MuseScore con la supervisión directa de la profesora. El hecho de no poder acceder al aula de informática, por encontrarse ocupada para el desarrollo de otras asignaturas, y la imposiblidad de utilizar ordenadores portátiles, porque no disponíamos de mesas en el aula para colocarlos, impidieron realizar prácticas que permitieran solucionar todas sus dudas en clase. Ante tal situación, elaboramos un guión con los pasos a seguir al crear sus propias canciones (anexo XIV) y un sencillo manual sobre el programa que debían utilizar (anexo XV), para que pudieran consultarlos en las prácticas realizadas en casa. Como tal solución no fue suficiente, solicitamos al equipo directivo del centro y a los profesores implicados modificar la organización de las clases durante un par de días para poder acceder al aula de informática con todos nuestros grupos, lo cual nos permitió realizar una práctica con ordenadores en la que participaron tanto los alumnos como los padres que quisieron acompañarles. Esta medida ayudó a resolver casi todas las dudas, aunque también tuvimos que responder algunas específicas mediante tutorías, el correo electrónico o la proyección de sus trabajos en clase a través de un proyector.

La siguiente dificultad que debimos afrontar fue la relativa al tiempo necesario para llevar a cabo nuestras propuestas didácticas, dentro y fuera del aula. Por un lado, nos dimos cuenta de que introducir las novedades planteadas requería más tiempo de dedicación en las clases del que habíamos previsto, lo cual nos obligó a reconducirlas para no dejar desatendidos otros 
contenidos de la asignatura. Por otro lado, las semanas en las que tocaba crear canciones en casa con el programa MuseScore, aumentaba el trabajo docente exhaustivamente, ya que había que corregir composiciones realizadas por siete grupos y devolver feed-back por correo electrónico a todos los alumnos, indicando su validez o los errores cometidos en las mismas. Además, en algunos casos, cuando las pautas eran más complejas y no las seguían correctamente, teníamos que corregir dos o, incluso, tres veces una misma composición, multiplicando aún más el tiempo de dedicación necesario y suponiendo, en ocasiones, una importante sobrecarga de trabajo. Esta barrera era difícil de eliminar, ya que la corrección individual y constructiva de las canciones resulta, inevitablemente, lenta, por lo que es algo que los docentes interesados en aplicar esta actividad deben estar dispuestos a asumir. No obstante, los resultados demuestran que compensa realizar dicho esfuerzo.

Finalmente, señalaremos que la barrera más importante a la que tuvimos que hacer frente, fruto de todas las anteriores, fue la inestabilidad emocional que experimenté durante el primer trimestre del curso escolar. Las críticas recibidas cuestionando el sistema, las dificultades surgidas por carecer de unos recursos tecnológicos idóneos, los límites de tiempo para desarrollar todas las actividades propuestas en el horario previsto, el gran número de horas que debía dedicar en casa a corregir las canciones compuestas por los alumnos y la imposibilidad de solucionar en clase todas las dudas del alumnado e, incluso, de sus padres, debilitó nuestra confianza y nos generó dudas sobre la viabilidad de nuestras innovaciones para mejorar el aprendizaje en el contexto en el que las estábamos aplicando.

Desde el punto de vista investigador, éramos conscientes de que un estudio es válido independientemente de que los resultados finales sean positivos y confirmen nuestras expectativas iniciales o, por el contrario, sirvan para rechazarlas, siempre y cuando se mantenga un rigor científico en su desarrollo, en lo cual sí fuimos cuidadosos. No obstante, nuestro compromiso docente nos planteaba importantes cuestiones éticas al tener que garantizar la consecución de una serie de objetivos didácticos a lo largo del curso, de lo cual no podíamos ofrecer una certera seguridad, a pesar de que los tuviéramos de referencia y trabajáramos caminando hacia los mismos. Esta situación nos generó tanta inseguridad que nos hizo plantearnos desistir de nuestro propósito, ya que constituía una amenaza para nuestra autoestima profesional.

La paciencia y la confianza transmitida por el equipo directivo, distintos compañeros y algunos padres, todos ellos conscientes de las dificultades que surgen al emprender nuevas propuestas, nos ayudaron a perseverar en el trabajo iniciado, aunque la barrera emocional generada no se disolvió 
completamente hasta que no comprobamos que los alumnos estaban disfrutando y empezaban a dominar tanto el método como los contenidos curriculares.

Aparte de identificar las barreras que nos hemos encontrado desde el punto de vista educativo al aplicar nuestras propuestas en el aula y la manera en que las hemos ido resolviendo, consideramos relevante señalar las dificultades y limitaciones que hemos detectado en el proceso investigador desarrollado, a lo cual dedicaremos el siguiente apartado.

\section{Dificultades y limitaciones de la investigación}

Al término de la investigación, resulta conveniente destacar las dificultades encontradas en su desarrollo y las limitaciones detectadas en la misma.

Varias de las dificultades eran inherentes al propio proceso investigador. Al respecto, cabe destacar que, a pesar de que el acceso a la muestra fue sencillo, el trabajo de campo ha resultado muy costoso porque, aunque teníamos claro el objeto de estudio, no nos resultó fácil determinar la mejor manera de recoger información relevante para su análisis. En este sentido, como pretendíamos ofrecer una visión lo más amplia y precisa posible de la realidad estudiada, preferimos pasarnos que quedarnos cortos y recogimos tanto material entre cuestionarios, opiniones de expertos, diversos trabajos de los alumnos, entrevistas individuales y colectivas de los distintos sectores de la comunidad educativa, correos electrónicos, diario de la profesora, etc., que organizarlo todo fue muy arduo y costoso, especialmente la transcripción de todas las entrevistas, por resultar, quizá, excesivas. Además, nos vimos en la necesidad de seleccionar cuál era realmente el material que nos iba a permitir configurar el discurso de la tesis y tuvimos que dejar, en un segundo plano, un número elevado de documentos, sobre todo relativos a trabajos realizados por el alumnado, ya que comprendimos que abordarlo todo con la profundidad deseada era demasiado dentro de un único trabajo de investigación.

Con respecto a la recogida de datos queremos destacar, asimismo, que el carácter experimental de algunas de nuestras propuestas, como la composición de canciones o el manejo de los acordes tonales, hizo pensar a algunos padres y alumnos que eran actividades "extras" para colaborar con el estudio de investigación desarrollado, pero no imprescindibles para el proceso de enseñanza-aprendizaje, ya que con otros profesores no se realizaban. Esta confusión generó malestar en algunos de ellos cuando tenían que "perder tiempo" corrigiendo las actividades que no estaban bien hechas. Por ello, hubo que aclararles que todas las tareas desarrolladas en clase y en casa se consideraban necesarias para sentar buenas bases con vistas a los 
sucesivos cursos de Lenguaje Musical y que se realizaban por dicho convencimiento, independientemente de que luego utilizáramos algunos de sus trabajos para efectuar una investigación científica con mayor profundidad.

Lo que también debemos reconocer es que, a veces, el ritmo de las clases era muy rápido, lo cual agobiada un poco tanto a la profesora como a los alumnos. Esto se debía a que había sesiones en las que teníamos que compaginar la enseñanza y aprendizaje de los contenidos correspondientes a la asignatura con otras actividades que permitieran registrar datos para la investigación, como cuando grabamos en video las interpretaciones de los alumnos o cuando realizamos pruebas específicas para medir su memoria auditiva a comienzo y a final de curso. Además, contábamos con la tensión añadida de tener que recoger y codificar cuidadosamente todos los trabajos de los alumnos y estar muy atentos de que no faltara ninguno de ellos los días que realizábamos las tareas más relevantes. En este sentido, contábamos con la facilidad de poder ofrecerles que asistieran a clase con otro grupo cuando faltaban a alguna sesión.

Centrándonos en los problemas relacionados con el análisis de los datos, la dificultad más relevante fue la de establecer las categorías definitivas que nos permitieran integrar la información procedente de los distintos instrumentos y técnicas utilizados para su recogida. A pesar de haberlas fijado finalmente en catorce, somos conscientes de que existe cierta influencia mutua entre unas y otras, así que, en algunos casos, nos hemos visto en la tesitura de tener que elegir entre repetir parte de información en varias de ellas o dejar sin analizar en toda su magnitud alguna categoría para no volver a incidir en aspectos que ya han sido expuestos con anterioridad.

En cuanto a las limitaciones o carencias de la investigación, observamos que las referencias bibliográficas relacionadas directamente con los objetivos que nos hemos marcado en esta tesis son un poco escasas. A pesar de que hemos encontrado trabajos previos relativos a la formación del oído musical, al desarrollo auditivo dentro del sistema tonal e, incluso, a la mejora del aprendizaje desde la propia asignatura de Lenguaje Musical, algunos resultan bastante antiguos. Aunque fuera de nuestras fronteras sí que existen investigaciones más numerosas y recientes, la mayoría de los temas tratados en las mismas son tangenciales a nuestro objeto de estudio, ya que no guardan una relación exacta con el mismo. Además, exigen el conocimiento de la lengua inglesa, ya que raramente se encuentran traducidas al castellano.

Otro aspecto a destacar es que, en la realización de las entrevistas, muy relevantes como fuentes de información en nuestro trabajo, cuidamos mucho crear un clima de confianza que facilitara a los alumnos, a los padres y a los 
profesores expresarse con libertad, insistiéndoles en la importancia de que hablaran abiertamente y de que destacaran tanto los aspectos positivos como los negativos para poder mejorar el proceso de enseñanza y aprendizaje, ya que en ningún caso iban a ser juzgados por sus comentarios, al ser todos valiosos y necesarios. No obstante, sabemos que el hecho de que dichas entrevistas hayan sido efectuadas por la propia profesora-investigadora y no por un investigador anónimo ha podido sesgar parte de los resultados, aunque es difícil determinar en qué medida.

Igualmente, somos conscientes de que, al tratarse de un estudio cualitativo, en la fase de análisis e interpretación de los datos han podido entrar en juego factores procedentes de la propia subjetividad de la investigadora. Al respecto, para minimizar su efecto, hemos fundamentado cada una de nuestras afirmaciones en información obenida a partir de diversas técnicas e instrumentos.

Por otro lado, al no existir grupos experimentales y grupos de control de la misma profesora, no podemos garantizar con absoluta certeza qué factores de la nueva propuesta educativa explican en mayor medida el buen rendimiento académico de los alumnos y su comprensión global de la música, dándose la posibilidad de que existan variables no controladas que hayan influido, asimismo, en dicho rendimiento. De hecho, en el aula hemos combinado aspectos innovadores junto con otros tradicionales, por lo que no podemos determinar si los buenos resultados obtenidos se deben solo a las novedades introducidas o a la interacción de estas con lo que ya veníamos haciendo en años anteriores. A pesar de que éramos conscientes de dicha limitación, no nos parecía ético privar a algunos alumnos de utilizar una nueva metodología que, a priori, se estimaba como más valiosa en pro de una investigación científica. Por ello, se descartó la posibilidad de discriminar a uno o más grupos a modo de control, porque consideramos que primaba la responsabilidad docente sobre la curiosidad investigadora.

Terminaremos señalando que, aunque nuestras propuestas hayan arrojado buenos resultados, estamos convencidos de que las iniciativas individuales tienen un efecto limitado, por lo que resulta fundamental conseguir dar el salto hacia compromisos compartidos por equipos de profesores que decidan trabajar en la misma línea. A su vez, dichos equipos docentes han de buscar el apoyo de sus directivos, asesores, inspectores, etc., cuya colaboración es definitiva para impulsar las reformas emprendidas. Solo así se pueden producir grandes cambios que transformen significativamente las prácticas educativas de un centro. 


\section{Sugerencias para futuras investigaciones}

Partiendo del convencimiento de que es necesario proporcionar al alumnado herramientas que le permitan controlar algo tan intangible como es el sonido, el trabajo de investigación que hemos realizado nos ha ayudado a encontrar algunas claves para favorecer su educación auditiva desde el contexto de la tonalidad, adquiriendo, al mismo tiempo, un conocimiento más integral y significativo de la construcción del lenguaje musical. Para ello hemos utilizado estrategias motivadoras y creativas, adaptadas a su etapa de maduración y caracterizadas por un marcado carácter lúdico, lo cual ha contribuido de forma decisiva a reducir la ansiedad y aversión que, con frecuencia, muestra el alumnado hacia las actividades referentes al reconocimiento auditivo de los diversos contenidos musicales.

En relación a dichos aspectos, durante la elaboración de la tesis nos han surgido numerosas ideas que podrían desarrollarse en futuras líneas de investigación, las cuales separaremos en dos apartados: las que guardan una relación directa con nuestro objeto de estudio y las que hacen referencia a temas complementarios, pero que también resultan fundamentales para producir avances en la misma dirección.

Entre las primeras, es decir, las investigaciones que guardan una relación directa con nuestro trabajo, destacamos la elaboración, experimentación y evaluación de propuestas didácticas que busquen profundizar en la educación auditiva de los alumnos desde el contexto tonal en las enseñanzas profesionales y superiores, tanto desde la asignatura de Lenguaje Musical como de otras afines, por ejemplo, las de Educación Auditiva, Acompañamiento, Fundamentos de Composición, Análisis o Armonía. A través de dichas propuestas, se debería facilitar a los alumnos el desarrollo de capacidades auditivas como: resolver dictados musicales a dos o más voces; acompañar armónicamente distintas melodías, deduciendo los acordes pertinentes en tiempo real; improvisar melodías a partir de la interiorización de esquemas armónicos cada vez más complejos; o comprender la música tonal escuchada, mediante la identificación auditiva de distintas regiones armónicas, modulaciones, etc.

En la misma línea, resultaría muy interesante investigar la eficacia de nuevas propuestas metodológicas dirigidas a favorecer la educación auditiva desde otros sistemas musicales: modales, pentatónicos, hexatonales, atonales..., para que los alumnos también pudieran familiarizarse con ellos.

Además, se podría estudiar la relación que guarda la identificación auditiva de los intervalos melódicos y armónicos con el desarrollo del oído musical y su repercusión para la comprensión global de la música. 
Por otra parte, durante el trabajo de campo realizado en esta tesis se han recogido otros documentos, especialmente trabajos del alumnado, que podrían proporcionar datos que condujeran a nuevas investigaciones. Así, por ejemplo, nos planteamos la posibilidad de realizar un estudio que examine la relación existente entre la especialidad instrumental de los alumnos y su mayor o menor facilidad para resolver determinadas tareas auditivas, tales como: resolución de dictados, identificación de acordes, reconocimiento de intervalos o detección de notas desafinadas. También podríamos emprender trabajos que estudien la influencia que ejercen distintos factores, como el timbre o la duración de los fragmentos escuchados, sobre la identificación auditiva.

Asimismo, dados los grandes avances tecnológicos del siglo XXI, consideramos imprescindible profundizar en el conocimiento de los materiales y recursos multimedia existentes y analizar las múltiples opciones que presentan para la formación del oído en la asignatura de Lenguaje Musical. Podríamos, incluso, plantearnos la creación, utilización y evaluación de materiales propios que se adapten de forma más específica a nuestros propósitos. En este sentido, nos llama especialmente la atención el estudio de las posibilidades que ofrecen las nuevas tecnologías 2.0, a través de la creación de blogs o recursos interactivos, como la utilización de la pizarra digital en el aula, lo cual no es aún común en los conservatorios.

En cuanto a las futuras líneas de investigación no directamente relacionadas con nuestro objeto de estudio, pero sí complementarias y necesarias para mejorar la calidad de la educación musical (en general) y auditiva (en particular), cabe destacar las relativas a los procesos de innovación curricular, formas de aprendizaje del alumnado, didáctica musical, coordinación docente y formación del profesorado en psicología y pedagógica infantil, todas ellas abordadas desde el contexto de las enseñanzas impartidas en los conservatorios, ya que es el ámbito desde el que resultan escasas.

Para terminar, queremos resaltar que el hecho de realizar esta tesis doctoral ha constituido un apasionante proceso de crecimiento personal y profesional, permitiendo que adquiramos valiosos conocimientos y experiencia en el campo de la educación auditiva para fomentar aprendizajes significativos y permanentes.

Muchos son los ámbitos de estudio que quedan abiertos a raíz de la misma y elevado es también nuestro deseo por emprender futuras investigaciones que nos ayuden a profundizar en el camino que hemos iniciado, siempre con el propósito de mejorar la educación musical de nuestros alumnos, por quienes todo esfuerzo merece la pena. 



\section{REFERENCIAS BIBLIOGRÁFICAS}

Abbadie, M., \& Gillie, A. M. (1976). El niño en el universo del sonido. Buenos Aires: Kapelusz.

Acaso, M. (2013). Reduvolution. Madrid: Paidós Ibérica.

Acorde. (2014) Real Academia Española. Recuperado de http://lema.rae.es/ drae/?val=acorde

Acuerdo de Pacto Local de Castilla y León, del 3 de noviembre de 2005. Recuperado de http://www.frmpcl.es/mh/documentos/convenios/ Acuerdo_Pacto_Local_3nov05.pdf

Aguilar, M. C. (2002). Aprender a escuchar música. Madrid: A. Machado Libros.

Aiello, R. (1994a). Introduction. Melodic Contour in Hearing and Rememberin Melodies. En R. Aiello \& J. A. Sloboda (Eds.), Musical perceptions (pp. 173-176). New York: Oxford University Press.

Aiello, R. (1994b). Music and language: Parallels and contrasts. En R. Aiello \& J. A. Sloboda (Eds.), Musical perceptions (pp. 40-63). New York: Oxford University Press.

Aiello, R., \& Williamon, A. (2002). Memory. En R. Parncutt \& G. E. McPherson (Eds.), The Science and Psychology of Music Performance. Creative Strategies for Teaching and Learning (pp. 167-181). New York: Oxford University Press.

Akoschky, J. (1996). La audición sonora y musical en la Educación Infantil. Eufonía. Didáctica de la Música, 46, 97-102. 
Akoschky, J., Alsina, P., Díaz, M., \& Giráldez, A. (2008). La música en la escuela infantil (0-6). Barcelona: Graó.

Alain, O. (1981). L’harmonie. París: Preses Universitaires de France.

Alberich, E. (2009). Textos de Música Moderna. Harmonia I. Barcelona: DINSIC Distribucions Musicals.

Alberich, E. (2010). Ejercicios de Entonación para la Educación del Oído. La tonalidad. Barcelona: DINSIC Distribucions Musicals.

Albert Gómez, M. J. (2006). La investigación Educativa. Claves teóricas. Madrid: McGraw-Hill.

Alborés, J. (2008). La educación del oído de los futuros músicos. Música y Educación. Revista Trimestral de Pedagogía Musical, 76, 110-116.

Alcáraz, J. A. (2000). Convivencia y disciplina escolar: el gobierno de la clase. Revista Electrónica de LEEME. Lista Electrónica Europea de Música en la Educación, 5. Recuperado de http://fresno.pntic.mec.es/ emod0002/disciplina.htm

Alemañy, C. (2009). La docencia: enfermedades frecuentes de esta profesión. Cuadernos de Educación y Desarrollo. Revista académica semestral, 1. Recuperado de http://www.eumed.net/ rev/ced/02/cam6.htm

Alonso, V. (2004). Optimización de la atención a través de un programa de intervención musical. (Tesis doctoral). Universidad de Valencia. Recuperado de http://www.tesisenred.net/handle/10803/10219

Anguera, M. T., et al. (1998). Métodos de investigación en psicología. Madrid: Síntesis.

Aróstegui, J. L. (2006). La formación del profesorado en Educación Musical ante la convergencia europea de enseñanzas universitarias. Revista de Educación, 341, 829-844.

Bachem, A. (1937). Various types of absolute pitch. Journal of the Acoustical Society of America, 9(2), 146-151.

Badia, M., \& Baucells, T. (2005). Música 2: educación primària, cicle inicial. Mètode Ireneu Segarra: llibre del mestre. Barcelona: Publicacions de l'Abadia de Montserrat. 
Ballesteros, M., \& García, M. (2010). Recursos didácticos para la enseñanza musical de 0 a 6 años. Revista Electrónica de LEEME. Lista Electrónica Europea de Música en la Educación, 26, 14-31. Recuperado de http://musica.rediris.es/leeme/revista/ ballesterosgarcia10.pdf

Balsera, F. J., \& Gallego, D. J. (2010). Inteligencia emocional y enseñanza de la música. Barcelona: DINSIC Distribucions Musicals.

Balo, M. (2014). La diversidad tímbrica en la educación auditiva del alumnado de lenguaje musical de los conservatorios profesionales de música de la Comunidad de Madrid. Efecto de la variación del timbre en la realización de dictados a dos voces. (Tesis doctoral). Universidad Nacional de Educación a Distancia. Recuperado de http://e-spacio.uned.es/fez/eserv/tesisuned:Educacion-

Mbalo/Balo_Gonzalez_Monica_Tesis.pdf

Balo, M., Lago, P., \& Ponce de León, L. (2014). Los alumnos ante el dictado musical. Las TIC como aliadas para mejorar las experiencias. Revista DIM. Didáctica, Innovación y Multimedia, 28, 1-14. Recuperado de http://www.raco.cat/index.php/DIM/article/view/ $291507 / 379988$

Balzano, G. T., \& Liesch, B. W. (1982). The Role of Chroma and Scalestep in the Recognition of Musical Intervals In and Out of Context. Psychomusicology, 2(2), 3-31.

Barba, J. J. (2013). La investigación cualitativa en educación: en los comienzos del siglo XXI. En A. Maravillas, \& A. Giráldez (Coords.), Investigación cualitativa en educación musical (pp. 2338). Madrid: Graó.

Barba, J. J., \& González-Calvo, G. (2013). Perseguir el sueño o caer en lo que existe: La socialización del maestro novel entre el habitus y la investigación-acción. Revista Interuniversitaria de Formación del Profesorado, 78(27), 137-144.

Barba, J. J., \& González-Calvo, G. (2014). La identidad afectivo-personal de un docente y su reflejo en el desarrollo de la identidad profesional. Profesorado. Revista de Currículum y Formación del Profesorado, 18(3). Recuperado de http://www.ugr.es/local/recfpro/rev181COL 12.pdf 
Barba, J. J., González-Calvo, G., \& Barba-Martín, R. A. (2014). Que la fuerza esté contigo: desvelar el lado oscuro de la investigación en educación. Magis. Revista Internacional de Investigación en Educación, 7(14), 125-140.

Barbacci, R. (1965). Educación de la memoria musical. Buenos Aires: Ricordi.

Barceló, B. J. (1995). Las funciones del canto. Música y Educación. Revista Trimestral de Pedagogía Musical, 24, 37-48.

Bautista, A., Pérez-Echeverría, M. P., \& Pozo, J. I. (2011). Piano teachers' conceptions of assessment. Revista de Educación, 355(1), 443-466.

Bautista, A., Pérez-Echeverría, M. P., Pozo, J. I., \& Brizuela, B. M. (2012) Piano students' conceptions of musical scores as external representations: A cross-sectional study. Journal of Research in Music Education, 57(3), 181-202.

Benso, C., \& Pereira, C. (Coords.) (2007). Familia y escuela: el reto de educar en el siglo XXI. Ourense: Concellería de Educación, D.L.

Bentley, A. (1967). La aptitud musical de los niños. Buenos Aires: Ed. Víctor Leru.

Bernal, J. (2003). Música y creatividad. En A. Gervilla (Ed.), Creatividad Aplicada. Una apuesta de futuro (pp. 841-863). Málaga: Dykinson.

Bernardi, N. F., Schories, A., Jabusch, H. C., Colombo, B., \& Altenmüller, E. (2013). Mental Practice in Music Memorization: an EcologicalEmpirical Study. Music perception, 30, 275-290.

Bernardini, A. (2010). La educación en valores hoy en día: entre conciencia crítica y respuestas constructivas. Innovaciones Educativas, 17, 1122.

Bernstein, L. (1976). The Unanswrered Question. Cambridge, MA: Harvard University Press.

Berrón, E. (2012). Dificultades vocales y auditivas en el primer curso de Lenguaje Musical: relaciones entre el dictado y la entonación. (Trabajo Fin de Máster). Segovia: Universidad de Valladolid. Recuperado de http://uvadoc.uva.es/handle/10324/1023 
Bharucha, J. J. (1984). Anchoring effects in music: The resolution of dissonance. Cognitive Psychology, 16, 485-518.

Bigand, E. (1994). Contributions de la musique aus recherches sur la cognition auditive humain. En S. Mc-Adams \& E. Bigand (Eds.), Penser les sons. Psychologie cognitive de l'audition (pp. 249-298). París: Presses Universitaires de France.

Blaxter, L., Hughes, C., \& Tight, M. (2008). Cómo se investiga. Barcelona: Graó.

Bonet, N. (1984). Tractat de Solfeig I. Introducció als elements essencials de la Música. Barcelona: Catalana d'Edicions Musicals.

Bonetto, V. A., \& Calderón , L. L.(2014). La importancia de atender a la motivación en el aula. PsicoPediaHoy, 16(1). Recuperado de http://psicopediahoy.com/importancia-atender-a-la-motivacion-enaula

Bono, A. (2010). Los docentes como engranajes fundamentales en la promoción de la motivación de sus estudiantes. Revista Iberoamericana de Educación, 2(52), 1-8. Recuperado de http://www.rieoei.org/deloslectores/3273Bono.pdf (6/08/2012)

Bono, A., \& Huertas, J, A. (2006) ¿Qué metas eligen los estudiantes universitarios para aprender en el aula? Un estudio sobre la motivación situada. Cronía. Revista de Investigación de la Facultad de Ciencias Humanas, 5(1), 1-17.

Boulez, P. (1981). Puntos de referencia. Barcelona: Gedisa.

Bravo, R., \& De Moya, M. V. (2006). Multiculturalidad musical para las aulas del siglo XXI. Ensayos, 21, 131-140.

Bregman, A. (1990). Auditory scene analysis. The Percetual Organization of Sound. London: The MIT Press.

Buendía, L., Colás, M. P., \& Hernández, F. (1999). Métodos de investigación en psicopedagogía. Madrid: McGraw-Hill.

Butler, D. (1989). Describing the Perception of Tonality in Music: A Critique of the Tonal Hierarchy Theory and a Proposal for a Theory of Intervallic Rivalry. Music Perception, 6(3), 219-242. 
Cabello, I., Molina, E., \& Roca, D. (2000). Armonía 1. Madrid: Real Musical.

Cabrera, M. (2010). El valor de la memoria en la educación y su relación con la inteligencia. Revista Digital Innovación y Experiencias Educativas, 36. Recuperado de http://www.csi-csif.es/andalucia/ modules/mod_ense/revista/pdf/Numero_36/MARIA_CABRERA_1. pdf

Cain, T. (2013). Investigación-acción en educación musical. En M. Díaz \& A. Giráldez (Coords), Investigación cualitativa en educación musical (pp. 57-76). Barcelona: Graó.

Campbell, P. S. (1998). Songs in their heads. Music and its meaning in children's lives. New York: Oxford University Press.

Cano, A. G., \& Nieto, E. (2006). Programación didáctica y de aula: de la teoría a la práctica docente. Cuenca: Ediciones de la Universidad de Castilla la Mancha.

Cañada, P., López, A., \& Molina, E. (2004). Cuadernos de teoría 1 y 2. Grado elemental. Madrid: Enclave creativa ediciones.

Cañada, P., López, A., \& Molina, E. (2005). Cuadernos de audición 1, 2 y 3. Grado elemental. Madrid: Enclave creativa ediciones.

Carretero, M. (2009). Comprensión y Motivación. Constructivismo y educación. Buenos Aires: Paidós.

Casals, J. (1993). El método Ireneu Segarra. Música y Educación. Revista Trimestral de Pedagogía Musical, 16, 51-74.

Casals, P., Gich, J., Diéguez, F., \& Busquets, E. (2005). Taller de memoria: ejercicios prácticos. Barcelona: Editorial Horsori.

Castillo, E., \& Vásquez, M. (2003). El rigor metodológico en la investigación cualitativa. Revista Colombia Médica, 34(3), 164-167.

Chailley, J. (1987). Enciclopedia Larousse de la Música (Vol. 1). Barcelona: Argos-Vergara.

Chailley, J., \& Challan, H. (1964). Teoría Completa de la Música. París: Éditions Leduc. 
Chapuis, J. (1995). Elementos de solfeo y armonía del lenguaje musical. Fribourg: Éditions Pro Musica.

Cheston, S. B. (1994). Relationships among harmonic complexity preference, musical training and experience, and music aptitude in high music students. (Tesis doctoral). Case Western Reserve University. Recuperado de http://www.ohiolink.edu/etd/ searche.cgi ?g=accession_number:case $1057865886 \& \mathrm{mlt}=\mathrm{y}$

Chomsky, N. (1957). Estructuras sintácticas. México: Siglo XXI Editores.

Clendinning, J. P., \& Marvin, E. W. (2011). The Musician's Guide to Theory and Analysis. New York, NY: W. W. Norton.

Coffey A., \& Atkinson P. (2005). Encontrar el sentido a los datos cualitativos. Estrategias complementarias de investigación. Alicante: Servicio de Publicaciones de la Universidad de Alicante.

Comellas, M. J. (2009). Familia y escuela: compartir la educación. Barcelona: Graó.

Contreras-Domingo, J. (1994). La investigación en la acción: ¿Qué es? Cuadernos de Pedagogía, 224, 8-12.

Cook, P. (1999). Music, Cognition and Computerized Sound. Londres: MIT Press.

Cook, N. D., \& Hayashi, T. (2010). Psicoacústica de la percepción de la armonía. Barcelona: Mente y Cerebro.

Cook, T. D., \& Reichardt, Ch. S. (1986). Métodos cualitativos y cuantitativos en investigación evaluativa. Madrid: Morata.

Copland, A. (2008). Como escuchar música. México: Editorial Fondo de Cultura Económica.

Córdoba, P., Coto, R., \& Ramírez, M. (2005). La enseñanza del inglés en Costa Rica y la destreza auditiva en el aula desde una perspectiva histórica. Actualidades Investigativas en Educación, 5(2), 1-12. Recuperado de http://redalyc.uaemex.mx/pdf/447/44750205.pdf

Coso, J. A. (1992). Tocar un instrumento. Madrid: Música Mundana. 
Costa-Giomi, E. (2001). El desarrollo de la percepción armónica durante la infancia. Cuadernos Interamericanos de Investigación en Educación Musical, 2, 43-56. Recuperado de http://www.journals.unam.mx/ index.php/cem/article/view/7311

Costa, M., Enrico, P., Bitti, R., \& Bonfiglioli, L. (2000). Psychological Connotations of Harmonic Musical Intervals. Psychology of Music, $28,4-22$.

Covarrubias, P., \& Piña, M. M. (2004). La interacción maestro-alumno y su relación con el aprendizaje. Revista Latinoamericana de Estudios Educativos, 34. Recuperado de http://www.redalyc.org/articulo.oa? $\mathrm{id}=27034103$

Cross, I., West, R., \& Howell, P. (1991). Cognitive correlates of tonality. En I. Cross, P. Howell, \& R. West (Eds.), Representing Musical Structure (pp. 201-243). London: Academic Press.

Cuartero, M., \& Payri, B. (2010). Tipos de memoria, aptitudes y estrategias en el proceso de memorización de estudiantes de piano. Revista Electrónica de LEEME. Lista Electrónica Europea de Música en la Educación, 26, 32-54. Recuperado de http://musica.rediris.es/ leeme/revista/cuarteropayri10.pdf

D’Alessio, A. (2013). Las competencias del docente ideal. Intersecciones. Revista Electrónica de la Facultad de Psicología de la UBA, 8. Recuperado de http://intersecciones.psi.uba.ar/index.php?option= com_content\&view=article\&id=53:las-competencias-del-docenteideal\&catid $=11$ :alumnos \&Itemid $=1$

Dalia, G. (2004). Cómo superar la ansiedad escénica en músicos. Madrid: Mundimúsica.

Davini, C. (2010). Métodos de Enseñanza: didáctica general para maestros y profesores. Buenos Aires: Santillana.

Decreto de 15 de junio de 1942, (BOE 4 de julio), sobre organización de los Conservatorios de Música y Declamación.

Decreto 2618/1966, de 10 de septiembre, sobre Reglamentación General de los Conservatorios de Música. 
Decreto 65/2005, de 15 de septiembre, por el que se aprueba el Reglamento Orgánico de los centros que imparten Enseñanzas Escolares de Régimen Especial.

Decreto 60/2007, de 7 de junio, por el que se establece el currículo de las Enseñanzas Elementales y Profesionales de Música de Castilla y León.

Decreto 1614/2009, de 26 de octubre, por el que se establece la Ordenación de las Enseñanzas Artísticas Superiores reguladas por la Ley Orgánica 2/2006, de 3 de mayo, de Educación.

Decreto 57/2011, de 15 de septiembre, por el que se establece el Plan de Estudios de las Especialidades de Composición, Interpretación y Musicología, de las Enseñanzas Artísticas Superiores de Grado en Música en la Comunidad de Castilla y León.

Delalande, F. (1995). La música es un juego de niños. Buenos Aires: Ricordi.

De la Torre, S. (2004). Aprender de los errores. El tratamiento didáctico de los errores como estrategias innovadoras. Buenos Aires: Editorial Magisterio del Río de La Plata.

Del Rincón, D., Arnal, J., La Torre, A., \& Sans, A. (1995). Técnicas de Investigación en Ciencias Sociales. Madrid: Dykinson.

Del Río, D. (2003). Métodos de investigación en Educación. Volumen I: proceso y diseños no complejos. Madrid: UNED.

Del Villar, F. (1994). El Diario de los Profesores de Educación Física. Un Instrumento de Investigación y Formación Docente. Revista Española de Educación Física y Deportes, 4, 20-23.

De Moya, M. V. (2005). Creatividad y docencia. Aprender a ser creativos para enseñar a ser creativos. En A. Gervilla (Coord.), Creatividad: aspectos psicológicos, educativos y sociales (pp. 281-296). Málaga: Dykinson.

Denzin, N. K. (1970). Sociological Methods: A Source Book. Chicago, IL: Aldine Publishing Company.

Despins, J. P. (2013). La música y el cerebro. Madrid: Gedisa. 
Deutsch, D. (Ed.) (1999). Psychology of Music. California, CA: Academic Press.

Deutsch, D., \& Feroe, J. (1981). The internal representación of pich sequences in tonal music. Psychological Review, 88(6), 503-522.

Deutsch, D., Henthorn, T., \& Dolson, M. (2004). Absolute Pitch, Speech, and Tone Language: Some Experiments and a Proposed Framework. Music Perception, 21, 339-356.

Díaz, M. (2004). La música en la educación primaria y en las escuelas de música: la necesaria coordinación. Revista Electrónica Complutense de Investigación en Educación Musical, 1(2). Recuperado de http://core.ac.uk/download/pdf/27144383.pdf

Díaz, M. (2005). La International Society for Music Education: una importante apuesta por la educación musical. Musiker, 14, 5-14.

Díaz, M. (Coord.) (2006). Introducción a la investigación en Educación Musical. Madrid: Enclave Creativa Ediciones.

Díaz, M. (2010). Metodologías y líneas actuales de investigación en torno a la enseñanza y el aprendizaje musical en educación secundaria. ¿Podemos formarnos para ser investigadores? En A. Giráldez (Coord.), Música. Investigación, innovación y buenas prácticas (pp. 133-155). Barcelona: Graó.

Díaz, M. (2012). Educación Musical: investigamos, luego avanzamos. Revista Electrònica d'Investigació $i$ Innovació Educativa $i$ Socioeducativa, 3(2), 67-76.

Díaz, M., \& Giráldez, A. (Coords.) (2007). Aportaciones teóricas y metodológicas a la educación musical. Barcelona: Graó.

Dierssen, M. (2001). La música y la mente humana. Neurobiología de la experiencia musical. Eufonía. Didáctica de la Música, 21, 85-97.

Díez, E. J. (2008). El Proyecto Educativo de Centro (PEC). León: Universidad de León.

Dillon, R. F., \& R. J. Sternberg (1986). Cognition and Instruction. California, CA: Academic Press. 
Domínguez, S. (2010). La Educación, cosa de dos: La escuela y la familia. Temas para la Educación. Revista digital para profesionales de la enseñanza, 8. Recuperado de http://extension.uned.es/archivos_ publicos/webex_actividades/4440/laeducacioncosadedoslaescuelayla familia.pdf

Dowling, W. J. (1994). Melodic Contour in Hearing and Remembering Melodies. En R. Aiello \& J. A. Sloboda (Eds.), Musical perceptions (pp. 176-190). New York, NY: Oxford University Press.

Dutto, S. (2007). El desarrollo del oído armónico a partir de la enseñanza de patrones armónicos presentes en la música popular. Actas del I Congreso Latinoamericano de Formación Académica en Música Popular (Comp). Recuperado de http://webnueva.unvm.edu.ar/ webs/congresomusica1/cronologia.html

Echeverría, R. (2002). Ontología del lenguaje. Santiago: Dolmen.

Egido, I. (2005). Reflexiones en torno a la evaluación de la calidad educativa. Tendencias Pedagógicas, 10, 17-28.

Eguilaz, M. J. (2009). La memoria en la interpretación guitarrística. Una aproximación a su problemática. Revista Electrónica LEEME. Lista Electrónica Europea de Música en la Educación, 24, 1-18. Recuperado de http://musica.rediris.es/leeme/revista/eguilaz09.pdf

Eisner, E. (1991). The Enlightened Eye. Qualitative Inquiry and the Enhancement of Educational Practice. New York, NY: McMillan Publ. Co.

Elliot, J. (1986). Investigación-acción en el aula. Valencia: Consejería de Educación. Servicio Publicaciones de la Generalitat.

Elliot, J. (1987). Teachers as researchers. Dunkin: J. M.

Elliot, J. (1990). La investigación-acción en educación. Madrid: Ediciones Morata.

Escudero, V., Gómez, B., \& Pérez, A. (2009). Cantábile. Lenguaje Musical 1. Enseñanzas Elementales. Santander: Ediciones Tantín.

Fear, R. (1979). La entrevista de evaluación. Buenos Aires: Paidós. 
Fernández Pérez, M. (1988). La profesionalización del docente. Madrid: Escuela Española.

Field, P. A., \& Morse, J. M. (1994). Nursing Research. The Application of Qualitative Approaches. London: Chapman \& Hall.

Flick, U. (2004). Introducción a la investigación cualitativa. Madrid: Morata.

Forest, C., \& García, F. J. (2006). Comunicación cooperativa entre la familia y la escuela: una guía para promover la colaboración entre profesores y padres. Valencia: Nau Llibres.

Fox, D. J. (1981) El proceso de investigación en Educación. Pamplona: Eunsa.

Franklin, C., \& Ballau, M. (2005). Reliability and validity in qualitative research. En R. Grinnell \& Y. Unrau (Eds.), Social work: Research and evaluation. Quantitative and qualitative approaches (pp.438449). Nueva York, NY: Oxford University Press.

Frega, L. (2005). Música para maestros. Barcelona: Graó.

Freire, P. (2007). Pedagogía del oprimido. Madrid: Siglo XXI.

Fuentes, P., \& Cervera, J. (1989). Pedagogía y didáctica para músicos. Valencia: Piles Editorial de Música.

Furnó, S. (2003). La formación de conceptos musicales. Cuadernos Interamericanos de Investigación en Educación Musical, 6, 81-108. Recuperado de http://revistas.unam.mx/index.php/cem/article/ view/7335

Galera, M. M., \& Pérez, J. (2008). La investigación en Educación Musical en la base de datos ERIC. Revista Electrónica de LEEME. Lista Electrónica Europea de Música en la Educación, 22. Recuperado de http://musica.rediris.es/leeme/revista/galeraetal08.pdf

Galera, M. M., Tejada, J., \& Trigo, E. (2013). El editor de partituras como medio para facilitar el estudio de la lectura musical cantada. Electronic Journal of Research in Educational Psychology, 11(1), 215-238. 
Galindo, J. (Coord.) (1998). Técnicas de investigación en sociedad, cultura y comunicación. México: Addison Wesley Longman.

Gallego, D. J., Alonso, C., Cruz, A., \& Lizama, L. (1999). Implicaciones educativas de la inteligencia emocional. Madrid: UNED.

Gallego Gil, D. J., \& Gallego Alarcón, M. J. (2004). Educar la inteligencia emocional en el aula. Madrid: PPC.

Gallego, D. J., \& Gatica, N. (2010). La Pizarra Digital: Una ventana al mundo desde las aulas. Sevilla: MAD.

Galvin, K. (1988). Listening by Doing: Developing Effective Listening Skills. Lincolnwook: National Texbook Company.

García Llamas, J. L. (2003). Métodos de investigación en Educación II: Investigación cualitativa y evaluativa. Madrid: UNED.

García-Retamero, J. (2010). De profesor tradicional a profesor innovador. Temas para la educación. Revista digital para profesionales de la enseñanza, 11. Recuperado de http://www.feandalucia.ccoo.es/docu/ p5sd7620.pdf

Garmendia, E. (1981). Educación audioperceptiva: bases intuitivas en el proceso de formación musical. Buenos Aires: Ricordi.

Gértrudix, F., \& Gértrudix, M. (2010). The Utility of Musico-visual Formats in Teaching. Comunicar, 34(17), 99-107.

Gértrudix, F., \& Gértrudix, M. (2012). Music in Virtual Worlds. Study on the Representation Spaces. Comunicar, 38(19), 175-181.

Gértrudix, F., \& Gértrudix, M. (2013). Aprender jugando. Mundos inmersivos abiertos como espacios de aprendizaje de los y las jóvenes. Revista de Estudios de Juventud, 101, 123-137.

Gimeno, J., \& Pérez, A. (1985). La Enseñanza: Su Teoría y su Práctica. Madrid: Akal.

Giráldez, A. (1997). Percepción auditiva y educación musical. Eufonía Didáctica de la Música, 7, 63-70.

Giráldez, A. (2012). TIC y educación musical: Una revisión de las líneas de investigación sobre la creación musical en las aulas. Revista de Red 
Educativa Musical. Recuperado de http://recursostic.educacion.es/ artes/rem/web/index.php/es/dossier-educativo/item/367-tic-y-educa ci\%C3\%B3n-musical

Glover, J. (2004). Niños compositores, 4 a 14 años. Barcelona: Graó.

Goetz, J. P., \& LeCompte, M. D. (1988). Etnografía y diseño cualitativo en la investigación cualitativa. Madrid: Morata.

Goleman, D. (1996). Inteligencia Emocional. Barcelona: Kairós.

Goleman, D. (2002). El líder resonante crea más: el poder de la inteligencia emocional. Barcelona: Plaza y Janés.

González, A. (2007a). Edwin E. Gordon. En M. Díaz \& A. Giráldez (Coords.), Aportaciones teóricas y metodológicas a la educación musical (pp. 173-180). Barcelona: Graó.

González, A. (2007b). Modelos de motivación académica: una visión panorámica. REME. Revista Electrónica de Motivación y Emoción, 10(25). Recuperado de http://reme.uji.es/articulos/numero25/ article1/article1.pdf

González, J. (2013). La aplicación del Método Dalcroze en las Enseñanzas Elementales del Conservatorio Profesional de Música "Tomás de Torrejón y Velasco" de Albacete. La rítmica vivencial de los conceptos del Lenguaje Musical. (Tesis doctoral). Universidad Nacional de Educación a Distancia. Recuperado de http://espacio.uned.es/fez/view.php?pid=tesisuned:Educacion-Jgonzalez

Gordon, E. E. (1997). Learning Sequences in Music. Chicago, IL: G.I.A. Publications.

Gotzens, A., \& Marro, S. (1999). Prueba de valoración auditiva. Explorando los sonidos y el lenguaje. Barcelona: Masson.

Grundy, S. (1991). Producto o praxis del curriculum. Madrid: Morata.

Guba, E. G. (2008). Criterios de credibilidad en la investigación naturalista. En J. Gimeno \& A. I. Pérez (Eds.), La enseñanza: su teoría y su práctica (pp. 148-165). Madrid: Akal. 
Guba, E. G., \& Lincoln, Y. S. (1981). Effective evaluation: improving the usefulness of evaluation results through responsive and naturalistic approaches. San Francisco, CA: Jossey-Bass.

Guba, E. G., \& Lincoln, Y. S. (1989). Fourth generation evaluation. Newbury Park: SAGE.

Gudmundsdottir, H. R. (1999). Children's auditory discrimination of simultaneous melodies. Journal of Research in Music Education, 47(2), 101-110.

Gurdián-Fernández, A. (2007). El paradigma cualitativo en la investigación socio-educativa. Costa Rica: Universidad de Costa Rica.

Hammersley, M., \& Atkinson P. (2001). Etnografía. Métodos de investigación. Barcelona: Paidós.

Hargreaves, D. J. (2002). Música y desarrollo psicológico. Barcelona: Graó.

Helmholtz, H. (1885). On the Sensations of Tone. Nueva York: Dover.

Hemsy de Gainza, V. (1964). La iniciación musical del niño. Buenos Aires. Ricordi.

Hemsy de Gainza, V. (1977). Fundamentos, materiales y técnicas de la educación musical: ensayos y conferencias, 1967-1974. Buenos Aires: Ricordi.

Hemsy de Gainza, V. (2003). La educación musical entre dos siglos: Del modelo metodológico a los nuevos paradigmas. Buenos Aires: Universidad de San Andrés.

Hernández, J. R., Hernández, J. A., \& Milán, M. A. (2007). La creatividad asociada al talento musical en alumnos superdotados. Respuestas educativas. Ensayos. Revista de la Facultad de Educación de Albacete, 22, 83-98.

Hernández, J. R., Hernández, J. A., \& Milán, M. A. (2010). Actividades creativas en Educación Musical: la composición musical grupal. Ensayos. Revista de la Facultad de Educación de Albacete, 25, 1123.

Hernández, J. R., Hernández, J. A., \& De Moya, M. V. (2011). Las bandas sonoras como base de la audición activa: experiencias educativas 
para el desarrollo musical infantil. Ensayos. Revista de la Facultad de Educación de Albacete, 26, 165-178.

Hernández, R., Fernández, C., \& Baptista, P. (2006). Metodología de la Investigación. México: Mc Graw Hill.

Herrera, R. (2009). Representación metafórica de la altura del sonido en personas ciegas: estudio de la metáfora espacial en el plano vertical. En S. Dutto \& P. Asís (Eds.), La experiencia artística y la cognición musical (pp. 29-30). Córdoba: EDUVM.

Herrera, R. (2010). Las representaciones internas de la altura y la escritura musical. En R. Herrera \& F. Shifres (Eds.), Adquisición y Desarrollo del Lenguaje Musical en la Enseñanza Formal de la Música (pp. 3742). Buenos Aires: SACCoM.

Highben, Z., \& Palmer, C. (2004). Effects of auditory and motor mental practice in memorized piano performance. Bulletin of the Council for Research in Music Education, 159, 58-65.

Hindemith, P. (1946). Adiestramiento elemental para músicos. Buenos Aires: Ricordi.

Hopkins, D. (1987). Investigación del profesor: retorno a lo básico. Revista de Innovación e Investigación Educativa, 3, 41-50.

Husén, T. (1988). Paradigmas de la investigación en educación: un informe del estado de la cuestión. Madrid: Narcea.

Ibarra, R. (2009). Neuroanatomía y neurofisiología del aprendizaje y memoria musical. Notas: Boletín Electrónico de Investigación de la Asociación Oaxaqueña de Psicología A.C., 5(1), 39-51. Recuperado de http://www.conductitlan.net/65_neuroanatomia_neurofisiologia _aprendizaje_musical.pdf

Imbernón, F. (Coord.). (2002). La investigación educativa como herramienta de formación del profesorado. Reflexión y experiencias de investigación educativa. Barcelona: Graó.

Jackendoff, R. (1998). La conciencia y la mente computacional. Madrid: Visor. 
Jacquier, M. (2009). La comprensión Metafórica del Tiempo Musical en la Educación Auditiva. En S. Dutto \& P. Asís (Eds.), La experiencia artística y la cognición musical (pp. 1-9). Córdoba: EDUVM.

Jaques-Dalcroze, E. (1965). Le rythme, la musique et l'éducation. Lausanne: Editions musicales Hug.

Järvelä, S. (2001). Shifting research on motivation and cognition to an integrated approach on learning and motivation in context. En S. Volet \& S. Järvelä (Eds.), Motivation in Learning Contexts. Theoretical Advances and Methodological Implications (pp. 3-14). Londres: Pergamon- Elsevie.

Jauset, J. A. (2011). Música y Neurociencia: la musicoterapia. Barcelona: UOC.

Jensen, E. (2010). Cerebro y aprendizaje. Competencias e implicaciones educativas. Madrid: Narcea.

Jude, S., \& Rickard, N. (2010). The effect of post-learning presentation of music on long term word list retention. Neurobiology of Learning and Memory, 94, 13-20.

Jurado, J. (1993). La canción en la educación musical primaria. Música y Educación. Revista Trimestral de Pedagogía Musical, 14, 27-32.

Juslin, P. N. (2005). From mimesis to catarsis: expresión, perception, and induction of emotion in music. En D. Meill, R. MacDonald, \& D. Hargreaves (Eds.), Musical Communication (pp. 85-115). Oxford, UK: Oxford University Press.

Juslin, P. N., \& Västfjäll, D. (2008). Emotional responses to music: the need to consider underlying mechanisms. The Behavioral and Brain Sciences, 31(5), 559-575.

Justel, N., \& Rubinstein, W. (2013). La exposición a la música favorece la consolidación de los recuerdos. Boletín de Psicología, 109, 73-83.

Justus, T. C. \& Bharucha, J. J. (2002). Music Perception and Cognition. En H. Pashler \& S. Yantis (Eds.), Stevens' handbook of experimental psychology (pp. 453-492). New York, NY: John Wiley \& Sons. 
Karpinski, G. S. (2000). Aural skills acquisition: the development of listening, Reading, and performing skills in college-level musicians. Oxford, UK: Oxford University Press.

Kenny, D. T. (2008). Music Performance Anxiety. Intenational Handbook of Musicians' Health and Wellbeing. Oxford, UK: Oxford University Press.

Kerlinger, F. N. (1982). Fundamentos de la Investigación del Comportamiento. México: Nueva Editorial Interamericana.

Killam, N. R.; Lorton, P. V., \& Schubert, E. D. (1975). Interval Recognition: Identification of Harmonic and Melodic Intervals. Journal of Music Theory, 19(2), 212-234.

Kincheloe, J. L. (2012). Teachers as Researches. Qualitative Inquiry as a Path to Empowerment. Wiltshire: Routledge.

Koelsch, S. (2014). Brain correlates of music-evoked emotions. Nature Reviews Neuroscience, 15, 170-180.

Koelsch, S., Kilches, S., Steinbeis, N., \& Schelinski, S. (2008). Effects of unexpected chords and of performer's expression on brain responses and electrodermal activity. PLoS One, 3(7). Recuperado de http://www.plosone.org/article/info:doi\%2F10.1371\%2Fjournal.pon e.0002631

Kohn, D., \& Eitan, Z. (2009). Musical Parameters and Children's Movement Responses. En, P. S. Eerola, T. Eerola, T. Himberg, J. Louhivuori, \& S. Saarikallio (Eds.), Proceedings of the 7th Triennial Conference of European Society for the Cognitive Sciences of Music (pp. 233-241). Jyväskylä, Finlandia: University of Jyväskylä.

Krumhansl, C. L. (2000). Rhythm and Pitch in Music Cognition. Psychological Bulletin, 126(1), 159-179.

Krumhansl, C. L. (2004). The Cognition of Tonality-as We Know it Today. Journal of New Music Research, 33(3), 253-268.

Krumhansl, C. L., \& Kessler, E. (1982). Tracing the dynamic changes in perceived tonal organization in a spatial representation of musical keys. Psychological Review, 89, 334-368.

Kühn, C. (2003). La formación musical del oído. Barcelona: Labor. 
Kuusi, T. (2007). Interval-class and Order of Presentation Affect Interval Discrimination. Journal of New Music Research, 36(2), 95-104.

Lacárcel, J. (1992). La Psicología de la Música en la Educación Primaria: El desarrollo musical de seis a doce años. Revista Interuniversitaria de Formación del Profesorado, 13, 35-52.

Lacárcel, J. (2001). Psicología de la música y educación musical. Madrid: A. Machado Libros S.A.

Lafarga, M., \& Sanz, P. (1998). Habilidad musical y habilidades tonales. Quodlibet: Revista de especialización musical, 10, 102-114.

Lago, P. (2004). Ópera abierta: el arte de escuchar música. Madrid: Sanz y Torres.

Laitz, S. G. (2012). The Complete Musician: An Integrated Approach to Tonal Theory, Analysis, and Listening. Oxford, UK: Oxford University Press.

Larson, S. (2004). Musical forces and melodic expectations: comparing computers models and experimental results. Music Perception, 21(4), 457-498.

LaRue, J. (1989). Análisis del estilo musical. Pautas sobre la contribución a la música del sonido, la armonía, la melodía, el ritmo y el crecimiento formal. Barcelona: Labor.

Lasuén, S. (2014). Alternativa a la enseñanza de la Armonía en los Conservatorios: hacia un enfoque conscientemente sincrónico. En Actas del Congreso CEIMUS III (Comp.) (pp. 345-357). Madrid: Enclave Creativa Ediciones.

Latorre, A. (1996). El Diario como Instrumento de Reflexión del Profesor Novel. En Actas del III Congreso de E. F. de Facultades de Educación y XIV de Escuelas Universitarias de Magisterio (Comp.) (pp. 251-273). Guadalajara: Ferloprint.

Latorre, A. (2003). La investigación-acción. Conocer y cambiar la práctica educativa. Barcelona: Graó.

Latorre, A., \& González, R. (1987): El maestro investigador. La investigación en el aula. Barcelona: Graó. 
Laucirica, A. (1999). Efectos del oído absoluto en la práctica musical. Musiker: cuadernos de música, 11, 117-130.

Laucirica, A. (2004). La Discriminación Tonal e Interválica en la Percepción General Muical y en el Oído Absoluto. Revista Mexicana de Psicología, 21, 83-93.

Laukka, P. (2004). Instrumental music teachers' views on expressivity: A report from music conservatories. Music Education Research, 6(1), 45-56.

Lavignac, A. (1961). La educación musical. Buenos Aires: Ricordi.

Lerdahl, F., \& Jackendoff, R. (1983). An overview of hierarchical structure in music. Music Perception, 1(2), 229-252.

Lerdahl, F., \& Jackendoff, R. (2003). Teoría generativa de la música tonal. Madrid: Akal.

Levitin, D. J. (2004). L'oreille absolue: autoréférencement et mémoire. L'année psychologique, 104 (1), 103-120. Recuperado de http://www.persee.fr/web/revues/home/prescript/article/psy_00035033_2004_num_104_1_3930?_Prescripts_Search_isPortletOuvrage $=$ false

Levitin, D. J. (2006). This is your brain on music: the science of human obsesión. New York, NY: Dutton Adult.

Levitin, D. J. (2012). What does it mean to be musical? Neuron, 73(4), 633637.

Ley 14/1970, de 4 de agosto, General de Educación y Financiamiento de la Reforma Educativa (LGE).

Ley Orgánica 1/1990, de 3 de octubre, de Ordenación General del Sistema Educativo (LOGSE).

Ley Orgánica 2/2006, de 3 de mayo, de Educación (LOE).

Ley Orgánica 8/2013, de 9 de diciembre, para la Mejora de la Calidad Educativa (LOMCE).

Llorent, V. J., \& López, R. (2012). Estudio de las relaciones interpersonales en aulas con alumnos "diferentes". Campo Abierto, 31(2), 87-109. 
Loebach, J. L., Conway, C. M., \& Pisoni, D. B. (2009). Audition: Conginitive Influences. Encyclopedia of Perception. Recuperado de http://www.sageereference.com/perception/Article_n50.html

López-Bernad, L. (2015). PIEC: Programa para el desarrollo de la inteligencia emocional en los conservatorios de música. (Tesis doctoral). Universidad Nacional de Educación a Distancia. Recuperado de http://e-spacio.uned.es/fez/view/tesisuned: Educacion-Llopez

López de Arenosa, E. (2004). Apuntes sobre didáctica musical. Madrid. Enclave Creativa Ediciones.

López de Arenosa, E. (2006). Educación Auditiva: Dictado Musical. Madrid: Enclave Creativa Ediciones.

López de Arenosa, E. (2008a). La música suena. En Actas del Congreso CEIMUS I (Comp.) (pp. 387-394). Madrid: Enclave Creativa Ediciones.

López de Arenosa, E. (2008b). Retos: Oído versus vista. La audición como vía de comprensión y conceptualización de la música. En M. A. Ortiz (Coord.), Música, Arte, Diálogo, Civilización (pp. 391-422). Granada: CIMA

López de Arenosa, E. (2009). Qué es y qué entendemos por aprender música. Revista Creatividad y Sociedad, 13, 32-51.

López-Íñiguez, G., Pozo, J. I., \& De Dios, M. J. (2014). The older, the wiser? Profiles of string instrument teachers with different experience according to their conceptions of teaching, learning, and evaluation. Psychology of Music, 42(2), 157-176.

Lorente, M. (1965). Contribución al estudio de la acústica musical. Serialización de los elementos musicales. Madrid: Instituto Leonardo Torres Quevedo.

Lorenzo, O. (2014). La Investigación Musical en el ámbito de la Educación Superior y su necesaria difusión internacional: mitos hacia el destierro y cauces para el cambio. En Actas del Congreso CEIMUS III (Comp.) (pp. 499-506). Madrid: Enclave Creativa Ediciones.

Lorenzo, O., Herrera, L., \& Hernández, M. (2007). Scientific production in music education at the international level: An analysis of the 
Educational Resources Information Center (ERIC) Database. Research Perspectives in Music Education, 11, 12-21.

Loui, P., \& Wessel, D. (2007). Harmonic expectation and affect in Western music: Effects of attention and training. Perception and Psychophysics, 69(7), 1084-1092.

Louvier, A. (1996). Audición, memoria, imágenes. Eufonía. Didáctica de la Música, 2, 21-26.

Lucca, N., \& Berríos, R. (2003). Investigación cualitativa, fundamentos, diseños y estrategias. Colombia: Ediciones S. M.

Luna, M. (2005). El rol de los docentes en el cambio educativo. Revista PRELAC, 1, 170-173.

Lynch, T., \& Mendelsohn, D. (2002). Listening. En N. Schmitt (Ed.), An Introduction to Applied Linguistics (pp.193-210). New York, NY: Oxford University Press.

Mackamul, R. (1982). Sensibilización al fenómeno sonoro. México: UNAM.

MacLachlan, H. (2011). Teaching Traditional Music Theory with Popular Songs: Pitch Structures. En N. Biamonte (Ed.), Pop-Culture Pedagogy in the Music Classroom (pp. 73-89). Lanham: Scarecrow Press.

Maideu, J. (1997). Música, societat i educación: recull d'escrits y allocucions sobre educación musical, música tradicional. Berga: Amalgama.

Malagarriga, T. (2002). Anàlisi i validació d'una proposta didáctica d'educació musical per a nens de cinc anys. (Tesis doctoral). Universitad Autónoma de Barcelona. Recuperado de http://www.tdx.cesca.es/TESIS_UAB/AVAILABLE/TDX-1127102$161610 /$

Malagarriga, T., \& Valls, A. (2003). La audición musical en la educación infantil. Barcelona: Planeta De Agostini Profesional y Formación.

Malagarriga, T., Gómez, I., \& Viladot, L. (2013). Bases de la propuesta. En T. Malagarriga \& M. Martínez (Eds), Todo se puede expresar con música: los niños y niñas de 4 a 7 años piensan la música, hablan de 
música, crean música (pp. 17-78). Barcelona: DINSIC Publicacions Musicals.

Malbrán, S. (1996). Los atributos de la audición musical. Notas para su descripción. Eufonía. Didáctica de la Música, 2, 55-68.

Malbrán, S. (2006). La formación auditiva como proceso cognitivo. Eufonía. Didáctica de la Música, 36, 50-62.

Malbrán, S. (2007a). El oído de la mente. Madrid: Akal.

Malbrán, S. (2007b). Teorías, modelos y métodos en investigación musical. Hacia la recuperación de sus figuras prominentes. En M. Díaz \& A. Giráldez (Coords.). Aportaciones teóricas y metodológicas a la educación musical (pp. 115-118). Barcelona: Graó.

Maldonado, A., \& Muñoz, E. (2009). Siempre la voz. Música y Educación. Revista Trimestral de Pedagogía Musical, 78, 65-69.

Maneveau, G. (1993). Música y Educación: ensayo de análisis fenomenológico de la música y de los fundamentos de su pedagogía. Madrid: Rialp.

Marcelo, C. (1987). El pensamiento del profesor. Barcelona: CEAC.

Marín, C., Pérez-Echeverría, M. P., \& Hallam, S. (2012). Using the musical score to perform: A study with Spanish flute students. British Journal of Music Education, 29(2), 193-212.

Marín, C., Pérez-Echeverría, M. P., \& Scheuer, N. (2013). Conceptions of woodwind students regarding the process of learning a pice of music. Research Papers in Education, 3, 1-33.

Marín, J. F. (2004). La memoria: Introducción a la memoria musical. Música y Educación. Revista Trimestral de Pedagogía Musical, 60, 15-36.

Marín, R., \& Pérez, G. (1985). El cuestionario y la Entrevista. En R. Marín, \& G. Pérez (Eds.), Pedagogía Social y Sociología de la Educación. Unidades Didácticas 1, 2 y 3. (pp. 161-186). Madrid: UNED.

Marshall, C., \& Roosman, G. (1989). Designing qualitative research. Londres: SAGE. 
Martenot, M. (1993). Principios fundamentales de formación musical y su aplicación. Madrid: Rialp.

Martínez, F. E. (2007). La incidencia de la memoria musical en el desarrollo de la competencia auditiva. Bogotá: Universidad Pedagogía Nacional.

Martínez, I. C. (2005). La Audición Imaginativa y el Pensamiento Metafórico en la Música. En F. Shifres (Ed.), Actas de las I Jornadas de Educación Auditiva (pp. 47-72). La Plata: CEA Ediciones.

Martínez, I. C. (2008). Cognición Enactiva y mente corporeizada: el componente imaginativo y metafórico de la audición musical. Número Monográfico sobre Psicología de la Música. Estudios de Psicología, 29, 31-48.

Martínez, I. C. \& Anta, F. (2008). Procesos de Mapeo Transdominio en la percepción de la música atonal. En M. de la P. Jacquier \& A. Pereira (Eds.), Actas de la VII Reunión de SACCoM. ObjetividadSubjetividad y Música (pp. 181-185). Santa Fé: SACCoM.

Martínez, P. E. (2009). Un acercamiento a la memoria musical a través de la teoría y la práctica. Bogotá: Universidad Pedagógica Nacional.

Martínez-Salanova, E. (2005). Jóvenes creativos en una sociedad mediática. Africa e Mediterráneo, 51, 86-90.

Maxwell, J. C. (2000). El lado positivo del fracaso. Miami: Editorial Caribe.

Maykut, P., \& Morehouse, R. (1994). Investigación cualitativa. Una guía práctica y filosófica. Barcelona: Hurtado.

McKernan, J. (1999). Investigación-acción y currículum. Métodos y recursos para profesionales reflexivos. Madrid: Ediciones Morata.

Merino, J. M. (2006). Las vibraciones de la música. Alicante: Editorial Club Universitario.

Mertens, D. (2005). Research and evaluation in Education and Psychology: Integrating diversity with quantitative, qualitative, and mixed methods. Thousand Oaks, CA: SAGE. 
Mertens, D. M., Sullivan, M., \& Stace, H. (2011). Disability Communities: Transformative Research for Social Justice. En N. K. Denzin \& Y. S. Lincoln (Eds.), The SAGE Handbook of Qualitative Research. (pp. 57-75). Thousand Oaks, CA: SAGE.

Meyer, L. B. (2005). Emoción y significado en la música. Madrid: Alianza Editorial.

Miguel-Tobal, J. J. (1990). La ansiedad. En J. Mayor \& L. Pinillos (Eds.), Tratado de Psicología General: Motivación y Emoción (Vol. 3), (pp. 309-344). Madrid: Alhambra.

Miles, M. B., \& Huberman, A. M. (1994). Qualitative Data Analysis. An Expanded Sourcebook. London: SAGE.

Miralles, P., Maquilón, J. J., Hernández, F., \& García, A. (2012). Dificultades de las prácticas docentes de innovación educativa y sugerencias para su desarrollo. Revista Electrónica Interuniversitaria de Formación del Profesorado, 15(1), 19-26.

Miranda, J. (2003). Elaboració d'un model multimèdia d'intervenció per a l'educació de l'oüda musical. (Tesis doctoral). Universidad Autónoma de Barcelona. Recuperado de http://www.tdx.cat/ bitstream/handle/10803/5040/jmp1de2.pdf?sequence $=1$

Miras, M. (2004). Un punto de partida para el aprendizaje de nuevos contenidos: los conocimientos previos. En C. Coll, E. Martín, T. Mauri, M. Miras, J. Onrubia, I. Solé, \& A. Zabala, El constructivismo en el aula (pp. 47-54). Barcelona: Graó.

Misas, M. C., \& Tobón, A. (2007). Dicta que dicta. Orientaciones pedagógicas y modelos de ejercicios para el desarrollo de la audición musical. Colombia: Editorial Universidad de Antioquía.

Miyazaki, K. (1993). Absolute Pitche as an inability: Identification of Musical Intervals in a Tonal Context. Music Perception, 11(1), 5572.

Molina, E. (2003). La lectura a primera vista y el análisis. Música y Educación, 16(2), 73-90.

Molina, E. (2004). Lenguaje Musical 3. Enseñanzas Elementales. Madrid: Enclave Creativa Ediciones. 
Molina, E. (2005). Lenguaje musical 4. Enseñanzas Elementales. Madrid: Enclave Creativa Ediciones.

Molina, E. (2008). La improvisación como sistema pedagógico. Funcionamiento, objetivos y resultados de la metodología IEM. En Actas del Congreso CEIMUS I (Comp.) (pp. 252-272). Madrid: Enclave Creativa Ediciones.

Molino, P. (2014). La importancia de la motivación en el aprendizaje de los adolescentes. Universo UP. Revista digital de la Universidad de Padres, 10. Recuperado de http://universoup.es/10/vivirenlafrontera/ la-importancia-de-la-motivacion-en-el-aprendizaje-de-los-adolescen tes/

Mónaco, M. G. (2007). Memoria de alturas y memoria interválica. Un estudio con niños de 7 a 9 años. En VI Reunión Anual de SACCoM: Sociedad Argentina para las Ciencias Cognitivas de la Música (Comp.). Recuperado de www.saccom.org.ar/saccom/PDF/14 Monaco.pdf

Monereo, C., Barberà, E., Castelló, M., Miquel, E., \& Pérez, M. (1998). Estratègies d'aprenentatge. Assessorament $i$ formació del professorat. Barcelona: Edicions de la Universitat Oberta de Catalunya.

Moog, H. (1976). The musical experience of the preschool child. Londres: Schott.

Mora, G. (2009). La función de los estímulos visuales en la experiencia multisensorial de los performances de música electrónica en la actualidad. Buenos Aires: Universidad de Buenos Aires.

Morán, M. C. (2010). Psichology and art: the perception of music. Ciencias, $100(4), 58-64$.

Morse, J. M. (2005). Asuntos críticos en los métodos de investigación cualitativa. Alicante: Servicio de publicaciones de la Universidad de Alicante.

Moya, A. M. (2010). La relación profesor-alumno. Revista digital Innovación y Experiencias Educativas, 27. Recuperado de http://www.csi-csif.es/andalucia/modules/mod_ense/revista/pdf/ Numero_27 /ANTONIA_MARIA_MOYA_MARTINEZ.pdf 
Munar, E., Rosselló, J., Mas, C., Morente, P., \& Quetgles, M. (2002). El desarrollo de la audición humana. Psicothema, 14(2), 247-254.

Muñoz, E. (2009). La voz en la formación de los maestros. Tendencias Pedagógicas, 14, 325-334.

Muñoz, E., \& Bonastre, C. (2013). La expresividad en la música. Quodlibet. Revista de especialización musical, 52, 40-52.

Muñoz, J. R. (2001). La voz y el canto en la educación infantil. Eufonía. Didáctica de la Música, 23, 43-54.

Musumeci, O. (2007). Adiós al dictado musical: propuestas cognitivas para una educación humanamente compatible utilizando música real. En M. Espejo (Ed.), II Jornada de Educación Auditiva (pp. 27-35). Tunja: Facultad de Ciencias de la Educación, UPTC.

Myers, D. G. (2005). Psicología. Buenos Aires: Editorial Médica Panamericana.

Nagy, J. (2014). Memoria musical. Temas para la Educación. Revista digital para profesionales de la enseñanza, 26. Recuperado de http://www.feandalucia.ccoo.es/docu/p5sd10782.pdf

Navarrete, B. (2009). La motivación en el aula. Funciones del profesor para mejorar la motivación en el aprendizaje. Revista digital Innovación y Experiencias Educativas, 15. Recuperado de http://www.csicsif.es/andalucia/modules/mod_ense/revista/pdf/Numero_15/BELE N_NAVARRETE_1.pdf

Oakes, W. F. (1951). An Alternative Interpretation of 'Absolute Pitch'. Transaction of the Kansas Academy of Science, 54, 396- 406.

Okuda, M., \& Gómez, C. (2005). Métodos en investigación cualitativa: triangulación. Revista colombiana de Psiquiatría, 34(1), 118-124. Recuperado de http://www.scielo.org.co/scielo.php?pid=S0034$74502005000100008 \&$ script $=$ sci_arttext

Orden de 30 de mayo de 1955, por la que se aprueba el nuevo cuestionario para la enseñanza de "Solfeo y Teoría de la Música" en los conservatorios oficiales de música. 
Orden EDU/1188/2005, de 21 de septiembre, por la que se regula la organización y funcionamiento de los conservatorios profesionales de música de Castilla y León.

Orden EDU/1118/2008, de 19 de junio, por la que se regula la evaluación de las enseñanzas elementales y profesionales de música en Castilla y León.

Orden EDU/938/2009, de 28 de abril, por la que se regula la impartición, organización y autorización de las asignaturas optativas y perfiles educativos correspondientes a los cursos quinto y sexto de las enseñanzas profesionales de música en la Comunidad de Castilla y León.

Orden EDU/1367/2010, de 29 de septiembre, por la que se establece con carácter experimental el plan de estudios para el primer curso de las Enseñanzas Artísticas Superiores de Grado en la Comunidad de Castilla y León.

Orden EDU/1221/2011, de 29 de septiembre, por la que se regulan determinados aspectos relacionados con la ordenación académica de las enseñanzas artísticas superiores de Grado en Música, en Arte Dramático y en Artes Plásticas en la Comunidad de Castilla y León.

Orden EDU/321/2013, de 8 de mayo, por la que se regula la simultaneidad de especialidades en las enseñanzas elementales y profesionales de música, en la Comunidad de Castilla y León.

Ortíz, T. (1999). Relaciones entre el cerebro y la música. En P. Lago (Ed.), Música y salud: Introducción a la musicoterapia. Madrid: UNED.

Osborne, M. S., Kenny, D. T., \& Holsomback, R. (2005). Assessment of MPA in late childhood. International Journal of Stress Management, $12,312-330$.

Palacios, F. (2001). Orden, memoria y creatividad en la audición musical. Madrid: Ministerio de Educación, Cultura y Deportes.

Palmer, A., \& Muñoz, E. (2008). El azar en las interacciones entre improvisación y composición. Música y Educación. Revista Trimestral de Pedagogía Musical, 21(76), 98-108.

Paney, A. (2007). Directing attention in melodic dictation. (Tesis doctoral). Texas Tech University. Recuperado de http://etd.lib.ttu.edu/ 
theses/available/etd-03192007-182211/unrestricted/Paney_Andrew_ Diss.pdf

Paoloni, P. V. (2011). Motivación y tareas académicas. Interacciones complejas en contextos reales de aprendizaje. En A. Vogliotti, N. E. Mainero, \& E. Medina (Eds.) (2011). Estudios en Educación Superior (pp. 297-312). Córdoba: Universitas.

Parncutt, R. (1988). Revision of Terhardt's Psychoacoustical Model of the Root(s) of a Musical Chord. Music Perception, 6(1), 65-93.

Pascual, P. (2002). Didáctica de la música para primaria. Madrid: Prentice Hall.

Pastor, P. (2014). Integración pedagógica, músico versátil. En Actas del Congreso CEIMUS III (Comp.) (pp. 321-337). Madrid: Enclave Creativa Ediciones.

Paynter, J. (1991). Oír, aquí y ahora. Buenos Aires: Ricordi Americana.

Peral, S. (2006). La memoria musical en la interpretación pianística. Resonancias, 2, 36-43.

Peralbo, A. (2011). Identificar el estrés infantil. Universo UP. Revista digital de la universidad de padres online, 12. Recuperado de: $\mathrm{http} / / /$ revista.universidaddepadres.es/index.php?option=com_content $\&$ view $=$ article\&id=833:el-estres-infantil\&catid=246:tribuhijos\&Itemid $=1022$

Perandones, M. A. (2005). El Lenguaje Musical y su enseñanza en los conservatorios. Concreciones didácticas y repercusión en la formación de los profesores. (Tesis doctoral). Universidad Complutense de Madrid. Recuperado de http://www.maperan dones.com/tesis

Pereira, A. (2009). El gesto manual en la tarea de lectura entonada a primera vista. Algunos aportes para su estudio. En P. Asís \& S. Dutto (Comp.), La Experiencia Artística y la Cognición Musical. VIII Reunión Anual de SACCoM (pp. 167-189). Buenos Aires: SACCoM.

Pérez, J. (2011). La música a la vida quotidiana d'infants de dos anys. Anàlisi de situacions musicals que es desenvolupen en context escolar. (Tesis doctoral). Univesitat Autònoma de Barcelona. Recuperado de http://www.tdx.cat/handle/10803/96096 
Pérez Juste, R. (1991). Pedagogía Experimental. La Medida en Educación. Madrid: UNED.

Persichetti, V. (1985). Armonía del siglo XX. Madrid: Real Musical.

Pflederer, M. (1964). The responses of children to musical simulus embodying Piaget's principle of conservation. Journal or Research in Music Education, 12, 251-268.

Pflederer, M., \& Sechrest, L. (1968). Conservation-type responses of children to musical stimuli. Bulletin for the Council of Research in Music Education, 13, 19-36.

Pintrich, P. (2006). Las creencias motivacionales como recursos y restricciones para el cambio conceptual. En S. Wolfgang, S. Vosniadou, \& M. Carretero (Comps.), Cambio Conceptual y Educación (pp. 53-86). Buenos Aires: Aique.

Piston, W. (1998). Armonía. Cooper City (FL): Span Press Universitaria.

Platt, J. R., \& Racine, R. J. (1994). Detection of Implied Harmony Changes in Triadic Melodies. Music Perception, 11(3), 243-264.

Ponsatí, I. (2011). Avaluació d'una proposta didáctica per a la identificació auditiva dels intervals harmònics musicals. Una experimentació al primer curs dels ensenyaments especialitzats de grau profesional dels conservatoris de música de Catalunya. (Tesis doctoral). Universidad Autónoma de Barcelona. Recuperado de http://dialnet.unirioja.es/servlet/tesis?codigo $=24235$

Porlán, R. (1987). El Maestro como Investigador en el Aula. Investigar para Conocer, Conocer para Enseñar. Revista Investigación en la Escuela, 1, 63-69.

Porlán, R., \& Martín, J. (1991). El Diario del Profesor. Sevilla: Diada.

Porta, A. (2014). La Educación Musical y su difusión científica. Una forma de aproximación a través del análisis de contenido. En Actas del Congreso CEIMUS III (Comp.) (pp. 605-613). Madrid: Enclave Creativa Ediciones.

Pozo, J. I. (2008). Aprendices y Maestros: La psicología cognitiva del aprendizaje. Madrid: Alianza Editorial. 
Programación didáctica de Lenguaje Musical del Conservatorio Profesional de Música de Segovia del curso 2012-2013. (2012). Conservatorío de Segovia. Recuperado de http://conservatoriosegovia. centros.educa.jcyl.es/sitio/upload/PROGRAMACION_L_Musical_1 2-13.pdf

Proyecto educativo del Conservatorio Profesional de Música de Segovia del curso 2012-2013. (2012). Conservatorío de Segovia. Recuperado de http://conservatoriosegovia.centros.educa.jcyl.es/aula/archivos.cgi?w Accion $=$ vergrupo $\&$ wIdGrupo $=944 \&$ id_curso $=41$

Puente-Ferreras, A. (2003). Memoria: cognición y aprendizaje. Fundamentos psicológicos. Madrid: Pirámide.

Rameau, J. P. (1722). Traité de l'Harmonie reduite à ses principes naturels. París: Ballard.

Randel, D. M. (2004). Diccionario Harvard de música. Madrid: Alianza Diccionarios.

Raya, I. (2011). La educación melódica. Canciones para educación infantil. Revista Digital Innovación y Experiencias Educativas, 47. Recuperado de http://www.csi-f.es/archivos/andalucia/ensenanza/ revistas/iee/Numero_47/INMACULADA_RAYA_2.pdf

Real Decreto de 25 de agosto de 1917, (Gaceta de 30 de agosto), por el que se establece el Reglamento para el gobierno y régimen del Real Conservatorio de Música y Declamación.

Real Decreto 756/1992, de 26 de junio, por el que se establecen los aspectos básicos del currículo de los grados elemental y medio de las enseñanzas de música.

Real Decreto 1577/2006, de 22 de diciembre, por el que se fijan los aspectos básicos del currículo de las Enseñanzas Profesionales de Música reguladas por la Ley Orgánica 2/2006, de 3 de mayo, de Educación.

Real Decreto 631/2010, de 14 de mayo, por el que se regula el contenido básico de las Enseñanzas Artísticas Superiores de Grado en Música establecidas en la Ley Orgánica 2/2006, de 3 de mayo, de Educación.

Real Decreto 21/2015, de 23 de enero, por el que se modifica el Real Decreto 1614/2009, de 26 de octubre, por el que se establece la 
Ordenación de las Enseñanzas Artísticas Superiores reguladas por la Ley Orgánica 2/2006, de 3 de mayo, de Educación.

Reglamento de Régimen Interno (RRI) del Conservatorio Profesional de Música de Segovia del curso 2012-2013. (2012). Conservatorío de Segovia. Recuperado de http://conservatoriosegovia.centros.educa. jcyl.es/aula/archivos.cgi?wAccion=vergrupo\&wIdGrupo=944\&id_c urso $=41$

Revesz, G. (1953). Introduction to the Psychology of Music. London: Longmans Green.

Rickard, N., Wing Wong, W., \& Velik, L. (2012). Relaxing music counters heightened consolidation of emotional memory. Neurobiology of Learning \& Memory, 97, 220-228.

Robalino, M. (2005). ¿Actor o protagonista? Dilemas y responsabilidades sociales de la profesión docente. Revista PRELAC, 1, 6-23.

Robles, G. (2003). Nuevo Lenguaje Musical I y II. Málaga: Ediciones Si bemol.

Roche, E. M. (1994). La enseñanza de la música en el marco de la LOGSE. Aula de Innovación Educativa, 24, 5-8.

Rogers, C. (1991). Libertad y creatividad en la educación. Barcelona: Paidós.

Roig-Francolí, M. A. (2011). Harmony in Context. New York, NY: McGraw-Hill.

Romero, G. (2008). Formar l'ö̈da. Metodologia i exercicis. Barcelona: DINSIC Distribucions Musicals.

Ruiz, J., \& Ispizua, M. (1989). La descodificación de la vida cotidiana. Bilbao: Universidad de Deusto.

Russo, F. A., \& Thompson, W. F. (2005a). The subjetive size of melodic intervals over a two-octave range. Psychonomic Bulletin \& Review, 12(6), 1068-1075.

Russo, F. A., \& Thompson, W. F. (2005b). An interval size illusion: The influence of timbre on the perceived size of melodic intervals. Perception and Psychophysics, 67(4), 559-568. 
Sabariego, M. (2004). La investigación educativa: Génesis, evolución y características. En R. Bisquerra (Coord.), Metodología de la investigación educativa (pp. 51-87). Madrid: La Muralla.

Sabbatella, P. (2000). Control del comportamiento y disciplina en el aula de música. Revista Electrónica de LEEME. Lista Electrónica Europea de Música en la Educación, 5. Recuperado de http://fresno.pntic.mec.es/ emod0002/disciplina.htm

Salmón, P. G. (1990). A Psychological Perspective on Musical Performance Anxiety: A Review of the Literature. Medical Problems of Perfarming Artists, 5, 2-11.

Samplaski, A. (2005). Interval and interval class similarity: results of a confusion study. Psychomusicology, 19(1), 59-74.

Sang, L. (2010). La educación musical del futuro. Revista Digital Innovación y Experiencias Educativas, 28. Recuperado de http://www.csi-csif.es/andalucia/modules/mod_ense/revista/pdf/ Numero_28/LYDIA_SANG_LEGRAN_01.pdf

Sanmartí, N. (2007). 10 ideas clave. Evaluar para aprender. Barcelona: Graó.

Santapau, V. (2014). Los profesores de instrumento de los Conservatorios también pueden ser profesores 2.0. En Actas del Congreso CEIMUS III (Comp.) (pp. 248-254). Madrid: Enclave Creativa Ediciones.

Sanuy, M. (1996). Aula sonora. Madrid: Morata.

Sanuy, M., \& González, L. (1969). Orff-Schulwerk. Música para niños. Madrid: Unión Musical Española.

Schafer, R. M. (1992). Cuando las palabras cantan. Buenos Aires: Ricordi Americana.

Schenker, H. (1990). Tratado de armonía. Madrid: Real Musical.

Schön, D. A. (1998). El profesional reflexivo. Cómo piensan los profesionales cuando actúan. Barcelona: Paidós.

Schönberg, A. (1969). Structural functions of harmony. New York, NY: Norton \& Company. 
Schönberg, A. (1974). Tratado de armonia. Madrid: Real Musical.

Schuman, H., \& Presser, S. (1981). Questions \& answers in attitude survey. En R. Sierra, Experiments on questions form, wording \& context (pp. 308-314). New York, NY: Academic Press.

Segovia, F., \& Beltrán, J. (1998). El Aula Inteligente. Nuevo horizonte educativo. Madrid: Espasa Calpe.

Selltiz, C., et al. (1976). Métodos de investigación en las relaciones sociales. Madrid: Rialp.

Sherman, R. R., \& Webb, R. B. (1988). Qualitative research in education: A Focus. En R. R. Sherman \& R. B. Webb (Eds.), Qualitative research in education: Focus methods (pp. 2-21). Filadelfia, PA: The Palmer Press.

Shifres, F. (2010). Tener oído. De la dimensión desconocida a las dimensiones reconocidas. En R. Herrera \& F. Shifres (Eds.), Adquisición y Desarrollo del Lenguaje Musical en la Enseñanza Formal de la Música (pp. 51-56). Buenos Aires: SACCoM.

Sierra, F. (1998). Función y sentido de la entrevista cualitativa en investigación social. En J. Galindo (Coord.), Técnicas de investigación en sociedad, cultura y comunicación (pp. 207-276). México: Addison Wesley Longman.

Sierra, F. (2008). Constructivismo y Educación Auditiva. Música y Educación, 73, 110-116.

Sierra Bravo, R. (1988). Técnicas de investigación Social. Teoría y Ejercicios. Madrid: Paraninfo.

Simons, H. (1996). El enfoque de estudio de casos en el proyecto sobre la enseñanza de ciencias, matemáticas y tecnología (SMTE) de la OCDE. Revista de Educación, 310, 173-185.

Sloboda, J. (1993). The Musical Mind. The Cognitive Psychology of Music. Oxford, UK: Oxford University Press.

Sonido. (2014). Real Academia Española. Recuperado de http://lema.rae.es/drae/srv/search?key=sonido

Stake, R. E. (1998). Investigación con estudio de casos. Madrid: Morata. 
Stake, R. E. (2006). Evaluación comprensiva y evaluación basada en estándares. Barcelona: Graó.

Stenhouse, L. (1987). La investigación como base en la enseñanza. Madrid: Ediciones Morata.

Sterling, P. A. (1985). The effects of accompanying harmonic context in children's vocal pitch accuracy of a melody. Psychology of Music, 13(2), 72-80.

Stipek, D. J. (1996). Motivation and Instruction. En D. C. Berliner \& R. C. Calfee (Eds.), Handbook of Educational Psychology (pp. 85-113). New York, NY: Macmillan.

Stringer, E. T. (2007). Action Research in Education. Upper Saddle River: Pearson.

Studer, R., Danusera, B., Hildebrandtb, H., Arial, M., \& Gómez, P. (2011). Hyperventilación complaints in music performance anxiety among classical music students. Journal of Psychosomatic Research, 70, 557-564.

Suzuki, S. (2007). Vivre c'est aimer. Marsella: Éditions Corroy.

Swanwick, K. (1991). Música, pensamiento y educación. Madrid: Morata.

Szönyi, E. (1976). La educación musical en Hungría a través del método Kodály. Budapest: Editorial Corvina.

Tafuri, J. (2006). ¿Se nace musical?: Cómo promover las aptitudes musicales de los niños. Barcelona: Grao.

Tafuri, J. (2008). Infant Musicality. New research for educators and parents. Surrey, UK: Ashagate.

Takeuchi, A., \& Hulse, S. H. (1993). Absolute Pitch. Psychological Bulletin, $113(2), 345-361$.

Taylor, S. J., \& Bodgan, R. (1986). Introducción a los métodos cualitativos de investigación. Buenos Aires: Paidós.

Teplov, B. M. (1966). Psychologie des aptitudes musicales. París: Presses Universitaires de France. 
Terhardt, E. (1978). Psychoacoustic evaluation of musical sounds. Perception \& Psychophysics, 23, 483-492.

Thompson, W. F., \& Parncutt, R. (1997). Perceptual judgments of triads and dyads: Assessment of a psychoacoustic model. Music Perception, 14(3), 263-280.

Tomatis, A. (1987). L'Oreille et la Voix. París: Robert Laffont.

Torrado, J. A. (2011). Un paseo por la clase de pedagogía, un lugar donde pensar sobre lo que tenemos asumido. FFF, Revista de Pensamiento Musical, 4, 61-68.

Torrado, J. A., \& Pozo, J. I. (2006). Del dicho al hecho: de las concepciones sobre el aprendizaje a la práctica de la enseñanza de la música. En J. I. Pozo et al. (Eds), Nuevas formas de pensar la enseñanza y el aprendizaje: Las concepciones de profesores y alumnos (pp. 205230). Barcelona: Graó.

Torre, S. (1995). Creatividad Aplicada. Recursos para una formación creativa. Madrid: Escuela Española.

Torre, S., Pujol, M. A., Lorenzo, N., \& Rajadell, N. (2011). Innovación y creatividad: la adversidad como oportunidad. Barcelona: GIAD-UB.

Torres, J. (1986). El Diario Escolar. Cuadernos de Pedagogía, 142, 52-55.

Torres, M. J. (2011). La importancia de la educación auditiva, rítmica y vocal en la etapa de educación infantil. Revista Digital Innovación y Experiencias Educativas, 39. Recuperado de http://www.csicsif.es/andalucia/modules/mod_ense/revista/pdf/Numero_39/MARI

A_JOSE_TORRES_MENDEZ_02.pdf

Trallero, C. (2008). El oído musical. Depósito digital de la Universidad de Barcelona. Recuperado de http://diposit.ub.edu/dspace/handle/ $2445 / 11525$

Trehub, S. E., \& Hannon, E. E. (2006). Infant music perception: Domaingeneral or domain-specific mechanismes? Cognition, 100, 73-99.

Ur, P. (1984). Teaching Listening Comprehension. London: Cambridge Universitey Press. 
Valenzuela, M. A. (2001). Reflexiones en torno a las asignaturas de solfeo y entrenamiento auditivo en la Escuela Nacional de Música. Cuadernos Interamericanos de Investigación en Educación Musical, 1, 79-107. Recuperado de http://www.ejournal.unam.mx/cem/vol0101/CEM01106.pdf

Vera, A. (2000). Introducción a la Psicología de la Música. En M. Betés, Fundamentos de musicoterapia (pp. 167-193). Madrid: Morata.

Viadel, R. M. (2011). Las investigaciones en educación artística y las metodologías artísticas de investigación en educación: Temas, tendencias y miradas. Educação, 34(3), 271-285.

Vilar, J. M. (1994). Recursos per aprendre a escoltar la música. Barcelona: Associació de Mestres Rosa Sensat.

Virues, R. A. (2005). Estudio sobre ansiedad. Revista Psicología Científica.com, 7(8). Recuperado de http://www.psicologia cientifica.com/ansiedad-estudio/

Visauta, B. (1989). Técnicas de investigación social I. Barcelona: PPU.

Walker, R. (1985). Doing research: A handbook for teachers. Londres: Methuen.

Ward, J. (1964). La méthode Ward. París: Desclée.

Webster, P. R. (2011). Key research in music technology and music teaching and learning. Journal of Music, Technology and Education, 4, 115130.

Weiten, W. (2006). Psicología: temas y variaciones. México: Cengage Learning Editores.

Whitehead, J. (1999). Educative Relations in a New Era. Pedagogy, Culture \& Society, 7(1), 73-90.

Willems, E. (1967). La preparación musical de los más pequeños. Buenos Aires: Eudeba.

Willems, E. (1981). El valor humano de la educación musical. Buenos Aires: Eudeba. 
Willems, E. (1984a). Las bases psicológicas de la educación musical. Buenos Aires: Eudeba.

Willems, E. (1984b). L'oreille musicale. La cultura auditive, les intervalles et les acords. Tome II. Fribourg: Editions Pro Musica.

Willems, E. (1995). Solfeo. Curso elemental. Libro del maestro. Fribourg: Éditions Pro Musica.

Willems, E. (2001). El oído musical. La preparación auditiva del niño. Barcelona: Ediciones Paidós Ibérica.

Wilson, G. D. (1997). Performance anxiety. En D. J. Hargreaves \& A. C. North (Eds.), The social psychology of music (pp. 229-248). Oxford, UK: Oxford University Press.

Yin, R. K. (1984). Case study research: Design and methods. Newbury Park, CA: SAGE.

Zabala, A. (2007). 11 Ideas claves para el aprendizaje y la enseñanza por competencias. Barcelona: Graó.

Zabalza, M. A. (2004). Diarios de clase. Un instrumento de investigación y desarrollo profesional. Madrid: Narcea.

Zbikowki, L. M. (2002). Conceptualizing Music. Cognitive Structure, Theory and Analysis. Oxford, UK: University Press.

Zeichner, K. M. (1993). El docente como profesional reflexivo. Cuadernos de Pedagogía, 220, 44-49.

Zenatti, A. (1975). Le Développemente génétique de la perception musicale. París: Centre National de la Recherche Scientifique. 